Universidade de São Paulo

Faculdade de Filosofia, Letras e Ciências Humanas

Departamento de Geografia

\title{
O circuito superior marginal: \\ Produção de medicamentos \\ e o território brasileiro
}

Edison Claudino Bicudo Junior

Orientadora

Profa. Dra. María Laura Silveira

Dissertação de mestrado apresentada ao Departamento de Geografia da Faculdade de Filosofia, Letras

e Ciências Humanas da Universidade de São Paulo

São Paulo 
Índice

$\begin{array}{ll}\text { Primeiras palavras } & 5\end{array}$

$\begin{array}{ll}\text { Produção de medicamentos } & 6\end{array}$

O espaço dividido

O circuito superior marginal da economia urbana 14

$\begin{array}{ll}\text { O processo de pesquisa } & 16\end{array}$

Primeira parte: O circuito superior marginal e a formação socioespacial brasileira $\quad 20$

$\begin{array}{ll}\text { A periodização como método } & 21\end{array}$

$\begin{array}{ll}\text { Os períodos históricos } & 21\end{array}$

I - A técnica e a produção de medicamentos 24

$\begin{array}{ll}\text { A precedência da técnica } & 24\end{array}$

1. O subperíodo maquínico 25

2. O subperíodo tecnológico 35

II - A ciência e a produção de medicamentos 45

O papel da síntese química 45

A extroversão do território

Os fenômenos de concentração $\quad 50$

III - A informação e a produção de medicamentos $\quad 61$

$\begin{array}{ll}\text { A revolução informacional } & 61\end{array}$

Informação e produção de medicamentos 62

$\begin{array}{ll}\text { As novas seletividades } & 66\end{array}$

$\begin{array}{ll}\text { A renovação do quadro institucional } & 71\end{array}$

$\begin{array}{ll}\text { Informação e polarização } & 76\end{array}$ 
Segunda parte: A racionalidade instrumental: Precedência das normas no atual $\begin{array}{ll}\text { período histórico } & 79\end{array}$

A norma como variável-força: Formação das densidades normativas $\quad 80$

IV - O controle da vida

1. A vida em suas estruturas biológicas elementares 83

O papel das biotecnologias 83

Biotecnologia e produção de medicamentos $\quad 87$

O alargamento dos círculos de cooperação 90

2. A vida em suas estruturas sociais elementares 93

O surto das pesquisas clínicas 93

Os novos sentidos da propaganda farmacêutica 101

A proliferação das farmácias e a expansão do crédito 103

A medicalização do território 105

$V$ - As densidades normativas e o território brasileiro 109

$\begin{array}{ll}\text { As normas e o território } & 109\end{array}$

$\begin{array}{ll}\text { As normas e a produção de medicamentos } & 110\end{array}$

As patentes e os medicamentos para tratamento da Aids: Produção $\begin{array}{ll}\text { particular e produção estatal } & 111\end{array}$

$\begin{array}{ll}\text { Anvisa: A renovação normativa e as armadilhas científicas } & 117\end{array}$

Lei dos medicamentos genéricos e formação das densidades $\begin{array}{ll}\text { normativas } & 127\end{array}$

$\begin{array}{ll}\text { Política farmacêutica e a ideologia do preço } & 137\end{array}$

VI - Polarizações espaciais: A produção de pontos luminosos 139

$\begin{array}{ll}\text { A face mercadológica da concentração } & 139\end{array}$

$\begin{array}{ll}\text { A face geográfica da concentração } & 148\end{array}$

$\begin{array}{ll}\text { A concentração do poder do político } & 156\end{array}$ 
Terceira parte: A racionalidade comunicacional: O território como coexistência de sistemas organizacionais

O espaço dividido 162

Um circuito econômico intermediário: Interpretações anteriores

$\begin{array}{ll}\text { A idéia de organização } & 165\end{array}$

$\begin{array}{ll}\text { Alargamento dos contextos } & 168\end{array}$

$\begin{array}{ll}\text { O superior marginal e os fluxos de medicamentos } & 174\end{array}$

$\begin{array}{ll}\text { Os fluxos de medicamentos: Situação das empresas distribuidoras } & 174\end{array}$

$\begin{array}{ll}\text { Um trabalho específico } & 179\end{array}$

As densidades comunicacionais e a produção de medicamentos 182

$\begin{array}{lc}\text { O espaço e suas divisões } & 188\end{array}$

VIII - Os círculos de cooperação: As novas faces do circuito superior marginal

Os círculos de cooperação

O peso das normas científicas

Medicamentos fitoterápicos e normas científicas

Relações entre os dois níveis do circuito superior

A informação converte-se em norma

IX - Os circuitos econômicos e as escalas temporais

Os novos dinamismos de Goiânia

Cidades médias e produção de medicamentos

Distribuição de medicamentos na região amazônica: Os tempos lentos

Os fluxos e as distâncias 


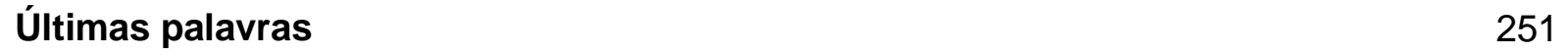

Os circuitos da economia e suas racionalidades espaciais 252

O circuito superior marginal: Mediador espacial 254

$\begin{array}{ll}\text { Território e conflito } & 258\end{array}$

$\begin{array}{ll}\text { A centralidade das normas } & 260\end{array}$

$\begin{array}{ll}\text { A regulação híbrida } & 263\end{array}$

Os discursos espaciais: A busca da transparência 264

$\begin{array}{ll}\text { Bibliografia } & 268\end{array}$

Anexos 


\section{Primeiras palavras}

Claramente: o mais prático dos sóis, o sol de um comprimido de aspirina: de emprego fácil, portátil e barato, compacto de sol na lápide sucinta.

João Cabral de Melo Neto A educação pela pedra (1966) 
Produção de medicamentos

A definição de medicamento é uma tarefa que deixamos aos farmacêuticos, clínicos, médicos em geral, químicos. Também não entraremos na discussão em torno da legitimidade ou falta de legitimidade destas ou daquelas terapias. O que nos interessa não é tanto o objeto técnico (o medicamento), mas sim a atividade (a produção de medicamentos). Com isso, ficamos mais próximos de uma categoria própria das ciências humanas (produção). Com isso, fugimos ao debate infértil acerca do objeto e passamos à discussão, muito mais rica e geográfica, sobre o sistema de objetos. Esta noção foi desenvolvida por Jean Baudrillard, que nos diz que os objetos tendem a se organizar, a se relacionar, formando uma ordem dotada de lógica própria, em que o homem é chamado a cumprir uma função de controle (Baudrillard, 1968).

"Um objeto isolado diz muito pouco [...]" (Vidal de La Blache, 1922, p. 9). Sem compreender os sistemas em que se enreda o objeto, com dificuldade poderemos apreender seu significado, pois este se define, justamente, em função dessas sistematizações. Segundo Milton Santos, o objeto tem valor como coisa, devido a sua existência corpórea, e tem valor como dado social, que vem de sua existência relacional (Santos, 1996, 2002, p. 156). É por isso, parece-nos, que Hägerstrand (1973, p. 71) vai dizer que os objetos se distorcem e interpenetram de várias maneiras.

Em matéria de medicamentos, esse fenômeno pode ser facilmente captado, pois que eles, na condição de objetos técnicos, pertencem a um denso conjunto de formas geográficas, técnicas e recursos que vão, a pouco e pouco, promovendo a medicalização da sociedade e do território. Esse processo, de expansão precária e seletiva, tem no hospital uma de suas máximas expressões ${ }^{1}$.

Aliás, entre as características precípuas de qualquer objeto socialmente usado, podemos contar as relações e as funções de que se revestem eles, no interior dos conjuntos que os homens inventam. Segundo Poincaré, é da busca dessas relações que depende a viabilidade das explicações da ciência. "[...] o que ela pode atingir não são as coisas em si mesmas, como pensam os dogmatistas ingênuos: são as relações entre as coisas. Fora dessas relações, não existe realidade cognoscível" (Poincaré, 1902, 1908, p. 4) ${ }^{2}$.

Segundo Karel Kosik, um certo pensamento econômico tende a substituir a "realidade objetiva" pela "realidade objetual" (Kosik, 1989, p. 88). É para fugir a essa troca

\footnotetext{
${ }^{1}$ Assim como não podemos de modo algum pensar em objetos espaciais fora do espaço, em objetos temporais fora do tempo, também não podemos pensar em nenhum objeto fora da possibilidade de sua ligação com outros (Wittgenstein, 1921, 1994, pp. 134-137).

2 “[...] os objetos em si são menos reais que as relações ęntre eles” (Sousa Santos, 1985, 1995, p. 34).
} 
perigosa que enfatizamos, logo de saída, a idéia de produção de medicamentos. Esta pode conduzir nosso olhar para quatro fenômenos cruciais.

Primeiramente, as produções implicam divisões territoriais do trabalho. As diversas etapas da produção ficam, ora dispersas, ora concentradas, de acordo com seu valor estratégico mais ou menos pronunciado.

Em segundo lugar, as atividades econômicas, nos quadros atuais do capitalismo, consolidam e promovem diferenciações socioespaciais. Há um uso diferenciado das infra-estruturas, das tecnologias, das normas, das informações. Conforme diremos, há um circuito superior e um circuito superior marginal. Trata-se de uma hierarquia espacial, que também se traduz em termos de temporalidades. Assim, mais do que indicar usos hierarquizados do espaço social, buscaremos demonstrar que há, também, usos hierarquizados do tempo social. Com isso, tentaremos evitar essa miopia temporal de que nos fala Milton Santos (1979, p. 45).

Um terceiro é que, em decorrência mesmo do que vimos de dizer, surgem fluxos mais ou menos velozes e precisos entre os lugares. Estes se integram, se associam, o que se pode realizar tanto em função das necessidades hegemônicas, como graças às ações marginais, também capazes de unificações espaciais.

Em quarto lugar, emergem, através dessas integrações e concentrações particulares, relações de competição e cooperação entre os diversos agentes. O fenômeno, reproduzido para os lugares, vai permitir que falemos em efeitos de coordenação ou fragmentação; forças espaciais dispersivas ou concentradoras.

Ao longo de nosso trabalho, falaremos da produção de medicamentos (ou da atividade farmacêutica) com referência à fabricação e distribuição de fórmulas terapêuticas segundo métodos padronizados. Essa padronização pode decorrer de requisitos técnicos (como no caso dos medicamentos similares), normativos (como no caso dos medicamentos genéricos), tradicionais (como no caso de alguns medicamentos fitoterápicos), ou mesmo filosóficos, no sentido fraco do termo (como no caso dos medicamentos homeopáticos ou dos medicamentos florais). No geral, a produção de medicamentos, conforme o uso que fazemos da expressão, requer a instalação de rotinas de trabalho, o que pede a prévia instalação, nos lugares, de infra-estruturas e sistemas técnicos permitindo a divisão e a repetição mais ou menos perfeita do trabalho ${ }^{3}$.

"A validade mercantil da técnica depende das garantias de que iniciada a ação ela vai ter a trajetória e os resultados programados" (Santos, 1996, 2002, p. 300). Isso já nos

\footnotetext{
${ }^{3}$ É preciso dizer, ainda, que nossa idéia de produção de medicamentos exclui de nossas preocupações a situação das farmácias de manipulação. Embora tais produções incluam certa rotinização de trabalho, suas integrações espaciais diferem substancialmente daquelas realizadas por laboratórios farmacêuticos e por distribuidores de medicamentos.
} 
remete à necessidade de um enfoque histórico, pois não estamos falando de qualquer produção de medicamentos, mas da produção de medicamentos que se realiza com importantes conteúdos técnicos e científicos, dentro da lógica mercantil do modo de produção capitalista. Mais do que isso, estamos interessados na produção farmacêutica tal como se desenrola no período contemporâneo, em que, após a consolidação dos processos de urbanização do território e da sociedade, a norma se vai impondo como a variável espacial mais decisiva.

Carlos Augusto Gadelha inclui na indústria farmacêutica três atividades: produção de medicamentos, ou categorias terapêuticas; produção de soros e vacinas, ou categorias profiláticas; e produção de reagentes para diagnósticos. (Gadelha, 1990) Com efeito, essa definição é totalmente plausível. Em nosso trabalho, porém, estudamos apenas a primeira atividade, pois as outras duas estão sujeitas a outras lógicas socioespaciais, sobretudo no que toca às tecnologias, ao consumo e à propaganda. Desse modo, vamos considerar, da assim chamada indústria farmacêutica, apenas o que Gadelha diz ser "o núcleo central", formado pela produção de medicamentos e princípios ativos ${ }^{4}$, produções essas que "possuem uma dinâmica estreitamente inter-relacionada" (Gadelha, 1990, p. 181).

Mas, além disso, interessar-nos-ão também as atividades de distribuição de medicamentos, uma vez que as empresas distribuidoras ficam, igualmente, bastante amarradas às lógicas econômicas dos laboratórios farmacêuticos. Mais do que isso, as táticas dos pequenos laboratórios são, muita vez, diretamente condicionadas pela presença de pequenos distribuidores locais.

Sempre que for necessário, tocaremos também, ainda que de modo mais superficial, na lógica de outras atividades cuja dinâmica atinge a produção de medicamentos. Por vezes, tal procedimento vai obrigar a desvios mais ou menos prolongados, mas, se o fazemos, é por acreditar que, dessa forma, melhor se pode apreender os fenômenos, e sobretudo os novos fenômenos, a que está submetida a produção de medicamentos. No mais, cabe assimilar as palavras de John Kenneth Galbraith (1967, 1982, p. 17): "Os limites de um assunto não são convencionais e artificiais; ninguém deve empregá-los para excluir o que é importante".

\section{O espaço dividido}

A formação socioespacial brasileira possui uma configuração totalmente particular. Apesar disso, recorre-se, por vezes, a idéias e teorias estrangeiras, para conformar interpretações que restam, assim, artificiais e limitadas. Embora numa circunstância bem

\footnotetext{
${ }^{4}$ Os princípios ativos são, nos medicamentos, aquelas substâncias responsáveis pela ação terapêutica.
} 
diferente, poderíamos repetir aqui esta passagem de Roberto Schwarz:. "Neste contexto, portanto, as ideologias não descrevem sequer falsamente a realidade, e não gravitam segundo uma lei que lhes seja própria [...]" (Schwarz, 1992, p. 17). Após decorridos vários séculos, nossas idéias permanecem, muita vez, fora do lugar, impedindo, ao mesmo tempo, explicações teóricas mais consistentes e projetos políticos genuinamente nacionais.

Na década de 1970, Milton Santos, esforçando-se por combater essas distorções analíticas, entrementes baseadas na aplicação da análise regional, aliás convertida a política espacial oficial do país, foi em busca dos aspectos particulares às formações socioespaciais subdesenvolvidas. A teoria dos dois circuitos da economia urbana surge nesse contexto, e se apresenta como a chave de entendimento dessa peculiaridade. Milton Santos identifica assim duas características básicas, definidoras das formações socioespaciais subdesenvolvidas. Primeiramente, no plano internacional, são espaços derivados, ou seja, espaços cuja constituição depende de processos e interesses gestados em países centrais do capitalismo. Segundamente, no plano nacional, são divididos em duas zonas de influência: os dois circuitos da economia urbana (Santos, 1979, 2004, p.22) 5 .

Para bem situar nosso tema de estudo, é preciso deixar claro, desde já, que operamos com a noção de espaço geográfico tal como definido por Milton Santos: o espaço é o conjunto indissociável de sistemas de objetos e sistemas de ações (Santos, 1991; Santos, 1996, 2004, p. 63).

Assim, não nos inquieta apenas a materialidade, muito menos os grupos sociais vistos em si próprios. O espaço, para nós, forma-se a partir da associação dessas duas realidades, material e social, pois, conforme disse Wittgenstein (1921, 1994, pp. 244-247): "O mundo e a vida são um só".

Assim pensado, o espaço constitui uma totalidade. Mas esta não pode ser bem apreendida se não se faz atenção a suas divisões, suas hierarquizações internas. Pois que, embora submetidos aos processos gerais dessa totalidade espacial, os diferentes lugares e agentes, presentes no espaço, vivem cada fenômeno, cada modernização, cada tendência, de uma forma específica. Segundo Yves Lacoste (1973, p. 258), existe uma "espacialidade diferencial": as distinções sociais implicam diferentes formas de apreensão do espaço e de ação no espaço.

As base precípua dessas divisões espaciais é o fato de ele ser regido, há longos séculos, por lógicas mercantis capitalistas que, muito embora renovadas a cada período histórico, não cessam de segregar e diferenciar os agentes, sobretudo nas concentrações urbanas, em que as variáveis modernas aparecem de maneira mais densa. Assim,

\footnotetext{
5 “Quando nós próprios propusemos a noção de um duplo circuito de economia nos países subdesenvolvidos, a isso fomos levados pela nossa incapacidade de chegar a uma interpretação mais dinâmica do espaço geográfico a partir das categorias econômicas oficiais” (Santos, 2002g p. 131).
} 
emergem nas cidades, não apenas grupos de agentes específicos, mas também atividades e relações econômicas específicas, expressado variadas lógicas e tendências. "Dentro de cada cidade, o princípio de unidade é dado, ao mesmo tempo, pelo mercado e pelo território, responsáveis pela unificação dos diversos segmentos característicos da vida urbana. Mercado urbano e território urbano são noções inseparáveis e realidades interdependentes, havendo, porém, submercados e subcircuitos espaciais da produção específicos, cada qual com a sua racionalidade" (Santos, 1996, 2002, p. 309).

Quanto mais complexas e mais densas ficam as cidades, tanto mais díspares são as situações, os agentes e os trabalhos que elas atraem. Não demora, as formas geográficas ali instaladas se diversificam, podendo acolher as atividades econômicas mantidas por vários grupos sociais. Assim, as concentrações urbanas, ao mesmo tempo em que cingem a racionalidade hegemônica, passam a permitir a emersão de outras racionalidades, imprevisíveis, marginais. Essa pletora de situações pode aparecer, nelas, em função de sua natureza tipicamente relacional. Vidal de La Blache traça um esquema do aparecimento das primeiras cidades. Aí, vemos como a cidade possui, desde sua gênese, uma vocação relacional, comunicacional, circulatória, comercial (Vidal de La Blache, 1922, pp. 33-41). "É um órgão político, um nó de relações [...]" (idem, p. 73).

As atividades urbanas, moldadas ao talhe da lógica do capitalismo, sofrem divisões, o que se expressa de duas maneiras principais.

Primeiro, a produção divide-se. As técnicas produtivas são seletivas, na medida em que elas, em suas formas mais aprimoradas, concentram-se nas mãos de poucos agentes e em poucas regiões. Da mesma forma, a ciência e a informação, duas variáveis decisivas nas atividades produtivas contemporâneas. Quanto mais se espraia a ideologia da competição livre e igualitária, tanto mais ficam rígidas as variáveis que regem a produção, o que diferencia e hierarquiza os agentes. Segundo Milton Santos, há, entre as produções mais modernas e as mais arcaicas, diferenças técnicas e normativas (Santos, 1979, 2004, p. 43). Em nosso trabalho, enfatizamos, sobretudo, as segundas, pois assim nos pareceu pertinente em face dos novos processos que definem a atual configuração do território.

Em segundo lugar, o consumo divide-se. As diferenças de renda, que nos países periféricos atingem graus rebarbativos, fazem com que as pessoas não possam ter acesso aos mesmos produtos. Neste ponto, pouco importa saber se contam mais as diferenças qualitativas ou as quantitativas, pois que ambas as duas realizam-se ao mesmo tempo. É Georg Simmel que nos diz que as diferenças entre os dinheiros possuídos pelos indivíduos são diferenças quantitativas que desencadeiam diferenças qualitativas (Simmel, 1900, 1997, p. 440). Mas, para captar essas desigualdades de maneira mais precisa, pode-se recorrer a Milton Santos, que vai dizer que elas se manifestam em termos de hierarquia. "Ao nível 
regional, as disparidades de rendas ocasionam uma seletividade das atividades, com tendências a uma hierarquização" (Santos, 1978, pp. 106-107).

Ora, esses diferentes potenciais de consumo, conjugados com a distribuição diferencial das técnicas produtivas, é que vai permitir a emersão, nas cidades, de dois circuitos econômicos: o circuito superior e o circuito inferior". "Desse modo institui-se um espaço urbano segmentado porque coexistem dois níveis de renda, dois consumos, dois tipos de comércio e de serviços. Uma forma urbana unitária, dois conteúdos urbanos" (Silveira, 1996, 1999, p. 396).

As produções mais modernizadas, utilizando técnicas, insumos, localizações e conhecimentos mais complexos, são mais custosas e resultam, muita vez, em produtos mais caros, com preços dificilmente suportáveis pelos pobres. Esse fenômeno, quando se manifesta para a atividade farmacêutica, conduz aos consabidos problemas de acesso aos medicamentos. As populações dos países mais pobres, cerca de $80 \%$ da população mundial, respondem por $20 \%$ das vendas anuais de medicamentos (Médicos sem Fronteiras, 2001, p. 8). No Brasil, o fenômeno se reproduz. Em 2003, 53\% da população não tinha acesso a medicamentos ou dispunham de acesso restrito (Ministério da Saúde apud Gazeta Mercantil, 30-07-03, p. A5). "Estima-se que 48\% dos produtos [farmacêuticos] são consumidos por $15 \%$ da população que tem renda superior a dez salários mínimos. Já as classes mais pobres, que ganham até quatro salários mínimos, compram apenas 16\% dos remédios produzidos no País" (Gazeta Mercantil, 17-03-04, p. A11) ${ }^{7}$.

Fernando Henrique Cardoso diz que, no Brasil, a passagem de um modelo agrícola exportador para um modelo baseado na indústria não se fez de maneira radical; um dos resultados é que os industriais, no que respeita aos seus interesses, seus móveis, sua ideologia, suas relações e seu posicionamento em face da modernização econômica, não chegam a formar um grupo coeso (Cardoso, 1972, pp. 169-198). Peter Evans, inspirando-se nessa análise de Fernando Henrique, diz que "[...] o capital nacional não pode ser avaliado como uma categoria homogênea" (Evans, 1979, 1980, p. 98).

Celso Furtado sustenta, por sua vez, que, num país como o Brasil, em que a modernização não levou a uma equalização dos padrões de consumo, surgiram dois setores industriais, o primeiro em expansão e voltado para a minoria de renda elevada, e o segundo em lenta expansão e voltado para a maioria de renda baixa (Furtado, 1974, pp. 98-99) . $^{8}$

\footnotetext{
${ }^{6}$ As diferenças de renda, entre as pessoas que convivem nas mesmas cidades e têm as mesmas necessidades é a base do aparecimento dos dois circuitos (Santos, 1979, 2004, pp. 35-38).

${ }^{7}$ Em 2004, a Febrafarma, Federação Brasileira da Indústria Farmacêutica, estimou que 39\% do consumo de medicamentos no Brasil era realizado pelos domićlios com renda acima de 10 salários mínimos, que representavam 19\% dos domicílios brasileiros (Febrafarma apud Capanema e Palmeira Filho, 2004, p. 31).

8 “[...] os dois setores industriais somente em grau muito pequeno competem pelos mesmos mercados e podem manter padrões diferentes de organização e mercadologiłą (marketing)” (Furtado, 1974, pp. 98-99).
} 
Milton Santos apreende esse processo de maneira mais sistemática, com uma visão geográfica, sobretudo na obra O espaço dividido $(1979,2004)$. Diz, assim, que se formam dois circuitos econômicos urbanos, cada um deles acolhendo práticas econômicas particulares. Eles podem ser pensados, então, como "duas áreas de mercado" (Santos, 1979, 2004, p. 353) Mas, não há pensar em dualismo. Ambos os circuitos estão ligados ao processo de modernização, do qual resultam, mas um de maneira dinâmica e outro de maneira derivada e subalterna. Essas são as duas únicas formas de inserção na modernização: há o pólo de geração e controle, e o pólo de recepção e adaptação. Por isso, só há dois circuitos econômicos: o superior e o inferior.

O circuito superior compreende as atividades capital-intensivas, realizadas em grandes escalas geométricas, apresentando um planejamento sofisticado, utilizando informações elaboradas, técnicas modernas. O circuito inferior compreende as atividades trabalho-intensivas, realizadas, freqüentemente, em pequenos empreendimentos e nas escalas geométricas pequenas, sem planejamentos sofisticados, denotando uma escassez de informações estratégicas, empregando técnicas arcaicas ou tradicionais.

Logo se vê que o circuito inferior tem sua existência baseada na massa de população pobre que se reúne nas cidades. "Os pobres não têm acesso aos produtos modernos e os mais pobres dentre eles só podem proporcionar-se consumos correntes por intermédio de um sistema de distribuição particular freqüentemente completado por um aparelho de produção igualmente específico e que é uma resposta às condições de pobreza da grande massa da população" (Santos, 1979, 2004, p. 196).

A divisão do espaço, nesses dois circuitos econômicos, vai-se expressar, de modo mais concreto, no aparecimento de várias empresas, com diversos graus de capitalização, bem como diversos conteúdos técnicos, científicos, informacionais. "Simplificando, dir-se-á que certas atividades, ou empresas, ocupam o território a partir de lógicas globais, outras operam segundo lógicas que não ultrapassam as fronteiras nacionais, mas incluem vastas áreas do território, enquanto ainda outras, como as atividades do circuito inferior da economia, são limitadas a áreas menores, freqüentemente intra-urbanas" (Santos e Silveira, 2001, 2004, p. 290).

A primeira contribuição, que nos fornece a teoria dos dois circuitos da economia urbana, é que, por meio dela, pode-se abandonar a idéia de que a cidade se produz e desenvolve segundo ritmos e lógicas homogêneas, que afetariam a todos os agentes indistintamente ${ }^{9}$.

\footnotetext{
9 “A idéia central desse estudo é que a cidade dos países subdesenvolvidos não funciona como um aparelho maciço ou, dito de outro modo, como um bloco. Ao contrário, no interior do sistema urbano, em si mesmo dependente de outros sistemas de nível superior, pode-se reconhecer a existência de dois subsistemas, dois circuitos econômicos” (Santos, 1979, 2004, pp. 38-39). 12
} 
Portanto, ao se referir a tal ou tal produção, temos que atentar para as diversas naturezas dos agentes, pois "[...] a organização do espaço não é indiferente à 'qualidade' do capital instalado nos diferentes pontos do espaço" (Santos, 1982, 2004, p. 23).

Joseph Schumpeter, cujas idéias obtêm, por vezes, uma recepção calorosa, dizia que, para bem compreender a natureza dos negócios sob o capitalismo, devemos observar o comportamento das empresas mais inovadoras e dinâmicas (Schumpeter, 1942, 1954, p. 171). Nos estudos sobre a produção de medicamentos, esse conselho tem-se seguido à risca. Os analistas não desprezam a existência dos pequenos laboratórios farmacêuticos, mas não Ihes dedicam senão linhas reticentes e exíguas. Essa parcimônia passa, distorcida, ao senso comum, e é quando as pessoas começam a associar a produção dos pequenos laboratórios com medicamentos de baixa qualidade, ou mesmo ineficazes. No mais, deve-se considerar que, em razão das metodologias de pesquisa consagradas, mas também por causa das estatísticas disponíveis, torna-se mais cômodo falar sobre as grandes empresas $^{10}$.

A danação das interpretações que, hoje, reproduzem métodos clássicos, é justamente o fato de que procedem, muita vez, a descrições que, mesmo não sendo falsas, são renitentemente parciais. O que resta constantemente sem explicação é justamente o circuito econômico marginal ${ }^{11}$.

Não nos podemos deixar enlear se há discursos que nos forçam a considerar tão-somente aquilo que seja rápido, moderno, sofisticado. "Quanto a nós, preferimos partir da noção de espaço banal, espaço de todas as pessoas, de todas as empresas e de todas as instituições, capaz de ser descrito como um sistema de objetos animado por um sistema de ações" (Santos, 1996, 2004, p. 283).

Os agentes hegemônicos têm cada vez mais aprimoradas suas condições de hegemonia. Isso acontece, também, porque seu discurso é por vezes perfilhado em análises disciplinares pouco precavidas. "O resultado é que a maior parte dos estudos não são feitos sobre a cidade inteira, mas sim sobre uma parte da cidade, impedindo, por isso mesmo, a formulação de uma autêntica teoria da urbanização" (Santos, 1979, 2004, p. 22). O resultado é que nos afastamos, assim, das tarefas recomendadas por Armando Corrêa da Silva: desenvolver e consolidar a geografia teórica, bem como estudar o espaço relativo ou relacional (Silva, A. 1986, p. 38-39).

\footnotetext{
10 “É muito mais fácil analisar o grande capital, naturalmente, do que o pequeno” (Evans, 1979, 1980, p. 98).

${ }^{11}$ Segundo Milton Santos, considera-se, muita vez, que só a instalação de indústrias de ponta pode incitar o crescimento econômico; com isso, o circuito inferior, "resultado da modernização tecnológica”, é desprezado, ou considerado como entrave ao crescimento (Santos, 1979, 2003, p. 173).
} 


\section{O circuito superior marginal da economia urbana}

Se apenas dois circuitos econômicos existem, o que vem a ser o circuito superior marginal?

Dentro do circuito superior, acontece uma subdivisão. De um lado, o nível do superior propriamente dito, reunindo, de maneira mais perfeita, as características citadas. De outro lado, um nível híbrido, o superior marginal ${ }^{12}$.

Pierre Bourdieu disse que as posições sociais intermédias caracterizam-se por oscilarem entre os pólos extremos, e por reunirem características de um e de outro pólo (Bourdieu, 1989, p. 136). Essa idéia poderia servir de ponto de partida. Aliás, em trabalho recente dizíamos que o circuito superior marginal caracteriza-se pela mistura de características do circuito superior e inferior (Bicudo, 2003). Ao longo do trabalho atual, esforçamo-nos por demonstrar que se trata, em verdade, da coexistência de duas racionalidades espaciais: a racionalidade instrumental, típica dos agentes hegemônicos, e a racionalidade comunicacional, típica dos agentes marginais.

Em grande medida, o caráter híbrido do circuito superior marginal se deve às renovações normativas que, no período contemporâneo, atravessam o território. Assim, o estudo desse subcircuito pode ajudar-nos a captar essa "história simultânea da materialidade e da organização" de que nos fala María Laura Silveira (1996, 1999, p. 125).

Assim pensamos poder situar nosso tema de estudo: o circuito superior marginal, que Milton Santos chama, certas vezes, de "circuito moderno marginal" (Santos, 1979, 2004, p. 318). Quais são os processos que determinam seu aparecimento e sua manutenção? De que modo esse circuito contribui para a formação dos sistemas de objetos e dos sistemas de ações que caracterizam o espaço geográfico? De que modo ele interfere no rearranjo dos sistemas de cidades? As respostas a essas perguntas só podem ser obtidas se, além do próprio superior marginal, busquemos entender suas integrações com o circuito inferior e com o superior propriamente dito.

Desde já, devem-se expurgar duas confusões. Primeiro, a diferenciação entre o superior e o inferior concerne a lógicas de uso do território, e não a aspectos de formalidade e informalidade. Uma empresa pode cumprir todos os requisitos de formalidade e, mesmo assim, reforçar, por suas ações, o circuito inferior. Segundo, o circuito superior marginal não pode ser associado ao que se chama de pequena e média empresa ${ }^{13}$. Grandes empresas,

\footnotetext{
12 "A atividade de fabricação do circuito superior divide-se em duas formas de organização. Uma é o circuito superior propriamente dito, a outra é o circuito superior marginal, constituído de formas de produção menos modernas do ponto de vista tecnológico e organizacional” (Santos, 1979, 2004, p. 103).

${ }^{13}$ O mesmo vale para o circuito inferior. Disse Milton Santos (Santos, 1979, 2004, p. 201-202) que o circuito inferior não se define pelo tamanho do empreendimento, pois empresas de reduzido porte podem ter suas ações integradas ao circuito superior. 
empregando muitas pessoas e utilizando máquinas modernas, podem expressar lógicas de produção mais características do superior marginal.

A atividade que nos vai preocupar é a produção de medicamentos. Muita vez, sabemos identificar e reconhecer os nomes de grandes laboratórios multinacionais, e, certas vezes, fazemo-lo com tanta mestria, que ficamos incapazes de supor a existência de pequenas empresas produtoras. Mas, conforme já disse Carlos Augusto Gadelha, atuam, no interior da indústria farmacêutica, empresas multinacionais líderes, mas também um variado grupo de "empresas marginais" (Gadelha, 1990, pp. 96-97 e 101).

Se olhamos os grandes agregados estatísticos, essas pequenas empresas são praticamente desprezíveis. Em 1999, por exemplo, cerca de 230 empresas farmacêuticas eram responsáveis por $6 \%$ das vendas do mercado, o que significava uma participação média de 0,03\% por empresa (E. Pinheiro apud Pereira, 2002, p. 13). Mas, como nos esforçaremos por demonstrar, essas pequenas empresas, mas sobretudo a associação de suas ações, podem pesar decisivamente para a definição de contextos locais e urbanos. Mais do que isso, suas produções podem constituir propostas alternativas para novas políticas farmacêuticas nacionais.

Reiteradas vezes, diz-se que, para os laboratórios multinacionais, o mercado brasileiro não se mostra muito interessante. E uma congérie de números e estatísticas se apresentam para que fique provada a insignificância desse mercado consumidor. Ocorre porém que, segundo veremos com mais detença, o mercado farmacêutico, para ser bem observado, requer a análise dos submercados que ele compreende. Quando realizamos essa análise mais fina, vemos que, por vezes, o Brasil aparece como um dos pontos mais estratégicos para as empresas multinacionais. Por um lado, o país destaca-se como mercado consumidor regional ${ }^{14}$. Por outro lado, o país destaca-se em certas classes de medicamentos. O Brasil é o segundo mercado mundial em medicamentos para disfunção erétil (Gazeta Mercantil, 10/11/12-10-03, p. A14). É o terceiro mercado mundial de contraceptivos, atrás apenas dos Estados Unidos e da Alemanha. (Gazeta Mercantil, 21-1003, p. A11) Não à-toa, as grandes corporações voltam maciços volumes de investimento para o país. Em 2004, o Brasil foi o sexto país em matéria de investimento das multinacionais farmacêuticas (Programa Projeto Brasil, TV Cultura, 11-10-04) ${ }^{15}$.

\footnotetext{
14 “O Brasil é considerado o décimo maior mercado em faturamento no setor de medicamentos e o primeiro maior mercado da América Latina, Caribe e África” (GT\&P Consultoria apud Gazeta Mercantil, 17-11-03, p. A3).

${ }^{15}$ Além disso, algumas classes de medicamentos passam, no Brasil, por notáveis expansões, como a classe dos medicamentos cardiovasculares, que, de 2003 para 2004, cresceu 28\% em vendas; e também a classe dos medicamentos para diabetes, que no mesmo lapso de tempo cresceu 30\% em vendas (Gazeta Mercantil, 21-09-05).
} 
Para enfrentar as questões levantadas, realizamos uma pesquisa de campo bastante longa, visitando pequenos laboratórios e pequenos distribuidores de medicamentos em diversas cidades brasileiras. Em verdade, essa pesquisa têm início por ocasião de uma pesquisa de iniciação científica, em 2001, e vai até 2005, já no mestrado. Seguimos um roteiro comum de entrevista, mas, em cada uma das empresas, exploramos em mais detalhes um certo aspecto. O desafio, aqui, foi perceber qual o problema, o assunto, que poderíamos explorar mais profundamente, de acordo com a situação específica da empresa. Essa tática nos pareceu decisiva perante o fato de que, em vista do escopo do trabalho, a pesquisa de campo não poderia ser exaustiva, sob pena de se arrastar por longos anos. Além disso, ela nos permite transcender as preocupações técnicas e captar, também, os aspectos políticos experimentados pelos laboratórios. Essas informações, apresentamo-las na terceira parte, nos capítulos VII, VIII e IX. Elas não correspondem, todas, ao mesmo ano. Por isso, pedimos se consulte o anexo 1, para que se saiba a qual momento se referem as informações de cada firma.

Não podemos deixar de agradecer imensamente aos representantes das empresas entrevistados. De maneira generosa, eles nos ajudaram profundamente na explicação dos problemas teóricos levantados.

No transcurso dessa pesquisa de campo, algumas pessoas tiveram, por vezes mesmo sem o saber, participação decisiva. Não posso deixar de agradecer, quanto a isso, a Rodrigo de Oliveira, um amigo para todas as cidades.

Também devo agradecer à Gabriela Farias Asmus a sua hospitalidade.

E também aos companheiros de Manaus: Tatiana Barbosa, Isaque dos Santos Sousa, e Edivaldo Bento Barbosa, também chamado Poti. Lembranças aos companheiros da Casa do Estudante de Manaus.

As informações da pesquisa de campo são adicionadas aos dados quantitativos de diversas fontes. Esses dados, sobretudo para as séries históricas da primeira parte, estão organizados segundo as unidades da federação. Mas, sempre que foi possível, apresentamo-los por cidades, pois, como veremos, esta é, muita vez, uma escala muito mais significativa para as pequenas firmas farmacêuticas.

$\mathrm{Na}$ coleta, organização e decifração desses dados quantitativos, contei com a colaboração estratégica de Edilson Bicudo, ele que, além de companheiro e parceiro, é meu irmão. Aliás, a ele devo não só esse apoio técnico, mas também um apoio filosófico.

Já dissemos que, por vezes, tivemos que verificar as integrações da produção de medicamentos com outras atividades urbanas: propaganda, contabilidade, consultorias, 
serviços de informática. Essa necessidade de, por assim dizer, extravasar as fronteiras da produção farmacêutica propriamente dita, faz com que tenhamos que recusar à clássica abordagem do setor econômico. Muita vez, os estudos setoriais têm por diretiva principal certas constatações empíricas imediatas, as quais vão induzindo a recortes clinicamente feitos. No limite, já não se pode conceber que os laboratórios farmacêuticos sejam estudados ao lado de outras atividades que não Ihes sejam perfeitamente vizinhas ${ }^{16}$.

Mas, ao mesmo tempo em que peca por essas especializações extremas, a análise setorial falha ao misturar as situações de empresas de diversas naturezas. Vale, com efeito, indagar da contribuição que nos pode fornecer a idéia geral de indústria farmacêutica, na medida em que, por meio dela, ficam misturadas as existências das grandes corporações multinacionais e das pequenas empresas familiares de escala de ação local.

Alternativamente, propomos ir em busca das outras atividades econômicas, sempre que tal possa contribuir para uma compreensão mais ampla da atividade que estudamos mais especificamente.

O desafio é explicar as diferenças entre as empresas, não em função de investimentos e fatores de produção; pois, atentando apenas para as diferenças quantitativas, poderíamos ser conduzidos, sub-repticiamente, a concluir pela desimportância das pequenas empresas. Pretendemos, antes, explicar as diferenças em função do uso do território; pois isso nos leva a observar de que maneira as diversas ações podem-se integrar nessa totalidade que é o território brasileiro.

Apresentamos nossas interpretações em quatro partes.

A primeira parte se dedica a uma revisão histórica da produção de medicamentos em território brasileiro. Realizamos uma periodização, de modo a saber identificar, em cada momento histórico, a variável capaz de conduzir as sistematizações espaciais. Assim, vamos falar, no capítulo I, da importância da técnica para a produção farmacêutica. No capítulo II, apresentamos a ciência como fator espacial revolucionário, promovendo uma hierarquização entre os agentes. O capítulo III vai tratar da informação e de seu uso diferencial pelas empresas farmacêuticas.

Na segunda parte, começamos a abordar o período contemporâneo, enfatizando as novas lógicas perfilhadas pelos agentes hegemônicos. O capítulo IV vem trazer uma reflexão sobre aquilo que chamamos de colonização da copresença, possibilitada por dois fenômenos principais: as revoluções produtivas realizadas pela biotecnologia, e a medicalização da sociedade e do território. No capítulo $\mathrm{V}$, começamos a analisar o papel das normas para as novas sistematizações espaciais hegemônicas. Nesse momento, vamos

\footnotetext{
16 “Tais estudos em profundidade, limitados por sua própria natureza especializada, podem originar inclusive um empobrecimento do saber científico, porque, em si mesmo, o conhecimento fragmentado não enriquece a ciência” (Anuchin, 1975, p. 73). 
interpretar a produção dos medicamentos para tratamento da Aids, a situação dos laboratórios farmacêuticos estatais, as renovações normativas realizadas pela agência sanitária brasileira, e a produção de medicamentos genéricos. O capítulo VI é dedicado às polarizações espaciais realizadas pelas ações hegemônicas, que se expressam na concentração do capital farmacêutico e na constituição de pontos luminosos do território.

É na terceira parte que procedemos, com mais detalhes, a uma interpretação do circuito superior marginal. O capítulo VII quer, sobretudo, captar os traços específicos do trabalho e da divisão do trabalho que se realizam nesse subcircuito. No capítulo VIII, tentamos analisar os dois movimentos a que estão submetidos os pequenos laboratórios farmacêuticos: por um lado, as renovações normativas impõem-lhes novos enquadramentos, o que reduz suas escalas de possibilidade; por outro lado, essas próprias normas renovadas alargam os círculos de cooperação, o que define consumos técnicos, científicos e informacionais mais ricos. O capítulo IX aprofunda a explicação do circuito superior marginal, mas ora por meio da noções de temporalidade e escala temporal.

A última parte, nossas últimas palavras, recupera algumas idéias e apresenta outras, suscitadas ao longo de nossa pesquisa.

Assim organizada, nossa dissertação pretende ajudar a dirimir essas concepções homogeneizadoras que assolam, tantas vezes, as análises disciplinares. O processo de globalização vai, sem dúvida, realizando a totalidade-mundo; o que não quer dizer, todavia, que as particularidades sejam por fim naufragadas. "A metamorfose do real-abstrato em real-concreto, da essência em existência, da potência em ato é, conseqüentemente, a metamorfose da unidade em multiplicidade" (Santos, 1996, 2002, p. 120).

Isso não indica, porém, que devamos realizar uma descrição exaustiva. Ficaremos satisfeitos se, com nossa pesquisa, tenhamos podido apontar algumas tendências e processos que, no período contemporâneo, marcam a formação socioespacial. Pois, como diz Kosik, compreender a totalidade não quer dizer: olhar todos os fatos; quer dizer: compreender a estruturação conflituosa desse sistema que é a totalidade (Kosik, 1989, pp. 7-54).

Ao longo dessas aproximações, fomos em busca, exatamente, dessas lógicas de estruturação do espaço, ou mais precisamente, das racionalidades espaciais. Assim como todos os processos induzidos por essa máquina desumana do capitalismo, a própria razão fica bifurcada, o que indica a presença de fenômenos cruéis, assombrosos, mas aponta, ao mesmo tempo, para a possibilidade de sistematizações espaciais mais equilibradas, espontâneas e livres.

Globais, os lugares ganham um quinhão (maior ou menor) da "racionalidade" do "mundo". Mas esta se propaga de modo heterogêneo, isto é, deixando coexistirem outras 
racionalidades, isto é, contra-racionalidades, a que, equivocadamente e do ponto de vista da racionalidade dominante, se chamam "irracionalidades". Mas a conformidade com a Razão Hegemônica é limitada, enquanto a produção plural de "irracionalidades" é ilimitada. (Santos, 2000, p. 115)

Enfim, é disso que vamos falar.

Se toda pesquisa constitui um percurso, os passos derradeiros serão, muita vez, os mais seguros. Em minha situação, sinto que pude evoluir com mais firmeza a partir do exame de qualificação, em que nossas questões teóricas e nossas opções metodológicas foram profundamente enriquecidas. Agradeço às professoras Adriana Bernardes e Mónica Arroyo, que, participando da banca de qualificação, permitiram esse avanço fundamental.

Não posso esquecer de agradecer ao professor Lúcio Kowarick, sob cuja direção trabalhei durante um ano. Um período cheio de aprendizados e avanços.

Aos amigos do Laboplan, saudações. Tenho que dizer que, de maneira mais ou menos intensa, todas essas pessoas deram contribuições valiosas para este trabalho. Foi decisiva a presença dessas pessoas, cujos nomes nem preciso mencionar, pois que se sentirão, certamente, concernidas. Apenas gostaria de lembrar, um pouco simbolicamente, a minha amiga Ana Elisa Pereira, cujos trabalhos vêm sustentando, há longos e profícuos anos, a existência de nosso laboratório.

Por fim, expresso o contentamento por este trabalho conjunto que já vem de alguns anos, tendo-se convertido em amizade. À Laura, minha eterna orientadora, a expressão do meu orgulho.

Isso posto, só me resta repetir as palavras de João Ubaldo Ribeiro, que, em tempos inspirados, escreveu: "Viva o povo brasileiro. Viva nós".

As atividades realizadas ao longo de nosso mestrado seriam impossíveis sem o apoio da Fapesp, que por meio de uma bolsa, viabilizou, de 2003 a 2005, o avanço de nossos trabalhos. 
Primeira parte

\section{O circuito superior marginal e a formação socioespacial brasileira}

Os vidros enfileiravam-se em ordem, à esquerda e à direita, com os ingredientes prontos para serem transformados em remédios ou essências.

O ar tinha um perfume inextricável.

Ana Miranda

Boca do Inferno (1998) 
A periodização como método

A compreensão dos fenômenos espaciais inclui a verificação de problemas e fenômenos referentes ao tempo. Assim como as unificações espaciais levam à difusão de um tempo hegemônico, assim também as divisões do espaço produzem temporalidades a hierarquizar os agentes. Conforme Anuchin (1975, p. 85), espaço e tempo são os dois "aspectos da existência da matéria".

À constituição de sistemas espaciais corresponde à formação de sistemas temporais, sendo porém necessário precisar que, nos dois casos, o processo nunca se finaliza, pois que o sistema anterior constrói as bases em que vão assentar as futuras sistematizações. "[...] uma nova totalidade existe, ao mesmo tempo passiva e unificada, mas sem cessar de se remanejar, seja sob a ação direta do homem, seja em virtude de suas próprias leis de exterioridade" (Sartre, 1960b, p. 172) ${ }^{1}$.

A lógica do capitalismo reforça tais dinamismos, pois que as inovações, as deslocalizações, os câmbios nem sempre suaves, não cessam de se produzir. Schumpeter ressaltou esse aspecto em suas análises, destacando a capacidade, que tem o sistema capitalista, para realizar constantes invenções e renovações do equipamento destinado à produção (Schumpeter, 1942, 1954, p. 211-213). Disse também que, muito embora trespassado por freqüentes crises, o sistema capitalista pode resistir a elas, justamente por constituir um quadro de constantes mudanças econômicas e sociais (idem, p. 202).

Considerando que as diferentes fases históricas apresentam-nos específicas sistematizações espaciais, ou seja, organizações particulares dos objetos e das ações, podemos passar, então, à idéia de período histórico. Este seria caracterizado por um lapso de tempo social em que o território, pelo arranjo de seus elementos componentes, possui uma configuração bem definida. Falamos, assim, de verdadeiros sistemas temporais (Santos, 2002, p. 254), que podem ser pensados, ainda, como sistemas de eventos (Santos e Silveira, 2001, 2004, p. 23), ou seja, como um conjunto de fenômenos que, muito embora particulares, derivam da mesma lógica de totalização espacial.

Os períodos históricos

Segundo Milton Santos, deixamos de atentar, muita vez, para a presença das temporalidades, e por isso o modo de produção converte-se em nossa ferramenta exclusiva para pensar o tempo (Santos, 1978, 2005, p. 64). Acontece que não é suficiente falar em

\footnotetext{
1 "A cada momento a totalidade existe como uma realidade concreta e está ao mesmo tempo em processo de transformação. A evolução jamais termina. O fato acabado é pura ilusão” (Santos, 1979, 2005a, p. 45).
} 
capitalismo. A cada momento, as variáveis do capitalismo se arranjam de um modo específico, o que corresponde, também, a sistemas espaciais plenos de particularidades que devem ser captadas e interpretadas pela geografia. Certamente que a persistência das relações capitalistas precisam figurar nas explicações. "Todavia, a necessidade de considerar as frações ou momentos do modo de produção introduz a necessidade de um refinamento, para podermos tomar em consideração certos fatos suficientemente importantes para mudar o curso da história sem alterar a coerência estrutural que caracteriza e define um modo de produção" (Santos, 1978, 2005, p. 64).

Daí, propormos falar em períodos históricos. Essa proposta conduz em seu bojo a idéia de formação, pois, conforme disse Hartshorne, "[...] todo e qualquer período posterior inclui, em sua herança social, as conseqüências de qualquer outro período anterior [...]" (Hartshorne, 1978, p. 168). Assim, o espaço real é o espaço trabalhado, usado e modificado pelas ações. "Em suma, os fatos gerais, na história das sociedades humanas, jamais se produzem de uma só vez [...] Um desenvolvimento embrionário precede a plena maturação do ser. É preciso olhar um pouco mais alto na cadeia dos fatos" (Vidal de La Blache, 1922, p. 212) ${ }^{2}$.

Em cada período, uma variável, ou um conjunto delas, tem a precedência, determinando as lógicas de organização do sistema total. Daí ser importante captar aquilo que Milton Santos chamou de os "fatores dinâmicos próprios a cada período" (Santos, 2002, p. 255-256). "A cada período podemos, assim, perguntar-nos o que é o novo no espaço e como se combina com o que já existia" (Santos e Silveira, 2001, 2004, p. 11).

A verificação dos períodos passados permite captar, por contraste, aquilo que é mais específico do período presente, cuja profunda particularidade pode, assim, desvendar-se. "A idéia é reconstruir um passado capaz de nos elucidar 'a engrenagem' do presente" (Grimm, 2002, p. 143) ${ }^{3}$. Por isso, é importante identificar o novo dos períodos anteriores, o que nos permite compreender o novo atual.

Uma periodização impõe-se como regra de método fundamental, pois permite distinguir pedaços coerentes de tempo nos quais um novo arranjo territorial revela uma modernização material e organizacional (Silveira, 1996, 1999, pp. 22-24).

\footnotetext{
2 “[...] uma sociedade não cria todas as peças de sua organização; ela a recebe, em parte, já pronta, das sociedades que a precederam” (Durkheim, 1968, p. 136). “[...] as fases de desagregação e colapso de uma forma social são essenciais para o aparecimento e a constituição da forma social subseqüente, tanto em termos estruturais quanto em termos dinâmicos" (Fernandes, 1974, 1981, p. 22). "Estruturas espaciais de vários tipos podem ser vistas historicamente (e muito esquematicamente) como resultados de uma sucessão na qual cada uma se sobrepõe, e se adiciona, aos efeitos das estruturas espaciais precedentes” (Massey, 1984, 1987, p. 118).

3 "A descrição explanatória de relações individuais pode exigir a análise de relações de processos que remontem consideravelmente ao passado. Entretanto, o propósito de tais mergulhos no passado não é delinear desenvolvimentos ou buscar origens, mas facilitar a compreensão do presente” (Hartshorne, 1978, p. 114).
} 
Nosso esforço consiste em definir os períodos históricos tendo por fundamento as atividades produtivas farmacêuticas, o que é possível na medida em que, no território, as atividades, embora possuindo suas dinâmicas particulares, são atravessadas pelas mesmas tendências e processos que determinam a configuração do espaço total ${ }^{4}$.

Fixar as extensões dos períodos, ressaltar estes ou aqueles aspectos históricos, selecionar as variáveis que sustentam a explicação, esses e outros procedimentos são necessários para a feitura de qualquer periodização. Neste particular, um certo nível de arbitrariedade, aliás inevitável, deve ser contrabalançado por uma coerência de análise. "Sem dúvida, toda percepção, toda observação é uma seqüência de escolhas, mas é próprio do processo científico procurar estabelecer, metodicamente, os critérios de seleção e as funções desses critérios" (Lacoste, 1973, p. 229).

Antecedendo o período contemporâneo, e fundando suas bases, identificamos três períodos históricos: o período técnico, o período científico, e o período informacional. Esquematicamente, considerando apenas um eixo temporal, eles assim poderiam ser representados.

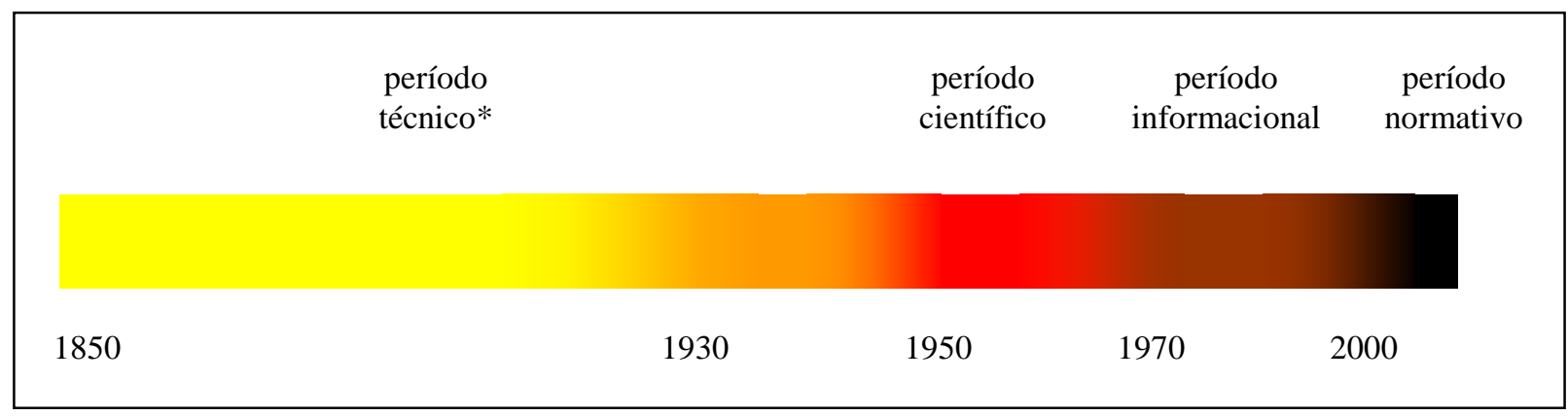

* O período técnico subdivide-se em dois subperíodos: até fins da década de 1920, vamos falar num subperíodo maquínico. Depois disso, e até o fim da segunda guerra mundial, vamos falar num subperíodo tecnológico.

\footnotetext{
4 “A análise supõe [...] que encontremos uma periodização para a história do subsistema que estamos estudando, essa história deve ter suas raízes nos períodos da história nacional, considerada em suas relações com a história mundial” (Santos, 1979, 2005a, pp. 48-49).
} 


\section{A técnica e a produção de medicamentos}

\section{A precedência da técnica}

As campanhas publicitárias de medicamentos celebrizaram-se nos anos 1930, 40 e 50, e hoje merecem, por vezes, os desvelos de nossa atenção estética ou nostálgica. Entanto, os medicamentos manufaturados são produtos mais antigos do que podem retroceder nossas tenras memórias, ou denunciar esses velhos registros publicitários. Com efeito, já em 1861 fora realizada a primeira Exposição Nacional de Produtos, na qual se apresentaram 488 produtos farmacêuticos fabricados no Brasil (G. Oliveira apud Pereira, 2002, p. 9). E em 1889, por ocasião do primeiro recenseamento, 35 empresas farmacêuticas foram identificadas (Geraldo Giovanni apud Pereira, 2002, p. 9).

Em termos de produção industrial, a segunda metade do século XIX mostrou-se particularmente auspiciosa ${ }^{5}$. Segundo as interpretações de Caio Prado Júnior, tal circunstância decorre de uma confluência de fatores favoráveis: a elevação das tarifas alfandegárias, sob pressão inglesa (p. 170; pp. 258-259); as divisas acumuladas em função das boas exportações de café (pp. 157-167); o fim do tráfico negreiro, e a conseqüente inversão dos capitais em novas atividades, entre as quais a indústria (pp. 142-154); o aparelhamento das atividades financeiras, com grande penetração estrangeira, e sobretudo inglesa (Prado Júnior, 1945, 1998, pp. 194-195).

Assim, quando se chega aos fins do século XIX, a situação industrial fazia claro contraste com os momentos anteriores. "Até o último quartel do século XIX, os estabelecimentos industriais existentes no Brasil são pouco numerosos e o seu conjunto inexpressivo" (Silva, S. 1986, p. 71).

Armem Mamigonian (1976) aponta a importância dessa fase para a industrialização nacional, destacando o papel de São Paulo e das populações de imigrantes europeus.

No Brasil como alhures, esses primeiros passos industriais definem uma transformação de natureza técnica. A pouco e pouco, a técnica vai-se estabelecendo como variável-chave, o que se verifica em dois processos. Primeiramente, a instalação de formas espaciais modernas, permitindo ganhos de produtividade, por meio da rotinização das

\footnotetext{
${ }^{5}$ Caio Prado Júnior chegou a escrever o que segue: "Nas transformações ocorridas no Brasil no curso do séc. XIX, nenhuma terá contribuído para modificar a fisionomia do país como a verdadeira revolução que se opera na distribuição de suas atividades produtivas. Tal revolução já se pode observar em seus começos na primeira metade do século; mas é na segunda que se caracteriza propriamente e se completa” (Prado Júnior, 1945, 1998, p. 157).
} 
tarefas. Segundamente, a constituição de novos modelos de organização do trabalho, seguindo uma nova racionalidade ${ }^{6}$, já atrelada, por vezes, à divisão internacional do trabalho.

Nesse final de século XIX, a produção de medicamentos caracterizava-se, em geral, pelo emprego de procedimentos rudimentares. Segundo Sérgio Queiroz e Alexis González, a produção artesanal de medicamentos só foi totalmente substituída pela produção industrial nos anos 1940 e 1950 (Queiroz e González, 2001, p. 139). Entanto, já se pode falar, para esta fase, de uma elevação da técnica à posição de variável-força, promovendo os primeiros movimentos de unificação e hierarquização dos vários agentes e empreendimentos.

Milton Santos falou num período tecnológico subdividido em duas fases. Na primeira fase, há, por parte dos países subdesenvolvidos, uma assimilação primeira da divisão internacional do trabalho. Na segunda fase, expande-se a produção e as importações, tendo início uma atividade exportadora que aos poucos se fortalece (Santos, 1979, 2004, pp. 9596). Considerando a produção de medicamentos, também se pode falar em dois subperíodos, com traços referentes ao que, nessa atividade, é peculiar. O longo período técnico, por nós identificado, abriga dois subperíodos: o maquínico e o tecnológico.

\section{O subperíodo maquínico}

Conforme acabamos de referir, as duas últimas décadas do século XIX são marcadas por um primeiro surto industrial. "Nesse [...] momento (mais ou menos da última década do século XIX à crise de 1929), a industrialização percorre todo um ciclo de expansão" (Fernandes, 1974, 1981, p. 241).

Até metade do século XIX, a produção de remédios se fazia em boticas, ou então de modo caseiro ${ }^{7}$. Depois disso, um maquinismo balbuciante começa a mudar a face do território, o que se verifica não apenas nas formas de produzir mas também nas infra-estruturas de circulação e produção de energia.

Porém, mesmo com a gênese desse maquinismo, escassos eram, na produção de medicamentos, os avanços do conhecimento científico. Dessa maneira, as distinções entre os diversos laboratórios não se deviam tanto ao conteúdo de suas produções; elas se deviam, isto sim, às suas diversas escalas produtivas, e estas, por sua vez, eram diferentemente fixadas em função das técnicas acessíveis aos diferentes produtores. Em termos de conteúdos científicos, reinava, pois, um ambiente produtivo de relativa

\footnotetext{
6 "As técnicas, em todos os seus domínios, existem como autorizações para o fazer [...] Pode-se [...] imaginar que um espaço tenderá tanto mais a se tornar um espaço racional quanto mais alto for nele o nível de artifício" (Santos, 1996, 2002, p. 296).

${ }^{7}$ Em 1836, por exemplo, havia 7 boticas na cidade de São Paulo (Daniel Pedro Müller apud Mattos, 1958, p. 28).
} 
homogeneidade ${ }^{8}$. Entre os diversos produtores, mas também no que respeita aos países, uma pauta de produção mais ou menos parecida se reproduzia. Hésio Cordeiro dá-nos um exemplo, dizendo que "[...] entre 1920-1930 a indústria nacional dispunha de tecnologia idêntica a indústria americana" (Cordeiro, 1980, p. 122).

Depois dessa década de 1930, essa relativa parecença deixa de haver, e é quando podemos constatar o fim do subperíodo.

Por ora, os agentes ficam diferenciados em função de seu acesso em relação às técnicas de produção. Para a maioria das empresas, verificava-se uma utilização de técnicas produtivas muito simples. Em 1920, 27 estabelecimentos produtores de medicamentos, ou seja, metade dos 54 recenseados, estão no grupo dos que "[...] não possuem motores propriamente machinicos e que se utilizam, portanto, em maior escala, do esforço braçal do operário" (Ministério da Agricultura e Commercio, Recenseamento do Brazil, 1920).

As máquinas surgem como a carnação dos avanços técnicos disponíveis neste subperíodo. Sua posse ou sua ausência vão definir fronteiras mercadológicas entre as empresas, pois, numa fase em que os produtos eram parecidos, maiores vantagens tinham os produtores que, podendo aumentar suas produtividades, chegassem a custos menos pronunciados. É por essa importância das máquinas, como esteios da tecnicidade predominante, que falamos num subperíodo maquínico.

Ora, a formação anterior de capital industrial, nos países centrais, faz com que as empresas estrangeiras, chegando ao Brasil, possuíssem mais recursos e acesso mais fácil às técnicas de produção, por vezes desenvolvidas por elas próprias. Assim, o grupo formado pelas empresas estrangeiras detém o controle da variável-chave do sistema.

Estamos, todavia, num período em que as técnicas de produção eram bastante rígidas; custosa e difícil era sua transferência. Com isso, as empresas estrangeiras instalam no país somente as etapas últimas da produção, quando não trazem para cá tão-somente procedimentos rudimentares, como as atividades de embalagem, e assim constituem supostos estabelecimentos fabris ${ }^{9}$. Em 1942, José Palmério escreve a respeito dos laboratórios estrangeiros instalados no Brasil: "O que fazem é importar a matéria principal,

\footnotetext{
${ }^{8}$ Até a segunda guerra mundial, o desenvolvimento farmacêutico do Brasil era similar ao dos países estrangeiros. As empresas estrangeiras eram maiores, mas detinham o mesmo tipo de tecnologia usado no Brasil (Paula, 1991).

${ }^{9}$ Caio Prado Júnior relata que a utilização contumaz de tarifas e da depreciação monetária tinham estimulado indústrias inteiramente fictícias, simples atividades de “'ajuntamento de peças', que dependiam de fontes externas e longínquas de abastecimento para todas as suas necessidades, desde a maquinaria até a matéria-prima e materiais semi-processados que empregavam” (Prado Júnior, 1945, 1998, pp. 262-263).
} 
mais ou menos secreta, e aqui engarrafar ou enlatar os medicamentos, após ligeiras operações de nula significação industrial" (Palmério, 1942, p. 311) ${ }^{10}$.

Malgrado a presença de algumas empresas dos Estados Unidos, a primeira fase da produção de medicamentos, em território brasileiro, realiza-se com a prevalência das empresas européias. Elas eram, não raro, empresas cujo nascimento prendia-se à revolução industrial, surgidas como farmácias pequenas ou como produtores de substâncias químicas $^{11}$.

Em 1907, considerando-se todos os tipos de produção, o Distrito Federal era a unidade federativa com mais estabelecimentos fabris, totalizando 652. A esse número podemos acrescentar os 126 estabelecimentos situados no Rio de Janeiro, o que totaliza 778 fábricas; Minas Gerais abrigava 528 estabelecimentos; e depois vinham São Paulo e Rio Grande do Sul, ambos com 314 (Centro Industrial do Brasil apud Mattos, 1958, p. 33). Apesar de não ser o segundo em número de estabelecimentos, São Paulo o é em valor da produção $^{12}$. Demais, São Paulo já demonstrava ritmos intensos de expansão industrial ${ }^{13}$.

Classicamente, admite-se que os princípios da industrialização em São Paulo, nas últimas décadas do século XIX e nas primeiras do século $X X$, relacionam-se à economia cafeeira. Aponta-se o café como fonte de uma acumulação que, mais tarde, quando a economia baseada na exportação agrícola começa a entrar em colapso, desvia-se para a indústria. Essa relação tanto é apontada de maneira mais direta (Dean, 1971; Cano, 1977; Fausto, 1978, pp. 44-46; Mattos, 1958, pp. 5-11) como de maneira mais relativizada, destacando-se os vaivéns e as contradições (Silva, 1986) ${ }^{14}$. Warren Dean sublinha,

\footnotetext{
10 "Naturalmente é muito variável, de uma empresa para outra, e mesmo para cada qual delas em épocas sucessivas, a parte do processo da produção que cabe a uma e outra seção. Na indústria química e farmacêutica, p. ex., há muitos casos em que a seção brasileira se limita quase só ao acondicionamento de artigos já acabados e produzidos na matriz” (Prado Júnior, 1945, 1998, pp. 266-267).

${ }^{11}$ Segundo explicação de Gary Gereffi, grande parte dos laboratórios farmacêuticos multinacionais iniciou suas atividades, em seus países de origem, como farmácias ou como produtores de colorantes e substâncias químicas. Empresas que começaram como farmácias: Merck \& Co., Americam Home Products, Warner Lambert, Eli Lilly, Upjohn, Squibb, Bristol-Myers, Schering-Plough, Smith Kline \& French, G. D. Searle (todas estadunidenses), Glaxo \& Wellcome, Boehringer Ingelheim, Merck (européias); como fabricantes de colorantes: Hoechst, CibaGeigy, Sandoz; como fabricantes de produtos químicos: Bayer, Hoffman-La Roche (Gereffi, 1986).

12 "Quanto à distribuição da indústria, 33\% da produção cabia ao Distrito Federal (capital da República, a que se podem acrescentar os 7\% do Estado do Rio de Janeiro, vizinho e formando geograficamente na mesma unidade); 16\% a São Paulo e 15\% ao Rio Grande do Sul. Nenhum outro Estado alcançará 5\%" (Prado Júnior, 1945, 1998, p. 260).

13 “[...] é bastante provável que, durante a [primeira] guerra, a produção industrial paulista tenha crescido a uma taxa mais elevada que a do país como um todo" (Suzigan, 1986, p. 52).

${ }^{14} \mathrm{Em}$ verdade, essas polêmicas se estendem a planos maiores, concernentes às próprias origens da indústria no Brasil. Segundo Suzigan, há pelo menos quatro interpretações clássicas a respeito dessas origens: 1. teoria dos choques adversos (Roberto Simonsen, Warren Dean, Celso Furtado, Maria da Conceição Tavares): a indústria decorre dos choques provocados pelas duas guerras mundiais e pela depressão da década de 1930; 2. industrialização liderada pelas exportações (Warren Dean, Robert Nicol, C. M. Peláez, Leff): a indústria foi acoroçoada pelas exportações brasileiras, sobretudo de café; 3. capitalismo tardio (Sérgio Silva, J. M. Cardoso de Mello, Maria da Conceição Tavares, Wilson Cano, L. M. Aureliano): o surgimento da indústria realiza tardiamente o capitalismo no Brasil; o setor agroexporatador promove uma acumulação que seria aproveitada no setor industrial, mas, ao mesmo tempo, obstrui, com sua configuração econômica e social, os avanços das
} 
sobretudo, o papel do café como atrator de equipamentos: linhas férreas, o porto de Santos, redes elétricas, além de uma mão-de-obra mais qualificada (Dean, 1971, p. 15).

Mas, quando consideramos as integrações internacionais do território, ainda é o Rio de Janeiro que prevalece, atraindo a maioria das empresas estrangeiras. As histórias da Bayer, da Merck e da Schering, três empresas de origem alemã, podem ilustrar o processo. A primeira, fundada em 1863, chega ao Brasil em 1921, instalando-se na cidade do Rio de Janeiro (RJ); em 1923, na mesma cidade, instala-se a Schering, empresa fundada em 1871; e a Merck, fundada em 1827, vai-se instalar em Palmira (MG), igualmente em 1923. Outros exemplos de produtores estrangeiros, que chegam neste subperíodo, são: Sidney Ross (Estados Unidos), chegando ao Brasil em 1920; Beecham (Estados Unidos), chegando em 1922; Andromaco (França), em 1928; Rhodia (França), em $1929^{15}$.

Este subperíodo é também cortado pela primeira guerra mundial. Há, na literatura histórica, sociológica e econômica brasileira, uma discordância quanto aos efeitos da guerra para a produção industrial do país. Perlongando essa polêmica, podemos dizer que, pelo menos para a atividade que nos interessa aqui, a produção de medicamentos, o conflito mundial parece ter levado a uma internalização produtiva. Segundo informações de Haddad, a fabricação de produtos farmacêuticos, de 1914 a 1918, cresceu em média 13,6\%, bem acima da média verificada para o total da indústria de transformação: 4,6\% (Haddad apud Suzigan, 1986, p. 54).

O censo industrial de 1920 mostra que as empresas produtoras de medicamentos continuavam bastante concentradas em São Paulo e no Rio de Janeiro, o que se deve à maior diversificação urbana desses lugares, circunstância fundamental para uma atividade que já nasce bastante integrada a outras atividades urbanas, como a publicidade em jornais, mas integrada ainda a um modo de vida propriamente urbano. Essa diversificação, para o Rio de Janeiro, devia-se às funções administrativas da cidade; e para São Paulo, como dissemos, ao café, mas também à gradual concentração de imigrantes e a uma precoce instalação do trabalho livre, começada nas lavouras ${ }^{16}$.

Com a tabela 1.2, a seguir, queremos chamar atenção para dois fenômenos que se manifestavam no fim do subperíodo maquínico. Primeiramente, a concentração das empresas estrangeiras no Distrito Federal. Segundamente, a preferência das empresas

relações tipicamente capitalistas; 4. industrialização promovida pelo Estado (F. R. Versiani e M. T. Versiani): a indústria foi fomentada, principalmente, pelo Estado, por meio de medidas como proteção aduaneira e concessão de incentivos e subsídios à indústria (Suzigan, 1986, pp. 21-44).

${ }^{15}$ As informações referentes às datas de instalação no Brasil obedecerão, sempre, aos seguintes critérios: 1. foram recolhidas, na maioria dos casos, nos sites das empresas; 2. quando os sites não continham tal informação, recorremos a diversas fontes: jornais, livros, artigos...; 3. quando a empresa começa como importadora de produtos acabados, o início dessa atividade importadora foi considerado como sua chegada ao Brasil; 4. quando ela resulta de uma fusão, consideramos, entre as empresas fusionadas, a data de instalação mais antiga no Brasil.

${ }^{16}$ Sobre esses dois últimos aspectos, podem-se consultar: Costa, 1966; Holloway, 1984. 
pelos contextos urbanos, o que não se verifica, todavia, em Minas Gerais, onde a formação urbana surtiu mais dispersa, graças a uma exploração itinerante que remonta à fase da mineração. Nos outros estados, porém, prevalece a localização urbana, representada pelas empresas nas capitais. Em 1942, José Palmério fala de "[...] certos preparados [farmacêuticos] que nada mais exigem para a sua fabricação que recursos técnicos de pequena monta mas que não podem ser satisfeitos em cidades muito pequenas e distantes [...]". (Palmério, 1942, p. 249) Assim, a produção de medicamentos é indiretamente acoroçoada pelo crescimento das concentrações urbanas. 
tabela I.2. Laboratórios farmacêuticos, segundo origem do capital e localização, por unidades da federação: Brasil*, 1938

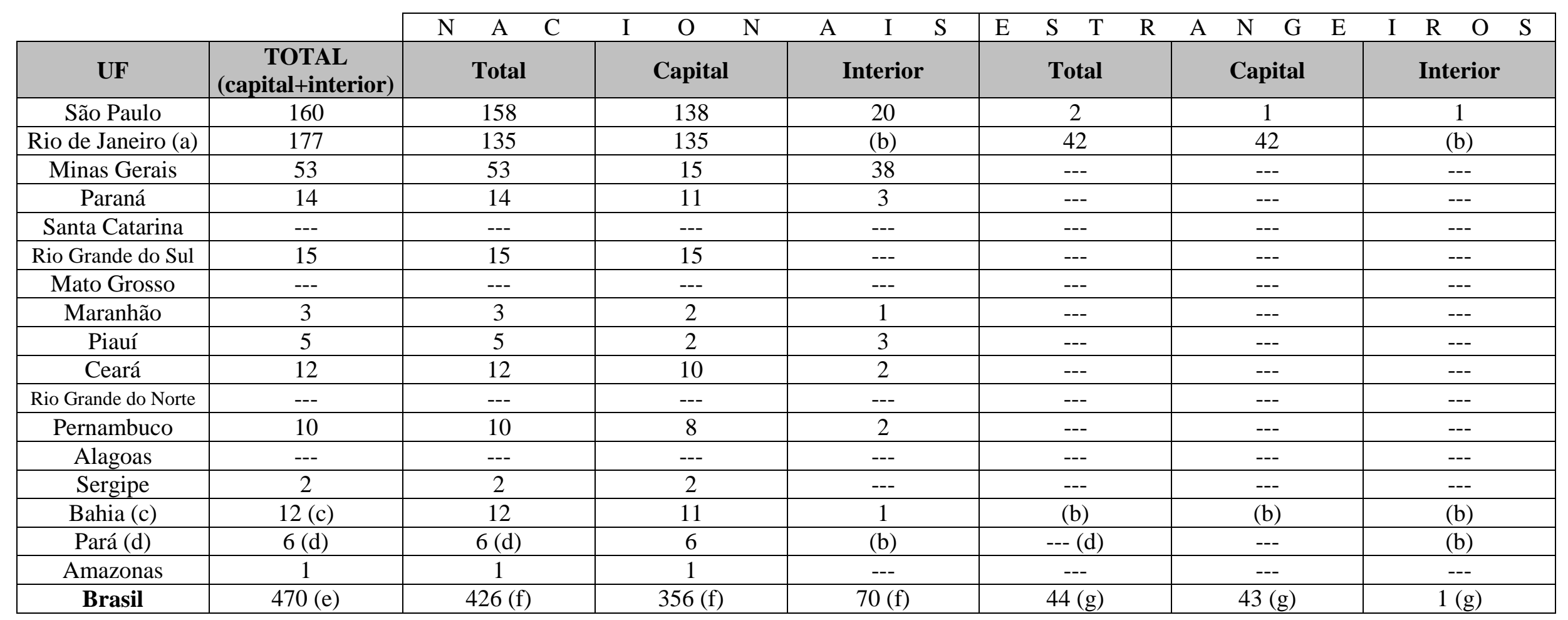

* Exceto os seguintes estados: Paraíba, Espírito Santo e Goiás. Na fonte, não há indicação sobre a inclusão ou exclusão dos dados referentes aos territórios.

(a) inclui apenas a capital do Distrito Federal; não inclui dados do Rio de Janeiro (b) dados não obtidos (c) não foram obtidos dados sobre laboratórios estrangeiros (d) não foram obtidos dados sobre o interior (e) exceto: os estados da Paraíba, do Espírito Santo, de Goiás e do Rio de Janeiro; o interior do Pará; e dados sobre laboratórios estrangeiros na Bahia (f) exceto: os estados da Paraíba, do Espírito Santo, de Goiás e do Rio de Janeiro (g) exceto os estados da Paraíba, do Espírito Santo, de Goiás, do Rio de Janeiro e da Bahia

fonte: elaboração própria, com dados de Fontoura, 1938 
Mas é preciso indagar das características desses primeiros produtores de medicamentos. Como já se viu, predominavam, em quantidade, os empreendimentos nacionais. $\mathrm{Na}$ tabela I.2, vemos que eles representavam cerca de $90 \%$ dos estabelecimentos. Ora, nos fins do século XIX e no começo do XX, produzir medicamentos consistia na reprodução de fórmulas curativas tradicionais, em pequenas empresas artesanais ou familiares, e numa produção que "partia principalmente do conhecimento empírico das propriedades terapêuticas de produtos naturais", ou seja, extratos vegetais ou produtos minerais (Gadelha, 1990, p. 71; p. 182) ${ }^{17}$. Tal circunstância, adicionada aos elementares procedimentos que, já o dissemos, vigoravam para algumas empresas estrangeiras, fazia com que não se tivesse, propriamente, uma indústria farmacêutica, mas sim uma espécie de artesanato agigantado; conforme disse José Palmério, muitas empresas, em vez de laboratórios, configuravam "manipulatórios" (Palmério, 1942, p. 314).

Ao longo do subperíodo, as unidades pertencentes a grupos estrangeiros não cessam de se proliferar. Em 1900, eles detinham 2,1\% do mercado farmacêutico nacional, proporção que se repete em 1910; já em 1920, respondiam por 7,3\%; e em 1930, por 13,6\% (Codetec apud Gadelha, 1990, p. 195). Mesmo assim, não ficava ameaçada a existência dos menores empreendimentos, podendo haver uma coexistência de empresas modernas e $\operatorname{arcaicas}^{18}$.

A base da existência desses pequenos produtores eram os pequenos graus de integração interna apresentados pelo território brasileiro. Com efeito, a precária fluidez territorial impedia a constituição de uma concorrência ampla, até porque o mercado, com dimensões nacionais, ainda não se tinha constituído ${ }^{19}$. Podiam, pois, os laboratórios ancorar-se em pequeninos mercados locais ou regionais, em que suas produções, ainda que tocadas por ritmos e lógicas obsoletas e artesanais, faziam-se viáveis. Para termos uma idéia, podemos recorrer a Maria Aparecida Pereira, que nos vai dizer que apenas em 1926 publica-se a primeira farmacopéia brasileira, ou seja, a primeira relação de medicamentos designados, pelo Estado, como respondendo às necessidades farmacêuticas mais elementares do país. E apenas em 1929 essa farmacopéia se declara como obrigatória, ou

\footnotetext{
17 “Até o início dos anos 30 tornava-se muito difícil perceber grandes diferenças qualitativas na produção de medicamentos no Brasil em relação a outros países do mundo. De um modo geral, todos os processos industriais utilizados no setor estavam limitados à manipulação de substâncias naturais, de origem animal ou vegetal, preparados em pequenos laboratórios, ou mesmo em farmácias ou boticas” (Giovanni, 1980, p. 50). Hésio Cordeiro (1980, p. 50) também conta que, nesta virada de século, a produção farmacêutica baseava-se em produtos naturais.

${ }^{18}$ Referindo-se ao período que antecede a primeira guerra mundial, Milton Santos escreveu: "Tanto no plano da produção como no da comercialização, a 'modernização' não levava à criação de unidades gigantescas. As grandes indústrias de então tampouco eram responsáveis pelo desaparecimento das unidades médias” (Santos, 1979, 2004, p. 79).

${ }^{19}$ Quanto a suas escalas de ação, as empresas de medicamentos seguem a linha descrita por Caio Prado Júnior, que, tratando da indústria brasileira na segunda metade do século XIX, disse: "Ela terá um caráter local limitado a pequenos mercados de curto raio” (Prado Júnior, 1945, 1998, p. 259).
} 
seja, como eixo das políticas farmacêuticas das diversas instâncias de governo (Pereira, 2002, p. 10). Antes dessa data, a pauta de produção dos laboratórios, bem como as técnicas produtivas empregadas, tinham por único esteio as tradições produtivas e as demandas terapêuticas locais.

Além disso, desenrolavam-se no Brasil certas pesquisas em produtos naturais, reforçando a viabilidade de empreendimentos nacionais. Em meados dos anos 1930, José Palmério indicava a existência de pesquisas: em alcalóides na Bahia; em matérias-primas em Mato Grosso; em produtos do reino animal no Espírito Santo; em insulina no Rio Grande do Sul (Palmério, 1942).

E a primeira guerra mundial, geradora de imensos vazios na pauta de importações, acabou estimulando as primeiras produções de matérias-primas voltadas à produção de medicamentos ${ }^{20}$.

O mapa I.1 traça um panorama sobre a formação das empresas produtoras neste subperíodo $^{21}$. Nele se vê que, embora num ritmo ainda modesto, os estabelecimentos se espalham pelo território, excetuando-se apenas aquelas porções, como Goiás, Acre ou Roraima, nas quais não havia concentrações populacionais, tampouco formações urbanas, consideráveis. Também nesse tipo de figuração, destacam-se os territórios do Rio de Janeiro e de São Paulo, apresentando os maiores índices de empresas fundadas por ano.

\footnotetext{
${ }^{20}$ Analisando a produção de matérias-primas industriais, e nisto incluindo as matérias-primas farmacêuticas, disse Wilson Suzigan: "As indústrias que processavam principalmente matérias-primas domésticas aumentaram a sua produção, ocupando as margens de mercado que antes da guerra ainda eram supridas por importações” (Suzigan, 1986, p. 55).

${ }^{21}$ Os períodos históricos estão imbricados, na medida em que um período posterior começa a se formar dentro do período anterior. Mas, a bem da operacionalização da análise, indicamos neste mapa, como nos seguintes, anos precisos em que os períodos começariam e terminariam. Por isso, não podemos deixar de sublinhar que “[...] desejamos realçar sobretudo as épocas e menos os marcos que as separam” (Santos e Silveira, 2001, 2004, p. 24).
} 
Numa visão geral, a evolução dos estabelecimentos aconteceu da seguinte maneira.

tabela I.3. Indústria farmacêutica: Número de fábricas registradas ${ }^{22}$ : Brasil, 1913-1936

\begin{tabular}{|c|c|}
\hline Ano & Fábricas \\
\hline 1913 & 765 \\
\hline 1916 & 945 \\
\hline 1918 & 1181 \\
\hline 1926 & 1356 \\
\hline 1928 & 1420 \\
\hline 1930 & 1329 \\
\hline 1932 & 1399 \\
\hline 1935 & 1488 \\
\hline 1936 & 1291 \\
\hline
\end{tabular}

Fonte: Palmério, 1942, p. 340

Como dissemos, a maioria das empresas era formada por pequenos estabelecimentos produtores. Tal circunstância prendia-se à baixa fluidez territorial, com a possibilidade de explorar mercados locais, mas também à presença de uma legislação frágil e frouxa, verdadeiro atrativo para indivíduos empreendedores que, pondo em práticas seus estros farmacêuticos, concebem fórmulas medicamentosas, ou então simplesmente aproveitam receitas local e tradicionalmente abonadas. O "Emplasto Brás Cubas", imaginado por Machado de Assis $(1881,1995)$, bem retrata as possibilidades abertas pela legislação em voga. Como tais empreendimentos prescindiam de grandes capitais, muita vez constituindo verdadeiras aventuras produtivas, puderam emergir várias produções de pequena monta. "[...] encontra-se excepcionalmente algum grande estabelecimento; o resto são pequenas unidades que não passam realmente de modestas oficinas com reduzido

\footnotetext{
${ }^{22} \mathrm{Em}$ razão das dificuldades de contagem vigentes à época, na qual nem sempre era simples diferenciar as boticas dos estabelecimentos industriais, devemos considerar que esses números são aproximativos. Além disso, o autor não indica com precisão as suas fontes. Entanto, parecem ser os números mais plausíveis para o período. O censo de 1920, realizado pelo Ministério da Agricultura e do Comércio, aponta resultados que subestimem claramente a atividade industrial, pois deixou de contar muitos estabelecimentos pequenos, predominantes à época. Esse censo indica, para o ano de 1907, 26 indústrias produtoras de especialidades farmacêuticas; para 1913, o número é de 139; para 1920, é de 54, claramente subestimado. Outra fonte seria a Abifarma, Associação Brasileira da Indústria Farmacêutica (Abifarma apud Pereira, 2002, p.10), indicando, para 1907, o número de 60 laboratórios farmacêuticos no Brasil; e, para 1920, o número de 186.
} 
número de operários e inversão insignificante de capital" (Prado Júnior, 1945, 1998, p. 261). Em 1907, a média de operários por estabelecimento, para a fabricação de especialidades farmacêuticas, era de 17, número que se reduz a 9 em 1913, passando a 13 em 1920 (Ministério da Agricultura e Commercio, Recenseamento do Brazil, 1920) ${ }^{23}$.

Nesses começos do século XX, conforme explica Eliza Almeida, o desenvolvimento da previdência social, ainda que limitado, leva à expansão do consumo de medicamentos, num período em que a medicina curativa, os serviços privados e o hospital se erigem como os pilares do sistema de saúde (Almeida, 2005, pp. 60-71).

A configuração territorial ainda era diretamente tributária dos processos econômicos havidos ao longo da era colonial. Estamos ainda num Brasil de base essencialmente agrária. Mas, conforme interpretam Fernando Henrique Cardoso e Enzo Faletto, o país, enquanto predominou a base agrária, conheceu diferenciações produtivas, o que leva à criação de atividades voltadas ao mercado interno e à formação dos primeiros núcleos urbanos (Cardoso e Faletto, 1967, 1969, pp. 48-63) ${ }^{24}$.

Essas diferenciações iniciais repousam sobre acréscimos técnicos, ou, mais precisamente, sobre a instalação de uma tecnicidade sobre o território. Os estabelecimentos produtivos ainda eram, na maioria, grandes artesanatos; e ainda não se tinha constituído um verdadeiro mercado nacional. Contudo, uma divisão do trabalho interna às fábricas, bem como um primeiro uso de equipamentos modernos, emergem neste subperíodo, baseando as posteriores evoluções da produção farmacêutica. Apesar da já notável presença de produtores estrangeiros, a dinâmica da atividade, podemos dizê-lo, estava marcada por uma tendência à dispersão dos estabelecimentos nacionais, formando pequenos universos, onde matérias-primas locais eram processadas, e os produtos finais escoados.

\section{O subperíodo tecnológico}

O acesso aos novos ritmos e organizações do trabalho eram possíveis, sobretudo, para aqueles agentes que podiam acolher mais fácil e rapidamente as inovações técnicas incorporadas nos equipamentos modernos. Para os demais, negava-se a tecnicidade, o que obrigava ao uso de objetos mais obsoletos, além de procedimentos manuais. Conforme dissemos anteriormente, os baixos conteúdos técnicos, apresentados pela maioria das

\footnotetext{
23 Neste último ano, a distribuição de estabelecimentos pelas classes de empregados era a seguinte: 28 estabelecimentos possuíam de 1 a 4 operários; 8 possuíam de 5 a 9; 9 possuíam de 10 a 19 ; 6 possuíam de 20 a 49; apenas 2 empregavam de 50 a 99 pessoas; e 1 somente contava com mais de 100 operários (Ministério da Agricultura e Commercio, Recenseamento do Brazil, 1920).

${ }^{24}$ Em 1900, estas eram as cidades mais populosas: Rio de Janeiro, São Paulo, Salvador, Recife, Belém (Santos, 1993, 2005a, p. 23). Esses núcleos é que vão constituindo a base de uma urbanização, ainda desarticulada.
} 
empresas, não gerava desvantagens mercadológicas. Porém, de maneira gradual, mudanças técnicas, científicas e territoriais começam a definir situações novas.

Os avanços da ciência foram fundamentais. No final do século XIX, os trabalhos de Pasteur demonstram que as doenças infecciosas e as inflamações eram devidas à ação de organismos invisíveis a olho nu, os micróbios; e Paul Erlich (1854-1915) demonstrou que certas substâncias podem agir sobre certos agentes patogênicos sem afetar o organismo do homem (Gadelha, 1990, pp. 56-57). Porém, é só mais tarde que as conquistas científicas vão chegar às províncias produtivas. Nesse desenvolvimento moroso, o ano de 1928 é particularmente importante. Pois, nesse ano, o bacteriologista escocês Alexander Fleming descobre, em seu laboratório, bactérias mortas em uma placa mofada. Fleming constata que uma substância produzida pelo fungo causador do mofo tem efeito bactericida. Assim se descobre o primeiro antibiótico, a penicilina. Em 1938, a droga é sintetizada em laboratório, por Ernst Boris Chain e Howard Walter Florey.

Com esses dois passos, abriam-se largos e novos caminhos para a produção farmacêutica. Pois se viu que era possível aproveitar os processos biológicos para recolher produtos com valor terapêutico. Na Europa, evoluem as pesquisas em produtos biológicos, e diferenças mais pronunciadas se delineiam, tanto entre as empresas como entre os países.

O movimento se estende à produção de medicamentos. Em 1930, já 13,6\% do mercado farmacêutico nacional estava sob controle das empresas estrangeiras; a proporção se eleva a 33,5\% em 1940; e, em 1950, já no fim do subperíodo tecnológico, ela passa a 47,1\% (Codetec apud Gadelha, 1990, p. 195). Em rigor, é só neste subperíodo que a produção de medicamentos conhece impulsos efetivamente vigorosos. "A indústria química pouco se desenvolveu no período anterior à década de 1930 [...] Os investimentos nas indústrias farmacêuticas e de cosméticos também foram limitados até a década de 1920, mas nessa década e nos anos 30 alguns dos grandes laboratórios e fabricantes de cosméticos internacionais começaram a estabelecer fábricas subsidiárias no Brasil" (Suzigan, 1986, p. 113). Cotejada com outras atividades produtivas, a produção de medicamentos faz então prova de uma precoce internacionalização, com efeitos sobre os arranjos técnicos e científicos do território.

No rol das empresas que chegam ao país, ainda são as européias que prevalecem. O grupo suíço Roche, fundado em 1896, instala-se na cidade do Rio de Janeiro em 1931. O laboratório Glaxo, inglês, instala-se em 1948 em Niterói (RJ). Mais alguns exemplos: os ingleses Johnson \& Johnson (chegando em 1933), Roussel (1936) e Glaxo (1936); os suíços Ciba (1937) e Sandoz (1947); o alemão Hoechst (1949).

As empresas estadunidenses também se fazem presentes, mas em número menor e chegando, sobretudo, já nos anos 1940. Um exemplo é o laboratório Abott, fundado em 1888, que se instala na cidade do Rio de Janeiro em 1937. Outros laboratórios dos Estados 
Unidos instalados neste subperíodo são: Merck Sharp \& Dohme (chegando em 1941); Bristol Myers (1943); Schering (1944); Wyeth (1949).

Por ora, ainda são os arranjos técnicos, levando a maiores escalas e menores custos, que sustentam as produções de maior fôlego. Certamente que os avanços do conhecimento científico levam a novas hierarquias, e é justamente por isso que identificamos um novo subperíodo. Entanto, elas estavam largamente calcadas em lucratividades obtidas graças ao domínio técnico, o qual representa, ainda, a força propulsora dos agentes.

Os laboratórios farmacêuticos estrangeiros continuam preferindo a cidade do Rio de Janeiro, em virtude de seus dinamismos econômicos e das infra-estruturas já instaladas. Ao mesmo tempo, São Paulo prossegue seus movimentos expansivos, que aos poucos se desprendem do café para adquirir aspectos verdadeiramente urbanos e industriais. Uma vida de relações mais intensa pode emergir nessas duas cidades, o que vai favorecer, também, a emersão de pequenos produtores de medicamentos. Para 1947, fins de nosso subperíodo tecnológico, um levantamento realizado pelo Sindicato da Indústria de Produtos Farmacêuticos detectou a presença de 611 empresas farmacêuticas no Brasil; delas, apenas 42 empresas estavam fora do eixo Rio-São Paulo (Abifarma apud Pereira, 2002, p. 11).

Em termos territoriais, acirram-se os esboços da divisão internacional do trabalho traçados ao longo do subperíodo precedente. Acentuam-se, agora, as exportações brasileiras de produtos primários medicinais ${ }^{25}$. Paralelamente, recrudescem as importações de produtos farmacêuticos acabados. Conforme os dados recolhidos por José Palmério, o valor das importações de "produtos farmacêuticos", de 1928 a 1937, aumentou 105,38\% ${ }^{26}$ (Palmério, 1942, p. 334).

A pouco e pouco, a racionalidade própria às maiores empresas, com escalas produtivas mais substanciais, impõe-se no território. Mas, como constata Caio Prado Júnior, ainda subsistem certos empreendimentos arcaicos, com menores capitais e técnicas envelhecidas; eles se reúnem, muita vez, em torno de produções desprezadas pelas maiores empresas (Prado Júnior, 1945, 1998, p. 279). Por isso, este subperíodo, ao invés

\footnotetext{
${ }^{25}$ No meio da década de 1930, eis algumas folhas, raízes e resinas medicinais exportadas pelo Brasil: guaraná, ipecacuanha, jaborandi, jatobá, jutaísica, timbó em rama, timbó em pó. Se considerarmos esses artigos, mais outros não especificados, vemos que, de 1935 a 1937, o valor de sua exportação, em mil réis da época, aumentou 166,72\% (Palmério, 1942, p. 336).

${ }^{26}$ No final da década de 1930, estes eram alguns medicamentos importados pelo Brasil: injeções medicinais, quinino, gotas medicinais, pílulas e drágeas, bálsamos e pomadas, codeína, morfina, purgativos, soros e vacinas, teobromina, cafeína, vitamina C (Palmério, 1942, p. 329). Em 1936, os principais produtos importados para fins farmacêuticos foram: elixires e licores medicinais, gotas medicinais, vacinas e soros, óleo de fígado de bacalhau, óleos e emulsões medicinais, preparados farmacêuticos e especialidades médicas, ampolas medicinais (p. 334). Essa classificação não é muito precisa, pois algumas rubricas são por demais abrangentes. Mesmo assim, pode-se ver que as importações brasileiras abrangiam largo espectro de medicamentos.
} 
de ser mortífero para os pequenos empreendimentos, traz uma verdadeira explosão de laboratórios, os quais aparecem num ritmo que jamais se vai repetir. É o que buscamos demonstrar com o mapa I.2.

Ali vemos que, tal como no subperíodo precedente, os laboratórios continuam sua dispersão pelo território. Esse movimento é porém mais importante para toda a faixa que vai desde a Bahia até o Rio Grande do Sul, com destaque para o Rio de Janeiro e São Paulo. No mais, deve-se dizer que, a exemplo do subperíodo maquínico, são as maiores cidades, e sobretudo as capitais, que sustentam essas vagas dispersivas.

Estas últimas são reforçadas por fortes e profundos processos: a manutenção de uma fraca vigilância sanitária; um primeiro impulso de banalização da técnica, às custas de uma primeira centralização científica; o aumento das concentrações urbanas, que leva à multiplicação das farmácias ${ }^{27}$ e também ao reforço das atividades de propaganda.

O território vai ganhando em fluidez ${ }^{28}$. Para permitir fluxos mais rápidos, grandes sistemas técnicos se instalam em vários pontos do território ${ }^{29}$. Ao mesmo tempo, certos agentes vão-se especializando em atividades relativas a esses fluxos cada vez mais intensos; é o caso dos distribuidores e dos importadores ${ }^{30}$. Tudo conduz a relações mais intensas entre os estados. Para a atividade farmacêutica, o processo traduz-se em freqüentes fluxos de medicamentos, que favorecem, principalmente, aos estados do Rio de Janeiro e de São Paulo. A tabela I.6 pretende ilustrar esse fenômeno. Ali, vemos, ainda, como os estados mais ligados à dinâmica do Rio de Janeiro e de São Paulo eram também os que amargavam maiores déficits; tal é a situação do Rio Grande do Sul ou da Bahia.

Apesar disso tudo, a integração do território permanecia, ainda, uma promessa, pois, em grande medida, persistiam as possibilidades de se agarrar aos quadros locais, fosse para obter as matérias-primas, fosse para topar com mercado consumidor. As grandes empresas, mormente as estrangeiras, já controlam consideravelmente os processos espaciais, o que não inviabiliza, porém, as pequenas produções locais ou regionais.

\footnotetext{
${ }^{27}$ Em 1938, das 6968 farmácias existentes no Brasil, 2460 estavam em São Paulo ; 1476 em Minas Gerais; 1217 no Rio de Janeiro (Distrito Federal + Rio de Janeiro); em quarto lugar, vinha o Rio Grande do Sul, com 256 farmácias (Fontoura, 1938).

${ }^{28}$ Conforme interpretam Milton Santos e María Laura Silveira: da mesma forma como há uma mecanização da produção, o início do século XX até a década de 1940 é marcado por uma mecanização da circulação, não apenas aquela voltada à exportação, mas também aquela que permitia os fluxos internos ao país. Por isso, podemos falar em mecanização e motorização do território (Santos e Silveira, 2001, 2004, pp. 37-38).

${ }^{29}$ É do início dos anos 1940 a construção do aeroporto de Manaus, bem como a ampliação do de Belém. Ambos os empreendimentos tiveram a participação de capitais estadunidenses, interessados em garantir o fornecimento de borracha em face do fechamento dos mercados asiáticos durante a guerra mundial (Oliveira, J. 2003, pp. 5359).

${ }^{30}$ Nas décadas de 1920 e 1930, tornam-se cruciais, sobretudo em São Paulo, os importadores. Eles controlavam os fluxos de produtos importados e, mais tarde, começando a comerciar também com produtos nacionais, tornam-se grandes atacadistas e distribuidores. Demais, seus lucros se destinaram, não raro, à instalação de unidades industriais (Dean, 1971, pp. 25-40).
} 
tabela I.6. Comércio de medicamentos interno ao território brasileiro: Exportações e importações, em volume e valor, segundo as unidades da federação: Brasil*, 1937

\begin{tabular}{|c|c|c|c|c|}
\hline \multirow[b]{2}{*}{ UF } & \multicolumn{2}{|c|}{$\begin{array}{c}\text { V O L U M E } \\
(\mathrm{t} \text { o n e l a d a s })\end{array}$} & \multicolumn{2}{|c|}{$\begin{array}{c}\text { V A L } \mathrm{O} \text { R } \\
\text { (contos de réis) }\end{array}$} \\
\hline & $\begin{array}{c}\text { Importações } \\
\text { (\%) (a) }\end{array}$ & Exportações (\%) & $\begin{array}{c}\text { Importações } \\
\text { (\%) (a) }\end{array}$ & Exportações (\%) \\
\hline São Paulo & 1,15 & 27,23 & 1,09 & 16,98 \\
\hline Rio de Janeiro (b) & 1,94 & 60,18 & 1,39 & 75,37 \\
\hline Espírito Santo & 3,14 & 0,05 & 2,23 & 0,03 \\
\hline Paraná & 3,13 & 0,14 & 3,35 & 0,12 \\
\hline Santa Catarina & 3,91 & 0,33 & 3,94 & 0,47 \\
\hline Rio Grande do Sul & 24,29 & 2,79 & 31,32 & 1,12 \\
\hline Mato Grosso & 0,02 & --- & 0,00 & --- \\
\hline Maranhão & 2,70 & 0,93 & 2,82 & 0,47 \\
\hline Piauí & 2,53 & 0,02 & 1,80 & 0,00 \\
\hline Ceará & 8,14 & 0,34 & 7,93 & 0,35 \\
\hline Rio Grande do Norte & 2,41 & 0,03 & 2,26 & 0,04 \\
\hline Paraíba & 1,86 & 0,05 & 1,67 & 0,03 \\
\hline Pernambuco & 12,31 & 3,93 & 13,59 & 1,51 \\
\hline Alagoas & 2,90 & 0,02 & 2,19 & 0,01 \\
\hline Sergipe & 2,58 & 0,02 & 1,58 & 0,01 \\
\hline Bahia & 17,67 & 1,17 & 14,52 & 0,65 \\
\hline Pará & 5,34 & 2,49 & 4,43 & 2,62 \\
\hline Amazonas & 3,98 & 0,28 & 3,89 & 0,22 \\
\hline Brasil (c) & $\begin{array}{c}100,00 \\
(8398 \text { (a)) }\end{array}$ & $\begin{array}{l}100,00 \\
(8446)\end{array}$ & $\begin{array}{c}100,00 \\
(112383(\mathrm{a}))\end{array}$ & $\begin{array}{c}100,00 \\
(112930)\end{array}$ \\
\hline
\end{tabular}

* exceto Minas Gerais e Goiás

(a) Excluindo os dados referentes a um “Território Federal” não identificado, correspondendo a 0,56\% das importações em volume e a 0,48\% das importações em valor (b) Rio de Janeiro + Capital Federal (c) Exceto Minas Gerais e Goiás

fonte: Palmério, 1942, p. 339

Por fim, este subperíodo tecnológico reforça as dinâmicas do estado de São Paulo. Mais ainda, o estado do Rio de Janeiro já não se mostra capaz de sustentar seu predomínio produtivo. Em 1938, o estado de São Paulo foi responsável por 40,17\% do valor total produzido pelas indústrias de produtos químicos, artigos de farmácias e perfumarias; o Rio 
de Janeiro (somando-se Distrito Federal e Rio de Janeiro) foi responsável por 38,89\%; o terceiro valor foi produzido pelo Rio Grande do Sul, com 6,74\%; o quarto e o quinto valores, por Pernambuco e Ceará, produzindo, respectivamente, 2,71\% e 2,61\% (Produção e crédito apud Palmério, 1942, p. 329). E o predomínio paulista se repete nas outras atividades ${ }^{31}$.

O processo expressa muito mais um dinamismo de São Paulo do que uma presumível estagnação do Rio de Janeiro. Segundo Caio Prado Júnior, São Paulo logra superar o Rio de Janeiro, economicamente, por vários fatores: a prosperidade geral do estado, carreada pelo café; a presença mais maciça do imigrante, que eleva o nível da mãode-obra; o tenro aproveitamento do potencial hidrelétrico existente próximo à capital (Prado Júnior, 1945, 1998, pp. 260-261). Milton Santos e María Laura Silveira ressaltam outro aspecto: em São Paulo, uma hinterlândia mais dinâmica se oferecia à capital, constituindo um próspero mercado, sustentando seu movimento ascensional; já no Rio de Janeiro, a existência de um entorno pobre não permitiu o mesmo fenômeno (Santos e Silveira, 2001, 2004 , p. 252) ${ }^{32}$. No mais, é patente que a vida econômica paulista já não dependia, como outrora, do café. É Wilson Cano quem diz que, depois da crise de superprodução do café, em 1929, e da subseqüente crise econômica internacional, o país viu-se obrigado a procurar "caminhos mais autônomos" para sua indústria. Com isso, a industrialização vai-se desligando do café (Cano, 1977, pp. 188-189).

Portanto, o subperíodo tecnológico traz uma inflexão histórica. As várias empresas continuam coexistindo, mas, doravante, constatam-se os primeiros fenômenos de hierarquização. Sua fonte principal são as diferenças referentes a esse conhecimento farmacêutico desenvolvido ao longo do subperíodo. Agora, ciência e técnica se associam para formar uma base tecnológica, sobre a qual repousam os novos poderes territoriais ${ }^{33}$. Conforme se depreende das exposições feitas por José Palmério (1942, pp. 194-204), os grandes e raros laboratórios nacionais e estrangeiros dedicavam-se, cada vez mais, à produção dos chamados específicos, que eram remédios relativamente mais sofisticados, com ação terapêutica restrita, enquanto os pequenos e numerosos laboratórios nacionais continuavam produzindo medicamentos de largo espectro, muita vez a partir de plantas e produtos naturais.

31 Esta foi a evolução da proporção do valor produzido por São Paulo: 15\% em 1907; 32\% em 1920; 43\% em 1940; 46,8\% em 1950 (Mattos, 1958, p. 34). Porém, Dirceu Lino de Mattos compara dados colhidos em dois censos, o que se deve fazer com reservas, pois cada censo adota critérios particulares, o que faz da comparação apenas um instrumento para ter uma idéia geral. Por isso, em nossos mapas, estamos analisando os períodos sem compará-los, e colhendo dados, sempre que possível, em apenas uma fonte por vez.

32 Já nos anos 1920, constatou-se um decréscimo populacional e industrial na Guanabara (Cano, 1977, pp. 191192).

33 "A partir da realização destes maciços investimentos na pesquisa e da descoberta de novas substâncias, que se dão a partir da década de 30, começa a se delinear uma nítida diferenciação qualitativa entre a indústria farmacêutica brasileira e as indústrias norte-americana, principalmente, e européias, que passam a assumir, sem jamais a perder, a dianteira da inovação tecnológica e o conseqüente domínio dos mercados mundiais” (Giovanni, 1980, p. 54). 
Gradualmente, os conhecimentos científicos vão passando ao centro da cena farmacêutica, até o momento em que se desvencilham, se autonomizam, decretando o fim do longo período técnico. Para isso vão contribuir as primeiras tentativas exitosas de emprego das técnicas de síntese química ${ }^{34}$.

Nesse ínterim, os sistemas de atenção à saúde continuam a se aproximar das lógicas empresariais. De 1933 a 1938 vigora o sistema dos IAPS, Institutos de Aposentadorias e Pensões, congregando os trabalhadores por categorias profissionais (Cohn, 1996, pp. 14-15) ${ }^{35}$. Com os IAPs, os recursos previdenciários passam a ser considerados como recursos de capital, tomando parte em investimentos, em empresas estatais, em grandes obras (pp. 16-17).

Porém, assim como estavam deitadas as bases para desenvolvimentos mais adictos à lógica das grandes empresas, o território também comportava certas forças capazes de promover desenvolvimentos mais ligados a dinâmicas internas. Assim podemos interpretar a dispersão dos laboratórios farmacêuticos pelos vários estados. Em verdade, estavam lançadas oportunidades e possibilidades várias. Ocorre que, no próximo período, lógicas de exclusão privilegiam, sobretudo, os poderes de extroversão, concentração e polarização espacial.

\footnotetext{
34 “Inicialmente, por volta de 1935, sucederam-se diversas descobertas das propriedades antiinfecciosas das sulfas, fruto das atividades de P\&D efetuadas por grandes empresas químicas produtoras de corantes (Bayer) e das pesquisas efetuadas por instituições científicas (Instituto Pasteur, por exemplo). A partir de então, diversos grupos de sulfas passaram a ser produzidos industrialmente por processos de síntese química” (Gadelha, 1990, p. $58)$.

35 "“...] o direito aos benefícios e prestações de serviços dos IAPs se constitui menos (ou quase nada) como função de sua condição de cidadão ou trabalhador, e sim do reconhecimento da sua situação ocupacional oficialmente legitimada e vinculada a uma obrigação contratual de caráter contributivo”. (Cohn, 1996, p. 16)
} 
A ciência e a produção de medicamentos

\section{O papel da síntese química}

Para a atividade farmacêutica, bem como para outras atividades econômicas, novos arranjos espaciais vão-se tecendo, na escala mundial, em decorrência da segunda guerra mundial. Os vários territórios são atravessados por novas e mais numerosas variáveis, o que determina um processo de complexificação ${ }^{1}$.

O conflito mundial leva a uma subversão da ordem econômica, o que dá margem a séries de manobras inusuais mercadologicamente. No que respeita à produção de medicamentos, vemos que, durante a segunda guerra mundial, laboratórios farmacêuticos foram nacionalizados. Por exemplo, o laboratório Pfizer, que em muitos critérios aparece, hoje, como a maior empresa farmacêutica mundial, tornou-se norte-americano ao longo da guerra, a partir de uma nacionalização unilateral. Certamente que as pesquisas básicas, desenvolvidas pelos Estados Unidos, contribuíram para o salto farmacêutico realizado por esse país. Carlos Augusto Gadelha dá-nos um exemplo, dizendo que o governo dos Estados Unidos apoiou a produção de penicilina, e também a produziu diretamente, como forma de proteger seus soldados (Gadelha, 1990, p. 58). Mas não se pode ocultar que, por ocasião da segunda guerra, esse país pôde apropriar-se do conhecimento reunido por algumas empresas de origem européia ${ }^{2}$.

No mais, a guerra mundial, por óbvias razões, ou desrazões, promove uma súbita elevação da necessidade de medicamentos e terapias. Assim, as pesquisas são acoroçoadas, e resultados importantes logo obtidos.

O emprego das técnicas de química sintética, de uso iniciado no meio da década de 1930, mostra-se particularmente exitoso. Em pouco tempo, esse método vai constituir a franja mais avançada e moderna das produções farmacêuticas. Em verdade, as primeiras utilizações da química sintética, para fins farmacêuticos, remontam ao período técnico, ainda em seu subperíodo maquínico. Conforme Nilce Fonte, foi Félix Hoffman que desenvolveu, em 1897, o primeiro medicamento sintético: a mundialmente famosa aspirina (Fonte, 2004, p. 49). Mas é só mais tarde, já nos anos 1930, que novos avanços

\footnotetext{
1 “O processo histórico é um processo de complexificação. Desse modo, a totalidade se vai fazendo mais densa, mais complexa. Mas o universo não é desordenado” (Santos, 1996, 2004, p. 117).

${ }^{2} \mathrm{O}$ mesmo fenômeno já tinha acontecido ao longo da primeira guerra mundial. "O desenvolvimento da indústria química de matérias orgânicas sintéticas só foi possibilitado nos Estados Unidos quando no período da guerra de 1914 o presidente Wilson autorizou o apropriamento das patentes químicas alemãs por parte das empresas americanas” (Palmério, 1942, p. 240 - nota).
} 
consideráveis são conseguidos, desta vez em diversos grupos de sulfas (Gadelha, 1990, p. 58).

A partir da segunda guerra mundial, as pesquisas têm seus tempos acelerados, o que vai conduzir a descobertas múltiplas, fazendo com que, para várias doenças, seja possível produzir medicamentos com emprego das técnicas sintéticas. No final da década de 1970, segundo Korolkovas e Burkhalter, 50\% dos medicamentos existentes já eram produzidos a partir de fontes sintéticas (Korolkovas e Burkhalter, 1980, p. 40). Neste momento emerge uma produção baseada em vários conhecimentos: química quantitativa, engenharia química, bioquímica, microbiologia, entre outros (Gadelha, 1990, pp. 71-72).

Em verdade, as revoluções permitidas pela química sintética não se restringem ao campo farmacêutico. Muito pelo contrário, trata-se de processos técnico-científicos possibilitando um alargamento das escalas de ação em várias atividades produtivas. Como se sabe, a química sintética caracteriza-se pela análise de substâncias químicas no nível de suas moléculas, de modo a precisar suas constituições e, posteriormente, buscar alterações moleculares. Com isso, podem-se criar novas substâncias, com propriedades inéditas. "A química sintética permitiu o desenvolvimento de uma gama larga de produtos, com características mecânicas, elétricas, químicas ou biológicas estruturalmente funcionais, que vão desde materiais essenciais que substituem a madeira, o aço e os tecidos naturais até agentes químicos e biológicos especializados e caros, para usos médicos ou outros" (Pavitt, 1984, p. 362).

Em 1964, Raymond Guglielmo dizia, da indústria química sintética, ser um dos símbolos dos novos tempos industriais, pois ela introduz um novo tipo de trabalho, possibilitando a produção das próprias matérias-primas (Guglielmo, 1964, pp. 208-209).

Se antes as lógicas produtivas eram condicionadas pelas possibilidades técnicas, agora a montagem de grandes escalas produtivas, com reduzidos custos, carece de senso estratégico se não é encimada por um potente conjunto de pesquisas científicas. De acordo com Thibaut, a ciência converte-se em força produtiva (Thibaut, 1967). Assim, consagrando a mudança que tem suas raízes no fim do período técnico, chega-se a um período novo em que a ciência, renovada, autonomiza-se ${ }^{3}$. Daí, falarmos num período científico da produção de medicamentos.

\footnotetext{
3 “Ora bem: foi a penetração da ciência, nos domínios mais recônditos da Natureza, que veio permitir aos engenheiros a utilização de forças naturais que o passado mal conhecera" (Heisemberg, 1958, 1981, p. 116). "O casamento da técnica e da ciência, longamente preparado desde o século XVIII, veio reforçar a relação que desde então se esboçava entre ciência e produção" (Santos, 1996, 2004, p. 177).
} 
Para a atividade farmacêutica, o trabalho de pesquisa mostra-se cada vez mais decisivo. As maiores empresas vão rapidamente montando grandes corpos de investigação, o que reitera seu predomínio ${ }^{4}$.

Por isso tudo, é relativamente simples fixar o princípio deste período científico: a segunda guerra mundial marca as passagens havidas.

É só neste momento que podemos começar a detectar um verdadeiro processo de globalização da economia, ou seja, uma organização mundial com traços realmente sistêmicos. Doravante, os capitais estrangeiros modificam profundamente os fácies dos territórios periféricos ${ }^{5}$. Por isso diz Milton Santos (2001, 2004, p. 47) que, ao fim da segunda guerra mundial, foi lançada "a semente da dominação do mundo pelas firmas multinacionais"6.

\section{A extroversão do território}

$\mathrm{Na}$ produção de medicamentos, esse novo poderio das empresas estrangeiras se deve, grandemente, ao fato de elas se terem precocemente apropriado dos conhecimentos científicos em desenvolvimento. Cada vez mais, a inovação farmacêutica se produz, em todos os países, nos laboratórios particulares, em detrimento do papel inovativo dos laboratórios estatais. Na década de 1950, a indústria particular foi responsável pela descoberta de $86 \%$ dos novos princípios ativos ${ }^{7}$; na década seguinte, ela descobriu $91 \%$ dos princípios ativos (Grabowiski e Vernon apud Gadelha, 1990, p. 74).

Uma circunstância que facilmente se converte em fonte de lucros, através dos chamados preços de transferência. Explicamos o mecanismo. Os laboratórios estrangeiros raramente realizam, neste período científico, produção de matérias-primas, e especialmente de princípios ativos, fora de seus países de origem. Assim, as subsidiárias instaladas em

\footnotetext{
${ }^{4}$ Em 1974, nos Estados Unidos, avaliaram-se 16 ramos industriais, controlados nacional ou internacionalmente, incluindo produtos químicos, maquinaria, máquinas elétricas e equipamento de transporte; a produção farmacêutica foi a que apresentou, no número total de empregados, a maior participação de cientistas e técnicos de pesquisa e desenvolvimento (National Science Foundation apud Evans, 1979, 1980, p. 112).

${ }^{5}$ Cardoso e Faletto relatam que, "[...] a partir de 1950, mais ou menos, as inversões estrangeiras se fazem no setor produtivo orientado para o mercado interno [...]". (p. 101) Dizem ainda que "[...] na década de 50 o movimento internacional de capitais se caracterizou por um fluxo - de curta duração - de transferências de capitais desde o centro até a periferia; as corporações industriais passaram a atuar como inversoras, o que constitui uma novidade em relação ao esquema anterior de inversões tipicamente financeiras ou de empréstimos para infra-estrutura” (Cardoso e Faletto, 1967, 1969, pp. 140-141).

6 "Em 1971, a participação de firmas estrangeiras no mercado de produtos farmacêuticos era de $73 \%$ no Reino Unido, 90\% na Holanda, 45\% na França, 34\% na Suíça, entre 65/85\% na Itália, 50\% na Suécia, e 25\% na Alemanha Ocidental” (Frenkel et alii, 1978, p. 62). "Portanto, ao se analisar o comportamento do setor em cada país, estar-se-ia considerando, implicitamente, a estratégia de expansão das grandes firmas multinacionais, além das situações específicas dos mercados locais” (p. 63).

${ }^{7}$ Os princípios ativos são as substâncias elementares que, no medicamento, são responsáveis pelos efeitos terapêuticos. Os demais componentes, chamados adjuvantes, reforçam a ação dos princípios ativos, minimizam os efeitos colaterais, ou simplesmente melhoram o sabor do medicamento.
} 
países periféricos devem comprar as matérias-primas de suas respectivas matrizes. Ora, como esta operação se realiza no seio de uma só firma, a matriz pode impor a sua filial os preços que bem desejar. De pronto, esse mecanismo se transforma num meio de enviar lucros ao exterior sem que se deva pagar impostos, já que tais operações aparecem como custos da filial, e não como remessas sujeitas a taxações. No Brasil, as subsidiárias de laboratórios multinacionais pagam, desde muito cedo, altos preços por suas matérias-primas. Em 1963, a Sidney Ross (Estados Unidos) declarou a US\$ 595 o quilo de uma matéria-prima cotada na Inglaterra e na Alemanha Ocidental a US\$100; a Parke Davis (Estados Unidos) declarou a US\$ 300 uma matéria-prima cotada nos Estados Unidos a US\$ 55; a Roche (Suíça) declarou a US\$ 1140 uma matéria-prima cotada na Itália a US\$ 100; a Bayer (Alemanha) declarou a US\$ 2,50 uma matéria-prima cotada na Itália a US\$ 1,10 (Cacex apud Pacheco, 1978, pp. 103-104). O governo fiscaliza tais operações, mas nada pode fazer, já que os laboratórios podem justificar esses preços dizendo que eles se devem a dificuldades técnicas internas à empresa ${ }^{8}$.

Outras maneiras de escamotear as remessas de lucros são as compras de serviços técnicos, que as subsidiárias realizam junto às suas respectivas matrizes; e também os royalties, pois que as subsidiárias devem pagar, às suas matrizes, os direitos de utilização das tecnologias e medicamentos patenteados no exterior. Desde o período precedente, a legislação brasileira não prevê patentes para medicamentos, mas, ainda assim, o pagamento de royalties, associados a tecnologias patenteadas em outros países, vai reforçar a sangria a que estavam submetidas as filiais brasileiras. Em 1960, o Brasil pagou US\$ 21 milhões em royalties, dos quais a indústria farmacêutica foi responsável por mais de US\$ 6 milhões, o que perfaz 28,5\% (Sumoc apud Pacheco, 1968, p. 66).

Quando a ciência se autonomiza, os laboratórios mais bem posicionados são aqueles que podem chegar, em tempos acelerados, a novas e sucessivas descobertas.

[...] o que realmente torna a indústria farmacêutica uma indústria de inovação é que esta inovação é a variável estratégica por excelência [...] Na realidade, é através da inovação que os laboratórios se fazem concorrência. Não inovar significa desaparecer rapidamente do mercado e ceder o lugar aos concorrentes (Dupuy e Karsenty, 1974, 1979, p. 67).

Com isso, um novo tempo se instaura. As empresas multinacionais se dedicam à renovação frenética das linhas de medicamentos ${ }^{9}$. Como os conhecimentos farmacológicos

\footnotetext{
${ }^{8}$ Diz Mônica Arroyo (2001, p. 73) que a intensificação das relações financeiras internacionais intragrupo tem como uma de suas principais implicações o pagamento dos chamados preços de transferência.

${ }^{9}$ Frenkel e colaboradores (1978) dizem que a inovação foi o motor do setor farmacêutico no período que vai do fim da segunda guerra mundial até meados da década de 1960.
} 
eram escassos, tratava-se, muita vez, de abrir caminhos pioneiros. Assim, podiam-se realizar, em poucos anos, avanços revolucionários em relação a terapias antigas. Noutras vezes, encontravam-se drogas destinadas a doenças então sem tratamento. É por tais fenômenos, e por seus efeitos mercadologicamente concentradores, que Carlos Augusto Gadelha diz que, desde os anos 1930, a indústria farmacêutica desenvolve-se como "um oligopólio de base científica, assentado na diferenciação de produtos" (Gadelha, 1990, p. $55)$.

Os tempos são portentosamente contraídos. A química sintética permite essa aceleração, de modo que, desde a pesquisa até a produção final, lapsos de tempo cada vez menores possam ocorrer. Afastamo-nos do velho ritmo de invenção, que pode ser expressado pela história da penicilina, identificada em 1928, mas cuja produção industrial só se realiza na década de 1950. Agora, neste período científico, as inovações se sucedem com desafiadora ligeireza. No final dos anos 1960, 50\% dos médicos tinham-se formado numa época em que $90 \%$ das drogas ainda não tinham sido descobertas (Walsh apud Gadelha, 1990, pp. 58-59).

Essa aluvião de medicamentos modernos vai conduzir à desvalorização das terapias antigas, agora vistas como sinais de épocas menos esclarecidas ${ }^{10}$. $E$ as primeiras produções a serem afetadas são, justamente, aquelas baseadas em plantas, ervas, produtos minerais ${ }^{11}$. Aos poucos, dissemina-se a ilusão de uma ciência todo-poderosa, posta a serviço do bem-estar geral. Esconsamente, porém, realizam-se acumulações de capital desumanamente gigantescas ${ }^{12}$; e se degradam, para os países periféricos, suas condições de uma evolução espacial livre e auto-centrada.

Ao mesmo tempo, esse frenesi farmacêutico vai possibilitar a prática de altos preços ao consumidor, já que, não raro, faltavam os critérios para julgar da justiça dos preços cobrados. "[...] certas empresas criaram novos produtos farmacêuticos que consistem apenas no medicamento antigo acrescido de um elemento realmente novo na fórmula" (Pacheco, 1968, p. 99) ${ }^{13}$.

Eram muito elevados os custos referentes às pesquisas em química sintética. Apenas os laboratórios estrangeiros a elas podiam dedicar-se. Mas os laboratórios

\footnotetext{
${ }^{10}$ Segundo Bruno Latour, a instauração do pensamento e da sociedade modernos implicou a criação de um tempo pretérito obscuro e confuso (Latour, 1991, 1997). "Nada é moderno sem ter sentido a beleza dessa aurora, sem ter vibrado com suas promessas” (p. 54).

11 "Com o desenvolvimento da indústria farmoquímica, de fato muitas das doenças incuráveis ou de difícil tratamento passaram a ser tratadas com sucesso e, obviamente, criou-se uma enorme expectativa que naturalmente marginalizou a terapia natural” (Fonte, 2004, p. 52).

${ }^{12}$ No limite, chega-se ao fenômeno identificado por Habermas: a técnica e a ciência como ideologia. Enquanto o sistema social fica determinado pela acumulação capitalista, difunde-se a idéia de que ele é conduzido pela lógica do progresso técnico e científico (Habermas, 1968, 1973, p. 45).

13 "Deve-se notar [...] que não há necessariamente correlação entre o preço comercial de um objeto técnico e sua qualidade elementar [...] nesse sentido, pode-se dizer que o valor técnico é bastante independente do valor econômico e pode ser apreciado segundo critérios independentes” (Simondon, 1958, 1969, pp. 75-76).
} 
nacionais tinham que adotar alguma tática para diminuir sua nova condição marginal. Começam a realizar, então, aquilo que Sérgio Queiroz e Aléxis González chamaram de pesquisa galênica, ou seja, uma pesquisa que leva à feitura de novas apresentações, sem que se alterem as constituições químicas dos produtos (Queiroz e González, 2001, p. 126). José Gomes Temporão nos ensina que a indústria farmacêutica brasileira realizava tão-somente as últimas etapas de produção, dispensando maiores atenções à diferenciação mercadológica dos produtos; com isso, o mercado brasileiro se cumula de medicamentos, resultantes de várias pseudo-inovações: nova tecnologia de acondicionamento; modificação da quantidade oferecida em cada embalagem; nova dosagem; nova forma de apresentação; nova fórmula composta de princípios ativos já conhecidos; nova marca, cópia de produto já existente no mercado (Temporão, 1986) ${ }^{14}$.

As multinacionais esparramam seus produtos em vários países, e empresas locais tratam de copiar essas novidades. Os diversos mercados nacionais se assemelham, o que provoca, forçosamente, profundas revoluções no consumo ${ }^{15}$.

Um sistema de necessidades vai-se constituindo, confundindo-se com as fronteiras nacionais, moldando-se conforme os ritmos e desígnios científicos dos grandes laboratórios farmacêuticos ${ }^{16}$. Demais, cresce o poder de penetração da psicoesfera emergente, em que as técnicas e conhecimentos científicos tendem a ser pensadas como a única modalidade terapêutica plausível.

\section{Os fenômenos de concentração}

Neste período científico, o país assimila uma certa política farmacêutica, realizada em moldes capitalistas.

Em conseqüência, surgem concentrações espaciais difíceis de reparar. Como a lógica da atividade prendeu-se aos vetores mundiais, somente alguns lugares, permitindo rápida ligação com o estrangeiro, são selecionados pelas empresas dominantes. E, como a política farmacêutica ganhou uma cara mercantil, tornou-se tributária de outras concentrações: bancos, canais de circulação, empresas de propaganda. Por isso, São Paulo

\footnotetext{
14 “Em junho de 1976 o número total de formas de apresentação postas à venda somava 11 300, correspondendo a 3496 medicamentos originais e 3659 similares” (Frenkel et alii, 1978, p. 112). “[...] a evolução do setor farmacêutico no após-guerra demonstrou que a maior parte dos produtos lançados no mercado representam cópias das características químicas ou terapêuticas de produtos já existentes”. (p. 138)

15 "De 1945-1950 em diante, o aprofundamento do capital já não mais se baseia unicamente na dependência de modelos de produção. Modelos de consumo, muito mais rapidamente difundíveis, também contribuem efetivamente para a penetração do capital e trazem os mesmos resultados, porque carregam em seu bojo os novos modelos de produção" (Santos, 1979, 2003, p. 16).

16 “[...] o sistema funcional em que as novas forças produtivas se inserem não é nem local nem regional, nem tampouco nacional. Tendo-se tornado internacional, é a lógica das firmas multinacionais que esse sistema obedece” (Santos, 1982, 2004, p. 22).
} 
desponta como a cidade mais dinâmica. De feito, essa cidade aparece, depois da segunda guerra mundial, como alvo principal das modernizações, o que se expressa desde os acréscimos de população ${ }^{17}$ até os impulsos de uma renovação econômica ${ }^{18}$. Tais são as bases de uma nova atratividade paulista, refletindo-se também na produção de medicamentos.

tabela II.1. Algumas empresas estrangeiras instaladas no período científico: Brasil, 1952-1954

\begin{tabular}{|c|c|c|c|c|}
\hline Empresa & País de origem & Fundação & Chegada ao Brasil (a) & Lugar de instalação \\
\hline Merck Sharp \& Dohme & Estados Unidos & 1788 & 1952 & Rio de Janeiro-RJ \\
\hline Pfizer & Estados Unidos & 1849 (b) & 1952 & Guarulhos-SP \\
\hline Boehringer & Alemanha & 1885 & 1953 & São Paulo-SP \\
\hline Altana Pharma & Alemanha & 1873 & 1954 & Rio de Janeiro-RJ \\
\hline
\end{tabular}

(a) consultar a nota 15 no capítulo I

(b) ano de fundação na Europa; durante a segunda guerra mundial, a Pfizer foi nacionalizada pelos Estados Unidos

Com o mapa II.1, pretendemos figurar esse novo destaque do território paulista. Veja-se como os ritmos de criação de laboratórios foram geralmente reduzidos em relação ao período técnico, mas dizem respeito, sobretudo, aos estados mais alheios às novas dinâmicas modernizadoras. São Paulo encabeça o processo de instalação de empresas, no que é seguido pelo Rio de Janeiro, Minas Gerais e o Rio Grande do Sul. Para os demais estados, retrocede-se às taxas verificadas no começo do século, ou então se verificam taxas nulas. Queremos destacar, nesse mapa II.1, a inflexão trazida por este período científico. A dispersão já não se mostra como regra, sendo sufocada, antes, por movimentos concentradores.

\footnotetext{
${ }^{17}$ A partir do decênio 1940-1950, o incremento demográfico da cidade de São Paulo, em números absolutos, é maior que o da cidade do Rio de Janeiro (Santos, 1993, 2005a, pp. 85-86).

${ }^{18}$ Diz Adriana Bernardes (Bernardes, 2001, p. 42) que, no pós-segunda guerra, São Paulo abriga os "vetores que anunciam a globalização”: a grande indústria, a tecnociência, os negócios internacionais.
} 
No capítulo precedente, vimos que as empresas européias predominaram durante o período técnico. Antes de 1940, havia no Brasil 10 laboratórios europeus e 3 estadunidenses (G. Oliveira apud Pereira, 2002, p. 10). Agora, as empresas européias se instalam com mais raridade, fosse porque já se encontravam instaladas, fosse por conta dos óbices econômicos enfrentados pelos países europeus depois da guerra. Alguns exemplos de instalação: o italiano Carlo Erba (instalado em 1950), o inglês Wellcome (em 1955).

Como reflexo da nova primazia mundial dos Estados Unidos, são muito mais numerosos os laboratórios que provêm desse país. Exemplos: Squibb (chegando em 1953); Upjohn (em 1954); Cyanamid (1955); Parke-Davis (1955); Syntex (1957); R. Merrel (1958); Searle (1959); Ayerst (1960); Mead-Johnson (1961); Eli Lilly (1962); ICN (1971); Smith Kline \& French (1973). "[...] das 20 maiores firmas americanas atuantes no Brasil até 1975, 14 entraram após 1945 [...]" (Frenkel et alii apud Gadelha, 1990, pp. 182-183).

Em termos científicos, o trunfo dessas empresas estadunidenses, a base de sua marcha mundial, foi o domínio das técnicas produtivas de antibióticos ${ }^{19}$. "[...] $64 \%$ das novas drogas introduzidas no período 1940-1975 se originaram nos EUA, e foi daí que se difundiram a maioria dos novos medicamentos, inclusive os antibióticos" (Frenkel et alii, 1978, p. 49).

Segundo Carlos Augusto Gadelha, a produção dessa classe de medicamentos começa em 1941 (Gadelha, 1990, p. 63). Das 14 firmas estadunidenses que chegam ao Brasil depois de 1945, pelo menos 7 lideravam a pesquisa e a produção de antibióticos: Wyeth, Squibb, Lederle, Park-Davis, Mead-Johnson, Eli Lilly e Pfizer (Frenkel et alii apud Gadelha, 1990, p. 221).

E o mercado brasileiro de antibióticos evolui de maneira tão célere quanto o avanço das pesquisas ${ }^{20}$.

Efeitos concentradores também se manifestam se passamos a uma análise mais estritamente mercadológica. Em 1950, os laboratórios estrangeiros detinham 47,1\% do mercado farmacêutico brasileiro, proporção que ascende a 73,3\% em 1960, passando em seguida a 77,7\% em 1970, e a 82,7\% em 1980 (Codetec apud Gadelha, 1990, p. 195).

\footnotetext{
${ }^{19}$ As mudanças da indústria farmacêutica nacional, na década de 1950, devem-se sobretudo à introdução da classe dos antibióticos, realizada sobretudo pelos laboratórios estadunidenses (Gadelha, 1990, pp. 220-221). “[...] foi a classe que liderou as inovações no pós-guerra [...]” (Gadelha, 1987, p. 7).

20 Já em 1974, os antibióticos formavam a classe de medicamentos mais vendida no Brasil, representando 19,2\% das vendas; em segundo lugar, estavam as vitaminas e multivitaminas, com 8,2\%, e depois os hormônios e corticosteróides, com 5,6\% (IMS apud Frenkel et alii, 1978, p. 100).
} 
Apesar da maior dinâmica apresentada pelas empresas estadunidenses, ainda eram as européias que prevaleciam no mercado, mas com pequena vantagem ${ }^{21}$.

Pela ação dos laboratórios estrangeiros, a produção de medicamentos, em território brasileiro, é portentosamente reforçada. Entre 1950 e 1970, ela foi quase sextuplicada; nesse lapso de tempo, o Brasil adquire, em matéria de faturamento das empresas, o primeiro lugar na América Latina e o sétimo lugar no mundo (Gadelha, 1990, p. 186). Com isso, puderam cair espantosamente os índices de importação. Entre 1953 e 1960, a participação das importações no consumo de medicamentos no Brasil passou de 70\% para 2\%, patamar que se conserva até a década de 1980 (González, 1999, p. 23).

Se antes podia haver uma coexistência de grandes e pequenas empresas, agora, pelo contrário, fenômenos predatórios se patenteiam. "O período entre 1957 e 1979 se caracterizou pela absorção dos grandes laboratórios nacionais por grupos estrangeiros" (Pereira, 2002, p. 11). Segundo Maria Carlota Paula, se consideramos a fase que vai desde o fim da segunda guerra mundial até 1982, temos que 38 laboratórios nacionais foram adquiridos por empresas estrangeiras, sendo que, deles, 20 foram comprados por empresas dos Estados Unidos (Paula, 1991, p. 218).

tabela II.2. Número de empresas brasileiras negociadas, segundo proveniência dos grupos adquirentes : Brasil, 1958 - 1972

\begin{tabular}{|c|c|c|}
\cline { 2 - 3 } \multicolumn{1}{c|}{} & \multicolumn{2}{c|}{ Empresas negociadas } \\
\hline Proveniência & N & \% \\
\hline Estados Unidos & 17 & 39,5 \\
\hline Europa & 17 & 39,5 \\
\hline Brasil & 8 & 18,7 \\
\hline América Latina & 1 & 2,3 \\
\hline TOTAL & 43 & 100,0 \\
\hline
\end{tabular}

fonte : CEME, Plano diretor de medicamentos, 1 fase, Brasília, 1973 apud Cordeiro, 1980

Uma infra-estrutura de produção instalada, um conhecimento do mercado local, e porventura também uma estrutura de distribuição, passam, com essas manobras, às mãos de agentes internacionais. É preciso relembrar que essas compras não eram fruto do acaso;

\footnotetext{
${ }^{21}$ Em 1962, os laboratórios europeus detinham 38\% do mercado farmacêutico brasileiro, proporção que ascende a 46\% em 1975; para os laboratórios estadunidenses, essas proporções foram de 36\% e 42\%; para os laboratórios
} 
muito pelo contrário, os laboratórios vendidos foram aqueles que, entrementes, apareciam no rol das maiores empresas farmacêuticas do Brasil.

Além disso, a Sumoc, Superintendência da Moeda e do Crédito faz publicar duas resoluções que facilitam a ação das empresas estrangeiras. De 1953 a 1961 vigorou a instrução 70, que reduzia as alíquotas de importação dos insumos e produtos farmacêuticos. A instrução 113, que valeu de 1955 a 1961, facilitou a importação de equipamentos, também através de isenções cambiais.

Analisando esses fenômenos, muitos autores falaram numa desnacionalização da indústria farmacêutica brasileira, explicação que se tornou, de certo modo, clássica. Por esse caminho, seguiram Frenkel e colaboradores (1978, pp. 71-73), Hésio Cordeiro (1980, pp. 120-121), Geraldo Giovanni (1980, pp. 59-62), Carlos Augusto Gadelha (1990, p. 183 e 194-197), entre outros.

Mas, o termo desnacionalização nos parece muito categórico. Conforme diz Carlos Augusto Gadelha, mesmo em face dessa situação, muitas empresas nacionais, a despeito de sua modéstia, mostravam-se, nos meados da década de 1960, bastante estáveis, com grandes perspectivas de sobrevivência. Demais, as pequenas firmas brasileiras demonstraram surpreendente astúcia competitiva, por vezes antecipando-se às estrangeiras no lançamento de algumas inovações. Um exemplo disso foi a pílula contra o cigarro, lançada pioneiramente por uma pequena empresa nacional (Gadelha, 1990, p. 118).

O termo desnacionalização parece, portanto, muito forte. Pois ele confere pouco destaque ao fato de que, mais do que um furto da atividade, por parte dos laboratórios estrangeiros, realizou-se um reordenamento sócio-espacial, no qual as empresas brasileiras se tornaram subordinadas, e no qual, também, as próprias necessidades das populações começaram a depender da ação desses agentes hegemônicos. Peter Evans se aproxima dessa análise, ao falar em marginalização e dependência, mas dela se afasta, pois também perfilha a tese da desnacionalização (Evans, 1979, 1980, pp. 112-122) ${ }^{22}$.

As atividades farmacêuticas são, realmente, submetidas a desígnios estrangeiros. Não é possível, porém, desprezar a permanência de uma quantidade maciça de empresas nacionais. Em 1974, o balanço industrial verifica a existência de 460 laboratórios nacionais, ao passo que os estrangeiros eram em número de 69 (Hésio Cordeiro apud Pereira, 2002, p. 11). Talvez, melhor que falar em desnacionalização da indústria farmacêutica, como um todo, seja falar em desnacionalização do mercado; pois que as lógicas deste começam a ser regidas, crescentemente, pelas empresas multinacionais, mas, ainda assim, à atividade se

\footnotetext{
nacionais, de $26 \%$ e $12 \%$ (Frenkel et alii, 1978, p. 76).

${ }^{22}$ No mais, a noção de dependência pode vir, aqui, menos de uma precisão de análise do que uma repercussão teórica, já que, nos 1970, ao final dos quais Evans escrevia, o conceito de dependência foi largamente usado pelas ciências sociais brasileiras.
} 
podiam dedicar várias empresas nacionais, cujas lógicas e existências não podemos desprezar sem mais considerações.

Ao mesmo tempo, começam a realizar-se grandes projetos que visavam promover uma integração territorial nacional mais expressiva ${ }^{23}$. Esse fenômeno corre paralelo ao desenvolvimento das mídias: jornais, televisão, rádio.

Outro evento que se deve sublinhar é a criação, em 1952, do BNDE, Banco Nacional de Desenvolvimento Econômico. No que toca à produção de medicamentos, o banco exercerá no futuro um papel destacado, como se verá nos próximos capítulos.

Com tudo isso, um mercado nacionalmente constituído pode emergir aos poucos. Facilitados os fluxos, aceleradas as relações, já se podem realizar atividades econômicas com escalas mais largas ${ }^{24}$.

O governo militar introduziu mudanças cruciais no controle das produções farmacêuticas. No momento imediatamente anterior à sua instalação, o governo federal realizava duas verificações principais. Por um lado, tinha criado, em 1963, o Geifar, Grupo Executivo para a Indústria Farmacêutica, cuja atividade principal era justamente o controle dos preços ao consumidor. Por outro lado, fiscalizava, por meio da Cacex, Carteira de Comércio Exterior, as contas de importação de matérias-primas, o que reduzia as possibilidades de superfaturamento. Com o golpe militar, ambos os controles foram abolidos, e o Geifar chegou mesmo a ser extinto. "Naquele momento, uma política voltada para a indústria farmacêutica nacional e para interesses sociais ficou definitivamente comprometida, dadas as alianças com os interesses estrangeiros e as diretrizes da política econômica que se passou a implementar" (Paula, 1991, p. 242). Uma inflexão que se transmite a todo o sistema de atenção à saúde ${ }^{25}$.

A nova submissão das lógicas econômicas aos processos mundiais não se expressa de modo exclusivo na produção direta; ela se verifica, também, numa divisão internacional do trabalho muito mais polarizada e rígida. De acordo com Maria Carlota Paula (1991), as

\footnotetext{
${ }^{23}$ Segundo Milton Santos e María Laura Silveira, a expansão das rodovias, o desenvolvimento do transporte aéreo, a expansão e especialização dos portos, marcam, já desde os anos 1950, a reconfiguração do território (pp. 57-62), renovando aquilo que os mesmos autores chamam de sistemas de movimento (Santos e Silveira, 2001, 2004, p. 21).

${ }^{24}$ Depois da segunda guerra, a unificação do território e a unificação do mercado são dois processos que correm paralelos e solidários (Santos e Silveira, 2001, 2004, pp. 252-253).

${ }^{25}$ Segundo Eliza Almeida, as políticas de saúde, com o governo militar, deixam de revelar a preocupação que vinha tendo, no início dos anos 1960, com a medicina preventiva, para acentuar a medicina curativa, baseada na prestação de serviços particulares, sobretudo hospitais particulares, por vezes remunerados com recursos do Estado. Além disso, esses serviços estavam bastante mal distribuídos pelo território nacional (Almeida, 2005, pp. 99-105).
} 
grandes empresas concentram suas etapas cruciais e espalham pelo mundo apenas aquelas etapas, finais, menos estratégicas ${ }^{26}$.

As empresas estrangeiras tinham que estar sensíveis ao clima social e político de cada país. A centralização de fazimentos estratégicos era, para elas, essencial num período em que a situação política mundial não tinha superado por completo as indecisões e incertezas da guerra. Doreen Massey ressalta que, para as atividades químicas, a centralização das pesquisas básicas derivou de receios políticos. "Acima de tudo, ela é uma resposta à localização das matérias-primas, de um lado, e a relações políticas entre as companhias e os Estados, e entre diferentes Estados, de outro lado. O temor da nacionalização de uma série de produtos vistos como 'estratégicos' e requerendo altos níveis de investimento de capital para sua produção, conta decisivamente" (Massey, 1984, 1987, p. 84).

Desses novos arranjos espaciais surdem os novos poderes de um limitado grupo de agentes. Ao mesmo tempo, resultados espaciais inéditos se manifestam. O principal deles foi a deterioração das diferenças entre os vários territórios nacionais ${ }^{27}$. Assim como surgem dois grupos de laboratórios, os inovadores e os não-inovadores, a mesma desigualdade se reproduz quanto aos países, sendo pouco numerosos os países de que provêm as inovações.

Nos países periféricos, os tempos e as características do mercado farmacêutico passam a estar subordinados, em largas medidas, às pesquisas estrangeiras. Em 1974, 90\% das drogas lançadas no mercado farmacêutico brasileiro decorreram de pesquisas realizadas no exterior (Hésio Cordeiro apud Pereira, 2002, p. 11). Nesse mesmo ano, 50\% dos fármacos utilizados foram importados (Hésio Cordeiro apud Pereira, 2002, p. 11), o que denota uma dependência que se estende às matérias-primas.

Pode-se dizer que, em função das operações dos laboratórios estrangeiros, os circuitos espaciais de produção se alargam, o que implica novas situações de subordinações para os agentes menos capitalizados. Em face desse condição, os pequenos laboratórios nacionais puderam subsistir refugiando-se nas produções de medicamentos à base de plantas, bem como nas produções de similares, ou seja, cópias de fórmulas inovadoras.

Para os agentes menos capitalizados, as escalas de possibilidade se estreitam. Se antes era possível criar fórmulas terapêuticas localmente, ou mesmo reproduzir fórmulas

\footnotetext{
${ }^{26}$ Estudando os grupos farmacêuticos franceses, Fernadez e Pilinski (1983) escreveram: "Não há um esquema único relativo à importância do território francês na estratégia desses grupos, mas há uma constante: a pesquisa e a produção de princípios ativos se realiza principalmente na França”.

27 "[...] a investigação capital-intensiva (assente em instrumentos caros e raros) tornou impossível o livre acesso ao equipamento, o que contribuiu para o aprofundamento do fosso, em termos de desenvolvimento científico e tecnológico, entre os países centrais e os países periféricos” (Sousa Santos, Boaventura. 1985, 1995, p. 35).
} 
consagradas nos lugares, agora mais nada parece ter precedência que não seja aprovado pela ciência mundializada, com base em sofisticadas pesquisas ${ }^{28}$. Uma lógica mundial de investigação e produção toma de assalto as atividades farmacêuticas, bem como vários elementos do sistema de atenção à saúde. Conforme Eliza Almeida (2005), os serviços de saúde, começam a incorporar, depois da guerra, conteúdos em técnica e ciência; o conhecimento médico também se tecnifica, passando por sucessivas especializações; e o hospital aparece como símbolo máximo desse processo. (pp. 75-86) "É importante lembrar que essa incorporação técnica irá consolidar a entrada de empresas multinacionais ligadas aos serviços médico-hospitalares" (Almeida, 2005, p. 78) ${ }^{29}$.

Ao longo deste período, a variável-força, isto é, a ciência, perde proteção jurídica. Em 1945, o Decreto-Lei 7093 recusa patenteabilidade aos processos para obtenção de medicamentos. Medida que, na interpretação de Maria Aparecida Pereira, fazia "parte da política de desenvolvimentismo nacionalista desenvolvida por Getúlio Vargas" (Pereira, 2002, p. 10) ${ }^{30}$. Em 1969, a lei de propriedade industrial mantém o não-patenteamento de processos, e deixa de reconhecer também as patentes para produtos acabados. Em 1971, o Código Nacional de Propriedade Industrial, através da lei 5772, de 21 de dezembro, regulamenta a lei de 1969. Apesar disso, os conhecimentos científicos, atrelados já ao processo de acumulação capitalista, possuía, por assim dizer, mecanismos de auto-defesa. Pois as pesquisas, como também as técnicas de similaridade, exigiam grandes aportes de capital, impossíveis para a maioria das empresas nacionais. Neste particular, é precisa a análise de Carlos Augusto Gadelha, dizendo que o ponto central não era a legislação de propriedade intelectual, mas sim o domínio técnico e científico; assim, as multinacionais, mesmo sem contar com patentes no Brasil, dominavam o mercado (pp. 203-204). "Sempre há vantagens em lançar um novo produto no mercado à frente das concorrentes ao se dispor de uma fonte de matérias-primas intra-firma. O não-patenteamento não reduz o período de monopólio da produção do novo produto a zero. Além do mais, mesmo sendo este período mais curto, é suficiente para que a poderosa estrutura de 'marketing' das empresas multinacionais garanta a difusão do novo produto junto aos médicos e consumidores com a sua marca comercial, garantindo sua liderança no mercado" (Gadelha, 1990, p. 204).

\footnotetext{
28 “[...] a pesquisa constitui um dos pilares das grandes firmas industriais internacionais. Como vimos, é por intermédio dos progressos tecnológicos assim obtidos que os monopólios e as corporações afirmam seu poderio sobre as outras firmas e sobre os países menos desenvolvidos" (Santos, 1979, 2004, p. 119).

${ }^{29}$ A expansão da indústria de equipamentos médico-hospitalares, a partir dos anos 1960, é típica desses processos havidos nesta fase. (Almeida, 2005, pp. 118-119)

${ }^{30}$ Sobre este ponto, Hilda Salomé Pereira escreve: "O não reconhecimento das patentes de medicamentos em 1945 tentava equilibrar o poder de competição das indústrias nacionais, que por não terem a capacidade de inovar das estrangeiras, ficavam em posição desigual perante estas” (Pereira, H. 1992, p. 75).
} 
O sistema oficial de saúde vai também sofrendo mudanças. Amélia Cohn nos relata as evoluções dos serviços previdenciários. Em 1966, os vários institutos de previdência são unificados sob a forma do INPS, o que acirra o perfil assistencialista do regime, mais que nunca baseado na assistência médica, e não mais nas aposentadorias e pensões. Os serviços, sobretudo de assistência médica, são oferecidos preferencialmente aos trabalhadores urbanos, e os empregados nos "setores de ponta" (p. 20) recebem-nos em condições melhores. Os trabalhadores perdem, com isso, uma luta que vinham travando desde os anos 1950, num esforço para ficar mais próximos do controle dos institutos (Cohn, 1996, pp. 18-19). A criação do INPS, expandindo as coberturas previdenciárias com base na assistência médica, vai reforçar as demandas por medicamentos ${ }^{31}$.

Quando se inicia o período, poucos fundamentos possuíamos para falar num circuito superior marginal, pois que, naquele momento, uma desintegração nacional, reforçada pela manutenção de mercados locais de bastante coerência interna, obstruía a formação de lógicas totalizantes. Sem estas, com efeito, os circuitos econômicos não podem surgir, já que eles são, fundamentalmente, produtos de hierarquizações espaciais, manifestadas em formações socioespaciais concretas. Mas, conforme o território vai ganhando em fluidez, permitindo ações e relações mais largas, diferenciando os agentes a partir de critérios uniformes, podemos então constatar a constituição gradual dos circuitos econômicos urbanos.

A situação é diferente daquela do passado, onde as ações de um nível inferior não eram obrigatoriamente hegemonizadas. Agora há uma clara hierarquia daquelas ações que se instalam em objetos igualmente hierarquizados. Mas esse processo não é técnico; ele é histórico (Santos, 1996, 2002, p. 222).

Fundamentalmente, assistimos a uma totalização temporal. Pois que, doravante, a pertinência das temporalidades locais é gravemente ameaçada pelo avanço de um tempo despótico ditado pelas empresas mundiais, no curso do lépido arrastão que promoviam. Graças à ciência, coroada como variável-força, pôde-se impor uma correria geral, os laboratórios multinacionais em busca de novas moléculas, os laboratórios nacionais mais capitalizados ávidos em copiar rapidamente essas invenções, e os outros laboratórios nacionais, com poucos recursos estratégicos, transidos e estupefatos perante esse alvoroço tão racional. Desenha-se uma hierarquia, que ainda carece de solidez, mas que já nos

\footnotetext{
31 “[...] dentro da ótica do paciente a qualidade da assistência médica prestada estará, no geral, subordinada a realização de exames e a prescrição de medicamentos. A criação do INPS fortalecerá essa prática médica de cunho predominantemente tecnológico, calcada no hospital, e escandalosamente entrelaçada com a expansão da indústria de equipamentos médicos-hospitalares, da indústria farmacêutica e das empresas de medicina privada e com o setor financeiro” (Almeida, 2005, p. 85).
} 
autoriza a captar a existência de um circuito superior marginal. Este, por enquanto, mistura-se de maneira quase automática à idéia de produção nacional. Pois, neste período científico, apenas os laboratórios multinacionais conseguem nutrir a existência de um verdadeiro circuito superior ${ }^{32}$.

Essa unificação tem fortes repercussões espaciais: os laboratórios agora têm escalas de ação distintas; surgem diferentes usos do território; as velocidades e formas de acesso às inovações são desiguais; a localização no território torna-se decisiva, pois as densidades diferentes definem estratégias particulares.

Ao longo da década de 1970, fenômenos inéditos, combinando-se com as evoluções anteriores, desenham novos sistemas, tornando possível a identificação de um novo período.

\footnotetext{
${ }^{32}$ Peter Evans apercebe-se do processo de hierarquização, dizendo que, de um lado, posicionam-se as empresas estrangeiras com sua capacidade de "inovação industrial ou tecnológica"; de outro, as empresas nacionais com sua "habilidade comercial” (Evans, 1979, 1980, p. 121).
} 
III

A informação e a produção de medicamentos

A revolução informacional

Segundo Max Pagès, a internacionalização das empresas passa por três fases: 1. as filiais apenas importam os materiais produzidos pela matriz; 2. as filiais começam a se incumbir de algumas fases da produção; 3. as filiais realizam a maior parte da produção, tendo inclusive alguma autonomia para certas questões (Pagès, 1978, 1984, pp. 43-44). Essa divisão corresponde, mais ou menos, aos nossos períodos técnico, científico e informacional.

Desde os fins do período científico, a topologia de um laboratório multinacional é típica: sediado num lugar de centralização do conhecimento farmacêutico, com unidades fabris dispersas por vários países. Mas, dessa mesma topologia, sobre a qual repousava o poder dos laboratórios multinacionais, começam a surdir, mais tarde, empecilhos e necessidades inéditos. A escala de suas ações, mundialmente alargada, vai exigir planejamentos prévios e refinados, pois, sem fazer atenção às particularidades nacionais, a expansão mundial dessas empresas careceria de eficiência. A questão resultava, pois, de uma intensificação desbragada dos fluxos, ou dos movimentos segundo a terminologia de Kevin Cox. "Movimentos requerem canais [...] Cada movimento pressupõe uma rede de canais de informação por meio da qual o promotor do movimento conhece as oportunidades abertas a ele em diferentes locais [...]" (Cox, 1972, p. 32).

É dessa necessidade de informações precisas, referentes aos diversos lugares do mundo, que as empresas multinacionais começam a padecer. Estamos em face de um fenômeno propriamente geográfico, pois a configuração espacial anterior vai forçando a uma configuração distinta.

E a nova necessidade de informação vai também afetar as atividades farmacêuticas. "Particularmente para os grandes laboratórios multinacionais, são vitais as informações sobre as particularidades da demanda de medicamentos de cada mercado nacional, pois permitem a seleção adequada do portfolio de produtos, gastos com esforços de vendas direcionado e maior eficácia na utilização dos canais de comercialização" (Magalhães et alii, 2003, p. 9).

Como o fenômeno se generaliza, mudando os matizes de produções diversas, os próprios territórios nacionais começam a ser reequipados, pois que, doravante, precisam 
acolher esses novos fluxos imateriais, informacionais ${ }^{1}$. A eles, são apostas várias formas geográficas modernas, filhas daquilo que Jean Lojkine (1992) chamou de a revolução informacional ${ }^{2}$. O resultado é o reforço das lógicas de um mercado que se globaliza.

A união entre ciência e técnica que [...] havia transformado o território brasileiro revigora-se com os novos e portentosos recursos da informação, a partir do período da globalização e sob a égide do mercado. E o mercado, graças exatamente à ciência, à técnica e à informação, torna-se um mercado global (Santos e Silveira, 2001, 2004, p. 52).

Essas três variáveis, com prevalência da informação, mudam o meio geográfico, e é nessa medida que se constitui, ao longo deste período, aquilo que Milton Santos (1994b; 1996, 2002) chamou de meio técnico-científico-informacional.

\section{Informação e produção de medicamentos}

Sob pena de malbaratar grandes oportunidades de lucro, as empresas multinacionais precisam realizar, agora, escolhas muito mais precisas, o que se refere, primordialmente, aos lugares em que devem realizar cada uma de suas operações, sejam elas de pesquisa, de controle ou de produção. Conhecer os lugares, em seus aspectos instrumentais, faz-se uma pré-condição das atividades. "Toda ação corretiva ou de controle passa por um melhor conhecimento dos mecanismos de evolução das cidades" (Dupuy, 1985, p. 47).

Uma circunstância fundamental vem reforçar o processo: uma subitânea queda do ritmo de inovações, por conta da saturação das possibilidades oferecidas pela química sintética. Os laboratórios inovadores, antes ciosos de lançar novas e novas drogas, passam a conhecer dificuldades, chegando a resultados satisfatórios menos freqüentes. Explica-nos Carlos Augusto Gadelha que alguns autores, por exemplo I. E. Schenee, atribuem a queda das inovações ao maior controle exercido pelas agências sanitárias, em decorrência de problemas de saúde causados por alguns medicamentos; com isso, as pesquisas teriam ficado mais custosas e duradouras. (pp. 103-106) Entanto, vários intérpretes, entre eles o próprio Gadelha, dizem que a explicação mais forte é mesmo a redução do potencial de inovação das técnicas sintéticas (Gadelha, 1990, pp. 106-107).

“Após um período de elevado progresso técnico na indústria farmacêutica nos anos 50 em termos da geração de novos produtos, iniciou-se um nítido processo de esgotamento

\footnotetext{
1 "Pode-se mesmo dizer que o território se informatiza mais, e mais depressa, que a economia ou que a sociedade. Sem dúvida, tudo se informatiza, mas no território esse fenômeno é mais marcante, na medida em que o trato do território supõe o uso da informação, que está presente também nos objetos” (Santos, 1989, 2005, p. 121).

${ }^{2}$ A partir dos anos 1970, as inovações informacionais se sucedem, definindo acelerações: telex, fax, serviços de telefonia, informática, fibras ópticas, satélites, telefonia celular (Santos e Silveira, 2001, 2004, pp. 72-73).
} 
do padrão de inovações [...]" (Gadelha, 1990, p. 103). José Gomes Temporão (1986) também detecta a súbita paralisia de inovações a partir dos anos 1970; e também Maria Carlota Paula (1991, p. 221) sublinha, para a mesma fase, tal "queda no ritmo inovativo".

Os dois gráficos seguintes constituem uma tentativa de mostrar o processo de saturação da química sintética.

A eficiência do investimento começa a depender, então, da capacidade de encontrar ou forjar lugares de alta produtividade. Isso requer, previamente, a elaboração e o uso de vastos conteúdos de informação ${ }^{3}$. "A presença de consultores e das fontes de informação (acesso à informação) é fundamental para desenvolvimento da alta tecnologia" (Benko, 1996, p. 134).

Entendemos a informação como uma série de produções imateriais (estatísticas, dados, instruções), necessários ao conhecimento dos quadros legislativos e políticos de cada país, bem como de seus mercados respectivos. "Estaríamos autorizados, por isso, a entender a informação como um recurso, com áreas de abundância e áreas de carências" (Santos e Silveira, 2001, 2004, p. 93).

A informação, passando ao papel de variável central, define mais um passo no rumo da mercantilização das políticas farmacêuticas nacionais. Pois a informação realmente estratégica não correspondente à vida, mas ao mercado. Daí, o aparecimento de cinco fenômenos.

Primeiramente, a dispersão mundial dos laboratórios multinacionais exige a adoção de tecnologias informacionais, para que se teçam redes corporativas solidárias e coesas.

\footnotetext{
3 “Os sistemas produtivos contemporâneos, particularmente aqueles dominados por corporações globais hegemônicas, dependem de conhecimentos estratégicos para que possam recriar permanentemente um cenário mundial de competitividade. A informação, nesse contexto, se define como um recurso tecnológico, utilizado seletiva e hierarquicamente” (Bernardes, 2001, p. 104).
} 


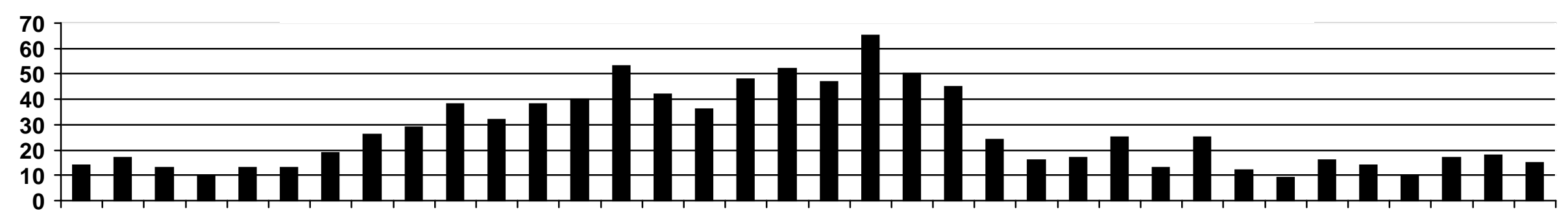

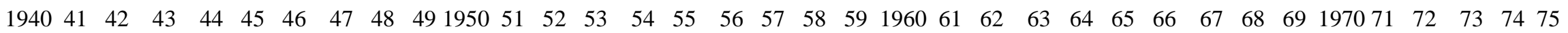

fonte: Pharmacy Times, abril de a976 apud Korolkovas e Burkhalter, 1980, p. 42

\begin{tabular}{|l|}
\hline * Inclui: \\
- \\
princípios ativos novos \\
duplicações (por forma \\
- $\begin{array}{l}\text { produtosentação) } \\
\text { associação de princípios } \\
\text { ativos) }\end{array}$ \\
novas dosagens \\
\hline
\end{tabular}

Novos produtos* lançados no mercado: Estados Unidos, 1950-1975

fonte: elaboração própria, com dados de J. L. Katz apud Gadelha, 1990, p. 104 
Segundamente, as produções farmacêuticas são afetadas por esta atividade bem típica de um período informacional: a consultoria ${ }^{4}$. Chegam a surgir consultorias especializadas em produções farmacêuticas, dentre as quais podemos destacar, sem dúvida, o IMS Health. Em 2002, Vicente Vilardaga pôde escrever: "Atualmente, o IMSHealth divide o País em 1,39 mil pequenas partes e tem condições de saber a participação de mercado de cada laboratório, classe terapêutica e medicamentos em todas elas. Nos próximos dois anos [...], a divisão será ampliada para 12 mil microrregiões, por onde estão espalhadas as cerca de 55 mil farmácias do País" (Vilardaga, 2002, p. C2). Aos poucos, o IMS Health torna-se uma fonte oficiosa de informações, vastamente usada pelas empresas, mas também por uma série de estudos governamentais. Isso apesar de a empresa levar em conta, em suas análises, apenas as vendas de medicamentos no varejo, desprezando, por exemplo, as compras governamentais ${ }^{5}$.

Em terceiro lugar, os laboratórios fazem largos usos de serviços altamente qualificados. Trata-se, primeiro, de acolher uma gama larga de profissionais incumbidos da realização de pesquisas cada vez mais sofisticadas, as quais fazem aumentar os conteúdos científicos e informacionais dos medicamentos ${ }^{6}$.

Em quarto lugar, produzir medicamentos pode implicar, agora, usos intensivos de novas tecnologias computacionais. O primeiro registro do uso de recursos da informática para o desenvolvimento de uma droga terapêutica data de 1984. Nesse ano, pelo uso de um programa de computador, pôde-se desenvolver a primeira droga para combater os sintomas da Aids, o AZT. Ao final dos anos 1990, já se utilizavam recursos de computação gráfica para desenvolver novos medicamentos. A partir de uma análise de imagens, tenta-se encontrar uma molécula que se encaixa na estrutura do vírus ou da bactéria causadora da doença. Assim, constituem-se bancos de imagens, contendo várias moléculas.

Um quinto fenômeno é que os laboratórios recorrem aos serviços do chamado setor terciário superior, ou quaternário ${ }^{7}$, seja pela contratação de empresas especializadas, seja

\footnotetext{
4 “[...] o forte crescimento das empresas de consultoria, sobretudo a partir dos países anglo-saxões, na década de 1970, foi uma resposta às exigências de empresas globais que não mais sobrevivem sem informações especializadas voltadas à gestão” (Bernardes, 2001, 2004, p. 420).

5 “Apesar dos possíveis vieses, é [a empresa IMS] uma fonte de informações reconhecida pela indústria, e, o que é mais importante, intensamente utilizada pelas empresas na avaliação do seu desempenho relativo e no planejamento comercial e de marketing” (Frenkel, 2001, p. 158).

${ }^{6}$ Nos fins da década de 1990, estes eram os principais especialistas atuando em pesquisa farmacêutica: químicos analistas, bacteriologistas, bioquímicos, engenheiros bioeletrônicos, biólogos, botânicos, biólogos celulares, engenheiros químicos, embriologistas, endocrinologistas, entomologistas, enzimologistas, imunologistas, hematólogos, matemáticos, micólogos, microbiologistas, especialistas em química orgânica, parasitólogos, patologistas, físicos, fisiologistas, psicólogos, químicos especializados em proteínas, médicos, farmacologistas, psiquiatras, farmacêuticos, químicos físicos, nutricionistas, analistas de radioatividade, sorologistas, estatísticos, químicos especialistas em síntese, veterinários, virologistas (Rigoni et alii apud Queiroz e González, 2001, p. 124).

${ }^{7}$ Adriana Bernardes ensina que a categoria de setor quaternário foi proposta por M. Porat, em 1976 (Bernardes, 2001, pp. 94-95).
} 
pela internalização de semelhantes atividades. Podemos citar a situação da Microstrategy, grande fornecedor mundial da chamada Business Intelligence, isto é, serviços informacionais que permitem acompanhar as vendas e facilitar o planejamento corporativo. Essa empresa possui, no rol de seus clientes, vários laboratórios multinacionais: AstraZeneca, Aventis Pasteur, Hoffman-La Roche, GlaxoSmithkline, Novartis, Pfizer, Pharmacia, Roche (Guimarães, 2003, p. ti2). Mas é preciso destacar também as atividades de marketing, pois, num mercado composto por linhas extensas de medicamentos e um grande rol de marcas, a propaganda se faz essencial. Segundo Gadelha, a queda no ritmo das inovações fez com que os laboratórios aumentassem, a partir da década de 1970, seus esforços em propaganda (Gadelha, 1990, pp. 107-109).

Trata-se de uma verdadeira difusão mundial de "objetos informacionais", conforme expressão de Adriana Bernardes (2001, p. 98). Nas vagas desse processo, os laboratórios multinacionais procuraram ou produziram lugares de vultosas densidades informacionais, para que pudessem desempenhar, com mais eficiência, a coordenação de seus vastos aparelhos de pesquisa e produção. É por isso que vemos, por exemplo, uma redefinição das topologias corporativas desde os 1960. Em 1961, a Pfizer muda sua sede mundial para Manhattan, e, em 1971, instala uma divisão central de pesquisas em Connecticut. Em 1983, a Glaxo instala um centro de pesquisas no Research Triangle Park, na Carolina do Norte, Estados Unidos ${ }^{8}$. Em 1991, A SmithKline Beecham muda sua sede mundial para New Horizons Court, Inglaterra.

\section{As novas seletividades}

Se, no período científico, os novos investimentos produtivos estrangeiros fizeram cair as importações brasileiras de medicamentos, agora se vão definindo especializações, o que induz a fluxos mais intensos e variados. De 1994 a 1997, as exportações brasileiras de medicamentos e fármacos cresceram, em média, 18\%; e as importações cresceram, em média, 26,2\% (Oliveira, R. 1999, pp. 108 e 113).

Mas, as heteronomias nacionais mal poderiam sustentar-se na ausência de centros de processamento e distribuição dentro dos países, capazes de realizar uma espécie de internalização do comando global. No Brasil, coube a São Paulo esse papel de entreposto informacional. "A metrópole paulistana refuncionaliza-se, transformando-se em grande centro urbano produtor de informações. Sua primazia não mais advém de sua atividade fabril, mas sim de sua capacidade de concentrar atividades de produção, coleta,

\footnotetext{
8 "O Research Triangle Park, na Carolina do Norte, mostrou-se uma localização popular para as multinacionais européias: a Glaxo, a Wellcome, a Ciba-Geigy e a Roche todas têm laboratórios de pesquisa nessa área” (Sharp e Senker, 1999, p. 289).
} 
classificação e redistribuição de informações" (Bernardes, 2001, p. 36). Ela se torna abrigo preferencial de atividades modernas, já nascidas com o selo da informação ${ }^{9}$.

A pouco e pouco, uma situação de verdadeira primazia vai-se definindo, pois que os novos trabalhos, centralizados na cidade de São Paulo, faziam-se cada vez mais estratégicos numa economia regida pelas especializações ${ }^{10}$. De acordo com Adriana Bernardes, a crescente primazia de São Paulo agrava as tendências de fragmentação do território (Bernardes, 2001, p. 16). "Das dez principais consultorias de gestão no mundo, todas têm escritórios regionais na cidade de São Paulo, existentes, com pequenas exceções, desde o início da década de 1970" (Bernardes, 2001, 2004, p. 422). É São Paulo, mas também o Rio de Janeiro, que vão abrigar as consultorias, multiplicadas ao longo da década de 1990 (Bernardes, 2001, pp. 135-140).

Em decorrência desses efeitos, desenha-se, no território brasileiro, uma região concentrada. Esta noção, primeiramente proposta por Milton Santos e Ana Clara Torres Ribeiro (1979), foi posteriormente precisada e atualizada por Milton Santos e María Laura Silveira. "Hoje, pode-se falar de uma região concentrada, que abrange, grosso modo, os estados do Sul (Paraná, Santa Catarina, Rio Grande do Sul), além de São Paulo e Rio de Janeiro, e parcelas consideráveis do Mato Grosso do Sul, Goiás e Espírito Santo. Trata-se de uma área contínua, onde uma divisão do trabalho mais intensa que no resto do país garante a presença conjunta das variáveis mais modernas - uma modernização generalizada - ao passo que, no resto do país, a modernização é seletiva mesmo naquelas manchas ou pontos cada vez mais extensos e numerosos onde estão presentes grandes capitais, tecnologias de ponta e modelos elaborados de organização" (Santos, 1993, 2005a, p. 43$)^{11}$.

O mapa III.1 pretende mostrar, para este período informacional, o ritmo de criação de laboratórios. Gostaríamos de sublinhar três fenômenos. Primeiramente, desenha-se, ali também, a região concentrada; segundo, estados que, no período precedente, não haviam abrigado fundações de empresas (Amazonas, Mato Grosso, Mato Grosso do Sul, Rio Grande do Norte e Sergipe), retomam agora uma certa dinâmica; em terceiro lugar, destacamos os estados de Pernambuco e Ceará, cujas dinâmicas se baseiam, certamente, em contextos locais, antecipando efeitos próprios do período posterior.

\footnotetext{
${ }^{9}$ Ao longo da década de 1970, São Paulo se torna a principal praça financeira do país, e assiste à expansão do terciário superior (Bernardes, 2001, pp. 15-16).

10 "A especialização dos lugares, que é também uma manifestação da divisão territorial do trabalho, exige a produção e a circulação de torrentes de informação, que ao mesmo tempo a retroalimentam (Santos e Silveira, 2001, 2004, p. 95).

${ }^{11}$ Os autores apontam ainda as características dessa região: implantação mais consolidada de ciência, técnica e informação; implantação mais perfeita do meio técnico-científico-informacional, pois constituído sobre um meio mecanizado; presença de um terciário superior, um quaternário e um qüinqüenário; presença de São Paulo, a metrópole nacional, posição garantida pelo trabalho com a informação (Santos e Silveira, 2001, 2004, pp. 268273).
} 
No mapa III.1, o desempenho demonstrado pela região concentrada vem, sobretudo, da criação de pequenos laboratórios nacionais que, aproveitando-se da expansão das necessidades farmacêuticas, entram a elaborar séries de produções menos complexas. Aproveitam-se, também, da presença, na região concentrada, de distribuidores especializados, bem como de vias de circulação permitindo maiores velocidades. Nos capítulos seguintes, veremos que as lógicas marginais operam por ultrapassagens, ou seja, fundam sua própria possibilidade de existência nos quadros espaciais concretos, ainda que estejam eles controlados por lógicas hegemônicas. Nessa medida, a instalação do meio técnico-científico-informacional, lá onde ela é mais perfeita, faz-se pré-condição para sistematizações espaciais alternativas.

Neste período informacional, as hierarquias são muito rígidas. Os agentes hegemônicos são os que produzem e consomem as informações estratégicas; os hegemonizados, aqueles que realizam o vôo às cegas da produção farmacêutica, ou dispõem de informações restritas. O novo do período funda uma diferenciação que deriva de fluxos não-materiais.

O ritmo de instalação de empresas no Brasil reduz-se. Em verdade, já atuavam no país, desde o começo dos anos 1980, os principais laboratórios que puderam realizar uma internacionalização de suas atividades.

O Farmalab Chiesi, laboratório italiano fundado em 1935, chega ao Brasil em 1976. O Genzyme, dos Estados Unidos, funda-se em 1981, chegando ao Brasil em 1992. Em 1997, pela fusão de duas empresas suíças, a Ciba Geigy (instalada no Brasil em 1937) e a Sandoz (instalada em 1947), cria-se o laboratório Novartis.

A ação das empresas multinacionais continua ligando o território brasileiro a dinâmicas internacionais. Ao fim deste período, aparece uma tendência que não cessa de se reforçar: a expansão, agora vertiginosa, da importação de fármacos ${ }^{12}$ e medicamentos prontos $^{13}$.

Formam-se verdadeiros mercados informacionais. Hoje, atuam no Brasil consultores especializados no ramo farmacêutico: IMS Health, Close-Up, Droga Raia, AuditPharma, Demanda Real. Podemos destacar a situação da Abifarma, Associação Brasileira da

\footnotetext{
${ }^{12}$ De 1989 a 1996, verifica-se um aumento de 179\% na importação de fármacos; o grande salto tem início em 1993 (Queiroz e González, 2001, p. 146). "Em 1996 [...], o consumo de fármacos pode ser estimado em um valor não inferior a US\$ 1,5 bilhão. Como a produção de fármacos destinada ao mercado interno não ultrapassa de US\$ 300 milhões, sobra uma diferença de aproximadamente US\$ 1,2 bilhão a ser coberta com importações" (p. 145).

13 "Entre 1993 e 1998, as importações de medicamentos cresceram à impressionante média anual de 40,2\%, atingindo US\$ 1,1 bilhão” (Queiroz e González, 2001, p. 149). Isso se deve, em larga medida, ao planejamento global das transnacionais, que elegem poucos países onde instalam plantas especializadas (pp. 149-150). Em 1989, o déficit da balança comercial de medicamentos era de US\$ 72 milhões; em 1993, US\$ 180 milhões; em 1995, US\$ 406 milhões; em 1998, US\$ 968 milhões (Secex apud Queiroz e González, 2001, p. 152).
} 
Indústria Farmacêutica, que funda, em associação com o Grupemef, um banco de dados permitindo acompanhar as vendas de medicamentos no Brasil. "Os dados do Grupemef não são estimativas baseadas em amostras, mas sim a partir de informações diretamente enviadas pelas próprias empresas. O número de empresas explicitadas está em torno de cinqüenta" (Frenkel, 2001, p. 158). Trata-se, pois, de uma espécie de reprodução do que faz, na escala mundial, o IMS Health; mas uma reprodução mais sofisticada, pois que, no caso brasileiro, os dados incluem não somente o mercado de farmácias, mas também o mercado hospitalar (p. 158).

No mais, o consumo de informações é forçoso num país em que a maioria dos agentes, estrangeiros como nacionais, apropriam-se de conhecimentos e técnicas desenvolvidos no exterior. Gadelha diz que, para os anos 1990, em matéria de produção de princípios ativos, verifica-se uma "[...] concentração das iniciativas locais em produtos cujos processos clássicos de obtenção já foram descritos há muito tempo, como é o caso da insulina (anos 30), penicilina (anos 40), tetraciclina (anos 50), entre outros" (Gadelha, 1990, p. 252). Esse fenômeno vem trazer uma lição fundamental. O próprio conhecimento científico, variável-força do período precedente, converte-se agora em informação. A variável mais dinâmica do sistema não apaga a força das outras variáveis, mas é capaz de abarcá-las em seu movimento expansivo e totalizador ${ }^{14}$.

Para atender às carências informacionais emergentes em território brasileiro, consultorias globalizadas mobilizaram seus arsenais informacionais ${ }^{15}$. Esses dados podem chegar a precisões extremas ${ }^{16}$. Mas, expressando as lógicas de exclusão do período, são os laboratórios multinacionais os principais usuários desses novos serviços, muito caros para as outras empresas ${ }^{17}$. "Dados estatísticos sobre o mercado em que uma firma se insere são normalmente difíceis de se conseguir e, sobretudo, caros. No Brasil, a obtenção destes dados, em geral, está atrelada à encomenda de estudos de mercado efetuados, sob demanda, por empresas de consultoria especializadas e acabam custando milhares de

\footnotetext{
${ }^{14}$ Para o período contemporâneo, conforme tentaremos demonstrar adiante, a informação também sofre uma crucial metamorfose, e cai nas teias de uma nova variável-força: a norma.

15 "A Cognos, líder mundial em soluções de BI [Business Intelligence], tem seus aplicativos rodando em mais de 30 laboratórios no Brasil” (Guimarães, 2003, p. ti1).

${ }^{16}$ Segundo relata Cristina Guimarães, a Microstategy, consultora global, fechou um acordo com a empresa de $e$ commerce Entire Technology Partners. Elas passaram a administrar um portal contendo informações sobre o mercado farmacêutico brasileiro. "Pelo portal, o laboratório pode acompanhar as vendas de seus produtos e dos concorrentes em tempo real, permitindo o acompanhamento de campanhas por região e informações de participação de mercado. Os dados são atualizados diariamente e com informações de farmácia por farmácia” (Guimarães, 2003, p. ti2). Outra situação é a da Genexis, cujas operações se expandem no Brasil. "O Índice Genexis de Demanda (IGD), disponível no novo portal da empresa, reúne informações de mercado em tempo real, com conteúdo aberto e fechado. O serviço permite avaliar o comportamento do consumo nas 25 classes terapêuticas em longos períodos passados e simular cenários futuros de negócios”. Entre os clientes da Genexis estão: Boehringer Ingelheim, Eli Lilly, Pfizer, Roche e Schering Plough (Guimarães, 2003, p. ti2).

17 "Para se ter uma idéia de quanto esse mercado de informações pode significar, o IMS cobra cerca de R \$ 150 mil por um pacote completo de serviços [...]” (Vilardaga, 2002, p. C2).
} 
dólares em média, além de demorarem meses para serem efetuados" (Grossmann, 1994, p. 96-97). Assim, desde o ponto de vista dos laboratórios multinacionais, o território brasileiro torna-se um conjunto de informações, que podem ser mais ou menos minuciosas conforme se esteja na sede mundial ou na subsidiária brasileira.

Assim, as empresas multinacionais dispõem de informações detalhadas que, nos eixos temporal e local, esquadrinham-lhes o mercado e o território brasileiro.

Mas essas empresas hegemônicas desenvolvem, por vezes, soluções internas. Foi assim que a Eli Lilly, dos Estados Unidos, criou um sistema próprio, com o qual gerencia seus desempenhos em vendas. A fonte das informações são diversas consultorias farmacêuticas, mas também os dados transmitidos pelos representantes comerciais, 150 dos quais trabalham com notebooks (Guimarães, 2003, p. ti1). "As soluções [...] desenvolvidas no Brasil estão sendo exportadas para a unidade australiana" (Guimarães, 2003, p. ti1).

Em razão de seus altos preços, tais recursos ficam alheios às situações da maioria das empresas nacionais. Entanto, algumas destas podem acolher certos usos informacionais ${ }^{18}$.

Segundo Milton Santos e María Laura Silveira, as atividades de assessoria e projetos econômicos, contabilidade, consultoria e auditoria, pesquisa de mercado e banco de dados, publicidade, convertem-se no lócus de produção daquilo que chamaram de "mercadorias informacionais" (Santos e Silveira, 2001, 2004, p. 220). No Brasil, os produtores multinacionais de medicamentos são grandes consumidores desse tipo de mercadoria. Para termos uma idéia, recorremos novamente a Cristina Guimarães (2003, p. ti2), para ver que, no Brasil, o terceiro maior mercado de um consultor mundial como a Cognos é justamente a indústria farmacêutica.

\section{A renovação do quadro institucional}

Poucas possibilidades restavam à maioria dos países, onde se não podiam identificar, propriamente, lógicas nacionais de produção farmacêutica. O mesmo acontece, desde princípios deste período informacional, com o Brasil. "[...] em 1973, a participação da indústria nacional atingiu seu mais baixo índice, representando apenas 16,4\% das vendas totais da indústria farmacêutica" (Paula, 1991, p. 223). Em face de semelhante situação, já gritante, o governo federal passou a uma série de medidas que, pretensamente, pudessem minimizar a dependência. Desde a década de 1970, várias instituições são mobilizadas no propósito de fortalecer a produção e a pesquisa nacionais: Ceme, STI, CNPq, Finep,

\footnotetext{
${ }^{18}$ A distribuidora Panarello, com sede em Goiânia (GO), tem usado o aplicativo de captação de pedidos ETP e-trade, o que facilita seu atendimento a mais de 35000 farmácias e 200 indústrias (Guimarães, 2003, p. ti2).
} 
BNDES, CDI. Assomam no palco as tantas siglas, próprias do governo militar; personagens de relevo neste enredo complexo, não puderam, porém, dar outros rumos à história, e, mal aparecidos em cena, já estão condenados a mortes súbitas e trágicas.

Em 1972, a criação da Ceme, Central de Medicamentos, é um marco deste período. Um ano mais tarde, elabora-se o Plano Diretor de Medicamentos. "A CEME apresentava-se com o objetivo inicial de fortalecer a indústria nacional e organizar a distribuição de medicamentos para a previdência social, objetivos estes consubstanciados no Plano Diretor" (Paula, 1991, p. 243). Entanto, os esforços realizados por meio da Ceme logo se mostraram insuficientes. A instituição, criada sobretudo para fomentar as atividades de pesquisa básica, terminou cumprindo, principalmente, papéis comerciais, de aquisição e distribuição de medicamentos. Seus investimentos se destinaram, de maneira crescente, para as aludidas funções comerciais, enquanto as funções propriamente científicas e técnicas avançaram sofregamente $^{19}$. A aquisição de medicamentos para distribuição em hospitais estatais, tarefa que, em princípio, deveria ser secundária, torna-se o foco principal das ações da Ceme. Tal fenômeno se deve a duas circunstâncias principais. Primeiramente, as pressões políticas exercidas pelas empresas multinacionais, ciosas de conservar o país em sua condição de dependência. Segundamente, as próprias necessidades dos pequenos laboratórios particulares e estatais causava a hipertrofia dos papéis comerciais da Ceme; pois que, para esses laboratórios, muitas vezes carentes de sólidos mercados, a existência da Ceme garantia, de modo providencial, um certo escoamento de suas produções.

A Ceme sobreviverá, assim diminuída, até fins dos anos 1990. Durante o breve momento em que foi o depositório de um sonho científico nacional, poucas realizações notáveis pôde promover. Não logrou sequer um fortalecimento econômico das empresas nacionais, pois, conforme explica Maria Carlota Paula, a Ceme dava preferência, nas suas compras, aos preços mais baixos, os quais eram muita vez oferecidos por laboratórios multinacionais; assim, acabou facilitando a inserção mercadológica dessas empresas (Paula, 1991, pp. 271-276).

A Codetec, Companhia de Desenvolvimento Tecnológico, começa a funcionar em 1984, congregando esforços de empresas nacionais e instituições estatais, com participação da Universidade de Campinas. Tratava-se de uma espécie de pólo de pesquisa e produção, de modo a gerar tecnologias de fármacos depois repassadas a empresas que as reproduzissem nas escalas industriais. "A construção da unidade piloto da CODETEC foi financiada na proporção de 52\% pela STI [Secretaria de Tecnologia Industrial, do Ministério da Indústria e Comércio], 35\% pela CEME e 13\% pelas empresas" (Paula, 1991, p. 259).

\footnotetext{
${ }^{19}$ Maria Carlota Paula (1991, pp. 276-286) também ressalta que os maiores gastos da Ceme destinaram-se à distribuição, restando uma porção irrisória para a pesquisa.
} 
Segundo relatam Queiroz e González, o projeto Codetec, instalado em Campinas, durou de 1984 a 1990; doze laboratórios e várias plantas-piloto surgiram; sessenta fármacos foram desenvolvidos, sendo que a produção de catorze deles iniciou-se até o final de 1990 (Queiroz e González, 2001, p. 133) ${ }^{20}$.

Mas, com a mesma rapidez com que surge essa forte possibilidade de uma autonomia brasileira em química farmacêutica básica, manobras certeiras apagam-na de um golpe. Como o crescimento obtido, apesar de vigoroso, não tinha sólidas bases, sua reversão mostrou-se bastante simples. Um fator espacial explica a citada fragilidade do projeto, a saber, a densidade técnica produzida em Campinas, às fímbrias da Unicamp, teve poucas repercussões noutras áreas do país, o que impediu a criação de um verdadeiro sistema de produção nacional de fármacos. Devem-se considerar também os arroubos políticos do governo federal, que, a partir dos anos 1990, vai adotando uma série de medidas extensamente favoráveis à modificação da economia em bases globais, com forte presença de capitais, produtivos, informacionais e financeiros, provenientes do exterior.

Mas há um derradeiro fator, que teve papel crucial no malogro dessas iniciativas: as já clássicas pressões exercidas, junto ao governo, por agentes estrangeiros, sempre desejosos de assistir a financiamentos estatais, desde que estes se voltassem para atividades puramente comerciais, e não tecnológicas ou científicas. Além disso, eles estavam em condições de realizar manobras comerciais que obstruíssem os projetos.

Mas antes que nos vejamos tomados de qualquer nostalgia, faz-se necessário relativizar as conquistas farmacológicas dos anos 1980. Já dissemos que elas ficaram territorialmente concentradas; diremos agora que, nalgumas situações, foram ardilosamente controladas por agentes estrangeiros.

A história da Biobrás, narrada por Carlos Augusto Gadelha, é ilustrativa. Fundada em 1975, em Montes Claros (MG), por iniciativa de professores e pesquisadores da UFMG, a empresa incorporou recursos provenientes dos incentivos à implantação de projetos industriais na região da Sudene. O BNDES teve participação acionária, controlando, até 1983, 15\% do capital. A Biobrás inicia suas operações prestando serviço tecnológico e produzindo insumos alimentícios e farmacêuticos. Em 1978, associa-se ao laboratório Eli Lilly, dos Estados Unidos, constituindo uma joint venture por nome de Biofar, com capital de 54\% da Biobrás e 46\% da Eli Lilly. A Biofar destinava-se à produção de princípios ativos para fabricação de insulina, tendo havido, para isso, treinamento de pessoal nas fábricas da Eli Lilly nos Estados Unidos e na Inglaterra. A parceria foi decisiva, pois que as técnicas de

\footnotetext{
${ }^{20}$ Às ações da Codetec veio somar-se a Portaria número 4 de 1984. "Essa Portaria regulamentou a concessão de autorização para produção de matérias-primas, insumos farmacêuticos e aditivos utilizados na fabricação de medicamentos. Por meio desse instrumento legal, o governo garantiu uma virtual reserva de mercado, proibindo importações, para os fármacos que viessem a ser fabricados no país” (Queiroz e González, 2001, p. 132).
} 
processamento da insulina não estavam divulgadas em literatura científica naquele momento. A parceria durou até 1982, quando a Biobrás já dispunha de uma experiência tecnológica suficiente para diversificar, por si própria, sua produção. Em 1986, assume a quarta posição entre os maiores produtores mundiais de cristais de insulina.Em 1990, após obter certificado junto à FDA, agência sanitária dos Estados Unidos, exportou cerca de 50\% da produção. Ainda em 1990, a Biobrás supriu cerca de 98\% dos princípios ativos de insulina consumidos no Brasil. Seu principal comprador era justamente a Eli Lilly, mas também um laboratório chamado Novo Industri. Para a Ceme, a Biobrás vendia tão-somente uma quantidade residual. Ao longo da década de 1990, começa a produzir medicamentos. Em sua escalada, a Biobrás recorreu sempre a serviços tecnológicos e consultorias; mesmo em suas fases iniciais, antes da parceria com a Eli Lilly, quando contava com menos recursos, buscava consultorias informais (Gadelha, 1990, pp. 246-250).

Aqui, a transferência de tecnologia se integra a uma estratégia de redução de custos por parte do laboratório estadunidense.

É parecida a história da Cibran, que, depois de uma parceria com o laboratório Abott, tornou-se, na década de 1980, o maior produtor de antibióticos da América Latina. A multinacional foi um dos principais compradores dos princípios ativos produzidos pela Cibran.

A criação de pólos industriais, tais como a Zona Franca de Manaus (criada em $1967^{21}$ ) ou o Distrito Agroindustrial de Anápolis (fundado em 1976) são exemplos de como o Estado, implementando medidas pretensamente dinamizadoras, acabava reforçando as polarizações. Tais medidas espelham a concepção que é perfilhada pelos quadros gestores militares. Essa concepção se inspirava nas idéias da chamada ciência regional, ou economia espacial, campo de conhecimento que investiga as leis de distribuição das atividades econômicas no espaço, preocupando-se principalmente com a desigualdade regional. Alfred Marshall (1842-1924), um dos precursores dessa corrente, forja a noção de distrito industrial, por sua vez ligada à noção de atmosfera industrial, ou seja, o conjunto de relações existentes em tal ou tal lugar dotado de uma concentração produtiva ${ }^{22}$.

Sempre nesse espírito, o governo militar, além dos pólos industriais, cria, na década de 1970 , as regiões metropolitanas, para fins de planejamento ${ }^{23}$.

\footnotetext{
${ }^{21}$ A Zona Franca de Manaus é criada em 1967; no ano seguinte, suas condições são estendidas a todo o estado do Amazonas, e a mais três estados: Acre, Rondônia e Roraima (Santos e Silveira, 2001, 2004, p. 116).

${ }^{22}$ François Perroux e Jacques Boudeville foram os principais divulgadores dessas idéias na França. Perroux (1961, 1991) propôs a idéia de pólo de crescimento: um lugar capaz de induzir dinâmicas econômicas noutros lugares. Boudeville (1968) desenvolveu a noção de região polarizada, segundo a qual certas regiões seriam capazes de difundir seu desenvolvimento para as regiões circunvizinhas.

${ }^{23}$ Essa estratégia territorial mostrou-se logo complicada, pois, conforme diz María Laura Silveira (2004), a partir das metrópoles, além da criação de riqueza, sempre se deu uma intensa produção de pobreza, o que bem se vê pelo processo de periferização. Apesar de bastante preso a essa época, esse recorte territorial ainda continua a orientar uma série de estudos geográficos, sobretudo aqueles que ficam reféns da disponibilidade de dados.
} 
Portanto, o malogro do sonho farmacológico e científico brasileiro, acalentado nos anos 1980, deveu-se a fenômenos espaciais estruturais. Primeiro, a variável-chave do sistema, rigidamente centralizada e resguardada por meio de preços exorbitantes, era base de várias desigualdades, mercadológicas, regionais, internacionais. Segundo, os esforços de pesquisa realizados foram, em certa medida, ilusórios, pois que, em verdade, representaram, o mais das vezes, cópias de produções e tecnologias pretéritas. Terceiro, os agentes estrangeiros puderam controlar, nalgumas situações, essa dispersão tecnológica, dela tirando proveito. Assim, era já difícil arrostar a lógica de funcionamento do território, configurado em benefício dos laboratórios multinacionais, o que rapidamente se traduz em controle de mercado. Em 1998, foram identificados pela Alanac, Associação dos Laboratórios Farmacêuticos Nacionais, 350 laboratórios farmacêuticos operando no Brasil, sendo que os multinacionais, em número de 56 , controlavam $72 \%$ do mercado (Pereira, 2002, p. 13) ${ }^{24}$.

A produção farmacêutica é trespassada pela informação, pois todas as etapas do trabalho farmacêutico (pesquisa, produção, distribuição, propaganda) passam a consumir quantidades cada vez maiores de informação, o que eleva também a demanda por trabalhos especializados.

Nesse velho período informacional, que se dissolve nos fins dos anos 1990, território e mercado estavam submetidos, conjuntamente, a uma totalização que desvalorizava os lugares. Com isso, os menores laboratórios, ancorados justamente nesses contextos locais, também se enfraqueciam territorial e mercadologicamente. Em vez de uma integração nacional, a modernização era promotora de uma fragmentação. E o Estado repercutia, muita vez, tais processos.

Na política farmacêutica, a Ceme nos anos 1970, bem como a Codetec nos anos 1980, terminam por encarnar os desejos de polarização, vistos apenas em sua dimensão positiva e saneadora. E os anos 1990 são marcados por uma espécie de renúncia, de resignação, como se o pólo já não pudesse fixar-se no interior do território. Ao invés de se alastrar, as dinâmicas obtidas se enrijecem, concentram, e geram proventos apropriados por agentes estrangeiros. O que se difunde, são as condições de penúria. Segundo Jorge Bermudez, 22\% da população brasileira (nada menos que 34 milhões de habitantes) não tinham, em 1995, nenhum tipo de acesso a serviços de saúde (Bermudez, 1995).

Desde seus princípios, o período informacional realça o aspecto assistencialista desses serviços. Segundo Amélia Cohn, o Ministério da Previdência e Assistência Social,

\footnotetext{
${ }^{24}$ Concentrações semelhantes se expressam quando verificamos números referentes às atividades econômicas em conjunto. De acordo com dados reproduzidos por Maria Aparecida Pereira, 85 empresas detinham 89\% do mercado brasileiro em 1979; já em 1998, 60 empresas detinham 94\% desse mercado (E. Pinheiro apud Pereira, 2002, p. 13).
} 
criado em 1974, responsabilizava-se por uma série de instituições, entre elas o INPS, o Inamps e também a Ceme. Em 1977, os benefícios previdenciários são deixados a cargo do INPS, e desvinculados da assistência médica, ora sob controle do Inamps (Cohn, 1996, pp. 22-24). Tal sistema, que em 1974 começa a emergir, acentua, segundo Eliza Almeida, o crescimento dos serviços particulares de saúde, com subvenções estatais (Almeida, 2005, pp. 126-128). E Maria Carlota Paula sublinha que a ligação da Ceme ao Ministério da Previdência faz prova do caráter assistencialista e populista da política farmacêutica militar (Paula, 1991, pp. 243-259).

O Inamps é desativado em 1993. Antes disso, em 1988, é criado o SUS, Sistema Único de Saúde ${ }^{25}$, que, segundo Eliza Almeida, baseia-se no princípio da universalidade e faz aumentar a demanda por serviços de saúde (Almeida, 2005, p. 159). E nisto podemos incluir, certamente, a procura por medicamentos.

Informação e polarização

O período informacional, que se encerra agora, traz, pois, efeitos polarizadores e centralizadores extremos. Aliás, tais fenômenos pertencem à lógica mesma da informação, desenvolvida segundo a racionalidade instrumental que é típica das ações hegemônicas. De acordo com interpretação de Simmel, os conhecimentos sistemáticos obedecem a leis de centralização. Assim como, nas atividades mais capitalizadas, um investimento adicional torna-se muito rentável, assim também aqueles que já têm altos níveis de conhecimento chegam a níveis ainda mais altos com pouco esforço, com poucas informações adicionais; por isso, o conhecimento vai tender a se concentrar lá onde já existem acúmulos anteriores (Simmel, 1900, 1997, p. 442). Na linguagem atual dos economistas, a produção de informações implica altos custos fixos e baixos custos de produção, ou seja, as etapas que implicam maiores sacrifícios econômicos são justamente as etapas iniciais, em que os primeiros aportes informacionais devem ser obtidos.

Em termos espaciais, esses fenômenos se expressam em centralizações regionais. Conforme quisemos demonstrar, a emersão da região concentrada, e notadamente a situação primaz da cidade de São Paulo, são manifestações desses processos. Daí, a existência de um meio técnico-científico-informacional cuja difusão realiza-se em manchas descontínuas $^{26}$. Ao mesmo tempo em que mercado e território se totalizam, seu uso pleno

\footnotetext{
${ }^{25}$ O SUS foi regulamentado pela lei 8 080, de 1990, a chamada Lei Orgânica da Saúde (Almeida, 2005, pp. 143144; p. 147).

26 "Embora as estatísticas por elas mesmas não o digam, definem-se agora densidades diferentes, novos usos e uma nova escassez” (Santos e Silveira, 2001, 2004, p. 53).
} 
se faz possível para um grupo restrito de agentes que, antes mesmo de agi-lo, podem conhecê-lo, ou mais precisamente, teleconhecê-lo.

O circuito superior marginal vive sua fase mais decadente e cruel. Fora da região concentrada, ele definha, desvive, condenado a situações cada vez mais drásticas de obsolescência. Dentro da região concentrada, ele é subordinado ao extremo, pois obrigado a reproduzir, canhestramente, alguns procedimentos científicos, técnicos e mercadológicos inventados pelos agentes hegemônicos. É nessa região que se oferece a possibilidade de um uso global do território; ao mesmo tempo, é nela que ele se recusa, pois, sem dispor de recursos que permitam previsão e teleação, nada mais resta aos agentes hegemonizados que as brigas violentas por migalhas de mercado relegadas pelas empresas dominantes. 
Segunda parte

\section{A racionalidade instrumental: Precedência das normas no atual período histórico}

O que nos traz finalmente [...]

para fora das províncias da mera imitação servil da natureza

em direção do mundo, muito mais interessante, da invenção humana.

Aldous Huxley

Brave new world (1947) 
A norma como variável-força: formação das densidades normativas

Desde os fins dos anos 1990, e estendendo-se aos nossos dias, identificamos um novo período, ao qual propomos chamar de período normativo.

O processo de globalização não quer dizer, apenas, a constituição do sistema-mundo. Junto com essa construção mundial, os poderes capitalistas se forjaram, também, a capacidade para controlar os subespaços. Primeiro, os agentes hegemônicos, buscando apoio no Estado, se apropriam das lógicas da formação socioespacial; depois, as tecnologias da informação permitem aprimorar as hegemonias, de modo que se possam conhecer e controlar também as situações regionais. No capítulo precedente, buscamos demonstrar como os serviços informacionais oferecem, aos laboratórios multinacionais, uma visão minuciosa dos mercados regionais brasileiros.

Hoje, os agentes hegemônicos ensaiam seu próximo passo, por meio do qual poderiam estender suas dominações espaciais até a escala do lugar. Trata-se de um fenômeno realmente inédito e voraz, dentro daquilo que Milton Santos chamou de "processo de dominação do homem pelo viés da dominação do espaço" (Santos, 1979, 2003, p. 155). Mais ainda, acrescentaríamos que, nas condições atuais, a hegemonia fica insustentável e decrépita sem investir sobre as próprias condições locais de vida.

Ocorre, porém, que os agentes hegemônicos, na hora de realizar esse passo adiante, devem lidar com duas limitações. Primeiramente, são vetores de uma racionalidade fria, organizacional, em suma de uma racionalidade instrumental. Essa racionalidade, sendo alheia aos códigos e às tradições dos lugares, prejudica a eficácia das ações hegemônicas. Segundamente, existem, dentro do circuito superior da economia, sucessivas operações de concentração e fragmentação, o que refreia, por vezes, a continuidade dos avanços do capital.

Baseados em progressos técnicos e científicos, os processos capitalistas conduziram à divisão profunda do espaço. Agora, os circuitos econômicos marginais (circuito inferior e circuito superior marginal) já estão plenamente consolidados, o que sempre constitui um desafio ao projeto gestor e totalizador que respeita aos agentes hegemônicos. Quanto mais se tecnificam os territórios, tanto mais se reforça a divisão do espaço (circuitos superior e inferior), perturbando a coerência dos sistemas hegemônicos. Se a técnica já não pode ser a base da ação espacialmente poderosa, é preciso fazer apelo, cada vez mais, à política. Surge um híbrido de técnica e política, com um poder inopinado ${ }^{1}$.

\footnotetext{
${ }^{1}$ De acordo com François Perroux (1961, 1991, p. 183), as mudanças técnicas e econômicas (funções) reclamam mudanças jurídicas e políticas (instituições).
} 
Trata-se de buscar uma normalização geral, que assegure um mínimo de coerência, mantendo os sistemas espaciais sob controle dos agentes hegemônicos. Assim, os aparatos normativos são desesperadamente renovados².

Trata-se, em primeiro lugar, de escudar a lógica do capitalismo, que sempre se manteve graças a pesados aparelhos normativos ${ }^{3}$; em segundo lugar, proteger a lógica de uma economia que, em benefício de poucos agentes, espalha-se por todo o mundo. "Em geral, as relações econômicas transnacionais exigem um conjunto de normas básicas para poderem permanecer estáveis, e quanto mais densa fica a arena econômica internacional, tanto maior é a necessidade desta clareza e desta estabilidade" (Dezalay, 1999, p. 299) ${ }^{4}$.

Em grande medida, essa regulação é garantida por instituições internacionais e nacionais, responsáveis por uma renovação normativa. Mas ela é também assegurada pelo próprio território, na medida em que ele, condicionando as ações de maneiras específicas, também exerce regulação. Ricardo Mendes Antas pôde, por isso, sustentar que o espaço geográfico é "fonte material e não-formal do direito" (Antas Jr., 2005) ${ }^{5}$.

A par de um processo de globalização da economia, que forma grandes conjuntos espaciais, ocorre a divisão do espaço, com circuitos relativamente coesos. Da coexistência desses fenômenos complementares, e de sua exacerbação, é que surdem as atuais ânsias normativas ${ }^{6}$.

A norma como variável central quer dizer que, hoje, a hegemonia não se baseia, como outrora, sobretudo no controle dos sistemas de objetos; ela se dedica, sobretudo, ao controle dos sistemas de ações. A ênfase passa, da face técnica das normas, à sua face política, pois assim deve ser quando as solidariedades verticais começam a apresentar falhas estratégicas. "[...] a eficácia dessa união vertical está sempre sendo posta em jogo e não sobrevive senão às custas de normas rígidas [...]" (Santos, 1994, 2005a, p. 144).

\footnotetext{
${ }^{2}$ Na interpretação de Habermas, a ação racional com relação a fins, antes suportada pelas técnicas produtivas, passam ao domínio das próprias relações sociais; nesse momento, todo o quadro institucional das sociedades se altera, de modo a permitir essa racionalização no nível dos sistemas sociais (Habermas, 1968, 1973, p. 47).

3 "Isto porque o moderno capitalismo racional baseia-se, não só nos meios técnicos de produção, como num determinado sistema legal e numa administração orientada por regras formais. Sem esta, seriam viáveis o capitalismo mercantil aventuroso e especulativo, e ainda toda espécie de capitalismo politicamente determinado, mas não o seria empresa racional alguma sob iniciativa particular, com capital fixo e baseada num cálculo seguro" (Weber, 1983, p. 10).

${ }^{4}$ Noutro lugar, Yves Dezalay escreve: “[...] o crescimento do tamanho do mercado conduz a um maior formalismo [...]” (Dezalay, 1992, p. 168).

5 "Indivíduos, grupos e/ou populações têm seus comportamentos constantemente submetidos a enquadramentos geradores de resultados 'socialmente desejáveis'. Essa coação produzida externamente aos sujeitos pode ter sua fonte numa materialidade apenas aparentemente inerte, uma vez que os conjuntos de objetos artificiais e humanizados que a constituem arranjam-se intencionalmente, de modo a obstaculizar dadas ações ou, ao contrário, a promover-lhes a fluência” (Antas Jr., 2005, p. 54).

6 "As novas necessidades de complementaridade aparecem paralelamente à necessidade de vigiá-las, acompanhá-las e regulá-las. Esta nova necessidade de regulação, de controle estrito, mesmo que à distância, dos processos da produção, mas também da distribuição e de tudo mais que envolva o processo de trabalho, é uma diferença entre a complementaridade atual e a do passado, ampliando a demanda de urbanização" (Santos, 1993, 2005a, p. 49).
} 
Hoje, a norma se impõe como a energia do trabalho, pois já não há relações, invenções e usos de objetos que não sejam assaltados pela vigilância normativa". "A produção material e imaterial nos lugares é, agora, precedida por um sistema normativo mundial [...] Isso é, certamente, uma novidade do nosso período" (Silveira, 1996, 1999, p. 248). Certamente que esse controle pelas normas falha nalgumas situações, mas não é por isso menos real.

Nunca será demais lembrar que, em nosso sistema, uma variável não é um número: é um sentido numa totalidade significante; não é só uma quantidade, mas, ao mesmo tempo, uma qualidade. Nesses termos, a norma será por nós pensada como relação socioespacial, como híbridos de técnica e política permitindo a realização de enquadramentos das ações.

[...] a produção de objetos perfeitos e sua localização seletiva associam-se a um sistema de ações que, por sua vez, se torna mais exato e pragmático. Cristalizadas em estruturas de diversa natureza, algumas dessas ações tornam-se princípios para outras, aperfeiçoam e completam o modo de usar os objetos e permitem-nos, assim, reconhecer normas (Silveira, 1997, p. 36).

É da configuração dos sistemas normativos em voga, e de sua relação com os diferentes grupos sociais, que dependem as escalas de possibilidade abertas a cada agente no espaço.

Cada regra delimita um espaço no interior do qual deve inscrever-se a ação. Cada situação é de fato codificada por uma multiplicidade de regras (técnicas, comerciais, financeiras, jurídicas...), de sorte que a solução é circunscrita pela intersecção dos espaços próprios a cada regra (Pagès, 1978, 1984, p. 64).

Por fim, à geografia podem interessar as normas porque, tal como outras variáveis, ela obedece a distribuições desiguais segundo os lugares. Daí, falarmos, com María Laura Silveira, em densidades normativas (Silveira, 1997). E, conforme Ricardo Mendes Antas, são justamente as cidades que recebem as maiores densidades normativas (Antas Jr., 2005, p. 52).

\footnotetext{
7 “As formas geográficas, isto é, objetos técnicos requeridos para otimizar uma produção, só autorizam essa otimização ao preço do estabelecimento e aplicação de normas jurídicas, financeiras e outras, adaptadas às necessidades do mercado" (Santos, 1993, 2005b, p. 151).
} 
O controle da vida

\section{A vida em suas estruturas biológicas elementares}

\section{O papel das biotecnologias}

Pode-se dizer que, através dos períodos históricos, o capital vai-se apossando de esferas cada vez mais fundamentais da sociedade. Nas páginas seguintes, buscamos retratar as novas condições desse avanço. Tal esforço nos obriga a dedicar uma atenção especial à reconfiguração do circuito superior. Como dissemos desde o começo, o circuito superior marginal constitui uma porção do circuito superior e pode ser pensado em função das subordinações que amarga em relação ao circuito moderno. Assim, uma revisão das mudanças do circuito superior poderá auxiliar na compreensão do superior marginal.

Disse Polanyi que, na evolução do capitalismo, foram-se formando mercados de produtos que, em princípio, nada tinham que ver com a circulação de valores de troca. Assim, formaram-se o mercado da terra, do trabalho e do dinheiro (Polanyi, 1944, pp. 6876). Hoje, após sucessivas acelerações do sistema capitalista, constitui-se o mercado da vida, ou, para usar expressão mais precisa, o controle e planejamento da vida. A partir dos anos 1980, os avanços da biotecnologia permitiram realizações humanas que, nos princípios dessa mesma década, eram difíceis de imaginar.

Graças às evoluções da biologia molecular, associadas aos desenvolvimentos das tecnologias computacionais, os processos vitais, em suas estruturas mais elementares, podem ser antecipados, previstos, manipulados e modificados com extrema precisão. Com isso, "o homem realiza o seu antigo anseio de inventar a natureza" (Santos e Silveira, 2001, 2004, p. 88). "Pela primeira vez na história, nós nos tornamos os engenheiros da própria vida. Começamos a reprogramar os códigos genéticos das formas viventes para que sigam nossas próprias necessidades e desejos culturais e econômicos" (Rifkin, 1998, p. 15). É a produção de híbridos, de quase-objetos, ou seja, formas difíceis de classificar, esses "monstros" (p. 72) que associam caracteres naturais e sociais, globais e locais, biológicos e sociológicos, materiais e simbólicos (Latour, 1991, 1997).

Carlos Augusto Gadelha define a biotecnologia como "[...] a utilização de material biológico em processos industriais, sejam microorganismos, vírus, seres superiores ou suas partes constitutivas (enzimas, anticorpos, tecidos, etc.)" (Gadelha, 1990, p. 62). Usaremos o termo num sentido menos amplo. Por biotecnologia, compreenderemos os métodos que se valem dos conhecimentos genéticos. Portanto, biotecnologia, aqui, condiz apenas às 
técnicas referidas por Gadelha sob o nome de "biotecnologia moderna" ou "biotecnologia nova", por oposição às "biotecnologias tradicionais".

No período precedente, com a química sintética sendo a técnica hegemônica de prospecção de novas drogas, as atividades farmacêuticas passaram por um gradual processo de estreitamento de suas capacidades inovativas. Já falamos sobre isso no capítulo anterior. O desenvolvimento da biotecnologia veio promover um alargamento dessas escalas de possibilidade, pelo surgimento de novas técnicas de investigação. As estruturas vitais, usadas em produções econômicas, são submetidas a verdadeiros ganhos de produtividade ${ }^{8}$.

É muito antigo o uso produtivo de organismos. Em 2000 a.C., os gregos já dominavam técnicas de fermentação. No século XIX, os caracteres da hereditariedade são descritos por Mendel. Louis Pasteur introduz a moderna microbiologia no processamento de alimentos, após ter elaborado um processo para seleção de microorganismos, com eliminação de micróbios ruins. Em 1928, a penicilina foi isolada por Fleming, a partir de fungos.

Mas as próximas descobertas aproximam-se mais do conhecimento das estruturas biológicas fundamentais. Em 1944, Avery, MacLeod e McCarthy identificam o DNA como depositário do material genético. Em 1953, Jim Watson e Francis Crick, jovens pesquisadores de Cambridge, Inglaterra, postularam uma estrutura química para o princípio hereditário: a hélice dupla do DNA. Num artigo de uma página para a revista Nature, eles mostraram aos cientistas que, sendo uma entidade química, essa estrutura pode ser submetida a pesquisa. Também propõem, nesse artigo, um possível mecanismo de cópia do DNA.

Wagner Montor e Mari Cleide Sogayar dizem que, na década de 1970, com o surgimento da engenharia genética, inaugura-se a biotecnologia moderna (Montor e Sogayar, 2003, p. 17). Com efeito, é a partir desse momento que os cientistas chegam a elevados graus de controle sobre estruturas e processos vitais. Nessa década, por exemplo, avançam as técnicas de inseminação artificial.

Mas, o evento que merece, talvez, nosso maior destaque se dá em 1973. Stanley Cohen e Herbert Boyer combinaram, em tubo de ensaio, fragmentos de DNA de bactérias e camundongos, introduzindo o material em microorganismos. Quando as células se duplicaram, o material genético estranho foi copiado, ou seja, toda a nova população bacteriana continha a nova informação genética; era a descoberta da técnica de DNA

\footnotetext{
${ }^{8}$ Em verdade, tal aceleração começa nas primeiras décadas do século $\mathrm{XX}$, antes mesmo de emergir a biotecnologia. Segundo informações anotadas por Gadelha, o rendimento de uma cepa produtora de penicilina aumentou, de 1928 a 1988, ou seja, em 60 anos, em aproximadamente 100 vezes (BID apud Gadelha, 1990, p. 232 - nota).
} 
recombinante; era a primeira produção de um organismo transgênico, ou seja, um organismo que adquiriu um gene proveniente de outro organismo. Mas também se deve destacar um evento posterior: a descoberta da PCR, sigla para reação em cadeia da polimerase (Polymerase Chain Reaction), que possibilitou amplificar quantidades mínimas de DNA, de tal forma que o DNA resultante pode ser analisado. Assim, torna-se possível controlar a evolução biológica de qualquer ser vivo.

Em 1974, assistimos à fundação da Genentech, primeira empresa de biotecnologia, com a participação de Herbert Boyer. É o princípio da exploração comercial da biotecnologia. A Genentech tornou-se, depois, uma das maiores empresas de biotecnologia do mundo.

No início dos anos 1980 são lançados os primeiros medicamentos resultantes de modificação genética. Em 1984, a empresa Monsanto lança a primeira semente transgênica de soja resistente a herbicidas Em 1986, na Inglaterra, obtém-se a primeira liberação, no ambiente, de um organismo geneticamente modificado. E os anos 1990 são marcados por dois eventos capitais. Primeiro, o desenvolvimento de técnicas de pesquisa sobre células-tronco, ou seja, células dotadas da capacidade para se diferenciar em qualquer outro tipo de célula. Segundamente, o embriologista escocês lan Wilmut anuncia, em 1997, a primeira clonagem de um mamífero, a ovelha Dolly 9 .

Em poucas décadas, os processos vitais elementares fundamentam a geração de valiosos conhecimentos, com grandes potenciais mercadológicos. Por isso, vão-se constituindo barreiras que asseguram direitos de exploração comercial. Já não é raro encontrar proteínas, substâncias, moléculas, devidamente protegidas por cartas-patente.

Os avanços biotecnológicos dinamizam muitas atividades econômicas. Na atividade farmacêutica, eles introduzem novas formas de produzir substâncias terapêuticas. Dentre as técnicas mais importantes, poderíamos destacar as quatro seguintes.

Primeiro, o uso de células como fábricas de substâncias terapêuticas, conforme explicação de Montor e Sogayar. Observando células de insetos contaminadas por vírus, pesquisadores perceberam que essas células passam a funcionar como fábricas de células virais. A partir disso, provocaram mudanças genéticas no DNA dos vírus, para que, em vez de produzir mais vírus, as células dos insetos entrassem a produzir alguma proteína de interesse dos pesquisadores. Não só foi possível provocar esse fenômeno, como também

\footnotetext{
${ }^{9}$ Em trabalho recente, procuramos uma periodização dos avanços biotecnológicos. Assim, falamos de um período experimental, iniciado com os trabalhos de Mendel e os de Pasteur; um período microbiológico, a partir de Alexander Fleming; um período genético, a partir da descoberta de Cohen e Boyer; e, finalmente, o período atual, que chamamos de período prospectivo, cujo princípio ficou marcado pela clonagem da ovelha Dolly e pela primeira cultura de células-tronco embrionárias humanas, em 1998 (Bicudo, 2006).
} 
elaborar técnicas iniciais de rotinização do processo, e aumentar o volume de proteína produzida em cada ciclo (Montor e Sogayar, 2003) ${ }^{10}$.

Segundo, bactérias e vírus também podem ser transmudados em biofábricas, mais ou menos como se faz com as células ${ }^{11}$.

Terceiro, o uso de células-tronco, induzindo a transformações que levem a substâncias terapêuticas. Nem todas as legislações nacionais permitem, porém, a aplicação dessas técnicas ${ }^{12}$. No Brasil, seu uso, para pesquisas com fins terapêuticos, foi aprovado em 2006.

Quarto, a associação entre os novos conhecimentos biotecnológicos e as antigas técnicas de computação e química sintética.

Para que a vida seja controlada e planejada, era preciso descobrir sua tecnicidade, feito que a biotecnologia realiza. Podem-se produzir e gerar organismos viventes como se fossem máquinas capazes de cumprir funções pré-definidas. Chega-se por fim a uma situação de hipertelia funcional dos processos vitais. Depois de tantas discussões sobre a possibilidade de a máquina substituir a vida, assistimos à vida substituindo a máquina, o que prova que, realmente, nossos debates estão, muita vez, defasados.

Surge um mercado global de células epiteliais, células-ovo, bactérias, genes. Aparecem novos cálculos de custos, do tipo: será mais barato produzir proteínas a partir de bactérias ou células de insetos ou células de mamíferos ou leveduras?

As conquistas biotecnológicas já permitem, portanto, a emersão de novas lógicas e mercados $^{13}$. Os processos espaciais não ficam indenes. Por um lado, os agentes que detêm semelhantes conhecimentos vão induzir a novas configurações do espaço, instalando unidades de pesquisa, travando relações com outras empresas (de consultoria, de financiamento, de análises clínicas), promovendo novas divisões internacionais do trabalho. Por outro lado, os próprios Estados nacionais começam a criar formas geográficas de modo a facilitar a instalação dessas pesquisas e produções, vistas como dinamizadoras ${ }^{14}$.

\footnotetext{
10 "Outra vantagem do sistema é a possibilidade de cultivar as células de inseto em suspensão, o que permite construir biorreatores - é possível cultivar essas células em reatores com capacidade para dezenas de litros, com densidade de até 10 milhões de células por mililitro de suspensão" (Montor e Sogayar, 2003, p. 23).

11 "Hoje [...] o uso de técnicas de engenharia genética torna possível identificar o gene humano responsável pela produção de insulina e transferi-lo para microorganismos, como bactérias, fazendo com que estas produzam a insulina humana” (Montor e Sogayar, 2003, p. 18).

${ }^{12}$ Estudamos essa questão, para a União Européia, em trabalho recente (Bicudo, 2006).

13 "As características da sociedade e do espaço, em um dado momento de sua evolução, estão em relação com um determinado estado das técnicas [...]” (Santos, 1996, 2004, p. 171).

14 Em 2004, por exemplo, o governo nacional de Cingapura investiu US\$ 600 milhões num complexo denominado Biopolis, oferecendo infra-estrutura para atrair empresas de biotecnologia (Gazeta Mercantil, 09-0304, p. A10).
} 
A biotecnologia revoluciona os ritmos e as lógicas das atividades agrícolas ${ }^{15}$. No Brasil, a Embrapa, Empresa Brasileira de Pesquisa Agropecuária, sediada em Brasília, começou a investir em biotecnologia na década de 1980, já tendo chegado a vários produtos transgênicos ${ }^{16}$.

\section{Biotecnologia e produção de medicamentos}

"Uma das áreas que mais cresceram com o desenvolvimento biotecnológico foi, sem dúvida, a farmacêutica: é grande o número de medicamentos nos quais um ou mais componentes foram gerados através da utilização de organismos vivos, geneticamente modificados ou não" (Montor e Sogayar, 2003, p. 18). Esse fenômeno é sublinhado e ressaltado em miríades de estudos sobre as atuais produções farmacêuticas. Talvez, mais eloqüente que uma relação desses trabalhos, cuja enumeração poderia tornar-se fastidiosa, seja recorrer a Capanema e Palmeira Filho, que, referindo-se ao ano de 2004, afirmam: "Mais de 30\% dos medicamentos em desenvolvimento são gerados por síntese biotecnológica" (Capanema e Palmeira Filho, 2004, p. 44).

De feito, como ressalta Gassen, a biotecnologia médica possui largos horizontes, até porque fica, o mais das vezes, livre das aversões sociais que freqüentemente se voltam contra a biotecnologia vegetal (Gassen, 2000, p. 16) ${ }^{17}$.

Um poderoso grupo de empresas especializa-se na produção biotecnológica de medicamentos. Algumas delas já se fazem presentes em território brasileiro.

A Serono Produtos Farmacêuticos é uma filial brasileira da multinacional sediada em Genebra, na Suíça. Fundada em 1906, ela se especializa, a partir dos anos 1980, em

\footnotetext{
${ }^{15}$ De maneira muito sumária, poderíamos citar os seguintes marcos históricos. Em princípio, usavam-se apenas os métodos tradicionais, ou seja, seleção e cruzamento conforme as leis de Mendel. 1986: Primeiros experimentos com plantas transgênicas, nos Estados Unidos e na França. Entre 1986 e 1995, realizaram-se mais de 3 mil experimentos em 34 países. Entre 1996 e 1997, 45 países realizaram experimentos, os quais atingiram, só nesses dois anos, o número de 10 mil. Milho, soja, tomate, canola, batata e algodão foram as culturas mais testadas. A maioria dos testes consistia em: tolerância a herbicidas, resistência a insetos, qualidade do produto, resistência a vírus. Início dos anos 1990: a China foi o primeiro país a comercializar plantas transgênicas, primeiro o fumo, depois o tomate. 1994: a Calgene obteve aprovação, nos Estados Unidos, pra comercializar o tomate transgênico Flavr-Savr, com amadurecimento retardado.

16 "A capital federal lidera o número de projetos de pesquisa em biotecnologia, pois abriga a sede da Embrapa e os centros genéticos e de biotecnologia” (Santos e Silveira, 2001, 2004, p. 91). Outras instituições realizando pesquisas em biotecnologia vegetal no Brasil são: Universidade de São Paulo, Instituto Butantã, Universidade de Campinas. Também se destacam algumas empresas, como Novartis, Monsanto, Copersucar e Dow Chemical. No que toca à produção de medicamentos, existem, por exemplo, estudos que tentam produzir princípios ativos empregando frutas transgênicas.

17 Já faz parte das cantilenas cotidianas o dizer que, para que a biotecnologia vegetal seja mais utilizada, é preciso aguardar a realização de pesquisas mais aprofundadas sobre os efeitos causados pelo consumo de alimentos transgênicos. O fato é que, num contexto mundial em que a penúria científica é, muita vez, a regra mais efetiva, os agentes mais aptos a realizar essas pesquisas são os mesmos agentes que teriam interesse em esconder possíveis efeitos maléficos. Por isso, as pesquisas não se fazem, e os aludidos discursos repetem-se à exaustão.
} 
produções farmacêuticas biotecnológicas. Em 2003, mais de $80 \%$ de seus produtos eram fabricados com técnicas de DNA recombinante. Possui oito fábricas no mundo, nenhuma delas no Brasil, que é abastecido pelas fábricas da Suíça e da Itália (Gazeta Mercantil, 0406-03, p. A13) ${ }^{18}$.

Em 1981, funda-se a Genzyme Corporation, multinacional dos Estados Unidos, especializada na produção biotecnológica de medicamentos. Em 2003, a empresa realizou maciços investimentos em pesquisas clínicas no Brasil, para testar a eficiência e a segurança dos seus produtos. É uma das quatro maiores empresas de biotecnologia do mundo (Gazeta Mercantil, 11-09-03, p. A13) ${ }^{19}$.

Grande número dessas empresas de biotecnologia foram criadas ao longo da década de 1980, ou seja, bem no fastígio da crise vivida pela química sintética. Nessa fase, os resultados satisfatórios são acelerados por uma conjunção de esforços, entre os quais se deve destacar, certamente, a pesada participação de capitais financeiros, praticando investimentos nem sempre seguros e promissores. No mais, como destacaram Sharp e Senker (1999), os primeiros passos das empresas de biotecnologia foram zelosamente amparados em práticas de capital de risco, em que as dinâmicas científicas de pequenas empresas foram conjugadas com o fôlego financeiro de grandes grupos capitalistas.

Conforme explica Milton Santos, uma nova técnica implica um novo comando do tempo e do espaço (Santos, 2002, p. 204). Na escala global, o desenvolvimento biotecnológico vai definir concentrações inéditas. A baía de San Francisco, nos Estados Unidos, área formada pela conurbação entre San Diego e La Jolla, e a região de Boston surgem como foco de concentração de muitas empresas de biotecnologia, o que, por sua vez, atrai os laboratórios farmacêuticos multinacionais (Zeller, 2004). Em 2002, por exemplo, o laboratório suíço Novartis funda seu novo instituto de pesquisa em La Jolla (Zeller, $2004)^{20}$.

De princípio, os laboratórios farmacêuticos mantiveram-se à espreita, sem grandes envolvimentos com as empresas de biotecnologia. Sobretudo a partir dos anos 1990, quando se evidenciaram os potenciais dessas novas técnicas, eles passam a diversas parcerias com essas empresas, quando não as adquiriram por completo ${ }^{21}$. Já em 1995,

\footnotetext{
${ }^{18}$ No Brasil, a Serono detém cerca $60 \%$ de participação no mercado de medicamentos para esclerose múltipla, no qual se movimentam R\$ 120 milhões por ano (Gazeta Mercantil, 04-08-03, p. A11).

${ }^{19}$ Outro exemple é o laboratório dinamarquês Novo Nordisk, que chega ao Brasil em 1993. Está presente em 68 países, com unidades produtivas na Dinamarca, França, Estados Unidos, Brasil e África do Sul. Comercializa seus produtos em 179 países. Atua no segmento de diabetes, terapia de reposição hormonal, e distúrbios de crescimento e de coagulação. Análogos de insulina são fabricados por meio de técnicas de DNA recombinante (Gazeta Mercantil, 27/28/29-02-04, p. A13).

${ }^{20}$ Outros laboratórios farmacêuticos instalados na região biotecnológica de San Diego-La Jolla: Pfizer (Estados Unidos), Merck (Alemanha), Johnson \& Johnson (Inglaterra), Roche (Suíça) (Zeller, 2004).

${ }^{21} \mathrm{Na}$ história da exploração comercial da biotecnologia, verifica-se o papel pioneiro que, Segundo Baran e Sweezy, as pequenas empresas podem desempenhar. "Quando uma nova indústria ou campo de operações está sendo aberto, a grande corporação tende a recuar deliberadamente e permitir que empreendedores individuais ou
} 
segundo Sharp e Senker (1999, pp. 284-285), cada laboratório farmacêutico de grande porte confiava pelo menos $10 \%$ de seu orçamento de pesquisas aos estudos em biotecnologia.

Logo vemos que essas técnicas são extremamente seletivas ${ }^{22}$. Não se deve, porém, concluir que os avanços biotecnológicos rocem apenas as superfícies dos territórios nacionais. "Cada vez que, no centro do sistema mundial, os subsistemas econômico, social, político e moral e seus respectivos suportes criam novas variáveis ou renovam as do passado, a projeção do sistema mundial sobre os espaços dependentes toma formas diferentes" (Santos, 1979, 2004, pp. 33-34). Desde os aspectos mais imediatos, até as configurações socioespaciais profundas, estamos em face de uma renovação capital.

Podemos constatar, por exemplo, a gênese de uma nova bateria de medicamentos, que alteram os valores dos produtos no interior das classes terapêuticas.

O mercado de medicamentos para diabetes foi um dos que se ressignificaram profundamente ${ }^{23}$. A Lantus é uma insulina de última geração produzida em Frankfurt, na Alemanha, pelo laboratório francês Aventis. Comercializada na Alemanha desde 2000, nos Estados Unidos desde 2001, no Reino Unido desde 2002, a Lantus chega ao mercado brasileiro em agosto de 2003, nesse mês sendo distribuída para farmácias de 222 cidades brasileiras ${ }^{24}$. Com técnicas de engenharia genética, a estrutura molecular da insulina foi alterada, proporcionando melhor absorção pelo organismo (Gazeta Mercantil, 20-08-03, p. $\mathrm{A} 11)^{25}$.

Por um lado, essas técnicas de produção passam ao largo da maioria das empresas, em razão de seus custos estratosféricos. Por outro lado, a complexidade das produções resulta em produtos caros, que dificilmente serão adquiridos pela maioria das populações ${ }^{26}$.

pequenos empreendimentos façam o trabalho pioneiro vital. Alguns falham e saem de cena, mas aqueles que têm sucesso traçam as linhas mais promissoras de desenvolvimento para o futuro. É nesse estágio que as grandes corporações ocupam o centro do palco" (Baran e Sweezy, 1966, p. 59).

22 "Quanto mais poderoso é o impacto da modernização, mais importante é a tendência à concentração da produção" (Santos, 1979, 2004, p. 305).

${ }^{23}$ Hoje, tem-se noção mais sofisticada a respeito da ação da insulina. "A partir do conhecimento de sua função no organismo humano (hormônio pancreático responsável pelo metabolismo de açúcares) e do gene responsável por sua produção, pode-se transferir esta informação genética para uma bactéria que passa a produzir insulina por processos biotecnológicos clássicos de fermentação, gerando-se um produto idêntico ao humano utilizado no tratamento de diabete" (Gadelha, 1990, p. 111).

${ }^{24}$ No mercado brasileiro de medicamentos para diabetes, a Aventis é a líder, sendo que a Novo Nordisk (Noruega) e a MSD (EUA) disputam o segundo lugar (Gazeta Mercantil, 20-08-03, p. A11).

${ }^{25}$ Mais um exemplo é a NovoMix, insulina produzida pela Novo Nordisk, laboratório dinamarquês, com técnicas de DNA recombinante. No Brasil, o lançamento desse produto, no primeiro semestre de 2004, levou à expansão do faturamento da subsidiária brasileira (Gazeta Mercantil, 19-08-04, p. A11). Em 2006, a Eli Lilly (Estados Unidos) lança no Brasil o Byetta, medicamento para diabetes tipo 2; a molécula foi sintetizada pela Amylin Pharmaceuticals, empresa de biotecnologia situada na Califórnia, nos Estados Unidos (Gazeta Mercantil, 14-11-05, p. C2).

26 “O paciente brasileiro terá de desembolsar R\$ 232 por mês para fazer o tratamento com Lantus, valor entre quatro e cinco vezes mais alto do que gasta com a terapêutica convencional” (Gazeta Mercantil, 20-08-03, p. A11). 
Apesar desses dois aspectos, cumpre considerar que existem, complementarmente, fenômenos que permitem uma certa penetração socioespacial da biotecnologia.

Primeiramente, as renovações da produção geram movimentos internacionais de renovação normativa, de modo que, finalmente, mesmo as empresas mais modestas acabam sentindo os influxos do novo período. É o que buscaremos demonstrar nos próximos capítulos $^{27}$. Segundamente, a biotecnologia, depois de ume certa letargia de inovação conhecida pelas produções farmacêuticas, vem dar-lhes novo alento, o que se reflete em discursos e ideologias. Com isso, pode-se insistir num processo de medicalização da sociedade, o que veremos ainda neste capítulo, mais adiante.

Em terceiro lugar, transformam-se os sentidos e condições de aquisição das mercadorias informacionais. Por um lado, a informação pode conservar sua relevância nos sistemas espaciais. Por outro lado, a informação tem seus sentidos alterados. Se, antes, ela foi a ferramenta que permitiu às multinacionais sua difusão global, hoje esse tipo de informação se rotiniza (se normatiza), e a informação mais estratégica diz respeito a quadros e fenômenos mais essenciais, mais vitais (mais locais). Para a produção farmacêutica hegemônica, profundamente associada aos conhecimentos biotecnológicos, a informação mais estratégica diz respeito às estruturas genéticas, ao seu funcionamento, às suas formas de manipulação. Proteínas, células, bactérias, técnicas genéticas, tais são os novos conteúdos de custosos banco de dados ${ }^{28}$.

\section{O alargamento dos círculos de cooperação}

Conforme explicam Bonacelli e Salles-Filho, as novas pesquisas de medicamentos são por demais custosas para serem sustentadas por laboratórios individuais, e por demais complexas para serem desenvolvidas exclusivamente no domínio corporativo; com isso, elaboram-se redes de pesquisa, que geram fluxos largos de informação, atravessando empresas, universidades, organismos, fronteiras (Bonacelli e Salles-Filho, 2000, pp. $23-24)^{29}$.

\footnotetext{
${ }^{27}$ Sobre a renovação normativa carreada pelas empresas multinacionais, ver também Bicudo, 2006.

28 "Vastos volumes de dados genéticos sobre plantas, animais e seres humanos estão sendo coletados e estocados em bancos de dados genéticos, para serem usados como recurso primário [...]” (Rifkin, 1998, p. 11). Poderíamos citar a DiscoverEase: biblioteca de proteínas e banco de dados com informações sobre cada uma delas. Organizada pelo Genetic Institute, dos Estados Unidos, com o propósito de descobrir proteínas com função terapêutica. Participantes: Scios (Estados Unidos), Bayer (Alemanha), Chugai Pharmaceutical (Japão), Kirin Brewery (Japão), Chiron (Estados Unidos), Genentech (Estados Unidos), Ontogeny (Estados Unidos) (Bonacelli e Salles-Filho, 2000, p. 27).

29 “[...] há inegavelmente uma revolução em curso, que permite a entrada de firmas especializadas e, principalmente, a reconversão de parte importante dos investimentos das grandes corporações que, direta ou indiretamente, estão envolvidas com a biotecnologia. Mais do que isso, essa revolução se dá também na órbita em que se faz a inovação; ou seja, ocorre na maneira de organizar a pesquisa e planejar o processo inovativo. Dá-se, sobretudo, pela formação de redes de inovação” (Bonacelli e Salles-Filho, 2000, pp. 20-21).
} 
Assim, o laboratório francês Rhône Poulenc, depois de comprar o laboratório Rorer, dos Estados Unidos, funda a Gencell, uma rede de pesquisa que envolve: mais de 400 pesquisadores; 14 instituições, entre empresas (6 no total, sendo 5 de biotecnologia estadunidenses e 1 filial francesa do grupo), laboratórios e institutos de pesquisa (um deles dos Estados Unidos e os outros franceses) ${ }^{30}$. À Gencell veio juntar-se a Introgen, uma empresa de biotecnologia dos Estados Unidos (Bonacelli e Salles-Filho, 2000, p. 26) . $^{31}$

Nessas redes globais de pesquisa, as universidades constituem pontos de apoio vitais, já vastamente empregados pelas empresas multinacionais.

Então, o laboratório farmacêutico, por capitalizado e moderno que seja, torna-se menos capaz de realizar inovações solitárias, heróicas, ao longo das quais suas informações restam guardadas com desvelo. Agora, ele se deve enroscar nessas teias globais, em que as informações serão tanto mais valiosas quanto mais forem divulgadas, emendadas, cambiadas. "O principal problema no desenvolvimento da biotecnologia, tanto para as grandes como para as pequenas companhias, é integrar as diferentes peças de conhecimento geradas por uma várias fontes" (Sharp et Senker, 1999, p. 299). Hoje, um modelo de inovação dispersiva vai sendo substituído por um modelo de inovação convergente. A diferença é que, no primeiro, o laboratório funcionava como um centro difusor; no segundo modelo, a empresa deve reunir invenções parciais ocorridas em várias partes do mundo. Sem dúvida, a inovação dispersiva ainda existe, mas o movimento mais importante e revelador é definido por esse segundo fenômeno de convergência. Apesar dessa mudança, que é de ordem técnica e social, a rigidez econômica permite que a inovação continue a ser patenteada individualmente, como se ainda fosse dispersiva. Nesse contexto, para salvar a natureza social de um trabalho científico que se globaliza, mais do que lutar por cartas-patente, seria importante pensar em cartas de não-patenteamento, resguardando produtos e técnicas.

No mais, a biotecnologia tem poder para modificar as lógicas espaciais mesmo com seus altos graus de seletividade. Estamos falando numa transformação de hierarquia de técnicas produtivas e, sobretudo, num rearranjo das formas materiais e da divisão do trabalho, processado em função dessa mudança de hierarquia. "As técnicas biotecnológicas não vêm substituir por completo as técnicas sintéticas. Muita vez, pelo contrário, elas se complementam" (Gadelha, 1990, pp. 170-174). Mas, doravante, a simples operação com as técnicas sintéticas já não garante os postos hegemônicos da hierarquia global farmacêutica.

\footnotetext{
30 Mais tarde, a Rhône Poulenc fundiu-se à Hoechst (Alemanha) e à Rhodia (França), formando a Aventis (França).

${ }^{31}$ Outro exemplo é e HGS, Human Genoma Sciences, um banco de dados criado em 1996, com gerência do laboratório inglês SmithKline Beecham, e participação dos seguintes laboratórios: Schering Plough (Estados Unidos), Takeda Pharmaceuticals (Japão), Merck (Alemanha) e Synthélabo (França). Cada companhia deve pagar para ter acesso às informações genômicas geradas pelo HGS (Bonacelli e Salles-Filho, 2000, p. 27).
} 
Os laboratórios brasileiros ficam, assim, submetidos a novas obsolescências, muito mais drásticas do que as pretéritas, pois, agora, já não podem sequer manter atividades de cópia dos medicamentos modernos.

No Brasil, a biotecnologia vegetal ${ }^{32}$ encontra-se mais desenvolvida que a biotecnologia médica, o que se deve, também, a poderosos interesses despejados sobre o agronegócio. Algumas iniciativas médicas merecem, porém, destaque ${ }^{33}$. Algumas empresas brasileiras, mas raras, aventuram-se no ramo da biotecnologia, um pouco ao estilo das empresas dos Estados Unidos ${ }^{34}$.

Mas a biotecnologia, no Brasil, está muito menos aprimorada que noutros países, mormente nos Estados Unidos e nos países europeus. Mesmo assim, como dissemos, essas atividades provocam novos arranjos espaciais na escala global. Alguns autores, Poulantzas (1974) por exemplo, distinguem as variáveis determinantes, ou seja, aquelas que ditam o ritmo, as lógicas do mundo, das variáveis dominantes, que são aquelas que aparecem na maioria dos lugares. Nem tudo o que é determinante (que gere), domina (se espalha). Carl Kasen disse que "uma influência pode ser invasora sem contudo ser poderosa" (Kaysen, 1959, p. 100). Assim também, pode-se pensar que uma influência pode ser poderosa sem contudo ser invasora. Numa análise geográfica, é o território e seus arranjos que nos dão as medidas e freqüências do poder de cada evento.

No território brasileiro, já se desenham as evidências do poder das técnicas biotecnológicas. Deixamos alguns exemplos de medicamentos que vêm alterar a dinâmica dos mercados. Mas há outras repercussões da revolução tecnológica sobre o território brasileiro. Senão, consideremos os dois aspectos seguintes.

Primeiro, a crescente necessidade de renovação normativa provocada pelas mudanças tecnológicas ${ }^{35}$. Recentemente, aprovaram-se as atividades de pesquisa com

\footnotetext{
${ }^{32}$ No Brasil foi desenvolvido o projeto que mapeou, pela primeira vez no mundo, um fitopatógeno, a bactéria Xylella fastidiosa, transmitida pela cigarra e causadora de uma doença que ataca os laranjais, conhecida como CVC (clorose variada dos citros) ou amarelinho. O projeto, envolvendo cerca de 35 laboratórios e 200 pesquisadores, foi concluído em janeiro de 2000 (Bonacelli e Salles-Filho, 2000, pp. 36-37).

${ }^{33}$ Segundo Bonacelli e Salles Filho, criou-se, em 1999, um projeto resultante de parceria entre a Fapesp e o Instituto Ludwig de Pesquisa sobre o Câncer, visando mapear seqüências de material genético extraído de tumores gástricos, de colo do útero, do pescoço e da cabeça. Com 30 laboratórios e cerca de 150 pesquisadores, o projeto foi, no ano 2000, o segundo maior fornecedor mundial de informações sobre câncer para o GenBank, um banco de dados internacional em que a informação torna-se pública (Bonacelli e Salles-Filho, 2000, pp. 37$38)$.

${ }^{34}$ Bonacelli e Salles-Filho nos falam da Valée S.A., empresa de capital nacional cujos principais produtos são vacinas para doenças da boca, além de antiparasitas; tendo parcerias com universidades e institutos, como o IPT, utiliza programas de agências de fomento, nacionais ou não, para desenvolver medicamentos com técnicas biotecnológicas (Bonacelli e Salles-Filho, 2000, pp. 40-41).

${ }^{35}$ Em 1995, foi sancionada a Lei de Biossegurança, e criada a CTNBio. "Constituída por 36 membros das mais diversas áreas do conhecimento e representantes de diferentes órgãos (empresarial, de defesa do consumidor, entre outros), a CTNBio tem como tarefa estabelecer normas e regulamentos relativos a projetos e atividades envolvidos com a moderna biotecnologia” (Bonacelli e Salles-Filho, 2000, p. 34). Nesse mesmo ano, a lei 8974 e o decreto 1752 estabelecem normas para a engenharia genética (Oda e Soares, 2000, pp. 53-54).
} 
células-tronco, para fins terapêuticos. Mesmo com esses mecanismos, a legislação brasileira carece de coesão, e os estados podem, por vezes, adotar medidas autônomas ${ }^{36}$.

Segundo, as produções biotecnológicas, pelo tipo de manipulações científicas realizadas, fazem aumentar as demandas por pesquisas clínicas. Alguns países, e entre eles o Brasil, conhecem uma notável expansão dessas atividades, conforme tentamos demonstrar em seguida.

\section{A vida em suas estruturas sociais elementares}

\section{O surto das pesquisas clínicas}

As técnicas de previsão, gestão e controle, que basearam os avanços capitalistas, começam a ser aplicadas à própria vida. Milton Santos diz que os acréscimos sucessivos de objetos técnicos, mecanizados e cibernéticos fazem com que a natureza artificial tenda a funcionar feito máquina (Santos, 1996, 2002, p. 63). Hoje, as técnicas biotecnológicas fazem com que a natureza primeira tenda a funcionar feito uma máquina. Abrahan Moles aponta a existência de uma distinção entre as coisas, produto de uma elaboração social, e os objetos, produto de uma elaboração social (Moles, 1969, 1971). Hoje, as biotecnologias parecem apagar essa distinção, ou pelo menos fazem com que ela se torne menos evidente.

Mas, o que vamos destacar a partir de agora é que esse processo não se dá somente pela manipulação dos materiais genéticos e moleculares. Em verdade, ele possui, também, um aspecto social, a saber, o controle da escala existencial da copresença. Cada vez mais, as pessoas, em seus lugares, são rodeadas por objetos técnicos modernos, o que Ihes altera não apenas as condições psicossociais, mas também suas possibilidades de ação concreta no território. "Vivemos, hoje, cercados de objetos técnicos, cuja produção tem como base intelectual a pesquisa e não a descoberta ocasional, a ciência e não a experiência. Antes da produção material, há a produção científica" (Santos, 1996, 2002, p. 215).

Os vetores globais, instalando-se nos lugares, distorcendo-os, vão permitir a perpetuação dos seculares artifícios de acumulação. Aprofunda-se o processo identificado por Polanyi, permitindo "[...] nada menos que a transformação da substância natural e humana da sociedade em mercadorias [...]" (Polanyi, 1944, p. 42).

\footnotetext{
36 “Os estados forjaram legislações próprias, tais como o Rio Grande do Sul, que prescreve estudos de impacto ambiental mesmo quando a CTNBio já autorizou o plantio” (Oda e Soares, 2000, pp. 56-57) Recentemente, o estado do Paraná impediu a circulação, pelo seu território, de soja de origem trangênica, o que deu azo a tensões políticas e debates na mídia.
} 
Nas produções farmacêuticas hegemônicas atuais, segundo propomos interpretar, a invasão dos objetos técnicos, mas também a mistura entre contextos locais e interesses globais, pode ser apreendida pela análise das pesquisas clínicas.

O desenvolvimento de um medicamento implica os seguintes estágios. Primeiramente, a pesquisa básica ou etapa laboratorial, que faz aumentar o entendimento sobre a doença, identificando algumas drogas que poderiam ser usadas terapeuticamente em seu tratamento. Elas são testadas mediante associações e reações in vitro. Em segundo lugar, a pesquisa pré-clínica, que envolve os primeiros estudos para avaliar a eficácia das drogas indicadas na pesquisa básica. Trata-se de estudos de otimização, síntese, dosagem, estabilidade, segurança e toxicologia. Realizam-se testes em animais. Em terceiro lugar, a pesquisa clínica, promovendo a aplicação gradual da droga selecionada em seres humanos.

Por sua vez, a pesquisa clínica possui quatro fases. A fase 1 dura, geralmente, de 6 meses a 1 ano; geralmente envolve cerca de 20 a 80 pessoas saudáveis, nas quais se aplica a droga para verificar sua interação com o organismo e para determinar a dosagem mais segura. A fase 2 leva, geralmente, de 2 a 3 anos; o medicamento é administrado em até 300 pacientes voluntários e doentes; aqui, testa-se a eficácia da droga, verificam-se efeitos colaterais de curto prazo, definem-se doses e posologias para uso a longo prazo. A fase 3 leva, geralmente, 3 anos; participam de 1000 a 5000 pessoas de diversas etnias e nacionalidades, número que pode chegar a 10 000; compara-se aqui o tratamento novo com o tratamento padrão existente. A fase 4 não tem duração definida, tampouco número preciso de pacientes; realiza-se quando o medicamento já está no mercado, e se destina à descoberta de possíveis riscos ou novos usos.

Até o período precedente, as pesquisas clínicas eram atividades diligentemente mantidas em países centrais ${ }^{37}$. Mas, no período atual, com a nova centralização representada pela biotecnologia, movimentos paralelos de desconcentração devem aparecer. E as pesquisas clínicas engrossam tais vagas dispersivas.

Sérgio Queiroz e Alexis González notam que, no final dos anos 1990, algumas empresas multinacionais começaram a realizar a fase clínica no Brasilis; são exemplos a Glaxo Wellcome, a Novartis e a Bristol-Myers Squibb. (Queiroz e González, 2001, pp. 126127) Os estadunidenses Pfizer e Eli Lilly ampliaram também suas atividades em pesquisas clínicas no Brasil (Gazeta Mercantil, 23-06-03, p. A15).

\footnotetext{
${ }^{37}$ Conforme Gadelha nos explica, a redução das inovações a partir dos anos 1970 fez com que os laboratórios realizassem políticas de contenção dos investimentos, uma das quais foi a concentração dos testes clínicos nos países "desenvolvidos" (Gadelha, 1990, pp. 107-108).

${ }^{38}$ Noutro lugar, Sérgio González (1999, pp. 65-68 e 92) faz a mesma afirmação.
} 
Com efeito, a evolução verificada ao final dos anos 1990 faz prova de uma verdadeira inflexão ${ }^{39}$.

Os laboratórios multinacionais já começam a considerar essas atividades como gastos correntes no Brasil. Em 2004, a Schering Plough (Estados Unidos) começa a explorar o mercado brasileiro de medicamentos cardiológicos; entre os investimentos, além da contratação e treinamento da equipe de vendas específica da área, propaganda médica e patrocínio de congressos, aparecem as pesquisas clínicas (Gazeta Mercantil, 13/14/15-0804$, p. $A 10)^{40}$.

Os novos medicamentos começam a incluir, nos seus conteúdos, os rastos dessas atividades clínicas desenvolvidas, ao mesmo tempo, em vários países. Em novembro de 2003, chegou às farmácias brasileiras o Emend, que pertence ao mercado de medicamentos para oncologia; mil pacientes participaram das pesquisas clínicas, 15\% deles em centros brasileiros (Gazeta Mercantil, 17-11-03, p. A13).

Como já tantas vezes escrevemos, os laboratórios multinacionais são os que têm mais capacidade para desempenhar esse tipo de atividade, mesmo porque elas estão, muita vez, mas não forçosamente, associadas com o lançamento de medicamentos inovadores. Porém, amplia-se também o número de empresas brasileiras que a ela se dedicam ${ }^{41}$.

A expansão das pesquisas clínicas, em território brasileiro, se apóia nos três pilares seguintes.

Primeiramente, o território apresenta, hoje, uma infra-estrutura capaz de acolher estudos médicos de grande sofisticação. "Universidades, instituições e hospitais com equipamentos de última geração, corpo clínico altamente especializado para a produção de pesquisas, farta população e leis bem definidas têm atraído cada vez mais os investimentos de laboratórios multinacionais [...]" (Gazeta Mercantil, 23-06-03, p. A15) ${ }^{42}$. Sem esse equipamento específico do território, o Brasil não teria conhecido o surto havido ao final dos

\footnotetext{
${ }^{39}$ Em 1995, foram investidos, em pesquisas clínicas no Brasil, R\$ 21,9 milhões; em 2001, foram R\$ 112 milhões; portanto, verificou-se, em seis anos, uma expansão de 411,4\% (Interfarma apud Gazeta Mercantil, 2306-03, p. A15). Por ocasião do I Workshop de Fármacos \& Medicamentos, organizado pela Sociedade Brasileira de Farmacologia e realizado na cidade de São Paulo, nos dias 16 e 17 de setembro de 2004, o diretor de assuntos corporativos da Merck Sharp \& Dohme, falando em nome da Interfarma, associação que reúne os laboratórios multinacionais, apresentou os seguintes números a propósito da pesquisa clínica: em 1995, os laboratórios pertencentes à Interfarma investiram R\$ 21,9 milhões em pesquisa clínicas no Brasil; em 2003, investiram R\$ 153,1 milhões.

${ }^{40}$ Comparando-se os anos de 2003 e 2004, os investimentos em pesquisas clínicas realizados pela Novartis (Suíça) cresceram 20\%; em setembro de 2005, o laboratório tinha 30 estudos em andamento no país (Gazeta Mercantil, 21-09-05).

${ }^{41}$ A Biosintética, laboratório nacional, realizou estudos clínicos para testar a eficácia de associações de moléculas; os estudos foram elaborados por universidades, tais como USP e Unicamp (Gazeta Mercantil, 28-0404, p. A13).

${ }^{42}$ Queiroz e Gonzáles dizem que, para o desenvolvimento das atividades de pesquisa clínica no Brasil, é precisão que as subsidiárias locais se tornam mais lucrativas. "Outra condição que deve ser satisfeita é a oferta de pessoal qualificado e de uma certa infra-estrutura. No que diz respeito à pesquisa clínica, esse aspecto parece estar sendo
} 
anos 1990. Quanto a isso, o território mostra aquilo que Milton Santos chama de inércia dinâmica, ou seja, a força que têm as formas antigas para fundamentar e atrair as ações atuais (Santos, 2002) ${ }^{43}$.

No Brasil, apesar de uma concentração dos centros clínicos na cidade de São Paulo, já se pode perceber uma difusão inicial das formas geográficas relacionadas à pesquisa clínica. Tentamos indicá-lo com o mapa IV.1. Ali, vemos como se destaca a cidade de São Paulo, bem como as cidades que lhe fazem o entorno, sobretudo Ribeirão Preto e Campinas. Também se destaca a cidade do Rio de Janeiro, como o segundo principal centro clínico do território. Mas é importante perceber como se dá uma expansão inicial em algumas capitais: Porto Alegre, Curitiba, Goiânia, Salvador, Recife, Fortaleza, Belém e Manaus.

A fonte consultada permite uma visão ainda mais minuciosa, que temos na tabela IV.1.

atendido. Os centros de pesquisa médica que vêm sendo envolvidos nas pesquisas estão dentro dos padrões exigidos pelas empresas” (Queiroz e González, 2001, p. 128).

43 "O resultado da perturbação e a forma e direção da mudança, que advém da inserção de uma área local numa nova divisão do trabalho, dependerão dos caracteres existentes da área, eles mesmos resultantes de uma história já de si longa e complexa [...] A vasta variedade de condições já existentes no nível local também afeta o modo como esses próprios processos operam” (Massey, 1984, 1987, p. 119). 
tabela IV.1. Pesquisas clínicas realizadas em alguns

centros clínicos selecionados: Brasil, 2002-2004

\begin{tabular}{|c|c|c|c|c|c|}
\hline Centro clínico & Cidade & UF & $\mathbf{2 0 0 2}$ & $\mathbf{2 0 0 3}$ & $\mathbf{2 0 0 4}$ \\
\hline Hospital das clínicas de São Paulo - USP & São Paulo & SP & 68 & 492 & 611 \\
\hline Hospital das Clínicas de Ribeirão Preto - USP & Ribeirão Preto & SP & (a) & 247 & 287 \\
\hline Instituto Fernandes Figueira - Fiocruz & Rio de Janeiro & RJ & 58 & 58 & 42 \\
\hline Centro de Pesq. Hosp. Evandro Chagas - Fiocruz & Rio de Janeiro & RJ & 36 & 43 & 53 \\
\hline Hospital de Clínicas de Porto Alegre & Porto Alegre & RS & 185 & 333 & 349 \\
\hline Pontifícia Universidade Católica & Porto Alegre & RS & 103 & 301 & 303 \\
\hline Santa Casa de Misericórdia de Belo Horizonte & Belo Horizonte & MG & 29 & 20 & 27 \\
\hline Fac. de Ciências da Saúde e Medicina - UnB & Brasília & DF & 10 & 49 & 50 \\
\hline
\end{tabular}

(a) centro ainda não-registrado na fonte nesse ano

fonte: elaboração própria, a partir das informações da CONEP, Comissão Nacional de Ética em Pesquisa: http://conselho.saude.gov.br/comissao/eticapesq.htm coleta e preparação dos dados: Edilson e Edison Bicudo

Segundamente, a expansão das pesquisas clínicas se deve à própria natureza dos novos medicamentos, incorporando conteúdos científicos mais sofisticados. Com isso, faz-se importante realizar baterias mais amplas de testes, respeitando variações étnicas. A produção biotecnológica de medicamentos reforça esta questão, já que passam a ser importantes mesmo as variações genéticas individuais. Assim, o lançamento mercadológico de um produto será tanto mais seguro quanto mais extensas forem as pesquisas clínicas, de preferência realizando-se em vários países.

Por fim, as pesquisas clínicas se expandem graças a uma renovação das leis nacionais que vai ao encontro dos anseios dos laboratórios estrangeiros. No Brasil, a adoção do acordo internacional de patentes, em 1997, estimulou os investimentos desses laboratórios.

Formam-se então verdadeiras redes de pesquisa, em que vários centros, institutos, universidades, são postos a estudar uma droga. Apesar dessa larga cooperação e dessa divisão do trabalho na escala mundial, e apesar de tão difundida realização das pesquisas clínicas, as patentes continuam sendo registradas em nome de uma empresa isolada. Quanto mais se alargam os círculos de cooperação, promovendo socializações do trabalho, mais se enrijece o quadro normativo, que defende uma apropriação particular dos lucros.

É claro que a expansão dos estudos clínicos não quer dizer, forçosamente, um reforço dos conhecimentos científicos ao dispor do país. Muita vez, as primeiríssimas fases 
de pesquisa clínica continuam centralizadas ${ }^{44}$. "A maioria das pesquisas em andamento no Brasil abrange da fase 2 a 5" (Gazeta Mercantil, 23-06-03, p. A15). A fase 1, que envolve "a descoberta da molécula e testes em animais e seres humanos sadios", permanece altamente centralizada (idem). No mais, esses estudos pretendem, por vezes, atender a meros desígnios mercadológicos e propagandísticos das empresas. Em vez de se voltarem a novas descobertas, eles podem representar um esforço para descobrir novos empregos para medicamentos antigos ${ }^{45}$.

Mesmo se a maioria das pesquisas podem ser apresentadas como atividade científica de valor social, o que dizer das já freqüentes guerras clínicas entre os laboratórios? Com efeito, vai-se fazendo comum uma sucessão de pesquisas internacionais, cada laboratório tentando mostrar a superioridade de sua droga em relação às concorrentes, artifício que pode beirar as raias da puerilidade ${ }^{46}$. Pesquisadores, centros clínicos, pessoas, corpos, são dessa maneira mobilizados para um conflito que, em larga medida, move-se por interesses mercantis. Dessa maneira, os territórios nacionais transformam-se em meras arenas em que as empresas multinacionais se digladiam cientificamente. Tais são os riscos de submeter os recursos do país a racionalidades corporativas.

Numa avaliação dos grupos de pesquisa em fitoterápicos existentes no Brasil e operando com financiamento estatal, Flávia Alves constatou que a maioria desses grupos atuam nas fases mais elementares de desenvolvimento dos fitoterápicos. Se consideramos apenas os grupos que dedicam a maior parte de suas atividades às pesquisas com plantas, vemos que, de um total de 180 grupos identificados, apenas 7 têm pesquisas na fase clínica (Alves, 2004, p. 177). Não temos dados sobre a pesquisa clínica feita com recursos estatais e referentes a medicamentos sintéticos. Mas é lícito supor que, também nessa área, a atividade é bastante fraca. Com isso, vemos que, em território brasileiro, são de fato as empresas particulares, mas sobretudo as multinacionais, que dominam a pesquisa clínica.

\footnotetext{
44 “[...] não se pode separar os processos de decentralização dos processos de centralização, como se faz com tanta freqüência [...] Os dois processos se desenvolvem simultaneamente e se reforçam. Uma descentralização operada dessa maneira reforça o controle central, permitindo que ele se dê com mais eficácia, e minimizando os riscos da centralização" (Pagès, 1978, 1984, p. 49).

${ }^{45}$ Foi assim que a Pfizer (Estados Unidos) divulgou, em 2003, um estudo mostrando que o Lípitor, medicamento mais vendido no mundo para redução de colesterol, também apresenta bons resultados no tratamento da arterosclerose coronariana, problema que decorre do colesterol alto (Gazeta Mercantil, 02-12-03, p. A15).

${ }^{46}$ Em novembro de 2003, a Bayer (Alemanha) divulgou os resultados de um estudo clínico sobre o Levitra, medicamento para disfunção erétil que produz em parceria com a Glaxo SmithKline (Inglaterra). O estudo clínico, patrocinado pelos dois laboratórios, foi realizado em centros clínicos de dez países, envolvendo 463 homens com características semelhantes, como idade e peso. $\mathrm{O}$ estudo visava mostrar as vantagens do Levitra sobre o Viagra, medicamento da Pfizer. O Viagra foi lançado em 1998; o Levitra, em 2003 (Gazeta Mercantil, 10/11/12-10-03, p. A14). Em outubro de 2003, a Pfizer tinha divulgado pesquisas mostrando o melhor desempenho do Viagra em relação ao Cialis, medicamento da estadunidense Eli Lilly; este último laboratório também divulgou, mais tarde, estudos mostrando o melhor desempenho do Cialis (Gazeta Mercantil, 24/25/2610-03, p. A13).
} 
Um primeiro efeito dessa difusão de pesquisas clínicas é uma transformação dos impactos espaciais provocados pelos agentes hegemônicos. Estes começam a esboçar aquilo que Heisemberg chamou de "ações diretas de evento a evento" (Heisemberg, 1958, 1981, p. 98). Os agentes hegemônicos, já não podendo sustentar sua hegemonia com base, exclusivamente, numa ligação de pontos luminosos, buscam penetrar nos pontos opacos, nos quadros da copresença. "Eles preferem o espaço reticular, mas sua influência alcança também os espaços banais mais escondidos" (Santos, 1996, 2004, p. 243).

Com as pesquisas clínicas, as ações hegemônicas deixam, pela vez primeira, de ser exclusivamente verticais, e passam a constituir pequenos contextos em que se alteram os ritmos e as lógicas da copresença. Como isso acontece ? Como se desenvolve a pesquisa clínica?

Quando o laboratório deseja testar clinicamente algum de seus medicamentos, precisa escolher, primeiramente, uma instituição em que se vão desenrolar os testes ${ }^{47}$. 0 centro clínico vai selecionar então os pacientes que participarão da pesquisa. Por isso, os laboratórios elegem, o mais das vezes, hospitais: estes já dispõem de uma relação de pacientes com tais ou tais males específicos. As pessoas selecionadas, às quais será aplicada a terapia em teste, passam a dispor de um acompanhamento médico especial e cuidadoso, tendo, inclusive, acesso facilitado aos especialistas, junto aos quais podem colher conselhos e orientações médicas. Os testes podem-se estender por dois, três anos e, ao longo desse período, podemos supor que os indivíduos adotem, aos poucos, novas idéias e comportamentos em relação às terapias científicas. Submersos, por meses ou anos, num micro-ambiente médico sofisticado e coeso, esses indivíduos podem acolher, com mais facilidade, uma visão mais positiva, ou mesmo técnica, a propósito de sua moléstia, seu corpo, seus modos de vida. Tal é o contexto quase-insular, quase-idílico, formado pelas atividades de pesquisa clínica. Aqui, a psicoesfera moderna chega a elevados graus de penetração ${ }^{48}$.

[...] essa combinação eficaz de elementos da instância econômica e da instância cultural está entre as bases da formação de uma psicoesfera, sem cujo funcionamento e leis o uso da tecnoesfera seria muito menos eficaz (Santos, 1993, 2005a, p. 51).

\footnotetext{
47 "Os estudos das multinacionais são realizados geralmente em parcerias com universidades e instituições privadas de saúde” (Gazeta Mercantil, 23-06-03, p. A15).

48 “A psicoesfera, reino das idéias, crenças, paixões e lugar da produção de um sentido, também faz parte desse meio ambiente, desse entorno da vida, fornecendo regras à racionalidade ou estimulando o imaginário" (Santos, 1996, 2004, p. 256).
} 
Forma-se uma nova teia de relações, que vai desde as estratégias das empresas globais até a existência particular das pessoas, captadas em sua corporeidade ${ }^{49}$. "[...] é sempre por sua corporeidade que o homem participa do processo de ação [...] A corporeidade do homem é um instrumento de ação. Mas é sempre preciso levar em conta que o governo do corpo pelo homem é limitado, nos dias atuais, e que é lento o progresso na produção de normas legais para protegê-lo" (Santos, 1996, 2004, p. 80).

Mas logo percebemos que a psicoesfera tem, por esses meios, limitado poder de penetração, já que da pesquisa clínica participam, em cada centro clínico, poucos indivíduos. Aliás, estamos aqui perante processos realmente complementares; pois se, de um lado, as empresas multinacionais realizam ações mais próximas de uma lógica horizontal, fazem-no, por outro lado, gerando mais exclusão, e assim reiteram sua natureza de empresas multinacionais. "Se estas podem colher indiretamente resultados globais, seus efeitos diretos são sobretudo pontuais ou lineares" (Santos, 1996, 2004, p. 152).

\section{Os novos sentidos da propaganda farmacêutica}

Entanto, as oscilações de fenômenos complementares não param por aí. Pois, se os agentes hegemônicos têm limitações intrínsecas para permear as escalas da copresença, outros fenômenos, paralelos, vão promover a difusão dos novos objetos técnicos farmacêuticos e a medicalização da sociedade. Senão, consideremos dois aspectos.

Primeiro, a ampliação das escalas de possibilidade dos agentes hegemônicos, realizada pela biotecnologia, permite que eles se dediquem, hoje, ao estudo de uma série de doenças raras e crônicas. As tecnologias são como setas indicando caminhos a seguir. "Noutras palavras, um paradigma tecnológico (ou programa de pesquisa) incorpora fortes prescrições sobre as direções de mudança técnicas a seguir e aquelas e negligenciar" (Dosi, 1984, p. 15). Nessa medida, os avanços da biotecnologia jogam luz, principalmente, sobre as doenças raras. Pesquisas complexas vão gerar medicamentos sofisticados, cujos preços não podem, por vezes, ser suportados mesmo pelos estratos sociais mais ricos. Assim, os Estados nacionais são chamados a custear os tratamentos relativos a doenças raras. Por um lado, as inovações biotecnológicas podem, assim, obter maior penetração social. Por outro lado, usos corporativos dos territórios podem ser, dessa maneira, amparados por recursos estatais ${ }^{50}$. De tudo aquilo que a Genzyme (Estados Unidos) fatura no Brasil, 90\%

\footnotetext{
49 “O homem é uma parte da natureza e fica limitado por ela, de modo que a humanidade não é somente um conceito social, mas também biossocial” (Anuchin, 1975, p. 79).

${ }^{50}$ Nos Estados Unidos, incentivos fiscais e extensão de patentes levaram ao desenvolvimento de pesquisas em doenças raras, dentro do segmento das chamadas drogas órfãs (Médicos sem Fronteiras, 2001, p. 25). "É importante notar, contudo, que a legislação sobre drogas órfãs teve êxito porque, além dos créditos e dos subsídios governamentais, as empresas podem recuperar os custos cobrando altos preços pelos remédios” (idem, p. 25).
} 
vêm do governo (Gazeta Mercantil, 11-09-03, p. A13) ${ }^{51}$. Para a Novo Nordisk (Dinamarca), $60 \%$ do faturamento de sua subsidiária brasileira é garantido pelo setor público, sobretudo em função das aquisições de insulina, produto que corresponde a $60 \%$ do faturamento da subsidiária (Gazeta Mercantil, 19-08-04, p. A11).

Segundo, os laboratórios multinacionais mudam aos poucos suas estratégias de propaganda. Agora, em vez de propagar tal ou tal marca de medicamento, parecem preocupados em realizar campanhas muito mais abrangentes, que dizem: Consulte seu médico.

Pode-se dizer que há três espécies de propaganda farmacêutica: 1. propaganda ao grande público, divulgando medicamentos específicos, que podem ser consumidos sem prescrição médica; 2. propaganda junto aos médicos, divulgando medicamentos específicos, para uso sob prescrição; 3. campanhas de medicalização, divulgando práticas e concepções médicas. As duas primeiras estão no nível da tecnoesfera; a terceira, no nível da psicoesfera. Num país em que é tão precário o acesso aos serviços médicos, os laboratórios precisam começar pelos primeiros estágios de propaganda. Nessa medida, sua preocupação, mais do que aumentar o número de prescrições, pode voltar-se para o aumento do número de diagnósticos. No mais, essa novidade é coerente com dois processos atuais: 1. a formação de grandes grupos farmacêuticos, aos quais interessa que a sociedade se medicalize, ou seja, que tanto as doenças graves como os mal-estares sejam pensados, sempre, em termos de intervenções farmacêuticas; 2. a tentativa de colonização dos contextos comunicacionais, pela difusão de uma psicoesfera cientificizada.

A esse tipo de propaganda inespecífica vem somar-se a propaganda subterrânea, que é bem típica das atividades farmacêuticas. Longe dos olhos do público, um batalhão de representantes comerciais vai, todos os dias, aos consultórios, a ensinar aos médicos quais são os novos avanços da técnica farmacêutica ${ }^{52}$. Fiando-se nesses cortejos pretensamente científicos realizados por representantes verdadeiramente comerciais, os laboratórios podem mesmo fazer cair os índices de investimento em campanhas ao grande público.

Dizem Dupuy e Karsenty que uma das especificidades do mercado farmacêutico é que, nele, o médico escolhe o produto em nome do consumidor (Dupuy e Karsenty, 1974, 1979 , p. 46 e 153) ${ }^{53}$. Em verdade, essa característica foi apontada por diversos autores,

\footnotetext{
${ }^{51} \mathrm{O}$ tratamento de reposição de enzima com o medicamento Cerezyme custa entre US\$ 60 mil e US\$ 90 mil por ano (US\$ de 5 mil a US\$ 7,5 mil por mês), para cada doente. Assim, o governo tem que auxiliar no custeio do tratamento. "Hoje, são 365 os casos de Gaucher diagnosticados no País, 350 deles em tratamento. O restante está a espera da liberação do governo para iniciar a terapia [...]”(Gazeta Mercantil, 11-09-03, p. A13).

52 Conforme Dupuy e Karsenty, a propaganda médica, além das visitas médicas, pode envolver: correspondências, anúncios em revistas especializadas, envio de amostras gratuitas (Dupuy e Karsenty, 1974, 1979, pp. 79-84).

53 "Quando o produto é novo no mercado, novo no seu sentido mais amplo, ou seja, química e terapeuticamente novo, o processo de difusão baseia-se essencialmente na interação entre o médico e os instrumentos de persuasão dos laboratórios, entre os quais o representante é o principal” (Frenkel, 2001, p. 167).
} 
mas os dois citados foram talvez os que ressaltaram, de maneira mais adequada, o fato de que essa escolha médica, ao invés de ser livre, é largamente condicionada pela propaganda escondida que fazem os laboratórios. Além disso, dizem esses autores que a liberdade de escolha do médico é restrita e ilusória também pelo fato de que, muita vez, os medicamentos disponíveis para uma só doença praticamente não diferem (Dupuy e Karsenty, 1974, 1979, pp. 242-243) ${ }^{54}$.

"Os 500 representantes comerciais da Roche no Brasil visitam 120 dos 285 mil médicos brasileiros" (Guimarães, 2003, p. ti2). A manutenção de uma tal força de propaganda é consideravelmente custosa. "Montar uma equipe de representantes, que cubra uma determinada área geográfica e uma especialidade médica, representa um procedimento muito oneroso, tornando-se o principal item de despesa dos laboratórios. A despesa com este item pode apropriar de 30 a 35\% da receita líquida do laboratório" (Frenkel, 2001, p. 172). A semelhantes investimentos, podem ser acrescentados, ainda, modos alternativos de sedução aos médicos ${ }^{55}$. Em 2005, entre os principais laboratórios multinacionais, a propaganda representou, em média, 35\% dos gastos realizados mundialmente, e a pesquisa, em média, 16\% (Sciences et Avenir, 2005, p. 59).

Adriana Bernardes ressalta o papel da publicidade no controle do consumo, dos valores, dos tempos (Bernardes, 2001, pp. 114-118). Os laboratórios farmacêuticos reforçam assim esse papel, fechando um verdadeiro ciclo. Por um lado, incentivam as consultas médicas; por outro lado, acorrem aos consultórios, no afã de influenciar as escolhas tomadas pelos médicos. Práticas e idéias concernentes aos cuidados corporais se difundem; a psicoesfera se densifica; as concepções da saúde e da doença são reconfiguradas; e, com isso tudo, são os interesses corporativos os maiores beneficiados ${ }^{56}$.

\section{A proliferação das farmácias e a expansão do crédito}

Mas há um terceiro fenômeno que nos convence dessa colonização da escala da copresença. Trata-se, agora, da espantosa difusão das farmácias em território brasileiro. Em 1998, considerando o comércio de produtos farmacêuticos, médicos e odontológicos,

\footnotetext{
54 “O diagnóstico na maioria das vezes é subjetivo, os caminhos terapêuticos a serem perseguidos são diversos dependendo do paciente e da formação/concepção do médico - e o médico, como qualquer consumidor, é sujeito a toda ordem de influência propagandística da indústria quanto à superioridade de alguns produtos e procedimentos frente a outros” (Gadelha, 1990, p. 69).

55 "Hoje, além de distribuir remédios gratuitamente entre os profissionais da saúde, os laboratórios bancam a ida de médicos a congressos e seminários internacionais, montados especialmente para a propaganda de um novo remédio [...]" (Veja, 2002, p. 100). Existe a figura do professor pesquisador, atuando especificamente na área de medicina clínica. Ele costuma publicar algumas pequenas pesquisas versando sobre tratamentos. Os laboratórios costumam financiar essas pesquisas (Luz apud Almeida, 2005, pp. 82-83).

${ }^{56}$ Pode-se ver o mesmo processo na produção agrícola. "Informações e conselhos sobre saúde, medicina e alimentação tornam-se normas para novos consumos alimentares, que não raro ofuscam os interesses do chamado agribusiness” (Santos e Silveira, 2001, 2004, p. 130).
} 
verificavam-se 4578 estabelecimentos (IBGE, Anuário Estatístico do Brasil, 2000). Em 2004, considerando apenas as farmácias e drogarias, chega-se a mais de 54 mil estabelecimentos (CFF, Conselho Federal de Farmácias apud Gazeta Mercantil, 22-03-04, p. A10). Esse número consabidamente excessivo indica um novo cerco às situações locais. A expansão é largamente realizada por grandes redes, que não raro têm-se válido de métodos financeiros, incentivando o consumo por meio de cartões de fidelidade ${ }^{57}$. Essas campanhas visam, principalmente, os aposentados, faixa de população que, evidentemente, precisará de cuidados médicos mais freqüentes. E, conforme diz Jacob Frenkel, os supermercados começam, na década de 1990, a atuar na área de medicamentos (Frenkel, 2001, p. 173).

Por meio dessa expansão do comércio e do consumo farmacêutico, os laboratórios têm seu campo de ação gradualmente ampliado. Em 2004, 80\% de suas vendas realizavam-se junto às farmácias, ao passo que o SUS absorvia $12 \%$ de suas vendas (Gazeta Mercantil, 22-03-04, p. A10). Em cada cidade brasileira, tal ou tal rede espalha seus estabelecimentos, convertendo-se quase num traço típico da paisagem ${ }^{58}$. 28 dessas grandes redes estão hoje representadas pela Febrafarma.

Essa expansão vem reforçar a racionalidade instrumental, que é típica do circuito superior, pois ela consagra uma série de elementos solidários a essa lógica hegemônica: amplia-se a creditização do território, por meio dos cartões de fidelidade; amplia-se a gama de medicamentos disponíveis, por meio da associação com os grandes distribuidores; amplia-se a informatização do território, por meio da associação com empresas de pesquisa de mercado; amplia-se a informatização das operações; difunde-se, com os medicamentos, uma psicoesfera ${ }^{59}$.

Com tais fenômenos, os medicamentos ganham mais poder para rodear os homens, constituir o meio comum que se erige nas cidades $^{60}$. Com eles, uma visão prática do corpo, a partir da possibilidade de certas intervenções técnico-científicas, quer-se impor. No limite, eles poderiam reforçar as novas ideologias que, não raro, se depositam sobre os objetos

\footnotetext{
57 "Foi nos últimos vinte anos que o Brasil conheceu uma extraordinária expansão dos consumos materiais e imateriais. Essa difusão não se faria sem a cooperação do crédito” (Santos e Silveira, 2001, 2004, p. 223). "Criou-se o cartão de crédito popular, que funciona como um crédito pré-aprovado, proporcional à renda e que pode ser usado numa rede comercial credenciada [...] Além de conseguir clientes cativos, essas empresas lucram com os juros decorrentes do parcelamento das compras” (Santos e Silveira, 2001, 2004, p. 223).

${ }^{58}$ Em São Paulo, temos a Droga Raia ou a Drogaria São Paulo; em Belém, a Big Ben; no Recife, a Farmácia dos Pobres; em Goiânia, a Drogaria Santa Marta ou a Drogaria Santa Mônica; em Fortaleza, a Pague Menos; entre outros exemplos.

${ }^{59}$ Por vezes, as redes de farmácia nascem a partir de empresas distribuidoras de medicamentos, sobretudo quando estas adquirem maior expressão mercadológica. Um exemplo é a rede Extrafarma, que nasce da distribuidora Imifarma, sediada em Belém (PA). A Extrafarma, criada em 1998, já dispõe de 84 lojas: 52 em Belém, 10 em Fortaleza, 22 em São Luís. Outro exemplo é a rede Droga Lins, criada pela Panarelo, o maior distribuidor de medicamentos de Goiás, um dos maiores do Brasil.

60 "Hoje, vivemos junto com os objetos técnicos, eles se apoderam do nosso cotidiano, mas com eles nossa interação é prática, mas não profunda” (Santos, 1996, 2004, p. 214).
} 
técnicos ${ }^{61}$. É a verticalização do cotidiano, apontada por María Laura Silveira (1996, 1999, p. 314).

Uma dispersão das farmácias poderia ter limitados efeitos num país em que a população possui ainda acesso precário aos sistemas de atenção à saúde. Entanto, sabe-se que, muita vez, os medicamentos podem ser adquiridos, e de fato o são, na ausência de consulta médica. É o que se chama automedicação, prática tão freqüente no Brasil. "Calcula-se que para um produto com difusão consolidada, a demanda através da automedicação represente em torno de 50\% da demanda total" (Frenkel, 2001, p. 167) ${ }^{62}$. Em 2003, os medicamentos livres de prescrição médica representaram $40 \%$ do mercado farmacêutico brasileiro, em dinheiro movimentado; é de supor que essa proporção vai-se ampliar, pois que as próprias legislações reforçam a tendência; entre meados de 2003 e janeiro de 2004, por exemplo, a legislação sanitária ampliou de 18 para 35 as classes terapêuticas cujos remédios não precisam de receita para serem comercializados (Gazeta Mercantil, 17-05-04, p. A13).

A expansão do consumo farmacêutico leva também à drenagem da massa de dinheiro local, que flui das farmácias até os distribuidores e os laboratórios.

Modelam-se dessa forma os contornos do "mundo cotidiano", conforme expressão de Clifford Geertz (1983, p. 86).

\section{A medicalização do território}

"Existe, finalmente, o fenômeno da 'medicalização do mal-estar', ou seja, a transformação de toda a falta de bem-estar, qualquer que seja sua natureza (más relações no trabalho, na família, etc.), em problema que se admite socialmente e que possa ser apresentado ao médico" (Dupuy e Karsenty, 1974, 1979, p. 261). Atualmente, já se fala mesmo em drogas de estilo de vida (antidepressivos, medicamentos para disfunção erétil, estimulantes, vitaminas), ou seja, medicamentos que podem garantir um gênero de normatização da saúde e do comportamento social. Em termos geográficos, pode-se identificar, paralelamente, a medicalização do território. Esta existe porque, no instante em que se pretendem formular projetos regionais ou nacionais de promoção à saúde, tende-se

\footnotetext{
61 “Em nossas sociedades, onde a técnica é considerada como suscetível de resolver todos os problemas, os instrumentos de dominação mágica do mundo que encontramos nas sociedades ditas 'primitivas' foram substituídos por objetos técnicos. O medicamento é um deles” (Dupuy e Karsenty, 1974, 1979, p. 191).

62 "A automedicação dá-se na medida em que as dificuldades socioeconômicas e o preço elevado dos medicamentos tornam difícil sua aquisição. Desta maneira pessoas do mesmo grupo de relações e que possuem sintomas semelhantes podem partilhar do mesmo medicamento sem passar pela consulta médica" (Ferreira, 2001, p. 71).
} 
a mobilizar um arsenal de medicamentos, uma pletora de laboratórios farmacêuticos e um exército de médicos.

No Brasil, sabe-se que é baixo o acesso aos medicamentos. Porém, as modalidades de consumo começam, hoje, mesmo antes da aquisição das mercadorias. Primeiro, trata-se de produzir o mercado, o público-alvo, o consumidor, e só então é que se elaboram as estratégias de venda efetiva. No que respeita aos medicamentos, essa produção de consumidores já se iniciou no Brasil, e se repete a cada dia por meio de uma gradual divulgação de informações e dados que induzem à identificação dos doentes. Enquanto os países centrais podem ser a província dos tratamentos, os países periféricos devem ser, primeiramente, o local de realização dos diagnósticos ${ }^{63}$. Umas das estratégias da Bayer para expandir o consumo do Levitra, no mercado estadunidense de disfunção erétil, dominado pelo Viagra da Pfizer, é "[...] ampliar o mercado consumidor tornando conhecido o problema da disfunção erétil, suas causas e tratamentos por meio de ações educacionais junto aos médicos e a população" (Gazeta Mercantil, 20-08-03, p. A11). Quando as lógicas do capitalismo se fazem dominantes, os pacientes são pensados como consumidores; os doentes sem acesso aos medicamentos, como demanda reprimida; os indivíduos cujo mal ainda não se diagnosticou, como mercado potencial.

No Brasil, sabe-se que é baixo o acesso aos medicamentos. Porém, as modalidades de consumo começam, hoje, mesmo antes da aquisição das mercadorias. Primeiro, trata-se de produzir o mercado, o público-alvo, o consumidor, e só então é que se elaboram as estratégias de venda efetiva. No que respeita aos medicamentos, essa produção de consumidores já se iniciou no Brasil, e se repete a cada dia por meio de uma gradual divulgação de informações e dados que induzem à identificação dos doentes. Enquanto os países centrais podem ser a província dos tratamentos, os países periféricos devem ser, primeiramente, o local de realização dos diagnósticos ${ }^{64}$. Umas das estratégias da Bayer para expandir o consumo do Levitra, no mercado estadunidense de disfunção erétil, dominado pelo Viagra da Pfizer, é "[...] ampliar o mercado consumidor tornando conhecido o

\footnotetext{
63 "Segundo os especialistas, das cerca de 10 milhões de pessoas com diabetes no País, somente 50\% sabem do diagnóstico e dos pacientes em tratamento, apenas $20 \%$ estão com a doença sob controle” (Gazeta Mercantil, 2008-03, p. A11). No Brasil, 10\% dos cerca de 5 milhões de homens com disfunção erétil e poder aquisitivo para fazer o tratamento utilizam os medicamentos orais. Outros 6 milhões não têm dinheiro para se tratar (Gazeta Mercantil, 23-10-03, p. A13). Segundo dados da Sociedade Brasileira de Cardiologia, $40 \%$ da população brasileira tem colesterol alto, e apenas 10\% dessas pessoas fazem tratamento médico (Gazeta Mercantil, 02-1203, p. A15).

64 "Segundo os especialistas, das cerca de 10 milhões de pessoas com diabetes no País, somente $50 \%$ sabem do diagnóstico e dos pacientes em tratamento, apenas 20\% estão com a doença sob controle” (Gazeta Mercantil, 2008-03, p. A11). No Brasil, $10 \%$ dos cerca de 5 milhões de homens com disfunção erétil e poder aquisitivo para fazer o tratamento utilizam os medicamentos orais. Outros 6 milhões não têm dinheiro para se tratar (Gazeta Mercantil, 23-10-03, p. A13). Segundo dados da Sociedade Brasileira de Cardiologia, 40\% da população brasileira tem colesterol alto, e apenas $10 \%$ dessas pessoas fazem tratamento médico (Gazeta Mercantil, 02-1203, p. A15).
} 
problema da disfunção erétil, suas causas e tratamentos por meio de ações educacionais junto aos médicos e a população" (Gazeta Mercantil, 20-08-03, p. A11). Quando as lógicas do capitalismo se fazem dominantes, os pacientes são pensados como consumidores; os doentes sem acesso aos medicamentos, como demanda reprimida; os indivíduos cujo mal ainda não se diagnosticou, como mercado potencial.

Os consumos são distorcidos no meio dessa "guerra das patentes", conforme expressão empregada pelo jornal Gazeta Mercantil (24/25/26-10-03, p. A13). O exemplo extremo tem sido o mercado dos medicamentos para disfunção erétil, que é cenário de recontros sangüíneos entre os laboratórios concorrentes ${ }^{65}$. $\mathrm{Na}$ esteira do processo, produz-se uma necessidade, um comportamento, e quiçá tais ou tais vícios biológicos e modificações psicológicas.

A copresença pode ser entendida como tendo, ao mesmo tempo, uma dimensão espacial, uma temporal, uma social; poderíamos pensar ainda numa dimensão psicológica, desde que isso não nos leve a esquecer as dimensões anteriores. É, hoje, um conceito mais preciso que o conceito de cotidiano, o qual já vem muito pleno de interpretações anteriores, imprecisas ou defasadas.

No fundo, com efeito, não há senão uma única situação para cada homem, a saber, a sua situação social, em fusão com a situação geográfica, resultante de heranças e inovações, fusão irreversível porque combinação química em que o conjunto das variáveis que caracterizam a sociedade global incide sobre o indivíduo concreto num lugar determinado (Santos, 1993, p. 87).

O mundo se artificializa ${ }^{66}$ por dois motivos. Primeiramente, as estruturas vitais elementares, genéticas, são objeto de ação planejadora. Segundamente, a escala da copresença, que, em termos espaciais, constitui a unidade social mais basilar, também cai vítima das intervenções instrumentais. Intensifica-se aquilo que Milton Santos chamou de a

\footnotetext{
${ }^{65}$ Quatro são os produtos: o Viagra, da Pfizer (Estados Unidos), lançado em 1998; o Cialis, da Eli Lilly (Estados Unidos), lançado em 2003 e produzido no Brasil, em São Paulo-SP, desde 2004; o Levitra, da Bayer (Alemanha), comercializado em parceria com a Glaxo SmithKline (Reino Unido) (Gazeta Mercantil, 23-10-03, p. A13); e o Vivanza, lançado em 2005 graças a um acordo entre a Bayer e o laboratório nacional Medley; o medicamento é produzido pela multinacional alemã em sua fábrica de Leverkusen, e apenas comercializado pela empresa brasileira; a previsão é de que o Vivanza torne-se o principal medicamento do Medley, em matéria de vendas. O laboratório nacional Cristália está desenvolvendo mais uma droga para disfunção erétil, mas não há, por enquanto, previsão para o lançamento do produto (Gazeta Mercantil, 23/24/25-09-05, p. C2). No referido acordo entre Bayer e Medley, o laboratório alemão demonstra o claro interesse de expandir suas vendas, pois, apesar de empregar o mesmo princípio ativo para o Levitra e o Vivanza, a diferenciação de marca o torna fornecedor de dois medicamentos para o Brasil. Além disso, pode agora contar com a ação dos representantes comerciais que serão mobilizados pela Medley.

66 "A artificialidade não é uma característica que denota a origem fabricada do objeto em oposição à espontaneidade produtora da natureza: a artificialidade é aquilo que é interior à ação artificializante do homem, intervenha essa ação sobre um objeto natural ou sobre um objeto completamente fabricado" (Simondon, 1958, 1969, p. 47).
} 
corporatização do território, isto é, a cirscunstância de que as empresas monopolistas ou transnacionais entram a moldar o território a seu talante (Santos, 1996, 2002, p. 252-253). As verticalidades, nas atuais condições do capitalismo, avançam sobre as horizontalidades, não apenas para controlá-las, como também para extrair a elas uma força vital. Formam-se estruturas e formas espaciais novas, híbridas, que caldeiam o poder da verticalidade com a força da horizontalidade. Poderíamos falar em transversalidades.

Torna-se cada vez mais impróprio separar o global do local, o social do natural; estamos em face de uma frenética produção de híbridos, esse trabalho de hibridação, como quer Bruno Latour $(1991,1997)$. Dizer que o espaço é a materialidade mais a vida, quer dizer que ele é o encontro entre a máxima determinação e a máxima contingência; entre a máxima indução e a máxima espontaneidade. O período em que se dá o controle da vida é o período em que o espaço adquire uma concreção inédita. "Já que a realização concreta da história não separa o natural e o artificial, o natural e o político, devemos propor um outro modo de ver a realidade, oposto a esse trabalho de purificação, fundado em pólos distintos" (Santos, 1996, 2004, p. 101).

Os vetores globais se procuram novos discursos, novas palavras, de modo a criar situações horizontais em que sua racionalidade se possa instalar em meio aos agentes marginais. Uma normatização da vida, em seus critérios biológicos e sociais, parece ser o novo requisito para a manutenção das coerências hegemônicas. 
As densidades normativas e o território brasileiro

As normas e o território

Neste período contemporâneo, as unificações espaciais promovidas pelos agentes hegemônicos retiram seu poder, sobretudo, da montagem de vastos aparatos normativos. É com base nesses quadros rígidos que se devem desenrolar as novas ações, tanto aquelas que vêm consolidar as lógicas dominantes, como aquelas que buscam superações, mudanças, ultrapassagens ${ }^{1}$.

Em tais condições, no período atual, a "organização" das "coisas" passa a ser um dado fundamental. Daí a necessidade de adoção, de um lado, de objetos susceptíveis de participar dessa ordem e, de outro lado, de regras de ação e de comportamento a que se subordinem todos os domínios da ação instrumental (Santos, 1996, 2004, p. 228).

Hoje, as normas têm peso cada vez maior sobre os trabalhos realizados sobre o território. Assim, os juristas se desvencilham por completo de sua condição de "metafísicos em política", epíteto que Saint-Simon (1821, 1925, p. 148) Ihes atribuiu.

Nos países periféricos, a constituição dessa base normativa torna-se ainda mais necessária, pois a presença de grande número de agentes marginais conduz à ameaça da dissolução do sistema hegemônico. Neste ponto, as normas adquirem um verdadeiro caráter de repressão política² .

Numa perspectiva geográfica, as normas têm um certo aspecto de materialidade, pois que, além de cruzar os períodos históricos mais ou menos inalteradas, ainda enquadram as ações, condicionando-as, feito objetos materiais. Por isso, diz Milton Santos que as normas podem modificar os eventos, reduzindo ou expandindo sua duração (Santos, 1996, 2002, p. 149).

Mas é preciso chamar a atenção para dois fenômenos.

\footnotetext{
${ }^{1}$ Segundo Sartre (1960a, p. 101-102), a ação de um indivíduo ou de um grupo, uma vez objetivada, torna-se objeto pra outras ações, que vão realizar uma ultrapassagem em relação à ação anterior; nessa sucessão de ultrapassagens, vão-se formando sistemas, aparelhos, como se a História não pertencesse aos homens.

${ }^{2}$ Fernando Henrique Cardoso e Enzo Faletto afirmam que o domínio não se sustém apenas pelas bases materiais estabelecidas: é preciso forjar meios institucionais e esquemas ideológicos assegurando a legitimidade do grupo hegemônico (Cardoso e Faletto, 1967, 1969, p. 39).
} 
Primeiramente, as normas, assim como as outras variáveis, espalham-se pelo território de maneira desigual ${ }^{3}$.

Naquelas áreas onde a lei do mercado e as demais normas globais agem mais profundamente, arrostando a exígua resistência das normas locais, identificaríamos uma maior densidade normativa e, portanto, uma construção mais agressiva e aperfeiçoada da ordem global (Silveira, 1997, p. 43).

Segundamente, a norma não revela seu poder apenas quando se faz efetiva, mas também naqueles instantes em que seus gestores podem, por assim dizer, desligá-la, adormecê-la, ou pelo menos abrandá-la. Isso é possível graças à nova partilha de funções normativas entre o Estado e as grandes corporações, configurando aquela burocracia mista que María Laura Silveira (1996, 1999) identificou4. A maior ou menor hegemonia dos agentes, bem como sua velocidade, define-se em função do sistema de normas do qual ele faz uso. É o conceito de organização.

\section{As normas e a produção de medicamentos}

No estudo da produção de medicamentos, as normas são um tema que se impõe, em razão da impressionante revolução normativa por que vem passando essa atividade nos últimos anos. As renovações produtivas descritas anteriormente mudam as hierarquias territoriais, gerando pontos de ruptura, tensões que se podem suavizar apenas mediante a renovação dos aparelhos normativos ${ }^{5}$.

Nas atividades farmacêuticas, a renovação normativa conhece três marcos fundamentais. Primeiro, a adesão do governo brasileiro, em 1994, ao acordo Trips, Traderelated Aspects of Intellectual Property. Segundo, a criação da Anvisa, Agência Nacional de Vigilância Sanitária, em 1999. Terceiro, a promulgação, nesse mesmo ano, da lei dos medicamentos genéricos.

Aos poucos, a ciência converte-se em norma, ou seja, os parâmetros científicos balizam, de modo compulsório, os procedimentos dos vários agentes.

\footnotetext{
3 "Haveria, assim, uma verdadeira segmentação normativa do território, que contribui para compartimentar o espaço em pedaços com maior ou menor aptidão para que os agentes privados e os segmentos do Estado possam desenvolver, com maior fluidez, suas atividades” (Silveira, 2000, p. 25).

4 "Nesse rearranjo jurídico, o protagonista é uma burocracia mista, porque formada de agentes públicos e privados, cuja principal novidade é o domínio ostensivo do conhecimento técnico-científico sobre o território e a sociedade”. (Silveira, 1996, 1999, p. 259)

5 "Não é a técnica em si que leva ao envelhecimento rápido das situações, mas a política” (Santos, 1996, 2002, p. 222).
} 
As patentes e os medicamentos para tratamento da Aids: Produção particular e produção estatal

Conforme explicação de Alexis González, o acordo Trips é um tópico específico, um tratado anexo, da criação da OMC, Organização Mundial do Comércio, em 1994. Aderindo à OMC, os países assinaram, automaticamente, o acordo Trips $^{6}$. Por esse mecanismo, que deriva de pressões diretas dos Estados Unidos, nenhum ramo tecnológico poderia ficar excluído da proteção de patentes (González, 1999, p. 61).

Ainda segundo González, o Congresso Nacional aprova, a 31 de dezembro de 1994, o acordo Trips; no dia primeiro de janeiro de 1995, o acordo começa a vigorar no Brasil; a 14 de maio de 1996, aprova-se no Congresso Nacional a lei 9 279, nova lei de propriedade industrial, que entra em vigor a 15 de maio de 1997, reconhecendo patentes para medicamentos inovadores, produtos químicos, alimentícios, e processos para obtenção ou modificação desses produtos ${ }^{7}$. Era a realização de um velho desiderato dos Estados Unidos, que, desde a década de 1980, vinham forçando para que os países da América Latina voltassem a reconhecer patentes (González, 1999, pp. 61-63). Os medicamentos, que desde 1945 estavam livres de proteções patentárias, voltam a ser defendidos por tal mecanismo jurídico ${ }^{8}$.

Por vezes, os laboratórios farmacêuticos, quando se aproxima a expiração de seu privilégio, entram com pedido de patente sobre o mesmo produto, mas baseando-se numa outra propriedade terapêutica posteriormente descoberta ao longo de pesquisas clínicas. Assim, as normas jurídicas e técnicas brasileiras, facilitando as pesquisas clínicas, vão ser conjugadas com as normas referentes à nova proteção patentária, o que resulta em conjunturas propícias para as organizações hegemônicas.

\footnotetext{
6 "Em 1995, cria-se a Organização Mundial do Comércio (OMC), que engloba os diversos acordos, artigos, códigos, cláusulas e tratados de todo o processo do GATT [General Agreement on Tarifs and Trade] desde 1947. É uma instituição internacional que tem como objetivo a regulação do sistema mundial de comércio" (Arroyo, 2001, p. 71). São 135 os países que compõem a OMC (Alves, 2004, p. 158 - nota 33).

${ }^{7}$ Pelo chamado mecanismo de pipeline, o país reconhece ainda patentes já concedidas no exterior a produtos que ainda estejam em fase de testes e, portanto, fora do mercado.

8 "Vale lembrar que quando a patente é concedida o seu detentor passa a ter direitos exclusivos de exploração do objeto protegido (produção, utilização, comercialização sem concorrência, venda ou importação) pelo período de 20 anos” (Anvisa, 2004, p. 11). Segundo explicação de Rogério Oliveira, não se obriga, pelo acordo Trips, o titular da patente a produzir no país em que ela se deposita (Oliveira, R. 1999, pp. 58 e 126). Ainda segundo Oliveira, a legislação brasileira torna possível a instituição de licenças compulsórias de importação (a chamada importação paralela) ou de produção, quando: o produto não estiver sendo produzido, ou quando o estiver apenas de modo parcial (o que se verifica após três anos de concessão da patente); a comercialização não suprir as demandas do mercado; houver práticas abusivas de exploração do mercado ou de formação de preços; existir a dependência de uma patente em relação a outra anterior; houver situações de emergência nacional ou interesse público (Oliveira, R. 1999, pp. 58 e 126). Entanto, sabe-se que a aplicação de licenças compulsórias implicaria tensões políticas internacionais de grande monta.
} 
[...] essas organizações e as ações que delas emanam encontram-se mediadas, com força crescente a cada dia, por sistemas de normas [...] Desse modo, as normas instalam-se em famílias, solidárias internamente, mas com vocação para substituir o conjunto normativo vigente (Silveira, 2000, p. 24).

Os medicamentos juridicamente protegidos se multiplicam rapidamente. Em outubro de 2003, eles já representavam 40\% do mercado farmacêutico brasileiro (Gazeta Mercantil, 29-10-03, p. A14) ${ }^{9}$.

Ao mesmo tempo em que as patentes farmacêuticas eram adotadas por diversos países, numa verdadeira vaga jurídica mundial, acaloravam-se os debates referentes aos medicamentos anti-retrovirais, isto é, os produtos que integram o chamado coquetel contra a Aids. A expansão do número de pessoas portadoras da síndrome se dá paralelamente à expansão das pesquisas e das forças produtivas. Em 1999, os medicamentos para Aids representavam a terceira classe em termos de novos medicamentos em desenvolvimento nos Estados Unidos, num total de 122; em primeiro lugar, aparecia o câncer (316), e em segundo lugar os medicamentos e vacinas infantis (146) (Oliveira, R. 1999, p. 90). Neste caso, a expansão da demanda se dissocia da expansão dos conhecimentos farmacêuticos, já que uma grande massa de pessoas têm acesso drástico, ou nulo, às produções anti-retrovirais.

Em território brasileiro, esse tipo de medicamento é produzido por dois tipos de agentes. Por um lado, há os laboratórios multinacionais, introdutores dessa produção no mundo. Por outro lado, os chamados laboratórios oficiais, ou seja, laboratórios farmacêuticos ligados a instituições governamentais ${ }^{10}$.

Em 2004, havia no Brasil 18 laboratórios oficiais, sendo 4 federais e ligados às forças armadas, 9 estaduais, e 5 ligados a universidades (Ministério da Saúde apud Gazeta Mercantil, 23/24/25-02-05, p. A11). São representados pela Alfob, Associação dos Laboratórios Oficiais do Brasil. Integrantes do Sistema Único de Saúde, eles estão proibidos, por lei, de vender seus produtos para farmácias e distribuidores comuns, e devem realizar uma produção voltada principalmente para as redes hospitalares estatais. Assim,

\footnotetext{
${ }^{9}$ As patentes se aplicam a medicamentos lançados após a assinatura do acordo Trips pelo Brasil. Mas, nalgumas situações, foi possível acionar recursos retroativos. O Nelfinavir, medicamento do laboratório Roche (Suíça), usado para tratamento da Aids, é um exemplo de patente retroativa. Não era fabricado no Brasil até a aprovação da nova lei de patentes, e era patenteado em seu país de origem. Pela ação do governo, e certamente por pressão do laboratório, pôde ser patenteado também no Brasil.

${ }^{10}$ Os laboratórios nacionais particulares, mesmo aqueles que são mais fortemente capitalizados, não se interessam por esse tipo de produção, seja por causa dos volumosos recursos iniciais exigidos, seja pela dificuldade de concorrer diretamente com os laboratórios multinacionais num segmento de mercado em que os preços são rigidamente controlados.
} 
seus clientes são, sobretudo, as diversas secretarias estaduais e municipais de saúde, além de Santas Casas e entidades que dispensam os medicamentos gratuitamente ${ }^{11}$.

Ocorre que, entre esses agentes e os laboratórios multinacionais, diferenças fundamentais se apresentam. Sobretudo porque, para os laboratórios oficiais, a capacidade para realizar pesquisas básicas é muito reduzida. Em 2004, entre os 18 laboratórios da Alfob, apenas seis desenvolviam atividades de pesquisa (Alfob apud Gazeta Mercantil, 2211-04, p. A16). Nalgumas situações, como a do Lifal $^{12}$, Laboratório Industrial de Alagoas (Maceió), as empresas definham sob crises financeiras ${ }^{13}$.

O Farmanguinhos (Rio de Janeiro-RJ), laboratório fundado em 1956 e ligado à Fundação Oswaldo Cruz desde 1970, representa uma situação bastante rica, não apenas por ser, dos laboratórios oficiais, aquele que tem conseguido maior fôlego de pesquisa ${ }^{14}$, mas também porque, por vezes, aparece na intersecção entre as lógicas da produção nacional e as lógicas mercantis dos laboratórios multinacionais. Isso acontece porque o Farmanguinhos, reproduzindo as moléculas dos laboratórios estrangeiros, pode referenciar a formação de preços dos medicamentos. Com isso, percebe-se, por vezes, que os laboratórios multinacionais estão fixando preços acima do que seria justificável se se guiassem por critérios especificamente científicos e tecnológicos.

No mais, não podemos deixar de ressaltar que foi graças às cópias realizadas pelo Farmanguinhos que o Brasil pode possuir, hoje, uma linha oficial de produtos anti-retrovirais $^{15}$. Além de sua produção direta, o Farmanguinhos, reproduzindo as moléculas estrangeiras, repassou a tecnologia de produção para algumas outras empresas da Alfob. Assim, o governo federal, por meio do Farmanguinhos, pode possuir argumentos científicos e tecnológicos, além dos políticos, nas ocasiões em que os laboratórios estrangeiros ampliam demasiadamente os preços dos medicamentos para Aids. Essa "função de referência de preços", desempenhada pelo Farmanguinhos, é também ressaltada por Flávia Alves (2004, pp. 97-98 e 101).

\footnotetext{
${ }^{11}$ Para uma relação completa dos laboratórios oficiais brasileiros, consultar o anexo 2.

${ }^{12} \mathrm{O}$ Lifal produz apenas medicamentos líquidos e comprimidos não-revestidos, que são tipos de produção de ínfima complexidade. Fabrica três itens anti-retrovirais.

${ }^{13}$ A partir de agora, começamos a usar as informações colhidas em pesquisa de campo. Para saber a que período corresponde a informação apresentada, consultar o anexo 1, onde se indicam os nomes dos laboratórios visitados, em ordem alfabética, bem como a data de realização da entrevista.

${ }^{14}$ Em 2004, a empresa possuía 14 patentes de princípios ativos depositadas, mas os respectivos fármacos não eram produzidos, em função das dificuldades envolvidas na passagem à etapa da produção em larga escala (Gazeta Mercantil, 22-11-04, p. A16). Em 2000, dos cerca de 500 funcionários do Farmanguinhos, cerca de 70 se incumbiam das atividades de pesquisa.

${ }^{15}$ Em 1997, 2 medicamentos anti-retrovirais eram produzidos no Brasil; em 2003, esse número se eleva a 8 medicamentos (GT\&P Consultoria apud Gazeta Mercantil, 17-11-03, p. A3).
} 
Podemos destacar também a situação da Furp, Fundação para o Remédio Popular, ligada à secretaria de Saúde do Estado de São Paulo ${ }^{16}$. Além de sua unidade produtiva na cidade de Guarulhos (SP), inaugurada em 1974, funda recentemente mais uma unidade, no município de Américo Brasiliense (SP), na região de Araraquara. Essas obras tiveram início em 2004, sendo concluídas em 2006. Maior laboratório oficial do Brasil, em termos de volume de produção, a Furp é também um dos maiores produtores de medicamentos do país, incluindo as empresas privadas. (Gazeta Mercantil, 21-08-03, p. A13; 29-01-04, p. A13; 18-02-04, p. A17; 22-1104, p. A16) ${ }^{17}$.

No estado de Pernambuco, encontramos o Lafepe. Foi o primeiro laboratório oficial a produzir um medicamento para o tratamento da Aids, o AZT, e sua produção de anti-retrovirais já alcança o número de sete medicamentos.

Nos anos 1970 e 1980, os laboratórios oficiais apoiavam-se na existência da Ceme, Central de Medicamentos, que absorvia a quase totalidade de seus produtos. Quando esse organismo se extingue, nos anos 1990, eles, subitamente órfãos, enfrentam graves dificuldades financeiras, pois passam a depender das compras fragmentadas feitas por secretarias de saúde. Como estas últimas conhecem, não raro, fraquezas financeiras, os laboratórios oficiais se contagiam dessa moléstia. $O$ encerramento das atividades do Bahiafarma, laboratório oficial baiano, é um claro sinal desse desamparo a que estão submetidos os laboratórios estatais.

Reforçando semelhante situação, os laboratórios oficiais, malgrado seu menor poderio mercadológico, precisam, muita vez, fazer face aos esquemas mercantis. Primeiramente, não dispõem de prazos ou tarifas especiais, junto à vigilância sanitária nacional ${ }^{18}$. Segundamente, não existe um canal oficial de importação de matérias-primas, o que leva os laboratórios oficiais a produzir sob os preços que vigoram nos mercados internacionais $^{19}$. Por fim, a inexistência de uma forte rede oficial de farmácias faz com que

\footnotetext{
16 “Apesar de ter no portfólio uma droga de sua autoria, o imunossupressor azatioprina criado na década de 1980, a Furp é tradicional fabricante de medicamentos já conhecidos no mercado - cujas patentes expiraram ou foram quebradas - e novas formulações” (Gazeta Mercantil, 22-11-04, p. A16).

17 "O maior comprador da Furp é o governo estadual, que absorve $55 \%$ da sua produção atual" (Gazeta Mercantil, 18-02-04, p. A17).

${ }^{18}$ O Iquego, Indústria Química do Estado de Goiás, está convertendo sua linha de similares em genéricos; para tanto, contrata os testes junto à Faculdade de Farmácia da Universidade Federal de Goiás, pagando os mesmos preços que as empresas particulares. O Iquego produz sete medicamentos anti-retrovirais; eles estão registrados como medicamentos similares, sendo possível transformá-los em medicamentos genéricos, desde que os respectivos medicamentos de referência não estejam protegidos por patentes. O Ministério da Saúde é o principal comprador dos produtos do Iquego.

${ }^{19}$ O vice-diretor do Laqfa, Laboratório Químico-Farmacêutico da Aeronáutica, deplora o fato de que os laboratórios oficiais tenham que registrar seus genéricos isoladamente, em vez de haver registros válidos para toda a rede de laboratórios estatais.
} 
esses laboratórios fiquem restritos ao mercado hospitalar, o que lhes dá menor dinamismo ${ }^{20}$. Em 2003, 10\% da produção farmacêutica brasileira era adquirida pelo setor público (Ministério da Saúde apud Gazeta Mercantil, 30-07-03, p. A5).

Assim, a única vantagem de que gozam esses laboratórios é o acesso privilegiado aos hospitais públicos, aos quais vendem seus produtos sem tomar parte em licitação. Essa vantagem fica, porém, diminuída se considerarmos que eles, na grande maioria dos casos, produzem medicamentos simples, e por isso baratos. Os laboratórios oficiais abastecem o Ministério da Saúde em 48\%, em volume; mas, da receita do ministério destinada à compra de medicamentos, eles absorvem só 15\% (Ministério da Saúde apud Gazeta Mercantil, 23/24/25-02-05, p. A11). Isso acontece porque eles produzem, principalmente, medicamentos de conteúdos científicos relativamente menores, tais como os oficinais ou os medicamentos similares.

O segmento hospitalar mais rentável fica sob controle das empresas particulares, capazes de realizar produções mais sofisticadas. Os laboratórios oficiais, a que se dispensa, na maioria das situações, um tratamento parecido com aquele que se dispensa às empresas particulares, são obrigados a curtir uma situação de precariedade científica e financeira. Tratá-los de maneira semelhante representa, ao final das contas, uma forma de piorar seus desempenhos comerciais e tecnológicos ${ }^{21}$.

Com tais situações de modéstia, ou mesmo de penúria, comparemos os portentosos desempenhos dos laboratórios multinacionais, e compreenderemos que são eles que possuem maior dinamismo e vigor para tocar as produções de anti-retrovirais em território brasileiro.

O governo federal tem mantido um programa, internacionalmente elogiado, voltado aos portadores do vírus HIV. A par de uma distribuição gratuita dos medicamentos, o programa prevê a fabricação, em laboratórios oficiais, de oito dos quinze produtos anti-retrovirais pertencentes ao coquetel. Mas, em face do predomínio dos laboratórios multinacionais, é inevitável que o programa se torne, a pouco e pouco, um duro fardo para as contas públicas. Todos os sete medicamentos que os laboratórios oficiais não produzem devem ser importados; três deles consomem $63 \%$ do orçamento do Ministério da Saúde ${ }^{22}$.

"O Brasil é o segundo país em investimentos para tratamento da Aids, só perdendo para os Estados Unidos" (Gazeta Mercantil, 16-02-04, p. A14). Sem dúvida que esses gastos são fundamentais, uma vez que se trata de proteger a saúde das pessoas

\footnotetext{
${ }^{20}$ Aqui, a exceção é o Lafepe, cujos produtos são vendidos numa pequenina rede própria, formada por quatro farmácias espalhadas pelo estado de Pernambuco. Uma das farmácias fica na rodoviária; outra, na própria fábrica. Nessas farmácias, vendem-se apenas os medicamentos do Lafepe.

21 "Lá onde a igualdade recai sobre fundamentos formais do relacionamento humano, ela serve para expressar desigualdades individuais mais acentuada e extensamente” (Simmel, 1900, 1997, p. 442).

${ }^{22}$ Trata-se do Lopinavir, produzido pela Abott (Estados Unidos), do Nelfinavir, da Roche (Suíça) e do Efavirenz, da Merck (Alemanha) (Gazeta Mercantil, 22-07-03, p. A5).
} 
contaminadas pelo vírus. Entanto, o que se deve deplorar é que eles terminam por integrar estratégias de grandes empresas estrangeiras, enquanto os laboratórios oficiais, em que se poderiam realizar produções alternativas, amargam precárias condições. É como se o país deixasse de investir em pesquisas básicas para importar o conhecimento já pronto, já coisificado, em operações comerciais que sufocam os orçamentos do Ministério da Saúde.

A existência das patentes vem reforçar as tendências, uma vez que as drogas anti-retrovirais mais recentes estão protegidas de cópias pelas novas barreiras jurídicas.

O Estado perfilha comportamentos por vezes paradoxais. Por um lado, vai acolher as patentes em 1997. Por outro, aferra-se no combate aos privilégios concedidos pelas patentes, lutando, por exemplo, para fazer cair os preços de medicamentos anti-retrovirais patenteados. Os laboratórios multinacionais mostram-se, não raro, cordatos para negociar mercadologicamente o preço de seus produtos ${ }^{23}$. Assim pode ser quando já têm garantido seu direito político à propriedade intelectual ${ }^{24}$.

Neste ponto, porém, é preciso cuidado para que não adentremos o labirinto das questões espúrias, tanto mais sedutoras quanto mais ociosas. Em princípio, é totalmente desnecessário que nos manifestemos de maneira favorável ou contrária às patentes. Se elas realmente são instrumentos indispensáveis para o avanço das terapias, isso nunca chegaremos a demonstrar ou negar de maneira objetiva; e, se não chegaremos, a discussão é totalmente baldada. Mas, se quisermos pensar que elas são de fato fundamentais, então que sejam aclamadas e adotadas em todo o mundo. Este não é o problema. O problema é que a existência das patentes pressupõe a existência de uma produção farmacêutica baseada em acréscimos fabulosos de ciência, técnica, informação. O ponto é dizer de que maneira, nessas condições, vamos permitir que todos possam fruir dos avanços realizados por essa indústria farmacêutica. Não basta despejar sobre o Estado a tarefa de possibilitar o acesso, aumentar o nível de renda, promover a igualdade. As diferenças socioespaciais não se exprimem apenas em termos de renda e consumo. Há, por exemplo, cruciais diferenças geográficas, e estamos tentando mostrar como os agentes hegemônicos contribuem, o mais das vezes, para agravá-las.

No Estado, fiamos com freqüência nossas esperanças mais sinceras. Por outro lado, as configurações espaciais tendem a transferir os poderes estatais para as corporações globais, que passam a regular, em grande medida, os territórios, com base em critérios mercantis. Em 2001, o continente africano representou 1\% do faturamento dos laboratórios

\footnotetext{
23 “A ameaça de licenciamento compulsório, recurso utilizado pelo governo anterior, fez cair o preço de três medicamentos em 2001 - o Indinavir, produzido pela Merck, em 64,8\%; o Efavirenz, também da Merck, em 59\% e ainda o Nelfinavir, da Roche, em 40\%” (Gazeta Mercantil, 22-07-03, p. A5).

24 "A evolução dos princípios reguladores do sistema de patentes no mundo resultou em uma mudança de conceitos, onde o objetivo original de incentivo e proteção à indústria nacional foi substituído pelos propósitos de apoio e consolidação do comércio internacional” (Oliveira, R. 1999, pp. 93-94).
} 
farmacêuticos multinacionais (Barros, 2001, p. 87). Sabemos que esse continente é o principal celeiro de propagação do vírus HIV. Ao mesmo tempo, é ali que os principais problemas de acesso aos medicamentos anti-retrovirais ocorrem. Para que essas tendências sejam revertidas, seria preciso que as políticas farmacêuticas fossem conduzidas em termos nacionais. Pois, hoje, prevalecem as lógicas mercantis globais, o que traz um risco, pois que as gigantes corporações capitalistas podem, a todo momento, sentir-se mais atraídas pelos 99\% representados pelas outras regiões do mundo.

\section{Anvisa: a renovação normativa e as armadilhas científicas}

Segundo Alexis González, as intervenções do Estado no mercado farmacêutico realizam-se através de normas econômicas e de normas sanitárias; estas últimas implicam o controle sobre: o número de medicamentos disponíveis; a eficiência e a segurança dos medicamentos; as atividades de promoção e propaganda das empresas farmacêuticas particulares; a distribuição dos medicamentos (González, 1999, p. 19).

No Brasil, a Anvisa, Agência Nacional de Vigilância Sanitária, encarrega-se dessas inspeções. Sua criação, em 1999, é outro evento que vem modificar profundamente o sistema normativo brasileiro ${ }^{25}$. Em verdade, suas feições se inspiram na agência sanitária dos Estados Unidos, a FDA.

Desde sua criação, a Anvisa tem favorecido sobretudo a penetração de lógicas verticais e globais nas atividades farmacêuticas.

De acordo com María Laura Silveira, as novas formas materiais entram em conflito com o velho quadro normativo, forçando a renovação desse quadro, em proveito, justamente, daqueles que controlam as novas formas materiais (Silveira, 1996, 1999, pp. 106-107). No capítulo precedente, buscamos revisar algumas das novas revoluções técnicas vividas pelas atividades farmacêuticas. Ora, essas transformações forçam uma renovação dos aparelhos normativos, sem a qual o sistema novo, submetido a ritmos e funcionamentos antigos, não poderia desenvolver todos os seus potenciais. Com isso, recrudescem os reclamos em favor de modernizações normativas, as quais se convertem, não raro, num verdadeiro cerco às lógicas seguidas pelas menores empresas. Isso acontece

\footnotetext{
25 “Em janeiro de 1999, foi criada pela Lei 9782 a Agência Nacional de Vigilância Sanitária (Anvisa), que incorporou as competências da Secretaria de Vigilância Sanitária do Ministério da Saúde, adicionadas a novas missões: coordenação do Sistema Nacional de Vigilância Sanitária (SNVS), do Programa Nacional de Sangue e Hemoderivados e do Programa Nacional de Prevenção e Controle de Infecções Hospitalares; monitoramento de preços de medicamentos e de produtos para a saúde; atribuições relativas à regulamentação, controle e fiscalização da produção de fumígenos; suporte técnico na concessão de patentes pelo Instituto Nacional de Propriedade Industrial (INPI); e controle da propaganda de produtos sujeitos ao regime de vigilância sanitária” (Capanema e Palmeira Filho, 2004, p. 36). Anvisa: “[...] uma autarquia sob regime especial, vinculada ao Ministério da Saúde, caracterizada pela independência administrativa, estabilidade de seus dirigentes e autonomia financeira, em substituição à Secretaria de Vigilância Sanitária” (Pereira, 2002, p. 16).
} 
tanto de maneira direta, com a interdição de laboratórios que não comprovem a eficácia científica de suas produções, como de maneira indireta, pela instituição de regras modernas de qualidade, às quais só os laboratórios multinacionais ou os maiores laboratórios nacionais conseguem atender facilmente.

Aqui, é preciso destacar uma questão. Nossa pesquisa se interessa, como dissemos já no começo, pela produção de medicamentos. Isso pressupõe uma integração com o sistema de ações que se configura ao redor da fabricação e distribuição dos produtos terapêuticos. Produções ilegais, ineficazes, falsificadas, devem, obrigatoriamente, integrar-se noutros sistemas de ações, em que os requisitos da modernidade podem ser completamente relegados. Não pertencem, pois, ao rol dos nossos interesses atuais as situações dos laboratórios fraudulentos, que aliás são raros no período atual, justamente em decorrência da ação eficaz da Anvisa. Portanto, quando falamos em cerco aos pequenos laboratórios, não nos referimos à coibição das falsas produções farmacêuticas. Referimo-nos, isto sim, à imposição de uma ordem produtiva que é típica do circuito superior e que, aplicada ao circuito superior marginal, torna-se fonte de corriqueiras desordens.

Assim, a Anvisa faz-se a carnação de uma fúria normativa que, em tempos acelerados, se despeja sobre o território brasileiro. Conforme Capanema e Palmeira Filho, a Anvisa publicou 19 resoluções apenas em junho de 2003 (Capanema e Palmeira Filho, 2004, p. 37). Esse mês foi decisivo, pois que tais resoluções alteram, por vezes de maneira fundamental, o fácies da atividade farmacêutica no Brasil. Abaixo, listamos algumas delas.

- RDC 133: torna obrigatórios os testes de biodisponibilidade para novos medicamentos similares;

- RDC 134: torna obrigatórios os testes de bioequivalência e biodisponibilidade relativa para os medicamentos similares já existentes;

- RDC 136: determina que se deve declarar uma previsão de preços no momento em que se registrarem os novos medicamentos;

- RDC 138: prevê novos critérios para os medicamentos de venda sem prescrição médica;

- RDC 139: estabelece uma legislação específica para medicamentos homeopáticos;

- RE 902: torna obrigatória a fabricação de lotes-piloto antes da aprovação do registro

(Capanema e Palmeira Filho, 2004, p. 37) ${ }^{26}$.

Tais renovações normativas, prevendo uma série de procedimentos mais modernizados, perturbam ou desestabilizam os pequenos laboratórios, que se devem esforçar por incorporar, em suas produções, novos conteúdos científicos, por meio de

\footnotetext{
${ }^{26}$ Em agosto de 2003, a RDC 210, que redefine as boas práticas de fabricação, também foi de importância maior (Capanema e Palmeira Filho, 2004, p. 37). Adiante, falaremos também da RDC 17, de 2000, que altera as condições da produção de medicamentos fitoterápicos. E, no capítulo VIII, veremos como algumas dessas resoluções afetam as operações das pequenas empresas produtoras de medicamentos.
} 
relações e atividades que, não raro, Ihes são bastante onerosas. Desde sua aparição, a Anvisa não cessa de lançar resoluções, prevendo exames adicionais, redefinindo suas taxas, requerendo sofisticações produtivas, girando suas engrenagens normativas. Hoje, o chamado setor farmacêutico tornou-se "um dos mais regulados do país" (Gazeta Mercantil, 26-07-04, p. A9).

Por vezes, essas novas normas se inspiram nas situações dos maiores laboratórios, os quais, indiretamente, convertem-se em pólos emissores de procedimentos e requisitos ${ }^{27}$. Assim, não é raro que pequenos laboratórios trabalhem, por vezes durante alguns anos, com licenças especiais da Anvisa, enquanto se esforçam para, finalmente, conseguir o certificado de Boas Práticas de Fabricação.

Não podemos deixar de reconhecer os méritos que tem a Anvisa, por haver finalmente fundado um sistema de vigilância coerente, fato que foi destacado por vários representantes de vários laboratórios, no curso de nossa pesquisa de campo $^{28}$. Entanto, suas ações, espalhando as lógicas técnicas e científicas, podem levar a atividade farmacêutica a perigosas armadilhas políticas.

Faz-se difícil considerar, sem maiores ponderações, que os acréscimos de ciência garantirão, necessariamente, a segurança e a qualidade das produções farmacêuticas. Aqui, não gostaríamos de usar o exemplo da Talidomida, pois que muitos pensariam que tais catástrofes pertencem às décadas pretéritas ${ }^{29}$. Brevemente, podemos citar casos mais atuais.

Em 2001, a Bayer (Alemanha) retira do mercado o Baycol, medicamento para controle do colesterol, que teve seu consumo relacionado à morte de pacientes (Gazeta Mercantil, 26/27/28-11-04, p. A11).

Ainda mais recente é o famigerado caso do medicamento Vioxx, lançado pela Merck (Alemanha), em 2000. Foi retirado do mercado em setembro de 2004 (Gazeta Mercantil, 1512-04, p. A11). A razão desse medida é que, segundo se constatou, o Vioxx poderia causar risco de distúrbio cardiovascular em tratamentos prolongados ${ }^{30}$. Em 2003, ele representou

\footnotetext{
${ }^{27}$ Para obter o certificado de Boas Práticas de Fabricação, a Colbras, empresa de Cotia (SP), teve que adquirir um sofisticado e caro sistema de tratamento de água; demais, a exigência de controle da qualidade ao longo da produção leva a um consumo intensivo de reagentes, que também são bastante onerosos. Com efeito, a consecução de semelhante certificado exige a absorção de vários procedimentos rígidos, próprios das maiores empresas: qualificação de fornecedores; validação de sistemas, processos e metodologias; aquisição de equipamentos modernos; contratação de funcionários para realizar as várias etapas de produção; garantia da qualidade de cada fase de produção.

28 “[...] dos anos 80 até início dos anos 90 não se faziam inspeções coordenadas no Brasil [...]” (Fonte, 2004, p. $61)$.

${ }^{29}$ Sobre e escândalo da Talidomida, ver Fonte, 2004, p. 52 e Gadelha, 1990, p. 103.

${ }^{30}$ Suspeita-se que o Vioxx tenha sido responsável por mais de cem mil acidentes cardio-vasculares e pela morte de cerca de trinta mil pessoas. Em agosto de 2005, no primeiro julgamento concernente a essas mortes, nos Estados Unidos, o laboratório foi julgado culpado. Durante o processo, foram apresentados alguns documentos mostrando que a companhia tinha, desde meados dos anos 1990, informações de que o medicamento acarretava
} 
$11 \%$ do faturamento global da Merck, sendo comercializado em mais de 80 países. Com a retirada do mercado, as ações da Merck caíram 32\% em outubro de 2004 (Gazeta Mercantil, 04-10-04, p. A13) ${ }^{31}$.

O caso do Vioxx apascenta um pouco as euforias ingênuas, ou interessadas, ou encomendadas. Aquando de seu lançamento, o produto foi aclamado pela imprensa de vários países, que lhe votou séries de elogios. No Brasil, o coro foi engrossado pela revista Veja, que incluiu o Vioxx na relação dos "super-remédios" ${ }^{\text {"32. }}$.

O caso do Vioxx tingiu, em certa medida, a credibilidade da FDA, cujos especialistas, ao aprovar a solicitação do registro, podem ter-se guiado mais por interesses decorrentes de suas relações com o laboratório do que por diretivas científicas. É o que se chama de conflito de interesse.

Em vários países, o que se tem verificado são laços ligando os cientistas às corporações farmacêuticas. Sabe-se que especialistas responsáveis pela avaliação dos medicamentos em agências sanitárias, como a FDA, têm relações estreitas com as empresas farmacêuticas ${ }^{33}$.

Desse modo, abala-se a idéia de que as agências sanitárias são como foros liberados e sapientes, em que se aconselham frios especialistas, capazes de bem decidir pela sociedade.

Não pretendemos subdizer que as mesmas relações aconteçam para o caso da Anvisa. Mas é preciso ressaltar que esta, bem como outras agências sanitárias de países periféricos, espelha-se, não raro, nas resoluções e pareceres expedidos pelas agências dos países centrais. Com isso, podem realizar a importação, não apenas de conhecimentos científicos elaborados, como também de relações mercantis escusas.

No mais, vale dizer que as empresas farmacêuticas multinacionais já controlam, profundamente, as lógicas da atividade médica ${ }^{34}$. Em 2000, a indústria farmacêutica promoveu, no mundo todo, mais de 314000 atividades médicas, entre congressos, fins de

problemas cardio-vasculares. A Merck, nos Estados Unidos, sofre 6400 acusações judiciais, além de 160 processos coletivos (Sciences et Avenir, 2005, pp. 50-54).

${ }^{31}$ A Merck elaborou um plano de reembolso aos pacientes. Apresentando a caixa do medicamento em farmácias determinadas, as pessoas foram ressarcidas de seu gasto.

${ }^{32}$ Numa edição de junho de 2002, a revista dizia que esses medicamentos "devolveram a milhões de pessoas uma qualidade de vida que parecia perdida para sempre". E continuava: "Estão para seus similares dos anos 80 assim como o Boeing 777 está para o 14-Bis, o avião de Santos Dumont” (Veja, 2002, p. 94).

33 "Interrogados pela revista britânica [Nature], um terço dos especialistas consultados confessam ligações com a indústria, que tomam a forma de honorários, de créditos para suas pesquisas, de conferências, de ações na bolsa... Assim, os especialistas realizam para as firmas ensaios clínicos, aconselham-nas em sua estratégia de desenvolvimento [...], tomam parte em simpósios financiados pelos laboratórios...” (Sciences et Avenir, 2005, p. 56).

34 "As companhias financiam e então controlam porções inteiras da atividade médica: estudos clínicos, publicações científicas, formação contínua, imprensa médica e numerosos congressos” (Sciences et Avenir, 2005, p. 59). 
semana, simpósios... (Journal of American Medical Association, dos Estados Unidos apud Sciences et Avenir, 2005, p. 59) ${ }^{35}$.

Com tudo isso, não pode o Brasil, por meio da Anvisa, fiar-se numa espécie de imparcialidade científica. Uma política farmacêutica nacional deve incluir o fenômeno técnico, ou seja, além de preocupações técnicas e científicas, as ponderações políticas ${ }^{36}$. De acordo com Bruno Latour, a técnica é a outra metade da política, e a política é a outra metade da técnica (Latour, 1991, 1997, p. 194-198).

Apropriada pelo capital, a ciência torna-se meio de controle e dominação; torna-se conhecimento instrumental $^{37}$. Assim, por um lado, são louváveis os esforços da Anvisa, que pretende achar critérios mais claros de vigilância ${ }^{38}$. Por outro lado, porém, os conhecimentos e procedimentos científicos estão largamente controlados por agentes globais, que, ditando os parâmetros internacionais, favorecem a fragmentação e a extroversão do território brasileiro.

O universal sempre contém um local; o necessário, sempre um contingente. Segundo Bruno Latour, as leis científicas podem ser pensadas como universais, mas desde que se admita expandir, para o universo, as regras de medição e cognição, locais, inventadas pelos tempos modernos (Latour, 1991, 1997, p. 162). O que se apresenta como universal, a ciência, não pode ser compreendido sem a participação de diversos interesses particulares mercantis ${ }^{39}$. Devemos então fugir a esse trabalho de purificação, que separa capital e ciência; fugir às seduções teóricas dessas "[...] liberdades referidas pelas doutrinas liberais, estas que, mesmo que certamente sem afastar o indivíduo da aquisição de bens de algum tipo, desprezam porém o fato de que apenas aqueles indivíduos já privilegiados de alguma forma ou de outra é que têm a possibilidade de obtê-los" (Simmel, 1900, 1997, p. 439).

${ }^{35}$ Guardando-se as proporções, laboratórios nacionais também financiam eventos médicos. O laboratório nacional Cristália (São Paulo-SP), por exemplo, possui uma casa bastante luxuosa no bairro de Pinheiros, em que hospeda médicos de todo o país, vindos a São Paulo para participar de congressos, simpósios, cursos.

36 " [...] a relação, que se deve buscar, entre o espaço e o fenômeno técnico, é abrangente de todas as manifestações da técnica, incluídas as técnicas da própria ação. Não se trata, pois, de apenas considerar as chamadas técnicas da produção, ou como outros preferem, as 'técnicas industrias', isto é, a técnica específica, vista como um meio de realizar este ou aquele resultado específico [...] Só o fenômeno técnico na sua total abrangência permite alcançar a noção de espaço geográfico” (Santos, 1996, 2002, p. 37).

${ }^{37}$ Segundo Milton Santos (2000, p. 53), a ciência, aliada à técnica e a serviço de interesses mercantis, é gabada e santificada; trata-se em verdade de uma ciência redutora e reduzida, porque destituída de seus ideais de busca da verdade.

38 "A mudança é gradual, em acordo com parâmetros internacionais, contudo levará a uma desejável realidade no futuro: a certeza de que todos os medicamentos à disposição no País terão acréscimos fundamentais nos quesitos de segurança, eficácia e qualidade” (Anvisa, 2004, p. 11).

39 "A atividade racional com relação a um fim é, em virtude mesmo de sua estrutura, o exercício de um controle. É por isso que, no espírito de uma tal racionalidade, a 'racionalização' das condições de existência é sinônimo da institucionalização de uma dominação que não é mais reconhecida como dominação política: a Razão técnica de um sistema social fundado na atividade racional com relação a um fim não perde, porém, seu conteúdo político” (Habermas, 1968, 1973, p. 5). 
Mais do que nunca, vale considerar, com María Laura Silveira, que o Estado não é ator neutro: muita vez, contribui para o uso corporativo do território (Silveira, 1997, p. 39) ${ }^{40}$. Assim como existem geografismos, existem sociologismos, e, entre estes últimos, um dos mais comuns tem sido a atribuição de vontades ao Estado. Mas ele não é um agente: é uma instância na qual se concentram alguns agentes sociais. "O Estado não é uma entidade instrumental intrínseca, não é uma coisa, mas a condensação de uma relação de forças" (Poulantzas, 1974, p. 106). Ao mesmo tempo em que se enrijecem as condições ditadas pelas corporações globais, que tendem a sobrepujar as prerrogativas do Estado, este se metamorfoseia, aprimorando sua configuração supostamente democrática. Um despotismo de mercado se faz acompanhar desse "ritualismo eleitoral", conforme a feliz expressão de Florestan Fernandes (1974, 1981, p. 208).

Uma renovação normativa que esteja baseada, exclusivamente, em medidas técnicas e na precaução da qualidade dos medicamentos acaba consagrando propósitos exteriores ao território brasileiro, na medida em que, dessa maneira, fica-se obrigado a importar séries de maquinarias, produtos, conhecimentos. As corporações, que lançam as regras na escala global, e o Estado, que perfilha as tendências assim produzidas, acabam realizando movimentos confluentes. Em períodos anteriores, essa conjunção realizava-se, principalmente, pelas ações produtivas diretas realizadas pelo Estado, bem como pela instalação de infra-estruturas que ele promovia ${ }^{41}$. Hoje, porém, o Estado parece incapaz de cumprir essas velhas funções, seja por efeito das privatizações, que the reduzem o papel econômico direto, seja por causa de seus endividamentos, que dificultam a instalação de infra-estruturas e dão origem às já famosas parcerias público-privadas. Porém, o Estado possui novo papel fundamental, sobretudo como pólo nacional de emissão de normas, o que, muita vez, constitui uma simples tradução de regras internacionais para a língua do

\footnotetext{
40 "Reorganizar a estrutura espacial pretérita, implantando macro sistemas de objetos técnicos informacionais no intuito de regular a fluidez e permitir a sobrevalorização fundiária significa criar um novo sub-espaço na metrópole que garanta as condições de competitividade - tornar produtivo o território - das corporações. Ora, isto envolve vultosas quantias de dinheiro seletivamente gasto, em detrimento de uma população carente de recursos básicos. Assim, a ordem pública e a ordem privada, neste caso, são, praticamente, a mesma ordem” (Bernardes, 2001, p. 177).

41 Em 1974, Poulantzas já dizia que, nos quadros do capitalismo monopolista, não se podia pensar separadamente a esfera político-ideológica (Estado) e a esfera econômica (produção). Pensava sobretudo no papel econômico ativo adquirido pelo Estado após a segunda guerra mundial (Poulantzas, 1974, pp. 106-111). Em 1979, disse Milton Santos que a generosidade do Estado para com os monopólios e as corporações se expressa em planos econômicos, cessão de infra-estruturas e condições especiais, concessão de benefícios e isenções, treinamento de mão-de-obra, operação do aparelho burocrático, investimento e atuação nas indústrias pesadas e de base, e outras coisas (Santos, 1979, 2004, pp. 161-162).
} 
país $^{42}$. No Brasil essa tarefa se realiza, não raro, graças à criação das agências reguladoras, ao estilo da Anvisa ${ }^{43}$.

Essas tendências normativas globais, aterrizando em países periféricos, vão ser a base de várias desordens e dificuldades. Exploramos essa questão sobretudo no capítulo VIII. Aqui, deixamos apenas um exemplo, referente aos medicamentos similares, ou seja, medicamentos que derivam de cópias de medicamentos inovadores ${ }^{44}$.

Desde o período ao qual chamamos de científico, os similares são uma produção tradicional das pequenas empresas brasileiras. Também são alvos importantes para as pequenas empresas distribuidoras de medicamentos. Pelas novas legislações, o registro desses produtos passa a ser condicionado à realização de testes de equivalência farmacêutica, ou seja, análises laboratoriais comprovando que eles têm a mesma constituição química do medicamento de referência. Uma vez que as pequenas empresas carecem da estrutura necessária para a realização dessas análises, devem procurar instituições, devidamente autorizadas pela Anvisa, junto às quais possam terceirizar esses testes ${ }^{45}$.

$\mathrm{Na}$ tabela V.1, pretendemos demonstrar que essas atividades de equivalência farmacêutica tendem a gerar concentrações espaciais. A cidade de São Paulo, como ali se vê, reúne a maior força para realizar os testes, o que se deve, sobretudo, à presença das

\footnotetext{
42 “O Estado cria um novo arcabouço jurídico para as relações de trabalho, visando dar respostas às demandas de flexibilidade política dos agentes hegemônicos” (Silveira, 1996, 1999, p. 276).

43 "A emergência das agências de regulação no Brasil parece-nos um caso emblemático da tentativa de dar conta dos novos recortes do espaço geográfico decorrentes do compartilhamento que a hegemonia soberana está impingida a realizar com as hegemonias corporativas [...]” (Antas Jr., 2005, p. 147).

44 "Os medicamentos similares devem conter o mesmo ou os mesmos constituintes ativos, apresentar a mesma concentração, forma farmacêutica, via de administração, posologia e indicação terapêutica e devem ser sempre identificados pelo nome de fantasia ou de marca” (Pereira, 2002, p. 25).

${ }^{45}$ Pra fazer parte da Reblas, Rede Brasileira de Laboratórios Analíticos em Saúde, a instituição deve passar por vistorias anuais da Anvisa, apresentar um quadro capacitado de recursos humanos, qualificar e revalidar anualmente todos os equipamentos utilizados, entregar à Anvisa relatórios mensais. A manutenção anual dessa estrutura é muito cara. Apenas para certificar um equipamento, é preciso solicitar a presença de um técnico da Anvisa, cujo deslocamento deve ser custeado pelo solicitante.
} 
grandes indústrias particulares. Quanto às menores, têm recorrido sobretudo às universidades. Assim, as pequenas empresas farmacêuticas devem incorporar esses custos referentes à compra de serviços científicos46. A ciência, convertida em norma, vai definir uma nova situação de rigidez, que abala as rotinas consolidadas em pequenos empreendimentos farmacêuticos. O consumo científico se torna freqüente, pois, a cada vez que vão renovar os registros de seus medicamentos, os laboratórios devem apresentar esses testes de equivalência farmacêutica.

\footnotetext{
${ }^{46}$ Em pesquisa de campo, um dos entrevistados referiu-nos que um teste de equivalência custaria R 99000 , por medicamento analisado.
} 
tabela V.1. Laboratórios de testes de equivalência farmacêutica em medicamentos autorizados pela Agência Nacional de Vigilância Sanitária: Brasil, 2004

\begin{tabular}{|c|c|c|c|c|c|c|}
\hline & & & Natureza & do & laboratório & \\
\hline $\begin{array}{l}\text { Unidade da } \\
\text { federação }\end{array}$ & TOTAL & Universitário & $\begin{array}{c}\text { Industrial (somente } \\
\text { pra uso próprio) }\end{array}$ & Industrial & $\begin{array}{l}\text { Oficial (somente pra } \\
\text { uso próprio) }\end{array}$ & Particular \\
\hline São Paulo & 18 & 3 & 12 & --- & 1 & 2 \\
\hline Rio de Janeiro & 8 & 3 & 3 & 1 & 1 & --- \\
\hline Minas Gerais & 2 & 1 & 1 & --- & --- & --- \\
\hline Paraná & 1 & --- & 1 & --- & --- & --- \\
\hline Rio Grande do Sul & 2 & 2 & --- & --- & --- & --- \\
\hline Goiás & 2 & 1 & 1 & --- & --- & --- \\
\hline Ceará & 1 & 1 & --- & --- & --- & --- \\
\hline Paraíba & 1 & 1 & --- & --- & --- & --- \\
\hline Pernambuco & 1 & 1 & --- & --- & --- & --- \\
\hline Bahia & 1 & --- & --- & --- & --- & 1 \\
\hline TOTAL & 37 & 13 & 18 & 1 & 2 & 3 \\
\hline
\end{tabular}

fonte : Reblas, Rede Brasileira de Laboratórios Analíticos em Saúde : www.anvisa.gov.br/reblas - elaboração própria 

Emerge um verdadeiro mercado científico, sufocando algumas empresas menores que, possuindo baixos níveis de capitalização, não podem seguir todas as regras novas e ficam, por isso, obrigadas a desistir de algumas de suas produções.

\section{Lei dos medicamentos genéricos e formação das densidades normativas}

A 10 de fevereiro de 1999, publica-se a lei 9787, estabelecendo o medicamento genérico. A lei foi regulamentada pelo decreto 3181, de 23 de setembro de 1999.

Em fevereiro de 2000 foram registrados os seis primeiros genéricos na Anvisa. Em janeiro de 2004, já eram 1033 genéricos registrados (Anvisa apud Capanema e Palmeira Filho, 2004, p. 32) ${ }^{47}$.

Desde sua criação, o mercado de genéricos se expandiu rapidamente ${ }^{48}$. Esse crescimento se deu a despeito da queda nas vendas da indústria farmacêutica e do aumento da capacidade ociosa ${ }^{49}$.

Esse tipo de medicamento foi uma produção instituída normativamente, mais uma vez com inspiração nas experiências de países estrangeiros. A exemplo dos medicamentos similares, os genéricos são cópias de um medicamento de referência. Mas, neste caso, trata-se de uma cópia mais sofisticada, mais perfeita, pois que seus produtores devem comprovar que o genérico produzido, além de ter a mesma constituição, ainda é absorvido pelo organismo humano com a mesma velocidade que apresenta o medicamento de referência. A própria definição de medicamento genérico já aponta para consumos científicos, já que, para ser classificado como genérico, o medicamento deve ser submetido a dois tipos de testes. Primeiramente, a bioequivalência, que vai determinar a similaridade das fórmulas. Segundamente, a biodisponibilidade, que vai dizer se o genérico produz, no organismo humano, exatamente os mesmos efeitos, nos mesmos intervalos de tempo. Além disso, o medicamento genérico não pode ser comercializado com nome de fantasia, mas sim com o nome científico (nome genérico) de seu princípio ativo principal ${ }^{50}$.

\footnotetext{
${ }^{47}$ Em 2003, os genéricos estavam distribuídos em 56 classes terapêuticas, 2893 apresentações e 237 princípios ativos (Pró-Genéricos apud Gazeta Mercantil, 18/19-06-03, p. A13).

${ }^{48}$ De 2003 para 2004, o mercado de genéricos cresceu 56\% em valor e 36\% em volume. De 2004 para 2005, o crescimento foi de $52 \%$ em valor e de 20,9\% em unidades vendidas (IMS Health apud Gazeta Mercantil, 05-0804, p. A16; 11/12/13-11-05, p. C2). Aqui, poderíamos lembrar Schumpeter (1942, 1954, p. 204-209): O capitalismo supera as crises econômicas e as reduções de demanda por meio da criação de novos mercados.

${ }^{49}$ De 2003 para 2004, o mercado de genéricos cresceu 56\% em valor e 36\% em volume. De 2004 para 2005, o crescimento foi de $52 \%$ em valor e de $20,9 \%$ em unidades vendidas. (IMS Health apud Gazeta Mercantil, 05-0804, p. A16; 11/12/13-11-05, p. C2) Aqui, poderíamos lembrar Schumpeter (1942, 1954, p. 204-209): O capitalismo supera as crises econômicas e as reduções de demanda por meio da criação de novos mercados.

50 "Os medicamentos genéricos são medicamentos similares a um produto de referência e precisam ser intercambiáveis com este, além de serem comercializados pela denominação comum brasileira (DCB) ou, na sua ausência, pela denominação comum internacional (DCI)” (Pereira, 2002, p. 25).
} 
Onde quer que tenham sido acolhidos, os medicamentos genéricos são usados para promover a melhoria do acesso aos medicamentos. Por um raciocínio econômico, presume-se que eles serão mais baratos, pelas seguintes circunstâncias. Primeiro, seus produtores ficam isentos das onerosas pesquisas clínicas. Segundo, supõe-se que eles não serão alvo de campanhas publicitárias, pois que um mesmo genérico pode ser produzido, simultaneamente, por várias empresas, todas elas empregando a mesma nomenclatura científica.

No que tange aos dois testes referentes aos medicamentos genéricos, apenas as maiores empresas poderão fazer face a esses custos sem dificuldades ${ }^{51}$. De início, tais exames se restringiam aos genéricos. Mas, desde meados de 2003, a Anvisa exige testes de biodisponibilidade e bioequivalência também para os similares (Gazeta Mercantil, 23/24/25-02-04, p. A11) ${ }^{52}$. Assim, a renovação normativa converte-se, para a maioria das empresas, num pesadelo científico, já que elas dispõem de escassos recursos para o consumo dos serviços científicos tornados compulsórios.

O começo efetivo das produções de genéricos constituiu uma etapa difícil, justamente por causa dos elevados custos dos testes de biodisponibilidade e bioequivalência. Dessa forma, foram poucos os agentes que obtiveram transpor essa barreira de entrada ao mercado dos genéricos. Para sermos específicos, foi preciso que, além da norma relativa aos genéricos, outras normas fossem ativadas, nos lugares, possibilitando a definitiva produção desse tipo de medicamento. Por essa razão, a história dos genéricos no Brasil é a história da instalação de novas densidades normativas, base de uma nova diferenciação das ações.

Em tempos de uso instrumental das normas, elas se complexificam, se diversificam, constituindo uma fauna variada e em processo de evolução rápida. Conforme disse María Laura Silveira, as normas são crescentemente híbridas, pois apresentam diversas facetas ao mesmo tempo: são técnicas, políticas, organizacionais, globais, nacionais, locais... (Silveira, 1997, p. 41).

Adolfo Sanchez Vásquez fala em normas morais, jurídicas, de trato social ou técnicas (Sanchez Vásquez apud Antas Jr., 2005, p. 135). Milton Santos fala em "normas jurídicas, financeiras e técnicas" (Santos, 1996, 2004, p. 252). Esta última tipologia nos parece mais precisa para fins geográficos, pois que nos permite ver, ao mesmo tempo, as dimensões materiais e sociais das normas.

\footnotetext{
51 "De acordo com especialistas, cada análise [de biodisponibilidade ou bioequivalência] custa R\$ 100 mil” (Gazeta Mercantil, 23/24/25-02-04, p. A11).

${ }^{52}$ Por ora, os genéricos ficam diferenciados dos similares pelo fato de portarem nomes científicos, em vez de marcas. No entanto, existem alguns similares com nomes científicos. A tendência é o desaparecimento do mercado de similares, todos os medicamentos imitadores classificando-se, então, como genéricos.
} 
Ora, a história dos medicamentos genéricos, no Brasil, também dá margem à mobilização de vários tipos de normas.

Primeiramente, aciona-se a norma jurídica, neste caso representada pela própria lei de $1999^{53}$.

Segundamente, as normas financeiras. A produção de medicamentos genéricos importa a realização de investimentos maciços, porque é preciso fazer face aos custos dos testes de bioequivalência e biodisponibilidade. Raramente, um laboratório manterá uma linha pequena de genéricos: os gastos iniciais serão recuperados com mais segurança e rapidez se a produção de genéricos for, desde o princípio, diversificada. Assim, vê-se que são portentosos os investimentos iniciais, para a realização dos testes. Em decorrência dessas particularidades, os laboratórios nacionais tiveram que se adequar a rígidas normas financeiras, sem o que não poderiam ter acesso aos financiamentos que lhes permitiram montar suas bases produtivas. Nessa parte da história entram em cena, sobretudo, as linhas públicas, com as quais os laboratórios obtiveram realizar seus investimentos iniciais.

A Medquímica, laboratório fundado em 1975, tem sede em Juiz de Fora (MG). Em 2004, ampliou sua unidade produtiva. 50\% do investimento foi do próprio laboratório, e 50\% do BDMG, Banco de Desenvolvimento de Minas Gerais. Após a ampliação, o laboratório, antes apenas produtor de similares, começa a produzir genéricos, além de pomadas, cremes dermatológicos e cosméticos. Assim, tornou-se o primeiro produtor mineiro de genéricos em grande escala (Gazeta Mercantil, 26-07-04, p. A9) ${ }^{54}$.

Concedendo suas graças financeiras, alguns bancos estatais começam a acender certos pontos no território brasileiro, numa criação de densidades normativas financeiras ${ }^{55}$. Subitamente, surgem grandes forças produtivas em tal ou tal lugar. Aqui, o risco é a produção de polarizações, pois, como sabemos, as lógicas financeiras, mesmo quando confiadas a instituições estatais, tendem a gerar movimentos auto-expansivos ${ }^{56}$.

"A preeminência da política de lucro se traduz num rigor todo particular das regras financeiras" (Pagès, 1978, 1984, p. 67). As menores empresas ficam sem condições de se adaptar a esses rigores. Trata-se de uma disciplina de operações e planejamentos bem distante da situação dos pequenos produtores. Estes, o mais das vezes, preferem mesmo

\footnotetext{
53 "Normas que limitam as possibilidades de uso derivadas de um objeto ou sistema técnico em diversas direções e vetores [...] Este é o tipo de norma, em geral, que corresponde à norma jurídica” (Antas Jr., 2005, p. 64).

${ }^{54}$ O laboratório Multilab (Porto Alegre/São Gerônimo-RS) tornou-se, com a produção de genéricos, a maior empresa farmacêutica ao sul do país. Essa produção teve início em 2002, após o laboratório ter mudado sua fábrica de Porto Alegre para a cidade de São Gerônimo. A nova unidade, maior e mais moderna, com a maioria dos equipamentos importada, foi construída graças a um financiamento realizado pelo estado do Rio Grande do Sul.

${ }^{55}$ Atualmente, o BNDES tem uma linha de crédito específica para os medicamentos genéricos.

${ }^{56}$ O BNDES investiu, na região sudeste, 45\% de seu orçamento em 1993; 44\% em 1994; 48\% em 1995; 54\% em 1996; 56\% em 1997. Na região norte, ele investiu 4\% de seu orçamento em 1993; 3\% em 1994; 3\% em 1995; 2\% em 1996; 2\% em 1997 (Gazeta Mercantil apud Bernardes, 2001, p. 232).
} 
evitar todo tipo de empréstimo, o que poderia representar, para eles, a aquisição de uma dívida futuramente insolvável. Se no circuito superior existe uma constante necessidade de regras formais, no inferior, e mesmo no superior marginal, a necessidade pode ser a criação de relações econômicas não formais.

As normas financeiras, alastrando-se, fundam uma hierarquia. Primeiro, vêm as empresas multinacionais, capazes de autofinanciamento. Em seguida, as grandes empresas nacionais, que podem aceder ao crédito e às produções de genéricos. Depois, os pequenos laboratórios nacionais, sem acesso aos financiamentos formais ${ }^{57}$. Maria Aparecida Pereira identificou, no Rio Grande do Sul, alguns pequenos laboratórios que estariam dispostos a produzir medicamentos genéricos. "Em relação às empresas interessadas na produção de genéricos, o maior problema encontrado para o início das atividades se refere à falta de capital para viabilizar os investimentos necessários à realização dos testes exigidos para a obtenção dos registros e, em alguns casos, à adequação da estrutura física para produção em escala" (Pereira, 2002, p. 95).

Nas atividades farmacêuticas, as lógicas financeiras já mostram, pois, todo o seu poder modelador ${ }^{58}$.

Em terceiro lugar, a produção de genéricos ativa as normas técnicas, que podem ser assimiladas a estas que Ricardo Mendes identificou: "Normas derivadas de objetos técnicos, ou de um conjunto de objetos, regendo as ações involuntariamente" (Antas Jr., 2005, p. 63). O mais das vezes, os genéricos possuem preços inferiores em relação aos medicamentos de referência. Assim, devem ser procuradas largas escalas de produção, de modo que os lucros unitários menores sejam compensados por grandes volumes vendidos. Os laboratórios produtores de genéricos, além de incorporar as novas tecnologias que são contemporâneas da lei de genéricos, buscam fugir à rigidez que é própria das unidades fabris antigas. É desse modo que, havendo adquirido acesso ao crédito, instalam novas indústrias, com grande potencial produtivo, algumas vezes em cidades até então intocadas pela atividade farmacêutica ${ }^{59}$.

Em matéria de densidades normativas técnicas geradas pela produção de genéricos, é didática a situação do DAIA, Distrito Agroindustrial de Anápolis. Fundado em 1976, filho da ciência regional tropical posta em prática pelos militares, esse pólo surge mais ou menos ao

\footnotetext{
${ }^{57}$ O Diproquifar (Recife-PE), empresa farmacêutica familiar, buscou financiamento em várias instituições, mas sempre inutilmente. O A\&C, pequeno laboratório que se localiza no Taboão da Serra (SP) teve crédito recusado junto ao BNDES.

${ }^{58}$ Outras instituições que financiam projetos de desenvolvimento de medicamentos, sobretudo na área de fitoterápicos: Finep, CNPq, Capes, MCT. (Alves, 2004, pp. 140-142) Nesses programas, a menor rigidez normativa permite a participação de pequenos laboratórios, atuando em parceria com universidades. Exploramos este ponto no capítulo VIII.

${ }^{59}$ Um exemplo é o Multilab, laboratório fundado em 1988, que transfere sua unidade produtiva de Porto Alegre para São Gerônimo, baseando sua produção nos medicamentos genéricos, além de produzir similares e fitoterápicos. Na capital gaúcha, manteve-se apenas o departamento comercial.
} 
mesmo tempo que outros distritos industriais ${ }^{60}$. Dessas instalações, o distrito industrial de Manaus, existindo sob as condições da Zona Franca, de 1967, é um dos casos mais conhecidos.

Anápolis é uma cidade que demora nas cercanias de Goiânia. Seu distrito industrial, o Daia, contém um pólo farmacêutico, composto por laboratórios atraídos, de um lado, pelas isenções fiscais e pelos preços baixos dos lotes, e, de outro lado, pela preexistência de uma infra-estrutura adaptada às necessidades da produção industrial ${ }^{61}$.

Em janeiro de 2001, havia 62 empresas instaladas no Daia, distribuídas em 36 atividades econômicas, sendo que a produção de medicamentos era a segunda atividade (com 6 empresas), seguida pela produção de alimentos (7 empresas). Em agosto de 2005, já eram 88 empresas, distribuídas em 44 atividades; a produção de medicamentos passa à condição de primeira atividade (13 empresas), ultrapassando a produção de alimentos (8 empresas) ${ }^{62}$.

Ocorre que o Daia ganha novo sentido com a lei dos medicamentos genéricos. Dois laboratórios ali situados, o Teuto e a Neoquímica, se lançam rapidamente à produção desse tipo de medicamento, passando ao rol dos maiores produtores de genéricos em território brasileiro. O processo foi rápido graças à aceleração permitida pela norma jurídica, mas também pela concentração anterior de normas técnicas, aqui representadas pelas infra-estruturas $^{63}$ e pela extrema fluidez permitida por um distrito industrial situado no coração do território brasileiro ${ }^{64}$. Também se pode considerar que jogaram, aqui, as normas

${ }^{60}$ O CIA, Centro Industrial de Aratu, no município baiano de Simões Filho, também data dos anos 1970. Ele abrigou o Bahiafarma, laboratório farmacêutico oficial do estado da Bahia, extinto em 1998. Mais tarde, em 2001, começa a funcionar nesse distrito o Officinalis, laboratório particular nacional, até hoje em operação. Outro pólo baiano é o pólo de Camaçari, onde o laboratório farmacêutico Eli Lilly, dos Estados Unidos, tem produção de fármacos. A propósito dos anos 1970, Milton Santos e María Laura Silveira escrevem: "É o momento de implantação de complexos e pólos industriais em diversas regiões do país: o Complexo Petroquímico de Camaçari na Bahia, o Complexo Siderúrgico de Itaqui no Maranhão, o Projeto Carajás, a indústria de derivados de cloro em Alagoas, o complexo eletrometalúrgico de Tucuruí". (Santos e Silveira, 2001, 2004, pp. 48-49) Em Goiás, além do distrito de Anápolis, existem o Diagri, Distrito Agroindustrial de Itumbiara, e o DMC, Distrito Mineroindustrial de Catalão.

${ }^{61}$ Os laboratórios farmacêuticos do DAIA criaram o IGTF, Instituto de Gestão Técnica e Farmacêutica, que consiste numa reunião periódica entre as empresas, para discussão de dificuldades, tendências e outros temas relativos à produção de medicamentos.

${ }^{62}$ Em 2005, havia no Daia 2 distribuidoras de medicamentos, 2 produtores de insumos farmacêuticos e 13 produtores de medicamentos. Os distribuidores eram a AB-Farmoquímica e a DHL (representante da Roche do Brasil). Os produtores de insumos eram o Champion e a Pharma Nostra. Os laboratórios farmacêuticos eram: FBM, Greenpharma, Genix, GeoLab, Heri, Melcon, Kinder, Genoma, Neoquímica, Ducto (pertencente ao mesmo grupo do Neoquímica), Teuto, Lasa e Vitapan. Merece destaque o aparecimento da Goyazes Biotecnologia, produzindo kits para análises clínicas, bem como a instalação de uma unidade do Inmetro.

${ }^{63}$ As empresas do Daia contam com estação de tratamento de água, rede de distribuição de água, estação de tratamento de esgoto, sistema exclusivo de energia elétrica dotado de subestação própria, central telefônica, agência dos correios.

${ }^{64} \mathrm{O}$ distrito está incrustado numa espécie de encruzilhada de labirinto, com diversas rodovias a passar por ele, a GO 330, a GO 222, a BR 060, a BR 114, sem citar a Belém Brasília, ou BR 153, que tem seu quilômetro zero em Anápolis, e o ramal da RFFSA, que integra o corredor de exportação Goiás - Minas Gerais - Espírito Santo. Desde 1998, funciona o Porto Seco, que já nasceu acoplado ao ramal ferroviário. 
financeiras, pois que, num distrito industrial, as empresas contam com mais facilidades de acesso aos lotes, além das clássicas isenções de impostos ${ }^{65}$.

Em 2004, havia 49 laboratórios nacionais produzindo genéricos, representando 52,2\% dos genéricos em comercialização no país (Anvisa apud Capanema e Palmeira Filho, 2004, p. 32). São nomes como Eurofarma, Medley, IF, Biosintética, EMS Sigma Pharma, Teuto, Neoquímica... que entram para o rol das grandes empresas, a despeito da origem brasileira de seus capitais. Doravante, seus crescimentos já podem acontecer com bases firmes ${ }^{66}$.

Esses e outros mais exemplos poderiam despertar certo patriotismo econômico. Entanto, que se refreie todo orgulho, pois que tais situações, além de fulgurantes, são muito raras. Em verdade, à exceção dos laboratórios multinacionais, e do pequeno grupo de laboratórios brasileiros que puderam vencer as dificuldades iniciais de produção, muito pouco numerosas são, atualmente, as empresas que podem iniciar-se nessas atividades. Criam-se, com isso, novas polarizações, que não são apenas mercadológicas, mas também espaciais. A cidade de Anápolis faz exceção no território brasileiro, pois sua virada genérica liga-se, fortemente, a concentrações técnicas e financeiras prévias, numa situação atípica.

No mais, apresentamos o quadro V.1, para ressaltar que, salvo exceções, a produção de genéricos vem reforçar as polarizações regionais, já que se foi concentrar em grandes cidades, sobretudo as capitais, além de reforçar as tendências a uma desconcentração produtiva com centralização da gestão nas capitais (laboratórios Cristália e Multilab).

\footnotetext{
${ }^{65}$ Ainda em 1984, oito anos após o surgimento do distrito, a prefeitura municipal de Anápolis divulgava isenções de cinco anos, a partir da instalação da empresa, nos seguintes tributos: taxa de expediente, taxa de licença pra funcionamento; taxa de licença pra construção; IPTU, imposto predial e territorial urbano; serviços de topografia e terraplanagem; ISSQN, imposto sobre serviços de qualquer natureza. Com o tempo, as isenções fiscais, ainda que estendidas para todo o município anapolino, tornaram-se menos importantes; mas, ainda hoje, as empresas do Daia contam com financiamento do ICMS, a juros baixos, além de uma ajuda financeira na fase de instalação. 66 “O laboratório Cristália, líder no mercado hospitalar doméstico, inaugurou uma unidade de síntese química em 2001. A operação dessa unidade permitiu a síntese de 25 moléculas utilizadas na formulação de medicamentos genéricos. Essa empresa exporta para Europa, Ásia e América Latina” (Magalhães et alii, 2003, p. 24). Sobretudo em função dos genéricos, os laboratórios Medley, Biosintética, Eurofarma, EMS, Biolab-Sanus e Teuto Brasileiro aumentaram sua participação no mercado brasileiro de 5,7\% para 7,8\%, entre 2000 e 2001, atenuando mesmo o efeito das fusões e aquisições entre as filiais dos laboratórios multinacionais" (Magalhães et alii, 2003, p. 32).
} 
quadro V.1. Localização de alguns laboratórios particulares nacionais

produtores de medicamentos genéricos: Brasil, 2006

\begin{tabular}{|c|c|c|c|}
\hline Laboratório & Fundação & Sede & Produção \\
\hline Eurofarma & 1966 & São Paulo (SP) & São Paulo (SP) * \\
\hline Biolab-Sanus & 1978 & São Paulo (SP) & São Paulo (SP) \\
\hline Cristália & 1973 & São Paulo (SP) & Itapura (SP) \\
\hline Medley & 1972 & Campinas (SP) & Campinas (SP) e Sumaré (SP) \\
\hline EMS & 1972 & São Bernardo do Campo (SP) & São Bernardo do Campo (SP) e \\
\hline Multilab & 1988 & Porto Alegre (RS) & São Gerônimo (RS) \\
\hline Medquímica & 1975 & Juiz de Fora (MG) & Juiz de Fora (MG) \\
\hline Teuto & 1971 & Anápolis (GO) & Anápolis (GO) \\
\hline Neoquímica & 1977 & Anápolis (GO) & Anápolis (GO) \\
\hline Vitapan & 1999 & Anápolis (GO) & Anápolis (GO) \\
\hline
\end{tabular}

* O Eurofarma vai transferir toda a sua produção para a cidade de Itapevi (SP); a transferência está prevista para o ano de 2008

Além disso, é notável a concentração dos produtores de genéricos no eixo centro-sul do país, o que também reforça velhas polarizações. Conta, aqui, entre outras coisas, o peso dos laboratórios multinacionais, que, há longos anos, atraem dinâmicas espaciais para essa porção do país, seja por conta das concentrações técnicas que promovem, seja em função de seus pressionamentos junto ao governo, o que se traduz, não raro, em práticas de lobby. Segundo Mónica Arroyo, o lobby, largamente usado pelos grandes grupos econômicos, "é o prelúdio da regulação" (Arroyo, 2001, p. 40) ${ }^{67}$. A produção de genéricos, que tanto estardalhaço produziu no centro-sul do país, contribui assim para sufocar os reclamos das outras regiões $^{68}$. Nessas condições, a produção de genéricos termina por consagrar uma transferência de renda que se realiza no interior do território. Mas, não bastaria buscar maneiras de fundar produtores também nas outras cidades; é preciso, antes, que essas produções estejam em sintonia com os quadros vitais existentes em cada região, sem provocar distorções do consumo ou do pensamento.

\footnotetext{
67 "Isso significa, então, que um pequeno número de empresas com posição dominante no mercado desempenha o papel de controle do território, não somente via produção mas, também, via regulação” (Arroyo, 2001, p. 42). “O próprio termo lobbying deixou de ter uma conotação pejorativa e passou a ser encarado como uma realidade do processo democrático contemporâneo, no qual há inclusive cursos preparatórios do exercício desse mecanismo de pressão para aprovação de novas leis” (Antas Jr., 2005, p. 143).

68 “Quanto mais longe dos centros do poder, mais difícil é fazer ouvir a própria voz” (Santos, 1993, p. 92).
} 
Os mesmos efeitos polarizadores se verificam se consideramos atividades adictas à produção de medicamentos genéricos. Com a tabela V.2, buscamos demonstrar a concentração dos agentes habilitados a realizar os testes de biodisponibilidade e bioequivalência, que dão aos medicamentos o estatuto de genéricos.

tabela V.2. Centros de biodisponibilidade e bioequivalência certificados pela Agência Nacional de Vigilância Sanitária: Brasil, 2004

\begin{tabular}{|c|c|c|c|c|c|c|}
\cline { 3 - 7 } \multicolumn{2}{c|}{} & \multicolumn{2}{c|}{ Natureza } & do & \multicolumn{2}{c|}{ laboratório } \\
\hline $\begin{array}{c}\text { Unidade da } \\
\text { federação }\end{array}$ & TOTAL & $\begin{array}{c}\text { Instituto } \\
\text { oficial }\end{array}$ & Universidade & $\begin{array}{c}\text { Fundação + Depto } \\
\text { Universidade }\end{array}$ & $\begin{array}{c}\text { Hospital } \\
\text { particular }\end{array}$ & $\begin{array}{c}\text { Laboratório } \\
\text { particular }\end{array}$ \\
\hline São Paulo & 23 & --- & --- & 7 & --- & 16 \\
\hline $\begin{array}{c}\text { Rio de } \\
\text { Janeiro }\end{array}$ & 2 & 2 & --- & --- & -- \\
\hline Goiás & 3 & --- & 2 & --- & 1 & -- \\
\hline TOTAL & 28 & 2 & 2 & 7 & 1 & 16 \\
\hline
\end{tabular}

Fonte: elaboração própria, com dados da Reblas, Rede Brasileira de Laboratórios Analíticos em Saúde : www.anvisa.gov.br/reblas

Além de extremamente concentrados em apenas três cidades (São Paulo, Rio de Janeiro e Goiânia), esses laboratórios estão ligados, na maioria, a capitais particulares, o que faz da lei, novamente, base de acumulações. Quanto a este ponto, é expressivo o caso do ICF, em Goiânia, instituto que é mantido por três laboratórios de Anápolis: Teuto, Neoquímica e Vitapan. Anteriormente, esse instituto recebia também recursos da Faculdade de Farmácia da Universidade Federal de Goiás; agora, ele se mantém apenas pelos três aludidos laboratórios. Trata-se, em verdade, de um instituto de pesquisa, cujos resultados visam, por vezes, aplicações industriais. Pesquisas de mestrado e doutorado já se desenvolveram nos quadros do ICF. Com isso, os três laboratórios, mas principalmente os dois primeiros, que são mais antigos e têm linhas genéricas maiores, tiram partido duas vezes da lei dos genéricos: de um lado, aproveitam-se do acesso ao crédito e da infraestrutura do distrito industrial; de outro lado, podem vender os serviços de testes, além de contar com uma instituição em que testam seus medicamentos a preço de custo.

Desde o começo de sua vigência, a lei dos genéricos fundou um segmento de mercado extremamente rígido, de acesso muito difícil. Em maio de 2003, quatro anos após 
a promulgação da lei, havia 37 empresas comercializando genéricos no Brasil (Gazeta Mercantil, 10-07-03, p. A14) ${ }^{69}$.

Com a lei dos genéricos, as empresas multinacionais, já produzindo esse tipo de medicamento em outros países, começam a importar seus produtos para o Brasil. Em 2004, 22,3\% dos genéricos em comercialização no Brasil eram importados; desses genéricos, $41 \%$ provinham da Índia, 29\% do Canadá, 13\% da Alemanha e os demais 8\% provinham de 13 outros países (Anvisa apud Capanema e Palmeira Filho, 2004, p. 32). Além disso, a lei dos genéricos atrai mais uma leva de laboratórios estrangeiros, que iniciam suas operações no Brasil com base nessa produção ${ }^{70}$. Vê-se que, apesar de inacessível para a maioria das empresas, o mercado dos genéricos se fez atrativo para os laboratórios estrangeiros.

Apesar dessa forte presença, os grandes laboratórios nacionais detêm a maior parte do mercado de genéricos. "Atualmente os laboratórios brasileiros dominam $75 \%$ do mercado, liderados pela Medley. Outras empresas que se destacam são a EMS, a Biosintética e a Eurofarma" (Gazeta Mercantil, 10-07-03, p. A14) ${ }^{71}$.

À rigidez do mercado, soma-se o fato de que, nem sempre, as atividades de propaganda são abolidas pelos produtores de genéricos. Jacob Frenkel fala na existência de genéricos de marca, ressaltando que, em certos casos, esses medicamentos são divulgados aos médicos, enfatizando-se o nome do laboratório produtor (Frenkel, 2001, p. 169) ${ }^{72}$. "Como a Lei dos Genéricos permitiu ao médico prescrever um medicamento de marca ou, se achar necessário, com nome genérico, as ações das equipes de marketing dos

\footnotetext{
${ }^{69}$ Vários são os óbices que tornam esse mercado impeditivo para as pequenas empresas. Voltamos à Maria Aparecida Pereira, que nos fala dos laboratórios gaúchos. "Quanto ao interesse atual em desenvolver produtos genéricos, constatou-se que a maioria [...] das empresas não pretende desenvolvê-los. A maior parte delas apresenta, como argumentos, a incompatibilização da produção de medicamentos genéricos com os produtos atuais da empresa, tanto nos processos produtivos, como no mercado de atuação, além do investimento necessário às instalações e aos processos para ampliação da capacidade produtiva, pois somente assim poderiam obter produção em escala e preços competitivos. Algumas empresas ainda citaram os aspectos concernentes à disputa de mercado com as empresas multinacionais e ao fato dos planos privados de saúde não ressarcirem os medicamentos no Brasil” (Pereira, 2002, p. 95).

${ }^{70}$ Em 2001, chega ao Brasil, instalando-se em Itatiba (SP), a Apotex, maior laboratório farmacêutico do Canadá, possuindo $40 \%$ do mercado canadense de genéricos e $17 \%$ do mercado geral; é também o segundo maior fabricante de genéricos do mundo; em julho de 2003, o laboratório já tinha 65 genéricos no Brasil (Gazeta Mercantil, 08-07-03, p. A11; 25/26/27-07-03, p. A9). Outros laboratórios são atraídos: são os casos do israelense Bioteva (em parceria com o nacional Biosintética); do indiano Strides Arcolab (em joint venture com o nacional Cellofarm), fundando uma fábrica em Serra (ES) para a produção de cardiológicos antivirais; do alemão Hexal, com fábrica em Cambé (PR); e dos indianos Ranbaxy (maior laboratório farmacêutico da Índia) e Torrent.

${ }^{71}$ Considerando o primeiro semestre de 2003 e o de 2004, o ranking dos fabricantes de genéricos no Brasil, em volume de vendas, não se alterou. Ele foi o seguinte, em ordem decrescente: Medley (Brasil), EMS Sigma Pharma (Brasil), Biosintética (Brasil), Eurofarma (Brasil), Ranbaxy (Índia), Apotex (Canadá), Merck (Alemanha), Novartis (Suíça) (IMS Health apud Gazeta Mercantil, 05-08-04, p. A16).

${ }^{72}$ Em 2005, o laboratório Biosintética elaborou uma grande campanha para divulgar seus produtos genéricos ao grande público. "A campanha terá anúncios em revistas femininas, de variedades e de saúde; spots em emissoras de rádio; painéis eletrônicos; e cerca de 170 outdoors espalhados pelas cidades do Rio de Janeiro e São Paulo [...]”. (Gazeta Mercantil, 23/24/25-09-05, p. C2) No mesmo ano, o laboratório Medley lançou uma campanha orçada em R \$ 15 milhões, o que envolvia anúncios em emissoras de televisão aberta, entre outras coisas (idem, p. C2).
} 
laboratórios, fabricantes de remédios de referência ou de genéricos, junto às farmácias ganharam importância" (Gazeta Mercantil, 22-03-04, p. A10).

Aquando do lançamento dos primeiros genéricos, o governo federal incumbiu-se de uma grande campanha publicitária, visando o esclarecimento da população. Com isso, produz-se uma necessidade entre os laboratórios, que, desde então, fazem renitentes apelos para que o Estado continue esclarecendo os cidadãos. A Pró-Genéricos, Associação Brasileira das Indústrias de Medicamentos Genéricos, que reúne os dez principais fabricantes que atuam no Brasil, com 90\% desse mercado (Gazeta Mercantil, 06/07/08-0204, p. A14), é a principal responsável por tais pressões ${ }^{73}$.

Como o governo vacila no atendimento a esses apelos, a Pró-Genéricos toma suas próprias iniciativas. Em 2003, uma campanha de R\$ 3 milhões foi levada a público, divulgando os genéricos; a campanha foi financiada por quatro laboratórios nacionais (60\% do financiamento) e sete multinacionais (40\%) (Gazeta Mercantil, 10-07-03, p. A14) ${ }^{74}$.

Portanto, os laboratórios não deixam de incluir, nos preços dos genéricos, os custos de propaganda; ou, se deixam, é possível que os insiram noutras espécies de medicamentos. Assim, no geral, os preços não caem de maneira suficiente para expandir o acesso aos medicamentos, sendo mesmo possível topar, nas farmácias, com genéricos mais caros que os medicamentos de referência. Uma vez que boa parte dos genéricos vendidos são importados, seus preços variam junto com as taxas de câmbio. A redução de preços que os genéricos promovem, ainda que seja notável para alguns produtos, leva apenas à ampliação do consumo de medicamentos pelas classes médias ${ }^{75}$. "Quem já comprava medicamento de marca passou a substituí-lo pelo genérico. E os consumidores que estavam à margem do mercado continuaram na mesma situação" (Gazeta Mercantil, 10-07-03, p. A14).

Os projetos dos laboratórios produtores e das redes de farmácias vão confluir na captura desse consumo das classes médias. Daí, a expansão apresentada pelos genéricos nas grandes redes. A Abrafarma, Associação Brasileira de Farmácias e Drogarias, que representa as grandes redes, constatou que 40\% das vendas de suas associadas são de medicamentos genéricos (Gazeta Mercantil, 06/07/08-02-04, p. A14). Trata-se, pois, de um

\footnotetext{
${ }^{73}$ Em fevereiro de 2004, sua diretora-executiva, em texto para o jornal Gazeta Mercantil, assevera: "O governo brasileiro tem à sua disposição uma série de iniciativas para permitir que a participação dos genéricos no mercado se expanda. Uma delas diz respeito a campanhas de esclarecimento público em conjunto com a indústria". E prossegue: "Em outra frente, é preciso discutir modelos alternativos de financiamento de compra de medicamentos para a população de baixa renda [...]” (Gazeta Mercantil, 27/28/29-02-04, p. A3).

${ }^{74} \mathrm{Em}$ 2004, a Pró-Genéricos realiza novas propagandas, sendo que, nesse ano, seus principais investimentos se destinaram ao rádio (Gazeta Mercantil, 05-08-04, p. A16).

${ }^{75}$ Segundo Frenkel, há três tipos de demanda por medicamentos: 1. "estratos superiores”: demanda inelástica ao preço; 2. "grupos intermediários": demanda elástica ao preço; 3. "segmento de renda mais baixa”: mesmo se os preços caem, o consumo de medicamentos não aumenta (Frenkel, 2001, p. 171). "Para os segmentos mais baixos, somente o atendimento gratuito pode garantir o acesso adequado ao medicamento, independente do nível de preços” (idem, p. 171).
} 
verdadeiro e novo sistema espacial, cujos elementos são a pesquisa, a produção, os testes, a propaganda, a comercialização. Em situações estratégicas, os maiores laboratórios saberão mover todas essas peças disponíveis sobre o tabuleiro farmacêutico ${ }^{76}$.

As novas legislações farmacêuticas produzem e disseminam uma carência científica, sem a preexistência de uma estrutura estatal capaz de atender a essa carência. Desse modo, a lógica das produções e dos testes fica entregue ao mercado, de duas maneiras. Primeiramente, a capacidade de seguir as novas normas tem ligação direta com os níveis de capitalização das empresas. Trata-se de uma diferenciação que tem por base, não o interesse social das atividades farmacêuticas, mas sim a maior ou menor soma de recursos instrumentais. Segundamente, como as novas normas estão em sintonia, sobretudo, com a situação das maiores empresas, mormente as estrangeiras, a pauta farmacêutica do país fica sujeita às decisões dessas empresas. Assim, por exemplo, a lei dos genéricos não implicou a definição, por parte do governo federal, de quais seriam os medicamentos prioritariamente convertidos em genéricos. Sem tais indicações, cabe aos laboratórios realizar suas escolhas. "As empresas têm optado por remédios mais caros, genéricos de medicamentos voltados para doenças crônicas, de longa duração, como hipertensão, colesterol e antibióticos" (Gazeta Mercantil, 10-07-03, p. A14).

\section{Política farmacêutica e a ideologia do preço}

Mais e mais, o sistema de atenção à saúde se mercantiliza ${ }^{77}$. Chegamos a uma situação tal que, pela produção em massa de normas, os agentes hegemônicos têm suas situações aprimoradas e melhoradas. Com isso, cada estrato componente do grupo hegemônico vai reclamar normas que tombem sobre suas atividades ${ }^{78}$.

Os governos nacionais restam cada vez mais combalidos. Mais do que isso, passam a ter seus movimentos controlados por lógicas mercantis ${ }^{79}$. Apesar dessa penetração do

\footnotetext{
${ }^{76}$ É ilustrativa a história do Fosamax, medicamento para osteoporose, produzido pela Merck (Alemanha). Como ele foi lançado antes da nova lei de patentes, pode ser copiado. No Brasil, há mais de 16 similares; na América Latina, mais de 45. Para vencer a concorrência, a Merck adotou várias medidas: reforçou a propaganda junto aos médicos; inventou um sistema em que os pacientes recebem, nos consultórios médicos, cupons de desconto para apresentar nas farmácias; fechou parcerias de redução de preços com as seguintes redes de farmácia: Drogasil, Droga Raia, Drogaria Pague Menos, Drogaria Pacheco, Droga Med, Drogaria Catarinense, entre outras; patrocinou uma pesquisa mostrando as vantagens do medicamento sobre 13 similares comercializados na América Latina, dois dos quais fabricados por laboratórios brasileiros (Gazeta Mercantil, 11-05-04, p. A14).

${ }^{77}$ Um diretor geral de negócios do Ridge Partners Financial Group, explicando como funcionam as empresas de saúde estadunidenses interessadas em investir no Brasil, chega a dizer: "É uma espécie de McDonald's do sistema hospitalar moderno" (Gazeta Mercantil, 06-11-03, p. A11).

${ }^{78}$ Consideremos a Abimip, Associação Brasileira da Indústria de Medicamentos Isentos de Prescrição, que reúne os 26 maiores fabricantes de medicamentos livres de prescrição médica. "A Abimip está reivindicando na Anvisa uma gerência voltada para o setor” (Gazeta Mercantil, 24-08-04, p. A11).

79 "No caso brasileiro, o papel desempenhado historicamente pelo Estado no Sistema de Saúde tem sido o de organizador dos consumidores, direcionador do financiamento e conciliador dos interesses organizados em torno
} 
Estado por ditames capitalistas, teimamos, com freqüência, em nossos trabalhos de purificação, pensando o Estado como um organismo em que se geraria uma vontade própria, geral $^{80}$.

Nessas condições, o Estado vê-se obrigado a realizar manobras simples, tópicas, paliativas, quase alegóricas. No que tange ao controle das atividades farmacêuticas, o Estado brasileiro se especializa nesses malabarismos, já tendo realizado nada menos que três CPIs dos medicamentos: em 1963, em 1979 (Paula, 1991) e em 2000, sem que, todavia, as dinâmicas da atividade se tenham direcionado para tendências mais sociais. Em seu esforço, muita vez louvável, o Estado fomenta o baile das instituições, que se sucedem, melancolicamente ${ }^{81}$.

A questão dos preços costuma constituir um dos pontos principais das políticas farmacêuticas e dos estudos sobre as produções de medicamentos. Já se criou uma disciplina, chamada farmacoeconomia, dedicada à elaboração de planos para que as produções farmacêuticas possam ter seus custos reduzidos, o que levaria a reduções salutares de preços. Pode-se dizer que, em larga medida, a lei dos genéricos se moveu por princípios farmacoeconômicos, pois, como dissemos, seu maior intuito foi promover a ampliação do acesso pela baixa dos preços. Ocorre, porém, que, muito provavelmente, uma produção farmacêutica de largo acesso não se concretizará sem que, primeiro, se promovam sistemas espaciais de produção mais equilibrados. Com base nas atuais polarizações, dependências e hierarquias espaciais, parece pouco provável que as necessidades concretas das populações sejam realmente supridas, ainda que, nalgumas situações, tais ou tais medicamentos possam ter seus preços reduzidos. Numa atividade literalmente vital, o pensamento economicista revela mais facilmente seus absurdos. Como poderíamos, por exemplo, empregar a idéia de custo de oportunidade para a produção de medicamentos?

da saúde, sobretudo daqueles articulados com os produtores privados, seja de serviços, insumos ou equipamentos [...]” (Elias, 1996, pp. 62-63).

${ }^{80}$ Esse trabalho de purificação se expressa, por exemplo, em documento da ONG Médicos sem Fronteiras. "Está claro que a indústria farmacêutica multinacional não pode encarregar-se de desenvolver os remédios necessários para tratamento das doenças que afligem os pobres do mundo. Os governos são, em última análise, responsáveis por assegurar o atendimento das necessidades dos indivíduos em termos de saúde" (Médicos sem Fronteiras, 2001, p. 18).

${ }^{81}$ A 26 de junho de 2003, a Medida Provisória 123 criou a Cmed, Câmara de Regulação do Mercado de Medicamentos, composta por representantes dos Ministérios da Saúde, da Justiça e da Fazenda, além da Casa Civil. A Cmed, instalada a 29 de julho de 2003, visa a fiscalização da fabricação, distribuição e venda de medicamentos no Brasil, bem como a regulação do mercado e a definição de critérios para fixação e ajuste de preços. Desde então, debate-se em complexos cálculos para o estabelecimento de preços. 
VI

Polarizações espaciais: A produção de pontos luminosos

\section{A face mercadológica da concentração}

Portanto, o aparecimento das novas densidades normativas altera as hierarquias espaciais precedentes. "A ordem mundial é cada vez mais normativa e, também, é cada vez mais normada" (Santos, 1996, 2002, p. 228) ${ }^{1}$.

A existência de um circuito superior marginal se deve à circunstância de que, para um numeroso grupo de agentes, a norma se impõe, ditando uma racionalidade, mas o baixo nível de capitalização impede uma assimilação total, perfeita, dessa racionalidade hegemônica. Assim, uma dependência constante, uma marginalidade sempiterna, se estabelece. Enquanto isso, desde o circuito superior, a hegemonia vai-se ampliando e reiterando ${ }^{2}$.

O circuito superior da economia surge como o celeiro de sucessivos movimentos de concentração. No nível das empresas, isso acontece por ocasião de fusões, que, na atividade farmacêutica, já merecem o nome de megafusões globais. Ao longo da década de 1990, tais fenômenos foram freqüentes.

Por um lado, os laboratórios farmacêuticos, já devidamente convencidos das forças produtivas biotecnológicas, passam a adquirir pequenas empresas de biotecnologia ${ }^{3}$. A Ciba-Geigy tem parceria com duas empresas de biotecnologia dos Estados Unidos: a Myriad Genetics e a Isis. Também se poderia citar a Sandoz, laboratório farmacêutico suíço, que adquire duas empresas biotecnológicas dos Estados Unidos: a Genetic Therapy e a Systemix. E poderíamos citar exemplos à exaustão. Sharp e Senker (1999) estudaram a importância adquirida pelas empresas de biotecnologia, as quais, por meio de aquisições ou parcerias, tornam-se um dos alvos maiores dos laboratórios farmacêuticos ${ }^{4}$.

\footnotetext{
1 “As formas geográficas, isto é, os objetos técnicos requeridos para otimizar uma produção, somente autorizam essa otimização ao preço do estabelecimento e da aplicação de normas jurídicas, financeiras e técnicas, adaptadas às necessidades do mercado. Essas normas são criadas em diferentes níveis geográficos e políticos, mas as normas globais, induzidas por organismos supranacionais e pelo mercado, tendem a configurar as demais" (Santos, 1996, 2002, p. 252).

${ }^{2}$ Conforme Rogério Vicentim Oliveira, a situação monopolística pode prolongar-se mesmo depois da expiração de uma patente, em função de vantagens técnicas e científicas adquiridas aquando da vigência desse tipo de monopólio jurídico (Oliveira, R. 1999, pp.59-60).

3 “Os avanços na área de genômica, biologia molecular e bioquímica abrem novas trajetórias tecnológicas para o desenvolvimento de novas drogas. As novas empresas de biotecnologia têm sido alvo de operações de fusões e aquisições pelos grandes laboratórios farmacêuticos globais. Em 1990, a Roche comprou a Greentech. A CibaGeigy, posteriormente fundida com a Sandoz [formando a Novartis], adquiriu parcela da Chiron em 1995” (Magalhães et alii, 2003, p. 32).

4 "Recentemente, vem ganhando espaço na indústria farmacêutica a rota biotecnológica para a síntese de farmoquímicos, setor em que predominam as pequenas e médias empresas de alto conteúdo tecnológico, as quais
} 
Por outro lado, operações de aquisição e fusão multiplicam-se no meio dos próprios laboratórios multinacionais ${ }^{5}$. "As operações de fusão de natureza global, na década de 1990, criaram os principais laboratórios da indústria farmacêutica mundial e, conseqüentemente, as empresas líderes no mercado doméstico [brasileiro]" (Magalhães et alii, 2003, pp. 26-27).

Nos quadro VI.1 e VI.2, buscamos tecer um panorama sobre as fusões mais importantes, havidas nos últimos anos, entre laboratórios multinacionais (quadro VI.1) ou envolvendo empresas nacionais (quadro VI.2).

Formam-se corporações de um vulto monstruoso, com largo domínio de um mercado globalizado. Em 1996, os cinco maiores laboratórios do mundo detinham 19,3\% do mercado mundial de medicamentos; em 1999, detinham 28,1\%; considerando os 11 maiores laboratórios, essas proporções eram de 36,1\% e 48,9\%, respectivamente (Magalhães et alii, 2003, p. 31).

Semelhantes operações não poderiam acontecer sem o concurso fundamental de capitais financeiros. Pois uma grande fusão requer a formação de um estado de liquidez só permitida pela colaboração de grandes prestamistas. Em função dessas manobras, aquecem-se as bolsas de valores ${ }^{6}$. E a concentração do capital leva também a novos consumos normativos, o que vai fomentar um trabalho jurídico efetuado na escala mundial ${ }^{7}$.

vêm atraindo cada vez mais o interesse das grandes corporações que dominam o setor farmacêutico e merecem atenção especial. Uma das principais formas de inserção das pequenas empresas de biotecnologia no mercado farmacêutico vem sendo através do licenciamento de suas tecnologias para as grandes corporações já atuantes nesse setor" (Capanema e Palmeira Filho, 2004, p. 44).

${ }^{5}$ De 1994 a 2000, somando fusões e aquisições, ocorreram 45 operações no setor de produtos químicos e farmacêuticos (exclusive as empresas fabricantes de produtos químicos e petroquímicos destinados à fabricação de combustíveis e derivados); essas operações de fusão e aquisição distribuíram-se, em cada ano, assim: 4 em 1994; 11 em 1995; 10 em 1996; 4 em 97; 4 em 98; 6 em 99; 6 em 2000 (KPMG apud Magalhães et alii, 2003, p. 26).

6 "Segundo a lista das maiores empresas elaborada pela revista Fortune em 2000, as empresas farmacêuticas lideram a indústria dos Estados Unidos em termos de retorno sobre investimento, representando um valor de 39\% para seus acionistas” (Médicos sem Fronteiras, 2001, p. 16).

${ }^{7}$ Yves Dezalay mostra a constituição de um mercado jurídico internacional, sustentado pelos processos de falência, fusões e aquisições de empresas multinacionais (Dezalay, 1992). "Tais conglomerados de serviços jurídicos realizam, neste contexto de expansão das corporações, a ação coordenada de fusões de multinacionais de modo a responder às exigências de uma nova reestruturação do setor financeiro e técnico das empresas, de acordo com a formação socioespacial onde estão instaladas as unidades produtivas e conforme as prerrogativas jurídicas de cada modelo de direito [...] Assim, à medida que as grandes corporações se difundiram pelo planeta, as empresas de serviços jurídicos acompanharam esse movimento” (Antas Jr., 2005, p. 150). 
quadro V.1. Principais aquisições e fusões entre laboratórios farmacêuticos multinacionais: 1990-2005

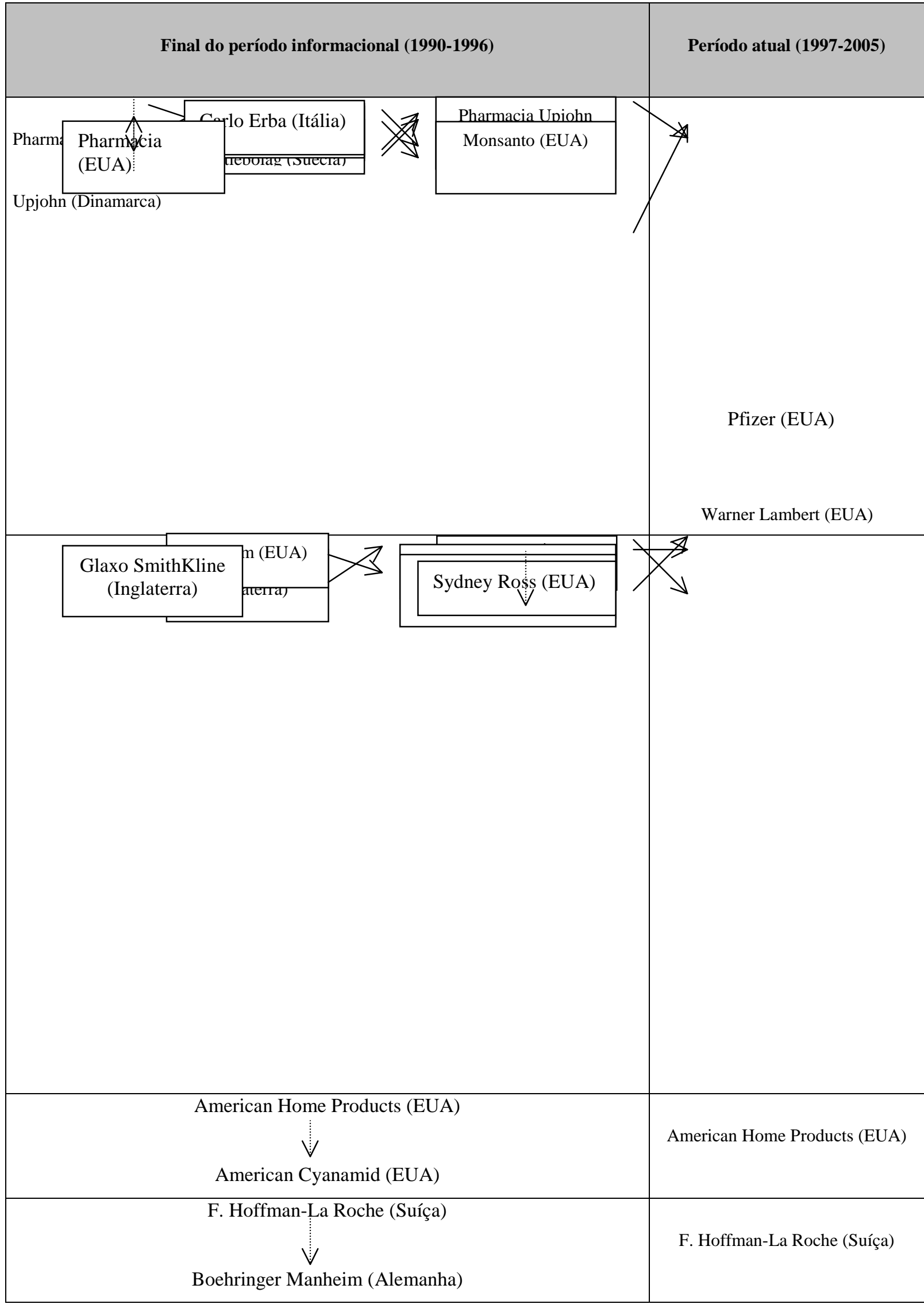

7 fusão

aquisição 
quadro V.1. Principais aquisições e fusões entre laboratórios farmacêuticos multinacionais: 1990-2005

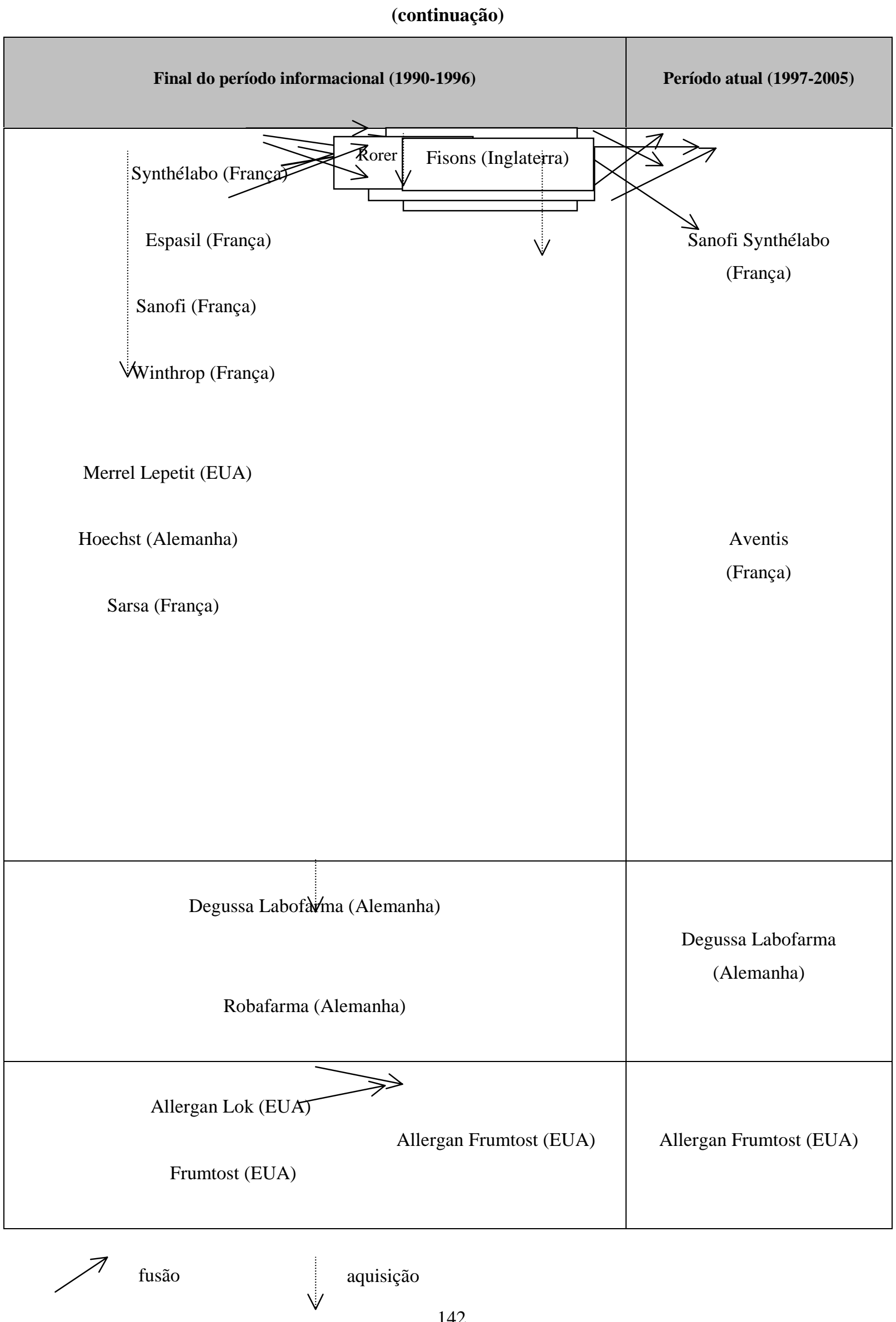


quadro V.1. Principais aquisições e fusões entre laboratórios farmacêuticos multinacionais: 1990-2005 (continuação)

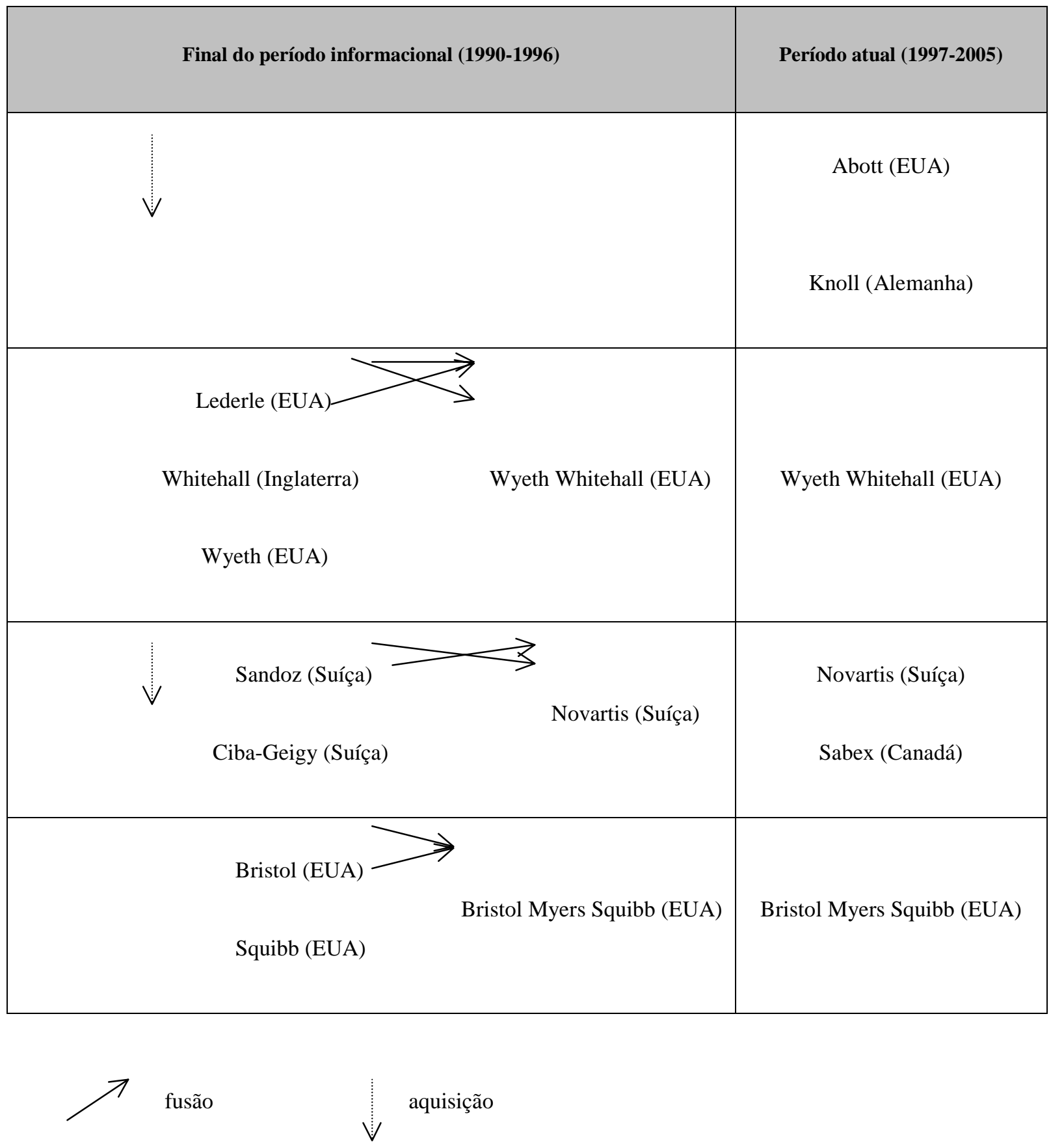


quadro V.2. Principais aquisições e fusões evolvendo laboratórios farmacêuticos brasileiros:

Brasil, 1990-2005

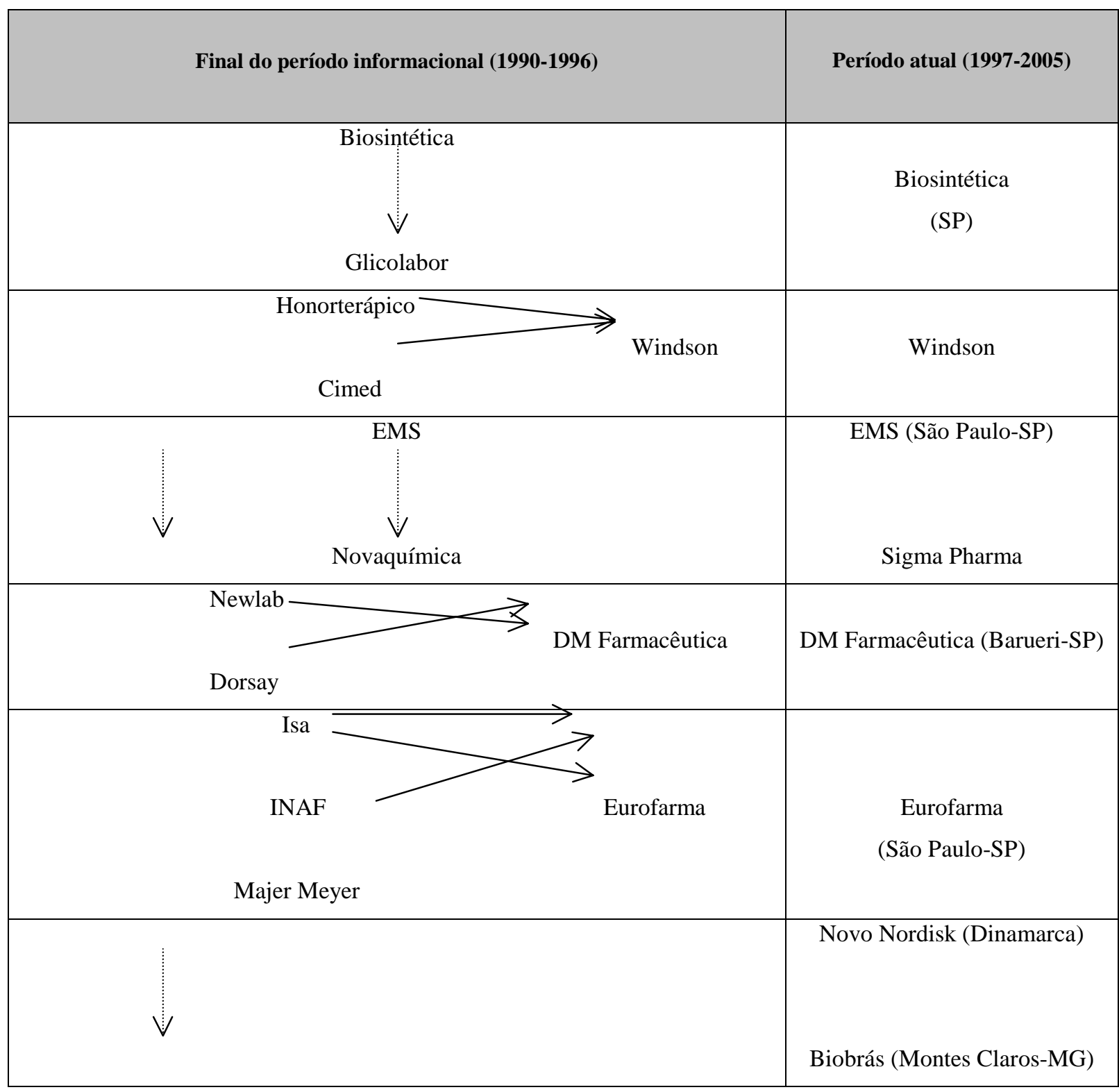

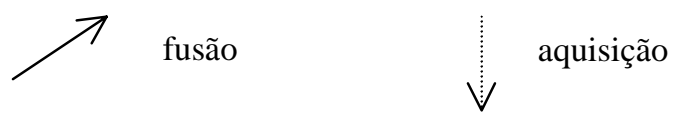


O poder mercadológico e político, nas produções de medicamentos, já descansa, hoje, sobre sólidas bases. Poderíamos citar, pelo menos, quatro pilares que o sustentam.

Primeiro, cada empresa multinacional enfatiza tal ou tal classe terapêutica ${ }^{8}$. Dentro desses submercados farmacêuticos, o controle pode chegar a taxas assombrosas. Em 1975, por exemplo, havia 103 empresas atuando no mercado brasileiro de antibióticos; as quatro principais empresas dominavam 35,4\% desse mercado. Para os medicamentos antianêmicos, fabricados por 166 empresas, as 4 primeiras controlavam 50,3\% do mercado. Para os anticoncepcionais hormonais, produzidos por 17 laboratórios, os quatro primeiros detinham 85,6\% do mercado (IMS apud Frenkel et alii, 1978, p. 102).

Por isso, Rogério Vicentin Oliveira diz que é nos submercados terapêuticos que se dão as características oligopolísticas da indústria farmacêutica (Oliveira, R. 1999, p. 60) ${ }^{9}$.

O fenômeno pode conduzir a monopólios mais ou menos perfeitos, como acontece no Brasil, hoje em dia, com a produção de insulina. No capítulo III, contamos a história da Biobrás, laboratório brasileiro que, nos anos 1980, foi um dos maiores produtores mundiais de insulina. Acontece que a Novo Nordisk, laboratório dinamarquês instalado no Brasil desde 1993, adquire a Biobrás em 2002, tornando-se o único produtor de insulina em território brasileiro ${ }^{10}$.

Um segundo fator, a sustentar o predomínio dos laboratórios multinacionais, é que eles gozam de uma plasticidade comercial, que vem de sua operação concomitante em várias atividades diferentes. Em 2003, 67\% do faturamento da Roche (Suíça) provinha da sua divisão farmacêutica; o restante provinha da área de diagnósticos (Gazeta Mercantil, 17/18/19-10-03, p. A13) ${ }^{11}$. Para outras empresas, os medicamentos podem possuir pesos ainda menores, como quisemos demonstrar com a tabela VI.1.

\footnotetext{
${ }^{8}$ Lembramos que as classes terapêuticas são os submercados farmacêuticos. Elas se definem pelo tipo de doença combatida pelos medicamentos. Assim, existe a classe dos antibióticos, dos anitérmicos, dos antitussígenos, das vitaminas... Diz Gadelha que, mesmo dentro das classes terapêuticas, se se faz uma análise mais detida, os produtos podem estar diferenciados de maneira a não se fazer concorrência (Gadelha, 1990, p. 96). Dentro da classe dos antibióticos, por exemplo, não há concorrência, visto que um antibiótico não pode ser substituído por outro; o mesmo acontece para as vitaminas (idem, p. 222 - nota).

9 “Assim sendo, devemos ter cuidado com definições rígidas dos segmentos relevantes do mercado farmacêutico, como forma de demonstrar que, apesar da baixa concentração vigente na indústria farmacêutica em seu conjunto [...], existe um elevado poder de mercado das firmas líderes ao nível de seus distintos segmentos” (Gadelha, 1990, p. 94).

10 "No Brasil, a Novo Nordisk tem sido, nos últimos três anos [2002, 2003 e 2004], a única fornecedora privada de insulina ao governo brasileiro, que responde por aproximadamente $60 \%$ da receita com vendas da subsidiária brasileira [...]” (Gazeta Mercantil, 27/28/29-02-04, p. A13). A Novo Nordisk é o líder mundial no mercado de insulina, com 47\%. Suas principais concorrentes são a Aventis (França) e a Eli Lilly (EUA).

11 "No limite, as operações da firma num mercado particular podem ser completamente, ou quase completamente, insensíveis à sua sorte econômica nesse mercado, e assim o escopo de decisões a ele relacionadas pode ser alargado muito além do que é possível às outras firmas, confinadas nas fronteiras desse mercado" (Kaysen, 1959, p. 91).
} 
tabela VI.1. Participação dos medicamentos nas vendas globais dos dez maiores

laboratórios farmacêuticas mundiais (segundo o critério de vendas): 1998

\begin{tabular}{|c|c|c|c|c|c|}
\hline Posição & Laboratório & País & $\begin{array}{c}\text { Vendas totais } \\
\text { (US\$ bilhões) } \\
\text { - A }\end{array}$ & $\begin{array}{c}\text { Vendas de } \\
\text { medicamentos (US\$ } \\
\text { bilhões) - B }\end{array}$ & $\begin{array}{c}\text { B / A } \\
\text { (\%) }\end{array}$ \\
\hline 1 & MSD & EUA & 26,9 & 13,7 & 50,9 \\
\hline 2 & Glaxo Wellcome & Reino Unido & 13,3 & 13,3 & 100,0 \\
\hline 3 & Bristol-Myers Squibb & EUA & 18,3 & 12,6 & 68,9 \\
\hline 4 & Pfizer & EUA & 13,5 & 12,2 & 90,4 \\
\hline 5 & Novartis & Suíça & 20,6 & 9,4 & 45,6 \\
\hline 6 & Roche & Suíça & 16,0 & 9,3 & 58,1 \\
\hline 7 & American Home Products & EUA & 13,5 & 8,9 & 65,9 \\
\hline 8 & Johnson \& Johnson & EUA & 23,7 & 8,6 & 36,3 \\
\hline 9 & Hoechst Marion Russel & Alemanha & 23,2 & 7,3 & 31,5 \\
\hline 10 & SmithKline Beecham & Reino Unido & 12,5 & 7,1 & 56,8 \\
\hline
\end{tabular}

Fonte: Queiroz e González, 2001, p. 125

Assim, um laboratório multinacional poderia permitir-se prejuízos temporários em certas classes, desde que, noutras, seus lucros sejam compensadores ${ }^{12}$.

Um terceiro fator, sustentando as hegemonias, são as cada vez mais freqüentes parcerias travadas entre os laboratórios multinacionais. Elas podem levar a produções conjuntas $^{13}$. Mas, o mais das vezes, tais parcerias dizem respeito às operações de comercialização e propaganda. Um medicamento cujo princípio ativo chama-se duloxetina, fabricado pela Eli Lilly (Estados Unidos), é promovido e comercializado em parceria com a Boehringer Ingelheim (Alemanha). Por dez anos, desde 2003, as empresas dividir-se-ão os investimentos em propaganda (Gazeta Mercantil, 20-10-03, p. A11) ${ }^{14}$. O Olmetec, medicamento inibidor de angiotensina II, uma das mais modernas classes terapêuticas para

\footnotetext{
${ }^{12}$ Poderíamos pensar, talvez, que as fundações e os institutos atuais são mercados sempre deficitários, os quais as grandes corporações decidiram explorar por causa do desempenho nos outros mercados, sempre superavitários.

${ }^{13}$ O Zetsim é um medicamento produzido em parceria, a partir de um princípio ativo da Schering Plough (Estados Unidos) e um da Merck (Alemanha) (Gazeta Mercantil, 13/14/15-08-04, p. A10).

${ }^{14}$ O Levitra, da Bayer (Alemanha), principal concorrente do Viagra da Pfizer (Estados Unidos), é promovido e comercializado em parceria com a Glaxo SmithKline (Reino Unido) (Gazeta Mercantil, 10/11/12-10-03, p. A14).
} 
tratamento de hipertensão, produzido pela Pfizer (Estados Unidos), é comercializado no Brasil em parceria com a Sankyo Pharma Brasil (Estados Unidos).

Grandes laboratórios nacionais já começam a tomar parte nesses acordos ${ }^{15}$.

Com isso, os laboratórios ampliam o campo de ação de seus tentáculos produtivos e propagandísticos, afirmando suas posições em vários países.

Citaremos, por fim, um quarto fator: o peso das marcas dos laboratórios multinacionais. Quando as empresas farmacêuticas chegam a ter marcas internacionalmente famosas, passam a contar com uma base mercadológica firme. Em 2002, 80\% do faturamento da Pfizer (Estados Unidos) era garantido por 8 medicamentos, dos 36 que o laboratório produzia; e, dos 60 medicamentos produzidos pela Merck (Alemanha), 5 garantiam 65\% de seu faturamento (Veja, 2002, p. 98). A concentração do capital quer dizer também a concentração da propriedade das grandes marcas.

O peso das marcas mina os objetivos da lei dos genéricos. Pois, mesmo com a existência de medicamentos mais baratos, vendidos sob denominações científicas, as marcas podem atrair, com mais eficácia, a preferência dos médicos ou mesmo dos pacientes. Assim, as contas nacionais prosseguem deteriorando-se em função das importações desses medicamentos cujas marcas se fazem, no limite, fetiches terapêuticos.

As empresas, a partir de seus oligopólios mercadológicos, podem passar a um verdadeiro controle sobre as dinâmicas de regiões ou mesmo de países. "Por isso, nessas condições, é lícito referirmo-nos à existência de verdadeiros oligopólios territoriais" (Santos e Silveira, 2001, 2004, p. 292). Que há de ser de uma política nacional de combate à diabetes, quando um só laboratório, estrangeiro, produz a insulina em território nacional?

Aliás, as grandes corporações farmacêuticas dispõem, no território brasileiro, de um ambiente mais ameno a partir de 1994, quando o governo federal libera os preços de medicamentos, os quais eram controlados ao longo da década precedente. Esse ano se converte, assim, numa espécie de divisor de águas. De 1980 a 1989, a rentabilidade do setor farmacêutico esteve abaixo da mediana dos setores; a partir de 1990, até 1998, ela se põe acima dessa mediana, atingindo um pico entre 1994 e 1995 (Queiroz e González, 2001, p. 140) ${ }^{16}$. Semelhante expansão dos lucros pôde-se dar por acréscimos de preço, pois que, em matéria de vendas, os números indicam redução. De 1992 a 1998, o volume de

\footnotetext{
${ }^{15}$ Um medicamento é fabricado pela AstraZeneca (Inglaterra) em Porto Rico e, embalado em Cotia (SP), deixa a fábrica sob duas marcas: Crestor, comercializado pela AstraZeneca, e Vivacor, comercializado pela Biosintética (Brasil). Com esse acordo de comercialização, o medicamento é divulgado, até 2009, por 300 propagandistas, que é a soma dos representantes de ambos os laboratórios. A Astra lança mão desse expediente porque, sozinha, não conseguiria reunir rapidamente um número tão expressivo de representantes (Gazeta Mercantil, 29-03-04, p. A20).

${ }^{16}$ De 1984 a 1988, os medicamentos demonstram uma taxa acumulada de reajuste 28,0 abaixo da taxa da inflação medida pelo IPC-Fipe; se estendemos essa contagem até 1997, vemos que os medicamentos apresentam uma taxa acumulada de reajuste 33,3 acima do IPC-Fipe (Queiroz e González, 2001, p. 140).
} 
unidades vendidas fica estável, porém multiplica-se por três o faturamento (Queiroz e González, 2001, p. 141) ${ }^{17}$. Para os anos mais recentes, o fenômeno se mantém. "[...] notase uma constante e discreta queda no volume de unidades vendidas no período 1997/2003, acompanhada por uma constante evolução no valor das vendas em reais" (Capanema e Palmeira Filho, 2004, p. 30) ${ }^{18}$.

Podemos supor que os medicamentos se tornam ainda mais inacessíveis para a maioria da população, enquanto as classes médias vão garantindo a expansão dos lucros dos laboratórios. Isso é possível na medida em que, sobretudo graças aos genéricos, produtos mais sofisticados passam a ser consumidos. "[...] parece ser razoável supor que o crescimento do faturamento dessa indústria, no período referido [1997 a 2003], deve ser conseqüência menos do reajuste de preços do que de mudanças qualitativas na demanda de medicamentos" (Capanema e Palmeira Filho, 2004, p. 30).

\section{A face geográfica da concentração}

Todos esses fenômenos são base e corolário de séries de polarizações espaciais. "A concentração geográfica está diretamente ligada à concentração econômica, já que as atividades modernas pretendem uma locação de acordo com a hierarquia, cujo ápice é encontrado onde a maximização da produção é possível" (Santos, 1973, 2005, p. 106).

Considerando os países latino-americanos, os efeitos concentradores já se patenteiam. "A Glaxo Wellcome, que chegou a ter 10 fábricas na América Latina, manteve apenas três: uma no Brasil, uma na Argentina e uma no México. Cada um desses centros é especializado em determinadas linhas de produção. O Brasil e a Argentina, por exemplo, ficaram com a fabricação de produtos para enfermidades respiratórias e de produtos antiinfecciosos (antibióticos), respectivamente" (González, 1999, p. 81).

Concentração e especialização parecem ser as palavras de ordem, tendências que atingem o território brasileiro. "[...] as fábricas que vêm sendo concentradas no país caracterizam-se por ser mais modernas, competitivas e voltadas à exportação. Em contrapartida, são muito mais especializadas, produzindo um número limitado de medicamentos já existentes" (González, 1999, p. 85). Isso faz aumentar as exportações, mas, sendo as plantas mais especializadas, eleva também as importações (idem, p. 142) ${ }^{19}$.

\footnotetext{
${ }^{17}$ Frenkel também diz que, na década de 1990, o número de unidades vendidas ficou estável, mas o faturamento da indústria farmacêutica foi aumentado (Frenkel, 2001, p. 158).

18 "As vendas da indústria [farmacêutica] crescem em valores nominais [faturamento] e caem em volume, ou unidades vendidas" (Gazeta Mercantil, 05/06/07-12-03, p. A3).

${ }^{19}$ A Roche fechou 8 das 11 fábricas que tinha na América Latina, conservando apenas as unidades do Brasil, da Argentina e do México; na América Latina, concentrou a produção em vitaminas e em medicamentos para tratamento e diagnóstico (González, 1999, p. 81).
} 
Como o fenômeno se intensifica sempre, mesmo a Argentina conhece, nos últimos anos, o abandono de alguns laboratórios. Brasil e México tornam-se os dois pólos produtores latino-americanos; o primeiro, sobretudo em função de suas tenras concentrações técnicas e, malgrado o baixo acesso aos medicamentos, em função também do tamanho de seu mercado ${ }^{20}$; o segundo, sobretudo graças à seu precoce reaparelhamneto normativo ${ }^{21}$. Entanto, escusa pensar que esses países tenham sido os vencedores das guerras globais de lugares; em verdade, seus verdadeiros prêmios são a extroversão dos territórios, além de um sufocante controle do mercado pelas multinacionais, no Brasil $^{22}$ como no México ${ }^{23}$.

Em verdade, o Brasil transforma-se numa grande plataforma de exportação de medicamentos, mormente para outros países da América Latina. Em 1989, 25\% das exportações farmacêuticas brasileiras tinham por destino a América do Sul; em 1998, foram 80\%; considerando os países hoje componentes do Mercosul, foram 11\% em 1989 e 54\% em 1998 (Queiroz e González, 2001, p. 152). Considerando os outros países, foram mais de 70\% em 1989 e 20\% em 1998 (González, 1999, p. 83).

"Para as empresas multinacionais e os monopólios, o investimento não é decidido em relação ao tamanho do mercado. Ele se torna 'autônomo'. As previsões nesse terreno são possíveis porque ou as corporações têm domínio das dimensões do mercado local, ou não têm necessidade dele, no caso das indústrias de exportação" (Santos, 1979, 2004, p. 140).

As produções de medicamentos são varridas por dois fenômenos.

Por um lado, crescem as exportações de fármacos, ou seja, as substâncias químicas que, nos medicamentos acabados, vão desempenhar o papel de elemento terapêutico principal. O Diovan é o medicamento mais vendido no mundo pela Novartis (Suíça); a produção de seu princípio ativo, o valsartan, é realizada em apenas dois países, a Suíça e o

\footnotetext{
${ }^{20}$ Queiroz e González também ressaltam que, nos anos 1990, as transnacionais fecharam unidades menores, concentrando a produção em grandes unidades regionais (Queiroz e González, 2001, p. 141). "O Brasil se beneficia desse processo por ser um candidato natural, sobretudo em função do tamanho de seu mercado, a se tornar uma grande plataforma fabril para a região" (idem, p. 141).

${ }^{21}$ O México começa a acolher as normas patentárias internacionais de medicamentos antes que o Brasil; sua legislação data de 1991, nos termos do GAT/OMC (Oliveira, R. 1999, p. 61 - nota 24). É o principal mercado varejista de medicamentos da América Latina (Gazeta Mercantil, 27/28/29-02-04, p. A13). É o quinto maior mercado farmacêutico do mundo (Gazeta Mercantil, 19-0804, p. A11).

${ }^{22}$ Considerando as quatro maiores companhias em atuação no Brasil, vemos que, em 1990, controlavam 15\% do mercado farmacêutico brasileiro, proporção que passa a 20\% em 1992, 15\% em 1993, 20\% em 1996, 25\% em 97; se tomarmos os dez maiores laboratórios, essas proporções variam, para os mesmos anos, da seguinte maneira: 30\%, mais de 35\%, 30\%, mais de 35\%, pouco menos de 45\% (Oliveira, R. 1999, p. 62).

23 “[...] foram levantadas algumas indicações para o México. Segundo estudo da CEPAL [...], a participação das 10 e 30 primeiras farmacêuticas passou de 28,20\% e 60,30\% respectivamente, em 1988, a 34,24\% e 72,10\% em 1998” (Oliveira, R. 1999, p. 60). Ainda com dados da Cepal, Oliveira prossegue: "Entre 1993 e 1996, a participação de empresas nacionais [no México] passou de 30\% do mercado para 27,8\%. Deve-se assinalar que a redução teria sido mais acentuada se não fossem as compras do governo, que passou a direcionar $80 \%$ de suas compras às empresas nacionais” (idem, p. 102).
} 
Brasil (Gazeta Mercantil, 11-03-04, p. A12). O processo é iniciado na Suíça, continuado no Brasil, onde se realizam quatro estágios de desenvolvimento da substância, e terminado na Suíça; com isso, a unidade brasileira exporta para a própria matriz (Gazeta Mercantil, 23-0604, p. A11).

Por outro lado, crescem as exportações de medicamentos acabados. "Entre 1993 e 1998 [...], as exportações de medicamentos mais que quintuplicaram, chegando a quase US\$ 150 milhões" (Queiroz e González, 2001, p. 151) ${ }^{24}$.

Nas estratégias espaciais das grandes corporações, o território brasileiro começa a pesar decisivamente, por vezes recebendo produções mundialmente exclusivas. Entre 70\% e $80 \%$ da produção da unidade da Rhodia, em Paulínia (SP), destina-se à exportação (Gazeta Mercantil, 11-03-04, p. A12). Até 2007,o laboratório dinamarquês Novo Nordisk investe em sua unidade de Montes Claros (MG); ela terá capacidade para um volume de produção seis vezes superior ao consumo brasileiro de insulina; com isso, a meta da Novo Nordisk é exportar até 80\% da produção, para diversos países (Gazeta Mercantil, 19-08-04, p. $A 11)^{25}$. A tabela VI.2 resume algumas outras situações.

O circuito superior da economia se consolida a despeito das situações concretas existentes em território nacional. Os mercados externos, as trocas internacionais, a instalação de verdadeiras unidades produtivas globais, são fenômenos corrediços.

[...] as verdadeiras possibilidades de crescimento endógeno do circuito superior são mínimas em toda parte. A política seguida pela grande empresa não se insere num desenvolvimento planificado da cidade (Santos, 1979, 2004, p. 123).

\footnotetext{
${ }^{24}$ Com efeito, a década de 1990 representou uma virada. Entre 1989 e 1993, as exportações conhecem um acréscimo bem modesto, chegando a pouco mais de US\$ 20 milhões; em 1995, já passavam de US\$ 60 milhões; em 1998, eram quase US\$ 150 milhões (Secex apud Queiroz e González, 2001, p. 151).
} 
tabela VI.2. Algumas produções realizadas no Brasil por laboratórios farmacêuticos multinacionais e destinadas a mercados externos: 2006

\begin{tabular}{|c|c|c|c|c|}
\hline & \multicolumn{2}{|r|}{ Fábrica } & & \\
\hline Laboratório & UF & Cidade & Produto & Mercado \\
\hline $\begin{array}{c}\text { Glaxo SmithKline } \\
\text { (Inglaterra) }\end{array}$ & RJ & Jacarepaguá & Diversos & Brasil e Mercosul \\
\hline $\begin{array}{l}\text { Boehringer } \\
\text { (Alemanha) }\end{array}$ & SP & $\begin{array}{c}\text { Itapecerica } \\
\text { da Serra }\end{array}$ & Diversos & $\begin{array}{c}\text { América do Sul e } \\
\text { Europa }\end{array}$ \\
\hline Hexal (Alemanha) & PR & Cambé & Diversos & América do Sul \\
\hline $\begin{array}{c}\text { Novo Nordisk } \\
\text { (Noruega) }\end{array}$ & MG & $\begin{array}{l}\text { Montes } \\
\text { Claros }\end{array}$ & Insulina & $\begin{array}{c}\text { Argentina, Colômbia } \\
\text { e Paraguai (a) }\end{array}$ \\
\hline Pfizer (EUA) & SP & Guarulhos & $\begin{array}{l}\text { Lípitor (redutor de } \\
\text { colesterol) }\end{array}$ & América Latina (b) \\
\hline $\begin{array}{c}\text { Boehringer Ingelheim } \\
\text { (Alemanha) }\end{array}$ & SP & $\begin{array}{c}\text { Itapecirica } \\
\text { da Serra }\end{array}$ & $\begin{array}{c}\text { Dexa-Rhino Spray } \\
\text { (descongestionante nasal) }\end{array}$ & Todo o mundo (c) \\
\hline Eli Lilly (EUA) & SP & São Paulo & Diversos & América do Sul \\
\hline Roche (Suíça) & RJ & $\begin{array}{l}\text { Rio de } \\
\text { Janeiro }\end{array}$ & Diversos & América do Sul \\
\hline
\end{tabular}

(a) a expansão da unidade da Novo Nordisk em Montes Claros será finalizada em 2006, e a meta da empresa é exportar $80 \%$ da produção para diversos países, além dos três citados. (b) a meta é exportar $20 \%$ da produção. (c) O produto é fabricado apenas no Brasil.

Estamos em face de uma redefinição da divisão internacional do trabalho. As carências particulares ao território brasileiro são desprezadas, em benefício de uma função abstrata que ele vai desempenhar no plano mundial ${ }^{26}$. Assim, o território brasileiro vai pagar o preço de ter sido eleito, pelas corporações multinacionais, como um elemento fundamental de suas estratégias ${ }^{27}$. Do ponto de vista do circuito superior, as unificações assim

\footnotetext{
${ }^{25}$ Em meados de 2006, a unidade da Roche em Jacarepaguá, cidade do Rio de Janeiro, será a única no mundo a produzir o medicamento anticoagulante Marcoumar, que não se trata de um medicamento inovador (Gazeta Mercantil, 21-10-04, p. A10).

26 “A divisão do trabalho não põe em contato os indivíduos, mas sim as funções sociais” (Durkheim, 1932, p. 403).

27 “O significante crescimento do mercado e a tendência à concentração de fábricas no país por parte dos grandes laboratórios, corrobora a idéia de que o Brasil esteja se convertendo num pólo regional produtor e exportador para os países da região, especializado em certas linhas de produção” (González, 1999, p. 90).
} 
produzidas fazem com que o território se torne mais concreto, no sentido de Gilbert Simondon: "[...] cada estrutura ganha, nessa redistribuição, uma riqueza funcional maior e uma precisão estrutural mais perfeita [...]" (Simondon, 1958, 1969, p. 33).

Ao mesmo tempo, as exportações de medicamentos implicam, necessariamente, mais consumos normativos. Pois que, para poderem colocar seus produtos em mercados internacionais, as empresas, sejam elas grandes laboratórios nacionais ou subsidiárias de laboratórios estrangeiros, deverão conformar-se a uma pletora de procedimentos e normas internacionais de qualidade. O mais das vezes, seguem-se as normas produzidas pela FDA dos Estados Unidos. Mais uma vez, as normas expõem suas presas hierarquizantes, pois, para a maior parte dos laboratórios brasileiros, as exportações ficam interditadas, justamente em função da incapacidade para seguir esses padrões internacionais ${ }^{28}$.

A rigidez internacional das normas vai-se conjugar com a rigidez das normas nacionais, agora renovadas. No mundo como nos países, densidades normativas formam ilhas de prosperidade, em que folgam os agentes hegemônicos ${ }^{29}$. No mundo como nos países, o mercado se faz cativo de um pequeno rol de laboratórios. Em 2004, Capanema e Palmeira Filho escrevem que as multinacionais respondem por $70 \%$ das vendas para 0 mercado interno, excluindo a parcela de compra feita pelo governo (Capanema e Palmeira Filho, 2004, p. 28). Dessa parcela, poderão elas abrir mão, pois as compras do governo correspondem a medicamentos menos complexos, logo mais baratos, cuja produção tem sido confiada, sobretudo, aos laboratórios oficiais. Em 2004, os 12 principais laboratórios farmacêuticos atuantes no Brasil dominavam 45,1\% do mercado nacional. Entre eles, havia apenas uma empresa nacional, o Aché ${ }^{30}$; as demais 539 empresas ficam com 54,9\% do mercado (Capanema e Palmeira Filho, 2004, p. 29).

A concentração de capital farmacêutico, nos anos 1990, representou novo desaparecimento de empresas nacionais. "O maior número de operações de aquisição teve como alvo empresas de capital nacional, embora [...] os maiores valores das transações de fusões e aquisições tenham ocorrido entre as subsidiárias estrangeiras" (Magalhães et alii, 2003, p. 32).

\footnotetext{
28 “Quando examinamos o processo de adoção dessas lógicas planetárias, o chamado imperativo de exportação é outro dado a ser levado em conta na medida em que acelera a necessidade de adoção dos modelos da economia global” (Santos e Silveira, 2001, 2004, p. 258).

29 "A competitividade dessas empresas, além de incluir os atributos inerentes aos lugares, depende das diferenças nas legislações nacionais, das medidas de apoio governamental referentes a produção, investimento, subsídios à pesquisa e ao desenvolvimento [...] As vantagens oferecidas pelo poder público às grandes empresas continuam hoje sendo centrais na sustentação da competitividade [...]” (Arroyo, 2001, p. 36).

${ }^{30}$ As proporções são as seguintes: Roche (Suíça) 6\%; Aventis (França) 5,6\%; Pfizer (Estados Unidos) 4,7\%; Novartis (Suíça) 4,5\%; Abott (Estados Unidos) 4,3\%; Schering (Alemanha) 3,1\%; Bristol (Estados Unidos) 3,0\%; AstraZeneca (Inglaterra) 2,8\%; Merck (Alemanha) 2,8\%; Aché (Brasil) 2,8\%; Janssen (Estados Unidos) 2,8\%; Boehringer (Alemanha) 2,7\%. Total: 45,1\% (Capanema e Palmeira Filho, 2004, p. 29).
} 
No território, notam-se fenômenos de polarização. Aqui, é expressiva a situação de Jacarepaguá, bairro do Rio de Janeiro que, na década de 1990, tornou-se um pólo de química fina, incluindo laboratórios farmacêuticos multinacionais, tal como foi estudado por Pierre Alves Costa (1999).

Paralelamente, o estado de São Paulo, mas sobretudo sua capital, consolidam sua primazia. Com a tabela VI.3, queremos demonstrar que os maiores laboratórios situam-se nesse estado. Para o ano de 1985, a Biobrás ilumina o estado mineiro, mas, em todas as outras fases, apenas os estados de São Paulo e Rio de Janeiro abrigaram as empresas mais poderosas.

tabela VI.4. Sede dos 15 maiores laboratórios: Brasil, 1976, 1985, 1995, 1999 e 2004

\begin{tabular}{|c|c|c|c|c|}
\hline Ano & Critério & São Paulo & Rio de Janeiro & Minas Gerais \\
\hline 1976 & Vendas & 10 & 5 & -- \\
\hline 1985 & Receita operacional líquida & 9 & 5 & 1 \\
\hline 1995 & Receita operacional líquida & 12 & 3 & -- \\
\hline 1999 & Receita operacional líquida & 12 & 3 & -- \\
\hline 2004 & Receita operacional líquida & 13 & 2 & --- \\
\hline
\end{tabular}

fonte: elaboração própria, com dados da Gazeta Mercantil, Balanço anual, 1977, 1986, 1996, 2000 e 2004

Essa concentração no estado de São Paulo deve-se, também, ao controle informacional permitido pela capital paulista ${ }^{31}$.

As empresas multinacionais transportam consigo duas necessidades indeléveis: realizar contatos rápidos com outros territórios nacionais, mormente aqueles em que estão suas matrizes; e ter acesso pronto a certos serviços modernos. Uma vez que São Paulo permite a realização dessas duas exigências, torna-se ponto de concentração de grandes laboratórios farmacêuticos. "Tudo, ou quase tudo, no domínio econômico passa pela metrópole econômica nacional" (Santos, 1979, 2004, p. 289). Com efeito, São Paulo permite uma concentração de serviços modernos, reunindo, majoritariamente, as empresas de

\footnotetext{
${ }^{31}$ Podemos citar a situação do laboratório Hisamitsu. Trata-se de um laboratório japonês, que chega ao Brasil em 1989, instalando-se na cidade de São Paulo. Em 2001, transfere sua produção para o distrito industrial de Manaus, mas conserva sua administração em São Paulo, onde se congregam os setores de vendas, estratégias de produção, propaganda, contato com os clientes. Apesar de possuir vários medicamentos em sua lista de produtos, o Hisamitsu fabrica, no Brasil, apenas um medicamento, produção apoiada por uma forte propaganda ao grande público. Seus princípios ativos são importados da matriz japonesa, mas são utilizados, ainda, alguns princípios ativos produzidos por empresas do estado de São Paulo. O volume de produção mensal é definido a partir da unidade paulistana.
} 
informática $^{32}$, propaganda ${ }^{33}$, consultoria ${ }^{34}$, entre outras. Configuram-se universos à parte, sobrepairando ao mundo da copresença.

Mas, se dizemos apenas isso, não fica totalmente explicada a situação de primazia da cidade de São Paulo. Kevin Cox tem razão dizendo que uma cidade nacionalmente dominante pode aparecer como dependente quando expandimos a escala e consideramos movimentos como os do comércio internacional ou das operações financeiras (Cox, 1972, p. 28). E ensina Milton Santos que a cidade primaz não é um sistema autônomo, mas um subsistema dependente (Santos, 1979, 2003, p. 78). Pagando royalties, mas também os preços de transferência ${ }^{35}$, os laboratórios estrangeiros instalados em São Paulo submetem a cidade a uma sangria de capital, fenômeno que não é exclusivo da produção de medicamentos ${ }^{36}$.

A primazia da cidade de São Paulo é geradora de fluxos internos ao estado, os quais vão terminar por dinamizar outros lugares. Desse modo, cidades como Campinas, Ribeirão Preto, Diadema, Barueri, Guarulhos, passam a abrigar novos agentes e atividades, graças à facilidade de integração com a cidade primaz.

Quanto a isso, é interessante considerar a situação da cidade de Cotia. Estendida às beiras da rodovia Raposo Tavares, a cidade possui rápida ligação com a capital paulista. Esse fato, somado à existência de grandes lotes e parques empresariais propícios à instalação de empresas, somado à promessa de construção de um Rodoanel circundando a cidade de São Paulo e passando por Cotia, mas também somado a uma certa política municipal, mesmo que balbuciante, de atração de empresas, vai levar à instalação de vários tipos de atividade, entre eles a atividade farmacêutica. Duas empresas multinacionais, a inglesa AstraZeneca (depois adquirida pela Glaxo, também da Inglaterra) e a Coopers, pertencente ao grupo da Schering Plough (Estados Unidos), vão-se instalar ali, tornando-se literalmente vizinhos. A par dessas empresas, outras, nacionais, surgem como representantes das várias categorias de agentes atuantes na produção de medicamentos. Assim, aparece um grande laboratório de capital nacional, o Blausiegel, fundado em 1987; o Latinofarma (fundado em 1990, mas iniciando a produzir apenas em 2002), laboratório pequeno, mas com certa dinâmica, proveniente de sua especialização produtiva

\footnotetext{
${ }^{32}$ Das duzentas maiores empresas de informática presentes no Brasil, 64\% estão no estado de São Paulo, 42\% na cidade de São Paulo (Bernardes, 2001, 2004, p. 423).

${ }^{33}$ Em 1994, o estado de São Paulo abrigava 52,1\% das agências de publicidade do Brasil. (Santos e Silveira, 2001, 2004, p. 224) Em 1997, ele reunia 51,65\% dessas agências (Antongiovanni, 2001, 2004, p. 406).

${ }^{34}$ Em 2001, a cidade de São Paulo reunia cerca de $37 \%$ dos serviços de assessoria e consultoria (Bernardes, 2001, 2004, p. 421). "Ora, entre as 15 principais consultorias de informática no Brasil, 11 encontravam-se em São Paulo [...]” (idem, p. 424).

${ }^{35}$ No capítulo II, explicamos o mecanismo dos preços de transferência.

${ }^{36}$ Considerando várias atividades, São Paulo e Rio de Janeiro apresentam déficits em sua balança comercial. Também o Amazonas, graças à presença da Zona Franca de Manaus. Outros estados, como Bahia, Paraná, Santa Catarina e Rio Grande do Sul, são superavitários (Arroyo, 2001, p. 88-90).
} 
(medicamentos oftalmológicos); um pequeno laboratório produtor de medicamentos florais ${ }^{37}$, o Laborciv, fundado em 1992; e até mesmo um laboratório de capitais latino-americanos, a Colbras, fundado em $1995^{38}$. Ali também se encontra o laboratório Itafarma, que produz dois tipos de antibiótico (cefalosporina e penicilina); fundado em Cotia, o laboratório conserva ali somente sua administração, transferindo sua fábrica para a cidade de Anápolis, em Goiás (mas fora do distrito industrial).

Retroalimentando-se, o processo vai ser a base da criação de empresas adictas. Em 2001, a Colorcon, empresa dos Estados Unidos, fundada em 1990, chega à cidade de Cotia. A Colorcon realiza dois tipos de atividade: distribuição de matérias-primas e insumos utilizados por laboratórios farmacêuticos; desenvolvimentos de plantas-piloto para a produção de medicamentos. Lado a lado com o estabelecimento da Colorcon, vamos encontrar a Blanver, uma empresa que presta serviços de produção para laboratórios farmacêuticos $^{39}$. E o laboratório Hertz, sediado em Porto Alegre (RS), instala, em 2003, uma unidade de sua distribuidora Hertz em Cotia, para abastecer exclusivamente os estados de São Paulo e de Minas Gerais ${ }^{40}$.

Adiante veremos que as novas dinâmicas da cidade de Cotia se explicam, também, pela ação de forças dispersivas que atravessam o território brasileiro no período contemporâneo. Por ora, queremos destacar apenas que, em função de suas fáceis relações com a capital paulista, Cotia pode ser atingida pela luminosidade que provém da cidade primaz. Um fenômeno que não se deve tão-somente à proximidade geométrica, mas que tem a ver com a instalação de infra-estruturas, materiais e não-materiais, permitindo relações cada vez mais velozes e eficazes. Se recorrermos à distinção feita por María Laura Silveira (1996, 1999, pp. 416-417), poderemos dizer que São Paulo representa uma área de luminosidade primária, a partir da qual se formam áreas de luminosidade secundária, como Cotia.

\footnotetext{
${ }^{37}$ Os florais são medicamentos usados na chamada medicina alternativa. Sua fabricação acontece por sucessivas diluições, assim como os homeopáticos. Utilizam-se apenas plantas e flores.

${ }^{38}$ A Colbras é fruto de um acordo entre duas empresas estrangeiras: a Recalcine, do Chile; e a Intercaps, da Venezuela. Essas duas empresas se associaram para constituir duas unidades produtivas: uma na Colômbia, onde se instalou a sede produtiva do empreendimento; e uma no Brasil, na cidade de Cotia (SP).

${ }^{39}$ Entre os clientes da Blanver, encontramos o Lafergs (Porto Alegre), laboratório oficial do Rio Grande do Sul. E a GeoLab, instalada no Distrito Agroindustrial de Anápolis, adquire insumos de revestimento de comprimidos junto à Blanver.

${ }^{40}$ Para os outros estados, o laboratório realiza diretamente sua distribuição. A distribuidora Hertz opera somente com os produtos de seu laboratório e com os medicamentos similares do Vitapan, localizado em Anápolis, no distrito industrial.
} 
Mas, aqui também, o processo tem seu reverso. Pois que as ligações freqüentes com a metrópole nacional conduz, rapidamente, a uma submissão aos ritmos e estratégias metropolitanos ${ }^{41}$.

Quando afirmamos que são problemáticas as concentrações da cidade de São Paulo, não é que pretendamos ver emergir um território quantitativamente equilibrado. $\mathrm{O}$ que é mais crucial é que os vários indicadores são, apenas, sinais superficiais de imensas desigualdades sociais e territoriais que, elas sim, devem despertar nossas inquietações políticas. As abundâncias da cidade de São Paulo seriam completamente inofensivas se, com base nelas, não se definisse, como tantas vezes ocorre, a penúria dos outros lugares.

Dentro dessa discussão, mais dois pontos se devem ressaltar.

Primeiramente, a produção de polarizações espaciais não é exclusiva da cidade de São Paulo. Sabe-se que, muita vez, a cidade do Rio de Janeiro também se eleva na hierarquização capitalista brasileira. Mas, além disso, quando pensamos nos estados individualmente, os estados como totalidade, polarizações ainda mais drásticas aparecem, pois que as metrópoles estaduais, freqüentemente as capitais administrativas, acaparam a quase totalidade dos vigores econômicos. O fenômeno pode chegar a extremos, como no caso de Manaus. No Rio Grande do Sul, considerando a produção de medicamentos, vemos que, dos 28 laboratórios pesquisados por Maria Aparecida Pereira em 2001, 67,86\% situavam-se em Porto Alegre; se consideramos também as cidades do entorno de Porto Alegre, a proporção vai a $85,72 \%$; os demais laboratórios (14,28\%) estavam no interior do estado (Pereira, 2002, p. 41).

Segundamente, é preciso muito cuidado com os discursos da pseudo-igualdade. O território não seria mais igualitário pela simples dispersão, quantitativamente equilibrada, das unidades industriais ou comerciais. Sem uma gestão autônoma dos lugares, sem a produção de quadros vitais que sejam social e espacialmente saudáveis, e não apenas científica e nosologicamente saudáveis, a igualdade permanecerá sendo uma tentativa, uma promessa.

As seletividades vão-se acentuando, e as populações, empobrecidas nas suas regiões empobrecidas, ficam sempre mais distantes das modernizações farmacêuticas.

\section{A concentração do poder político}

As normas disseminam lógicas de concentração. Acirram-se todos os fatores que, segundo Capanema e Palmeira Filho, fazem com que a indústria farmacêutica apresente

\footnotetext{
41 “As cidades médias comandam o essencial dos aspectos técnicos da produção regional, deixando o essencial dos aspectos políticos para aglomerações maiores, no país ou no estrangeiro, em virtude do papel dessas metrópoles na condução direta ou indireta do chamado mercado global” (Santos e Silveira, 2001, 2004, p. 283).
} 
uma estrutura concentrada e oligopolista: proteção de patentes, necessidade de altos investimentos em pesquisa, controle do fornecimento de princípios ativos, reputação das marcas dos laboratórios líderes (Capanema e Palmeira Filho, 2004, p. 26). Os poderes políticos obedecem, da mesma forma, a forças de concentração. A um quadro institucional variado, que vigia no período precedente, segue-se, hoje, a formação de um grande bloco de agentes, os quais vão confluir para o seio da Febrafarma, Federação Brasileira da Indústria Farmacêutica. Fundada em 2002, ela substitui a Abifarma, cuja figura se tinha desgastado após a CPI dos medicamentos, que se realizou em $2000^{42}$.

As concentrações podem ficar menos evidentes porque, sobretudo após a lei dos medicamentos genéricos, surgiram grandes laboratórios de capital nacional. Por vezes, esses agentes vão assumir discursos ou comportamentos supostamente patrióticos, apresentando-se como os paladinos dos anseios nacionais. Ocorre que, subterraneamente, seus poderes e suas ações estão fortemente baseados em acordos fechados com laboratórios estrangeiros. Poderíamos começar pelo EMS (São Bernardo do Campo-SP). "Esse laboratório mantinha um acordo de fornecimento de medicamentos genéricos com a empresa canadense de genéricos Apotex" (Magalhães et alii, 2003, p. 23 - nota 35). Em 2003, a Apsen (São Paulo-SP) estava fechando parcerias com laboratórios internacionais (Gazeta Mercantil, 23-06-03, p. A15). O laboratório Aché (Guarulhos-SP) possui 42\% da filial brasileira da estadunidense Schering-Plough; mantém, desde 1988, 51\% da joint venture Prodome com a MSD, dos Estados Unidos (González, 1999, pp. 76-81). A Medley fechou acordo com a Bayer (Alemanha) para comercializar um medicamento para disfunção erétil, produzido pela multinacional alemã (Gazeta Mercantil, 23/24/25-09-05, p. C2) ${ }^{43}$.

Esses grandes laboratórios podem, ainda, participar das vantagens conferidas pelo uso de grandes marcas estrangeiras. De 1 de janeiro de 1990 a 17 de novembro de 1999, as empresas de produtos farmacêuticos averbaram 766 certificados junto ao INPI, Instituto Nacional de Propriedade Intelectual; desses contratos, 660, ou seja $86,1 \%$, referiram-se à utilização de marca, sistema pelo qual um laboratório, nacional ou estrangeiro, concede a

\footnotetext{
42 A Febrafarma inclui: a Interfarma, Associação da Indústria Farmacêutica de Pesquisa (27 laboratórios multinacionais em 2003); Abir, Associação Brasileira da Indústria da Automedicação Responsável, ex-Abips (produtores de medicamentos vendidos sem receita médica); Alanac, Associação dos Laboratórios Farmacêuticos Nacionais (produtores de similares; 70 associados em 2003); Grupo Pró-Genéricos (produtores de genéricos); Sindusfarma, Sindicato da Indústria de Produtos Farmacêuticos no Estado de São Paulo; Sinfar, Sindicato da Indústria de Produtos Farmacêuticos no Estado do Rio de Janeiro.

${ }^{43}$ O Cristália tem acordos internacionais com várias empresas transnacionais em todo o mundo. Tais acordos regulam venda e compra de produtos prontos, de semiacabados e de matérias-primas; desse modo, o Cristália pode espalhar seus produtos, em diversas fases de produção, por quase todo o mundo, além de comprar produtos, também nas diversas fases de produção, de vários países. Não estranha, pois, que seu gerente de marketing defina o laboratório como uma "empresa multinacional”.
} 
outro, o mais das vezes nacional, o direito de utilizar certa marca de medicamento (Oliveira, R. 1999, p. 83) $)^{44}$.

Nossas precauções teóricas nunca serão suficientes; não podemos sequer usar desavisadamente a palavra capital. Segundo Peter Evans, quando se considera o capital nacional, é preciso distinguir entre aquele capital que tem ligações estreitas com agentes internacionais e o "capital nacional menor" (Evans, 1979, 1980, p. 98) ${ }^{45}$. Em termos geográficos, podemos falar em hegemonia, mas compreendendo que, em vez de haver um bloco hegemônico indiferenciado, há diferentes estratos de agentes hegemônicos ${ }^{46}$. Ou seja, dentro do circuito superior, há novas hierarquias, além de interesses nem sempre concordantes, e estratégias diferenciadas de manutenção no bloco hegemônico. Para os grandes laboratórios nacionais, a preservação das forças concentradoras será, em vários aspectos, benéfica; pois, quando os vetores da globalização pululam e recrudescem, eles podem fruir de efeitos secundários, que asseguram seu controle subalterno do mercado. Demais, é importante, para as corporações multinacionais, a existência de um pequeno grupo de fortes empresas locais, pois estas podem, muita vez, incumbir-se de certas produções e atividades (sobretudo propagandísticas) que, por assim dizer, preparam o terreno para o avanço dos agentes verdadeiramente hegemônicos. Aliás, o fato de que esse pujante grupo capitalista local deve ser, forçosamente, pouco numeroso, é mais uma das faces da seletividade do capital hegemônico ${ }^{47}$.

Os estratos hegemônicos podem contar com densidades normativas que lhes permitem maior fluidez e precisão. Vimos isso no capítulo anterior, quando falamos que, por ocasião da lei dos genéricos, as maiores empresas começam a dispor de grandes quantidades de recursos financeiros, técnicos, científicos, informacionais. Paralelamente, os agentes marginais ficam presos a normatizações antigas.

Mas, neste capitalismo normativo, a hegemonia, além de se instalar pela ativação de certas regras, instala-se pela capacidade para fazê-las repousar, adormecer, em certos momentos. Para ilustrar esse fato, podemos recorrer à questão das farmacopéias.

\footnotetext{
44 E em junho de 2003, o presidente da Associação dos Laboratórios Farmacêuticos Nacionais, talvez inspirando-se no clima da Febrafarma, em que laboratórios nacionais e estrangeiros convivem, escreve o seguinte: "Se a nossa indústria farmacêutica desenvolver uma fusão com uma empresa média européia ou americana, isso significará melhoria de competitividade e inserção em nível mundial” (Gazeta Mercantil, 01-0604, p. A3). Sabe-se que o referido presidente cumpria também, nessa ocasião, a função de diretor-presidente do Hebron, o maior laboratório farmacêutico particular de Pernambuco.

${ }^{45}$ Para Poulantzas, existe o capital monopolista com estratégia de expansão internacional e o capital monopolista com estratégia de expansão nacional (Poulantzas, 1974, p. 149).

${ }^{46}$ Florestan Fernandes $(1974,1981)$ já usava a idéia de um grupo hegemônico composto por vários estratos.

${ }^{47}$ Estamos de acordo com Doreen Massey: reforçar as empresas locais não é solução, pois isso, em vez de solucionar o problema fundamental, que é a distribuição social da riqueza, apenas fomenta o surgimento de uma classe capitalista local (Massey, 1984, 1987, pp. 102-103).
} 
Uma farmacopéia consiste numa relação de medicamentos, que um Estado nacional faz publicar para que as empresas, as instituições, possam guiar-se por essas orientações gerais. No Brasil, em 1974, elabora-se a Rename, Relação Nacional de Medicamentos Essenciais, em que se encontram os nomes e as fórmulas dos produtos. Pode-se considerar que, no período contemporâneo, a Rename tem o sentido de um sistema de normas, já que, para produzir os medicamentos que ela preconiza, é preciso recorrer a certas normas técnicas e científicas. Em 1999, a Rename foi atualizada. Porém, mesmo com essa atualização, sabe-se que a farmacopéia brasileira, cotejada com farmacopéias estrangeiras, encontra-se bastante obsolescida. Em verdade, ela indica a produção de medicamentos muito simples, iodos, sulfas, sais, xaropes, tudo muito aquém das atuais complexidades estadeadas pelos medicamentos modernos. Aliás, costuma-se chamar de oficinais, ou farmacopéicos, os medicamentos indicados pela Rename, e a tal espécie de produção dedicam-se, hoje em dia, apenas os laboratórios oficiais, bem como as empresas farmacêuticas mais modestas. Estas optam pelos medicamentos oficinais porque, para produzi-los, não é preciso pagar taxas de registro junto à Anvisa.

E quanto aos maiores laboratórios? Eles costumam utilizar farmacopéias estrangeiras, pois têm os recursos necessários para reproduzir as fórmulas e os procedimentos (as normas técnicas) que nelas são recomendadas. No Brasil, a USP (United States Pharmacopoeia) é largamente usada, por laboratórios estrangeiros mas também por grandes laboratórios nacionais; nela se encontram especificações de matérias-primas, de produtos acabados e de procedimentos referentes à análise de ambos os dois.

Assim, de acordo com o grau de capitalização das empresas, tem lugar um consumo diferencial de normas ${ }^{48}$. No circuito superior, elas surgem como o cimento a garantir unificações espaciais de uma complexidade jamais vista; para o circuito superior marginal, elas vão ganhando um matiz repressivo, de modo a conservar os agentes em postos subalternos de uma totalidade mundial.

Segundo Max Pagès, o capital se concentra à medida que a divisão do trabalho se difunde; ao mesmo tempo, a elaboração das normas se concentra à medida que elas se aplicam a porções cada vez mais largas da sociedade (Pagès, 1978, 1984, p. 77). As novas resoluções sanitárias brasileiras, que vigoram na escala nacional, promovem um consumo compulsório de certas normas científicas, financeiras, informacionais. Mas, por outro lado, importam-se normas globais, cuja produção e consumo conservam-se rigidamente concentrados, ao dispor dos vários estratos que formam o bloco hegemônico.

\footnotetext{
${ }^{48}$ Os ofertantes de produtos, entre si, e os demandantes de produtos, entre si, podem experimentar condições diferentes por estarem submetidos a formas de regulação diferentes (Nádia Guimarães, no curso: Sociologia econômica, Departamento de sociologia, USP, primeiro semestre de 2003).
} 
Terceira parte

\section{A racionalidade comunicacional: \\ O território como coexistência de sistemas organizacionais}

Vou aplicar uma penicilina, anuncia.

Vasculha a maleta, tira de lá um frasco com o pó branco, a ampola de diluente.

Moacyr Scliar

A majestade do Xingu (1997) 
A formação socioespacial, nos países periféricos, deu-se de maneira tal que as modernizações, controladas externamente, ficaram concentradas em poucos lugares do território. É pelo fato de que, nos sucessivos momentos do processo de modernização, poucos agentes e poucos lugares são beneficiados, selecionados, que falamos em seletividade $^{1}$. Aliás, esses efeitos de exclusão e distorção fazem parte da própria racionalidade instrumental própria às operações capitalistas ${ }^{2}$.

Poucas empresas, e poucas pessoas, têm acesso à produções e consumos modernos. O espaço se divide: pontos luminosos e pontos opacos; escala do mandar e escala do fazer; circuito superior e circuito inferior.

Acontece porém que as opacidades territoriais, multiplicando-se, tornam-se base forte para uma série de atividades econômicas. María Laura Silveira diz que a pobreza também tem seus dinamismos e também é geradora de economia e trabalho (Silveira, 2004). Ora, esses fenômenos já não têm um caráter simplesmente reativo. Mais do que nunca, o circuito inferior da economia, bem como o superior marginal, estão bastante consolidados, mais importante, expressando uma racionalidade espacial que lhes é própria.

\section{Um circuito econômico intermediário: interpretações anteriores}

Ao longo do desenvolvimento das ciências humanas, várias interpretações foram elaboradas acerca do aparecimento de empresas menores, empregando técnicas mais ou menos rudimentares.

Joseph Ramos (1970), estudando as empresas latino-americanas, enfatizou o tipo de mão-de-obra. Identificou três grupos. Primeiro, as manufaturas tradicionais, reunindo empresas que geralmente empregam poucas pessoas, utilizam trabalho familiar e autônomo. Segundo, as manufaturas modernas relativamente intensivas em trabalho qualificado. E, em terceiro lugar, um grupo intermediário formado pelas manufaturas relativamente intensivas em trabalho não qualificado (Ramos, 1970, pp. 150-151).

Nos anos 1970, Nicos Poulantzas (1974) desenvolve uma análise voltada para a estruturação do capitalismo e para as relações entre as diferentes frações do capital, e destas com as classes dominadas. Diz ele que, depois da passagem para a fase histórica

\footnotetext{
${ }^{1}$ As forças de modernização são extremamente seletivas tanto quanto à forma como aos efeitos. As variáveis modernas não se difundem homogeneamente através do espaço operacional, alterando-se a importância de cada uma delas (Santos, 1979, 2003, p. 125).

2 “Operações feitas com o propósito do lucro, para fazer 'frutificar' um capital, são por definição (mas sem que isto seja tautológico) ‘seletivas’” (Chesnais, 1994, 1997, p. 31).
} 
do capitalismo monopolista ${ }^{3}$, formam-se três grandes grupos: primeiro, o pequeno capital, reunindo os empreendimentos menores; segundo, o capital monopolista, reunindo as frações capitalistas mais poderosas; e, por fim, o capital não monopolista, ou capital médio 4 . Apesar de suas desvantagens, o capital não monopolista logra preservar-se (Poulantzas, 1974, pp. 99-204) ${ }^{5}$. Assim, Poulantzas vê as empresas médias como subprodutos de uma acumulação capitalista que, necessariamente, gera monopólios e dependências ${ }^{6}$.

André Granou (1974) separa as diversas empresas em função de suas taxas de lucro. Aqui, não temos uma classificação muito sistemática das empresas; mas é possível perceber pelo menos três grupos: primeiro, as grandes empresas, internacionalizadas, realizando as maiores taxas de lucro; segundo, as pequenas empresas, dotadas de um capital cujo ciclo costuma ser local, e realizando as menores taxas de lucro; terceiro, as empresas médias, cujo capital segue um ciclo que é, quando muito, nacional, e realizando uma taxa intermediária de lucro (Granou, 1974, pp. 7-62).

John Kenneth Galbraith $(1967,1982)$ enfatiza a utilização de recursos informacionais pelas empresas. Segundo Galbraith, o desenvolvimento técnico fez com que as atividades econômicas digam respeito a um número muito maior de matérias e problemas. Assim, as empresas precisam dispor de um grupo, tão numeroso quanto possível, de especialistas capazes de abarcar toda a complexidade da economia. Esse grupo constitui a tecnoestrutura ${ }^{7}$. Dentro desse novo estado industrial, as empresas conhecem uma nova hierarquização. Galbraith não explora a fundo este ponto, mas, do que ele diz, é possível concluir que a economia se divide em três partes: "o mundo de milhares de pequenos proprietários tradicionais"; segundo, "o mundo das empresas tecnicamente dinâmicas, maciçamente capitalizadas e altamente organizadas" (Galbraith, 1967, 1982, p. 19); terceiro,

\footnotetext{
${ }^{3}$ Nos anos 1930, Joan Robinson e E. H. Chamberlin propõem a idéia de que as teorias do equilíbrio econômico eram falhas pois a competição capitalista é imperfeita e monopolista. A idéia de capitalismo monopolista é desenvolvida por Michal Kalecki nos anos 1940, por Josef Steindl nos anos 1950, por Baran e Sweezy nos anos 1960.

${ }^{4}$ Em comparação com o grande capital, o capital médio se define pelas seguintes características: menor participação do capital constante em relação ao capital variável; ausência de uma capacidade de autofinanciamento; ação num só ramo industrial, concentrando-se em poucos produtos; menores taxas de lucro; ação nos setores econômicos menos rentáveis; custos de produção mais elevados; associação entre controle do processo produtivo e propriedade dos meios de produção (Poulantzas, 1974, pp. 99-204).

5 “[...] de fato, o capitalismo concorrencial (capital não monopolista) se reproduz constantemente, ainda que de maneira dependente, sob o capitalismo monopolista e suas diversas fases” (Poulantzas, 1974, p. 139).

${ }^{6}$ Jean Lojkine desenvolve uma análise parecida, falando em camadas intermediárias do capital. "Não é por uma espécie de incapacidade teórica que se emprega, a respeito do conjunto das camadas não monopolistas, a expressão camadas intermediárias, mas sim para traduzir cientificamente o fato atual de que essas camadas não se reproduzem mais de forma autônoma, como as frações industriais, comerciais ou bancárias do estágio concorrencial [...]” (Lojkine, 1981, p. 111).

7 "O poder, na realidade, passou para aquilo que qualquer pessoa em busca de novidades consideraria justificado em chamar de novo fator de produção. É a associação de homens de diversos conhecimentos técnicos, experiência ou outro talento que a tecnologia moderna e o planejamento requerem [...] É da eficiência dessa organização, com o que a maioria das doutrinas econômicas concorda, que depende hoje o êxito da empresa
} 
as empresas modernamente organizadas, mas cujas tecnoestruturas não chegam a ser totalmente independente, precisando recorrer a informações e auxílios exteriores, como a indústria de consultoria de administração (idem, pp. 132-137).

David Vallat (2002) busca, por assim dizer, um olhar desde baixo, mais preocupado com as questões de exclusão social. A economia é pensada como um lugar de socialização, ou seja, uma instância em que os indivíduos, adquirindo uma função, podem ver-se ligados a outros indivíduos e à sociedade. Formam-se três estágios, ou três andares, econômicos. O térreo seria constituído pela "civilização de mercado", reunindo a economia doméstica, a economia informal, o trabalho autônomo, regidos pelas relações pessoais, pela lógica da proximidade e, por vezes, pelas trocas não-monetárias; trata-se da "infraeconomia", conceito cunhado por Fernand Braudel, e desenvolvido por Vallat. O segundo andar reuniria as atividades propriamente capitalistas, os monopólios, os oligopólios; trata-se de um estágio dominado pelas empresas multinacionais, cuja principal força é o acesso às informações. $O$ primeiro andar reuniria a "economia de mercado", ou seja, um estágio no qual a concorrência realiza-se de maneira mais aberta; aqui vamos encontrar as pequenas e médias empresas (Vallat, 2002).

A interpretação que nós propomos, com base na teoria de Milton Santos sobre os dois circuitos da economia urbana, possui um caráter eminentemente geográfico. Com isso, pretendemos apontar para três elementos fundamentais. Primeiramente, estamos interessados em captar as dinâmicas espaciais, e não tanto em proceder a classificações de empresas. Segundamente, buscamos, desde o princípio, um enfoque histórico, para desse modo fugir a categorias e interpretações gerais ou abstratas. Por fim, estamos interessados em situações concretas, em cidades particulares, que existem numa formação socioespacial igualmente peculiar.

Para que não fiquemos amarrados aos casos das empresas, estamos propondo captá-las como sistemas organizacionais, ou seja, como conjuntos de ações que se realizam em torno de certas normas jurídicas, técnicas, financeiras, informacionais. Para os agentes com menos recursos, a montagem de sistemas organizacionais consiste numa verdadeira atividade inventiva, pois é necessário superar as carências e deficiências, encontrar os interstícios por onde as ações possam realizar-se. Com certeza, essa atividade encontra-se profundamente limitada, controlada, uma vez que há regras de ação que não podem ser infligidas: o funcionamento das técnicas, as imposições da lei, as densidades espaciais, em suma o território, ele próprio uma norma. Mas, por outro lado, a nova natureza das técnicas, mais doces, e o fato de que a política se realiza, hoje, sobretudo nos lugares, alargam as escalas de possibilidade, sobretudo para os agentes hegemonizados.

moderna [...] Criar uma organização desse tipo para executar uma nova tarefa é um empreendimento difícil, dispendioso e incerto" (Galbraith, 1967, 1982, p.55). 
VII

Os sistemas organizacionais

A idéia de organização

A partir de agora, analisamos especificamente a situação dos pequenos laboratórios farmacêuticos nacionais. Talvez, pudéssemos começar por dizer quantos são, mas, se não o fazemos, isso se deve a duas razões.

Primeiro, não se pode chegar a um número conclusivo, uma vez que as várias fontes, e mesmo as oficiais, são divergentes. O problema já vem de longo tempo, e começa pelas próprias contagens feitas pelo IBGE. Nos censos de 1940 e 1950, o IBGE valeu-se da mesma classificação industrial ${ }^{8}$. Com tal classificação temos, para 1940, 1610 estabelecimentos químicos e farmacêuticos, e, para 1950, 2 672, estabelecimentos. Não se tem, assim, uma boa idéia da produção de medicamentos, pois ela ficou misturada à classe dos produtos químicos, muito diferente. O censo de 1980, com uma classificação bastante profícua para fins de análise ${ }^{9}$, fala na existência de 455 estabelecimentos de produtos farmacêuticos e veterinários. Mas o censo de 1985 muda a forma de contagem, dizendo haver, para o ano de 1980, 1122 estabelecimentos de produtos farmacêuticos e veterinários, e, para o ano de 1985, 930 estabelecimentos.

O IBGE volta a valer-se de uma classificação que nos seria útil na Pesquisa Industrial de 1995. Em verdade, é a mesma classificação do censo de 1980, ou seja, aquela que foi elaborada pelo Departamento de Contas Nacionais. Mas a Pesquisa Industrial de 1996 abandona esses critérios e passa a valer-se da CNAE, Classificação Nacional de Atividades Econômicas ${ }^{10}$. Os dados apresentados são inviáveis, para nossos fins, pois a produção de medicamentos fica misturada com a indústria de equipamentos médicos, o que superestima a contagem ${ }^{11}$.

\footnotetext{
${ }^{8}$ A classe "Química e farmacêutica” envolve: “Fabricação de produtos químicos”, "Fabricação de pigmentos, corantes, substâncias tanantes e mordentes", "Fabricação de artigos de perfumaria, sabões e velas" e "Fabricação de sabão".

${ }^{9}$ A classificação do censo de 1980 foi elaborada pelo Departamento de Contas Nacionais. O nível 20 denomina-se "Fabricação de Produtos Farmacêuticos e de Perfumaria"; ele inclui dois subníveis: "Indústria farmacêutica" e "Indústria de perfumaria, sabões e velas". Os dados apresentam os dois subníveis separados, ou seja, a indústria farmacêutica aparece de maneira pura.

${ }^{10}$ Na divisão 24 aparece a "Fabricação de Produtos Químicos"; no grupo 24.5 está a "Fabricação de produtos farmacêuticos", envolvendo quatro classes: "Fabricação de produtos farmoquímicos", "Fabricação de medicamentos para uso humano", "Fabricação de medicamentos para uso veterinário" e "Fabricação de materiais para usos médicos, hospitalares e odontológicos".

${ }^{11}$ Segundo a Pesquisa Industrial de 1995, havia 319 empresas na indústria farmacêutica (e este é o último dado utilizável do IBGE). Segundo a Pesquisa Industrial de 1996, havia 711 empresas na fabricação de produtos farmacêuticos, número claramente superestimado.
} 
Outras instituições apresentam contagens improváveis, inverossímeis por vezes. Segundo a Alanac, Associação dos Laboratórios Farmacêuticos Nacionais, havia, em 1998, cerca de 350 laboratórios farmacêuticos no Brasil, o que nos parece bastante razoável. Em 2000, a Anvisa informou à CPI dos medicamentos a existência de 628 laboratórios. Em 2002, a mesma Anvisa indica um número de 1088 empresas, entre laboratórios farmacêuticos e importadoras de medicamentos (Pereira, 2002, p. 12). Há, para 2004, dados razoáveis do IMS Health, empresa internacional de auditoria: "Segundo informações da Federação Brasileira da Indústria Farmacêutica (Febrafarma), o IMS Health identificou um total de 551 laboratórios no Brasil [...]" (Capanema e Palmeira Filho, 2004, p. 28) ${ }^{12}$.

Existe porém um segundo aspecto que nos desvia da procura do número preciso de laboratórios existentes no Brasil. Mais do que saber a quantidade exata, importa-nos, aqui, saber interpretar o papel desempenhado por esses agentes na formação socioespacial.

A idéia principal é que, entre os pequenos laboratórios e as corporações multinacionais, as diferenças não são, mais uma vez, puramente quantitativas. Trata-se, antes, de possibilidades particulares de uso do território. Por outro lado, é preciso fugir ao risco de uma incomensurabilidade, ou seja, o risco de concluir que, sendo assim, não há qualquer espécie possível de comparação entre os agentes hegemônicos e os marginais. Para dar conta, ao mesmo tempo, das diferenças e da necessidade de uma visão totalizante do território, vamos recorrer à idéia de organização.

Em Olin Wright, a organização é definida como um bem que se usa no processo de produção. Nesses termos, tem o mesmo estatuto que os meios de produção ou as qualificações (Wright, 1989, pp. 14-22) ${ }^{13}$. Apesar de essa interpretação realizar o importante avanço de separar a organização dos meios de produção das qualificações, parece-nos que se chega, com ela, a uma definição ainda acanhada. Aliás, é a visão mais disseminada, ou seja, a organização vista como o ato de reger a divisão do trabalho produtivo. Em geografia, essa definição corrediça de organização aparece, por exemplo, em Doreen Massey, que fala na "organização espacial da produção". Aliás, Massey chega a citar Olin Wright (Massey, 1984, 1987, pp. 70-82). Nesse sentido, a organização é a atividade de concepção e controle

\footnotetext{
${ }^{12}$ Essas dificuldades de contagem se repetem quando se verificam os dados referentes às unidades da federação. Em 2001, o Conselho Regional de Farmácia do Paraná registrava 33 laboratórios farmacêuticos no estado; a Vigilância Sanitária do Paraná registrava 34. Apesar da pequena diferença, cotejando a lista das duas instituições, apenas 12 firmas coincidiam (Fonte, 2004, 64). Em 2002, havia 34 laboratórios farmacêuticos cadastrados na Secretaria de Saúde do Estado do Rio Grande do Sul, e 48 no Conselho Regional de Farmácia; o IBGE indicava 82 unidades farmacêuticas; e a Federação das Indústrias do Estado do Rio Grande do Sul indicava 38 empresas (Pereira, 2002, pp 38-39). "Esta diferença ocorre devido aos diversos critérios de cadastramento" (idem, p. 38)

13 "A atividade de uso desse bem é a tomada de decisão coordenada sobre uma divisão do trabalho complexo" (Wright, 1989, pp. 14-22p. 17).
} 
de uma divisão territorial do trabalho produtivo, o que envolve não só a produção propriamente dita, mas também a de gestão e a pesquisa ${ }^{14}$.

Em nosso sistema de idéias, buscamos uma definição mais ancha da organização. Esta se definiria, então, pelo conjunto de normas (técnicas, jurídicas, financeiras, informacionais) que funcionam por ocasião de uma atividade econômica ${ }^{15}$. Ora, é justamente a montagem desse conjunto coeso de normas que vai definir os diferentes sistemas organizacionais, conceito que nos vem de María Laura Silveira: "O sistema técnico é sobretudo organizacional, porque o arranjo dos novos objetos técnicos para a produção e circulação não se faz sem normas. Enquanto, no período anterior, a continuidade na fabricação era sobretudo técnica, hoje a busca de um processo ininterrupto tem bases organizacionais e normativas" (Silveira, 1996, 1999, p. 292).

Se pensarmos, com Jacques Ellul, que a norma é um instrumento para conduzir o sistema e forçar uma certa relação entre seus elementos (Ellul, 1954, 1964), então os próprios objetos técnicos representam normas, na medida em que são revestidos de rígidas intencionalidades, hipertelias. Num espaço cujas divisões se intensificam, as operações normativas são convocadas para manter as coerências dos sistemas hegemônicos ${ }^{16}$.

Os vários empreendimentos, realizando uma seleta mais ou menos poderosa de normas, desencadeiam verdadeiros fenômenos espaciais. Assim, ultrapassamos a visão das empresas individuais, para chegarmos às dinâmicas do território.

Hoje, a concentração da produção de normas vai junto com as centralizações do capitalismo. Nas produções de medicamentos, os agentes hegemônicos vêem suas escalas de possibilidade ampliadas, por três fatores principais. Primeiramente, os laboratórios multinacionais expandem seus círculos de cooperação, pois que passam a ter contato com um grupo sempre mais diversificado de agentes: universidades, bancos, empresas de consultoria, empresas de biotecnologia. Segundamente, amplificam-se suas escalas de ação, pois que novas atividades vão assolar diversos países, o que típico para as pesquisas clínicas. Por fim, os novos avanços técnico-científicos, notadamente no campo da biotecnologia, permitem que se façam escolhas mais amplas: doenças a pesquisar, técnicas a utilizar, informações a consumir, agentes a contatar. Assim, o circuito superior reafirma sua vocação global. Paralelamente, porém, correm três fenômenos.

\footnotetext{
14 “[...] não apenas há uma divisão técnica do trabalho na produção, como também seus diferentes estágios são confiados a diferentes regiões. Demais, da mesma forma como a divisão do trabalho entre diferentes trabalhadores pode incrementar a produtividade e conseqüentemente o lucro, assim também o pode sua divisão entre as regiões, permitindo aos diferentes estágios de produção que respondam mais exatamente a seus fatores de localização específicos” (Massey, 1984, 1987, p. 74).

${ }^{15}$ A importância do fenômeno organizacional começa a crescer dentro do próprio circuito superior, quando o chamado toyotismo mostra que outros arranjos produtivos eram possíveis a partir dos mesmos objetos.

16 “É por meio da elaboração de um sistema de regras dinâmicas que se mantém a centralidade da organização e, conseqüentemente, o poder da direção central. Esta define assim as modalidades de funcionamento do conjunto e é com referência nos seus princípios de base que se tomam as decisões” (Pagès, 1978, 1984, p. 52).
} 
Primeiro, as diversas formas de seletividade capitalista geram diversas formas de pobreza, requerendo a produção de uma economia que lhe seja concernente. Karl Marx já tinha prevenido que, no capitalismo, a acumulação da riqueza implica, necessariamente, uma acumulação paralela de pobreza e miséria (Marx, 1950, pp. 126-137) ${ }^{17}$. María Laura Silveira diz que a cidade não cresce apenas pelo acúmulo de riqueza, mas, sobretudo, de pobreza (Silveira, 2004, p. 60) ${ }^{18}$.

Segundo, surgem técnicas mais doces, mais maleáveis, que podem ser mobilizadas em vários contextos locais. Segundo Hoover, os fatores de produção podem facilitar ou dificultar os ajustes promovidos pelas empresas; um dos aspectos que facilitam esses ajustes é a "adaptabilidade a outros usos" (Hoover, 1948, 1951, pp. 170-171). Hoje as novas tecnologias disponíveis, por exemplo as novas tecnologias informacionais, tornam-se adaptáveis a vários usos, em vários ritmos. "Além disso, a base técnica da indústria farmacêutica caracteriza-se pelo emprego de plantas de escalas médias ou pequenas - em comparação com outras indústrias -, o que facilita os investimentos bem como sua renovação [...]" (Gadelha, 1990, p. 119) ${ }^{19}$.

Em terceiro lugar, o território vai ganhando em fluidez, ou seja, permite fluxos mais rápidos, materiais como não materiais. Tal circunstância realiza-se pode ser também aproveitada pelos agentes marginais.

Esses três fatores favorecem a emersão, nas produções farmacêuticas, de um circuito superior marginal. Isso quer dizer a formação de sistemas organizacionais peculiares e, em grande medida, híbridos. Em linhas gerais, pode-se dizer que suas características precípuas são o emprego simultâneo de normas globais e técnicas locais; o uso de objetos técnicos menos sofisticados; o acesso menos fácil às normas financeiras. Em tais circunstâncias, o superior marginal aparece como um mediador entre a economia mundial e a economia local. Nele, convivem os efeitos de um alargamento dos contextos e de uma lugarização das ações.

\section{Alargamento dos contextos}

Segundo Milton Santos, as modernizações conduzem a um alargamento dos contextos, ou seja, as ações humanas passam a ser cada vez mais influenciadas por

\footnotetext{
17 "A difusão espacial do circuito superior também significa a difusão do empobrecimento" (Santos, 1979, 2004, p. 369).

18 “[...] a grande cidade, mais do que antes, é um pólo da pobreza (a periferia no pólo...), o lugar com mais força e capacidade de atrair e manter gente pobre, ainda que muitas vezes em condições sub-humanas” (Santos, 1993, 2005a, p. 110). Ver também Santos, 1979, 2003, p. 82 e Santos, 1989, 2005, p. 128.

${ }^{19}$ Hoover diz que as grandes fábricas tendem a ser mais rígidas, menos flexíveis. Isso acontece quando, em função de sua organização em várias seções, a fábrica possui máquinas e operários cuja orientação não pode ser rapidamente alterada junto com as mudanças do mercado (Hoover, 1948, 1951, pp. 95-96).
} 
fenômenos e interesses gerados em escalas mais amplas que o lugar onde elas se realizam concretamente (Milton Santos, 1996, 2002, p. 254-255) ${ }^{20}$. "De um lado, a divisão do trabalho se amplia abrangendo muitos mais espaços, e, de outro lado, ela se aprofunda interessando a um número maior de pontos, de lugares, de pessoas e de empresas em todos os países. $\mathrm{Na}$ medida em que se multiplicam as interdependências e cresce o número de atores envolvidos no processo, podemos dizer que não apenas se alarga a dimensão dos contextos como aumenta a sua espessura" (Santos, 1996, 2002, p. 254).

Como vimos nos capítulos anteriores, a pesquisa e a produção farmacêuticas de base concentrou-se nos países centrais. No Brasil, isso fica expresso pela redução das atividades farmoquímicas, ou seja, as atividades de produção das matérias-primas farmacêuticas. "O investimento na indústria de fármacos [no Brasil] foi cerca de dez vezes inferior ao da indústria de medicamentos, se comparados dados de 1999" (Magalhães et alii, 2003, p. 19). Ao mesmo tempo, as empresas nacionais ficam mais dependentes de equipamentos produzidos no exterior. Magalhães e colaboradores dizem que as empresas nacionais "de grande e médio porte" são obrigadas a importar mais máquinas e equipamentos estrangeiros (Magalhães et alii, 2003, p. 21).

A importação de fármacos se expande mais do que as exportações ${ }^{21}$. "Se em 1987 a produção [de farmoquímicos] atendia pelo menos $60 \%$ do mercado, no final dos anos 90 não atinge sequer 20\% [...] Como dos US\$ 500 milhões produzidos, algo como US\$ 200 milhões são destinados a exportações, deduz-se que o auto-abastecimento está na casa dos 18\%" (Queiroz e González, 2001, p. 135) ${ }^{22}$. Os laboratórios nacionais são os que mais padecem dessa dependência em relação aos fármacos, pois se produzem rupturas em seus circuitos espaciais de produção. As poucas empresas nacionais que produzem fármacos ${ }^{23}$ não podem suavizar a situação dos laboratórios farmacêuticos nacionais. As farmoquímicas

\footnotetext{
20 “O 'habitat dos homens' já não se restringe ao espaço pequeno no qual se dava, antes, a produção e o consumo" (Santos, 2002, p. 210).

${ }^{21}$ O déficit comercial em farmoquímicos foi de US\$ 1,25 bilhão em 1999; US\$ 1,17 bilhão em 2000; US\$ 1,25 bilhão em 2001; US\$ 1,23 bilhão em 2002 (Abiquif, Associação Brasileira da Indústria Farmoquímica apud Gazeta Mercantil, 04-12-03, pp. A1 e A11).

$2271,7 \%$ do valor em dólares, referente ao consumo de farmoquímicos no país, em 2000, foi oriundo das importações (Abiquif apud Pereira, 2002, p. 63). Em 2003, 90\% dos fármacos utilizados no Brasil foram importados. Há de seis a oito indústrias farmoquímicas no Brasil (GT\&P Consultoria apud Gazeta Mercantil, 1711-03, p. A3).

${ }^{23}$ Algumas farmoquímicas brasileiras: Labogem, Formil, Nortec, Microbiológica (Queiroz e González, 2001, p. 136). No I Workshop de Fármacos \& Medicamentos, organizado pela Sociedade Brasileira de Farmacologia e realizado na cidade de São Paulo, nos dias 16 e 17 de setembro de 2004, o presidente da Abiquif, citando informações do Ipea, Instituto de Pesquisa Econômica Aplicada, disse haver no Brasil 49 empresas produtoras de princípios ativos, fabricando um total de 351 produtos.
} 
estrangeiras, detendo produções mais sofisticadas e diversificadas, controlam o mercado brasileiro ${ }^{24}$.

Para os medicamentos prontos, o movimento é parecido ${ }^{25}$. Ao longo da década de 1990, as importações brasileiras de medicamentos aumentaram 1400\% (Gazeta Mercantil apud Pereira, 2002, p. 14). Como já dissemos, esse fenômeno se deve às especializações produtivas das subsidiárias estrangeiras ${ }^{26}$. Segundo Queiroz e González, outro motivo por que é tão elevado o número de importações é a nova lei de propriedade industrial, que elimina a figura do remédio similar, para os novos produtos; como, na divisão internacional do trabalho contemporânea, ao Brasil cabem as produções mais tradicionais e baratas, vai crescendo a compra de medicamentos modernos e caros (Queiroz e González, 2001, p. 150) $)^{27}$. A adoção da nova lei de patentes vai reforçar o processo, pois, como dissemos no capítulo $\mathrm{V}$, o acordo Trips não obriga o laboratório a produzir no país em que deposita a patente $^{28}$. Nem é por outro motivo que, nas últimas décadas, a produção de medicamentos é uma das atividades cuja balança comercial conhece os déficits mais preocupantes ${ }^{29}$. Em 2003, o Brasil foi o país com maior déficit no setor farmacêutico em todo o mundo (Gazeta Mercantil, 04-06-03, p. A13).

Esses fluxos globais de fármacos e medicamentos são permitidos por um novo conjunto de normas jurídicas regulando as transações internacionais. "[...] as alíquotas de importação para farmoquímicos e medicamentos encontram-se entre $0 \%$ e 14\%, sendo predominante a ausência de alíquota, válidas até 31 de março de 2004 (Resolução no 41 da Camex, de 2003), o que favorece a entrada de produtos importados no país" (Capanema e Palmeira Filho, 2004, p. 33). O consumo de medicamentos pode ser expandido sem que exista uma necessária expansão das atividades produtivas no território. Para Capanema e Palmeira Filho, a expansão na demanda por medicamentos e o déficit na balança comercial

\footnotetext{
24 “No ano passado [2002], dos US\$ 5,2 bilhões de faturamento do setor [farmoquímico], 70\% das vendas internas foram feitas por laboratórios estrangeiros, em minoria no Brasil - não chegam a representar 25\% do número de laboratórios que operam por aqui” (Gazeta Mercantil, 04-12-03, pp. A1 e A11).

${ }^{25}$ De 1989 a 1996, 21 novos medicamentos surgiram na pauta de exportações, acrescentando US\$ 24 milhões às exportações; no mesmo período, 42 novos medicamentos foram importados, ou seja, o dobro de itens; entanto, eles acescentaram US\$ 239 milhões ao valor das importações, ou seja, 10 vezes mais que o valor acrescentado às exportações (Queiroz e González, 2001, p. 153).

26 "A tendência das grandes empresas em realocar suas atividades produtivas em plantas especializadas resulta no aumento das importações pelas multinacionais, especialmente as de alto conteúdo tecnológico" (Pereira, 2002, p. 14).

27 "Para dar um exemplo a Pfizer fabrica o Viagra em uma única planta que abastece o mundo todo" (Queiroz e González, 2001, p. 150).

28 "O fortalecimento e/ou introdução das patentes, sem a obrigação de exploração industrial da invenção no país onde foi registrada, deve levar a variações nos fluxos de comércio, gerando ou estimulando déficits comerciais nas contas externas, como resultado de um aumento tanto no volume quanto nos termos de intercâmbio dos produtos importados [...] Com efeito, é possível que a produção local em países subdesenvolvidos seja substituída progressivamente pela importação de produtos finais e semi-elaborados” (Oliveira, R. 1999, p. 55).

29 "Entre 1993 e 1999, a taxa média de incremento das importações brasileiras de fármacos e remédios foi de 36,6\% ao ano, e a das exportações, de 24,6\%. O déficit comercial aumentou 7,5 vezes, de US\$ 171 milhões em 1993 para US\$ 1,28 bilhão em 1999” (Gazeta Mercantil, 10-07-03, p. A14).
} 
são índices do "claro movimento de desindustrialização pelo qual vem passando o setor" (Capanema e Palmeira Filho, 2004, p. 34).

Os vetores da globalização promovem concentrações na escala global. Com isso, as atividades que se desempenham nos lugares, para se realizar, passam a necessitar, forçosamente, de relações e contatos mais amplos. Noutras palavras, as próprias transformações geradas no circuito superior impelem o superior marginal a uma expansão de seus horizontes. Na produção de medicamentos, os pequenos laboratórios devem recorrer a fornecedores estrangeiros, de maneira direta ou mediatizada por outros agentes nacionais. Ao mesmo tempo, a maior fluidez territorial permite que suas produções alcancem mercados mais amplos ${ }^{30}$.

O alargamento dos contextos vai definir, com certeza, maiores dependências em relação a recursos controlados por agentes estrangeiros ${ }^{31}$. Por outro lado, porém, 0 processo vai alargar as escalas de possibilidades dos agentes marginais. Pois que eles, agora mais habituados a procurar princípios ativos estrangeiros, aprendem a lidar com as possibilidades oferecidas pelo mercado internacional. $O$ fenômeno ganha força principalmente em função do surgimento de empresas farmoquímicas situadas fora do eixo hegemônico de produção. É dessa forma que assistimos ao nascimento de importantes produtores de matérias-primas na China e na Índia, um evento que marca o período contemporâneo. Até o período precedente, os Estados Unidos e a Europa dominavam por completo o fornecimento de princípios ativos.

A situação da Índia é exemplar. O país aderiu ao acordo Trips em 1994, mas obteve um período de 10 anos de transição. Assim, começa a reconhecer patentes para medicamentos apenas em 2004 (Barros, 2001, p. 87). Com isso, as normas globais se instalam no território indiano de maneira defasada, o que permite a formação de fortes produtores de princípios ativos e de medicamentos. Esses agentes chegam a comprar importantes marcas de medicamentos. Mais ainda, as empresas indianas começam a comprar outros laboratórios, nos Estados Unidos e noutros países ${ }^{32}$.

Índia e China desenvolvem, de maneira parecida, suas produções farmoquímicas e farmacêuticas. Apesar da perseguição que os países mais ricos empreendem a essas novas produções, acusando-as de pirataria ou de baixa qualidade, trata-se de uma atividade já bastante consolidada. A partir disso, o território brasileiro pode participar de outras espécies

\footnotetext{
30 Segundo Maria Aparecida Pereira, 62\% dos laboratórios gaúchos, em 1992, destinavam suas vendas exclusivamente ao próprio estado; em 2001, essa proporção descende a 3,57\% (Pereira, 2002, pp. 98-99).

${ }^{31}$ De acordo com Paulo Elias, há, por exemplo, “[...] uma lógica de financiamento que privilegia a assistência mais sofisticada, que demanda procedimentos que utilizam tecnologia de última geração, em detrimento da mais simples" (Elias, 1996, p. 103).

${ }^{32}$ Foi assim que o Dr. Reddy's Laboratoires, segundo maior laboratório farmacêutico da Índia, comprou em 2004 a Trigenesis Therapeutics, nos Estados Unidos; no mesmo ano, a Ranbaxy, primeiro laboratório indiano, adquiriu a divisão de genéricos da Aventis (França) (Gazeta Mercantil, 10-08-04, p. A13).
} 
de integração produtiva, o que é reforçado pelo fato de que, não raro, as matérias-primas chinesas e indianas apresentam menores preços. Assim, o circuito superior marginal tem sua existência reforçada.

Apesar das polêmicas por vezes provocadas por essas importações, podemos dizer que elas ainda representam pequenas proporções das importações brasileiras ${ }^{33}$. Mesmo assim, o fenômeno já altera as dinâmicas de muita empresa dedicada às atividades farmacêuticas ${ }^{34}$. O processo toca também aos laboratórios estatais, sobretudo porque, em face de suas condições financeiras nem sempre folgadas, as economias permitidas por esses fármacos tornam-se vitais. Sabe-se que, em 2004, 85\% das matérias-primas adquiridas pelos laboratórios oficiais provinham da China e da Índia (Gazeta Mercantil, 2408-04, p. A11).

Os pequenos laboratórios particulares nacionais precisam realizar as mesmas economias. O Ágape (Ananindeua-PA) vale-se de princípios ativos da Índia, China e Taiwan. Para o Madrevita (Fortaleza-CE), muitas matérias-primas são importadas, sobretudo da China e da Índia.

A dependência tecnológica e científica se acirra, mas agora em novas bases, menos rígidas. O mundo continua sendo permeado por uma lógica técnica totalizadora. Mas essa totalização tem suas condições alteradas, já que as operações individuais encontram novas formas e modelos de integração. "Quando falamos em unicidade técnica, estamos referindo a existência de uma só hierarquia técnica, e não de uma só forma de produzir" (Santos, 1996, 2004, p. 193).

O que é interessante ressaltar é que esse alargamento dos contextos, que vai permitir novas maleabilidades espaciais, é possível, em grande medida, pela existência da metrópole nacional que, rigidamente, centraliza diversas atividades estratégicas.

Primeiramente, é em São Paulo que se vai alojar a maioria das empresas importadoras de fármacos, assim permitindo que os pequenos laboratórios tenham acesso a tais produtos. O Isofarma (Eusébio-CE), vale-se de matérias-primas adquiridas em São Paulo, junto a produtores farmoquímicos e importadores. O Farmácia-Escola (Fortaleza-CE), laboratório oficial do estado do Ceará, adquire a maioria das matérias-primas sintéticas em São Paulo ${ }^{35}$.

É interessante a situação da Fraccionata (Porto Alegre-RS), uma pequena distribuidora de princípios ativos para medicamentos, produtos veterinários e cosméticos,

\footnotetext{
${ }^{33} \mathrm{Em}$ 1998, os produtos farmoquímicos chineses representaram 5,4\% das importações brasileiras; os indianos, 2,6\% (Secex apud Queiroz e González, 2001, p. 147).

${ }^{34}$ A SP Farma, distribuidora de matérias-primas sediada na cidade de São Paulo, importa $90 \%$ dos produtos que distribui; desses produtos importados, 90\% provêm da China e da Índia (Gazeta Mercantil, 10-08-04, p. A13).

${ }^{35}$ Embora isto seja raro, alguns laboratórios fazem importações diretas. O Halex Istar (Goiânia-GO) sempre faz importações diretas de matérias-primas. O Quimsul (Porto Alegre-RS) utiliza, sobretudo, princípios ativos de origem nacional; uma pequena proporção dos fármacos utilizados é, todavia, diretamente importada.
} 
fundada em 1994. Assim como todas as importadoras, a Fraccionata se dedica a três atividades principais: compra, fracionamento e revenda de princípios ativos. Ocorre que todos os seus fornecedores estão em São Paulo. A distribuição se faz apenas no Rio Grande do Sul. A exceção é o Lafesc, Laboratório Farmacêutico do Estado de Santa Catarina, um laboratório oficial, único cliente que a empresa possui fora do Rio Grande do Sul. A empresa Francisco Eudes (Fortaleza-CE), vive uma situação parecida. Entre os princípios ativos que distribui, alguns são produzidos em países estrangeiros, como Índia, China, Argentina, Itália, Alemanha. Porém, a empresa não faz importação direta: adquire os produtos junto a importadores situados em São Paulo.

O estado de São Paulo também reúne a maioria dos produtores de equipamentos para a indústria farmacêutica. Em verdade, essa produção de equipamentos chega atualmente a graus elevados de sofisticação, sendo já possível montar um laboratório farmacêutico relativamente moderno apenas com máquinas produzidas em território brasileiro $^{36}$. Para as menores empresas, tal possibilidade se faz essencial ${ }^{37}$.

Se consideramos os medicamentos fitoterápicos, tão importantes para os pequenos laboratórios, o papel do estado de São Paulo não é menos central. Ali estão situados não apenas fornecedores de plantas in natura, como também agentes que realizam um primeiro beneficiamento dos produtos, e, além disso, empresas que, a partir das plantas, produzem extratos, largamente usados por laboratórios farmacêuticos ${ }^{38}$.

O laboratório Wesp (Rio Grande do Sul-SP) adquire em São Paulo os extratos das plantas; segundo os farmacêuticos, há fornecedores de plantas no sul do país, mas eles as vendem a empresas de São Paulo, que então produzem os extratos e os distribuem para todo o Brasil $^{39}$. O Panizza (Taboão da Serra-SP), especializado em fitoterápicos, utiliza principalmente plantas nativas do Brasil, mas também algumas plantas chinesas, japonesas,

${ }^{36}$ O laboratório Anchieta (Goiânia-GO) dispõe de máquina rotuladora, seladora, de envase; são máquinas nacionais adquiridas junto a indústrias de São Paulo; apenas o setor de análises microbiológicas tem máquinas importadas, também adquiridas em São Paulo. O GeoLab, segundo sua farmacêutica, é um laboratório bastante modernizado, em matéria do fluxo da produção e dos equipamentos; estes foram adquiridos junto a representantes situados na cidade de São Paulo.

${ }^{37}$ Em 1996, no estado de São Paulo, os menores laboratórios (0 a 99 empregados) dedicaram a maior parte de seus investimentos $(40,0 \%)$ à aquisição de máquinas e equipamentos nacionais; em matéria da parcela dos investimentos dedicada à compra de máquinas e equipamentos nacionais, eles ficam em primeiro lugar, vindo em segundo os laboratórios nacionais contando com 100 a 499 empregados (39,9\% dos investimentos) e em terceiro lugar os laboratórios estrangeiros com 100 ou mais empregados (33,2\%) (Paep apud Magalhães et alii, 2003, p. 22).

${ }^{38}$ A Galena Química e Farmacêutica, fundada em 1987, com sede em Campinas (SP), produz, fraciona e distribui insumos para o mercado fitoterápico, químico e de manipulação; a empresa tem parcerias internacionais, como: Wolff Cellulosics, empresa ligada à Bayer (Alemanha); Symrise (Alemanha); Interchemical (China); Bioton (Estados Unidos); Vevy (Itália) (Gazeta Mercantil, 09-08-04, p. A15). A SP Farma é uma distribuidora nacional e fracionadora de matérias-primas para laboratórios farmacêuticos, indústrias de cosméticos, bionutrientes, produtos veterinários, fitoterápicos e produtos de manipulação; foi fundada em 1991, com sede na cidade de São Paulo (SP) (Gazeta Mercantil, 10-08-04, p. A13).

${ }^{39}$ Nilce Fonte afirma que tal mecanismo é comum no Paraná (Fonte, 2004, p. 69). 
européias; todas essas plantas são obtidas junto a importadores e fornecedores situados na cidade de São Paulo.

Essas pequenas empresas devem, pois, travar relações que transcendem a escala local $^{40}$. São tecnologias mais ou menos sofisticadas, não raro importadas, a que elas podem acessar graças à existência da metrópole nacional, em que se produzem essas tecnologias, ou por meio da qual se internalizam as modernizações exteriores. Em São Paulo, a intersecção de circuitos espaciais de produção vai reforçar o circuito superior marginal.

\section{O superior marginal e os fluxos de medicamentos}

Os contextos se alargam, mas, de maneira complementar, o circuito superior marginal precisa refugiar-se, ancorar-se, no lugar. Pois se, de um lado, as tendências gerais do território reclamam relações mais expandidas, as limitações de capital forçam, por outro lado, a escalas de ação mais reduzidas. "Assim, frente às possibilidades oferecidas pelo meio geográfico, cada empresa apresentará uma capacidade maior ou menor de usufruí-las. Enquanto grandes empresas buscam a conquista do território como um todo, mas apenas utilizam em alguns pontos os atributos que consideram relevantes, empresas pequenas não podem ter o território como um todo e utilizam integralmente os espaços dos quais depende a sua existência" (Grimm, 2002, p. 145).

Em muitas situações, as relações serão mais viáveis e eficazes se forem travadas em pequenos contextos.

O laboratório Officinalis (Simões Filho-BA), sem conseguir encontrar um bom fornecedor de garrafa plástica, desenvolveu por si mesmo o produto. Desenhou-se e fabricou-se o molde de uma garrafa plástica. Então, repassaram o molde a uma empresa localizada no município de Santo Amaro (BA), nas cercanias de Salvador. Hoje, utilizam-se as garrafas produzidas em Santo Amaro. Trata-se de uma situação bastante rica, na qual, inexistindo os agentes para que se travassem as relações locais, o próprio laboratório se produz um agente local, resolvendo seu problema de maneira criativa. Trata-se de uma produção horizontal de economia, realidade longínqua dos discursos oficiosos que prezam, tantas vezes, a chamada geração de empregos indiretos.

Os fluxos de medicamentos: situação das empresas distribuidoras

Mas, na maioria das situações, as relações locais aparecem de maneira mais espontânea. É o que se pode observar para a distribuição dos medicamentos.

\footnotetext{
40 "São as relações com pontos longínquos que se tornam fundamentais para explicar as novas relações do lugar" (Silveira, 1996, 1999, p. 31).
} 
Em 2000, havia 1500 empresas distribuidoras de medicamentos no Brasil (CPI dos Medicamentos, relatório final). Nesse ano, os atacadistas e distribuidores foram responsáveis por $72 \%$ das entregas de medicamentos no Brasil, atendendo a $98 \%$ das farmácias existentes no país (Gazeta Mercantil apud Pereira, 2002, p. 100). Hoje, tais empresas são cruciais para os laboratórios farmacêuticos, sejam eles grandes ou pequenos. Os distribuidores atacadistas são cruciais para o funcionamento da atividade por conta de suas estruturas logísticas, já que nem as indústrias nem as farmácias podem reter grandes estoques de medicamentos.

Mas, tal como se dá com os laboratórios produtores, as empresas distribuidoras também se organizam num circuito superior, de um lado, e num superior marginal, de outro $^{41}$. Para os maiores distribuidores, vale aquilo que disseram Dupuy e Karsenty: "[...] os comerciantes utilizam os mais modernos métodos de gestão e distribuição automatizados. Seu equipamento informático é notável" (Dupuy e Karsenty, 2003, p. 52). Aqui, reforça-se a idéia de que, além da força produtiva, é crucial a capacidade para gerar fluxos. As farmácias vão procurar o distribuidor que ofereça os menores preços. Ora, são com freqüência os maiores distribuidores que, tendo maiores escalas, podem ofertar os menores preços. Mas existem os medicamentos mais simples, tradicionais, cujo preço é livre de controle, e que formam mercados intersticiais em que os menores distribuidores podem operar.

As grandes empresas distribuidoras nacionais se ajustaram às normas de qualidade e financeiras dos laboratórios multinacionais (prazos de pagamento, volumes de lotes, prazos de entrega, sistemas de crédito). Isso desautoriza, em muitas situações, a integração dos pequenos laboratórios com esses agentes distribuidores de longo alcance ${ }^{42}$.

É certo que as distribuidoras grandes podem operar com produtos de pequenos laboratórios. Entanto, esse fenômeno é, para elas, perfeitamente residual. Elas estão, com efeito, mais ligadas às lógicas dos laboratórios multinacionais, que operam com volumes imensos, em velocidades aceleradas. Desencadeiam-se, no circuito superior, complexos fluxos de medicamentos, que se modificam e reforçam ao sabor das variações estaduais do $\mathrm{ICMS}^{43}$. Os pequenos laboratórios ficam, de certa maneira, desamparados, mesmo porque não dispõem, o mais das vezes, de frotas de veículos para suas distribuições ${ }^{44}$. Tais são as bases do surgimento de pequenas distribuidoras de medicamentos ${ }^{45}$.

\footnotetext{
41 “A circulação é uma das bases de diferenciação geográfica” (Arroyo, 2001, p. 52).

${ }^{42}$ Entre as maiores distribuidoras de medicamentos brasileiras, podemos lembrar: Panarelo (Goiânia-GO), Grupo Majela (Fortaleza-CE), Intermed (Rio de Janeiro-RJ), Santa Cruz (Rio de Janeiro-RJ).

${ }^{43}$ O ICMS é o principal imposto que recai sobre os medicamentos (Gazeta Mercantil, 03-06-03, p. A12).

${ }^{44}$ O fenômeno é antigo. Hoover (1948, 1951, pp. 75-78) já dizia que aos distribuidores grandes interessam os grandes transportes em grandes quantidades, o que os pode levar a desprezar locais intermediários, nos quais, aproveitando-se do baixo custo de transferência, podem surgir distribuidores locais.

${ }^{45}$ No Rio Grande do Sul, em 2001, de 28 laboratórios pesquisados, 26 vendiam seus produtos a distribuidoras; 17 vendiam seus produtos a farmácias (Pereira, 2002, p. 99). Das 28 empresas, 15 utilizavam distribuidoras e farmácias; 6 utilizavam apenas distribuidoras (idem, p. 100).
} 
Em tempos de alargamento dos contextos, pode haver, mesmo assim, agentes incrustados em contextos locais, o que nos mostram certas situações de empresas distribuidoras. A Goiasmed (Goiânia-GO) distribui só em Goiás. A Farmakus (Niterói-RJ) foi fundada em 1994, derivando da farmácia Apolo; a distribuição realizada por ela se restringe ao estado do Rio de Janeiro. Poderíamos dizer que empresas desse tipo, em vez de distribuidoras, são antes concentradoras, pois que adquirem produtos fabricados em diversas nesgas do território, espalhando-os num mercado restrito.

As novas legislações reforçam o fenômeno. Antigamente, uma a autorização de fabricação implicava uma autorização de distribuição. Recentemente, a legislação foi alterada, e a fabricação foi dissociada da produção, limitando-se à transformação industrial propriamente dita. Para cumprir as novas exigências normativas, os laboratórios precisariam, praticamente, manter uma distribuidora dentro do laboratório. Como tal é raramente possível, acontece uma integração local de ações, os pequenos laboratórios travando relações constantes com as pequenas distribuidoras.

Muita vez, esses laboratórios, justamente para fugir aos tempos e relações típicos das maiores empresas, preferem trabalhar exclusivamente com distribuidores pequenos, fechando contratos que têm validade local ou estadual. O Vitapan (Anápolis-GO) selecionou, nalguns estados, distribuidores trabalhando sob regime de exclusividade, como a Total no Ceará e a Delano no Maranhão. O Natulab (Santo Antonio de Jesus-BA), produtor de similares, distribui seus medicamentos apenas por meio de distribuidores de porte pequeno e alcance regional; são 14 distribuidores baianos, localizados em Vitória da Conquista, Jequié, Salvador e Feira de Santana.

Como se disse no capítulo $\mathrm{V}$, a produção de medicamentos genéricos, em função dos vultosos investimentos iniciais, opera sempre nas grandes escalas. Esse expediente, passando à fase da distribuição, vai impedir, muita vez, que os pequenos distribuidores operem com esse tipo de medicamento. Assim, os medicamentos farmacopéicos, os fitoterápicos e os similares tornam-se os alvos preferenciais das pequenas empresas distribuidoras.

Essas relações fortes, que são possíveis no interior do circuito superior marginal, são criadoras de espaço e de racionalidades espaciais. Aqui, as lógicas hegemônicas podem, muita vez, ser desprezada. Com isso, quebram-se barreiras financeiras, jurídicas, territoriais que, para o circuito superior, estão solidamente erigidas. Pontos opacos do território podem acolher sistemáticos fluxos de medicamentos e pequenos capitais. A Buarque (FortalezaCE) realiza a maioria de suas distribuições no estado do Rio Grande do Norte. Um dos principais clientes do laboratório Brasterápica (São Paulo-SP) é a distribuidora Disprofarma, sediada no Maranhão. 
Antigas ligações espaciais, obsolescidas pelos agentes hegemônicos podem ser assim mantidas e revalorizadas. É o que se dá, por exemplo, entre o norte do estado de São Paulo e a região do Triângulo Mineiro ${ }^{46}$. A distribuidora Oriente, com sede em Ipatinga (MG), tem mais duas filiais nesse estado: nas cidades de Uberlândia e Belo Horizonte; a empresa atende o norte do estado de São Paulo a partir da filial de Uberlândia, uma das principais cidades do Triângulo Mineiro. A distribuidora Navarro (São Paulo-SP) atua nos seguintes estados: São Paulo (seu principal mercado), Rio de Janeiro e Minas Gerais; neste último estado, a Navarro atende a região de Belo Horizonte e a região do Triângulo Mineiro.

Os circuitos econômicos realizam-se dentro das cidades, mas também se realizam entre as cidades. As seletividades modernas favorecem a emersão de relações e fluxos novos, encetados por meio de acordos intersticiais. Em Habermas vamos aprender que, na inexistência de normas preestabelecidas para certas relações sociais, a validade das ações deve ser procurada pelos próprios agentes (Habermas, 1981, 1987, p. 309-310).

Os agentes marginais poderão também aproveitar-se indiretamente das infra-estruturas, dos acordos e das normas cuja criação deve atender, sobretudo, aos interesses hegemônicos. Uma fluidez territorial, de origem material ou normativa, pode generalizar-se. Foi assim que, em 2001, um laboratório do Rio Grande do Sul realizava exportações para os países do Mercosul (Pereira, 2002, p. 98).

Num território em que o meio construído varia consideravelmente de uma cidade para outra; em que as diversas legislações nacionais fixam alíquotas particulares para a circulação das mercadorias, é não raro vantajoso contar com uma estrutura localizada de distribuição. É por esse motivo que, por detrás das grandes estruturas das maiores distribuidoras, escondem-se distribuidoras menores. A Santa Cruz, que é um dos maiores distribuidores, tem um centro de distribuição em Brasília. Os medicamentos que são adquiridos, por exemplo, no Rio Grande do Sul, são levados até Brasília, e então redistribuídos para outros estados.

A Intermed (Rio de Janeiro-RJ) é mais um dos grandes distribuidores de medicamentos. Foi fundada em 1964, em Minas Gerais, e hoje tem sede na Barra da Tijuca, no Rio de Janeiro. É um exemplo de expansão que se realiza por meio da aquisição de distribuidoras locais: a Albatroz, que atuava em Minas Gerais; a Faria, no Rio de Janeiro e no Espírito Santo; a Atalaia, na Bahia e em Sergipe; a PG, em Alagoas, Pernambuco, Paraíba e Rio Grande do Norte ${ }^{47}$.

\footnotetext{
46 Ao fim dos anos 1950, Dirceu Lino de Mattos apresentava o Triângulo Mineiro como vasta área “estreitamente ligada à vida paulista” (Mattos, 1958, p. 88).

${ }^{47}$ Além da Viafarma (Maceió-AL) e da Comtac (ambas do mesmo grupo), a Intermed é a única distribuidora de medicamentos atuando nas Alagoas. Essa baixa atividade distribuidora nas Alagoas deve-se ao pequeno potencial de consumo do estado; às precárias condições de circulação oferecidas por boa parte das vias; e à presença decisiva da Intermed, que também tem forte atuação na Bahia.
} 
Desse modo vemos que mesmo as grandes empresas, em face da configuração espacial variada, realizam uma espécie de imitação das pequenas empresas, mantendo centros de distribuição de alcance regional. Seus escritórios nacionais, instalados em lugares de altas densidades informacionais, controlam um sistema baseado em centros regionais de distribuição, cada um deles habituado aos tempos definidos pelo meio construído. Trata-se de uma circunstância interessante para vermos que o circuito superior precisa recorrer, por vezes, a práticas que são típicas do superior marginal. "Nessas condições, é a velha materialidade que dissolve o novo tempo e são os tempos do lugar que dissolvem o tempo do mundo" (Santos, 1996, 2002, p. 236).

Mas, para os agentes marginais, o ancorar-se no lugar não deriva de uma escolha estratégia, sendo, pelo contrário, a única tática possível. Aqui, a idéia de rede fica pouco explicativa, pois já não se trata de um uso de certos pontos selecionados, mas sim de um uso completo, cabal. Todos os elementos locais devem ser considerados, até o ponto em que a própria sina do empreendimento mistura-se com a história do lugar.

Podemos lembrar a situação da Edfarma, pequena distribuidora fundada em 1979 no centro de Fortaleza. Depois da chegada de grandes empresas distribuidoras ao Ceará, sediadas noutros estados, as pequenas distribuidoras que, nos anos 1980, pululavam no centro de Fortaleza, foram desaparecendo. A Edfarma, cuja existência baseava-se na dinâmica oferecida por tal aglomeração, vai definhando ao mesmo tempo em que o lugar se faz letárgico.

Aqui, buscamos ressaltar apenas o papel das pequenas empresas distribuidoras. Para finalizar, poder-se-ia dizer que também as pequenas farmácias apóiam a existência do circuito superior marginal na produção de medicamentos. A proliferação das grandes redes, que reforçam as lógicas do circuito superior, não faz desaparecer de todo os pequenos estabelecimentos comerciais. Em 2003, 78,4\% da comercialização de medicamentos no Brasil se fez nas farmácias independentes, ou seja, não associadas à Abrafarma, Associação Brasileira de Farmácias e Drogarias (Pró-Genéricos apud Gazeta Mercantil, 06/07/08-02-04, p. A14). O desejo controlador, próprio dos agentes hegemônicos, já se volta contra esses agentes intersticiais, que passam a ser associados a formas não racionais, ou mesmo ilícitas, de comercialização ${ }^{48}$. Seja como for, as pequenas farmácias, bem como os pequenos distribuidores, vão ter suas ações integradas às produções farmacêuticas dos pequenos laboratórios, formando um vero circuito superior marginal. Veremos no próximo capítulo que, hoje, outras atividades vêm reforçar essas unificações espaciais marginais.

\footnotetext{
48 Por encomenda da Pró-Genéricos, o Instituto Ipsos Opinion realizou uma pesquisa em farmácias independentes de quatro capitais: São Paulo, Rio de Janeiro, Recife e Curitiba; a pesquisa mostra que, nessas farmácias, os balconistas trocam, ardilosamente, os medicamentos genéricos prescritos por similares (Gazeta Mercantil, 06/07/08-02-04, p. A14).
} 


\section{Um trabalho específico}

O circuito superior marginal, assim que não disponha de recursos modernos, vai recorrer, se as normas jurídicas abrem tal espaço, a formas, objetos, relações e lógicas que, ao menos em aparência, parecem mais atinentes ao circuito inferior49. Nos momentos em que não jogam os efeitos de alargamento dos contextos, vale aquilo que disse Milton Santos: "As atividades do circuito superior marginal parecem-se com as do circuito inferior, uma vez que são criadas em função da demanda regional e não têm um âmbito extraregional" (Santos, 1979, 2003, p. 179). Nesses momentos, e só neles, o circuito superior denota menor repulsa à lentidão, acolhe relações de trabalho menos rígidas, por vezes baseadas em critérios de pessoalidade, tem uma vocação a constituir contextos locais em que as ações marginais, congregadas, sustentam-se mutuamente.

Para os pequenos laboratórios farmacêuticos, apresentam-se formas específicas de trabalho. Gostaríamos, aqui, de apontar sete fatores que particularizam o trabalho próprio desses agentes marginais.

Primeiro, trata-se de um trabalho realizado em menores escalas, e por isso mesmo com pouca divisão geométrica das etapas. Na pesquisa de Maria Aparecida Pereira, constatou-se que, de 28 laboratórios gaúchos, todos possuíam apenas um estabelecimento (Pereira, 2002, p. 39). Em nossa pesquisa de campo, verificamos o mesmo fenômeno, sendo mesmo raro encontrar uma empresa em que estejam dissociadas geometricamente as atividades de produção e gestão.

Segundo, é um trabalho que se desencadeia sob graus relativamente reduzidos de modernização tecnológica, malgrado os constantes esforços de renovação dos equipamentos. No laboratório Ravick (Fortaleza-CE), a maior parte da produção envolve processos manuais; todas as máquinas utilizadas são antigas e foram compradas de outros laboratórios cearenses ${ }^{50}$.

É por causa dessas limitações técnicas que certos laboratórios dão preferência à forma de apresentação líquida ${ }^{51}$, cujo processo de produção é mais simples do que as formas sólida ou semi-sólida ${ }^{52}$. No Rio Grande do Sul, em 2001, de 28 laboratórios, todos

\footnotetext{
${ }^{49}$ Milton Santos (1979, 2004, p. 315) já tinha notado que o superior marginal persiste, malgrado a hegemonia do superior, graças à possibilidade de recorrer, por vezes, às forças produzidas no circuito inferior.

${ }^{50}$ Também o laboratório Pronatus (Manaus-AM) adquiriu a maioria de seus equipamentos de outros laboratórios farmacêuticos.

51 Formas líquidas: soluções, xaropes, emulsões, líquidos envasados, elixires, tinturas, suspensões, xampu. Formas sólidas: pós, comprimidos, cápsulas, sachets, espécies (droga vegetal seccionada, moída ou rasurada), comprimidos revestidos, bastões, granulados. Formas semi-sólidas: pomadas, cremes, sabonetes, pastas, ungüentos e géis, supositórios e óvulos. (Pereira, 2002, pp. 77-78)

52 "A predominância de produtos na forma farmacêutica líquida pode estar relacionada à baixa complexidade tecnológica necessária à sua produção, na qual a maioria dos processos requer operações de simples mistura. Em
} 
tinham formas líquidas, 22 tinham formas sólidas, 15 tinham formas semi-sólidas (Pereira, 2002, p. 76). No laboratório Klein (Porto Alegre-RS), 90\% dos medicamentos são produzidos sob a forma líquida; há também chás e pomadas; a empresa não possui equipamento para produzir comprimidos.

A esta segunda característica, referente aos menores graus tecnológicos dos pequenos laboratórios, podemos incluir a circunstância de que operam, por vezes, em unidades fabris que derivam de adaptações. O laboratório Aclimação (São Paulo-SP), embora disponha de equipamentos bastante modernos, está situado em área residencial, no bairro do Cambuci, operando num sobrado com subsolo. O Ravick (Fortaleza-CE) está instalado num prédio inicialmente feito para ser uma residência; nessas condições, é mais difícil realizar um ciclo de produção contínua, como lhe pede a Anvisa.

Terceiro, essas empresas, por ocuparem postos subalternos do mercado farmacêutico, têm menores possibilidades de previsão e planejamento. Desse modo, suas divisões do trabalho tornam-se, muita vez, produto de improvisações, a partir das injunções que se geram no circuito superior.

A distribuidora Reydrogas (Goiânia-GO) já teve um centro de distribuição em São Paulo, na cidade de São Carlos. Ele foi fechado em janeiro de 2005, após ter funcionado por 4 anos. Por meio dessa unidade, eram atendidos apenas os mercados de São Paulo e Minas Gerais. Como esses estados têm políticas de ICMS protecionistas, não é vantajoso distribuir para eles a partir de outros estados. Assim, por exemplo, a cidade mineira de Uberlândia está bem próxima de Goiânia (GO), mas o ICMS cria uma barreira intransponível para as pequenas distribuidoras. Antes da criação da unidade paulista, a Reydrogas atendia ao mercado mineiro por meio da unidade de Goiânia. Instalado o centro de distribuição de São Carlos, o mercado mineiro passou à sua responsabilidade. Fechado esse centro, a empresa teve que renunciar ao mercado mineiro.

Quarto, existe uma diversificação produtiva extremamente reduzida. O mais das vezes, os medicamentos são a única produção dos laboratórios. Se existe uma diferenciação, ela se restringe a produtos cuja fabricação assemelha-se à dos medicamentos, como os cosméticos ou certos produtos alimentares a partir de plantas. No Rio Grande do Sul, em 2001, entre 28 laboratórios, 15 produziam apenas medicamentos (Pereira, 2002, p. 42) Considerando as 13 empresas com outros tipos de produção, vemos que 11 delas tinham nos medicamentos de 81 a 100\% de seu faturamento (idem, p. 43).

alguns casos, tratava-se de simples operações de envase, denominada também reembalagem [...] Em outros casos a empresa adquire a forma farmacêutica final e somente realiza a etapa de embalagem [...]” (Pereira, 2002, pp. 76-77). 
Quinto, no circuito superior marginal, em comparação com o superior, o fator capital não é tão mais abundante que o fator trabalho53; e o trabalho não material é menos decisivo que o trabalho material. Com isso, existe uma baixa especialização das funções, o que leva à pouca diferenciação dos cargos, e muita vez à mistura de cargos. Com isso, existe uma baixa especialização das funções, o que leva à pouca diferenciação dos cargos, e muita vez à mistura de cargos. O laboratório Anchieta (Goiânia-GO) não contrata serviços jurídicos, pois um dos sócios, sendo advogado, cuida desses assuntos. O Panizza (Taboão da Serra-SP) possui 16 funcionários; desse total, apenas dois funcionários trabalham na administração, sendo que um deles é o próprio farmacêutico, que, além de suas funções técnicas, desempenha funções de gerente geral.

Sexto, em conseqüência do fenômeno anterior, a procura de trabalhadores torna-se menos rígida, podendo obedecer a critérios de pessoalidade, o que aproxima, novamente, o circuito superior marginal do circuito inferior ${ }^{54}$. No laboratório Aclimação (São Paulo-SP), são raras as demissões e contratações, estas realizadas, o mais das vezes, entre conhecidos e familiares dos próprios funcionários. Em vários outros laboratórios tal circunstância persiste mesmo com uma notável difusão dos registros formais, bem como da contratação de serviços terceirizados. Nessa mesma classe de característica podemos incluir o fato de que, muita vez, as empresas são mantidas como empresas familiares. Em verdade, esses empreendimentos estão a meio caminho entre a vera empresa familiar e a vera empresa capitalista. Na distribuidora Francisco Eudes (Fortaleza-CE), trabalham, além do proprietário, mais duas pessoas, e há colaborações esporádicas da esposa e do filho do proprietário. O laboratório Diproquifar (Recife-PE) é também uma empresa familiar, sendo que os dois sócios são casados. O laboratório Fitovida (Uberlândia-MG) é uma empresa familiar que, depois do falecimento do proprietário, passou a ser administrada por sua esposa.

Consideremos, finalmente, uma sétima característica. Agora, queremos chamar atenção para a atividade produtiva propriamente dita, ela que também expressa diferenciações entre os vários laboratórios. Aliás, é justamente em função dessa produção efetiva que todos os demais fatores, técnicos e políticos, mercadológicos e sociais, são diferencialmente organizados e mobilizados pelas empresas, levando a unificações espaciais $^{55}$. No circuito superior, o trabalho produtivo deve obedecer a ritmos e calendários peculiares. Os diversos recursos, financeiros, técnicos, científicos, informacionais, sendo

\footnotetext{
${ }^{53}$ María Laura Silveira (2004, p. 65) diz que, para os agentes hegemônicos, o capital é sempre mais abundante que o trabalho, ao passo que, para a "economia real do país e da cidade", o trabalho é sempre mais abundante que o capital.

${ }^{54}$ No circuito inferior, segundo Milton Santos (1979, 2004, pp. 204-205), os empregados são encontrados com facilidade, porque a notícia da oportunidade de trabalho circula rapidamente.

55 "As fases ou momentos produtivos podem desenvolver-se em frações diferentes do território, mas haverá sempre uma unidade do movimento” (Arroyo, 2001, p. 57).
} 
mais raros, devem ser aproveitados mais perfeitamente. Com isso, o trabalho, uma vez desencadeado, é muito mais intenso, tem muito mais produtividade. Em muitos laboratórios, toda a planta produtiva, incluindo todas as pessoas e todas as máquinas, é empregada, no intervalo de um dia, para produzir apenas um produto. Desse modo, ao final do dia, todo um lote é produzido, o que, nos parâmetros de um pequeno laboratório, é uma vasta produção. Bastaria dizer que, possivelmente, esse mesmo medicamento só voltará a ser produzido no mês seguinte. Esse tipo de sistema se realiza, por exemplo, nos laboratórios Klein (Porto Alegre-RS) e Ophthalmos (São Paulo-SP).

O circuito superior marginal dá-nos um exemplo de máxima intensidade produtiva, com o emprego de todas as forças disponíveis, ainda que sejam necessários certos momentos de pausa, para adaptação da produção. Com essa característica, poderíamos cotejar a situação do circuito superior, no qual vigora, não raro, um estado de ociosidade planejada. Ou, pelos menos, é o que nos dizem as estatísticas, que refletem sobretudo a situação dos grandes laboratórios. Em 2004, a Febrafarma detectou, para o setor farmacêutico, uma capacidade ociosa de 40\% (Febrafarma apud Capanema e Palmeira Filho, 2004, p. 31). No mais, sabe-se que, na lógica do capitalismo, os investimentos adicionais sempre tendem a gerar trabalhos menos intensos ${ }^{56}$.

Até hoje, quando se pensou nos problemas de desemprego e subutilização das forças instaladas, buscou-se, o mais das vezes, maneiras de ampliar a intensidade verificada nas grandes empresas; poderíamos pensar, alternativamente, em maneiras de acabar com a intermitência dos trabalhos realizados em pequenas empresas, o que nos levaria, forçosamente, a elaborar novos modelos socioespaciais.

A economia regional clássica recorreu à idéia de produto regional, cujo crescimento deveria ser estimulado. Pode-se pensar que, mais importante que isso, seria preservar a dinâmica local, pois ela se relaciona com a possibilidade da vida nos lugares. As empresas pequenas, nalgumas atividades, favorecem a dinâmica do lugar e da região, ajudando a integrar o meio comum, ainda que, muita vez, contribuam pouco, em termos contábeis, para o incremento do aludido produto regional.

\section{As densidades comunicacionais e a produção de medicamentos}

Os laboratórios pequenos, bem como as distribuidoras pequenas, podem sucumbir aos jogos da competição quando se arriscam a transcender as escalas espaciais locais. Nalgumas situações, isso tem relação com o fato de que, em certos lugares, certos medicamentos, por força de um uso tradicional, mas também como efeito de campanhas

56 "De fato, temos o direto de dizer, sem se afastar muito da verdade, que quase todo novo processo economicamente aplicável economiza, ao mesmo tempo, mão-de-obra e capital” (Schumpeter, 1942, 1954, 213). 
locais de propaganda, podem adquirir a condição de terapêutica tradicional. Isto é crucial pois, como disse Milton Santos, a demanda tem um "papel motor" para o circuito inferior e para o superior marginal (Santos, 1979, 2004, pp. 315-316). Assim, o laboratório Wesp (Porto Alegre-RS), fundado em 1916, mantém-se há dez anos produzindo apenas a Olina, medicamento bem conhecido nos três estados ao sul do país.

Medicamentos antigos, localmente consagrados, podem atravessar os períodos, por vezes subsistindo mesmo ao desaparecimento de seus produtores iniciais. O Laperli (Recife-PE) é um laboratório que vive em função do Sanativo, um medicamento fitoterápico que, em 1888, começou a ser produzido pelo laboratório Zita; na década de 1940, 0 Sanativo começa a ser produzido pelo Laperli ${ }^{57}$.

Quando essas produções se consolidam, práticas terapêuticas e formas de pensamento locais podem sobreviver paralelamente à psicoesfera moderna.

Esses fenômenos poderão ser reforçados a partir das ações do circuito superior, as quais, por meio de campanhas de propaganda, podem criar uma necessidade que seja atendida por um medicamento, mais barato, feito por um pequeno laboratório. Tais são as duas faces do consumo atual, existentes porque "[...] a maior parcela da sociedade busca não ser excluída desse consumo e, ao abrigo desse processo, certa produção não-hegemônica se fortalece. Um circuito inferior e um circuito superior marginal remanescentes da economia urbana ganham, nos dias de hoje, um maior desenvolvimento" (Silveira, 2004, p. 66).

Essa popularidade de certos medicamentos pode manifestar-se mesmo se eles, em vez de apresentarem marcas, sejam comercializados com nomes não específicos, tais como o nome de plantas ou de fórmulas farmacopéicas. Nesse caso, seu uso pode extravasar as fronteiras locais ${ }^{58}$.

O importante, aqui, é que o medicamento seja conhecido, usado, recomendado, comunicado localmente ${ }^{59}$. Para reforçar esse processo, é muito importante a realização de propagandas em rádio, esse meio de comunicação difundido e popular ${ }^{60}$. A difusão do rádio

\footnotetext{
${ }^{57}$ Entre os medicamentos produzidos pelo Ravick (Fortaleza-CE), um dos mais vendidos são as Pílulas Purgativas do Doutor Matos. Em 1904, Joaquim de Alencar Matos inventou esse remédio. A marca passou depois à propriedade do seu filho; depois, foi adquirida por Francisco Matos, professor da Universidade Federal do Ceará; foi então vendida ao laboratório Belém Carneiro, que se funde mais tarde ao laboratório Ravick, pertencente aos mesmos proprietários.

${ }^{58} \mathrm{Um}$ mesmo produto farmacopéico, chamado Aguardente Alemã, é produzido pelo Ravick (Fortaleza-CE), e aparece na relação dos produtos mais vendidos do laboratório Odaly Soares (Caucaia-CE) e do laboratório Anchieta (Goiânia-GO).

${ }^{59}$ Paulo Sérgio Arrais e colaboradores realizaram um estudo sobre a automedicação nas cidades de Fortaleza e Belo Horizonte, além de cinco regiões de saúde do estado de São Paulo. De um total de 5332 especialidades farmacêuticas adquiridas como automedicação, 51\% tinham sido recomendadas por pessoas leigas (Arrais et alii, 1997).

60 "Com uma presença maciça tanto na cidade como no campo, o rádio mostra-se bem eficiente no seu papel de transmissor de informação e de elo de comunicação. Mais de 70\% de todos os domicílios - urbanos e rurais - do Brasil possuíam, em 1995, um aparelho de rádio” (Santos e Silveira, 2001, 2004, p. 241).
} 
deriva da existência de densidades comunicacionais, e, ao mesmo tempo, reforça as densidades comunicacionais preexistentes. Daí, a importância do rádio nos estados mais populosos ou urbanizados ${ }^{61}$. O rádio, justamente porque permite maior participação de pequenos capitais, se comparado à televisão por exemplo, pode ser a base de uma circulação de informações menos instrumental, mais comunicativa. A distribuidora Alefarma (Ananindeua-PA), depois de fechar uma parceria de distribuição exclusiva com um laboratório do estado do Rio de Janeiro, realiza propaganda de um medicamento num pequeno jornal local e numa emissora de rádio de Belém ${ }^{62}$.

Desde que um medicamento recebe esse reconhecimento popular, é como se se tornasse parte do cabedal terapêutico de um lugar. Como dissemos, sua produção, apoiada assim nas densidades comunicacionais ali vigentes, pode resistir até mesmo ao desaparecimento das empresas. Poderíamos então pensar que, mais do que possuído por tal ou tal laboratório, o medicamento seria de posse do lugar?

De feito, a coexistência demonstra, aqui, toda a sua centralidade. "De um ponto de vista geográfico, o fato da coabitação, isto é, o uso comum de um certo espaço, é o fundamento de tudo" (Vidal de La Blache, 1922, p. 104).

Habituados a tratar das estratégias das maiores empresas, muito bem sabemos que as lógicas da materialidade podem moldar as lógicas das ações sociais. Agora, será preciso dizer que, desde o ponto de vista das forças do lugar, e de maneira perfeitamente complementar, as ações também fundamentam a existência de certa produção de objetos, ainda que marginal. Daí, termos dito que, assim como a materialidade reclama certas ações, estas reclamam certa materialidade (Bicudo, 2005). Com isso, as produções e os empreendimentos, mesmo que bastante ligados ao processo de modernização, também não perdem suas relações com as tradições, os sentidos horizontalmente construídos, as vivências concretas, que são os conteúdos do lugar ${ }^{63}$. Maria Aparecida Pereira, pesquisando os laboratórios farmacêuticos do Rio Grande do Sul, chama a atenção para o "[...] tipo de medicamento produzido no Estado, baseado principalmente em um arsenal terapêutico

\footnotetext{
${ }^{61}$ Em 2001, o estado de São Paulo tinha 548 emissoras de rádio; Minas Gerais, 369; Rio Grande do Sul, 330. "Destacam-se, ainda, Estados como Ceará, Bahia, Rio de Janeiro, Paraná e Santa Catarina, que abrigam, cada um deles, mais de cem emissoras de rádio" (Santos e Silveira, 2001, 2004, p. 241).

${ }^{62}$ Ao longo de nossa pesquisa de campo, estes foram alguns dos laboratórios com experiência de propagandas regulares ou esporádicas em rádios locais: o Aclimação (São Paulo-SP); o Ravick (Fortaleza-CE), também realizando campanhas em canais locais de televisão; o Real Puríssimo (Goiânia-GO); o Laperli (Recife-PE), também realizando campanhas para a televisão; o Wesp (Porto Alegre-RS); o Kriff (Salvador-BA). É interessante a situação do laboratório Klein (Porto Alegre-RS). A Espinheira Santa, medicamento digestivo que a empresa produz, tem boas vendas na Bahia; para reforçar esse desempenho, o laboratório faz campanhas em rádios baianas.

${ }^{63}$ Jacqueline Ferreira, estudando o consumo de medicamentos numa vila de população pobre de Porto Alegre, escreve: "Os medicamentos para os grupos populares têm seu efeito dependente de vários fatores, ultrapassando a conotação de simples agente quimioterápico” (Ferreira, 2001, p. 69).
} 
ligado à cultura tradicional regional" (Pereira, 2002, p. 63), fenômeno que também notamos em pesquisa de campo realizada em Porto Alegre.

A comunicação, numa perspectiva geográfica, é também uma variável, e é por isso que falamos em densidades comunicativas. Trata-se também de um recurso, mas de um recurso largamente peculiar, já que sua produção exige quadros vitais concretos, relações de copresença, necessidades radicais. Quanto mais avança o processo de globalização, quanto mais os lugares se informacionalizam e tecnificam, tanto mais o espaço se divide em circuitos econômicos, e tanto mais as densidades comunicativas pesam, decisivamente, na configuração dos vários subespaços.

Os lugares, pois, se definem pela sua densidade técnica, pela sua densidade informacional, pela sua densidade comunicacional, cuja fusão os caracteriza e distingue. Essas qualidades se interpenetram, mas não se confundem (Santos, 1994, 2005b, p. 160).

Estamos em face da acentuação extrema de fenômenos antigos. No filosofia da física, é aquilo que Heisemberg chamou de ações de contigüidade (Heisemberg, 1958, 1981, p. 98). É aquilo que Habermas chamou de mundo vivido (Habermas, 1981, 1987, p. 289 e 338); que Milton Santos chamou de cotidiano territorialmente partilhado (Santos, 1993, 2005b, p. 151) ou simplesmente de cotidiano partilhado (Santos, 1996, 2002, p. $258)^{64}$. Acontece que esse espaço da contigüidade vai-se misturar de maneira indissociável com as atividades econômicas, num híbrido de modernidade e tradição. Mais do que um meio construído, trata-se de um meio comunicado, ou, mais precisamente, um meio comum.

Certamente que as densidades comunicativas emergem sem o planejamento de qualquer agente. Mesmo assim, podem ser pressentidas, intuídas, e é nesse momento que passam a fazer parte da própria tática dos agentes do circuito inferior, mas também daqueles que reforçam o superior marginal ${ }^{65}$.

Fujamos, assim, à tentação de pensar o superior marginal com base nas práticas do superior, o que provoca distorções. No superior marginal, é muito menos apropriado falar numa produção dos gostos pela propaganda. É bem válido pensá-la como criadora de mercado, mas, estender essa idéia aos circuitos marginais pode equivaler a introduzir a racionalidade instrumental num meio que não é próprio dela. Os agentes marginais também podem ser beneficiários da psicoesfera que os agentes hegemônicos difundem através das

\footnotetext{
${ }^{64}$ Milton Santos fala também de entorno vivido (Santos, 1993, p. 61), de cotidiano compartido (Santos, 1994, 2005a, p. 140), de território compartido (idem, p. 142) e de cotidiano da contigüidade (Santos, 2005, p. 168). Bruno Latour se refere ao "nosso universo cotidiano" (Latour, 1991, 1997, p. 98).

65 "Algumas empresas [entre 28 laboratórios gaúchos] consideram seus produtos tradicionais, com uma divulgação já consolidada, cujo uso se faz a partir da procura espontânea pelo paciente, além de acreditar na divulgação do produto 'boca a boca' [...]” (Pereira, 2002, p. 102).
} 
mídias $^{66}$; e os laboratórios pequenos podem ser beneficiados pela medicalização da sociedade e do território. Contudo, a psicoesfera é una: não cabe supor que exista algo como uma psicoesfera marginal.

As densidades comunicacionais emergem nos lugares de concentração populacional, de fluxos intensos de mercadoria e notícias, de circulação acelerada de objetos e dinheiro, ainda que em volumes reduzidos. Esses lugares tornam-se profícuos para a instalação de várias atividades marginais, entre elas as farmacêuticas. Aqui, a integração da atividade com o meio comum é completa.

O laboratório São Lucas (Belém-PA), além de produzir alguns medicamentos localmente reconhecidos, ainda goza de uma localização tática, próximo que está dos mercados centrais de Belém; assim, o laboratório, tirando partido da circulação maciça de pessoas, pode vender seus artigos numa pequena unidade ligada à fábrica. No centro da cidade do Recife (PE), junto ao mercado São José, vamos encontrar uma porção de pequenas distribuidoras, cada uma delas especializada num tipo de medicamento (similares, genéricos, sem prescrição). Essas distribuidoras, conhecidas como drogarias, aproveitam-se da concentração das farmácias na região ${ }^{67}$, bem como da circulação intensa de pessoas.

Também é bastante interessante a situação da Prospitalar (Uberlândia-MG), distribuidora fundada em 1993. A empresa distribui medicamentos similares e materiais hospitalares. A Prospitalar tem distribuição apenas no Triângulo Mineiro e na região do Alto Paranaíba (oeste de Minas), sendo que o maior volume das vendas está concentrado em Uberlândia. Há um ano, o proprietário tenta obter registro para distribuir também os medicamentos controlados, porque sabe que assim terá maior lucratividade. Ele pensa sobretudo nas clínicas de estética e saúde, que demandam, por exemplo, anestésicos e hormônios. Essas clínicas apareceram em número apreciável no centro de Uberlândia, desde que esta cidade se tornou uma espécie de pólo hospitalar do Triângulo Mineiro. Assim, a própria configuração regional, concedendo à cidade de Uberlândia uma função médica específica, muda o meio construído e, ao sabor dessa mudança, os agentes locais redefinem suas táticas.

Todos esses fenômenos fazem com que, para os pequenos laboratórios, seja mais interessante produzir medicamentos livres de prescrição médica. Desse modo, eles fogem aos vultosos gastos sempre necessários à propaganda médica, além de poderem fruir das difusões espontâneas, que podem consagrar certos medicamentos. Observemos duas

\footnotetext{
${ }^{66}$ Milton Santos já dizia que o circuito superior marginal pode-se beneficiar indiretamente das campanhas publicitárias empreendidas pelo circuito superior (Santos, 1979, 2004, p. 105). "Dessa forma, a publicidade realizada por grandes empresas, que despendem consideráveis somas de seus orçamentos para esse uso, acaba, por sua vez, incentivando também o consumo dos produtos das demais empresas [...]” (Grimm, 2002, p. 110).

${ }^{67}$ Várias redes de farmácia infestaram a capital pernambucana: Farmácia dos Pobres, Farmácia Guararapes, Hipermed, Starfarma, Casa Caiada, supermercado Bompreço.
} 
estatísticas. Em 1998, segundo a Alanac, Associação dos Laboratórios Farmacêuticos Nacionais, $11,72 \%$ do total de unidades comercializadas pela indústria farmacêutica no Brasil corresponderam aos medicamentos de venda livre; 88,28\%, aos medicamentos de venda sob prescrição médica (Alanac apud Pereira, 2002, p. 101). No Rio Grande do Sul, em 2001, de 873 medicamentos produzidos por oito laboratórios entrevistados, 85,22\% eram de venda livre; 14,78\%, de venda sob prescrição médica (Pereira, 2002, p. 46). O paradoxo se explica: os números da Alanac ficam distorcidos pelas produções dos maiores laboratórios, que sempre têm maior peso nos grandes agregados estatísticos, e que preferem a produção de medicamentos controlados. Já os números de Maria Aparecida Pereira, por derivarem de uma pesquisa em que aparecem poucos laboratórios grandes, e nenhum multinacional, podem captar a lógica do circuito superior marginal. Eis então o caráter ladino e perigoso das estatísticas: elas escondem, muita vez, as situações vividas pela maioria das empresas, e induzem a medidas que beneficiam às maiores, sobretudo as multinacionais; mostrando o setor, elas escondem o território ${ }^{68}$.

Neste ponto, não se pode afirmar que os pequenos laboratórios ocupam um nicho de mercado. Em verdade, tudo se passa como se o movimento produtivo inicial se realizasse, não nas empresas produtoras, mas nos reclamos específicos de certos quadros vitais. O lugar vai, com todas as suas forças intrínsecas e tradições, moldar, em certa medida, as ações das empresas. Vale considerar que a larga produção de fitoterápicos, pelos pequenos laboratórios, ancora-se em práticas terapêuticas populares que chegam, ressignificadas, aos novos contextos urbanos ${ }^{69}$. Não se trata, pois, de um filão de economia, mas de uma outra economia, regida por outra racionalidade.

É esse tipo de riqueza local que a medicalização do território põe em risco. O laboratório Kriff (Salvador-BA), incapaz de cumprir todas as novas exigências científicas determinadas pela Anvisa, vai aos poucos abandonando sua produção de medicamentos, em benefício da produção de $\operatorname{cosméticos}^{70}$. Assim, marcas conhecidas em Salvador, sobretudo por pessoas mais velhas (Cadina, Cajuzinho, Sal dos Meninos) ficam fadas ao desaparecimento.

O mesmo se dá com produtos mais simples, como as plantas. As novas legislações, exigindo lógicas científicas de controle e beneficiamento, inviabiliza certas produções, e assim condena a perpetuação de práticas tradicionais. "[...] as plantas medicinais secas, in

\footnotetext{
68 “[...] a contabilidade econômica que trata como um dado homogêneo o que é cada vez mais heterogêneo é, assim, incapaz de ajudar a reconhecer o movimento real da sociedade e da economia [...]” (Santos, 1979, 2005b, p. 78).

69 “[...] as práticas de cura com ervas medicinais, longe de representarem remanescências de um passado rural, são modos de pensar e agir absolutamente contemporâneos, reinterpretações de novas condições de vida encontradas no meio urbano, tendo como base um sistema lógico que ordena e dá sentido aos cuidados corporais, às relações interpessoais e à vida como um todo" (Araújo, 1998, pp. 7-8).

${ }^{70}$ Segundo a farmacêutica do Kriff, a produção de cosméticos é regida por uma legislação muito mais suave.
} 
natura - que não passaram por processos industriais a não ser o de secagem e eventual rasura - têm sido consideradas medicamentos fitoterápicos, segundo a RDC [17 de 2000, resolução da Anvisa para fitoterápicos]. Ou seja, as indústrias que desejam comercializar plantas medicinais secas e rasuradas não têm outra opção senão a de considerarem-nas medicamentos fitoterápicos para fins de legalização [...] Produzir e comercializar folhas de alguma planta medicinal de uso tradicional, mesmo que sob condições de qualidade, passa a ser tratado como crime hediondo. E a população, principalmente a concentrada nos centros urbanos e destituída de espaços para cultivar suas próprias plantas medicinais, perde também esta alternativa terapêutica - fundamentada no uso tradicional - e, obviamente, a perpetuação deste conhecimento também se perde" (Fonte, 2004, p. 90).

A exigência de rigores científicos, muita vez transportada por vetores da globalização, vai atravessar os lugares, desestabilizando suas configurações precedentes. O lugar enriquece sua vida de relações, mas, de modo complementar, sua configuração geográfica interna conhece um profundo empobrecimento. Um dos índices dessa nova pobreza local é, justamente, a extinção de marcas, usos e produções terapêuticas localmente tradicionais.

\section{O espaço e suas divisões}

Portanto, a verificação do circuito superior marginal nos leva a considerar a existência de várias lógicas a presidir as atividades econômicas. "A cidade, portanto, não pode mais ser estudada como uma máquina maciça" (Santos, 1979, 2004, p. 22) ${ }^{71}$. De acordo com as características do empreendimento, o trabalho, organizado de maneira específica, vai-se integrar de uma certa maneira ao meio comum ${ }^{72}$.

O processo de globalização, que vai criando uma totalidade mundial, exige que nosso olhar saiba também atentar para as rupturas, as divisões ${ }^{73}$. Com Lacoste, poderíamos pensar que se elaboram vários tipos de espacialidade. "Vivemos, a partir do momento atual, numa espacialidade diferencial feita de uma multiplicidade de representações espaciais, de

\footnotetext{
71 "Do mundo urbano visto como cenário homogêneo e privilegiado chega-se, hoje, a um cenário urbano marcado pela heterogeneidade e por injustiças. Assim, não há como não incorporar à questão da cidadania não apenas o território, mas também o espaço, dada a heterogeneidade das cidades e da sua conformação marcada por profundos traços da segregação espacial e social” (Bousquat, 2001, p. 89).

${ }^{72} \mathrm{O}$ território, considerado como território usado, é objeto de divisões de trabalho superpostas. Desse modo, a expressão divisão territorial do trabalho acaba sendo um conceito plural. Pode-se considerar também que cada atividade ou cada empresa produz a sua própria divisão do trabalho (Santos e Silveira, 2001, 2004, p. 290).

73 “O conhecimento da totalidade pressupõe [...] sua divisão. O real é o processo de cissiparidade, esfacelamento. Essa é a história do mundo, do país, de uma cidade... Pensar a totalidade, sem pensar a sua cisão, é como se a esvaziássemos de movimento” (Santos, 1996, 2004, p. 118).
} 
dimensões muito diversas, que correspondem a toda uma série de práticas e de idéias, mais ou menos dissociadas [...]" (Lacoste, 1976, 1997, p. 49) ${ }^{74}$.

Talvez se possa, com isso, chegar, por exemplo, a compreensões mais precisas com respeito ao meio construído urbano. Este é freqüentemente visto como um corpo em deplorável processo de putrefação, requerendo a busca de remédios rejuvenescedores. A cidade perfeita seria, desse modo, a cidade nova. Grandes projetos supostamente revitalizadores, apoaidos por vezes em capitais financeiros internacionais, tentam eliminar as formas antigas, os objetos arcaicos, em suma, aquilo que Milton Santos chamou de as rugosidades ${ }^{75}$. Ora, do ponto de vista dos agentes marginais, as formas geográficas antigas nem sempre são empecilhos para o desenvolvimento das atividades econômicas. Uma prática antiga, uma forma instalada em períodos anteriores, um objeto técnico envelhecido, uma função urbana tradicional, podem converter-se em ponto de apoio para as divisões do trabalho das menores empresas. As rugosidades não são meramente resquícios: são híbridos de tempo, pois que expressam trabalhos do passado e apontam possíveis trabalhos futuros. Comparadas com as formas geográficas modernas, têm a vantagem de trazer em si reunidas as acumulações pretéritas. Por vezes, a instalação dos mais sofisticados e modernos objetos faz-se mesmo inútil, já que, nos contextos locais específicos, eles só podem ser usados segundo ritmos lentos ${ }^{76}$.

Mais do que isso, a instalação de formas e atividades sofisticadas pode converter-se, também, num reforço às racionalidades marginais, já que nem sempre se pode regular por completo as relações desencadeadas no meio comum. Consideremos a situação da Civi, Companhia Industrial de Vidros, sediada na cidade de Recife (PE). A expansão da Civi deveu-se, em grande medida, às complementaridades com grandes empresas; basta dizer, por exemplo, que ela é fornecedora da Coca-Cola. Com isso, instala-se em Pernambuco um potencial de produção de embalagens de vidro, que vai depois ser aproveitado pelos pequenos laboratórios farmacêuticos, em sua busca por embalagens. O Vitapan (AnápolisGO), o Diproquifar (Recife-PE), o Madrevita (Fortaleza-CE) e o Wesp (Porto Alegre-RS) são exemplos de laboratórios que adquirem produtos junto à Civi.

É mais uma dinâmica auferida pelo território de Pernambuco, a qual, no que tange à produção de medicamentos, está fortemente ligada à presença de pequenas e antigas

\footnotetext{
${ }^{74}$ Segundo Yves Lacoste (1976, 1997, p. 49 - nota 2) explica, Alain Reynaud foi o primeiro a falar em espacialidade diferencial, mas num sentido distinto do que aqui se aplica.

75 "Chamemos rugosidade ao que fica do passado como forma, espaço construído, paisagem, o que resta do processo de supressão, acumulação, superposição, com que as coisas se substituem e acumulam em todos os lugares" (Santos, 1996, 2002, p. 140).

76 "“...] uma técnica é nominalmente plena, absoluta, mas raramente é usada em plenitude. Cada ator a toma segundo uma maneira. Teoricamente, ela é plena; na prática não o é. Através da facticidade, passamos do 'absoluto' irrealizado ao 'relativo' realizado: para cada caso, uma certa combinação de quantidades e qualidades” (Santos, 1996, 2002, p. 124).
} 
empresas, muitas delas trabalhando com produtos fitoterápicos. A difusão recente de grandes redes de farmácia vai garantir a intromissão da racionalidade instrumental, mas vai, ao mesmo tempo, repercutir em consumos e produções próprios do circuito superior marginal e sua lógica. Não apenas a capital, onde se encontra a maior parte das empresas, se beneficia. Podemos perceber uma presença de laboratórios em Olinda; e uma pequena concentração na cidade de Jaboatão dos Guararapes.

A existência de outros agentes consolidam o processo. Além da Civi, devemos destacar o papel do Lafepe, laboratório oficial de Pernambuco, que, em capacidade de produção, só fica atrás, no território pernambucano, do laboratório particular Hebron. Este último, fundado em 1990, possui fábrica na cidade de Caruaru, instalando sua administração no Recife em 1998. Graças ao controle informacional permitido pela capital pernambucana, o Hebron pode controlar uma rede de unidades espalhadas por várias cidades ${ }^{77}$.

As empresas são dessemelhantes, assim como as configurações espaciais dos lugares e o uso que se faz do meio construído ${ }^{78}$. Os lugares apresentam, entre suas características mais essenciais, um conjunto de empresas operando com topologias, divisões do trabalho, técnicas e consumos normativos particulares ${ }^{79}$. Entre as atividades mais tangidas pelos vetores da modernização, vamos encontrar um conjunto de relações expressando um circuito superior, que, segundo Milton Santos, representa uma "forma de organização" da atividade produtiva (Santos, 1979, 2004, p. 103). Aqui, são ativadas as normas sofisticadas e modernas. A par desse conjunto de relações, identifica-se outro conjunto, igualmente relevante, expressando um superior marginal que funciona segundo normas envelhecidas, ou cumprindo precariamente as prerrogativas das normas que são compulsórias (como as jurídicas). "A existência desses dois níveis de circuito superior deve-se antes de tudo às bases de organização". (Santos, 1979, 2004, p. 105)

O consumo diferencial de normas define os diferentes sistemas organizacionais. Estes, ao mesmo tempo, conjugam-se de maneira particular nos lugares, diferenciando os subespaços.

\footnotetext{
77 Além do escritório de Boa Viagem, no Recife, o Hebron dispõe de outras unidades representativas nas seguintes cidades: Rio de Janeiro, Goiânia, Florianópolis, Fortaleza, São Luís, Belém e Manaus. A função dessas unidades é controlar a equipe de representantes e cuidar das vendas em seus respectivos locais.

${ }^{78}$ Segundo Milton Santos, as diferentes empresas, de acordo com sua força e seu processo produtivo, vão configurar diferentes divisões do trabalho (Santos, 1996, 2002, p. 135). "Conjunto de todos os instrumentos de trabalho e de todas as formas de fazer, a cidade somente poderá ser entendida ao considerar a coexistência de divisões territoriais do trabalho" (Silveira, 2004, p. 60).

79 "Cada lugar, cada subespaço, assiste, como testemunha e como ator, ao desenrolar simultâneo de várias divisões do trabalho”. (Santos, 1996, 2002, p. 136)
} 
VIII

Os círculos de cooperação e as novas faces do circuito superior marginal

Os círculos de cooperação

A idéia de organização aponta para dois fenômenos. Por um lado, existe uma fragmentação espacial, com a emersão de vários grupos de normas, mais ou menos modernos. Por outro lado, existem unificações espaciais, pois que os agentes recorrem a tais ou tais normas, sistematizando-as. Os agentes marginais também realizam tais sistematizações normativas, ainda que de maneira freqüentemente derivada. Para captar o processo diferencial de constituição das organizações, propomos enfrentar a questão dos círculos de cooperação, idéia primeiramente proposta por Milton Santos (1997) e depois desenvolvida por Milton Santos e María Laura Silveira (2001, 2004). Os círculos de cooperação decorrem das diversas relações estabelecidas entre as empresas, mas igualmente entre os lugares. Trata-se de um conceito por meio do qual se pretende captar a dinâmica do território, seus fluxos imateriais e transformações ${ }^{1}$.

Assim, pretendemos escapar à idéia de que o espaço é, meramente, um fator, a interferir nas ações daqueles que seriam, pretensamente, os veros agentes, humanos. Preferimos pensar o espaço como dotado de um papel ativo, a inércia dinâmica referida por Milton Santos (2002).

Os círculos de cooperação constituem uma ferramenta teórica para compreender, no plano dos agentes, suas formas de hierarquização; e, no plano das cidades, suas mudanças de conteúdo e, conseqüentemente, seus novos papéis na formação socioespacial.

O peso das normas científicas

Como dissemos desde o começo, os circuitos da economia urbana não são unidades estanques. Por isso, a cada nova totalização realizada pelos agentes hegemônicos, os demais agentes tiveram suas situações alteradas. "Imperativos de qualidade, de

\footnotetext{
1 “A especialização das tarefas e dos lugares demanda um leque de formas de cooperação entre atividades econômicas - transportes, comunicações, finanças, publicidade, organizações -, que se tecem no território para unir pontos e áreas de produção dispersos. São os círculos de cooperação" (Silveira, 2003, p. 11). Mónica Arroyo (2001, p. 58) diz que os círculos de cooperação conformam "fluxos não-materiais, como capital e informação".
} 
competitividade e de fluidez tornam-se normas que estabelecerão um patamar, por baixo do qual encontraremos os 'não-modernos' [...]” (Silveira, 2004, p. 66)².

Hoje, as novas hierarquizações mundiais vão-se processando ao sabor da instalação de bases normativas modernizadas. Certamente, essas normas novas têm natureza técnica, isto é, condicionam os processos produtivos imediatos ${ }^{3}$. Mas uma variável, passando ao controle do sistema espacial, rouba para si a lógica das outras variáveis. Assim, devemos ir além da verificação das normas jurídicas e técnicas, uma vez que o fenômeno normativo estende seus tentáculos, gerando normas financeiras, científicas, informacionais. Trata-se de um processo global, por meio do qual se constitui a totalidade normativa do mundo. Estamos de acordo com Abrahan Moles (1990, p. 15): o "imperativo de normalização" é sinônimo do "imperativo de universalidade".

Em face das revoluções trazidas pelas técnicas biotecnológicas, os atrasos e as carências científicas dos pequenos laboratórios ficam piorados. E aqui chegamos a uma das principais características do circuito superior marginal no período contemporâneo. É que, em função de um aparato normativo novo, torna-se cada vez mais ampla a gama de serviços e bens que devem ser adquiridos e usados dentro da lógica da modernização.

Sem dúvida, as soluções e técnicas tradicionais não deixam de ser utilizadas, mas, nos aspectos mais decisivos da produção farmacêutica, as diferentes empresas são levadas a um consumo compulsório de formas espaciais, objetos técnicos e conhecimentos típicos do processo de modernização. Atualmente, um laboratório produtor de medicamentos precisa, com efeito, buscar relações com várias outras instituições: distribuidores, consultores, universidades, assessores jurídicos, assessores técnicos, instituições que realizam testes de qualidade científica, bancos, forncedores de equipamentos e matérias-primas, empresas de contabilidade, propaganda, informática, entre outros.

As novas resoluções da Anvisa não alteram, em muitos casos, as situações dos laboratórios multinacionais, visto que eles já operam, há vários anos, sob as normas de qualidade exigidas pela vigilância sanitária. Para os pequenos laboratórios nacionais, porém, trata-se de uma verdadeira revolução, pois eles ficam obrigados a práticas e relações que lhes são inéditas ${ }^{4}$.

Assim, o ritmo dos maiores laboratórios fica inalterado, enquanto os pequenos laboratórios devem lidar com novos óbices, que refreiam seus ritmos já de si reduzidos. María Laura Silveira diz que a norma pode criar flexibilidade, fluidez, mas sempre tem, para

\footnotetext{
${ }^{2}$ Preocupado com a situação das micro e pequenas indústrias, Antonio Carlos de Cerqueira (1996, p. 18) diz que a circulação mais extensa dos produtos, como resultado do processo de globalização, faz com que os empresários menos preparados conheçam perdas de eficiência.

3 “Tão logo a normalização industrial intervenha, traz consigo essa tendência que inevitavelmente desvaloriza os velhos tipos econômicos e as velhas organizações industriais” (Ellul, 1954, 1964, p. 172).

${ }^{4}$ No Rio Grande do Sul, em 1992, 63,6\% dos laboratórios tinham dificuldades para registrar produtos; em 2001, a proporção passa a 85,72\% (Pereira, 2002, pp. 93-94).
} 
os agentes não hegemônicos, efeitos impositivos (Silveira, 1997, 37-38). "Daí considerarmos a rigidez como a cara oculta da flexibilidade" (idem, p. 38). Com efeito, as modernizações normativas têm por critério e parâmetro, não raro, as necessidades e os procedimentos das grandes empresas. "Legitimada pela ideologia do crescimento, a prática da modernização cria, no território como um todo e em particular nas cidades, os equipamentos mas também as normas indispensáveis à operação racional vitoriosa das grandes firmas, em detrimento das empresas menores e da população como um todo" (Santos, 1993, 2005a, p. 114).

Instalam-se quadros normativos que, muita vez, são totalmente alheios às situações concretas das pequenas firmas. A farmacêutica do laboratório Amazonas (Feira de SantanaBA) conta que, por ocasião das inspeções feitas pelos fiscais da vigilância sanitária, a maioria dos itens do roteiro de inspeção é preenchida como: não se aplica.

Um primeiro impacto dessa renovação normativa é a generalização de um consumo científico, pois, desde agora, os medicamentos devem ser submetidos a baterias complexas de testes, sob pena de serem retirados do mercado. Conforme já vimos no capítulo $\mathrm{V}$, os testes de biodisponibilidade, bioequivalência, equivalência, outrora típicos das produções hegemônicas, vão agora banalizando-se. Isso exige dos pequenos laboratórios um grande investimento, e, como são poucos os seus capitais, não é raro encontrar uma empresa que, nos últimos anos, teve sua linha drasticamente reduzida. A escapatória encontrada foi retirar os medicamentos menos importantes e manter no mercado apenas os produtos de melhor desempenho, sobre os quais se aplicam então os referidos testes.

O laboratório Sanífer (Porto Alegre-RS) chegou a ter 43 produtos, sendo cerca de 30 homeopáticos. Com dificuldades para se adequar às novas legislações, a empresa não pôde manter senão sua pequena linha atual, composta por 9 produtos ${ }^{5}$. O laboratório Natulab (Santo Antonio de Jesus-BA), depois da RDC 17, resolução de 2000 que trata dos medicamentos fitoterápicos, abandona esse tipo de produção, restringindo-se aos similares.

Além de uma redução das linhas de produtos, assistimos a uma redução das atividades inovativas desses laboratórios ${ }^{6}$. De 2002 a 2005, o laboratório Klein (Porto Alegre-RS) não lançou nenhum medicamento novo, por não conseguir atender às rígidas exigências sanitárias ${ }^{7}$.

\footnotetext{
${ }^{5}$ O Sanífer está em fase de adaptação às boas práticas de fabricação. Enquanto não se adequar, não poderá lançar novos medicamentos. Falta-lhe atualizar sua documentação, renovar registros de medicamentos, aprimorar as instalações, adquirir alguns equipamentos.

6 "Os fatores relacionados a esta redução no número de lançamentos de novos produtos podem estar ligados às alterações quanto aos níveis de exigências legais necessárias ao seu registro, tais como complexidade dos testes, custo das taxas e dos testes associados” (Pereira, 2002, p. 90).

${ }^{7}$ O laboratório chegou a produzir 120 medicamentos, número que foi reduzido para 13. A redução da linha deveu-se à diminuição das suas vendas e às dificuldades quanto às exigências feitas pela Anvisa. Vários medicamentos, classificados como tinturas, tiveram que deixar o mercado em 2001, após a publicação de uma resolução da Anvisa.
} 
Como corolário desses fenômenos, as empresas terão seus lucros reduzidos. Em 2001, 10\% do faturamento do laboratório Diproquifar (Recife-PE) era conseguido com o mercúrio cromo, que foi depois retirado do mercado pela Anvisa, pois foi considerado um produto ineficaz.

Voltamos a dizer que as preocupações da Anvisa não carecem de fundamento. Pelo contrário, é de fato fundamental conhecer e garantir a qualidade dos medicamentos em comercialização. Entanto, como esses cuidados são perseguidos por meio da imposição de altos conteúdos científicos, bem como da prescrição de procedimentos modernos, à imagem das maiores empresas, apenas a exclusão pode ficar assim garantida. Além disso, não apenas os medicamentos ineficazes desaparecem, mas também outros, eficazes, cujos testes não puderam ser realizados pelas empresas pouco capitalizadas. Em 2001, conforme relata Nilce Fonte, o Ministério Público do Paraná moveu ação para regularizar a situação dos produtores de fitoterápicos, de modo que eles se ajustassem à nova legislação. Empresas foram fechadas, mudaram de ramo de atividade, e "produtos sem qualidade" foram tirados de circulação (Fonte, 2004, p. 86). "Por outro lado, não foram disponibilizados apenas produtos desqualificados, mas muitos produtos de excelente qualidade, tradicionais e produzidos com responsabilidade, que por falta de 'comprovação científica' acabaram recebendo o mesmo tratamento que os 'medicamentos irregulares'" (idem, p. 86).

Os testes de qualidade, sem dúvida necessários e importantes, tornam-se a base de hierarquizações, pois ficam abandonados à lógica de exclusão do mercado. Aqui, torna-se claro como a ciência, que em períodos precedentes cumpriu uma função de variável de renovação, converte-se agora em variável de enquadramento, logo em norma ${ }^{8}$. Assim, a norma, variável central, estende sua lógica às atividades científicas.

Noutras vezes, não somente as linhas de produtos, mas o próprio laboratório, é considerado como ineficaz, passível, portanto, de ser interditado. Em 2004, o Ágape (Ananindeua-PA) ficou interditado por quarenta dias, para se adequar às normas da vigilância sanitária. Em 1996, o laboratório Amazonas (Feira de Santana-BA) foi interditado pela vigilância sanitária, pois não seguia todos os procedimentos indicados. O laboratório levou três meses para se regularizar, o que demandou atualização dos procedimentos e gastos, sobretudo em novos equipamentos.

O processo pode ser ainda mais desenvolvido, levando à extinção das empresas. De acordo com a Divisão de Vigilância Sanitária da Secretaria de Saúde e Meio Ambiente do Rio Grande do Sul, havia, em 1994, 62 laboratórios farmacêuticos no estado; em 1997,

\footnotetext{
${ }^{8}$ No princípio dos anos 2000, o BNDES lança o Profarma, programa destinado a financiar pesquisas e reestruturações empresariais propostas por laboratórios farmacêuticos nacionais. Em certos casos, o acesso ao financiamento pode ficar relacionado apenas à adequação aos padrões regulatórios da Anvisa, o que envolve, entre outras coisas, a feitura dos testes científicos. Assim, as normas financeiras se enlaçam às normas científicas.
} 
havia 43; em 1998, 36; em 2001, já depois da criação da Anvisa, a tendência confirma-se, e o número de laboratórios vai a 24 (DVS/SSMA/RS apud Pereira, 2002, pp. 20-22) 9 .

São duas as mudanças principais. Primeiramente, os laboratórios ficam menos confinados, pois que, para cumprir os novos requisitos científicos, devem travar relações com novos agentes, por vezes localizados em cidades longínquas; é toda uma redefinição dos círculos de cooperação. Segundamente, alguns lugares se iluminam, por acolher serviços que, doravante, são obrigatórios.

Entre os aludidos serviços, aparecem os testes de medicamentos. O problema não é proceder aos exames mais elementares, mas sim realizar testes mais sofisticados (microbiológico, biológico, de equivalência), que as novas legislações requerem. Obrigados a encontrar novas saídas, os pequenos laboratórios ampliam seus círculos de cooperação. Nessa tarefa, as universidades estatais começam a desempenhar um papel crucial $^{10}$. O Ágape (Ananindeua-PA) tem convênio com a UFPA para os testes físico-químicos e microbiológicos. O Klein (Porto Alegre-RS) realiza os testes físico-químicos junto à UFRGS.

Em face desses processos, as empresas começam a absorver mais trabalhadores especializados ou formados em cursos superiores. Um dos sócios da distribuidora Amazon Med (Belém-PA), também seu gerente comercial, é formado em administração pela Universidade Federal do Pará. Na distribuidora Buarque (Fortaleza-CE), o contador formou-se em ciências contábeis pela Universidade Estadual do Ceará. Um farmacêutico do lquego (Goiânia-GO), laboratório oficial de Goiás, é formado pela Universidade Federal de Goiás, tendo realizado um estágio no laboratório particular Neoquímica (Anápolis-GO).

Absorvendo esse trabalho mais qualificado, as empresas podem buscar operações mais criativas e ousadas. É interessante aqui a situação do Halex Istar (Goiânia-GO), empresa que usa equipamentos desenvolvidos por ela própria. Para tanto, conta com um departamento de engenharia. Em média, um equipamento leva dois anos para ficar pronto. Como resultado, a empresa pode produzir também as próprias embalagens.

\section{Medicamentos fitoterápicos e normas científicas}

Assim como os sistemas técnicos, os sistemas normativos aparecem, com freqüência, como tendências globais que, mais tarde, pelas pressões políticas de agentes hegemônicos, instalam-se nas formações socioespaciais. Assim foi com os sistemas de

\footnotetext{
${ }^{9}$ Um desses laboratórios extintos é o Gaúcho (Cachoeirinha-RS), cujo gerente administrativo entrevistamos em pesquisa de campo. A empresa localizava-se no distrito industrial de Cachoerinha, nas cercanias de Porto Alegre. Produzia 35 medicamentos oficinais e 8 similares, sob as formas líquida e de cápsulas. Da Anvisa, o entrevistado afirmou que realizava "exigências de primeiro mundo", que só podiam ser atendidas com extrema dificuldade.

10 “A RDC $\mathrm{n}^{\circ}$ 17, que recentemente foi substituída pela RDC n 48, também é uma ação governamental que, devido às exigências de testes completos de eficácia e segurança, acaba por estimular as empresas a buscarem apoio técnico e científico nas universidades” (Alves, 2004, p. 183).
} 
normas que regulam a produção de medicamentos fitoterápicos. De acordo com Flávia Alves, a Organização Mundial da Saúde preconiza, desde 1978, o uso de medicamentos baseados em plantas, mas desde que elas sejam avaliadas cientificamente, por meio de testes que são muito parecidos aos que se aplicam aos medicamentos sintéticos (Alves, 2004, pp. 144-145). Eis então a tendência normativa global que, mesmo defasadamente, vai assolar os diversos territórios nacionais.

Em 1995, no Brasil, a Secretaria de Vigilância Sanitária (SVS), começa a prever estudos comprovando a eficácia e a segurança dos fitoterápicos, proibir associações não testadas, e estabelecer prazos para revalidação dos produtos (Alves, 2004, p. 145). Uma vez que o conhecimento científico das plantas estava pouco evoluído no país, essas normas conduzem, necessariamente, ao uso de conhecimentos só disponíveis em países estrangeiros. "Para esta regulamentação, a SVS reconheceu as monografias produzidas na Alemanha, as aprovadas pela Organização Mundial de Saúde e as adotadas pela Comunidade Européia, além de publicações com o mesmo teor de outros países, utilizando um critério de pontos dependendo das informações contidas em cada monografia ou publicação. A combinação destas fontes serviria como documento para o registro de um fitoterápico" (Alves, 2004, p. 145).

A Anvisa, Agência Nacional de Vigilância Sanitária, que em 1999 substitui a SVS, consagra as tendências globais, principalmente por meio da RDC 17, de 2000, uma resolução que regula a produção de fitoterápicos. "Segundo esta resolução, o registro de um medicamento fitoterápico deve ser amparado por estudos científicos conduzidos dentro de parâmetros aceitáveis de qualidade, especialmente os estudos quanto à eficácia e à segurança de uso clínico" (Siani et alii, 2003, p. 30). Essa norma já nasce ligada a um conjunto coerente de normas, criando rígidos enquadramentos sobre a atividade produtiva ${ }^{11}$.

Ao mesmo tempo em que se difunde na escala da formação socioespacial, abarcando o território em sua totalidade, a norma traz efeitos fragmentadores em seu próprio seio. Conforme explica Flávia Alves, a RDC 17 cria dois tipos de registros para medicamentos fitoterápicos: 1. registro simplificado, para medicamentos com plantas de eficácia já comprovada, a partir de uma lista acadêmica internacional; 2. registro padrão, muito parecido com o que se utiliza para os medicamentos sintéticos. Em 2004, a lista do registro simplificado expandiu-se de 17 pra 34 plantas, sendo que a grande maioria delas não é nativa do Brasil (Alves, 2004, p. 146). Assim, a maior parte dos pequenos laboratórios

\footnotetext{
11 “Junto a esta RDC foram publicadas as seguintes resoluções que a complementam: RE n 88, de 16/03/04, que determina a publicação da lista de referências bibliográficas para avaliação de segurança e eficácia de fitoterápicos; RE $n^{\circ} 89$, de 16/03/04, que determina a publicação da lista de registro simplificado de fitoterápicos; RE $n^{\circ}$ 90, de 16/03/04, que determina a publicação da guia para a realização de estudos de toxicidade pré-clínica de fitoterápicos; RE $\mathrm{n}^{\circ}$ 91, de 16/03/04, que determina a publicação da guia para realização de alterações, inclusões, notificações e cancelamentos pós-registro de fitoterápicos” (Alves, 2004, p. 149).
} 
farmacêuticos é atirada, abruptamente, no grupo do registro simplificado, por ser possível sustentar-se nos estudos científicos anteriores. Caso pretendam realizar os registros padrão, ou seja, caso pretendam lançar produtos cujas plantas carecem dos exames científicos requeridos, devem arcar com os custos desses exames, caros e demorados.

A normatização da Anvisa reedita um fenômeno já verificado anteriormente: fica-se na dependência de conhecimentos e técnicas estrangeiros. Por um lado, é preciso comprovar a eficácia das plantas. Por outro lado, há, por parte da maioria das empresas, dificuldades em recorrer às pesquisas científicas de comprovação, sobretudo em matéria de plantas, cuja avaliação resulta, por vezes, mais complexa que os testes de produtos sintéticos ${ }^{12}$. Siani e colaboradores dizem que, apesar de seu largo uso e aceitação, a maioria dos medicamentos fitoterápicos ainda não foi objeto de pesquisas mais aprofundadas, em matéria de eficácia e segurança; o mais das vezes, não se conhece quais os constituintes responsáveis pela propriedade farmacológica, e poucos ensaios clínicos foram realizados nessa área (Siani et alii, 2003, p. 26).

Em face dessas carências científicas, chega-se a uma situação tal que a maioria das plantas nativas do Brasil deixam de ser utilizadas em produções fitoterápicas, ao passo que plantas nativas de outros países, já cientificamente conhecidas, passam a ser intensamente elaboradas em pequenos laboratórios farmacêuticos nacionais ${ }^{13}$. De acordo com Nilce Fonte, das doze plantas apontadas na RDC como isentas de testes de toxicidade e eficácia, todas são estrangeiras (Fonte, 2004, pp. 88-89). "[...] a própria ANVISA confirma que a maioria dos medicamentos fitoterápicos para os quais não têm sido concedidos registros são aqueles produzidos a partir de nossa flora nativa [...]" (idem, p. 101) ${ }^{14}$.

No laboratório Klein (Porto Alegre-RS), 50\% das plantas utilizadas são nativas de outros estados brasileiros ou de países estrangeiros. Com as novas legislações, a empresa teve que abdicar de algumas produções fitoterápicas. A maioria dos medicamentos extintos utilizava plantas do Rio Grande do Sul. Hoje, muitas plantas utilizadas são da Ásia ou da Amazônia.

\footnotetext{
12 “[...] os medicamentos sintéticos são perfeitamente conhecidos e relativamente simples na sua composição. Sendo assim, os estudos e ensaios científicos, particularmente os pré-clínicos e clínicos (realizados respectivamente em animais e em humanos), em que pese sua complexidade, são bastante mais fáceis de serem executados com medicamentos sintéticos comparativamente aos ensaios com plantas medicinais e fitomedicamentos" (Fonte, 2004, p. 42).

13 “[...] os poucos medicamentos fitoterápicos que vêm sendo regularmente aprovados são basicamente os à base de plantas exóticas, em detrimento dos produzidos a partir de nossa flora local” (Fonte, 2004, p. 95).

14 "Na quase totalidade, esses produtos [fitoterápicos vendidos no Brasil] são obtidos de plantas européias [...]" (Siani et alii, 2003, p. 28).
} 
A despeito da louvada biodiversidade brasileira, somos conduzidos, assim, a sistemáticos déficits monetários em matéria de plantas medicinais ${ }^{15}$. Intensifica-se a extroversão do território pela via da recusa do local.

Certamente que existem esforços de pesquisa, mas eles ficam sujeitos às seletividades anteriores, o que apenas reforça as polarizações regionais e as carências científicas. Segundo Flávia Alves, os Estados ao norte do país, apesar de sua maior riqueza em plantas, são os que apresentam menor número de grupos envolvidos em pesquisas de plantas medicinais e medicamentos fitoterápicos (Alves, 2004, pp. 170-179) ${ }^{16}$.

Temos então mais um subsídio para denunciar o sistemático empobrecimento ao qual fica submetido o território brasileiro. Freqüentemente, votamos nossas inquietações à penúria monetária vivida pelas populações, o que merece, com efeito, ser objeto de medidas e políticas de reparação. Tudo não passará, porém, de paliativos se não se combatem pobrezas mais fundamentais, que se expressam territorialmente. No capítulo anterior buscamos demonstrar como os lugares, despojados de suas terapêuticas e marcas tradicionais, restam mais pobres. Agora, vemos que, em função de tendências normativas e tecnológicas mundiais, a riqueza da natureza primeira fica subitamente convertida em pobreza, já que se impõem dificuldades quanto à realização dos exames científicos previstos pela nova legislação sanitária17. "As modificações propostas na legislação vêm gradativamente dando características de produtos tecnológicos a produtos que realmente não o são, na sua essência" (Fonte, 2004, p. 95) ${ }^{18}$.

Novos empobrecimentos podem advir, já que, tendo sua produção baseada em plantas estrangeiras, o território nacional preenche-se de uma lógica passível de favorecer futuras investidas de agentes hegemônicos. Apesar de as produções sintéticas e biotecnológicas serem, hoje, mais interessantes para os laboratórios multinacionais, já vemos que eles têm presença notável no ramo de fitoterápicos. "[...] os medicamentos de origem vegetal mais vendidos são de laboratórios multinacionais e na quase totalidade são obtidos de plantas que não são nativas do Brasil" (Alves, 2004, p. 130) ${ }^{19}$.

\footnotetext{
${ }^{15}$ Em 1990, o Brasil exporta US\$ 2,2 milhões em plantas medicinais, e importa US\$ 2,7 milhões, o que faz um déficit de US\$ 500 mil. Em 2000, o Brasil exporta US\$ 5,7 milhões, e importa US\$ 6,7 milhões, o que faz um déficit de US\$ 1 milhão (Secex apud Fonte, 2004, p. 56).

16 "[...] os grupos de pesquisa estão concentrados principalmente nos Estados de São Paulo, Rio de Janeiro, Minas Gerais, Paraná, Santa Catarina e Rio Grande do Sul" (Alves, 2004, p. 176).

${ }^{17}$ Neste particular, é de extrema felicidade e precisão o comentário de Nilce Fonte: entre a fitoterapia como ramo industrial lucrativo e a fitoterapia como tratamento tradicional e mais barato, as legislações têm favorecido apenas a expansão da primeira (Fonte, 2004, p. 96).

18 "Não se questiona a exatidão na composição dos medicamentos, em absoluto, muito menos a rigidez exigida por legislação para estes produtos. Mas se questiona se este cuidado deve se estender para todos os produtos utilizados como medicamentos, ou seja, a mesma exigência para medicamentos químicos e medicamentos fitoterápicos”. (Fonte, 2004, p. 95)

${ }^{19}$ Em 1998, 68\% das vendas de fitoterápicos, no Brasil, concentram-se em 25 medicamentos, produzidos por grandes empresas, estrangeiras na maioria (IMS apud Alves, 2004, pp.130-134).
} 
Mas, além desses testes relativos ao lançamento de novos fitoterápicos, existe outro grupo de exames, que se banalizam mais rapidamente, pois dizem respeito aos medicamentos já presentes no mercado. Neste caso, a exigência de testes mais sofisticados vai também levar a novas relações com as universidades e com instituições particulares ${ }^{20}$.

Para os medicamentos fitoterápicos repete-se o fenômeno existente para os sintéticos: os laboratórios carecem, o mais das vezes, da estrutura permitindo a realização de exames mais complexos, os quais são contratados, sobretudo, junto às universidades estatais. Para os testes mais simples, são preponderantes as instituições particulares. Mas, quando se trata dos testes biológicos, envolvendo pesquisas clínicas em miniatura, são as universidades que vão atender a maior parte dessa demanda científica.

Desencadeados, esses serviços científicos vão alterar os ciclos de cooperação, bem como os conteúdos e funções dos vários lugares. No quadro VIII.1, queremos destacar essa divisão territorial do trabalho científico. É importante ressaltar que estamos em face, aqui, de forças diversas das estratégias das empresas transnacionais. Com isso, vê-se, no quadro VIII.1, que já não é o estado de São Paulo que aparece nos primeiros postos; e que já não pesam tanto as capitais dos estados, pois, mesmo em São Paulo, de suas 16 instituições entrevistadas, apenas 5 estão localizadas na capital, existindo mais 7 outras cidades realizando esse tipo de exame. O Ceará, graças à presença de sua universidade federal, surge como o estado de mais alta média mensal de realização dos testes em fitoterápicos. Além disso, a UFCE tem sido um centro importante para formação de profissionais que, mais tarde, podem ser mobilizados pelos pequenos laboratórios da região ${ }^{21}$.

\footnotetext{
${ }^{20}$ No mês de maio de 2003, as cinco principais instituições realizadoras de ensaios em medicamentos fitoterápicos no Brasil foram as seguintes: 1. Universidade Federal de Alfenas em associação com a Universidade Federal de Juiz de Fora; 2. O laboratório particular T\&E (Campinas-SP); 3. Universidade Estadual de Campinas; 4. O laboratório particular Bioagri (Piracicaba-SP); 5. Laboratório de Controle de Qualidade e Pesquisa (Curitiba-PR), empresa particular. Essa avaliação considerou 50 instituições que responderam a uma pesquisa promovida pela Agência Nacional de Vigilância Sanitária (Bicho, 2003, pp. 9-12 e 19).

${ }^{21}$ O Ravick (Fortaleza-CE) tem quatro funcionários com formação superior: 3 farmacêuticos e 1 administrador de empresas, todos formados pela UFCE. No Odaly Soares (Caucaia-CE), a diretora e farmacêutica responsável é formada em farmácia pela UFCE, com curso de especialização em indústria farmacêutica realizado em João Pessoa, na Paraíba. No Madrevita (Fortaleza-CE), dois farmacêuticos são formados pela UFCE.
} 
quadro VIII.1. Testes em medicamentos fitoterápicos: Médias de ensaios realizados por unidade da federação*,

e localização das instituições entrevistadas**: Brasil, maio de 2003

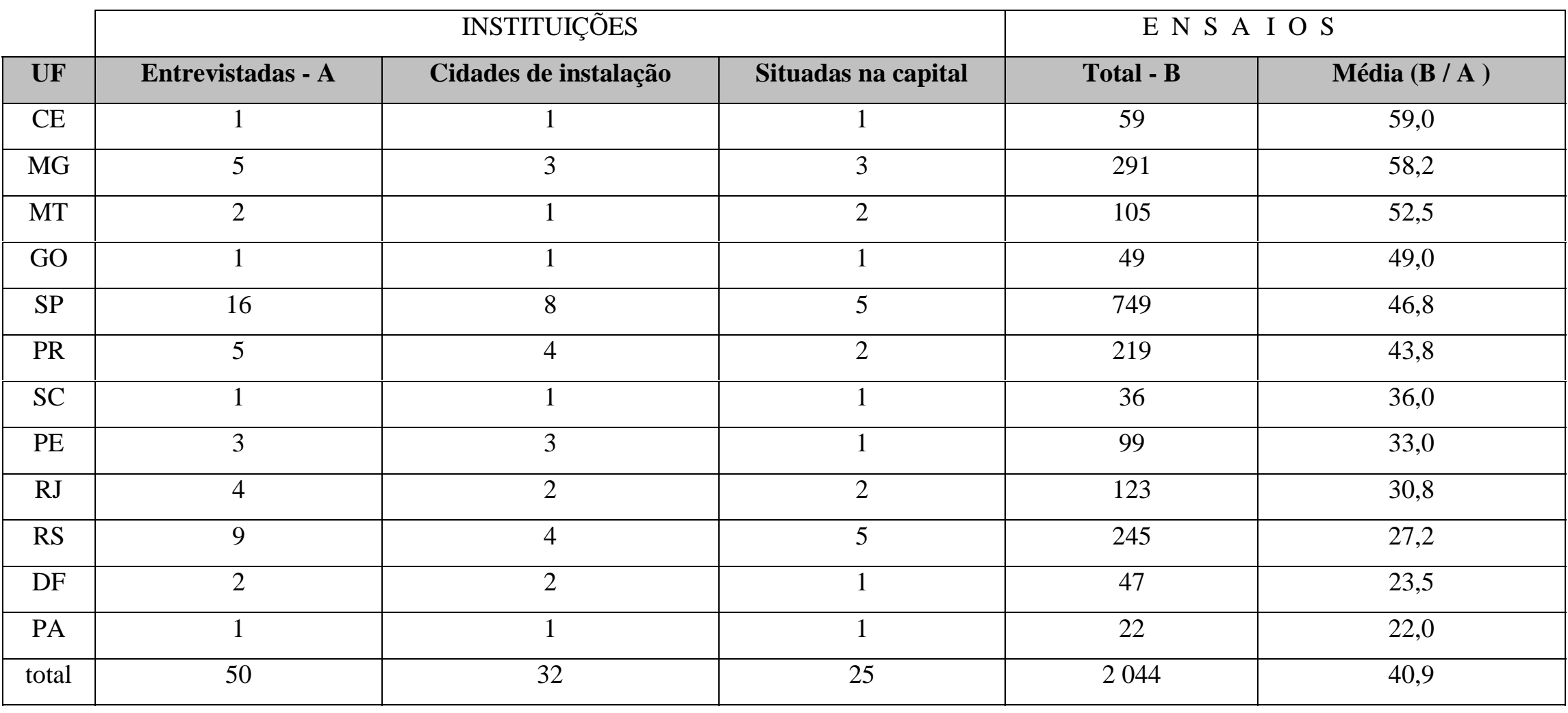

* Os laboratórios que participaram da pesquisa estavam situados apenas em doze unidades da federação

** 50 laboratórios responderam à pesquisa enviada pela Agência Nacional de Vigilância Sanitária

Fonte: elaboração própria com dados de Bicho, 2003, pp. 9-12 e p. 18 
Numa cidade como Fortaleza, em que terapêuticas tradicionais atravessam os tempos, a universidade tem-se convertido num motor científico que não permite a obsolescência cabal da atividade farmacêutica. Vale destacar o papel do Farmácia-Escola (Fortaleza-CE), órgão de apoio ao ensino farmacêutico do Departamento de Farmácia da UFCE, também sendo o laboratório oficial do estado de Ceará. Produzindo medicamentos desde os anos 1980, dispõe de uma pequena planta produtiva. A maior parte da produção destina-se ao complexo hospitalar da universidade e, em pequeno volume, às secretarias de saúde O Farmácia-Escola vende serviços de controle da qualidade e testes analíticos a alguns laboratórios particulares. As empresas que o procuram para esse tipo de serviço são, principalmente, laboratórios farmacêuticos do Ceará e dos estados mais próximos, como Pernambuco, Piauí ou mesmo a Bahia ${ }^{22}$.

Além da UFCE, merece destaque a Faculdade de Farmácia da Universidade Federal de Goiás, também responsável por vários exames em medicamentos fitoterápicos ${ }^{23}$.

O alargamento dos contextos reforça-se, pois que, não raro, as empresas vão encontrar menores preços noutros estados, em que passam, então, a testar seus produtos.

Essa nova aproximação entre laboratórios e universidades, fruto dos novos enquadramentos normativos, gera, por outro lado, um alargamento das escalas de possibilidade desses agentes marginais, pois que, assim, os pequenos laboratórios começam a ter acesso a atividades de pesquisa de que estavam, antes, completamente afastados. Então, aparecem parcerias para desenvolvimento de novos produtos, o que se verifica naquelas empresas que dispõem de um maior dinamismo. Podemos citar a parceria entre o Officinalis (Simões Filho-BA) e a Universidade Federal da Bahia; o Pronatus (Manaus-AM) e suas parcerias de pesquisa com a Universidade Federal do Amazonas e a Universidade Federal do Ceará; a parceria entre o Fitovida (Uberlândia-MG) e a Universidade Federal de Uberlândia.

Como tais parcerias não podem, muita vez, sustentar-se nos escassos capitais dos pequenos laboratórios, tornam-se fundamentais certos apoios estatais, que assim garantem esse tipo de relação. Em 2001, através do Programa de Biotecnologia e Recursos Genéticos, o Ministério da Ciência e Tecnologia, juntamente com o CNPq, apoiaram 33 projetos de pesquisa em fitoterápicos, envolvendo parceria entre uma universidade estatal e

\footnotetext{
${ }^{22}$ Também ligado ao Departamento de Farmácia da UFCE, encontramos o Cedefar, Centro de Desenvolvimento de Fármacos: O Cedefar vende aos laboratórios farmacêuticos particulares os seguintes serviços obrigatórios: controle da qualidade, teste de equivalência farmacêutica, testes analíticos. Entre setembro e dezembro de 2004, o Cedefar teve uma programação de cerca de 80 estudos por realizar. A maioria desses oitenta estudos são de equivalência farmacêutica, em medicamentos candidatos a genéricos.

${ }^{23}$ Os dados que apresentamos, relativos aos testes em medicamentos fitoterápicos, não os possuímos para os medicamentos sintéticos. Mesmo assim, vale ressaltar o valor dos dados utilizados, pois, como dissemos e diremos, os fitoterápicos têm sido produzidos, sobretudo, pelos pequenos laboratórios nacionais.
} 
um laboratório nacional, freqüentemente uma empresa pequena (CNPq apud Alves, 2004, p. 141 e 216$)^{24}$.

As universidades são fundamentais, pois que os laboratórios não podem, sozinhos, realizar pesquisas cuja duração pode chegar a três ou quatro anos. Por meio delas, os pequenos produtores de medicamentos podem realizar um novo consumo de normas científicas, aprimorando seus sistemas organizacionais. A venda desses serviços científicos mostra que, em decorrência das novas normas sanitárias, os pequenos laboratórios devem utilizar o território de maneira um pouco mais integral. Sintomaticamente, são as empresas mais recentes, ou aquelas que passaram por reestruturações administrativas, que têm conseguido fazer face, com mais eficácia, aos requisitos do período contemporâneo.

\section{Relações entre os dois níveis do circuito superior}

Se se trata de realizar uma geografia que se preocupa dos fluxos e das relações, é preciso adaptar nossa visão, pois, não raro, os fenômenos mais significativos apenas se esboçam, nas entrelinhas de fatos mais evidentes. É assim que, por exemplo, novas relações e totalizações espaciais vão-se afirmando, plenas de futuro ${ }^{25}$.

Por meio da análise dos círculos de cooperação podemos captar não apenas as unificações espaciais produzidas no interior do circuito superior marginal. É possível averiguar, também, de que modo a presença do circuito superior vai alimentar a existência do superior marginal, e inversamente. É essencial identificar esse fenômeno, pois sempre existe o perigo de pensar os circuitos da economia como entidades isoladas ${ }^{26}$.

Este ponto é fundamental, para que extirpemos de vez qualquer visão compartimentada, ou mesmo maniqueísta, dos circuitos econômicos. O superior e o superior marginal podem aparecer associadamente, o que se faz ainda mais provável nas maiores cidades. "Nas metrópoles, o circuito superior marginal pode ser taticamente um aliado do circuito superior quando e onde ambos formem um sistema baseado numa comunidade de interesses quanto à formação de preços e à partilha do mercado" (Santos, 1979, 2003, p. 179). Entre os dois níveis do circuito superior, os fenômenos predatórios são coevos dos fenômenos de simbiose.

\footnotetext{
${ }^{24}$ Considerando-se a sede da universidade, os projetos se distribuíram assim: 6 projetos em São Paulo; 5 no Paraná; 4 no Ceará e em Santa Catarina; 3 em Minas Gerais e no Rio de Janeiro; 2 no Pará e no Rio Grande do Sul; 1 projeto em Goiás, Maranhão, Pernambuco e Paraíba. O mais das vezes, o laboratório pertence ao mesmo estado que a universidade. Mas há exceções. (CNPq apud Alves, 2004, p. 141 e 216) Mesmo assim, os recursos destinados não são, por vezes, suficientes para que se chegue a resultados industriais (idem, 2004, p. 142).

25 “[...] descobrimos a cada instante novas ligações entre objetos que pareciam ficar para sempre separados; os fatos esparsos deixam de ser mutuamente estranhos; eles tendem a se ordenar numa síntese impositiva” (Poincaré, 1902, 1908, p. 202).

${ }^{26}$ Assim, não há dualismo: os dois circuitos têm a mesma origem, o mesmo conjunto de causas e são interligados (Santos, 1979, 2004, p. 56).
} 
Ensina Milton Santos que a demanda pela formação de um circuito superior marginal pode vir tanto do circuito inferior como do superior (Santos, 1979, 2004, p. 103). É justamente pelo fato de provir, simultaneamente, desses dois circuitos, que o superior marginal torna-se um mediador espacial. No capítulo precedente, quando abordamos o tema das densidades comunicacionais, buscamos indicar de que modo o superior marginal se apóia nos fenômenos que também geram o circuito inferior. É então momento de mostrar como ele se reforça, também, pelos fenômenos que geram o circuito superior.

Os círculos de cooperação podem estar configurados de maneira tal que passam a existir relações solidárias entre as maiores e as menores empresas. Desse modo, nem sempre é válido pensar que, em decorrência da instalação de um grande poder econômico, no lugar, as menores empresas deverão ter, forçosamente, sua situação piorada. Aqui, é interessante a história do Multilab (Porto Alegre/São Gerônimo-RS). Como dissemos no capítulo $\mathrm{V}$, esse laboratório se torna, após a lei dos genéricos, uma empresa de forte expressão, principalmente se se considera a região sul do país. Em função de seu novo dinamismo, o laboratório consegue manter uma estrutura de distribuição que a maioria dos produtores de medicamentos não é capaz de sustentar. Com isso, alguns pequenos laboratórios da região começam a recorrer às atividades de distribuição do Multilab, assim podendo expandir suas escalas de ação ${ }^{27}$.

As Integrações entre o circuito superior e o superior marginal multiplicam-se rapidamente. São quatro os fenômenos que pretendemos destacar.

Primeiramente, os pequenos laboratórios nacionais mais recentemente fundados, em vez de ter uma produção própria, estão-se especializando em vender etapas de produção. Seus clientes são pequenos laboratórios, mas principalmente os multinacionais. Estes, a instalar máquinas e setores para realizar etapas específicas, preferem contratar outra empresa que realiza essa atividade, o que Ihes permite uma redução de $\operatorname{custos}^{28}$.

A Colbras (Cotia-SP) vende serviços de produção, tendo nos laboratórios multinacionais seus maiores clientes; especializou-se numa tecnologia de cápsulas moles, de rara produção em território brasileiro. O Almapal (São Paulo-SP), fundado em 1982, presta serviços de produção. Produz apenas sob a forma de sólidos, que, já o vimos, requer processos que, relativamente à produção de líquidos, são mais sofisticados. O Almapal vende seus serviços tanto a laboratórios grandes como a pequenos. Os grandes laboratórios procuram a Almapal nos períodos de pico de produção ou em casos de

\footnotetext{
${ }^{27}$ O laboratório Klein (Porto Alegre-RS), por exemplo, tem no Multilab seu cliente exclusivo. Por meio dessa parceria, o Klein logra distribuir seus produtos por vários estados brasileiros.

${ }^{28}$ Na legislação, a terceirização é considerada como mudança do local da fabricação, e deve ser aprovada pela Anvisa. Pode ser total (todas as etapas da produção) ou parcial (algumas etapas).
} 
problemas em seus equipamentos; essas procuras são esporádicas e incertas ${ }^{29}$. Os pequenos laboratórios procuram o Almapal como forma de realização de suas estratégias produtivas rotineiras ${ }^{30}$.

Existem outras empresas que, mais ou menos como o Almapal, vendem serviços de produção de medicamentos: Blanver (Itapevi-SP), Serpac (São Paulo-SP), Blisfarma (Diadema-SP), Malavasi (Diadema-SP), Brascap (Sorocaba-SP), Laborpal (Santana de Parnaíba-SP). Tais empresas por vezes viabilizam a manutenção de certas linhas de pequenos produtores. Em face das carências tecnológicas das pequenas empresas, e de sua capacidade para mobilizar as forças dos lugares, vale indagar se não seria importante a criação de novos laboratórios oficiais que, em vez de manterem as organizações dos antigos, assumissem essa tática moderna de prestação de serviços, representando um grande cruzamento de ações, e permitindo o alargamento dos círculos de cooperação.

Um segundo fenômeno, típico das novas relações entre os circuitos superior e superior marginal, é a contratação de serviços, feita por laboratórios pequenos, junto às multinacionais. Sobretudo as etapas de produção mais sofisticadas, envolvendo o emprego de máquinas modernas, torna-se objeto dessas transações. O GeoLab (Anápolis-GO) compra serviços de encapsulamento junto à Pfizer (Estados Unidos, São Paulo-SP). No Viternat (São Paulo-SP), parte do encapsulamento é contratado junto a três laboratório situados na cidade de São Paulo: Cardinal, uma multinacional; Pick, laboratório suíço; e Helt, laboratório nacional; o encapsulamento contratado se refere a uma técnica denominada soft-gel, que é bastante cara.

Temos que atentar, simultaneamente, para dois aspectos. Por um lado, esse tipo de relação faz com que as grandes corporações submetam as pequenas empresas aos tempos e aos interesses que lhe são característicos ${ }^{31}$. Por outro lado, porém, deve-se considerar que também as pequenas empresas, por meio dessas relações, têm seus interesses viabilizados. Elas podem realizar suas táticas espaciais, convocando as grandes empresas, o que demonstra que, segundo a configuração do meio comum, também os agentes marginais dispõem de certa margem de escolha e criatividade.

\footnotetext{
${ }^{29}$ Exemplos de grandes laboratórios que usam com mais freqüência os serviços do Almapal: Wyeth (Estados Unidos, São Paulo-SP), Aché (Guarulhos-SP), Hexal (Alemanha, São Paulo-SP), Merck (Alemanha, Rio de Janeiro-RJ), Medley (São Paulo-SP), Apsen (São Paulo-SP).

${ }^{30}$ Os clientes mais freqüentes são os seguintes: Delta (São Paulo-SP), Bunker (São Paulo-SP), Caresse (Araçatuba-SP), Bionatus (São José do Rio Preto-SP), Laborsil (Natal-RN), Geyer (Porto Alegre-RS), Multilab (São Gerônimo-RS), Madrevita (Fortaleza-CE), Bergamo (Taboão da Serra-SP), Ariston (São Paulo-SP). Também alguns laboratórios oficiais aparecem no rol de clientes do Almapal: Iquego (Goiânia-GO), Funed (Belo Horizonte-MG), Furp (Guarulhos-SP), Laboratório da Aeronáutica (Rio de Janeiro-RJ), Farmanguinhos (Rio de Janeiro-RJ), Lafepe (Recife-PE).

31 "Para produzir modernamente, essas indústrias convocam outros atores a participar de suas ações hegemônicas, levados, desse modo, a agir segundo uma lógica subordinada à da firma global. No plano da produção, conflitos se eliminam e a modernidade se instala... à custa das empresas tributárias” (Santos e Silveira, 2001, 2004, p. 112).
} 
Ressaltamos um terceiro fenômeno. Algumas empresas, com acesso privilegiado a certas tecnologias, começam a vender serviços aos laboratórios farmacêuticos. Outra vez, a renovação normativa dá início ao processo espacial. Capanema e Palmeira Filho relatam que, pela RE 902 da Anvisa, editada em junho de 2003, fica obrigatória a feitura de um lote-piloto para aprovação do registro do medicamento (Capanema e Palmeira Filho, 2004, p. 37). Ora, a realização de um lote-piloto não é tarefa simples, já que se faz preciso uma certa pesquisa tecnológica, de modo a estabelecer os procedimentos ótimos, levando a uma pequena produção inicial, depois reproduzida em grandes escalas. A Colorcon (Cotia-SP) é uma empresa proveniente dos Estados Unidos, fundada em 1990, tendo chegado ao Brasil em 2001. Além de realizar uma distribuição de princípios ativos e insumos, desenvolve plantas-piloto para laboratórios farmacêuticos.

Os pequenos produtores de medicamentos, embora recorram a tais serviços com menos freqüência, ficam legalmente obrigados a utilizá-los vez por outra, sob pena de ver suas atividades paralisadas. O GeoLab (Anápolis-GO) vale-se dos insumos fornecidos pela Blanver (Cotia-SP), pelo Almapal (São Paulo-SP) e pela Colorcon (Cotia-SP). O Lafergs (Porto Alegre-RS), laboratório oficial do Rio Grande do Sul, tem cinco de seus medicamentos terceirizados junto ao laboratório paulista Blanver.

Destacamos finalmente um quarto aspecto. As relações entre as maiores e as menores empresas podem acontecer de maneira mais invisível, quando há uma migração de funcionários entre esses dois grupos de agentes. O gerente de operações industriais do laboratório Melcon (Anápolis-GO), antes de ser contratado por essa empresa, trabalhou em laboratórios multinacionais: Bristol Myers, Boehringer e Roche; também trabalhou em grandes empresas nacionais: EMS e Eurofarma. O proprietário da Amplomed (Manaus-AM), antes de fundar essa distribuidora, foi representante comercial, no Amazonas e em Roraima, destes laboratórios multinacionais: Merck, Bristol, Ciba-Geigy, Abott. Como atentamos, em nossa pesquisa de campo, sobretudo para a situação das menores empresas, não pudermos detectar um fluxo inverso, ou seja, pessoas passando dos pequenos aos maiores laboratórios. Entanto, é possível supor que esse tipo de migração também se dê.

As relações entre o circuito superior e o superior marginal podem ser bons parâmetros para que saibamos diferenciar as funções de cada cidade na formação socioespacial. Quando há, num lugar, intensas relações entre os circuitos, isso indica uma divisão do trabalho mais densa e uma vida de relações mais espessa. As empresas surtirão mais especializadas naquelas áreas que Milton Santos e María Laura Silveira caracterizaram como "áreas de maior espessura da divisão do trabalho" (Santos e Silveira, 2001, 2004, p. 37). É por isso que, o mais das vezes, as empresas fornecedoras de serviços de produção instalam-se em São Paulo: as infra-estruturas de informação e transporte, mais densificadas e sofisticadas nesse estado, favorecem as atividades de agentes cujo mister é 
nada mais nada menos que a relação. É por isso também que, nessas áreas de divisão do trabalho mais espessa, os laboratórios produtores podem ser, por assim dizer, menos completos, comprando os serviços de que não dispõem internamente. Já noutras cidades, como Salvador, Belém ou Manaus, os laboratórios são, não raro, mais completos, terceirizando apenas aquelas atividades que requerem grandes conteúdos tecnológicos.

Não basta, pois, apontar a existência de um circuito superior marginal na escala da formação socioespacial. É preciso atentar, ainda, para suas diversas formas de manifestação nos lugares ${ }^{32}$. Nas menores aglomerações urbanas, o superior marginal poderá cultivar temporalidades e ações mais independentes, o que já não se dá em grandes aglomerações, em que a maior divisão do trabalho vai disseminando uma temporalidade mais totalizadora. Por isso, Milton Santos ensina que, na "metrópole completa", o superior e o superior marginal estão muito próximos e se tornam quase complementares (Santos, 1979, 2004, p. 314). No próximo capítulo, buscamos uma diferenciação mais sistemática entre as formas do circuito superior marginal segundo as cidades.

Vemos então que, entre os dois níveis do circuito superior, pode haver comunicações diretas. Elas vão-se tornar possíveis também graças à normalização dos tempos realizada pelos bancos, os quais aparecem como agentes intermediários cruciais. Assim, é notável que os vários contatos de fornecimento e pagamento são, na imensa maioria das vezes, mediados pelos bancos. O sistema do boleto bancário transforma-se, quase, num procedimento universal, possibilitando as relações das várias empresas. O circuito superior marginal, como gerador e canal de riqueza, vai também ser alvejado pela ação canalizadora dos bancos. É nessa medida que Milton Santos (1979, 2004, p. 370) afirma que o circuito superior marginal, assim como o inferior, torna-se um canal por onde a poupança popular pode fluir rumo do circuito superior.

Mas, além das relações diretas, há relações indiretas entre os dois níveis do circuito superior. Várias possibilidades de uso do território são ditadas pelas formas de ação dos agentes hegemônicos. O mais das vezes, isso se expressa pelo preenchimento das lacunas deixadas pelas ações seletivas, próprias do circuito superior. Assim podemos interpretar o sentido da produção dos medicamentos fitoterápicos, os quais, até agora, pouco despertaram o interesse dos laboratórios multinacionais ${ }^{33}$. Mesmo tendo essa modesta expressão, e mesmo sendo açoitada por uma série de rígidas normas, a produção de fitoterápicos intensifica-se, ainda constituindo um refúgio para muito laboratório ${ }^{34}$.

\footnotetext{
32 "É freqüente encontrarem-se atividades do circuito superior marginal nas cidades intermediárias. Mas suas características e suas relações com outras atividades da cidade não são as mesmas que nas metrópoles” (Santos, 1979, 2004, p. 314).

${ }^{33}$ Em 1998, o mercado de fitoterápicos foi estimado em 5,5\% do mercado total de medicamentos no Brasil (Gazeta Mercantil apud Pereira, 2002, p. 17).

${ }^{34}$ Segundo dados de González, em 1994, para os laboratórios multinacionais, a participação dos fitoterápicos em suas vendas totais dificilmente superava os $20 \%$. Era o caso do alemão Knoll (22\%) e da Byk (21\%). Para os
} 
Facilmente encontramos, nos vários estados, laboratórios cuja produção principal, ou exclusiva, dedica-se aos medicamentos à base de plantas. O A\&C (Goiânia-GO), fundado em 2001, é um laboratório que produz apenas fitoterápicos. O Panizza (Taboão da SerraSP) produz medicamentos e cosméticos, sempre a partir de plantas.

A produção de oficinais é mais um caso de lacuna deixada pela ação dos grandes laboratórios, para os quais não se faz interessante reproduzir as fórmulas envelhecidas que a farmacopéia brasileira preconiza. O Diproquifar (Recife-PE) produz apenas oficinais. A JS (Feira de Santana-BA), distribuidora fundada em 1986, trabalha só com similares e oficinais; o maior volume de medicamentos destina-se ao interior da Bahia.

O circuito superior marginal, na produção de medicamentos, também é condicionado pelo circuito superior quando as pequenas empresas, copiando as fórmulas dos laboratórios inovadores, vão-se ocupar da produção dos chamados medicamentos similares. O Lafare (Olinda-PE) é um exemplo de empresa que produz apenas similares e oficinais.

Em seu esforço de adaptação e criação, os laboratórios mais recentemente fundados ou reestruturados vão consagrando táticas novas. Entre elas, duas táticas, que também são duas modalidades de uso do território, parecem ganhar mais força de futuro.

Primeiramente, algumas empresas tentam aproximar-se mais dos laboratórios multinacionais, comprando-Ihes ou vendendo-Ihes serviços. O laboratório Melcon, instalado no Distrito Agroindustrial de Anápolis (GO), foi fundado em 2003, mas apenas começou a produzir em 2005. A empresa não tem produto próprio: apenas terceiriza serviços de produção, e apenas no segmento de hormônios, como pílulas do dia seguinte ou repositores hormonais. Esse tipo de produção requer alguns equipamentos e instalações específicos. Por isso, há laboratórios que, em vez de fazer esses investimentos, preferem terceirizar a produção, seja em sua totalidade, seja em apenas algumas de suas etapas ${ }^{35}$.

A adoção de frações do processo produtivo das multinacionais, por parte dos pequenos laboratórios, configura aquilo que os economistas chamam de "desintegração vertical" da empresa multinacional. Esse fenômeno acentua as situações de dependência das menores empresas, que devem submeter-se às normas técnicas e aos tempos ditados pelas multinacionais ${ }^{36}$. Ao mesmo tempo, todavia, os menores laboratórios podem, por assim dizer, buscar refúgio na mansão científica das multinacionais. Pois, vendendo

\footnotetext{
maiores grupos, essa proporção é menor: 1\% para a Bristol Meyers Squibb; $13 \%$ para a Wellcome, $17 \%$ para a Merck. Já os os laboratórios de capital nacional apresentaram, nesse mesmo ano, proporções muito maiores: 100\% para a Barrenne (Rio de Janeiro-RJ); 100\% para o Cânone (Rio de Janeiro-RJ); 77\% para a Infabra (Rio de Janeiro-RJ); 68\% para o Fontovit (São Paulo-SP); 59\% para o Millet-Roux (Rio de Janeiro-RJ); 39\% para o Hebron (Recife-PE); 31\% para o Laboratório Catarinense (Joinville-SC) (González, 1999, p. 89).

${ }^{35} \mathrm{O}$ Melcon dá início às suas operações produzindo para o laboratório Neoquímica, também situado no distrito industrial. Mas fecha depois acordos com outras empresas: Merck (Estados Unidos, Jacarepaguá-RJ), Aché (Guarulhos-SP), Farmasa (São Paulo-SP), Cimed (MG).

${ }^{36}$ Sobre a desintegração vertical, George Benko escreveu: "Uma parceria se desenvolve no bojo da dominação hierárquica das empresas” (Benko, 1996, p. 143).
} 
serviços de produção, eles não precisam mais registrar produtos, realizar testes, elaborar dossiês científicos, tarefas de que se incumbem os verdadeiros proprietários dos medicamentos, as multinacionais. Aqui, essas pequenas empresas encontram, verdadeiramente, um vácuo normativo, em que, malgrado sua submissão tecnológica, podem-se refugiar.

Segundamente, algumas empresas estão buscando especializações acentuadas, atuando em sub-segmentos de segmentos farmacêuticos, em que evitam a concorrência da maioria dos laboratórios. O segmento de medicamentos oftalmológicos foi o objeto de especialização tanto do Ophthalmos (São Paulo-SP), fundado em 1985, como do Latinofarma (Cotia-SP), fundado na década de 1990, mas cuja produção começa apenas em 2002. Os medicamentos oftalmológicos formam, junto com os injetáveis, a classe dos produtos estéreis, os quais requerem condições especiais de produção. Eles demandam, portanto, maiores conteúdos técnicos, com a participação de profissionais especializados. Todas essas condições parecem reunir-se nas cidades mais dinâmicas ${ }^{37}$.

Mas, outras especialidades farmacêuticas, de produção mais simples, podem ser objeto de especializações parecidas. Foi assim que o Darrow (Rio de Janeiro-RJ), fundado em 1964, especializou-se no ramo dermatológico.

São tendências fortes que, mantidas, afastam o circuito superior marginal de suas possíveis ligações com o circuito inferior. Elas confirmam a hipótese levantada por Dupuy e Karsenty: "Tende-se [...] para uma estrutura onde coexistirão um certo número de grupos líderes em competição, agrupando as empresas de grande porte e, mais ou menos ligados a eles, os laboratórios menores e, geralmente, bastante especializados" (Dupuy e Karsenty, 1974, 1979, p. 61).

Mas essas especializações extremas podem adquirir outras espécies de manifestação, por vezes bastante engenhosas. Em Belém, por exemplo, o comércio de medicamentos foi dominado por grandes redes de farmácia, que dispõem de redes próprias de distribuição ${ }^{38}$. Com isso, distribuidores pequenos instalados em Belém devem realizar suas vendas exclusivamente junto aos hospitais (distribuidoras Compmed e Góes e Góes) ou junto a pequenas farmácias do interior do Pará (distribuidora Amazon Med) ${ }^{39}$.

Outra rica situação detectamos em Salvador (BA), com a distribuidora Fastmed, fundada em 2001. A empresa distribui apenas dois tipos de medicamentos: anestésicos

\footnotetext{
${ }^{37}$ Quanto aos medicamentos injetáveis, ou parenterais, são usados apenas em hospitais; são produzidos, no Brasil, por apenas 17 laboratórios, a maioria deles nacionais. São exemplos: Madrevita (Fortaleza-CE), Baxter (São Paulo-SP), Fresenius (Campinas-SP), Halex Istar (Goiânia-GO), Isofarma (Eusébio-CE).

${ }^{38}$ Em Belém, o mercado farmacêutico foi dominado, quase totalmente, por grandes redes, como a Extrafarma, a Takeda ou a Big Ben.

${ }^{39}$ Uma situação parecida é vivida, nas Minas Gerais, pela distribuidora Oriente (Uberlância-MG). Tendo sua sede em Ipatinga, e unidades em Belo Horizonte e em Uberlândia, a Oriente tem vendas expressivas no norte de Minas, uma região desprezada pela maior parte dos distribuidores, sobretudo os grandes.
} 
similares e antibióticos controlados, com tarja preta, medicamentos da linha hospitalar. Distribui tanto medicamentos de referência como genéricos ${ }^{40}$. Especializou-se no atendimento a pedidos esporádicos, de reposição dos estoques dos hospitais e clínicas, o que possibilita fugir à concorrência dos grandes laboratórios e distribuidores que tomam parte em licitações. A Fastmed opera apenas em território baiano, e numa faixa restrita desse território: Salvador e cidades vizinhas, como Feira de Santana ou Camaçari. Aqui, além de uma especialização mercadológica e territorial, estamos em face de uma verdadeira especialização temporal, visto que a empresa propõe-se a preencher as lacunas deixadas pelos processos de licitação, quando seus clientes precisam de entregas rápidas. Uma situação interessante em que uma distribuidora pequena prima, ao contrário das expectativas, pela rapidez, o que deve ser, contudo, contrapesado por sua restrita escala de ação.

Tais são as duas novas táticas surgidas no período presente. Os laboratórios se aproximam das empresas multinacionais, ou então procedem a especializações acentuadas. Nambos os casos, é preciso realizar um uso mais dinâmico do território. Aqui, o circuito superior marginal flerta com o circuito superior, seja através de relações diretas, seja cobrindo os buracos deixados pelas ações hegemônicas. O esquema VIII.1 pretende ilustrar os tipos de relações entre os dois níveis do superior entre si, e deles com o circuito inferior, para a atividade farmacêutica. Vale destacar que, por relações, entendemos a existência de fluxos, sejam eles materiais ou imateriais. As relações residuais seriam, assim, aquelas que se dão com menos freqüência, além de ser menos vitais para cada subtotalidade espacial.

Hoje, os imperativos de controle, emergentes no circuito superior, realizam-se, principalmente, pela vigilância normativa sobre o superior marginal. Quando eles se aproximam, a racionalidade instrumental difunde-se mais rapidamente pelo território, o que prejudica as situações próprias do circuito inferior. O que está em jogo é a viabilidade de atividades econômicas fundadas em densidades comunicacionais e nas forças do lugar. Uma gestão induzida do território tenta prevalecer sobre uma gestão espontânea.

\footnotetext{
${ }^{40}$ Os fornecedores da Fastmed são os seguintes laboratórios: Cristália (São Paulo-SP), Hypofarma (Ribeirão das Neves-MG), Ariston (SP), Bioquímica (RJ), Dermo (Rio de Janeiro-RJ), Asta Médica (SP) e Farmace (Barbalha$\mathrm{CE}$ ). A Fastmed distribui mais de cem produtos, cada um deles adquiridos e repassados em quantidades pequeninas. Seus clientes são apenas hospitais e clínicas.
} 
esquema VIII.1. Relações entre os circuitos econômicos na produção de medicamentos

espaço geográfico

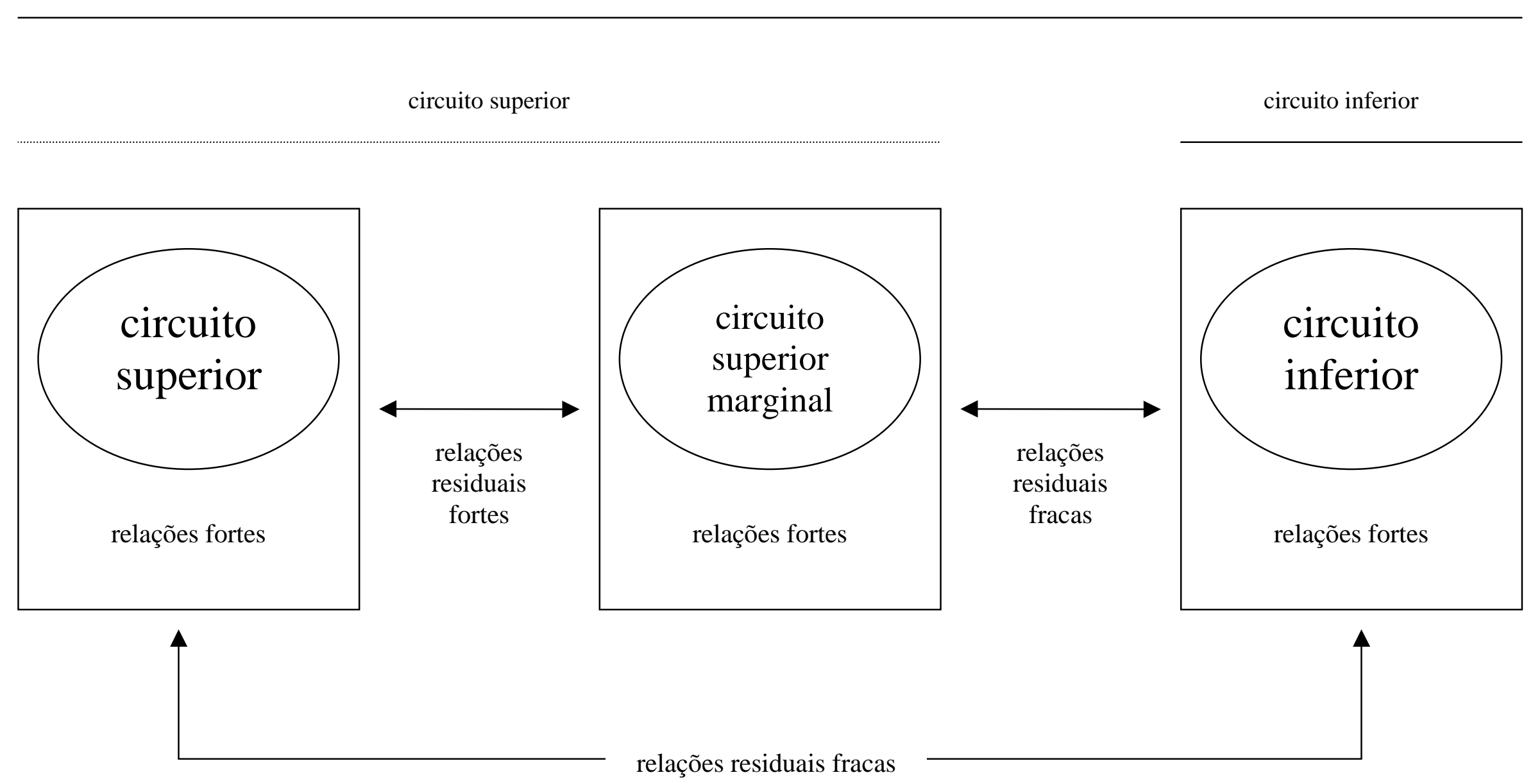




\section{A informação converte-se em norma}

No período precedente, o caráter revolucionário da informação deveu-se, em grande medida, ao fato de que ela estava extremamente concentrada entre os agentes hegemônicos. As novas sistematizações espaciais vão mudando o estado de coisas. Agora, os agentes marginais começam, porque assim deve ser garantida sua subsistência, a travar contatos mais freqüentes com empresas que, segundo expressão de María Laura Silveira, são empresas de informação (Silveira, 2003, p. 47).

Um primeiro aspecto, que deve ser cuidadosamente ressaltado, é que esses pequenos laboratórios se aproximam de uma atividade que, outrora, Ihes era bastante estranha: a consultoria. Com efeito, os primeiros movimentos de banalização das atividades de consultoria constituem um dos fenômenos mais marcantes do período contemporâneo. Ocorre que, perante a complexificação do território brasileiro e da própria atividade farmacêutica, o conhecimento intuitivo do mercado, a manutenção de usos tradicionais do território, não bastam para que um pequeno laboratório subsista. As mercadorias informacionais passam então a fazer parte do rol de carências dos pequenos laboratórios. É possível atender a essa necessidade na medida em que novos agentes, recentemente nascidos, vêm cumprir o papel de fornecer às pequenas empresas farmacêuticas um leque mais ou menos extenso de informações. Esses novos agentes aparecem sob três formas.

Primeiramente, alguns projetos estatais, por vezes ligados a iniciativas particulares, prestam uma assistência técnica e informacional a pequenas empresas. Quanto a isso, um bom exemplo é o Centro de Biotecnologia da Amazônia (CBA). O projeto visa formar um contexto local de empresas pesquisando e utilizando produtos naturais típicos da região. Encabeçado pelo Ministério da Ciência e Tecnologia, o projeto prevê um apoio às empresas de medicamentos. Os laboratórios selecionados gozam de acesso a linhas públicas de financiamento, além de um rol de informações sobre plantas e sobre mercados. O laboratório Pronatus (Manaus-AM) foi selecionado para o centro de incubação e desenvolvimento empresarial da área de fitoquímica e farmacologia do CBA. A participação nessa incubadora disponibiliza ao laboratório uma série de assessorias.

Assim, produz-se uma densidade informacional específica, por meio da qual pequenas empresas podem partir para um conhecimento mais sistemático das possibilidades do mercado e da técnica.

Segundamente, algumas redes de farmácia e grandes empresas distribuidoras passam a vender serviços informacionais. Um exemplo nos vem da distribuidora Panarelo (Goiânia-GO). "A empresa começa a vender informações sobre os destinos e os volumes exatos dos remédios que distribui por todo o País. A rede paulista Droga Raia abriu trilha semelhante [...], com o fornecimento, para laboratórios, de seus dados comerciais [...] $\mathrm{O}$ 
conteúdo mais valioso comercializado pela Droga Raia é o que está contido nas receitas médicas que chegam até suas lojas. Os laboratórios querem saber quais são os médicos que prescreveram ou ignoraram seus produtos para avaliar o trabalho de seus divulgadores e compensar deficiências" (Vilardaga, 2002, p. C2). No bojo de uma tendência maior, farmácias e distribuidores aproximam-se das atividades de consultoria ${ }^{41}$. Certamente que as maiores empresas vão ser os consumidores mais freqüentes dessas informações. Entanto, como se multiplicam os consultores, e como se difunde a necessidade de informações, os preços tendem a cair, tornando-se abordáveis pelos pequenos laboratórios. Assim, farmácias e distribuidores contribuem para a banalização das informações e das tecnologias informacionais entre os agentes ligados à atividade farmacêutica ${ }^{42}$.

Em terceiro lugar, surgiram pequenas empresas de consultoria que, elas sim, voltam-se particularmente para os pequenos laboratórios. São exemplos a Consulfarma (Campinas-SP), a All Pharma (Araraquara-SP), a Pharmanet (Rio de Janeiro-RJ), a Theriaga (Belo Horizonte-MG). Ao contrário do que anteriormente se deu, essas novas consultorias podem ficar menos concentradas, já que sua existência vai-se apoiar em pequenas empresas produtoras, espalhadas pelo território. "Entre as grandes empresas de consultoria, cuja escala de atuação compreende todo o planeta, existem ricos mercados locais onde pequenas empresas também operam de modo mais personalizado" (Bernardes, 2001,2004 , p. 422). As mercadorias informacionais que elas oferecem abrangem uma gama larga, desde apoio técnico para obtenção do certificado de boas práticas de fabricação, até uma atualização sobre as resoluções da Anvisa. Aliás, este serviço torna-se cada vez mais necessário, pois que as resoluções sanitárias sucedem-se rapidamente, e os pequenos laboratórios não dispõem, com freqüência, de funcionários ou setores incumbidos de acompanhar essas renovações normativas. Assim, as pequenas consultorias vão contribuir para a banalização dos serviços legais de que nos fala Yves Dezalay (1999, pp. 298-299).

Assim como já se dá com as pequenas farmácias e os pequenos distribuidores, essas consultorias novas podem reforçar as relações fortes que se desenrolam dentro do circuito superior marginal. Pode-se mesmo pensar num circuito superior marginal informacional. María Laura Silveira diz que a chegada de "novos objetos e novas formas de fazer" gera uma série de escritórios e empresas prestando serviço a outras empresas, formando assim "[...] um novo circuito superior marginal, embrenhado em codificar e

\footnotetext{
${ }^{41}$ Conforme Adriana Bernardes, as atividades de consultoria atraem várias espécies de empresas: gabinetes de auditoria, escritórios de contabilidade e advocacia, serviços de informática, agências de informação, sociedades de comunicação, bancos, institutos de planejamento econômico, entre outros (Bernardes, 2001, 2004, p. 421). A venda de informação por farmácias e distribuidores faz prova de um estágio avançado desse processo.

${ }^{42}$ Podemos citar o caso da Profarma (Rio de Janeiro-RJ), um dos maiores distribuidores nacionais. A Profarma costuma realizar promoções, num esforço para vencer as concorrências. Entre essas promoções, encontramos um incentivo ao contato entre empresas de informática e farmácias, de modo que estas últimas tenham seus estoques e suas operações informatizados.
} 
decodificar os objetos e as normas necessárias ao novo momento do modo de produção" (Silveira, 2004, pp. 66-67).

Também se pode sublinhar, aqui, o papel da Associação dos Laboratórios Farmacêuticos Nacionais (Alanac). A instituição oferece aos associados diversos serviços, com freqüência próximos de atividades informacionais ${ }^{43}$. Assim, forma-se mais um pólo emissor de informações, ao dispor de agentes nacionais.

É de suma necessidade ressaltar que essa banalização primitiva dos recursos informacionais descansa, em larga medida, em fatores técnicos. As novas tecnologias da informação tornam-se, ao mesmo tempo, mais baratas e mais doces, isto é, mais maleáveis às diversas condições de uso. A internet bem representa essas tendências. Aliás, a emersão de muitas pequenas consultorias farmacêuticas não seria possível sem a maleabilidade informacional permitida pela internet. Nessas pequenas empresas informacionais, a internet converte-se na principal ferramenta de trabalho. E também os laboratórios produtores aprendem a lidar com os recursos disponíveis na rede. No Rio Grande do Sul, em 2001, dos 28 laboratórios entrevistados por Maria Aparecida Pereira, 11 referiram as consultas a bancos de dados na internet como forma de atualização em relação às tecnologias (Pereira, 2002, p. 96).

Já se podem constatar os efeitos decisivos da operação das pequenas consultorias farmacêuticas. Foi a consultoria ATM (Goiânia-GO) que indicou ao laboratório Melcon (Anápolis-GO) a estratégia de prestar serviços de produção a outros laboratórios, em vez de possuir produtos próprios. No momento em que se decidiu a montar um laboratório produtor, o proprietário do laboratório Med Farma (Uberlândia-MG) contratou os serviços de uma consultoria ligada à Unaerp, Universidade de Ribeirão Preto. A consultoria elaborou então um relatório, que indicava, basicamente, telefones e endereços eletrônicos por meio dos quais a Med Farma poderia encontrar os diversos serviços de que precisaria, desde insumos de produção até equipamentos.

Em certas situações, o recurso a consultores passa ao rol dos gastos freqüentes de pequenos laboratórios. O Natulab (Santo Antonio de Jesus-BA), para aquisição das boas práticas de fabricação, orientação das formulações, melhoramento tecnológico e melhoramento dos processos, recorre a técnicos e consultores, o que eleva seus custos. A

43 Alguns serviços fornecidos pela Alanac: assistência técnica; representação junto à Febrafarma; acompanhamento do Diário Oficial da União, no qual se publicam as legislações sanitárias; assessoria em comércio exterior; bancos de dados de patentes, a partir dos dados do Instituto Nacional de Propriedade Industrial, nisto incluindo as informações tecnológicas contidas nos documentos de patentes; projeto de patentes, auxiliando os possíveis depósitos; pesquisa de produtos, gratuita para as sondagens mais simples e paga para as sondagens mais detalhadas; palestras, seminários, debates, workshops; notícias do setor farmacêutico. 
consultoria, no dizer do diretor comercial, é sempre "importada": o mais das vezes da cidade de São Paulo; outras vezes, de Fortaleza ${ }^{44}$.

O surgimento das pequenas consultorias deve-se, em grande medida, às carências informacionais que, por sua vez, nascem dos constrangimentos impostos pelo novo quadro normativo. Assim, reedita-se na produção de medicamentos aquele fenômeno apontado por Yves Dezalay: há consultores interessados em seduzir pequenas e médias empresas (Dezalay, 1999, pp. 301-302).

Outras atividades e eventos ajudam a disseminar um consumo informacional mais vasto. Assim, as feiras dedicadas à atividade farmacêutica. Entre elas, a FCE Pharma, realizada anualmente na cidade de São Paulo, tornou-se bastante conhecida em meio às empresas farmacêuticas ${ }^{45}$. Vale destacar ainda o Congresso Brasileiro de Medicamentos Genéricos, que se realiza na cidade de Caldas Novas (GO).

É certo que a cidade de São Paulo tenderá a reunir o maior número de feiras, congressos e outros eventos, já que oferece melhores estruturas de circulação, além de uma rede hoteleira mais sofisticada. Porém, já é possível notar uma dispersão desses eventos, que se realizam em várias cidades brasileiras.

Num período em que os laboratórios são levados a estender suas escalas de ação, as feiras são importantes para que novas relações sejam iniciadas. A Fracionata (Porto Alegre-RS) distribui princípios ativos para medicamentos, produtos veterinários e cosméticos. A empresa começa a fazer importações diretas de princípios ativos farmacêuticos indianos depois que seu comprador fechou acordo por ocasião da FCE Pharma.

As empresas também têm acesso à informação por meio de revistas especializadas, cujo número vai-se ampliando ${ }^{46}$. No quadro VIII.2, voltamos a destacar o papel das universidades, agora como editoras de revistas voltadas ao ramo farmacêutico. Em grande medida, isso tem relação com a nova fonte de divisas que elas têm ao se aproximar dos laboratórios.

\footnotetext{
${ }^{44}$ O laboratório Madrevita (Fortaleza-CE) utiliza várias consultorias; os setores financeiro e de recursos humanos costumam recorrer a consultores de Fortaleza; o departamento de recursos humanos tem sessões semanais de consultoria; a montagem do novo sistema de tratamento de água foi feita com auxílio de consultores paulistanos; e a própria adequação do laboratório, sua reestruturação material, foi planejada por uma empresa de consultoria da cidade de São Paulo.

${ }^{45}$ Citamos outras feiras farmacêuticas: Farma Expo (São Paulo-SP), Techno Plus (São Paulo-SP), Expofar (São Paulo-SP), Feirafarma (Rio de Janeiro-RJ), Expofarma (Fortaleza-CE), Fepefarma (Recife-PE), Boafarma (Salvador-BA).

${ }^{46}$ De um levantamento em que se detectou a presença de 27 revistas farmacêuticas, 6 tinham periodicidade bimestral; 2 tinham periodicidade trimestral; 1 quadrimestral; 9 semestral; 6 anual; e 3 tinham periodicidade desconhecida (ISSN).
} 
quadro VIII.2. Algumas revistas de publicação corrente de interesse para a atividade farmacêutica, segundo os estados de publicação e a natureza do editor: Brasil, 2005

\begin{tabular}{|c|c|c|c|c|c|}
\hline & & & RESPONSÁVEL & & \\
\hline UF & Total & Universidade & Laboratório farmacêutico & Editora & Institutos e sociedades \\
\hline SP & 13 & 7 & 1 & 2 & 3 \\
\hline RJ & 4 & 1 & ---- & 1 & 2 \\
\hline MG & 1 & 1 & --- & --- & --- \\
\hline ES & --- & --- & --- & --- & --- \\
\hline PR & 2 & 2 & --- & --- & --- \\
\hline $\mathrm{SC}$ & --- & --- & --- & --- & --- \\
\hline RS & 1 & 1 & --- & --- & --- \\
\hline MT & --- & --- & --- & --- & --- \\
\hline MS & --- & --- & --- & --- & --- \\
\hline GO & 1 & 1 & --- & --- & --- \\
\hline $\mathrm{DF}$ & 3 & --- & --- & 1 & 2 \\
\hline TO & --- & --- & --- & --- & --- \\
\hline MA & --- & --- & --- & --- & --- \\
\hline PI & --- & --- & --- & --- & --- \\
\hline $\mathrm{CE}$ & 1 & --- & --- & --- & 1 \\
\hline RN & --- & --- & --- & --- & --- \\
\hline PB & 1 & 1 & --- & --- & --- \\
\hline $\mathrm{PE}$ & --- & --- & --- & --- & --- \\
\hline $\mathrm{AL}$ & --- & --- & --- & --- & --- \\
\hline $\mathrm{BA}$ & --- & --- & --- & --- & --- \\
\hline PA & --- & --- & --- & --- & --- \\
\hline AP & --- & --- & --- & --- & --- \\
\hline RR & --- & --- & --- & --- & --- \\
\hline AM & --- & --- & --- & --- & --- \\
\hline $\mathrm{AC}$ & --- & --- & --- & --- & --- \\
\hline RO & --- & --- & --- & --- & --- \\
\hline Brasil & 27 & 14 & 1 & 4 & 8 \\
\hline
\end{tabular}

processamento das informações: Edilson Bicudo

fonte: elaboração própria, com dados solicitados junto ao ISSN 
Uma vez que sua aquisição representa baixos custos, as revistas são fontes de informação bastante usadas pelas empresas produtoras de medicamentos ${ }^{47}$. Além dessa função de atualização, as revistas são canais de propaganda. O Halex Istar (Goiânia-GO) faz anúncios esporádicos em revistas especializadas. A Farmoquímica (Rio de Janeiro-RJ), além de realizar anúncios em revistas especializadas, produz sua própria publicação, o Caderno Terapêutico, que é preparado em conjunto pela divisão médica e pelo departamento de marketing, e é distribuído pelos representantes comerciais.

Através dos serviços vendidos por agências de propaganda, os laboratórios também se aproximam das mercadorias informacionais. Mais uma vez, o circuito superior marginal pode expressar-se de maneira completa, já que se mobilizam, com freqüência, pequenas agências instaladas na mesma cidade em que estão os laboratórios, ou em capitais próximas; além disso, mídias locais propagam as campanhas assim elaboradas. O Laperli (Recife-PE) encomendou a elaboração de três pequenos comerciais para divulgar seu principal medicamento, o Sanativo; esses filmes, preparados pela agência recifense Duplo A, foram transmitidos por redes locais de televisão. O Panizza (Taboão da Serra) contratou uma empresa de propaganda da cidade de São Paulo, responsável por elaborar campanhas voltadas, sobretudo, para os comerciantes de fitoterápicos.

As feiras farmacêuticas, as revistas especializadas e as agências de publicidade mostram que, a despeito das concentrações espaciais, que persistem, há forças dispersivas permitindo a emersão de cada uma dessas atividades em vários lugares. Mais do que isso, pode haver, neles, uma integração de ações marginais, em verdadeiros círculos de cooperação. Para isso, as concentrações urbanas regionais (cidades intermediárias) passam a desempenhar um papel central, pois, com base nelas, as pequenas empresas não precisam recorrer, em todos os momentos, à metrópole nacional ${ }^{48}$. De feito, as concentrações regionais, como Fortaleza, Goiânia, Manaus, Belém, vão reunir serviços essenciais, como os de publicidade, já que eles, muita vez, raramente vão aparecer em aglomerações menores ${ }^{49}$.

O consumo de informações, além de generalizado, vai-se tornando impositivo, pois que, sem elas, os laboratórios têm agora menos possibilidades de boa manutenção. A informação se torna uma fase necessária do trabalho, condicionando-o, normatizando-o. Por

\footnotetext{
${ }^{47}$ No Rio Grande do Sul, em 2001, 28 laboratórios indicaram suas formas de atualização em relação às tecnologias; 24 referiram os cursos; 23, as feiras; 23, os congressos e eventos; 22, as revistas especializadas (Pereira, 2002, p. 96).

48 "Quando as indústrias são voltadas para o mercado interno, podem demandar mais serviços à cidade em que estão instaladas. As indústrias ‘marginais’ [...] dependem ainda mais dos serviços locais” (Santos, 1979, 2004, p. 347).

49 “A instalação de inúmeros serviços é função de um meio particular, que não pode ser encontrado abaixo de um nível de atividade geral” (Santos, 1979, 2004, p. 348).
} 
outro lado, esse trato com as normas informacionais faz com que os sistemas organizacionais fiquem mais sofisticados, pois que as pequenas empresas, embora contando com informações menos estratégicas, já podem possuir mais que um simples conhecimento empírico, intuitivo, do território ${ }^{50}$.

Ora, essa nova possibilidade se realiza na medida em que as técnicas se adoçam. Por técnicas doces, expressão cunhada por Milton Santos, entendemos todo esse conjunto de modernas tecnologias cujos usos se tornam menos rígidos, podendo acontecer em várias atividades, empresas, lugares, contextos.

É assim que as novas tecnologias da informação já podem ser largamente usadas por pequenas empresas farmacêuticas. O estoque da Reydrogas (Goiânia-GO) foi informatizado. O programa de computador foi desenvolvido pela própria empresa, em seu setor de informática. Desse modo, é possível um giro intenso de produtos, necessário porque, às vezes, por exemplo, uma mesma drogaria pode fazer até dez pedidos diferentes num só dia. Os vendedores da distribuidora Navarro (São Paulo-SP), utilizam palm tops para transmitir as encomendas eletronicamente ${ }^{51}$.

A novidade do período é que a informação vai-se impondo, cada vez mais, como um elemento necessário do processo produtivo. Desprezando-o, o laboratório vai curtir um descompasso em relação às situações que podem garantir sua subsistência. Daí, falarmos em normas informacionais. Num período em que as normas jurídicas se sucedem com rapidez, exigindo novos procedimentos e usos, é preciso dedicar-se a um crescente consumo de informações. "Informar e organizar são, pois, ações correlatas e essenciais da trama de eventos da globalização" (Bernardes, 2001, p. 7).

Nas empresas, essas duas tarefas (consumo de normas jurídicas e consumo de normas informacionais) vão-se misturando profundamente. É interessante a situação do Vitapan (Anápolis-GO): o laboratório criou um departamento de assuntos regulatórios, que se dedica exclusivamente aos registros de medicamentos e a todos os processos burocráticos relacionados com a vigilância sanitária ${ }^{52}$.

\footnotetext{
50 “"...] melhor do que tentar furar o segredo que cerca certas informações muito precisas, cujo interesse é acima de tudo bastante conjuntural, é dispor de um método que permita organizar uma massa confusa de informações parciais [...]" (Lacoste, 1976, 1997, p. 51).

${ }^{51}$ A distribuidora Oriente (Uberlândia-MG) possui um corpo de 73 vendedores. Eles entregam folhetos em farmácias e recolhem as encomendas. Para esse último trabalho, estão munidos de palm tops, com os quais podem consultar, em tempo real, o estoque da empresa, e enviar eletronicamente os pedidos. O diretor comercial da empresa, formado em sistemas da informação, por uma universidade de Governador Valadares, desenvolveu o programa que permite o controle do estoque. Além disso, através de um contrato com a Embratel, os três bancos de dados das três unidades (a sede de Ipatinga, mais as unidades de Belo Horizonte e Uberlândia) foram interligados.

${ }^{52}$ Em razão das constantes renovações normativas por que passa a atividade farmacêutica, o Madrevita (Fortaleza-CE) contratou uma farmacêutica para cuidar dos assuntos regulatórios. Sua função é fazer com que a empresa possa acolher rapidamente as novas resoluções, conforme forem elas aparecendo, e atualizar as documentações e os registros dos produtos. Para tanto, é preciso consultar constantemente o site da Anvisa, de modo a saber se houve modificações normativas.
} 
Aqui, portanto, vemos casos didáticos, em que o trabalho informacional confunde-se com o trabalho jurídico. Mais do que isso, para tratar das normas jurídicas e informacionais, as empresas podem mobilizar farmacêuticos, que saberão lidar também com as normas científicas tão abundantes na atividade.

Mas, quando são incapazes de internalizar esses trabalhos jurídico-informacionais, as pequenas empresas podem contratá-los alhures. De novo, as aglomerações urbanas regionais mostram sua relevância. Para assessoria jurídica, o São Lucas (Belém-PA) contrata uma empresa de advocacia de Belém. O laboratório Sanífer (Porto Alegre-RS), por não ter um setor jurídico, contrata uma consultoria situada na cidade do Rio de Janeiro. Um escritório situado em Salvador tem contrato de assessoria jurídica fechado com o Natulab (Santo Antonio de Jesus-BA). Fenômeno parecido acontece para os serviços de contabilidade ${ }^{53}$.

María Laura Silveira diz haver "[...] de um lado, uma informação destinada à produção e, de outro, uma nova informação banal" (Silveira, 1996, 1999, p. 206). No superior marginal, esses dois tipos de informação começam a misturar-se.

A informação se impõe como fator de produção compulsório. Nessa medida, ela própria se converte em norma. Não queremos negar a relevância que a informação ainda possui, tampouco a hierarquização que se realiza em função dela. "Muito custosas, são praticamente as grandes empresas que conseguem obter as informações mais importantes, isto é, aquelas informações que previnem riscos, antecipam lucros, sugerem comportamentos, inovam a produção" (Bernardes, 2001, p. 112). Entanto, esses efeitos hierarquizantes acontecem, principalmente, como um resquício do período precedente ${ }^{54}$.

Agora, o papel mais típico da informação, nos sistemas espaciais já não parece ser o de manter, por si própria, as condições de hegemonia. Agora, ela participa da vigilância normativa que, desde o circuito superior, dissemina-se pelo território. Daí, seus sucessivos movimentos de banalização.

Por um lado, os agentes marginais passam a ter acesso a novas e inéditas mercadorias e tecnologias informacionais, graças ao surgimento desses "serviços intersticiais" identificados por María Laura Silveira (1996, 1999, p. 327). Por outro lado, os próprios agentes hegemônicos passam a fazer, da informação, usos menos estratégicos. É assim que eles, na tentativa de conferir matizes mais objetivos a seus interesses, começam a recorrer a institutos de pesquisa, que lhes vão produzir subsídios informacionais para seus

\footnotetext{
53 A distribuidora Alefarma (Ananindeua-PA) contrata um escritório de contabilidade em Ananindeua. O laboratório A\&C (Taboão da Serra-SP) vale-se dos serviços de um escritório de contabilidade situado na cidade de São Paulo. A distribuidora Amplomed (Manus-AM) contrata, para a contabilidade, uma empresa de Manaus.

54 “[...] em uma fase de transição, as estruturas vindas do passado, ainda que parcialmente renovadas, tenderão a continuar reproduzindo o todo tal como era na fase precedente” (Santos, 1982, 2004, p. 75).
} 
discursos ${ }^{55}$. Assim, os grandes laboratórios já rotinizaram seus altos consumos informacionais, referentes ao conhecimento dos mercados e dos territórios. Ora, esse conhecimento é que se banaliza, ainda que de modo imperfeito e primitivo. O que é novo, é que as multinacionais, ao recorrer às empresas produtoras de informação, demandam pesquisas e estatísticas, a partir das quais vão pressionar os governos, em busca, justamente, de mais normas.

Com essa banalização dos serviços informaconais, os sistemas organizacionais do circuito superior e os do circuito superior marginal, ainda que mantenham suas especificidades, aproximam-se um pouco mais ${ }^{56}$. Ao longo desse processo, os tempos da produção ficam notavelmente acelerados, pois tal deve ser, necessariamente, os efeitos de uma incorporação mais intensiva de informações nas atividades produtivas. "Com efeito, a informação será tanto mais útil, numa regulação, quanto menor for o atraso com que ela intervenha" (Simondon, 1958, 1969, p. 133) ${ }^{57}$. Assim, a própria temporalidade do circuito superior marginal se aproxima daquela que se expressa no superior.

Mais do que uma simples difusão de serviços e procedimentos, estamos em face da difusão da racionalidade instrumental, gerada no circuito superior. Cabe ressaltar que a disseminação dessas lógicas repousa nos fenômenos havidos no período anterior, quando o território foi modificado em favor de uma circulação mais larga das informações ${ }^{58}$.

Se a norma ganha a precedência no sistema espacial, é possível reconhecer que ela aparece, muita vez, sob a forma de informação. Nesses termos, as palavras de Jacques Ellul aparecem, hoje, com força de vaticínio: "Não é suficiente seguir, meramente, o curso dos dados estatísticos. É necessário erigir anteriormente um sistema de normas de progressão dos elementos de um dado sistema econômico, permitindo, a cada momento, estimar a divergência de cada elemento do sistema em relação à norma" (Ellul, 1954, 1964, p. 171).

\footnotetext{
55 Aqui, citamos apenas um exemplo. Em 2004, a Associação da Indústria Farmacêutica de Pesquisa (Interfarma), que reúne os laboratórios multinacionais, encomendou uma pesquisa ao BCG, Boston Consult Group, empresa estadunidense especializada em consultoria. A pesquisa mostrou que há uma evasão de divisas no setor farmacêutico brasileiro, por meio de sonegação e de venda de produtos não registrados na Anvisa. A Interfarma diz que isso é reflexo da alta carga tributária que pesa sobre a indústria farmacêutica no Brasil (Gazeta Mercantil, 22-12-04, p. A10).

${ }_{56}$ Paula Baran e Paul Sweezy dizem que as grandes corporações espalham um “ethos racionalista”, disseminado junto com os métodos de gestão: “[...] contabilidade, orçamento, processamento de dados, consultoria administrativa, operações de pesquisa, e muito mais” (Baran e Sweezy, 1966, p. 59).

57 "Os bancos de informação constituem sobretudo um dado constitutivo do tempo, na medida em que sua utilização permite uma nova aceleração” (Silveira, 1996, 1999, p. 208).

${ }^{58}$ Conforme Cilene Gomes, as infra-estruturas de informação difundiram-se por todo o território nacional, a partir dos anos 1970, muito embora as disparidades e as concentrações regionais tenham-se ampliado (Gomes, 2001, 2004).
} 
Assim, as normas garantem uma certa coerência das sistematizações espaciais hegemônicas, pelo extensão dos círculos de cooperação ${ }^{59}$.

Em 1993, Milton Santos afirmou que a urbanização da sociedade estava consolidada, restando processar-se a urbanização do território (Santos, 1993, 2005a). Ora, após as profundas mudanças territoriais havidas ao longo da década de 1990, é possível concluir que também a urbanização do território encontra-se, agora, em fases bem avançadas. Por esse motivo, podem surgir novas relações entre várias cidades, por vezes fora do velho eixo Rio-São Paulo. Por esse motivo também, podemos apontar a constituição de um novo período histórico, em que o território se rege, mais do que nunca, pelas lógicas urbanas. Novas possibilidades se apresentam, muito embora constatemos que, o mais das vezes, as evoluções espaciais apontam para a prevalência da racionalidade instrumental, que é típica dos agentes hegemônicos.

\footnotetext{
59 “Como hoje aumenta a repartição do trabalho no território, ao sabor das vocações técnicas e normativas das regiões, cresce também a necessidade de unir o trabalho segmentado. É a cooperação que une as etapas do trabalho e, assim, entretece círculos no território” (Santos e Silveira, 2001, 2004, p. 270).
} 
IX

Os circuitos econômicos e as escalas temporais

Tempo e território

Em discursos e políticas, oficiais ou oficiosas, a idéia de progresso, de desenvolvimento, é com freqüência brandida como fora a redenção de todos os males. Entanto, cabe contestar essa noção, que remete a uma evolução temporal contínua e homogênea, como se todos os elementos do sistema socioespacial evoluíssem conjuntamente nos esquemas capitalistas. "[...] o tempo é tomado como algo de maciço, uno, apenas fisicamente divisível. E, quando se fala em tempo social, é freqüente a ilusão de pensar que uma sociedade inteira funciona segundo uma única medida de tempo" (Santos, 1978, 2005, p. 64) ${ }^{1}$.

Bem ao contrário de uma suposta homogeneização dos tempos, verifica-se uma divisão dos subespaços e dos agentes, cada qual submetido a sua temporalidade própria. A formação socioespacial pode ser pensada como uma certa combinação de específicas temporalidades ${ }^{2}$.

No capítulo VII, buscamos demonstrar que as diferentes empresas procedem a divisões do trabalho que Ihes são particulares. Ora, essa definição vai levar, exatamente, a uma temporalidade ${ }^{3}$. Nesses termos, pode-se passar, de uma concepção absoluta do tempo, a uma concepção mais relativística, o tempo visto como um conjunto de relações ${ }^{4}$. "O tempo não é um quadro general, mas o resultado provisório da ligação dos seres" (Latour, 1991, 1997, p. 101).

No pensamento geográfico, tais ligações correspondem à mobilização de certas formas e normas particulares, que, postas para funcionar solidariamente, vão definir as unificações e as racionalidades espaciais. Por isso, a noção de tempo se faz, para a

\footnotetext{
${ }^{1}$ Em Sartre, aprendemos que o processo de reprodução do capital gera uma temporalidade contínua, que não pode, porém, ser tomada como o tempo social por excelência (Sartre, 1960a, p. 63 - nota 2).

2 "Aqueles elementos definidores do modo de produção seriam a medida geral do tempo, à qual se referem, para serem contabilizados, os tempos relativos aos elementos mais 'atrasados', heranças de modos de produção anteriores. Visto em sua particularidade - isto é, objetivado - e, portanto, com a sua cara geográfica, o tempo, ou melhor, as temporalidades, conduzem à noção de formação socioespacial” (Santos, 1996, 2002, p. 136).

3 “[...] podemos dizer que cada divisão do trabalho cria um tempo seu próprio, diferente do tempo anterior [...] É assim que, a partir de cada agente [...], se estabelecem as temporalidades [...] que são a matriz das espacialidades vividas em cada lugar” (Santos, 1996, 2002, p. 136).
} 
geografia, menos útil que a noção de temporalidade. Com efeito, cada circuito da economia urbana pode ser pensado como um subuniverso dotado de uma temporalidade, como um sistema de referência no qual iremos topar com um cronômetro específico.

Há dois fenômenos paralelos. Primeiramente, cada lugar abriga uma certa combinação de formas geográficas e técnicas, numa totalidade que permite usos mais ou menos acelerados ${ }^{5}$. Segundamente, cada lugar demonstra uma combinação específica de ações, com maiores ou menores conteúdos em técnica, ciência, informação, num arranjo que, da mesma forma, configura tempos lentos ou velozes ${ }^{6}$. Mesmo que um lugar se preencha de formas sofisticadas e modernas, a presença de agentes com limitações de recursos pode levar à instalação de tempos lentos. Por isso, é necessário diferenciar a fluidez potencial da fluidez efetiva ${ }^{7}$.

A concretização do espaço é, também, a concretização do tempo. Sem esta, aquela não é possível nem faz sentido. Espaço vivido e tempo vivido são conceitos irmãos. O uso do espaço, a formação do meio comum, as temporalidades, são idéias que ajudam a enfrentar essa questão. Os agentes hegemônicos, em seu esforço para manter a hegemonia, devem seqüestrar as temporalidades mais lentas, impondo uma aceleração generalizada, tarefa que, logo veremos, não podem realizar por completo.

A questão fundamental é que, em face das novas possibilidades de fluidez oferecidas pelos territórios nacionais, os agentes hegemônicos buscam reforçar ainda mais a velocidade dos fluxos, já nem tanto pela instalação de bases materiais, mas sim pela renovação das bases normativas ${ }^{8}$.

Ocorre, porém, que esses fenômenos acabam levando a novas diferenciações temporais, o que se passa de duas maneiras principais. Primeiramente, no eixo das sucessões, as normas acoroçoam o processo de modernização, o qual, além de produzir o veloz e o novo, produz o lento e o velho. Segundamente, no eixo das coexistências,

\footnotetext{
4 "Não podemos comparar nenhum processo com o "decurso do tempo" - que não existe - mas apenas com um outro processo (digamos, a marcha do cronômetro)” (Wittgenstein, 1921, 1994, pp. 270-271).

5 "As técnicas são datadas e incluem tempo, qualitativamente e quantitativamente. As técnicas são uma medida do tempo: o tempo do processo direto de trabalho, o tempo da circulação, o tempo da divisão territorial do trabalho e o tempo da cooperação” (Santos, 1996, 2002, p. 54).

6 “[...] não há nenhum espaço em que o uso do tempo seja idêntico para todos os homens, empresas e instituições” (Santos, 1996, 2002, p. 159).

7 "Devemos, assim, distinguir entre a produção de uma expectativa de fluidez, isto é, a criação das condições para sua existência e o uso da fluidez por um agente, isto é, sua efetivação empírica” (Santos, 1996, 2002, p. 277).

${ }^{8}$ Mónica Arroyo diz que a nova fluidez, ou seja, mudanças na base material (portos, ferrovias, hidrovias) acompanha-se de uma nova porosidade, ou seja, mudanças na base normativa (impostos, acordos, leis) (Arroyo, 2001, p. 58-59).
} 
verificam-se usos diferenciais de normas, ou seja, a constituição de sistemas organizacionais particulares, levando à emersão de específicas temporalidades.

Pode-se pensar que o produtor não produz simplesmente mercadorias: em termos geográficos, ele produz uma certa capacidade de fluidez e de velocidade ${ }^{9}$. É por isso que, para os produtores dotados de menos recursos instrumentais, não só a circulação é menos extensa, como se realiza em tempos lentos. Aliás, os instrumentos e as formas geográficas mais modernas permitem, hoje, ao mesmo tempo, maiores escalas e maior velocidade de circulação. A lentidão, junto com o uso parcial do território, aprecem, pois, como sinais de marginalidade espacial.

Por isso, queremos chamar atenção para os mapas seguintes, em que retratamos parte dos circuitos espaciais de produção de alguns laboratórios farmacêuticos ${ }^{10}$.

No mapa IX.1, figuramos a situação do laboratório Sanífer (Porto Alegre-RS). Produzindo medicamentos oficinais e fitoterápicos, o Sanífer possui um certo confinamento regional, pois que os maiores distribuidores, de alcance nacional, não costumam privilegiar esse tipo de produto. Em verdade, esses medicamentos são fabricados em várias partes do país, sendo perfeitamente intercambiáveis. Os maiores distribuidores preferem trabalhar com produtos que são, por assim dizer, mais específicos e raros, o que é particularmente o caso dos medicamentos de referência produzidos pelas multinacionais. Assim, mesmo utilizando os serviços da Santa Cruz, um dos maiores distribuidores, o Sanífer terá seus produtos espalhados regionalmente, chegando, quando muito, e de maneira residual, ao estado do Mato Grosso.

O mapa IX.2 mostra a situação do Pronatus (Manaus-AM), enquanto o mapa IX.3 retrata a situação do Ravick (Fortaleza-CE). Para as duas empresas, reproduzem-se escalas regionais, mas é preciso dizer que as temporalidades são, aqui, ainda menos intensas. Isso acontece porque ao norte do país, e sobretudo na região amazônica, atuam vários distribuidores regionais que se valem, não raro, de transportes fluviais tradicionais. Trataremos desse fenômeno mais adiante.

As escalas de ação e as temporalidades podem ficar reduzidas ao extremo, como na situação do laboratório Amazonas (Feira de Santana-BA), que figuramos no mapa IX.4. Neste caso, temos a produção exclusiva de medicamentos farmacopeicos, pois que,

\footnotetext{
9 "Não basta, pois, produzir. É indispensável pôr a produção em movimento. Em realidade, não é mais a produção que preside à circulação, mas é esta que conforma a produção” (Santos, 1996, 2002, p. 275). “A circulação repercute sobre a produção, obrigando-a a modernizar-se. Os fluxos multiplicam-se, diversificam-se, tornam-se ainda mais importantes para a realização da produção” (Arroyo, 2001, p. 58).

${ }^{10}$ De acordo com a proposição de Mónica Arroyo, os circuitos espaciais de produção podem ser entendidos como "fluxos de matéria" (Arroyo, 2001, p. 58).
} 
em decorrência das renovações normativas, a empresa abandona sua linha de fitoterápicos. O Amazonas é um caso raro de laboratório com distribuição própria. Apenas, contrata uma distribuidora local para suas entregas no Sergipe.

No mapa IX.5, destacamos que mesmo o laboratório Anchieta (Goiânia-GO), instalado num lugar de extrema fluidez espacial, fica restrito a certos corredores territoriais. Seu maior feito é acessar o mercado mineiro, de extrema concorrência, além de uma política de impostos protecionistas. Sua atuação em Tocantins e no Maranhão se deve às integrações marginais entre Goiás e Maranhão, sendo que, neste último estado, nota-se uma forte presença de distribuidoras locais.

Para todos esses mapas, é importante ressaltar o papel do estado de São Paulo, que, muito embora raramente apareça como mercado consumidor, aparece sistematicamente como fonte de princípios ativos, plantas e extratos. Já tínhamos destacado, no capítulo VI, essa onipresença do estado paulista, e sobretudo de sua capital.

Certamente que nem todos os pequenos laboratórios apresentarão essas escalas regionais de ação. Quando se instalam em cidades mais dinâmicas, tais como São Paulo, Rio de Janeiro ou Porto Alegre, eles podem mesmo chegar a uma distribuição nacional de seus produtos. Mas, os pequenos produtores, mesmo obtendo essas escalas mais amplas, dificilmente poderão evitar os tempos lentos que são típicos do trabalho no circuito superior marginal.

Os menores conteúdos em recursos instrumentais (capitais, ciência, informação, técnicas) fazem com que as ações marginais tenham poder apenas para realizar-se nas escalas regional ou local. Mas, como já dissemos, o alargamento dos contextos vai sugerindo e provocando relações maiores, mais distanciadas. Assim, é como se o território fosse uma grande barreira de energia, que os agentes marginais precisam vencer para atender aos reclamos de uma vida de relações mais densa. Para realizar tais saltos territoriais, eles precisam, primeiro, buscar acesso a formas espaciais permitindo maior dinamismo: créditos, informações um pouco mais sofisticadas, conhecimentos e contatos novos, distribuidores de maior abrangência. Em suma, eles devem tentar ampliar, ao mesmo tempo, suas escalas espaciais e temporais, ou seja, expandir a abrangência de suas relações e realizá-las em tempos um pouco mais céleres ${ }^{11}$.

\footnotetext{
11 “Muito se fala em escala do espaço e jamais na escala do tempo”. (Santos, 1978, 2005, p. 63)
} 
IX.1 Sanífer 
IX.2 Pronatus 
IX.3 Ravick 
IX.4 Amazonas 
Quando se analisa o superior marginal, notamos que, de acordo com a especificidade do arranjo espacial local, o circuito pode revestir-se mais de um caráter emergente, ou mais de um caráter residual. Ao dizermos isso, devemos realizar, imediatamente, uma ressalva crucial.

Esse circuito superior marginal tem [...] ao mesmo tempo um caráter residual e um caráter emergente (Santos, 1979, 2004, p. 103).

Esses dois atributos convivem no interior desse subcircuito econômico. Ele é, com efeito, uma forma de existência. Um superior marginal emergente não está fadado a transformar-se em circuito superior: apenas está mais integrado ao processo de modernização, cujas variáveis acolhe mais rápido e mais suavemente. E um superior marginal residual não vai tornar-se inferior: apenas se integra com mais dificuldade e lentidão às acelerações contemporâneas. Podemos falar de camadas intermediárias, tal como foram pensadas por Jean Lojkine. "Camadas intermediárias na medida em que elas estão não 'no meio', mas no duplo movimento ascendente-descedente que dissolve os antigos lugares no processo global de produção [...]" (Lojkine, 1981, p. 112).

Mais uma vez, o superior marginal desvela sua natureza híbrida, pois emergência e decadência estão, nele, sempre reunidas, complementando-se. Mas, um desses atributos pode prevalecer, de acordo com as características do lugar: a fluidez que ele permite, a qualidade e a quantidade dos agentes presentes, a qualidade e a quantidade de fluxos materiais e imateriais que atravessam o lugar, as densidades (normativas, informacionais, comunicacionais) que ali vamos encontrar; não podemos esquecer, ainda, as características do meio construído ${ }^{12}$.

Emergência e decadência também se referem a temporalidades. As cidades permitindo a emersão de um superior marginal mais emergente são aquelas que, pela coexistência de formas e agentes mais integrados à modernização, permitem uma fluidez mais eficaz, além de contatos mais velozes. $E$ as cidades em que o superior marginal vai adquirindo feições mais residuais são aquelas cidades às quais os vetores modernos acorrem com tardança.

\footnotetext{
12 “[...] além da divisão do trabalho vivo, há uma divisão territorial do trabalho morto. A ação humana tanto depende do trabalho vivo como do trabalho morto. O trabalho morto, na forma de meio ambiente construído (built environment) tem um papel fundamental na repartição do trabalho” (Santos, 1996, 2002, p. 139).
} 
Ao longo da segunda e terceira parte deste trabalho, destacamos a importância que adquirem, na produção farmacêutica atual, certas cidades. Algumas delas, como São Paulo, Fortaleza, Ribeirão Preto, Campinas, Anápolis, Recife ou Belo Horizonte, devem sua força às acumulações de variáveis realizadas em períodos precedentes. Outras cidades, porém, dinamizam-se em função das novas forças dispersivas que dão menor rigidez ao território. Paralelamente, algumas outras cidades parecem ofertar menores condições de dinamismo à produção de medicamentos, e o circuito superior marginal vai, nelas, demonstrando sinais de obsolescência. Tal nos parece ser o caso, por exemplo, das cidades de Salvador e Belém, e, em menor grau, da cidade de Porto Alegre.

Três são as razões que nos levam a apontar esse menor dinamismo. Primeiramente, o meio construído se envelhece, sendo procurado, doravante, por ações típicas do circuito inferior ${ }^{13}$. Segundamente, cidades vizinhas começam a reunir condições mais interessantes para as instalações industriais farmacêuticas ${ }^{14}$. Em terceiro lugar, os agentes situados nessas cidades mostram maiores dificuldades para adaptar-se à nova atmosfera normativa, sucumbindo, por vezes, em função de obsolescências crônicas. Aqui, é ilustrativa a situação do laboratório Kriff (Salvador-BA), que tende a converter-se numa empresa produtora de cosméticos, abandonando as atividades farmacêuticas.

Tais forças dispersivas ganham, no período contemporâneo, tão grande importância que já podemos perceber o início de uma reconfiguração do sistema produtivo $^{15}$. O acesso a certos capitais financeiros, o novo consumo de normas, o alargamento dos contextos, a redefinição dos círculos de cooperação, o uso de técnicas mais doces, o primeiro movimento de banalização da informação, fazem com que não as capitais, mas as cidades médias, tornem-se o abrigo principal dos laboratórios nascidos recentemente. Com efeito, os novos laboratórios, filhos do período contemporâneo, já não se instalam preferencialmente nas capitais dos estados, o que se dava até o período informacional. São as cidades médias, como Canoas (RS), Jaboatão dos Guararapes (PE), Cotia (SP), Diadema (SP), Caucaia (CE), que vão abrigar as novas empresas.

\footnotetext{
13 “[...] é lícito admitir que vivemos em um mundo onde os lugares mostram uma tendência a um mais rápido envelhecimento de um ponto de vista técnico e socioeconômico, com ritmos diversos e, mesmo, inesperados, segundo regiões e países” (Santos, 1996, 2002, p. 248).

${ }^{14}$ No caso de Porto Alegre, muito embora se conservem ali algumas sedes empresariais regionais, já vemos que outras cidades gaúchas vão-se fazendo tanto ou mais atrativas. Daí, a transferência da fábrica do Multilab para a cidade de São Gerônimo, assim como a transferência do laboratório Wesp para a cidade de Canoas, onde o superior marginal parece revestir-se, antes, de características ascendentes.

15 “[...] toda localização industrial resulta da combinação de múltiplos dados, uns que se tornaram caducos, outros que, pelo contrário, estão em plena evolução, ainda que sob ritmos diferentes” (Guglielmo, 1964, p. 227).
} 
Com os mapas IX.6 e IX.7, buscamos uma comparação entre o período atual e o precedente, indicando a proporção de laboratórios novos instalados nas capitais dos estados. Devemos reconhecer que nossa fonte falha, para o período atual, na identificação de algumas instalações que, apesar de pouco numerosas, são bastante significativas. Assim, por exemplo, a instalação de dois laboratórios em Canoas (RS) e de um laboratório em Manaus (AM), que não foram identificados pela Anvisa em seu banco de dados. Mesmo assim, esses mapas dão uma idéia geral do que se passa em território brasileiro com a produção de medicamentos. Com base neles e em nossas pesquisas, queremos destacar dois fenômenos.

Primeiramente, é perceptível a redução do papel de algumas capitais, sobretudo Salvador (BA), São Paulo (SP), Cuiabá (MT), Porto Alegre (RS). É notável a situação de Teresina (PI), pois que o estado do Piauí manteve seu ritmo de aparecimento de empresas, mas a capital, que no período precedente abrigou todas as novas empresas, agora não assiste à fundação de qualquer laboratório.

Segundamente, é importante perceber que os estados que parecem haver o maior dinamismo são justamente aqueles em que diminui o peso da capital, ou aqueles em que se mantém uma fraca participação da capital na renovação das unidades produtivas. Aqui, o caso mais ilustrativo é o da Bahia, pois, enquanto o estado amplia seu ritmo de fundações, a capital simplesmente não abriga nenhum novo laboratório. Nas antípodas do processo baiano vamos encontrar o Rio de Janeiro, pois ali, mantendo-se o peso esmagador da capital, o estado vê decrescer o ritmo de aparecimento de empresas. Também é interessante constatar o que se passa em Santa Catarina. Desde o período informacional, sua capital apresenta fraca participação, a qual se reduz ainda mais, enquanto Santa Catarina passa ao grupo dos estados com maior ritmo de aparecimento de laboratórios.

Finalmente, não podemos deixar de sublinhar o fato de que o estado de São Paulo tem sua dinâmica de fundações de empresas igualada por outros estados: Minas Gerais, Goiás, Santa Catarina.

É claro que devemos realçar o que vimos de ver, pois, conforme sabemos, os efeitos da desconcentração produtiva costumam ser contrabalançados pela centralização administrativa e informacional. Entanto, já tentamos demonstrar que, no período atual, há certas atividades que, desconcentrando-se, reduzem um pouco os efeitos das polarizações espaciais. 
Os novos dinamismos de Goiânia

Podemos voltar aos dois mapas anteriores para destacar a situação de Goiânia. Notamos que, na passagem dos períodos, a cidade começa a atrair mais laboratórios. O território de Goiás é um caso particular, pois, nele, a presença de um distrito industrial em Anápolis deu a esta cidade, no que tange à produção de medicamentos, um dinamismo maior que o da própria capital. Acontece que, no período contemporâneo, o processo de urbanização tem na cidade de Goiânia um de seus principais alvos ${ }^{16}$. Mais recentemente ainda, o processo fica reforçado pela modernização da agricultura, que, tendo integrações urbanas, favorece a dinâmica de Goiânia ${ }^{17}$.

Inicialmente, a atividade farmacêutica estava, em Goiânia, apoiada em suas integrações com o distrito industrial de Anápolis. Assim, a distribuição de medicamentos pôde-se expandir, expressando um acontecer complementar ${ }^{18}$. Mas, no período atual, forças dispersivas invertem o processo, trazendo à cidade de Goiânia uma dinâmica produtiva. Laboratórios antigos se consolidam, e laboratórios novos aparecem, congregando forças típicas de um circuito superior marginal ascendente. O Halex Istar, fundado em 1969, é um dos grandes laboratórios goianos, possuindo três escritórios de representação, nas seguintes cidades: São Paulo, Rio de Janeiro e Recife. É um dos maiores produtores de soluções parenterais do Brasil. O TKS, laboratório fundado em 2002, aparece hoje como um dos principais laboratórios de medicamentos similares de Goiânia, denotando um rápido crescimento.

A pouco e pouco, a cidade de Goiânia tem sua fortuna mais desligada de Anápolis. Em verdade, as transformações espaciais recentes fazem com que a cidade ganhe uma

\footnotetext{
${ }^{16}$ Esse fenômeno remonta à construção de Brasília, que, de acordo com Milton Santos, foi um dos principais estimulantes da urbanização de Goiás. (Santos, 1993, 2005a, p. 69) De 1940 a 1996, o estado de Goiás foi um dos maiores expoentes da urbanização brasileira, e sua capital contribuiu decisivamente para essa expansão; em 1940, 81,5\% da população goiana era classificada como rural; em 1996, a proporção descende a 14,22\% (Santos e Silveira, 2001, 2004, p. 211).

17 "O caso de Goiás é emblemático [...] O novo urbano chega antes da modernização dos transportes, da modernização do consumo e, de modo mais geral, da modernização do país [...] Graças às novas relações espaço/tempo, cidades médias relativamente espaçadas [...] desenvolvem-se rapidamente, e, reforçada, Goiânia pode pretender a condição metropolitana, apesar de sua proximidade de Brasília” (Santos, 1993, 2005a, p. 69).

${ }^{18}$ Milton Santos fala de três tipos de acontecer. O acontecer complementar caracteriza-se por relações de integração e cooperação. $\mathrm{O}$ acontecer homólogo realiza-se em espaços contíguos, em que atividades mais ou menos similares se realizam. O acontecer hierárquico expressa relações assimétricas (Santos, 1994, 2005b, pp. 157-159; Santos, 1996, 2002, pp. 165-168).
} 
vida de relações muito mais rica. Já falamos, por exemplo, do IFC, instituto que realiza os raros testes de biodisponibilidade e bioequivalência, necessários para o registro de medicamentos genéricos. Esse instituto, apesar de sustentado por empresas de Anápolis, tira partido das possibilidades de fluidez permitidas por Goiânia. É o que faz, também, uma das maiores distribuidoras do país, a Panarelo, que, a partir de sua sede em Goiânia, é geradora de rápidos fluxos materiais e imateriais percorrendo o território.

Assim, Goiânia desprende-se um pouco de Anápolis e, ao acontecer complementar, sucedem-se outros tipo de acontecer: homólogo, hierárquico. É interessante a situação da distribuidora Distak. Fundada em 1995, a Distak Farmacêutica inicias suas operações como distribuidor exclusivo dos medicamentos do laboratório Teuto, localizado no distrito industrial de Anápolis. Em 2005, encerra-se a parceria. Em sua procura por um novo laboratório fornecedor, os contatos avançaram mais rapidamente junto a dois laboratórios: Pharlab (Lagoa da Prata-MG) e Divicon, do estado de São Paulo. Assim, vemos um exemplo de como, rompida a relação estreita com Anápolis, um agente situado em Goiânia busca novas integrações, encontrando contatos justamente em São Paulo e Minas Gerais.

Estamos em face de uma situação bastante singular, em que, sob a ação das forças espaciais dispersivas, é a capital, e não a cidade média, que é dinamizada com maior intensidade. Assim, Goiânia passa ao rol das cidades que, no período atual, tem permitido a formação de um superior marginal ascendente na produção farmacêutica.

\section{Cidades médias e produção de medicamentos}

O que se tem passado nessas cidades em que o circuito superior marginal é predominantemente ascendente? Nelas, várias escalas espaciais e temporais podem coexistir, o que amplia o leque de possibilidades para os agentes marginais. Nelas, já percebemos a fixação de serviços informacionais. Nelas, uma infra-estrutura científica mais sólida se instala, por meio de universidades ou laboratórios produtores de testes. Nelas, os conteúdos tecnológicos se complexificam, em razão do maior acesso às máquinas ou da instalação de empresas de assessoria técnica. Certamente que esses fenômenos poderão ser atrativos, também, para os agentes hegemônicos. Entanto, já buscamos demonstrar que, nem sempre, o reforço do circuito superior vai destruir as existências marginais, havendo mesmo situações em que tal reforço conduz, pelo contrário, à viabilização de existências marginais. 
Mas é preciso lembrar que essa configuração espacial não se realiza de maneira independente, como se as cidades fossem mônadas livres. Em verdade, trata-se de um constante vaivém, ao longo da qual passamos, desde a formação socioespacial, até os subespaços, e em cada uma dessas escalas vamos encontrar um jogo de forças e interesses particular ${ }^{19}$.

A força do circuito superior marginal pode prescindir das extremas densidades que aparecem nas duas grandes metrópoles brasileiras (São Paulo e Rio de Janeiro). Atentando para o superior marginal, vemos que as ações marginais, quando manifestadas em Goiânia, Cotia, Santo Antonio de Jesus, Manaus, Jaboatão dos Guararapes, Fortaleza, Simões Filho, Canoas, Juiz de Fora, podem gozar de um certo dinamismo ${ }^{20}$.

Certamente que tal fato se deve ao crescimento populacional conhecido por essas aglomerações médias ${ }^{21}$. Porém, mais do que isso, a força das médias aglomerações advém do fato de que elas se mostram capazes de acolher uma pluralidade de ações. "A maior riqueza das cidades é que elas podem abrigar todos os tipos de trabalho, com diversos níveis técnicos, de capital e de organização" (Santos, 1996, 2004, p. 308)22.

Ora, essa pluralidade dos sistemas de ações baseia-se na pluralidade dos sistemas de objetos existentes em concentrações urbanas ${ }^{23}$. Nestas, formas geográficas modernas podem conviver com formas arcaicas, o que amplia as escalas de possibilidade dos agentes marginais, os únicos dispostos a fazer suas ações incidir sobre ambos os dois grupos de materialidade. As formas novas, instaladas para atender aos desideratos de agentes hegemônicos, podem ser também aproveitadas por agentes marginais. Assim, aquilo que era pleno de racionalidade instrumental, fonte de ações roubadas, pode-se converter em base de racionalidade comunicacional, expressando ações recuperadas.

Assim como as novas tecnologias se fazem mais doces, o próprio meio construído urbano se preenche de maior flexibilidade. As ações marginais vão difundindo lógicas inventivas, surpreendentes por vezes, tudo acompanhado de uma produção possível de

\footnotetext{
19 "Desta forma, a definição de cada subespaço é, em cada período, o resultado de um grupo de relações cuja escala não é a mesma do subsistema e coincide, no mais das vezes, com a escala do Estado-Nação" (Santos, 1979, 2005a, p. 49).

${ }^{20}$ Milton Santos já havia constatado que nas cidades intermediárias prevalece o caráter emergente do circuito superior marginal (Santos, 1979, 2004, p. 103).

${ }^{21}$ Manaus, Campinas e Goiânia, por exemplo, entram, em 1991, na lista de cidades com mais de quinhentos mil habitantes, posição que ainda não ocupavam em 1980 (Santos, 1993, 2005a, p. 97).

${ }^{22}$ A cidade é, na formação socioespacial, o lugar com maior pluralidade econômica. Assim, três conceitos vão-se enredando: região, urbanização e economia. Apesar disso, torna-se cada vez mais rígida uma suposta tripartição da geografia: regional, urbana e econômica.

${ }_{23}$ "A paisagem urbana reúne e associa pedaços de tempo materializados de forma diversa, autorizando comportamentos econômicos e sociais diversos” (Santos, 1996, 2002, p. 308).
} 
um sentido local. O meio comum fica mais denso e mais maleável, fenômeno que ajuda a consolidar os efeitos dispersivos que já transfundem o território brasileiro ${ }^{24}$.

Se identificamos um novo dinamismo nas cidades médias, ele se deve, em larga medida, ao superior marginal, e não ao circuito superior. Assim, pode-se contestar a idéia de que só a economia moderna é geradora de dinamismo econômico. Como disse Milton Santos, o superior marginal, fora das metrópoles, tem "[...] um certo poder multiplicador, agindo sobre a economia da cidade e sobre os seus arredores" (Santos, 1979, 2004, p. 316). Suas integrações internacionais são menos profundas, havendo mesmo situações em que os trabalhos que se desenrolam no interior do superior marginal expressam uma integração local exclusiva e completa. Mais uma vez Milton Santos vem trazer dois ensinamentos fundamentais. Por um lado, os resultados da atividade econômica tendem a se multiplicar no lugar quando ela se volta a uma demanda interna ao país (Santos, 1979, 2004, p. 363). Por outro lado, alguns tipos de produção industrial não existiriam, nas cidades intermediárias, sem o circuito superior marginal (idem, p. 315).

Todos esses fenômenos acendem a força do lugar, pois, desde o ponto de vista do superior marginal, usos eficazes e duradouros do território não requerem, necessariamente, um desmesurado acúmulo anterior de tecnologias modernas ${ }^{25}$. Pode-se contestar, agora, o discurso corrente segundo o qual uma economia nacional precisa ter por meta principal e necessária a instalação de formas geográficas modernas.

É mister apontar a existência de diversas escalas temporais, ou seja, aquilo que Milton Santos chamou de tempos rápidos e tempos lentos (Santos, 1996, 2002, p. 266267). Não nos deve seduzir o discurso de que apenas o veloz tem valor. Na realidade, os atributos de velocidade ou lentidão não tem, só por si, qualquer sentido ${ }^{26}$. Se os agentes marginais são, desde o ponto de vista da modernização, os menos privilegiados, podem ser, do ponto de vista da formação de contextos locais, os mais dinâmicos.

De acordo com Milton Santos, "[...] a plena eficácia do sistema técnico está condicionada a uma articulação entre as suas diversas peças" (Santos, 1996, 2002, p.

\footnotetext{
24 "Pode-se dizer, no caso do Brasil, que, ao longo de sua história territorial, as tendências concentradoras atingiam número maior de variáveis, presentes somente em poucos pontos do espaço. Recentemente, as tendências à dispersão começam a se impor e atingem parcela cada vez mais importante dos fatores, distribuídos em áreas mais vastas e lugares mais numerosos” (Santos, 1993, 2005a, pp. 99-100).

25 "Uma boa parcela da economia urbana pode, assim, desenvolver-se sem custos de investimentos adicionais em infra-estruturas, já que somente as atividades hegemônicas exigem a renovação do espaço construído" (Santos, 1993, 2005a, p. 136).

26 “Cada corpo de referência (sistema de coordenadas) possui seu tempo próprio. Uma especificação temporal só tem sentido quando se indica o corpo de referência ao qual esta indicação se refere” (Einstein, 1916, 1999, p. 28).
} 
42). Então, o sistema mais eficaz nem sempre é o mais moderno, já que os agentes marginais, compreendendo melhor as línguas do lugar, podem chegar a sistematizações espaciais mais eficazes. Isso é provável na media em que, para funcionar, esses sistemas espaciais poderão prescindir da máxima capitalização, da máxima fluidez ${ }^{27}$. É claro que, numa visão geral, o predomínio em situações locais pode não parecer vantajoso nem compensador quando comparado ao poder global e nacional dos agentes hegemônicos. Entanto, é possível reconhecer que, muita vez, a existência de empreendimentos pequenos se deve justamente a uma necessidade de subsistência, nos lugares, sem que se coloquem desígnios mais abrangentes e ambiciosos. É certo que o território não pode ficar sujeito a essa divisão desigual do poder político, mas também é certo que, em muitas situações, os agentes marginais logram realizar suas táticas mais imediatas, ainda que, dessa maneira, vejam consagradas suas marginalidades.

Os contextos locais têm baseado não apenas a emersão da economia pobre, do circuito inferior, mas também de algumas atividades do superior marginal. Na produção de medicamentos, isso acontece de duas maneiras.

Primeiro, a existência de uma massa de população pobre pode alimentar o superior marginal, na medida em que existe uma necessidade de medicamentos menos complexos. Não é certo pensar que, em todos os casos, os laboratórios menores são os que produzem os medicamentos mais baratos. Aliás, a comparação é, muita vez, impossível, pois nem sempre os diversos medicamentos são concorrentes entre si. Todavia, podemos dizer que os produtos dos laboratórios menores são fruto de uma produção menos complexa. Aí, estão ausentes as atividades de pesquisa, os equipamentos mais modernos, os profissionais mais qualificados, os conhecimentos farmacológicos mais avançados, as fórmulas mais modernas, as divisões do trabalho mais desenvolvidas. Com isso, existe uma forte tendência à produção de medicamentos que, nas farmácias, vão apresentar os menores preços. Aliás, nos discursos dos entrevistados em pesquisa de campo, aparece, com freqüência, essa preocupação de chegar aos consumidores mais pobres.

Segundo, as ações do circuito superior marginal, com acesso menos rápido às modernizações, são por outro lado mais integradas às formas locais. Os agentes do circuito superior produzem um espaço reticular, e suas ações se instalam em poucos

\footnotetext{
27 “As exigências de fluidez não são as mesmas para todos os tipos de capital. A cada momento, o capital hegemônico necessita de maior fluidez que os outros, e, entre outras razões, exatamente porque lhe cabe operar em área maior” (Santos, 1993, 2005a, p. 114).
} 
pontos iluminados. Já no circuito superior marginal as ações tendem a se integrar mais no lugar, e fazer do meio construído local um uso mais completo.

Distribuição de medicamentos na região Amazônica: os tempos lentos

Em grande medida, o uso mais completo dos elementos reunidos num lugar ocorre por ser ali que se encontram as soluções de produção e distribuição mais baratas. De extrema representatividade, quanto a essa possibilidade de topar, no lugar, com formas de transporte mais baratas, é a situação dos laboratórios e distribuidores situados ao norte do país, os quais podem valer-se dos fluxos tradicionais de mercadorias através dos rios, sobretudo o rio Amazonas. Os elementos da natureza primeira, bem como os objetos técnicos, são integrados ao meio comum na medida em que são usados, apropriados. Assim, um rio, uma via precária, plantas medicinais, certamente são objetos menos complexos, mas, em relação às formas e objetos modernos, possuem o mesmo estatuto de elementos do espaço geográfico ${ }^{28}$.

Indivíduos e empresas, imersos nesse meio comum, sabem que dispõem de uma alternativa barata, posto que morosa, de movimentação. A tradição regional de uso dessas técnicas de fluxo produz um contexto em que, mesmo sem normas formais, palavras ou regras explícitas, uma comunicação é possível, coordenando as várias ações. "O cotidiano imediato, localmente vivido [...] é a garantia da comunicação" (Santos, 1996, 2002, p. 339). Forma-se aquele saber coloquial (ou banal, conforme se prefira traduzir colloquial reason) de que nos fala Clifford Geertz (1983, p. 78).

Mas, além desse conhecimento banal que se difunde em meio aos indivíduos e empresas, existe uma espécie de tradição regional, supra-individual, que promove um tipo específico de integração regional entre as cidades. Com efeito, vale pensar, por exemplo, de que forma os transportes fluviais contribuem, até os dias atuais, para a integração entre as duas principais aglomerações urbanas da região amazônica, Manaus e Belém.

Aqui, é o rio, como elemento da natureza primeira assimilado ao meio construído urbano, que vai garantir uma comunicação efetiva, realizando-se entre as cidades, entre as empresas, entre os objetos e as ações. Pois, como diz Sartre, o homem é mediado

\footnotetext{
28 "A paisagem urbana, especialmente numa cidade dos trópicos, também comporta as coisas da natureza" (Oliveira, J. 2003, p. 28). "A verdade é que, para os fins de nossa análise, mesmo os objetos naturais poderiam ser incluídos entre os objetos técnicos, se é considerado o critério do uso possível” (Santos, 1996, 2002, p. 38).
} 
pelas coisas na mesma medida em que as coisas são mediadas pelos homens (Sartre, 1960b, p. 165).

$\mathrm{Na}$ atividade farmacêutica, várias empresas vão recorrer às "estradas líquidas" da Amazônia, bela expressão de Caio Prado Júnior (1945, 1998, p. 72). Em pesquisa de campo, estas foram as empresas que declararam valer-se dos transportes pelo rio Amazonas: as distribuidoras Compmed (Belém-PA), Góes Góes (Belém-PA), Amazon Med (Belém-PA), Alefarma (Ananindeua-PA), Amplomed (Manaus-AM); os laboratórios Ágape (Ananindeua-PA), São Lucas (Belém-PA), Pronatus (Manaus-AM) ${ }^{29}$.

Os vetores da modernização, quando chegam à região amazônica, alteram os conteúdos que são próprios dela, sem poder, porém, transformar-lhe todas as condições vitais. Aqui também, o espaço divide-se, abrigando fluxos rápidos e lentos ${ }^{30}$. Por um lado, conforme diz Fabio Contel, os fluxos aéreos permitem, na Amazônia, uma "integração literalmente 'por cima"', "pontual", com uma "ação 'cirúrgica"' empreendida pelas empresas hegemônicas (Contel, 2001, 2004, p. 372). Por outro lado, realizam-se fluxos lentos, menos precisos e pontuais. É o próprio Fabio Contel que diz que, na Amazônia, a navegação interior também está ligada aos fluxos não-hegemônicos (Contel, 2001, 2004, pp. 358-359) ${ }^{31}$.

Em vez de falar num tempo abstrato, numa suposta homogeneidade espacial, por meio da qual todos os agentes concretizariam os mesmos ritmos, devemos estar preocupados com o tempo concreto. "Este é, na verdade, o tempo da história real tal qual é vivida pelos homens" (Santos, 1979, 2003, p. 67).

Mas, nunca será demais dizer que as divisões espaciais não se realizam de maneira inequívoca. Quando falamos num superior marginal, não estamos referindo a um grupo de empresas, mas sim a certos sistemas de ações, cujos efeitos manifestam-se no território. As ações de uma empresa individual são, muita vez, híbridas, podendo reforçar, ao mesmo tempo, tanto o circuito superior como o superior marginal. Aproveitando nossa

\footnotetext{
${ }^{29}$ O Pronatus distribui seus medicamentos para o interior do Amazonas por meio de barcos de linha, os mesmos que transportam passageiros. Aos municípios mais distantes, os barcos chegam com sete ou oito dias de viagem, o que varia conforme o tempo que faz. O preço desse transporte é barato: $\mathrm{R} \$ 5$ por caixa, não importando o tamanho da caixa. Desse modo, o laboratório faz pacotes tão grandes quanto os permitidos pelas normas sanitárias, o que denota uma rica associação de normas nacionais e tradições locais. Uma embarcação que transportava medicamentos do Pronatus afundou certa vez.

${ }^{30}$ No interior das próprias cidades amazônicas, essa divisão já se expressa. “[...] Manaus revela, de um lado, territórios pretéritos que se caracterizam pela predominância de movimentos lentos a serviço de atividades tradicionais e, de outro, territórios novos que comportam movimentos rápidos com atividades fluidas impostas pela modernização" (Oliveira, J. 2003, p. 21).
} 
análise dos fluxos de mercadorias na região amazônica, verificamos que uma mesma empresa pode recorrer aos transportes rápidos e aos lentos. A distribuidora Imifarma (Belém-PA), quando vai expedir medicamentos aos locais distantes do Pará, mas também aos outros dois estados em que atua (Amazonas e Amapá), contrata transportadores, via terrestre, fluvial ou aérea.

Dissemos anteriormente que os distribuidores são peça fundamental do sistema farmacêutico por realizar a mediação entre a lógica econômica dos laboratórios e a lógica econômica das farmácias. Mas, é preciso ir além; pois, muita vez, os distribuidores possibilitam, com efeito, a comunicação entre as escalas temporais amplas, definidas pelos processos que se desenrolam nos pontos luminosos do território, e as escalas temporais estreitas, que se realizam nos pontos opacos do território ${ }^{32}$. Por isso, as pequenas distribuidoras não maculam a genuinidade dos contextos locais pelo fato de operar, por vezes, com medicamentos produzidos por laboratórios multinacionais ${ }^{33}$.

Repetimos, por ser importante, que o circuito superior marginal constitui uma categoria teórica. Mais do que um grupo de agentes, ele é um subsistema de ações. Sua existência se alimenta dos fazimentos das empresas, cuja realização devemos observar e compreender, mas o circuito existe para além delas. É por isso que uma mesma empresa, por meio de seus usos do território, pode reforçar tanto o circuito superior como o superior marginal. Diz Milton Santos que, assim como as camadas da população podem consumir fora de seu circuito imediato, as empresas podem misturar características dos circuitos. (Santos, 1979, 2004, pp. 42-43) Isso é ainda mais provável para os distribuidores, em razão de suas integrações mistas, envolvendo grandes e pequenas empresas. Essa é outra maneira de mostrar que os circuitos, ao invés de ser entidades isoladas, são subsistemas prontos para travar relações exteriores, indo em busca dos outros circuitos. Mais do que isso, pode-se dizer que, tendencialmente, as integrações entre os circuitos e subcircuitos aumentam, o que é mais provável para os dois níveis do circuito superior. À medida que as modernizações se aceleram, a lógica desses dois subsistemas se

\footnotetext{
31 “Como se torna um espaço informado para os agentes hegemônicos, as ações [na Amazônia] são pontuais, precisas e pragmáticas, utilizando estradas, hidrovias e sistemas de informação, enquanto a maior parte da sociedade continua a viver em tempos mais lentos” (Santos e Silveira, 2001, 2004, p. 104).

32 "Graças à presença dos intermediários e dos atacadistas, os tempos dos diversos agentes podem ser conciliados. Eles se tornam um elo entre a demanda e a oferta, as quais nem sempre aparecem simultaneamente. Nessa medida, sua função de conservação de estoques é central” (Santos, 1979, 2004, p. 226).

33 “E, por vezes, a recepção de objetos modernos no lugar não significa a adoção total de um know-how importado. Os objetos continuam a ser regulados por práticas antigas, e a produtividade do lugar é menor que a planejada” (Silveira, 1996, 1999, p. 428).
} 
misturam, e o superior marginal se consolida. Exemplo disso é o transporte, ao longo dos rios, dos medicamentos produzidos por laboratórios multinacionais: produtos do circuito hegemônico submetidos ao tempo do circuito marginal ${ }^{34}$.

Os fluxos e as distâncias

Diz Milton Santos que a cada lugar corresponde um tempo espacial particular (Santos, 2002, pp. 256-257) ${ }^{35}$. Mas é importante frisar que tal circunstância não promove qualquer espécie de hegemonia marginal, pois que a existência das temporalidades também é base de hierarquia, de modo que os agentes marginais aparecem, mais uma vez, desfavorecidos politicamente ${ }^{36}$. As menores empresas, mal situadas nessa hierarquia de tempos, ficam sujeitas a três formas de distanciamento.

Primeiramente, há uma distância geométrica, na medida em que essas empresas podem recorrer com menos freqüência aos sistemas de movimento rápido. Seus tempos ficam piorados, pois agora se referem aos tempos cada vez mais velozes das empresas multinacionais. Para as pequenas empresas, é como se o território se expandisse, multiplicando muitas vezes os valores quilométricos a serem vencidos. O processo vai-se reforçando, pois que os sistemas de transporte são aprimorados lá onde já se verificam fluxos intensos. Poder-se-ia lembrar, aqui, a situação do laboratório Ágape (AnanindeuaPA). A empresa tem parte de seus fornecedores localizada em São Paulo. Freqüentemente, os produtos que saem de São Paulo levam sete dias para chegar a Belém. No inverno, com as chuvas, esse transporte pode ficar ainda mais demorado. Por causa das chuvas, o laboratório precisa assumir os riscos do transporte dos vidros, ao qual renunciam os fornecedores ${ }^{37}$.

"A noção de distância, na forma em que é utilizada nas teorias correntes, é uma categoria de emprego uniforme, como se todas as instituições e todas as firmas tivessem permanentemente e totalmente à sua disposição a rede de transportes; como se todos os

\footnotetext{
34 A hegemonia do modo de produção capitalista acontece no muno, mas nem sempre nos lugares. (Maria Adélia de Souza, no curso: Lugar e território: Compreendendo o sistema de ações, Departamento de Geografia, USP, segundo semestre de 2003)

35 "Cada objeto ou ação que se instala se insere num tecido preexistente e seu valor real é encontrado no funcionamento concreto do conjunto. Sua presença também modifica os valores preexistentes [...] É dessa maneira que se constitui uma espécie de tempo do lugar [...]” (Santos, 1996, 2002, p. 59).

36 “O tempo rápido não cobre a totalidade do território nem abrange a sociedade inteira [...] Mas, graças à globalização e a seus efeitos locais, os tempos lentos são referidos ao tempo rápido, mesmo quando este não se exerce diretamente sobre lugares ou grupos sociais” (Santos, 1996, 2002, p. 267).

${ }^{37}$ Vemos assim que, tal como dissera Marcos Xavier, a expansão qualitativa e quantitativamente desigual da rede rodoviária constitui um "tempo múltiplo e desigual” (Xavier, 2001, 2004, p. 340).
} 
homens fossem capazes de utilizar todas as estradas e todos os veículos, sob condições idênticas" (Santos, 2002, p. 104).

Se, como disseram Milton Santos e María Laura Silveira, existem espaços da rapidez e espaços da lentidão (Santos e Silveira, 2001, 2004, pp. 262-264), então é forçoso reconhecer que estes últimos costumam ser utilizados pelos agentes marginais. Mais do que isso, a lentidão vai definir, também, maiores riscos. Para o laboratório Pronatus, vimos que perdeu medicamentos em decorrência do naufrágio de uma embarcação. Para o laboratório Ágape, vimos que deve arriscar-se em transportes de vidros em rodovias de condições não muito favoráveis. Apesar disso, os discursos correntes buscam denunciar, principalmente, os riscos a que estão submetidas as maiores empresas, o que logo se converte em argumento para novas normatizações. Se é certo que também as grandes empresas devem conviver com riscos, talvez até mais variados, cabe dizer que, por outro lado, suas condições de hegemonia não ficam por isso prejudicadas, uma vez que elas podem acessar aos produtos e serviços das empresas de seguros, o que não pertence à realidade dos pequenos empreendimentos.

Em verdade, a distância física de que vimos de falar é a dimensão menos importante do alheamento vivido pelos agentes marginais ${ }^{38}$. Existe um segundo aspecto: as pequenas empresas devem curtir um distanciamento de caráter tecnológico. Num enfoque tecnológico, o fato de que algumas regiões são menos dinâmicas, com menos consumidores endinheirados, fazem com que os agentes hegemônicos concentrem suas principais inovações longe delas. Cava-se um fosso tecnológico sempre mais profundo.

Em terceiro lugar, as pequenas empresas, mas sobretudo aquelas situadas em regiões menos dinâmicas economicamente, vivem um distanciamento em relação aos canais de representação. Os estados mais fortes acabam tendo representação mais eficaz nas esferas governamentais. Ao mesmo tempo, as pressões das grandes empresas, junto aos governos, levam a novas concentrações de poder econômico e administrativo nas mãos das regiões mais ricas. Em nossa pesquisa de campo, os representantes das pequenas empresas, sobretudo as situadas mais ao norte, deploram, de maneira mais ou menos explícita, os ritmos diferenciais em que são tratadas as solicitações burocráticas, pois, segundo afirmam, as empresas do centro-sul, sobretudo as grandes empresas, costumam ter suas requisições atendidas em prazos mais curtos.

\footnotetext{
38 “O termo distância deve ser tomado numa acepção socioeconômica que caracteriza a situação geográfica das periferias; não é uma questão de distância física, mas de acessibilidade” (Santos, 1979, 2002, p. 292).
} 
O circuito superior marginal e sua função de mediação espacial

Vidal de La Blache apresenta o homem como o senhor das distâncias (Vidal de La Blache, 1922, p. 15). Nos esquemas capitalistas, notamos clivagens nas condições de semelhante senhorio. A divisão desigual dos sistemas de movimento geram temporalidades. Ao mesmo tempo, as totalizações normativas realizam um enquadramento temporal dos agentes marginais, obrigados a correr atrás; obrigados a seguir, ainda que precariamente, os ritmos definidos pelos agentes hegemônicos. Na maioria das situações, o superior marginal é mais dependente que o circuito inferior, pois neste o afastamento em relação ao processo de modernização pode ser tão brutal que surgem espaços amplos para a criação de novas relações e sistemas espaciais. Já o circuito superior marginal é sempre arrastado, de maneira mais ou menos veemente, pelas acelerações definidas pelos agentes hegemônicos. Assim, o tempo hegemônico mostra sua verdadeira cara, revelando-se como "tempo despótico", segundo expressão de Milton Santos (2005, p. 167).

Os tempos hegemônicos, frenéticos por natureza, podem ser ainda mais acelerados nestas novas condições de um capitalismo normativo. Com mestria, Durkheim disse que a existência de contratos faz com que os indivíduos, a cada relação, não precisem realizar uma nova negociação (Durkheim, 1932, pp. 184-197). Portanto, uma normatização jurídica permite uma aceleração dos tempos, ao mesmo tempo em que funda uma ordem. A multiplicação das normas jurídicas, bem como a diferenciação da norma que vai conduzir à emersão de outras formas normativas (financeiras, técnicas, informacionais), fazem com que o território conheça novas acelerações.

Como tentamos demonstrar, a ciência converteu-se numa importante ferramenta para realizar tal aceleração produtiva. Entanto, os agentes hegemônicos, aliás imitados em certas análises tidas por objetivas, pretendem que as atividades farmacêuticas modernas representam verdadeiro sacrifício de capitais e tempos, uma vez que, segundo se afirma, as pesquisas de medicamentos são por demais duradouras e, na maioria das vezes, não conduzem a resultados viáveis economicamente. Porém, os laboratórios farmacêuticos, na condição de empresas capitalistas que são, almejam em primeiro lugar a expansão dos lucros, e não a glória científica do homem. Se é preciso realizar pesquisas de dezenas de anos; se é preciso testar dezenas de milhares de substâncias, entre as quais apenas uma se mostra viável terapeuticamente, isso é a natureza de uma atividade que, mesmo assim, torna-se cada vez mais lucrativa. Se, por um lado, o 
conhecimento farmacológico evolui às duras penas, os lucros dos laboratórios multinacionais, por outro lado, não cessam de se expandir, atingindo níveis anti-humanos. Uma empresa de biotecnologia não costuma ter mais que uma dezena de produtos em seu catálogo, e muitos de seus estudos não levam, de fato, a resultados comerciais. Isso não impede, porém, que o empreendimento seja rentável, pois a descoberta de uma só substância justifica os vultosos dispêndios de capital e tempo. Além disso, o discurso que tenta mostrar o heroísmo dos laboratórios farmacêuticos esconde o fato de que foram constituídos ingentes fundos financeiros. A ação do capital financeiro global diminui de muito o suposto risco nobre das corporações farmacêuticas multinacionais.

No território brasileiro, multiplicam-se as formas geográficas instaladas para permitir ações instantâneas em escalas mais largas. O fenômeno se concentra em poucos estados, sobretudo São Paulo e Rio de Janeiro, mas também se realiza noutros lugares. Um simples exemplo nos vem da distribuidora Ita (Salvador-BA), cuja sede foi instalada no Rio de Janeiro e mais tarde transferida para Belo Horizonte.. Em 1992, um centro de distribuição foi criado no porto seco de Pirajá, bem na entrada da cidade de Salvador. O porto seco, além de suas atividades aduaneiras, reúne empresas de logística e transporte, em diversas ramos econômicos. A Ita, segundo sua gerente de logística, é um dos maiores distribuidores nacionais. Entra em processo de fusão com a Intermed, outra das maiores distribuidoras farmacêuticas do país, com centros de distribuição por todo o território nacional e com vasta penetração nos estados ao norte. Assim, a expansão da empresa pode ser reforçada pelo uso de uma infra-estrutura criada justamente para permitir rápidos fluxos.

A convergência dos momentos, realizada pelos agentes hegemônicos, é mais cruel para aqueles agentes que têm poucas possibilidades para acolher a temporalidade veloz. Do ponto de vista das pequenas empresas, a colonização da copresença manifesta-se, entre outras coisas, pela imposição das lógicas temporais do circuito superior. Assim, as novas exigências de testes de medicamentos vão definir um novo tempo, prejudicando o ajuste aos contextos locais, outrora característico do superior marginal na produção farmacêutica. No Rio Grande do Sul, em 2001, entre 22 laboratórios capazes de desenvolver produtos, 9 os desenvolviam num período de 7 a 18 meses (Pereira, 2001, p. 93). Este prazo, relativamente curto, é necessariamente alongado em função das novas legislações, exigindo exames científicos mais rigorosos. Uma lógica de planejamento longo e de aderência ao futuro, típica do superior, é imposta ao superior marginal, o que define uma nova marginalidade. 
Daí, a situação precária, residual, vivida por alguns laboratórios pequenos, muitos dos quais já desapareceram nos últimos anos. Em contrapartida, vemos a emersão de empresas que, muito embora marginalizadas, realizam misturas eficazes entre formas antigas e modernas, em verdadeiros sistemas híbridos ${ }^{39}$. Usadas sob tempos e lógicas locais mesmo as formas modernas ficam distorcidas, e ganham significados inopinados. "Trata-se [...] de outra forma de produzir e não simplesmente de aperfeiçoamento dos meios de produção, de sua posse e de sua gestão" (Lefèbvre, 1976, p. 126).

Apesar dessa riqueza de situações guardada pelo circuito superior marginal, vários estudos sobre a indústria farmacêutica prosseguem fixando o olhar, exclusivamente, nos grandes laboratórios. Podemos admitir, por certo, que se trata de um sacrifício metodológico, feito em nome do acesso aos dados, os quais desprezam, não raro, a situação das pequenas empresas. O problema é que, dessa maneira, a geometria parcial dos agentes hegemônicos é apresentada como a geometria por excelência. Mas também se pode pensar que esse fascínio do circuito superior existe porque, muita vez, os próprios conceitos e concepções já não podem elucidar senão situações e sistematizações hegemônicas ${ }^{40}$.

Ao falarmos em temporalidades, o principal fenômeno que pretendemos apontar é a constituição de sistemas espaciais particulares. Técnicas, normas, informações, conhecimentos, são mobilizados pelos diversos agentes, e o conjunto resultante resta capaz de uma certa rapidez, de um certo desempenho ${ }^{41}$.

Nos circuitos econômicos marginais, a carência das normas científicas vem provocar a obsolescência, mas este fenômeno se refere, mais uma vez, à temporalidade hegemônica. Do ponto de vista dos próprios agentes marginais, esse menor conteúdo normativo exige a resolução dos problemas em bases menos sistemáticas, posto que mais criativas ${ }^{42}$. No circuito superior marginal, essa criatividade vai-se expressar em séries de ações, desde a invenção de máquinas próprias até os artifícios inventados para contornar as normas jurídicas sem, contudo, cair em situações de ilegalidade.

\footnotetext{
39 "Dessa forma, segundo a dimensão de cada empresa existem diferentes lógicas territoriais, e cada empresa tem sua própria lógica, que a difere das demais, inclusive segundo as condições impostas pelo próprio meio geográfico” (Grimm, 2002, p. 48 - nota 57).

40 "Uma geometria não pode ser mais verdadeira que uma outra; apenas, pode ser mais cômoda" (Poincaré, 1902, 1908, p. 67).

41 “[...] em si mesma, uma temporalidade nada possui de temporal. É um modo de arranjo que liga os elementos. Se mudamos o princípio de classificação, obtemos uma outra temporalidade a partir dos mesmos eventos" (Latour, 1991, 1997, p. 102).

${ }^{42}$ Por isso Milton Santos afirma que, no circuito superior, prevalece a imitação; no inferior, a criação (Santos, 1973, 2005, p. 100).
} 
Vale pensar, então, na possibilidade de gerir a formação socioespacial em função da criatividade ínsita aos lugares e às regiões, em vez de regê-la com base num processo modernizador que leva, necessariamente, à extroversão e à dependência. Pois, como disse María Laura Silveira (2004, p. 66), o novo não é obrigatoriamente o moderno.

É preciso, porém, relativizar e ponderar as idéias. Por um lado, as normas não garantem uma vigilância perfeita sobre as ações marginais. Por outro lado, escusa concluir que a revanche do território já se finalizou e que, doravante, os marginais passam aos postos antes ocupados pelos hegemônicos. Uma vez que as simultaneidades marginais realizam-se, hoje, nas escalas locais, concluir pela vitória desses agentes poder-nos-ia levar a uma renúncia da noção de totalidade, bem como da noção de concretude territorial $^{43}$. No mais, o que parece mais interessante não é a fundação da hegemonia marginal, mas a fundação de um território comunicativo, livre de suas divisões em pólos, em circuitos, em grupos de agentes com poderes diversos, em racionalidades.

O espaço resulta do jogo entre os poderes de extroversão e as forças locais genuínas. As horizontalidades e verticalidades, apontadas por Milton Santos (1996, 2002, p. 281-288), ficam melhor compreendidas se as captamos ao longo do mesmo movimento cognitivo $^{44}$. É justamente naqueles lugares em que o território mais se instrumentaliza, mais se artificializa e normatiza, que surgem as condições propícias para as ultrapassagens sociais, que levam à emersão de novas lógicas. Pois, como disse Max Pagès, a organização é o espaço que jaz entre a rigidez da norma e a flexibilidade das ações (Pagès, 1978, 1984, pp. 56-59).

Em nossas lentas aproximações, chegamos, então, ao cerne do circuito superior marginal: essa possibilidade para acolher, ao mesmo tempo, duas racionalidades que se expressam territorialmente: a racionalidade instrumental, própria aos agentes hegemônicos; e a racionalidade comunicacional, própria aos agentes marginais. Como um circuito econômico híbrido, um mediador espacial, o superior marginal faz-se objeto para ricas interpretações de nossos novos tempos. E os contextos urbanos, igualmente povoados por tendências, processos, trabalhos díspares e complementares, constituem situações de extrema valia geográfica.

\footnotetext{
43 “[...] propomos denominar concretude territorial esse processo de construção de um meio perfeito, povoado de híbridos na forma de objetos, ações e normas, e que é simultâneo à produção de outras instâncias da sociedade”. (Silveira, 1997, p. 43)

44 "Forças centrípetas conduzem a um processo de horizontalização, forças centrífugas conduzem a um processo de verticalização. Mas, em todos os casos, sobre as forças centrípetas, vão agir forças centrífugas [...] Tal superposição faz com que a explicação do que se passa dentro de cada área deva obrigatoriamente incluir as escalas superiores” (Santos, 1996, 2002, p. 287).
} 


\section{Últimas palavras}

[...] mostrou-me o anúncio de um medicamento novo, o rábano iodado [...].

E leu-me que o rábano curava todas as doenças que o óleo de fígado já não podia curar pretensão de todo medicamento novo.

Machado de Assis

Crônicas escolhidas (1885) 
Os circuitos da economia e suas racionalidades espaciais

A teoria dos dois circuitos da economia urbana pretende, a um só tempo, fundar uma visão alternativa da economia dos países periféricos, tomada como totalidade, e estimular essas reviravoltas conceptuais capazes de revelar novas dimensões da vida social e denunciar as hipóstases hegemônicas.

Se falamos na existência de dois circuitos econômicos, é por termos identificado a constituição e preservação, através dos períodos históricos, de dois subsistemas espaciais, cada qual subordinado às lógicas e processos atinentes ao sistema total. Assim como o espaço é um conjunto de sistemas de objetos e sistemas de ações, cada um desses circuitos ordenam, à sua maneira, os objetos e as ações oferecidos, ou recusados, pela totalidade mundial. Esses circuitos aparecem de maneira diferenciada, além de estarem hierarquizados. O circuito superior é o pólo mais dinâmico e moderno, comportando objetos e ações mais sofisticados, ao passo que, no circuito inferior, identificamos formas e processos mais arcaicos e menos complexos.

Dir-se-ia também que os circuitos são atravessados, cada um deles, por uma lógica, uma racionalidade, que lhes é particular. Se se formam os sistemas de objetos e os sistemas de ações, isso não quer dizer apenas uma reunião de elementos mais ou menos variados. Quer dizer, sobretudo, que esses objetos e essas ações se organizam em obediência a certas regras, certas ordens. Recorrendo aos termos de Wittgenstein, diríamos que existem as coisas e os estados de coisas. "No estado de coisas os objetos estão uns para os outros de uma determinada maneira" (Wittgenstein, 1921, 1994, pp. 140-141) ${ }^{1}$.

Aliás, os circuitos econômicos marginais são possíveis justamente porque a materialidade pode sofrer diversos arranjos. Assim, à hipertelia definida pelas ações hegemônicas, pode fazer contraponto uma pluralidade de fins, ainda que restrita às escalas locais. Trata-se de um sentido diferente que os mesmos objetos adquirem ao serem usados por outras ações, movidas por outras necessidades ${ }^{2}$.

Buscamos demonstrar que os rearranjos da produção farmacêutica levam os pequenos laboratórios a travar relações mais amplas, com uma gama larga de agentes. Mas, esse alargamento dos contextos, ainda que eleve o acesso às maquinarias e princípios ativos modernos, não apaga a temporalidade mais lenta e as integrações locais que são, em larga medida, a base da existência de um circuito superior marginal da produção de medicamentos.

\footnotetext{
${ }^{1}$ Sartre faz uma distinção bastante parecida; para ele, existem as coisas e a ordem das coisas (Sartre, 1960a, p. 98).

2 “Cada coisa está como que num espaço de possíveis estados de coisas [...] Os objetos contêm a possibilidade de todas as situações (Wittgenstein, 1921, 1994, pp. 136-139)”.
} 
Os objetos apenas terão sentido, portanto, em função do contexto em que serão usados. Mais ainda, poderíamos pensar, com Milton Santos (1977, 2005, p. 31), que tal sentido varia segundo as condições específicas de cada formação socioespacial. Além da forma, cabe indagar do conteúdo conferido a cada objeto, em situações concretas ${ }^{3}$.

Muito embora contando com escalas de possibilidade mais reduzidas, os agentes marginais são também capazes de formar sistemas, os quais poderiam, em certas situações, ser considerados como contra-sistemas. É nessa medida que, em oposição aos sofisticados sistemas dos laboratórios multinacionais, os laboratórios familiares, para constituir seus sistemas alternativos, recorrem a formas simples e baratas: princípios ativos adquiridos junto a produtores asiáticos; máquinas menos sofisticadas, por vezes compradas de outros produtores; uma divisão do trabalho mais simples; utilização de distribuidores regionais ou locais; propagandas em pequenas emissoras locais de rádio; entre outras coisas.

O território, mesmo que densamente controlado, tecnificado e normatizado, ainda é uma produção humana, passível portanto de novas ultrapassagens; ainda se cobre de certos insterstícios por onde penetram racionalidades indomadas ${ }^{4}$. É nessa medida, certamente, que Maria Angela Faggin Leite pôde falar na emersão de uma "anticidade", ou seja, na criação, pelos pobres, de inopinados esquemas de vida, em face de uma modernidade urbana que leva a séries de exclusões (Leite, 2001, 2004, p. 445).

As normas, ocupando hoje um posto central, apenas reforçam o processo. Pois, no mesmo instante em que elas exigem a obediência a certos procedimentos e padrões modernos, induzem a uma desenfreada busca de soluções alternativas, de arranjos que possam, ao mesmo tempo, serenar a fúria normativa e respeitar a escassez de recursos instrumentais. As renovações normativas realizadas pela Anvisa definem rígidos enquadramentos às pequenas empresas, mas, por isso mesmo, conduzem a novos contatos (por exemplo, com as universidades), o que amplia as escalas de possibilidade dos agentes marginais.

Segundo Milton Santos, as normas têm uma dimensão negativa, proibitiva, que interdiz a mudança das formas; e uma dimensão positiva, que encoraja a mudança das formas (Santos, 1982, 2004, pp. 27-28). Com efeito, numa abordagem preocupada com a

\footnotetext{
3 “O objeto, matéria inerte, torna-se o depositário de uma migalha de movimento, torna-se forma-conteúdo, quando associado a uma totalidade social que age como uma força de transformação” (Santos, 1979, 2003, p. 200).

4 "Essas contra-racionalidades se localizam, de um ponto de vista social, entre os pobres, os imigrantes, os excluídos, as minorias; de um ponto de vista econômico, entre as atividades marginais, tradicional ou recentemente marginalizadas; e, de um ponto de vista geográfico, nas áreas menos modernas e mais 'opacas', tornadas irracionais para usos hegemônicos. Todas essas situações se definem pela sua incapacidade de subordinação completa às racionalidades dominantes, já que não dispõem dos meios para ter acesso à modernidade contemporânea” (Santos, 1996, 2002, p. 309).
} 
totalidade, os conceitos sempre serão bifrontes, pois que tanto podem ser vistos sob a ótica do circuito superior como interpretados segundo a visão do circuito inferior.

Os agentes marginais, premidos pelas normas, resolvem suas situações buscando mais cooperação. Assim, acentiam suas semelhanças em relação ao circuito inferior da economia. Neste, com efeito, vige a continuidade, a cooperação. Já o circuito superior, não apenas produz séries de fragmentações, como carrega, em seu bojo mesmo, uma grande ruptura. A lógica do capital vai diferenciando sempre os agentes, num movimento voraz de que as fusões, as aquisições, a formação de imensos e raros grupos capitalistas, são as manifestações mais evidentes. É por isso que o circuito superior não pode existir senão fragmentado, separado em duas seções: o superior propriamente dito e o superior marginal.

\section{O circuito superior marginal: mediador espacial}

Mesmo sem ter lógica própria, o circuito superior marginal constitui uma forma de existência, ou seja, ele não se refere a situações mais ou menos instáveis e provisórias. No capítulo IX, dizíamos que, em certas cidades, ele pode haver mais um caráter ascendente; noutras, mais uma feição decandente. Porém, preponderando seu caráter ascendente, isso não quer dizer que ele se vai transmudar em circuito superior; e, quando é sua dimensão decadente que prevalece, não teremos, no futuro, um novo circuito inferior. Essas são, isto sim, duas maneiras de integração do circuito ao processo de modernização. Lá onde o superior marginal se mostra mais ascendente, é mais intensa e vívida sua participação nos processos de modernização, e mais profundos os benefícios que ele pode retirar. Conforme a explicação de Milton Santos, não existe, entre os circuitos inferior e superior, um continuum, como se as características do circuito inferior reproduzissem, numa escala menor, aquelas do circuito superior (Santos, 1979, 2004, p. 53). Da mesma forma, não é lícito pensar o superior marginal como um circuito superior em miniatura, tampouco pensar que ele tenda a se dissolver nos outros circuitos. É de novo Milton Santos quem diz que as desigualdades de renda, agravando-se, reproduzem todas as divisões econômicas e espaciais (Santos, 1979, 2004, p. 316). "Essa organização do espaço leva pois à perpetuação tanto do circuito superior marginal como, e principalmente, do circuito inferior" (idem, p. 369).

Assim, o circuito superior marginal aparece como um dos elementos fundamentais que estruturam o espaço dos países periféricos. Sua eliminação requereria, com efeito, a desaparição das clivagens profundas que assolam o próprio espaço total.

Certamente, sua existência reforça-se, na grande maioria das vezes, em função das ações das menores empresas. Uma vez que estas apresentam, não raro, elevados graus de mortalidade, poderíamos ser tentados a pensar que também o circuito marginal ver-se-ia, 
mais cedo ou mais tarde, sob grave ameaça de extinção. Mas, como constata Milton Santos, a clara instabilidade dos pequenos empreendimentos é compensada pelo fato de que, em pouco tempo, surgem novas empresas pequenas, que vão cumprir as mesmas funções das suas predecessoras (Santos, 1994a, p. 104) ${ }^{5}$. Desse modo, o que é mais crucial "não é a quantidade ou o tempo de 'duração' das empresas e sim as facilidades e entraves oferecidos pelo meio geográfico em suas várias constituições no Brasil, bem como os usos possíveis do território brasileiro, divergentes segundo cada empresa" (Grimm, 2002, p. 147).

Desse modo, é importante ressaltar que o superior marginal constitui-se numa subtotalidade, e, sendo assim, não pode ser pensado como simples soma de empresas possuidoras destas ou daquelas características distintivas. Certamente que as empresas individuais sustentam, com suas ações específicas, a existência do superior marginal; por isso, devemos atentar para suas operações. Entanto, a instabilidade dos pequenos empreendimentos não implica a instabilidade do circuito econômico, pois este se esceve no espaço, apoiado por fenêmenos geográficos profundos. Durkheim nos ensina que "[...] um todo não é idêntico à soma de suas partes; ele é distinto disso, e suas propriedades diferem daquelas que apresentam as partes de que se compõe" (Durkheim, 1968, p. 102) ${ }^{6}$. Por isso, devemos escapar a três equívocos.

Primeiramente, a definição do circuito superior marginal pode relegar as considerações acerca do porte das firmas. Por isso, não se deve dizer, sem mais ponderações, que ele é composto pelas médias empresas. Pois, quando as grandes empresas se beneficiam de formas e lógicas locais, participam do superior marginal; e, quando as pequenas e médias empresas realizam usos mais dinâmicos e velozes do território, podem fortalecer o circuito superior ${ }^{7}$. Estamos falando, sempre, de processos espaciais.

Segundamente, circuito superior marginal nem sempre rima com empresa nacional. Já dissemos que as empresas hegemônicas podem, por vezes, reforçar o circuito inferior. Mas, com mais freqüência, algumas empresas nacionais podem fortalecer, de modo precípuo, o circuito superior. Isto é corriqueiro para os grandes laboratórios de capital nacional que, travando várias relações com os laboratórios multinacionais, acabam nutrindo a lógica do circuito superior. Foi o que tentamos demonstrar no capítulo VI.

\footnotetext{
${ }^{5}$ Da física nuclear, nos vem este valioso ensinamento acerca da matéria: fenômenos estáveis podem ser compostos por elementos e processos espantosamente instáveis e fugazes. Poderíamos falar, quiçá, numa forma de existência (o estável) e numa forma de aparência (o fugaz). Seriam dois níveis concomitantes e necessários da materialidade.

${ }^{6}$ Também Kosik (1989, pp. 7-54) nos diz que a totalidade não é uma soma de fatores isolados.

7 “[...] o problema se situa muito mais no nível tecnológico e na administração do que na quantidade de capital empregado" (Santos, 1979, 2004, p. 104).
} 
Por fim, a teoria dos circuitos da economia não tem propósitos classificatórios. Se dela nos valemos, é para captar os processos espaciais particulares aos países periféricos, e jamais para dizer se tal ou tal empresa pertence a tal ou tal circuito.

Com essa mudança, poderíamos abandonar a grave tentação da competitividade nacional, que nos leva a gastar esforços buscando planos e metas para fazer mais competentes e fortes as empresas nacionais. "Para enfrentar o processo de desenvolvimento geograficamente desigual, pouco ajudam os esforços para criar as condições que permitam aos lugares entrar na batalha da competitividade. Ela é de natureza essencialmente excludente". (Arroyo, 2001, p. 3) Essa tentação da competitividade se expressa, por exemplo, num trabalho recente realizado nos quadros do BNDES. "No Brasil, existem hoje várias empresas de medicamentos de controle familiar dividindo um mercado que vem crescendo. Com o intuito de fortalecê-las para que possam ter uma atuação competitiva não só no mercado interno, mas também voltada para a exportação, além de torná-las capazes de se aventurarem no primeiro estágio de desenvolvimento da cadeia farmacêutica - atividades de P\&D -, caberia ao BNDES induzir o movimento de concentração no setor, criando empresas nacionais mais robustas". (Capanema e Palmeira Filho, 2004, pp. 46-47) Existe, assim, um discurso de antecipação de movimentos de concentração. Esquece-se que a produção de medicamentos não é um fim em si mesmo, ou seja, que ela, em vez de servir de base ao fortalecimento do capital nacional, serve antes para ofertar medicamentos à população, suprindo uma necessidade. Presas à axiologia da modernização, algumas interpretações se enredam à ilusão do que o destino do circuito superior marginal deve ser sua conversão em circuito superior. Além de ser uma fábula, isto é uma impossibilidade.

A destituição da gestão induzida do território, que hoje predomina contra uma gestão espontânea, depende dessas ultrapassagens socioespaciais que já se verificam atualmente, e que já vão desafiando as condições da hegemonia global ${ }^{8}$.

Certamente que a existência do superior marginal repousa sobre certas circunstâncias de natureza técnica. Assim, por exemplo, o fato de que, nele, capital e trabalho misturam-se de maneira profunda, pois, nem a produção pode basear-se numa aplicação maciça e extensa de capital, nem pode haver, como no circuito inferior, empreendimentos cuja base quase exclusiva é o trabalho. Porém, há fenômenos espaciais gerais a sustentar a existência do superior marginal. Entre eles, o mais importante é o próprio fácies da formação socioespacial, em que trabalho e capital obedecem a diversas distribuições, de acordo com as histórias específicas de cada lugar, de cada região.

\footnotetext{
8 “Aliás, a força própria do lugar vem das ações menos pragmáticas e mais espontâneas, freqüentemente, baseadas em objetos tecnicamente menos modernos e que permitem o exercício da criatividade" (Santos, 1996, 2002, p. 228).
} 
Nas cidades, o meio construído se instala como testemunho dessa história, abrigando, ora formas envelhecidas, ora formas típicas das mais recentes vagas de modernização. A materialidade, além de garantir a comunicação no interior de cada circuito econômico, também permite uma comunicação entre os circuitos. Por isso, o superior marginal pode ser pensado como um sistema técnico híbrido, como se nele convivessem os dois circuitos fundamentais; igualmente, pode ser pensado como um sistema organizacional híbrido. Na linguagem de Wittgenstein (1921, 1994), o superior e o inferior seriam proposições elementares; o superior marginal, uma proposição derivada, mas derivada, ao mesmo tempo, de duas proposições elementares diferentes. Essa coexistência, sempre com a linguagem de Wittgenstein, mostra que, entre o superior e o inferior, a relação não é de tautologia (completa coincidência) nem de contradição (completa oposição). Propomos dizer que a relação é de complementaridade.

Daí a natureza híbrida do superior marginal, verdadeiro mediador espacial. As ações que o reforçam ficam normativamente obrigados a acolher procedimentos e lógicas instrumentais próprios do circuito superior. Assim, o novo consumo de informações e normas jurídicas, tal como se quis ilustrar no capítulo VIII. Por outro lado, as ações do circuito superior marginal podem-se aproximar dos conteúdos do lugar, o que é mais típico do circuito inferior. Foi o que se quis demonstrar no capítulo VII com a discussão sobre as densidades comunicacionais. Desse modo, o superior marginal se alimenta, ao mesmo tempo, das lógicas do superior e do inferior. Nele, a racionalidade instrumental coexiste com a racionalidade comucacional, e é assim que sua existência torna-se forte e duradoura.

Trata-se também de superar o encantamento que, tantas vezes, devotamos às formas e lógicas modernas. Estamos em face de duas ordens: a ordem (ou razão) global e a ordem (ou razão) local (Santos, 2005; Santos, 1996, 2004, p. 338-339). A expansão do circuito inferior, mas também do superior marginal, em várias cidades brasileiras, pode ajudar-nos a ver que não há, em termos espaciais, monopólio da razão.

O circuito inferior, mas também o superior marginal, possibilitam a fundação de empreendimentos mesmo em face de situações de carência de capitais e recursos instrumentais. Com isso, forças dispersivas podem contrabalançar os choques de concentração gerados pelos agentes hegemônicos; cidades médias podem ganhar novas dinâmicas; pontos opacos sair um pouco de seus estados letárgicos.

Em tempos de aceleração moderna, são os circuitos econômicos marginais que vão assegurar, minimamente, a existência de um direito à lentidão. Ainda que tal circunstância vá representar, em critérios mercadológicos, a geração de lucros totais menos volumosos, é dela que depende a sobrevivência de grande número de empreendimentos urbanos. As ações marginais conformam um sistema de coordenadas em que se entorta o eixo do 
tempo. Aos objetos modernos, se deles se dispõe, novos ritmos são atribuídos, pois é o funcionamento que deve primar sobre a função ${ }^{9}$.

No limite, podemos identificar, com Milton Santos, a produção de uma contra-ordem, que é paralela à produção em massa de pobres, marginalizados (Santos, 2000, p. 114). As normas globais falham, aqui, no seu propósito mais fundamental: promover uma rotinização das ações. Elas que, se bem-sucedidas, fundariam as obediências compulsórias, vão-se tornando a base de múltiplas desobediências ${ }^{10}$. A gestão induzida do território vê-se, com isso, ameaçada gravemente.

Tais considerações nos obrigam a verificar, além das formas e relações já existentes, aquelas que se esforçam por emergir e consolidar. Desde os circuitos econômicos marginais, os fenômenos chegam, freqüentemente, como tendência, tentativa, proposta. É dessas lutas atuais que depende a configuração futura do território ${ }^{11}$. Por isso falamos anteriormente (Bicudo, 2005) numa geografia dos possíveis. Se ficarmos amarrados às escalas espaciais e temporais hegemônicas, renunciando às escalas marginais, mais facilmente recusaremos à verificação das possibilidades guardadas pelo território.

\section{Território e conflito}

Hoje, apenas essas mudanças de escala permitem ver que, desafiando as conclusões fatalistas que tantas vezes nos cortejam, novos conflitos perpassam o território, que está longe de constituir o reino incontestável dos agentes hegemônicos. Modos de produção paralelos, alternativos, prosseguem existindo, e lutam para se afirmar ${ }^{12}$. A revanche do território vale-se de armas concretas e materiais (necessidades, objetos usados, corpos, técnicas, linguagens) contra as hostes do abstrato e do imaterial (acumulação, objetos trocados, informação instrumental, crescimento econômico) ${ }^{13}$. espaço não deixa de ser atravessado por lutas históricas, mas elas já se dão sobre arenas

\footnotetext{
9 "O progresso técnico permite, ainda que potencialmente, outras formas de utilização do território, um novo uso do tempo e do espaço” (Ramos, 2001, 2004, p. 385).

10 "Nesse sentido, as ações a distância são indiferentes aos lugares; em vez de as ações se ajustarem ao lugar e às suas particularidades geográficas, buscam transformá-los, neste caso, através das leis, segundo a lógica que conduz a uma relativa homogeneização do espaço. Relativa, pois os lugares, em suas culturas, políticas e economias enraizadas e dependentes de nexos geridos apenas e tão somente nessa escala, correspondem à inflexão dessa lógica; correspondem à resistência e ao atrito das políticas globais universalizantes da hegemonia corporativa” (Antas Jr., 2005, p. 153).

${ }^{11}$ Segundo Sartre (1960a, p. 65), o futuro tem um lado incerto, referente àquilo que falta, que não está pronto, que não se prevê; e um lado previsível, referente àquilo que é constante, que se apóia num status quo.

12 "A cada momento, diferentes áreas podem mudar de maneiras contrastantes, diferentes batalhas podem ser travadas, diferentes problemas enfrentados” (Massey, 1984, 1987, p. 117).

13 “A complexidade do mundo contemporâneo se deve, em grande parte, ao fato de que às inúmeras razões locais existentes em todos os continentes veio se sobrepor uma razão global inteiramente instrumental às necessidades de fluidez das grandes organizações capitalistas. Há, portanto, um forte campo de tensões, de conflitos, que se dá
} 
completamente renovadas. E a nova luta realiza-se principalmente como luta pelo lugar, onde aliás se trava a maioria das batalhas diárias ${ }^{14}$. Trata-se de uma dura competição cujo maior prêmio será a possibilidade de fruir das densidades comunicativas, abundantes sobretudo nas cidades ${ }^{15}$. Os agentes marginais dispõem de armas escassas e precárias; logram, porém, mover-se melhor pelo campo do lugar. Desse conflito global vai derivar, ou o aprofundamento da racionalidade instrumental, ou as primeiras fases da construção do espaço em bases comunicacionais. Nas maiores cidades brasileiras, esta segunda hipótese parece predominar, o que se nota pela difusão do circuito inferior, já mais dinâmico e lábil do que seu par complementar, o circuito superior.

No espaço, a política se lê menos em palavras, em discursos nítidos e conscientes, que em sistemas de ações. Em termos geográficos, ação política é, com efeito, ação sobre o território, expressando um sentido e um projeto. O território só é um campo de forças porque há diferentes e conflitantes discursos territoriais, projetos territoriais.

Dizer que o espaço foi anulado equivale a camuflar a evidência de que as lutas espaciais se reproduzem constantemente. Os agentes marginais ocupam, sem dúvida, posições desfavoráveis estrategicamente; mas isso faz aumentar as tensões, reforçando aquilo que Milton Santos (1996, 2002, p. 322) chamou de o confronto entre organização e espontaneidade. Certamente, a má distribuição dos recursos faz piorar, sempre mais, a distribuição dos poderes efetivos. "Mas o conflito não pode ser suprimido da história do território" (Santos e Silveira, 2001, 2004, p. 112). Mesmo nas escalas pequenas, um saber propriamente geográfico se constitui, formando a base dessas "ações rebeldes à lógica dominante", conforme expressão de María Laura Silveira (2000, p. 25).

Mas, nem a existência dessa rebeldia espacial não redime a nação, nem sua identificação redime as ciências. Em verdade, mesmo o circuito inferior, mais infenso às lógicas hegemônicas, reforça, de certo modo, os desequilíbrios atuais ${ }^{16}$. Por isso, nossa meta maior não é promover a ascensão do circuito inferior, mas acabar com a divisão do espaço; e a elisão do espaço dividido quer dizer a constituição do espaço coordenado.

Essas tarefas políticas e teóricas são prementes, pois a racionalidade comunicacional assenta sobre certa margem de competição. Se os efeitos de coordenação forem sufocados pelos projetos hegemônicos, nada mais sobrará senão a concorrência total

\footnotetext{
a partir do impacto de um sistema temporal hegemônico sobre temporalidades locais, regionais e nacionais” (Bernardes, 2001, p. 49).

14 “O confronto das forças ao nível planetário se desenrola não somente através das estruturas nacionais, mas até no emaranhado dos componentes políticos de certos lugares” (Lacoste, 1976, 1997, p. 50).

15 "Mesmo nos lugares onde os vetores da mundialização são mais operantes e eficazes, o território habitado cria novas sinergias e acaba por impor, ao mundo, uma revanche [...]” (Santos, 1994, 2005, p. 138).

16 “Se o circuito inferior não deve permanecer o que é, é porque seu papel, muito antes de ser o de provedor de ocupações e de fornecedor dos meios de sobrevivência, é o de perpetuador da pobreza, servindo de coletor da poupança popular, canalizada em seguida para o circuito superior por intermediários de todos os tipos” (Santos, 1979, 2004, p. 368).
} 
e generalizada ${ }^{17}$. Pior do que uma guerra civil, assistiríamos à constituição de uma guerra fria territorial, em que os conflitos mais cruentos emergiriam em todas as relações cotidianas, entre todos os agentes, mas de uma forma jamais explícita. Em cidades em que as tensões chegam a extremos, como São Paulo ou Rio de Janeiro, a imagem da guerra civil não seria metáfora nem exagero.

\section{A centralidade das normas}

Em função das mudanças técnicas, os recursos disponíveis adquirem novos sentidos. Doravante, depois das revoluções permitidas pelas biotecnologias, cumpre dispensar um novo desvelo à flora nativa, que passa por sucessivas explorações mercantis, de maneira nem sempre clara ${ }^{18}$.

Essa concupiscência que se precipita sobre os espaços mais opacos nos fala de um período em que a vida vai sendo colonizada em várias de suas esferas fundamentais. Tratase de uma nova reunião, mais profunda, de poderes globais e forças locais; de horizontalidades e verticalidades, constituindo subtotalidades híbridas, transversalidades que aproveitam aos agentes hegemônicos. É a biotecnologia: o domínio tecnológico da vida. Etimologicamente. Fizemos essa discussão no capítulo IV.

Mais uma vez, o território brasileiro se revaloriza sob os auspícios de evoluções e interesses estrangeiros. Mesmo assim, seria possível aproveitar a situação, orientando-a no rumo de caminhos mais proveitosos para o país.

Com base nesses eventos, podemos atentar para o exemplo das Farmácias Vivas, experiência que pode aliar as tradições curativas locais aos avanços da terapêutica científica $^{19}$. A partir de usos locais tradicionais, hortas coletivas são cultivadas, sob a coordenação de profissionais da área farmacêutica. Assim, a ciência já não é quaquer coisa que se impõe às pessoas, mas uma ferramenta a mais, capaz de reforçar e ajustar as práticas do lugar. As transversalidades não são, forçosamente, daninhas, desde que seu modo de existência seja condicionado, não por interesses alheios ao lugar, mas sim pelas

\footnotetext{
17 “Centro da ação contraditória de hostilidades tão diversas, joguete de vetores cuja cara não vêem e cuja ação não podem interpretar diretamente, os cidadãos se atordoam em sua luta, freqüentemente errando de alvo e, desse modo, despendem energias que, em outras direções, teriam resultados mais eficazes”. (Santos, 1993, p. 132)

${ }^{18}$ Para uma discussão sobre biopirataria, bioprospecção e as legislações brasileiras relacionadas, ver Alves, 2004, pp. 149-154.

19 "Este foi um projeto desenvolvido em 1983 pelo professor titular da Universidade Federal do Ceará (UFCE), Francisco José de Abreu Matos, a partir de recomendações da OMS para oferecer assistência farmacêutica fitoterápica, sem fins lucrativos, para comunidades não atendidas pelos programas de saúde pública. O principal objetivo é promover o uso correto das plantas locais ou regionais que tenham atividade terapêutica cientificamente comprovada” (Alves, 2004, p. 144).
} 
necessidades localmente geradas ${ }^{20}$. A promoção dessas transversalidades poderia ser a base de uma outra globalização. São os poderes globais a serviço das forças locais.

O saber tradicional é um sistema de ações que, transfundindo os períodos, vai adquirindo valores inéditos. Mas, a discussão dos sistemas de ações tona-se inócua sem um debate, paralelo, sobre os sistemas de objetos. Estes, seu funcionamento, seu uso, estão sob o rígido controle dos agentes hegemônicos, o que nos exige, também, uma discussão política. Assim, ao invés de sucumbirmos ao discurso entusiástico da biodiversidade brasileira, vale explicitar as formas extrovertidas que, muita vez, assumem os usos dessas riquezas ${ }^{21}$.

Por ora, cada mudança técnica e normativa que se realiza no território pretende, mais do que tudo, ampliar as escalas de possibilidade próprias aos diversos estratos hegemônicos ${ }^{22}$. Por vezes, tais manobras chegam a ser também aproveitadas pelos agentes marginais; o que se dá, porém, de maneira indireta e não planejada. Hoje, o exercício do poder, além de provir de mecanismos de produção, distribuição e elaboração de conhecimentos, pode repousar sobre trabalhos normativos que se dedicam, sobretudo, à definição das escalas de possibilidade aplicadas a cada grupo de agentes. "O exercício do poder não consiste em ordenar, em tomar decisões, mas em delimitar o campo, em estruturar o espaço no qual são tomadas as decisões" (Pagès, 1978, 1984, p. 53) ${ }^{23}$.

As novas possibilidades oferecidas pelas técnicas hegemônicas, bem como a difusão de outras técnicas, mais doces, são o ponto de partida para um trabalho normativo que pretende fixar o campo dos possíveis para campo de agentes ${ }^{24}$. Daí, o papel central que desempenham as agências de regulação, tais como a Anvisa. Ao longo das partes 2 e 3, revisamos várias alterações provocadas pela Anvisa, buscando mostrar que, muita vez, elas sufocam as situações das menores empresas. No capítulo $\mathrm{V}$, dizíamos que, a partir da lei dos genéricos, foram criadas várias densidades normativas (jurídicas, técnicas, informacionais), que reforçam as polarizações espaciais, criando um mercado extremamente fechado às menores empresas. Desse modo, instala-se um acontecer

\footnotetext{
20 “[...] para desempenhar por completo o seu papel, a cultura deve incorporar os seres técnicos sob forma de conhecimento e de sentido de valor” (Simondon, 1958, 1969, p. 9).

21 "Não se trata apenas do acesso facilitado a uma biodiversidade particularmente rica, mas também, ou principalmente, da existência de uma certa competência científica já instalada capaz de explorar esse potencial e extrair resultados interessantes em termos de novos medicamentos” (Queiroz e González, 2001, p. 129).

22 "E, de acordo com Milton Santos, a formação socioespacial revela aqui sua centralidade, pois, se os vetores globais carecem de uma ordem assegurada pelas normas, estas só têm eficácia como normas nacionais” (Santos, 1996, 2002, p. 335-337).

${ }^{23}$ A idéia de escala de possibilidade, como a propomos, aproxima-se da idéia de poder em Kaysen (1959): o poder como o campo de escolhas socialmente significativas disponível a cada agente.

24 "Se a técnica é virtualmente capaz de oferecer novos horizontes, as normas seriam, porém, um limite, uma seletividade à realização do mundo dos possíveis” (Silveira, 1996, 1999, p. 443). “[...] o papel mais típico do direito: a manutenção de uma dada ordem social” (Antas Jr., 2005, p. 50).
} 
hierárquico, que, segundo Milton Santos (1996, 2004, p. 167), estabelece a primazia das normas, realçando-se o fato da política ${ }^{25}$.

Mas, se as normas favorecem, atualmente, aos diversos estratos de agentes hegemônicos, não se deve, por isso, condená-las definitivamente, e propor uma espécie de anarquia espacial. Durkheim disse que, para existir liberdade, o homem deve elevar-se por sobre as coisas, elaborando uma lei que as regule (Durkheim, 1932, p. 381). Trata-se, pois, da humanização do mundo, alternativa à situação atual, em que a ordem dos objetos é que prevalece.

É perfeitamente possível pensar que, havendo normas rígidas, abstratas e duras, pode haver também normas incorporando qualidades outras. Aliás, as normas serão tanto mais perfeitas quanto mais comportarem certo grau de indeterminação, em respeito às diversidades, às temporalidades. Haveria normas doces e duras, abertas e fechadas, ou, melhor dizendo, rígidas e maleáveis. O que nos permite pensar numa regulação que não pretenda, forçosamente, fazer os pequenos laboratórios familiares obedecer às mesmas lógicas e tempos atinentes às corporações farmacêuticas multinacionais.

Mas essa passagem não se faz em nome de empresas ou de grupos de empresas, em benefício dos quais devamos garantir os chamados nichos de mercado, eliminar os chamados gargalos produtivos e corrigir os chamados desequilíbrios econômicos. O capital nacional não é mais benévolo nem menos fragmentador que o capital estrangeiro. $\mathrm{E} o$ principal objetivo não é uma sociedade empresarial, mas uma sociedade comunicacional ${ }^{26}$.

Com freqüência, fala-se no direito à propriedade intelectual, à apropriação dos lucros, à importação de maquinaria de ponta. De alguma forma, esses direitos podem levar a resultados sociais benéficos, cuja manifestação aguardamos com anseio. Mas é preciso que se fixem e respeitem, ainda, outras espécies de direito. Assim, pode-se falar num direito à lentidão ${ }^{27}$ e à particularidade ${ }^{28}$. Produzir não deve ser, forçosamente, uma tarefa de imersão total e cega nos quadros abstratos que os vetores da globalização pretendem pintar. Se é no lugar que se cunham as necessidades, e se é na formação socioespacial que elas se sistematizam, impõe-se pensar em normas que, sendo efetivas, não estilhacem

\footnotetext{
25 "Não é esse um dos menores paradoxos a que nos leva o discurso contemporâneo: quando tanto se fala em flexibilização e flexibilidade como características do presente modelo de acumulação, defrontamo-nos com um verdadeiro endurecimento organizacional, devido à indispensabilidade das normas de ação, tanto mais rígidas quanto mais se pretende alcançar a produtividade e a sacrossanta competitividade” (Santos, 1996, 2002, p. 180).

26 “"[...] o que interessa ao povo não é o êxito dos industriais nacionais, porém, insistimos, é poder comprar remédios de qualidade assegurada e por preços acessíveis enquanto o Governo não puder fornecê-los de graça” (Pacheco, 1968, p. 201).

27 “[...] a velocidade é, por si mesma, um conflito. O interesse das grandes empresas é economizar tempo, aumentando a velocidade da circulação. $\mathrm{O}$ interesse das comunidades locais e até mesmo das menores empresas (por exemplo, os comércios locais) freqüentemente é o oposto” (Santos, 1996, 2002, p. 336).

28 "De imediato, a relação dessa totalidade parcial com a totalidade total se manifesta como conflito. A integração absoluta exige que seja rompida a determinação singular na medida em que ela ameaça constituir uma
} 
contudo a coerência de um projeto centrado em particularidades, carências e tempos concretos. Assim, muito mais do que um progresso abstratamente concebido, poder-se-ia colimar a constituição de um sistema produtivo capaz de promover a saúde, essa necessidade radical.

\section{A regulação híbrida}

Certamente que as normas sempre desempenharam papel relevante, na formação dos sistemas espaciais. No capítulo III, revisamos, para os anos 1970 e 80, algumas iniciativas governamentais que, por meio da produção de uma série de normas, interferiram decisivamente nos rumos que, entrementes, ganhava a atividade farmacêutica. Vimos ali como as normas se voltavam, sobretudo, a uma defesa dos agentes e das produções nacionais, gravemente ameaçados de paralisia. Hoje, porém, a fúria normativa do Estado se realiza, principalmente, em benefício dos agentes hegemônicos, e é justamente por isso que ela, a norma, pode passar ao centro do sistema contemporâneo. É também por esse motivo que as densidades normativas são cada vez mais seletivas.

"A sociedade [...] não se rege, apenas, por leis, decretos, portarias aos níveis federal, estadual ou municipal. As relações atuais entre as firmas e o poder público atribuem às empresas um certo poder de regulação da vida social. Cada vez mais, e a cada dia que passa, as empresas ditam normas, que são freqüentemente ainda mais rígidas que as do poder público [...]" (Santos, 1993, p. 67).

Agora, a norma incorpora, ao mesmo tempo, a lógica do Estado e a lógica da empresa. Do Estado, ela retém sobretudo seu lado geométrico, sua generalidade, sua força para se impor na formação socioespacial; das empresas, ela retém seu lado geográfico, seu poder para difundir uma racionalidade, seu afã de favorecer a busca do lucro. Daí, falar-se numa regulação do território pelo mercado (Santos e Silveira, 2001, 2004, p. 22). O resultado são esses híbridos organizacionais apontados por María Laura Silveira (1996, 1999, p. 262) ${ }^{29}$.

Ricardo Mendes Antas (2005) estudou com detalhes esse fenômeno. Da globalização, ele nos diz, surde um "pluralismo jurídico" (p. 60), pois que a "hegemonia

nova pluralidade. Inversamente, a inércia e as necessidades da integração parcial obrigam cada parte da totalidade relativa a resistir às pressões do todo” (Sartre, 1960b, p. 172).

29 "Nesse rearranjo do território e da economia, uma burocracia mista - porque formada por agentes públicos e privados -, cuja principal novidade é o domínio ostensivo do conhecimento técnico-científico sobre o território e a sociedade, assume papel central. Nas mãos dessa neoburocracia pertencente aos órgãos fiscalizadores das empresas privadas de serviços públicos, ao próprio Estado reformulado e às empresas nacionais e estrangeiras, fica o comando técnico dos novos usos do território nas próprias regiões” (Silveira, 2003, p. 59). 
corporativa" torna-se "uma fonte de poder com pretensões de regular o território juntamente com o Estado territorial" (Antas Jr., 2005, p. 77) ${ }^{30}$.

Nesse contexto, a chamada desregulação aparece como mais uma das fábulas da globalização ${ }^{31}$.

Neste novo capitalismo normativo, prejudicam-se aqueles agentes que não podem contar com proteções e densidades normativas. Se, conforme disse Milton Santos, "[...] existem num mesmo país diferentes situações de pobreza" (Santos, 1993, p. 94), então será lícito considerar a existência da "pobreza legal" denunciada por David Vallat (2002, p. 49).

O fenômeno normativo se manifesta no duplo movimento que vai da internacionalização das formas jurídicas até a manutenção das particularidades normativas nacionais; graças a esse movimento pendular, a instalação das normas globais não leva a uma uniformização dos quadros normativos nacionais (Bicudo, 2006). Quanto mais existe, por parte dos agentes hegemônicos, um esforço para manter a coerência do sistema global, tanto mais o espaço se divide, consolidando circuitos econômicos plenos de racionalidades próprias, muita vez conflitantes com as lógicas do capitalismo.

\section{Os discursos espaciais: A busca da transparência}

A proliferação de discursos busca, desde o circuito superior, disseminar séries de mistificações e ideologias. Em se tratando da produção de medicamentos, essa é a natureza de uma fileira de pesquisas, velhas ou recentes, que, baseando-se unicamente em situações hegemônicas, levam ao seio da sociedade, sub-repticiamente, certas interpretações enviesadas. Assim, quer difundir-se a idéia de que um plano de produção de medicamentos precisa basear-se, forçosamente, na ação das empresas multinacionais ou, pelo menos, em seus paradigmas de ação; de que, para expandir o acesso aos medicamentos, a redução dos preços é medida suficiente; de que pequeno laboratório é sinônimo de baixa qualidade produtiva; de que as produções nacionais só terão viabilidade quando chegarem a níveis tecnológicos iguais ou comparáveis aos que se verificam nas produções estrangeiras; de que produção racional de medicamentos, bem como seu consumo racional, realizam-se apenas em contextos metropolitanos ou, pelo menos, com a participação das racionalidades metropolitanas. Poderíamos citar outras idéias que se vão

\footnotetext{
30 “Advém daí a proposta de um entendimento de que a regulação do território nacional hodierna atravessa uma transição para uma evidente divisão ente poderes: de um lado o poder monolítico e extensivo da hegemonia soberana, de outro, o poder fragmentado, especializado por setores econômicos (não necessariamente produtivos), formados por redes técnicas e organizacionais, que seria a hegemonia corporativa” (Antas Jr., 2005, p. 164).

31 "Esse processo, que faz alusão à eliminação de normas pretéritas, é freqüentemente denominado desregulação. Todavia, à ruptura do arcabouço jurídico segue-se a imposição de novas normas fiscais que tornam viável a ação das firmas no território" (Silveira, 2003, p. 57).
} 
disseminado, em benefício dos agentes hegemônicos e das forças espaciais concentradoras. Constitui-se um discurso estruturado, que é poderoso na medida em que repousa, não sobre falsidades, mas sobre verdades parciais. Fundamentalmente, esse discurso esconde a existência das racionalidades produtivas e consumptivas marginais, apresentando as soluções dominantes como as únicas passíveis de crédito e consistência.

Mas, como vimos dizendo, as ações marginais promovem a montagem de sistematizações alternativas, em que sejam mais claros os discursos, menos individuais os projetos. Trata-se de um discurso das ações recaindo sobre os objetos, baseado na copresença e na cooperação. Os sistemas espaciais alternativos fazem parte da busca pela transparência, pois, conforme Habermas, "[...] as ações sociais podem ser distinguidas em função da atitude adotada pelos participantes, segundo essa atitude seja orientada para o sucesso ou para a intercompreensão [...]" (Habermas, 1981, 1987, p. 296).

O discurso territorial dos agentes marginais está, em grande medida, consolidado. Disso provém o fato de que, para um certo grupo de empresas, a concorrência não se realiza em termos de predação, conflito e fusão; de que as trocas e as cooperações podem acontecer mesmo se os agentes curtem situações de extrema subordinação mercadológica; de que se pode realizar um trabalho com menos conteúdos em capital, ciência e informação, sem que isso deva conduzir à dissolução dos circuitos econômicos marginais; de que a escala do lugar pode ser esteio de uma pletora de ações econômicas, mesmo em face de um processo de alargamento dos contextos.

E essa busca se faz plausível desde o momento em que, pelas novas plasticidades técnicas e pelas confluências de ações marginalizadas, podem-se constituir unificações espaciais alternativas, ou mesmo contra-sistemas, incorporando lógicas menos rígidas e excludentes. As ações marginais alastram-se pelas cidades, por vezes ditando sua nova dinâmica. Ao mesmo tempo em que o território repercute os abalos da razão global, torna-se meio de vida para as ordens locais. De acordo com Milton Santos, o espaço geográfico é, ao mesmo tempo, uma condição para a ação, uma estrutura de controle, um limite à ação, um convite à ação (Santos, 1996, 2004, p. 321). "Nas condições atuais do mundo, ainda mais que na era precedente, o espaço está chamado a desempenhar um papel determinante na escravidão ou na liberação do homem" (Santos, 2002, p. 266).

No que se refere à produção de medicamentos, o circuito superior marginal abriga as sistematizações, as divisões do trabalho, as temporalidades alternativas. Ao mesmo tempo, ele se vai sufocando pela vigilância normativa que provém do circuito superior. De sua ligação com os lugares e com as densidades comunicacionais depende, em larga medida, a preservação de uma atividade farmacêutica vinculada às reais necessidades que emergem no território. E esse tipo de ligação, repetindo-se nas várias atividades produtivas, é a garantia da construção de uma verdadeira economia nacional. Esta pensada não como um 
conjunto mais ou menos coeso de indicadores e estatísticas, mas segundo a explicação de Caio Prado Júnior (1945, 1998, p. 298), ou seja, a economia nacional como "[...] um sistema organizado de produção e distribuição dos recursos do país para a satisfação das necessidades de sua população"32.

Se dizemos que a saúde se torna uma necessidade radical, é por pensar que, nas condições atuais, ela não pode ser provida sem uma transformação das estruturas sociais e espaciais. Políticas farmacêuticas, sem o amparo de sistemas espaciais mais igualitários, tendem a surtir limitadas. Os projetos e respostas marginais aí estão, a forçar os rumos do país na direção de sistematizações espaciais menos pragmáticas e artificiais. Como contraponto a esta gestão induzida do território, que aproveita aos agentes hegemônicos e consagra os vetores da globalização, as divisões marginais do trabalho vêm propor a possibilidade de uma produção calcada em necessidades e invenções endógenas, signos de uma gestão espontânea do território.

\footnotetext{
32 “As necessidades de saúde, como também as necessidades em geral, não são atributos de indivíduos isolados, do Homem a-histórico, atemporal da filosofia idealista” (Cordeiro, 1980, p. 100).
} 
Bibliografia

ALMEIDA, Eliza. Refuncionalização da metrópole no período técnico-científicoinformacional. In: SANTOS, Milton; SILVEIRA, María Laura. [2001] O Brasil: Território e sociedade no início do século XXI. $6^{\text {a }}$ ed. Rio de Janeiro, Record, 2004. pp. 389-400.

_ Uso do território brasileiro e os serviços de saúde no período técnicocientífico-informacional. Tese de doutoramento apresentada ao Departamento de Geografia da Universidade de São Paulo. São Paulo, FFLCH/USP, 2005.

ALVES, Flávia Neves Rocha. Desafios para o desenvolvimento de fitomedicamentos no Brasil no contexto da indústria farmacêutica. Dissertação apresentada à Escola Nacional de Saúde Pública Sérgio Arouca, para obtenção do título de mestre em Ciências na área de Saúde Pública. Rio de Janeiro, ENSP/Fiocruz, julho de 2004.

ANTAS JR., Ricardo Mendes. Território e regulação: Espaço geográfico, fonte material e não-formal do direito. São Paulo, Fapesp, 2005.

ANTONGIOVANNI, Lídia. Alguns nexos entre a atividade publicitária e o território brasileiro. In: SANTOS, Milton; SILVEIRA, María Laura. [2001] O Brasil: Território e sociedade no início do século XXI. 6a ed. Rio de Janeiro, Record, 2004. pp. 401-411.

ANUCHIN, V. A. Teoría de la geografía. In: CHORLEY, Richard J. (org.): Nuevas tendencies en geografía. Traducción de Joaquin Hernández Orozco. Madrid, Instituto de Administración Local, 1975 (Colección Nuevo Urbanismo). pp. 71-99.

ANVISA, Agencia Nacional de Vigilancia Sanitaria. Política vigente para a regulamentação de medicamentos no Brasil (folheto institucional). Brasília, Anvisa, setembro de 2004. 
ARAÚJO, Melvina Afra Mendes de. Das ervas medicinais à fitoterapia: Encontros e desencontros entre as lógicas biomédica e popular. Dissertação de mestrado apresentada ao Departamento de Antropologia da Universidade de São Paulo. São Paulo, FFLCH-USP, 1998.

ARRAIS, Paulo Sérgio et alii. Perfil da automedicação no Brasil. In: Revista de Saúde Pública, vol. 31, n 1. São Paulo, 1997. pp. 71-77.

ARROYO, Mónica. Território nacional e mercado externo: Uma leitura do Brasil na virada do século $X X$. Tese de Doutorado apresentada ao Departamento de Geografia da Universidade de São Paulo. São Paulo, FFLCH-USP, 2001.

ASSIS, Machado de. Crônicas escolhidas. São Paulo, Ática/Folha de São Paulo, 1994.

BARAN, Paula A.; SWEEZY, Paul M. Monopoly capital: An essay on the american economic and social order. Middlesex, Penguin Books, 1966.

BARROS, José Augusto Cabral de. Genéricos versus patentes: O caso dos antiretrovirais põe a nu os interesses das multinacionais farmacêuticas. In: Saúde em debate, ano XXV, v. 25, $n^{\circ}$ 57. Rio de Janeiro, Centro Brasileiro de Estudos em Saúde, jan/abr 2001. pp. 85-89.

BAUDRILLARD, Jean. Le système dês objets. Paris, Gallimard, 1968.

BENKO, Georges. Economia, espaço e globalização na aurora do século XXI. Tradução de Antônio de Pádua Danesi. São Paulo, Hucitec, 1996.

BERMUDEZ, Jorge. Indústria farmacêutica, Estado e sociedade. São Paulo, Hucitec, 1995. 
BERNARDES, Adriana. A contemporaneidade de São Paulo: Produção de informações, o novo uso do território brasileiro. Tese de doutorado apresentada ao Departamento de Geografia da Universidade de São Paulo. São Paulo, FFLCH-USP, dezembro de 2001.

A nova divisão territorial do trabalho brasileira e a produção de informações na cidade de São Paulo (as empresas de consultoria). In: SANTOS, Milton; SILVEIRA, María Laura. [2001] O Brasil: Território e sociedade no início do século XXI. $6^{\mathrm{a}}$ ed. Rio de Janeiro, Record, 2004. pp. 413-432.

BICHO, Galdino Guttmann (coord.). Levantamento dos ensaios clínicos realizados por laboratórios prestadores de serviços na área de medicamentos fitoterápicos. Brasília, Anvisa/Reblas, setembro de 2003.

BICUDO, Edison. O circuito intermediário da economia urbana e a produção de medicamentos no território brasileiro. In: Anais do VI Congresso Brasileiro de Geógrafos. Goiânia, 2003.

. Sistemas de ações e o meio construído urbano: Por uma geografia dos possíveis. Anais do X Encontro de Geógrafos da América Latina. São Paulo, 2005.

Normes, territoires et aménagement : Les recherches biotechnologiques dans l'Union européenne. Mémoire de recherche soutenu dans l’Université Paris 1 (Panthéon Sorbonne). Paris, 2006.

BONACELLI, Maria Beatriz M.; SALLES-FILHO, Sergio L. M. Estratégias de inovação no desenvolvimento da moderna biotecnologia. In: GASSEN, Hans Günter et alii. Biotecnologia em discussão. São Paulo, Fundação Konrad Adenauer, outubro de 2000 (Cadernos Adenauer, 8). pp. 19-48. 
BOUDEVILLE, Jacques. Les notions d'espace et d'intégration. Dans : BOUDEVILLE, Jacques (sous la direction de). L'espace et les pôles de croissance: Recherches et textes fondamentaux. Paris, Presses Universitaires de France, 1968. pp. 2340.

BOUSQUAT, Aylene. Conceitos de espaço na análise de políticas de saúde. In: Lua Nova, n 52. São Paulo, Centro de Estudos de Cultura Contemporânea, 2001.

CANO, Wilson. Raízes da concentração industrial em São Paulo. Rio de Janeiro, Difel, 1977.

CAPANEMA, Luciana Xavier de Lemos; PALMEIRA FILHO, Pedro Lins. A cadeia farmacêutica e a política industrial: Uma proposta de inserção do BNDES. In: BNDES Setorial, $\mathrm{n}^{\circ}$ 19. Rio de Janeiro, março de 2004. pp. 23-48.

CARDOSO, Fernando Henrique. Empresário industrial e desenvolvimento econômico no Brasil. $2^{\text {a }}$ ed. São Paulo, Difusão Européia do Livro, 1972 (Corpo e Alma do Brasil, XIII).

CARDOSO, Fernando Henrique; FALETTO, Enzo. [1967] Dependência y desarrollo em América Latina. $8^{\mathrm{a}}$ ed. México, Siglo XXI, 1969.

CERQUEIRA, Antonio Carlos Nogueira de. Linhas de financiamento a micro e pequenas indústrias na Bahia: Mito e realidade. Monografia de bacharelado apresentada ao Departamento de Ciências Econômicas da Universidade Estadual de Feira de Santana. Feira de Santana, UEFS, 1996.

CHESNAIS, François. [1994] La mondialisation du capital. Paris, Syros, 1997 (Alternatives économiques). 
COHN, Amélia. A saúde na previdência social: Antigos estigmas e novos desafios. In: COHN, Amélia; ELIAS, Paulo. Saúde no Brasil: políticas e organização de serviços. São Paulo, Cortez, 1996. pp. 11-55.

CONTEL, Fábio Betioli. Os sistemas de movimento do território brasileiro. In: SANTOS, Milton; SILVEIRA, María Laura. [2001] O Brasil: Território e sociedade no início do século XXI. $6^{\mathrm{a}}$ ed. Rio de Janeiro, Record, 2004. pp. 357-374.

CORDEIRO, Hésio. A indústria da saúde no Brasil. Rio de Janeiro, Graal, 1980.

COSTA, Emília Viotti da. Da senzala à colônia. São Paulo, Difusão Européia do Livro, 1966.

COSTA, Pierre Alves. Geografia da indústria de química fina na Região Metropolitana do Rio de Janeiro, um estudo de caso: O pólo de química fina de Jacarepaguá. Dissertação de Mestrado apresentada ao Departamento de Geografia da Universidade Federal do Rio de Janeiro. Rio de Janeiro, UFRJ, 1999.

COX, Kevin R. Man, location, and behaviour: An introduction to human geography. New York, John Wiley \& Sons, 1972.

DEAN, Warren. A industrialização de São Paulo, 1880-1945. Tradução de Octavio Mendes Cajado. São Paulo, Difusão Européia do Livro, 1971 (Corpo e Alma do Brasil, XXXIII).

DEZALAY, Yves. Marchands de droit: La restructuration de l'ordre juridique international par les multinationals du droit. Paris, Fayard, 1992.

DOSI, Giovanni. Technical change and industrial transformation. New York, St. Martin’s Press, 1984. 
DUPUY, Gabriel. Systèmes, réseaux et territoires: Príncipes de réseautique territoriale. Paris, Presses de l’École Nationale dês Ponts et Chaussées, 1985.

DUPUY, Jean-Pierre; KARSENTY, Serge. [1974] A invasão farmacêutica. Tradução de Carlos Roberto Oliveira. Rio de Janeiro, Graal, 1979 (Biblioteca de Saúde e Sociedade, 6).

DURKHEIM, Émile. De la division du travail social. 6ème ed. Paris, Félix Alcan, 1932.

_ Les règles de la méthode sociologique. 17ème ed. Paris, Presses Universitaires de France. 1968.

EINSTEIN, Albert. [1916] A teoria da relatividade especial e geral. Tradução do original alemão de Carlos Almeida Pereira. Rio de Janeiro, Contraponto, 1999.

ELIAS, Paulo. Estrutura e organização da atenção à saúde no Brasil. In: COHN, Amélia; ELIAS, Paulo. Saúde no Brasil: políticas e organização de serviços. São Paulo, Cortez, 1996. pp. 57-117.

ELLUL, Jacques. [1954] The technological society. New York, Vintage Books, 1964.

EVANS, Peter. [1979] A tríplice aliança: As multinacionais, as estatais e o capital nacional no desenvolvimento dependente brasileiro. Tradução de Waltensir Dutra. Rio de Janeiro, Zahar, 1980.

FAUSTO, Boris. A revolução de 1930: Historiografia e história. $5^{\mathrm{a}}$ ed. São Paulo, Brasiliense, 1978. 
FERNANDES, Florestan. [1974] A revolução burguesa no Brasil: Ensaio de interpretação sociológica. $3^{\mathrm{a}}$ ed. Rio de Janeiro, Zahar, 1981 (Biblioteca de Ciências Sociais).

FERREIRA, Jacqueline. A saúde em comprimidos: Influências socioculturais na interpretação de sintomas e terapias medicamentosas em uma vila de classe popular de Porto Alegre. In: Saúde em debate, v. 25, n. 59. Rio de Janeiro, Centro Brasileiro de Estudos de Saúde, set/dez 2001. pp. 67-72.

FONTE, Nilce Nazareno da. A complexidade das plantas medicinais: Algumas questões atuais de sua produção e comercialização. Tese de doutoramento em Agronomia apresentada ao Setor de Ciências Agrárias da Universidade Fedral do Paraná. Curitiba, UFPR, 2004.

FONTOURA, Cândido. Pharmacia e pharmaceuticos no Brasil. São Paulo, Instituto Medicamenta, 1938.

FRENKEl, Jacob et alii. Tecnologia e competição na indústria farmacêutica brasileira. São Paulo, Finep, 1978.

FRENKEL, Jacob. O mercado farmacêutico brasileiro: A sua evolução recente, mercados e preços. In: NEGRI, Barjas; GIOVANNI, Geraldo di. (orgs.): Brasil: Radiografia da saúde. Campinas, Unicamp/IE, 2001. pp. 157-174.

FURTADO, Celso. O mito do desenvolvimento econômico. Rio de Janeiro, Paz e Terra, 1974.

GADELHA, Carlos Augusto Grabois. Determinantes econômicos e tecnológicos da produção de fármacos no Brasil: O caso dos antibióticos. Brasília, Centro de Estudos em Política Científica e Tecnológica, 1987. 
. Biotecnologia em saúde: Um estudo da mudança tecnológica na indústria

farmacêutica e das perspectivas de seu desenvolvimento no Brasil. Dissertação de mestrado apresentada ao Instituto de Economia da Universidade Estadual de Campinas. Campinas, Unicamp, 1990.

GALBRAITH, John Kenneth. [1967] O novo estado industrial. Tradução de Leônidas Gontijo de Carvalho. São Paulo, Abril, 1982 (Os economistas).

GASSEN, Hans Günter. Biotecnologia para países em desenvolvimento. Tradução de Pedro Maia Soares. In: GASSEN, Hans Günter et alii. Biotecnologia em discussão. São Paulo, Fundação Konrad Adenauer, outubro de 2000 (Cadernos Adenauer, 8). pp. 9-18.

GEERTZ, Clifford. Local knowledge: Further essays in interpretative anthropology. New York, Basic Books, 1983.

GEREFFI, Gary. Industria farmacéutica y dependencia en el Tercer Mundo. México, Fondo de Cultura Económica, 1986.

GIOVANNI, Geraldo. A questão dos remédios no Brasil: Produção e consumo. São Paulo, Polis, 1980.

GOMES, Cilene. Telecomunicações, informática e informação e a remodelação do território brasileiro. In: SANTOS, Milton; SILVEIRA, María Laura. [2001] O Brasil: Território e sociedade no início do século XXI. $6^{\text {a }}$ ed. Rio de Janeiro, Record, 2004. pp. 345-356.

GONZÁLEZ, Alexis Jesús Velásquez. A industria farmacéutica na década de 90: Mudanças na pesquisa \& desenvolvimento, na produção de fármacos e de medicamentos. Dissertação de mestrado apresentada ao Departamento de Ciência Política da Universidade de Campinas. Campinas, Unicamp, 1999. 
GRANOU, André. [1973] A crise internacional do capitalismo. Tradução de Alberto Saraiva. Porto, Escorpião, 1974 (Cadernos O homem e a sociedade).

GRIMM, Flávia Christina Andrade. Uso do território e coexistências de empresas de refrigerantes no Brasil. Dissertação de mestrado apresentada ao Departamento de Geografia da Universidade de São Paulo. São Paulo, USP-FFLCH, dezembro de 2002.

GROSSMANN, Luiz. O uso de bases de dados no gerenciamento estratégico empresarial. In: São Paulo em Perspectiva, v. 8, n 4, out/dez 1994. pp. 95-100.

GUGLIELMO, Raymond. Géographie active de l'industrie. In: GEORGE, Pierre; GUGLIELMO, Raymond; KAYSER, Bernard; LACOSTE, Yves. La géographie active. Paris, Presses Universitaires de France, 1964. pp. 192-228.

GUIMARÃES, Cristina Borges. Indústria farmacêutica investe no conhecimento do mercado. In: Gazeta Mercantil, 17 de junho de 2003. pp. ti1-ti2 (Caderno Tecnologia da Informação).

HABERMAS, Jürgen. [1968] La technique et la science comme "idéologie". Paris, Gallimard, 1973.

. [1981] Théorie de l'agir communicationnel, tome 1: Rationalité de l'agir et rationalization de la société. Traduit de l'allemand par Jean-Marc Ferry. Paris, Fayard, 1987.

HABERMAS, Jürgen. [1968] La technique et la science comme "idéologie”. Paris, Gallimard, 1973.

HARTSHORNE, Richard. Propósitos e natureza da geografia. $2^{\mathrm{a}}$ ed. Tradução de Thomaz Newlands Neto. São Paulo, Hucitec, 1978. 
HEISEMBERG, Werner. [1958] Física e filosofia. Tradução de Jorge Leal Ferreira. Brasília, Editora da Universidade de Brasília, 1981 (Coleção Pensamento Científico, 1).

HOLLOWAY, Thomas H. Imigrantes para o café: Café e sociedade em São Paulo, 1886-1934. Tradução de Eglê Malheiros. Rio de Janeiro, Paz e Terra, 1984.

HUXLEY, Aldous. Brave new world. London, Albatros, 1947.

KAYSEN, Carl. The corporation: How much power? What scope? In: MASON, Edward S. (edit.) The corporation in modern society. Cambridge, Harvard University Press, 1959. pp. 85-105.

KOROLKOVAS, Andrejus; BURKHALTER, Joseph. Química farmacêutica. Tradução de Andrejus Korolkovas. Rio de Janeiro, Guanabara Dois, 1982.

KOSIK, Karel. Dialética do concreto. $5^{\mathrm{a}}$ ed. Tradução de Célia Neves e Alderico Toríbio. Rio de Janeiro, Paz e Terra, 1989.

LACOSTE, Yves. A geografia. In: História da filosofia: Idéias e doutrinas, 7: A filosofia das ciências sociais: De 1860 aos nossos dias. Rio de Janeiro, Zahar, 1973. pp. 221-274.

LATOUR, Bruno. [1991] Nous n’avons jamais été modernes: Essai d'anthropologie symétrique. Nouv. éd. Paris, La Découverte, 1997 (Sciences humaines et sociales, 26).

LEFÈBVRE, Henri. Espacio y política: El derecho a la ciudad, II. Traducción de Janine Muls de Liarás y Jaime Liarás García. Barcelona, Península, 1976.

LOJKINE, Jean. O Estado capitalista e a questão urbana. $1^{\mathrm{a}}$ ed. São Paulo, Martins Fontes, 1981 (Série Novas Direções). 
LOJKINE, Jean. La révolution informationnelle. Paris, Presses Universitaires de France, 1992.

MAGALHÃES, Luís Carlos G. de et alii. Estratégias empresariais de crescimento na indústria farmacêutica brasileira: Investimentos, fusões e aquisições, 1988-2002. Brasília, IPEA, Instituto de Pesquisa Econômica Aplicada, novembro de 2003 (Texto para Discussão $\mathrm{n}^{\circ}$ 995).

MAMIGONIAN, Armen. “O processo de industrialização em São Paulo”. In: Boletim Paulista de Geografia, nº 50. São Paulo, 1976. pp. 83-102.

MARX, Karl. Le capital, tome IV: Le procès de la production du capital. Traduit par J. Roy. Paris, Alfred Costes, 1950.

MASSEY, Doreen. [1984] Spatial divisions of labour: Social structures and the geography of production. London, MacMillan, 1987.

MATTOS, Dirceu Lino de. O parque industrial paulistano. In: AZEVEDO, Aroldo de. (dir.) A cidade de São Paulo: Estudos de geografia humana, volume III: Aspectos da metrópole paulista. São Paulo, Companhia Editora Nacional, 1958.

MELO NETO, João Cabral. [1966] A educação pela pedra. Rio de Janeiro, Nova Fronteira, 2001.

MINISTÉRIO DA AGRICULTURA E COMMERCIO, Diretoria Geral de Estatística. Recenseamento do Brazil, 1920.

MIRANDA, Ana. Boca do inferno. $4^{\mathrm{a}}$ ed. São Paulo, Companhia das Letras, 1998.

MOLES, Abrahan. [1969] Objeto y comunicación. In: MOLES, Abrahan; BAUDRILLARD, Jean; BOUDON, Pierre; VAN LIER, Henri; WAHL, Eberhard; 
MORIN, Violette. Los objetos. Traducción de Silvia Delpy. Buenos Aires, Tiempo Contemporáneo, 1971.

_ Les sciences de l’imprécis. Paris, Seuil, 1990.

MONTOR, Wagner Ricardo; SOGAYAR, Mari Cleide. “Insetos como biofábricas de proteínas humanas”. In: Ciência hoje, vol. 33, n 196. Rio de Janeiro, SBPC, agosto de 2003. pp. 16-23.

OLIVEIRA, José Aldemir de. Manaus de 1920-1967: A cidade doce e dura em excesso. Manaus, Valer, 2003.

OLIVEIRA, Rogério Vicentim Ferraz de. A rodada do Uruguai e suas implicações para a indústria brasileira: O caso dos direitos de propriedade intelectual na indústria farmacêutica. Monografia apresentada ao Instituto de Economia da Universidade Estadual de Campinas. Campinas, Unicamp, 1999.

PACHECO, Mário Victor de Assis. Indústria farmacêutica e segurança nacional. Rio de Janeiro, Civilização Brasileira, 1968 (Retratos do Brasil, volume 69).

PAGÈS, Max. «L'autonomie contrôlèe ou les techniques de gouvernement à distance ». In: PAGÈS, Max; BONETTI, Michel; GAULEJAC, Vincent de; DESCENDRE, Daniel. [1978] L'emprise de l'organisation. 3ème édition. Paris, Presses Universitaires de France, 1984. pp. 43-77.

PALMÉRIO, José. O custo dos remédios e a economia médico-farmacêutica. São Paulo, 1942.

PAULA, Maria Carlota de Souza. Oportunidades e entraves ao desenvolvimento tecnológico no Brasil: As experiências da indústria aeronáutica e farmacêutica, volume II 
(Indústria farmacêutica). Tese de doutorado ao Departamento de Ciência Política da Universidade de São Paulo. São Paulo, FFLCH-USP, 1991.

PAVITT, Keith. "Sectoral patterns of technical change: Towards a taxonomy and a theory”. In: Research Policy, vol. 13, n. 6. North Holland, December 1984. pp. 343-373.

PEREIRA, Hilda Maria Salomé. Patentes na indústria farmacêutica: A adoção de patentes e o acesso a produtos farmacêuticos no Brasil. Tese de mestrado apresentada ao Departamento de Administração da Faculdade de Economia e Administração da Universidade de São Paulo. São Paulo, FEA/USP, 1992.

PEREIRA, Maria Aparecida Cunha. Perfil da indústria farmacêutica do Rio Grande do Sul. Dissertação de mestrado apresentada ao Departamento de Ciências Farmacêuticas da Universidade Federal do Rio Grande do Sul. Porto Alegre, UFRGS, 2002.

PERROUX, François. [1961] «La notion de pôle de croissance ». In : Oeuvres complètes, V-Théorie générale: Les concepts ; l'économie de XXe siècle. Grenoble, Presses Universitaires de Grenoble, 1991. pp. 177-189.

POINCARÉ, Henri. [1902] La science et l'hypothèse. Paris, Ernest Flammarion, 1908 (Bibliothèque de Philosophie Scientifique).

POLANYI, Karl. The great transformation. New York, Farrar \& Rinehart, 1944.

POULANTZAS, Nicos. Les classes sociales dans le capitalisme aujourd'hui. Paris, Seuil, 1974.

PRADO JÚNIOR, Caio. [1945] História econômica do Brasil. 45ª reimpr. São Paulo, Brasiliense, 1998. 
QUEIROZ, Sérgio; GONZÁLEZ, Alexis Jesús Velásquez. “Mudanças recentes na estrutura produtiva da indústria farmacêutica”. In: NEGRI, Barjas; GIOVANNI, Geraldo di. (orgs.): Brasil: Radiografia da saúde. Campinas, Unicamp/IE, 2001. pp. 123-155.

RAMOS, Joseph R. Labor and development in Latin América. New York, Columbia University Press, 1970.

RIFKIN, Jeremy. The biotech century: Harnessing the gene and remaking the world. New York, Tarcher \& Putnam, 1998.

SAINT-SIMON, Henri de. [1821] Contre les légistes. In: L'oeuvre d'Henri de SaintSimon: Textes choisis. Paris, Presses Universitaires de France, 1925. pp. 144-148.

SANTOS, Milton. O trabalho do geógrafo no terceiro mundo. $3^{\mathrm{a}}$ ed. Tradução de Sandra Lencioni. São Paulo, Hucitec, 1978.

_ Espaço e sociedade. Petrópolis, Vozes, 1979.

— “O espaço: Sistemas de objetos, sistemas de ações”. In: Anais do IV Encontro Nacional da ANPUR. Salvador, 1991. pp. 35-39.

. O espaço do cidadão. 2.ed. São Paulo, Nobel, 1993 (Coleção Espaços).

. Por uma economia política da cidade. São Paulo, Hucitec, 1994a.

- Técnica espaço tempo: Globalização e meio técnico-científicoinformacional. São Paulo, Hucitec, 1994b. . Metamorfoses do espaço habitado: Fundamentos teóricos e metodológicos da geografia. 5 ed. São Paulo, Hucitec, 1997. 
. Por uma geografia nova: Da crítica da geografia a uma geografia crítica. São Paulo, Edusp, 2002 (Coleção Milton Santos, 2).

• [1996] A natureza do espaço: Técnica e tempo. Razão e emoção. São Paulo, Edusp, 2002. (Coleção Milton Santos, 1).

• [1979] Economia espacial: Críticas e alternativas. Tradução de Maria Irene de Q. F. Szmrecsányi. 2. ed. São Paulo, Edusp, 2003.

. [1979] O espaço dividido: Os dois circuitos da economia urbana dos países subdesenvolvidos. 2. ed. Tradução de Myrna T. Rego Viana. São Paulo, Edusp, 2004 (Coleção Milton Santos).

_ [1982] Pensando o espaço do homem. 5 ed. São Paulo, Edusp, 2004 (Coleção Milton Santos, 5).

_ _ "Razão global, razão local. Os espaços da racionalidade". In: .$D a$ totalidade ao lugar. São Paulo, Edusp, 2005 (Coleção Milton Santos, 7). pp. 165-170.

. [1973] "Os dois circuitos da economia urbana e suas implicações espaciais”. In: _ . . Da totalidade ao lugar. São Paulo, Edusp, 2005 (Coleção Milton Santos, 7). pp. 93-116.

. [1978] "A divisão social do trabalho como uma nova pista para o estudo da organização espacial e da urbanização nos países subdesenvolvidos”. In: __ . Da totalidade ao lugar. São Paulo, Edusp, 2005 (Coleção Milton Santos, 7). pp. 53-116.

. [1979] “O Estado-Nação como espaço, totalidade e método”. In:

Da totalidade ao lugar. São Paulo, Edusp, 2005 (Coleção Milton Santos, 7). pp. 43-51. 

• [1989] "Meio técnico-científico e urbanização: Tendências e perspectivas". In: _ _ . Da totalidade ao lugar. São Paulo, Edusp, 2005 (Coleção Milton Santos, 7). pp. 119-136.

. [1993] A urbanização brasileira. 5. ed. São Paulo, Edusp, 2005a (Coleção Milton Santos, 6).

. [1993] "Os espaços da globalização". In: . Da totalidade ao lugar. São Paulo, Edusp, 2005b (Coleção Milton Santos, 7). pp. 145-154.

_ • [1994] “O retorno do território”. In: . Da totalidade ao lugar. São Paulo, Edusp, 2005a (Coleção Milton Santos, 7). pp. 137-144.

__ . [1994] "O lugar: Encontrando o futuro". In: . Da totalidade ao lugar. São Paulo, Edusp, 2005b (Coleção Milton Santos, 7). pp. 155-164.

SANTOS, Milton; SILVEIRA, María Laura. [2001] O Brasil: Território e sociedade no início do século XXI. $6^{\text {a }}$ ed. Rio de Janeiro, Record, 2004.

SARTRE, Jean-Paul. Question de méthode. Paris, Gallimard, 1960a.

SARTRE, Jean-Paul. Critique de la raison dialectique, tome I: Théorie des ensembles pratiques. Paris, Gallimard, 1960b (Bibliothèque des idées).

SCLIAR, Moacir. A majestade do Xingu. São Paulo, Companhia das Letras, 1997.

SCHUMPETER, Joseph. [1942] Capitalisme, socialisme et démocratie. Traduzido do inglês por Gael Fain. Paris, Payot, 1954.

SCHWARZ, Roberto. Ao vencedor as batatas. $4^{\mathrm{a}}$ ed. São Paulo, Duas Cidades, 1992. 
SCIENCES ET AVENIR. Paris, décembre 2005.

SHARP, Margaret; SENKER, Jacqueline. "European biotechnology: Learning and catching-up”. In: GAMBARDELLA, Alfonso; MALERBA, Franco. The organization of economic innovation in Europe. Cambridge, Cambridge University Press, 1999. pp. 269302.

SIANI, Antonio Carlos et alii. Desenvolvimento tecnológico de fitoterápicos: Plataforma metodológica. Rio de Janeiro, Scriptorio, 2003. (Relatório PPA/MCT 20002003).

SILVA, Armando Corrêa da. De quem é o pedaço? Espaço e cultura. São Paulo, Hucitec, 1986.

SILVA, Sérgio. Expansão cafeeira e origens da indústria no Brasil. $7^{\mathrm{a}}$ ed. São Paulo, Alfa-Ômega, 1986.

. [1996] Um país, uma região: Fim de século e modernidades na Argentina.

São Paulo, Fapesp/Laboplan, 1999.

SILVEIRA, María Laura. “Concretude territorial, regulação e densidade normativa”. In: Experimental, ano I, $\mathrm{n}^{\circ}$ 2, março de 1997. São Paulo, Laboplan/Departamento de Geografia-FFLCH-USP. pp. 35-45.

. [1996] Um país, uma região: Fim de século e modernidades na Argentina. São Paulo, Fapesp/Laboplan, 1999.

• "Por um conteúdo da reflexão epistemológica em geografia”. In: SOUZA, Álvaro José de; SOUZA, Edson Belo Clemente de; MAGNOMI Jr. (orgs.): Paisagem, território, região: Em busca da identidade. Cascavel, Edunioeste, 2000. pp. 21-28. 
. Argentina: Território e globalização. São Paulo, Brasiliense, 2003.

. São Paulo: "Os dinamismos da pobreza”. In: CARLOS, Fani Alessandri; OLIVEIRA, Ariovaldo Umbelino de (orgs.): Geografias de São Paulo: Representação e crise da metrópole. São Paulo, Contexto, 2004. pp. 59-70.

SIMMEL, Georg. [1900] The philosophy of money. Traduzido por Tom Bottomore and David Frisby. $2^{\text {nd }}$ ed. London, Routledge, 1997.

SIMONDON, Gilbert. [1958] Du mode d'existence des objets techniques. Paris, Aubier, 1969 (Collection Analyse et raisons, 1).

SOUSA SANTOS, Boaventura de. [1985] Um discurso sobre as ciências. $7^{\mathrm{a}}$ ed. Porto, Afrontamento, 1995.

SUZIGAN, Wilson. Indústria brasileira: Origem e desenvolvimento. São Paulo, Brasiliense, 1986.

TEMPORÃO, José Gomes. A propaganda de medicamentos e o mito da saúde. Rio de Janeiro, Graal, 1986.

THIBAUT, J. «Réflexions sur le rôle actuel de la science ». In: Économie et politique, 161. Paris, Henri Jourdain, déc. 1967.

VALLAT, David. «Contre le chômage et l'exclusion, le dynamisme de la petite économie ». In: Innovations: Cahiers d'économie de l'innovation, n. 15. Dunkerque, Université du Littoral, 2002. pp. 47-72.

VIDAL DE LA BLACHE, Paul. Principes de géographie humaine. Paris, Armand Colin, 1922. 
VILARDAGA, Vicente. "Distribuidores e as redes de farmácias vendem informação”. In: Gazeta Mercantil, 19/20/21 de julho de 2002. p. C2 (Indústria \& Serviços).

XAVIER, Marcos. “Os sistemas de engenharia e a tecnicização do território: O exemplo da rede rodoviária brasileira”. In: SANTOS, Milton; SILVEIRA, María Laura. [2001] O Brasil: Território e sociedade no início do século XXI. 6 ${ }^{\mathrm{a}}$ ed. Rio de Janeiro, Record, 2004. pp. 329-343.

WITTGENSTEIN, Ludwig. [1921] Tractatus lógico-philosophicus. 2a Tradução de Luiz Henrique Lopes dos Santos. São Paulo, Edusp, 1994.

ZELLER, Christian. North Atlantic innovative relation of Swiss pharmaceutical and the proximities with regional biotech arenas. In: Economic Geography, vol. 80. Worcester, jan 2004. pp. 83-112. 
Anexo 1

Empresas produtoras de medicamentos entrevistadas em pesquisa de campo, por ordem alfabética

\begin{tabular}{|c|c|c|c|c|c|c|}
\hline & Empresa & Natureza & UF & Cidade & Entrevista com & Data \\
\hline 1 & A \& C Laboratórios Ltda. & LP & SP & Taboão da Serra & 1. farmacêutica & 15-02-2005 \\
\hline 2 & ACLIMAÇÃO, Laboratório & LP & SP & São Paulo & 1. diretora & $14-04-2000$ \\
\hline 3 & ÁGAPE Produtos Farmacêuticos Ltda. & LP & PA & Ananindeua / Ananindeua & 1. sócio & 05-08-2004 \\
\hline 4 & ALMAPAL S/A & LP & SP & São Paulo & $\begin{array}{l}\text { 1. gerente da garantia da } \\
\text { qualidade }\end{array}$ & 07-07-2005 \\
\hline 5 & $\begin{array}{l}\text { AMAZONAS Comércio e } \\
\text { Indústria de Produtos Químicos }\end{array}$ & LP & BA & Feira de Santana & 1. farmacêutica & 04-08-2003 \\
\hline 6 & $\begin{array}{l}\text { ANCHIETA Produtos Químicos e } \\
\text { Farmacêuticos Ltda. }\end{array}$ & LP & GO & Goiânia & 1. farmacêutica & 17-08-2005 \\
\hline 7 & BRASTERÁPICA & LP & SP & São Paulo & 1. diretora de marketing & 14-09-2005 \\
\hline
\end{tabular}




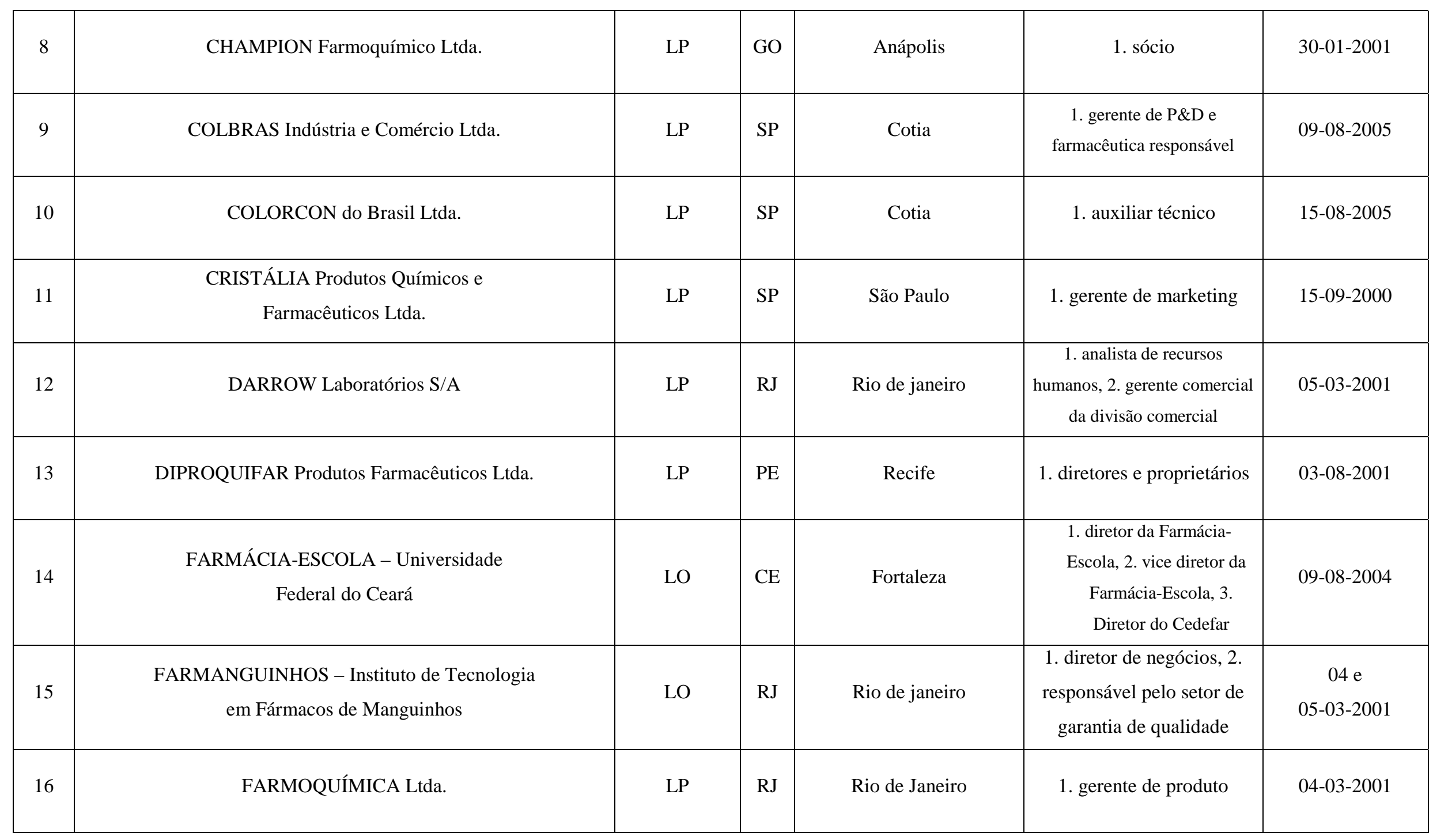




\begin{tabular}{|c|c|c|c|c|c|c|}
\hline 18 & FURP - Fundação para o Remédio Popular & LO & SP & Guarulhos & $\begin{array}{l}\text { 1. assessora de atendimento } \\
\text { ao cliente }\end{array}$ & $26-09-2000$ \\
\hline 19 & GAÚCHO Ltda., Laboratório Industrial & LP & RS & Cachoeirinha & 1. gerente administrativo & 06-02-2002 \\
\hline 21 & GREENPHARMA Química e Farmacêutica Ltda. & LP & GO & Anápolis & 1. assessor de marketing & 01-02-2001 \\
\hline 22 & HALEX ISTAR Indústria Farmacêutica Ltda. & LP & GO & Goiânia & 1. gerente comercial & $18-08-2005$ \\
\hline 24 & HISAMITSU Farmacêutica de Manaus Ltda. & LM & $\mathrm{AM}$ & Manaus & 1. farmacêutica & $26-07-2004$ \\
\hline 25 & IQUEGO - Indústria Química do Estado de Goiás S/A & $\mathrm{LO}$ & GO & Goiânia & $\begin{array}{c}\text { 1. farmacêutico do controle } \\
\text { da qualidade }\end{array}$ & $17-08-2005$ \\
\hline 26 & ISOFARMA Industrial Farmacêutica & LP & $\mathrm{CE}$ & Eusébio & $\begin{array}{c}\text { 1. responsável pelo } \\
\text { departamento de recursos } \\
\text { humanos }\end{array}$ & $13-08-2004$ \\
\hline
\end{tabular}




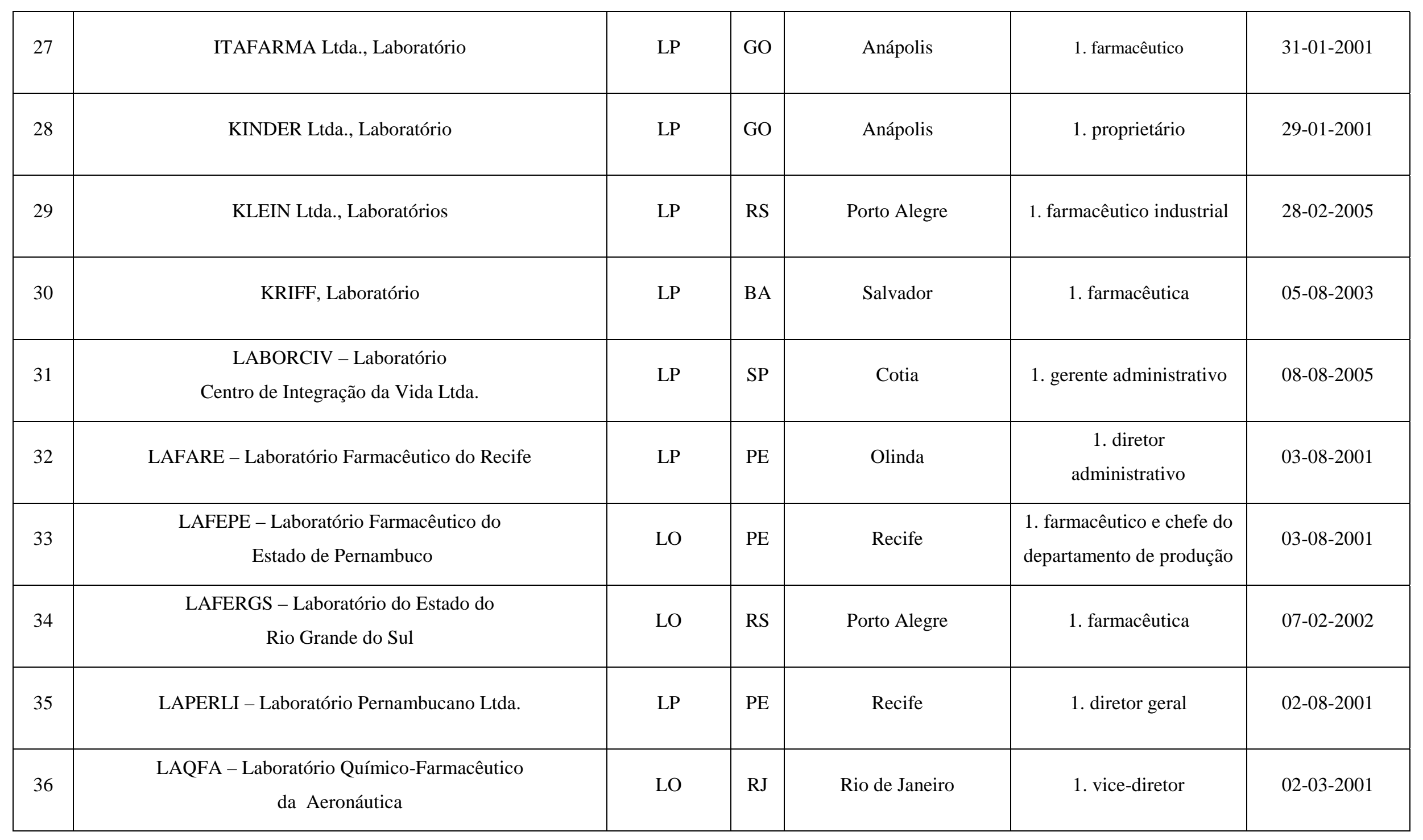




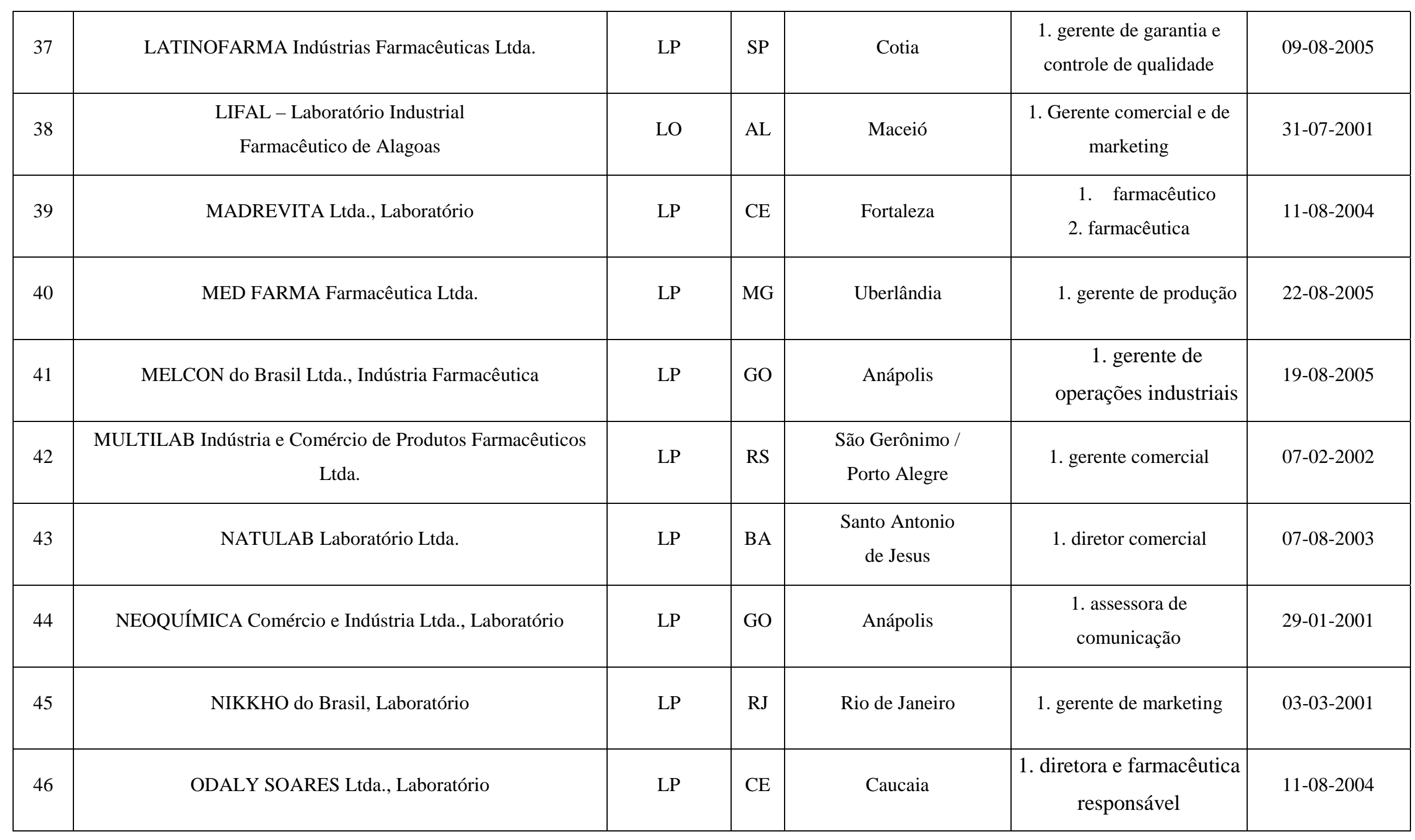




\begin{tabular}{|c|c|c|c|c|c|c|}
\hline 47 & OFFICINALIS Química e Farmacêutica Ltda. & LP & BA & Simões Filho & $\begin{array}{c}\text { 1. sócio e } \\
\text { gerente geral }\end{array}$ & 06-08-2003 \\
\hline 48 & $\begin{array}{l}\text { OPHTHALMOS Indústria e Comércio de Produtos } \\
\text { Farmacêuticos Ltda. }\end{array}$ & LP & SP & São Paulo & 1. proprietário & 27-06-2005 \\
\hline 49 & PANIZZA Ltda., Laboratório & LP & SP & Taboão da Serra & $\begin{array}{l}\text { 1. farmacêutico e gerente } \\
\text { geral }\end{array}$ & 22-11-2001 \\
\hline 51 & QUIMSUL Ltda., Laboratório & LP & RS & Porto Alegre & $\begin{array}{l}\text { 1. gerente de } \\
\text { marketing }\end{array}$ & 08-02-2002 \\
\hline 52 & RAVICK Produtos Químicos e Cosméticos Ltda. & LP & $\mathrm{CE}$ & Fortaleza & 1. proprietário & 09-08-2004 \\
\hline 54 & SÃO LUCAS, Laboratório & LP & PA & Belém & 1. proprietário & 03-08-2004 \\
\hline 55 & SANIFER S/A, Laboratório & LP & RS & Porto Alegre & 1. farmacêutico & 01-03-2005 \\
\hline 56 & SAÚDE Ltda., Laboratório & LP & RS & Porto Alegre & 1. gerente de marketing & 08-02-2002 \\
\hline
\end{tabular}




\begin{tabular}{|c|c|c|c|c|c|}
\hline 57 & VITAPAN Indústria Farmacêutica Ltda. & LP & GO & Anápolis & $\begin{array}{c}\text { 1. diretora industrial; } \\
\text { 2. funcionário do depto de } \\
\text { assuntos regulatórios; } \\
\text { 3. gerente de marketing; } \\
\text { 4. farmacêutico do controle } \\
\text { da qualidade }\end{array}$ \\
\hline 58 & VITERNAT Laboratórios Ltda. & LP & SP & São Paulo & $\begin{array}{c}\text { 1. proprietária e diretora } \\
\text { industrial }\end{array}$ \\
\hline 59 & WESP Ltda., Laboratório & LP & RS & Porto Alegre & 1. farmacêutica \\
\hline
\end{tabular}


Anexo 1 - continuação

Empresas distribuidoras de medicamentos entrevistadas em pesquisa de campo, por ordem alfabética

\begin{tabular}{|c|c|c|c|c|c|}
\hline & Empresa & UF & Cidade & Entrevista com & Data \\
\hline 1 & ALEFARMA Distribuidora Ltda. & PA & Ananindeua & $\begin{array}{l}\text { gerente comercial } \\
\text { de vendas }\end{array}$ & 03-08-2004 \\
\hline 2 & AMAZON MED Ltda. & PA & Belém & $\begin{array}{l}\text { sócio e } \\
\text { gerente comercial }\end{array}$ & 05-08-2004 \\
\hline 3 & AMPLOMED Ltda. & AM & Manaus & proprietário & 27-07-2004 \\
\hline 4 & $\begin{array}{l}\text { ANAVENTEC Comércio e Representação de Materiais } \\
\text { Farmacêuticos e Hospitalares }\end{array}$ & $\mathrm{CE}$ & Fortaleza & sócia & 12-08-2004 \\
\hline 5 & AUDIFAR Comercial & $\mathrm{PE}$ & $\begin{array}{l}\text { Guarulhos ( SP ) / Teresina } \\
\text { ( PI ) / Recife ( PE ) }\end{array}$ & assessor de marketing & 02-08-2001 \\
\hline 6 & BUARQUE Comércio e Representações Ltda. & $\mathrm{CE}$ & Fortaleza & contador & 10-08-2004 \\
\hline 7 & CERVOSUL Distribuidora de Medicamentos Ltda. & RS & Porto Alegre & gerente comercial & 07-02-2002 \\
\hline 8 & COMPMED Comércio e Representações Ltda. & $\mathrm{PA}$ & Belém & assistente administrativo & 02-08-2004 \\
\hline
\end{tabular}




\begin{tabular}{|c|c|c|c|c|c|}
\hline 9 & DISTAK Farmacêutica Ltda. & GO & Goiânia & 1. proprietário & $18-08-2005$ \\
\hline 10 & DROGAFONTE Ltda. & $\mathrm{PE}$ & Recife & $\begin{array}{c}\text { diretora do } \\
\text { departamento jurídico }\end{array}$ & 01-08-2001 \\
\hline 11 & DROGARIA SANTA MARIA Ltda. & $\mathrm{PE}$ & Recife & gerente geral & 03-08-2001 \\
\hline 12 & EDFARMA Produtos Famacêuticos Ltda. & CE & Fortaleza & proprietário & $12-08-2004$ \\
\hline 13 & FARMAKUS Medicamentos Ltda. & RJ & Rio de Janeiro & $\begin{array}{c}\text { gerente administrativa } \\
\text { e comercial }\end{array}$ & 05-03-2001 \\
\hline 14 & $\begin{array}{l}\text { FASTMED Comécio de Medicamentos e } \\
\text { Produtos Farmacêuticos }\end{array}$ & BA & Salvador & auxiliar administrativo & $05-08-2003$ \\
\hline 15 & FRACIONATA Química e Farmacêutica Ltda. & RS & Porto Alegre & comprador & 08-02-2002 \\
\hline 16 & FRANCISCO EUDES Apolinário Gomes & $\mathrm{CE}$ & Fortaleza & proprietário & $13-08-2004$ \\
\hline 17 & GOIASMED Distribuidora Ltda. & GO & Goiânia & proprietário & 29-01-2001 \\
\hline 18 & GÓES GÓES Distribuidora Ltda. & PA & Belém & proprietário & 02-08-2004 \\
\hline
\end{tabular}




\begin{tabular}{|c|c|c|c|c|c|}
\hline 19 & HERTZ Sudeste Distribuidora de Medicamentos Ltda. & SP & Cotia & gerente de operações & 15-08-2005 \\
\hline 20 & $\begin{array}{l}\text { IMIFARMA Produtos Farmacêuticos e } \\
\text { Cosméticos Ltda. }\end{array}$ & PA & Belém & diretor de PCE & 06-08-2004 \\
\hline 21 & INTERMED Distribuidora de Medicamentos Ltda. & RJ & Rio de Janeiro & $\begin{array}{c}\text { gerente de } \\
\text { recursos humanos }\end{array}$ & 02-03-2001 \\
\hline 22 & $\begin{array}{c}\text { ITA Representações de } \\
\text { Produtos Farmacêuticos S/A }\end{array}$ & BA & Salvador & gerente de logística & 06-08-2003 \\
\hline 23 & JS Distribuidora de Produtos Farmacêuticos & BA & Feira de Santana & gerente geral & 08-08-2003 \\
\hline 24 & LOOK FARMA Distribuidora de Medicamentos Ltda. & GO & Goiânia & diretor de marketing & 01-02-2001 \\
\hline 25 & MAJELA, Grupo & $\mathrm{CE}$ & Fortaleza & gerente de vendas & 10-08-2004 \\
\hline 26 & NAVARRO Distribuidora & SP & São Paulo & gerente de vendas & 07-09-2005 \\
\hline 27 & $\begin{array}{l}\text { ORIENTE Farmacêutica Comércio } \\
\text { Importação \& Exportação Ltda. }\end{array}$ & MG & Uberlândia & assistente administrativo & 23-08-2005 \\
\hline 28 & $\begin{array}{l}\text { PROFARMA Distribuidora de } \\
\text { Produtos Farmacêuticos S/A }\end{array}$ & SP & São Paulo & $\begin{array}{l}\text { chefe do departamento } \\
\text { comercial }\end{array}$ & $15-05-2000$ \\
\hline
\end{tabular}




\begin{tabular}{|c|c|c|c|c|c|}
\hline 29 & PROSPITALAR & MG & Uberlândia & proprietário & $23-08-2005$ \\
\hline 30 & REYDROGAS Comercial Ltda. & GO & Goiânia & $\begin{array}{c}\text { 1. assessor de gestão e } \\
\text { logística }\end{array}$ & $18-08-2005$ \\
\hline 31 & SILVEIRA, Distribuidora & CE & Fortaleza & assistente administrativa & $11-08-2004$ \\
\hline 32 & SULFARMA Ltda. & RS & Porto Alegre & $\begin{array}{c}\text { gerente administrativo } \\
\text { e financeiro }\end{array}$ & 06-02-2002 \\
\hline 33 & VIA FARMA Ltda. & AL & Maceió & $\begin{array}{c}\text { gerente administrativa } \\
\text { e financeira }\end{array}$ & $31-07-2001$ \\
\hline
\end{tabular}




\section{Anexo 2}

Laboratórios pertencentes à Associação dos Laboratórios

Farmacêuticos Oficiais do Brasil (Alfob): 2006

\begin{tabular}{|c|c|c|}
\hline Laboratório & Estado & Cidade(s) \\
\hline Farmanguinhos & Rio de Janeiro & Rio de Janeiro \\
\hline FFOE & Ceará & Fortaleza \\
\hline Funed & Minas Gerais & Belo Horizonte \\
\hline Furp & São Paulo & Guarulhos e Américo Brasiliense \\
\hline Instituto Vital Brasil & Rio de Janeiro & Niterói \\
\hline Iquego & Goiás & Goiânia \\
\hline Lafepe & Pernambuco & Recife \\
\hline Lafergs & Rio Grande do Sul & Porto Alegre \\
\hline Lefesc & Santa Catarina & Florianópolis \\
\hline Laqfa & Rio de Janeiro & Rio de Janeiro \\
\hline LEPEMC & Paraná & Maringá \\
\hline LFM & Rio de Janeiro & Rio de Janeiro \\
\hline Lifal & Alagoas & Maceió \\
\hline Lifesa & Paraíba & João Pessoa \\
\hline LPM & Paraná & Londrina \\
\hline LQFE & Rio de Janeiro & Rio de Janeiro \\
\hline LTF & Paraíba & João Pessoa \\
\hline NUPLAM & Rio Grande do Norte & Natal \\
\hline
\end{tabular}

Fonte: site da Alfob: www.alfob.com.br 
Subperíodo maquínico: Empresas da indústria química e farmacêutica instaladas, de 1850 a 1929. Ano-base: 1950

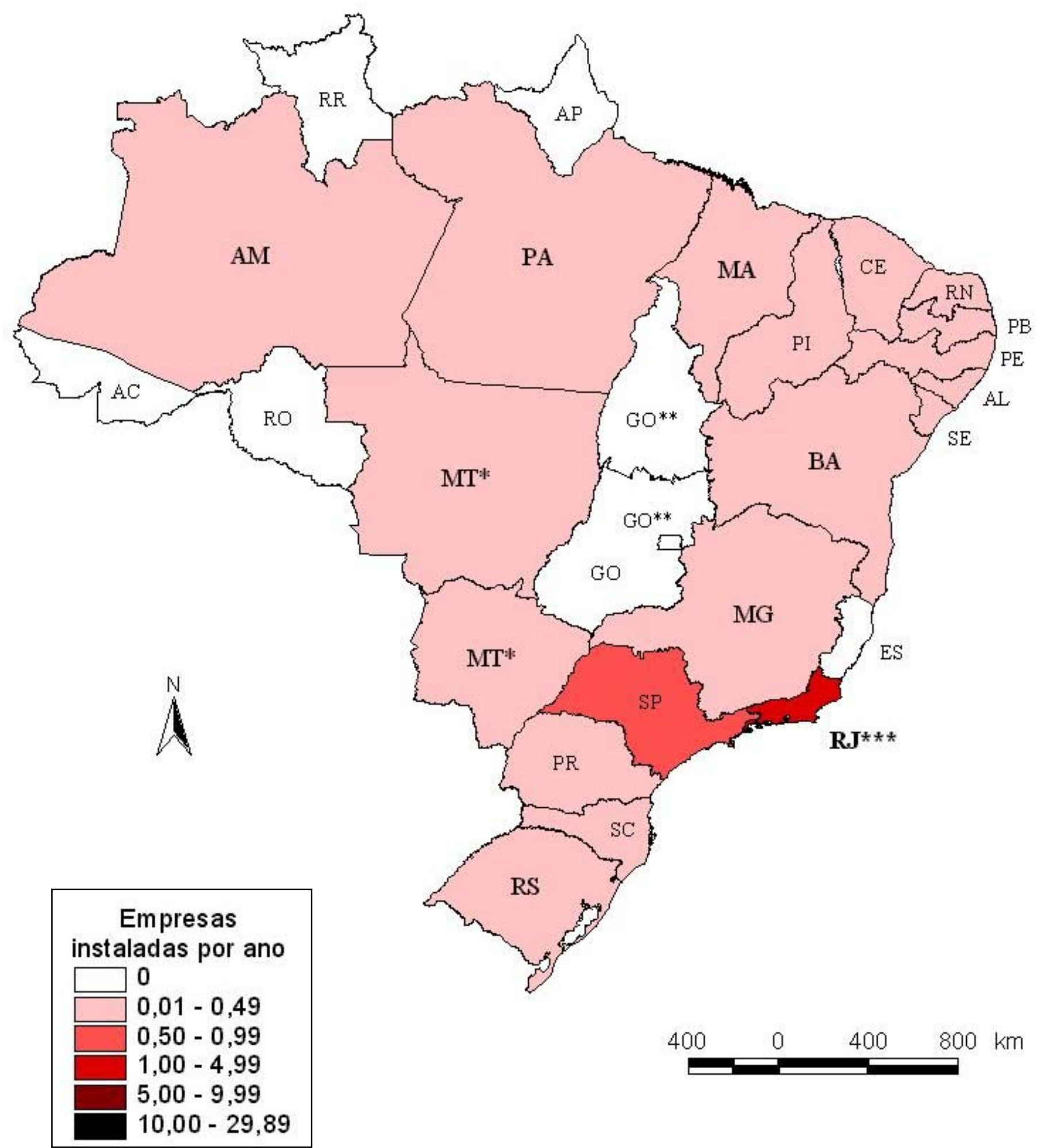

* Os territórios atualmente pertencentes aos estados de Mato Grosso e Mato Grosso do Sul estavam, em 1930, reunidos num só território, sob o nome de Mato Grosso ** Os territórios atualmente pertencentes ao estado de Tocantins e ao atual Distrito Federal faziam parte, em 1930, do estado de Goiás. ** Rio de Janeiro mais o Distrito Federal.

fonte: elaboração própria, com dados do IBGE, Censo industrial, 1950

cartografia: Edison Bicudo 


\section{mapa I.2}

Subperíodo tecnológico: Empresas da indústria química e farmacêutica instaladas, de 1930 a 1949. Ano-base: 1950

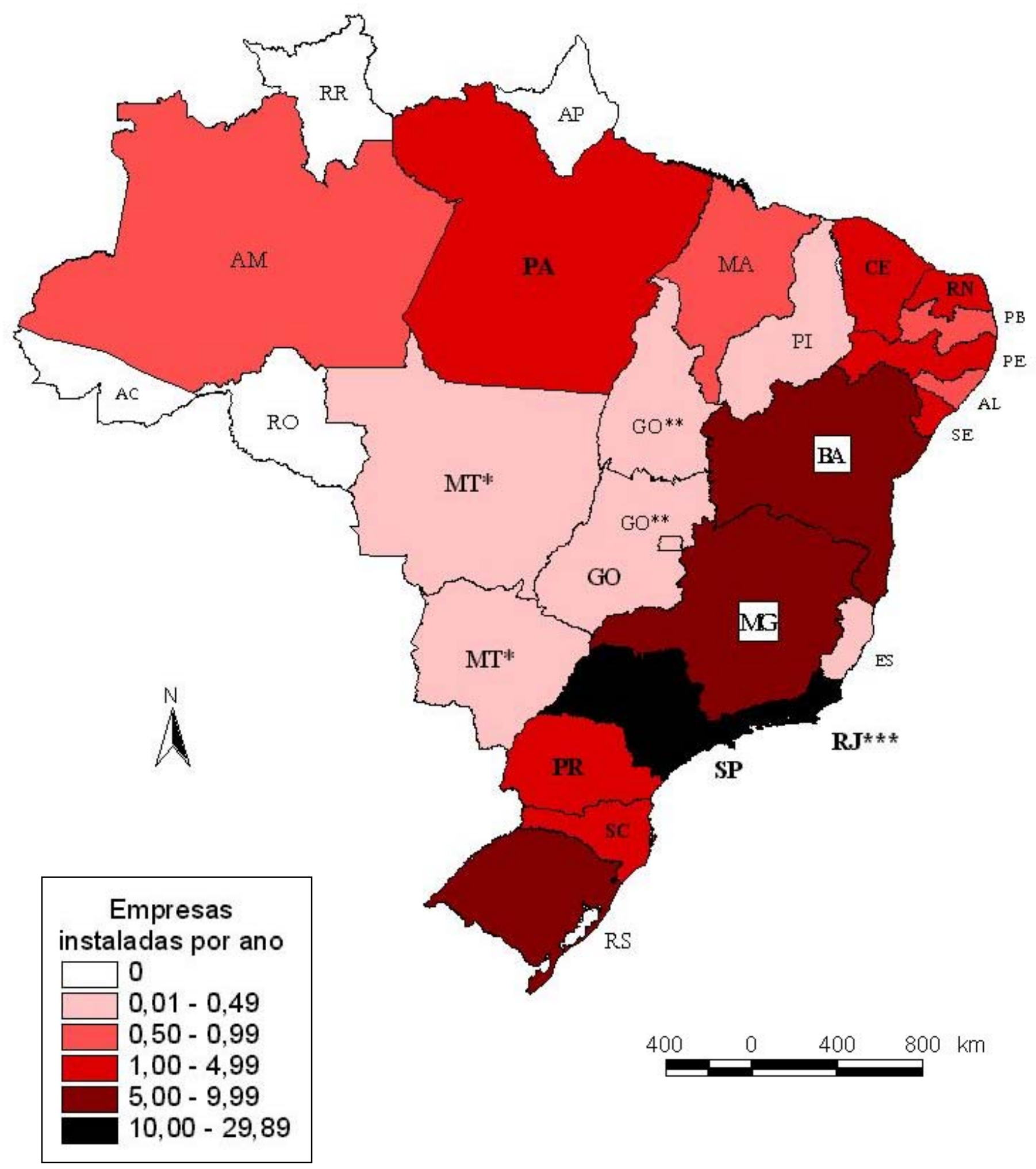

* Os territórios atualmente pertencentes aos estados de Mato Grosso e Mato Grosso do Sul estavam, em 1930, reunidos num só território, sob o nome de Mato Grosso ** Os territórios atualmente pertencentes ao estado de Tocantins e ao atual Distrito Federal faziam parte, em 1930, do estado de Goiás. ** Rio de Janeiro mais o Distrito Federal.

fonte: elaboração própria, com dados do IBGE, Censo industrial, 1950

cartografia: Edison Bicudo 


\section{mapa II.1}

Período científico: Estabelecimentos da indústria farmacêutica e veterinária instalados, de 1950 a 1959, e de 1961 a 1975. Anos-base: 1975

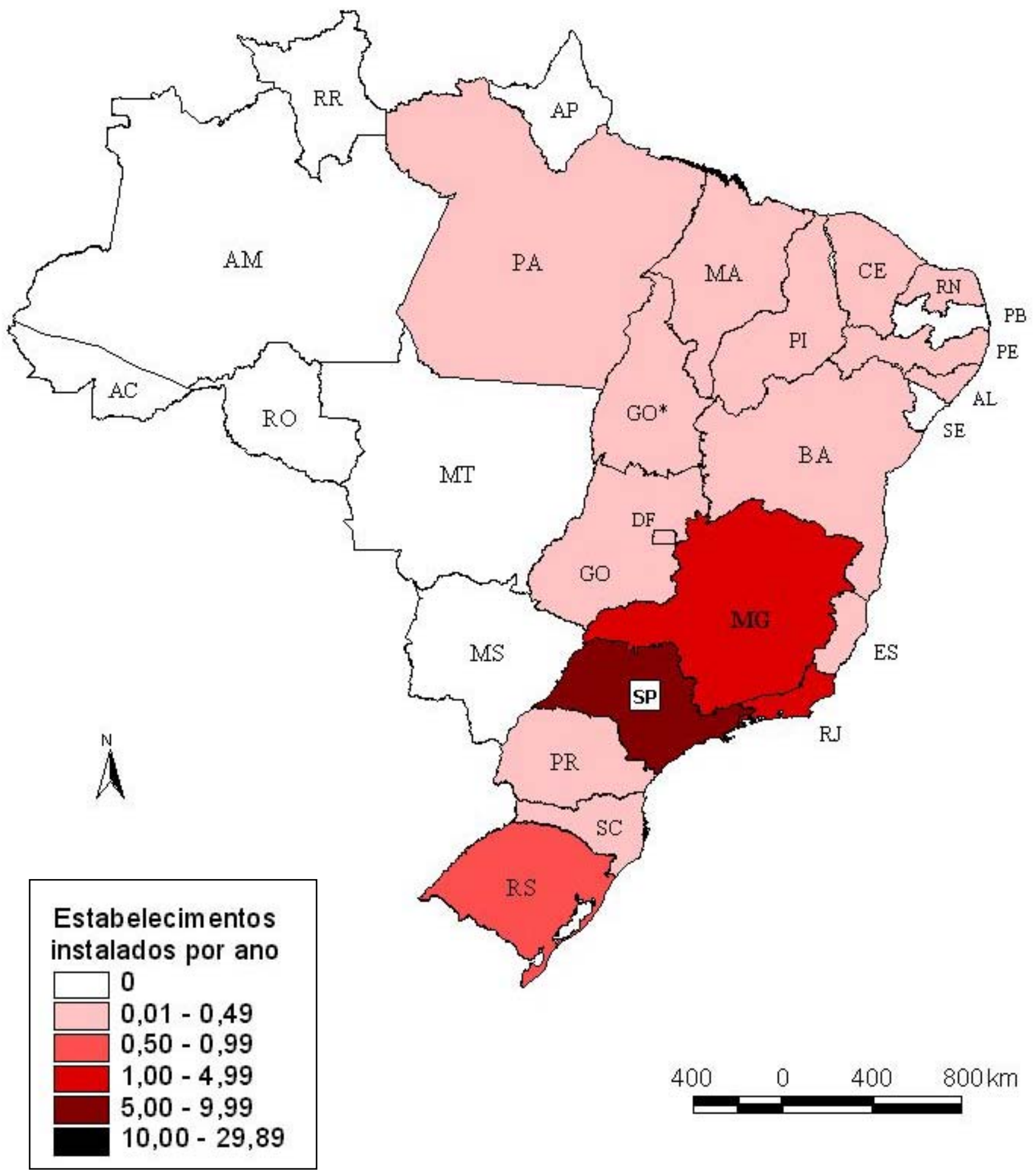

* O território atualmente pertencente ao estado de Tocantins fazia parte, em 1975, do estado de Goiás. fonte: elaboração própria: 1950-1959: Evans, P. 1980; 1961-1975: IBGE, Censo industrial, 1975 cartografia: Edison Bicudo 
mapa III.1

Período informacional: Fundação das unidades autorizadas a produzir medicamentos, de 1976 a 1996. Ano base: 2003

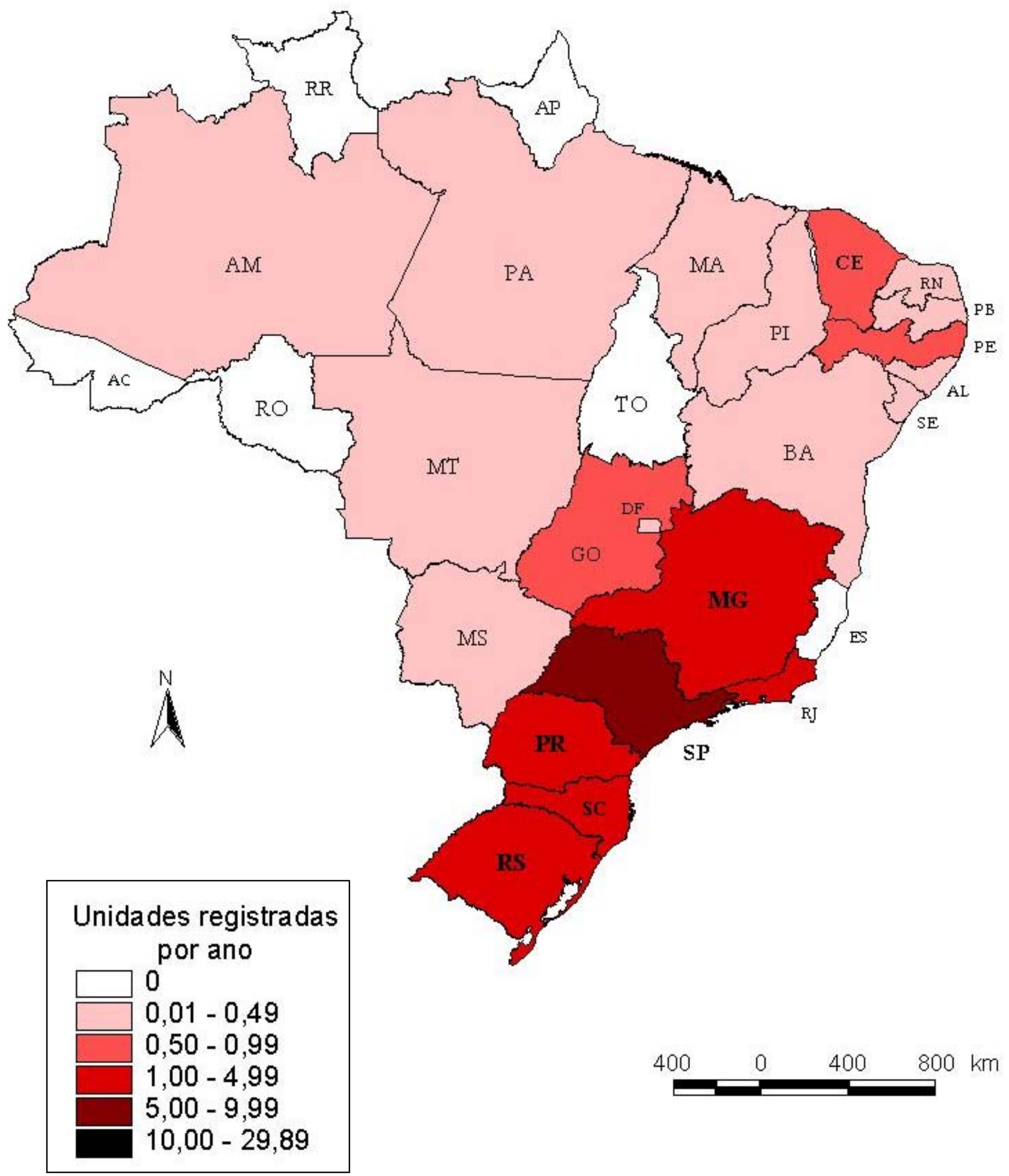

fonte: elaboração própria, com dados da Anvisa, Agência Nacional de Vigilância Sanitária, e do CNPJ, Cadastro Nacional da Pessoa Jurídica coleta e preparação dos dados: Edilson e Edison Bicudo; cartografia: Edison Bicudo 


\section{mapa IV.1}

Comitês de Ética e Pesquisa (CEPs): Brasil, 2005

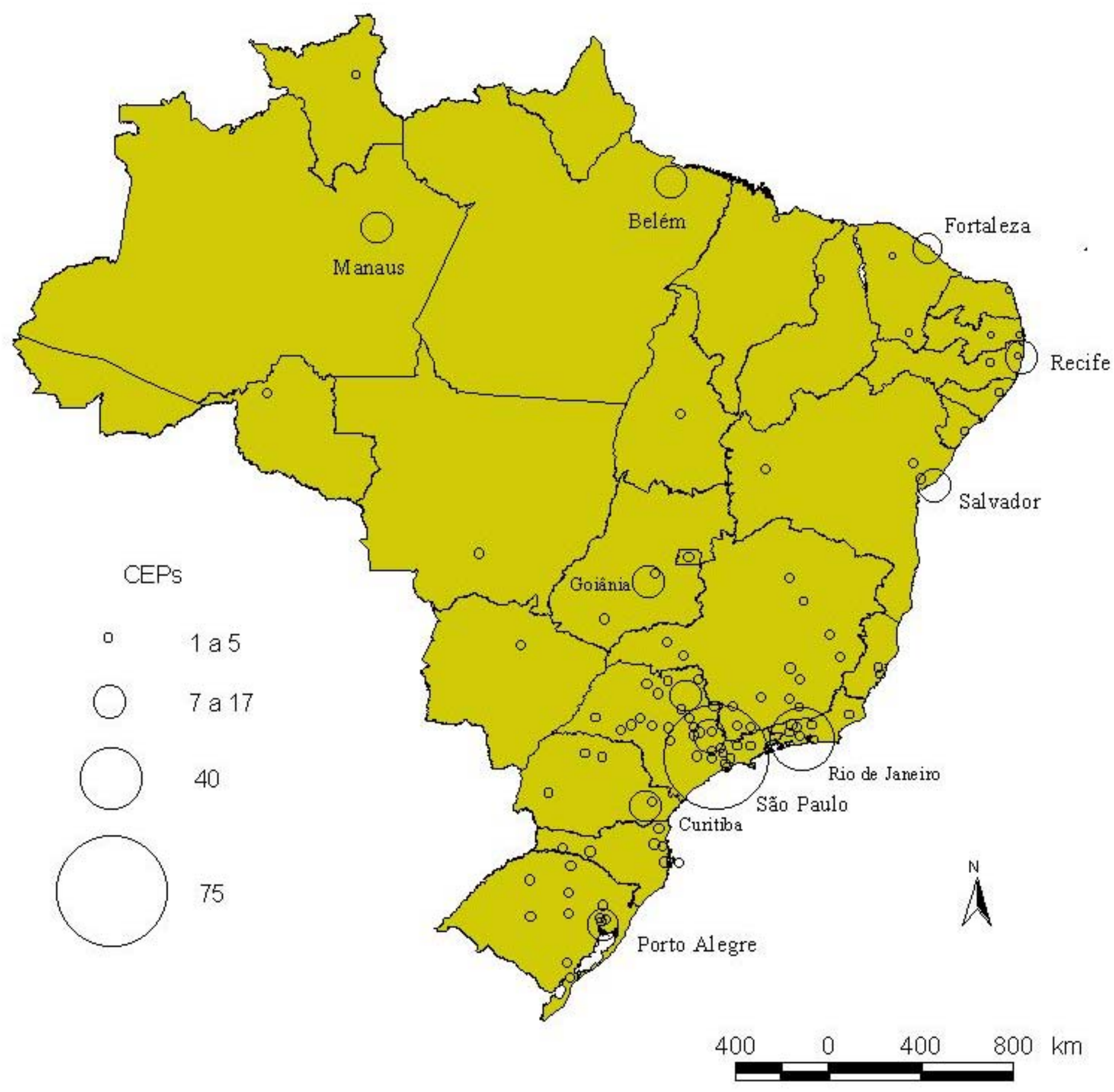

fonte: elaboração própria, a partir das informações da CONEP, Comissão Nacional de Ética em Pesquisa: http://conselho.saude.gov.br/comissao/eticapesq.htm coleta e preparação dos dados: Edilson e Edison Bicudo; cartografia: Edison Bicudo 


\section{mapa IX.1}

Circuito espacial de produção do laboratório Sanífer: 2005

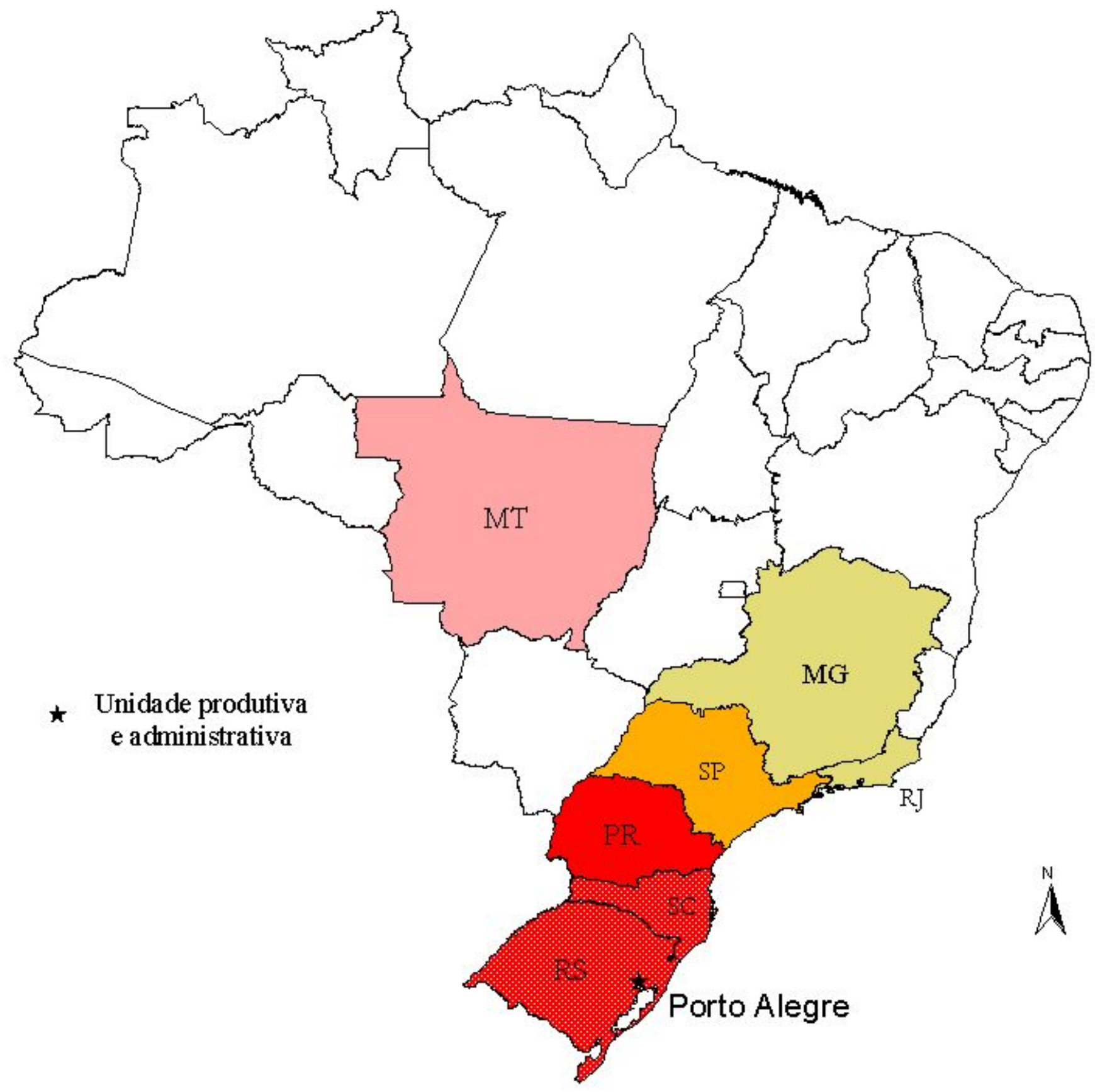

Estados com os fornecedores de plantas e primeiro volum e de distribuiçẫo Estado com o primeiro volum e de distribuiçấo 



\section{mapa IX.2}

Circuito espacial de produção do laboratório Pronatus: 2004

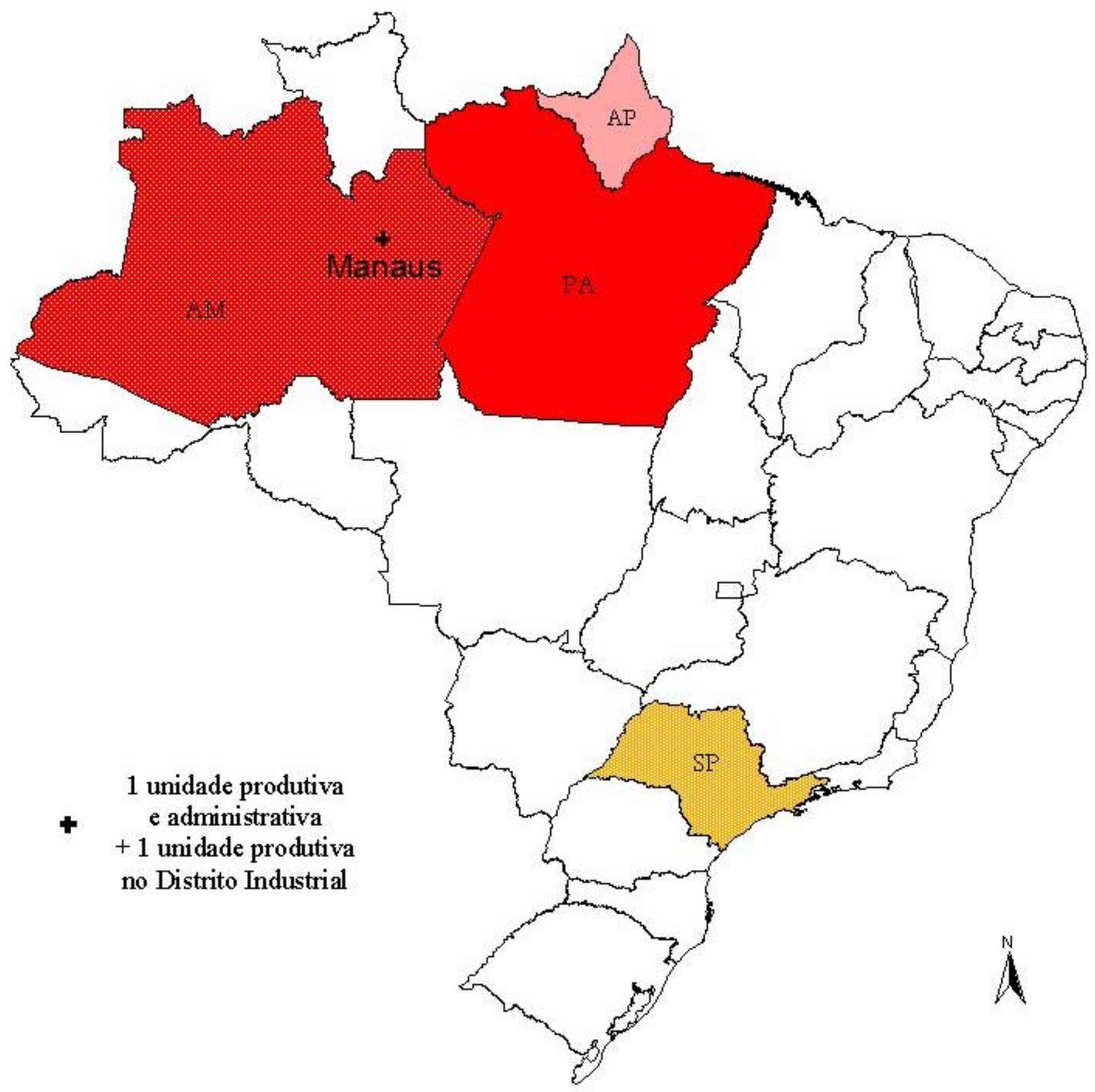

Estado com os principais fornecedores e prime iro volume de distribuição 


\section{mapa IX.3}

Circuito espacial de produção do laboratório Ravick: 2004

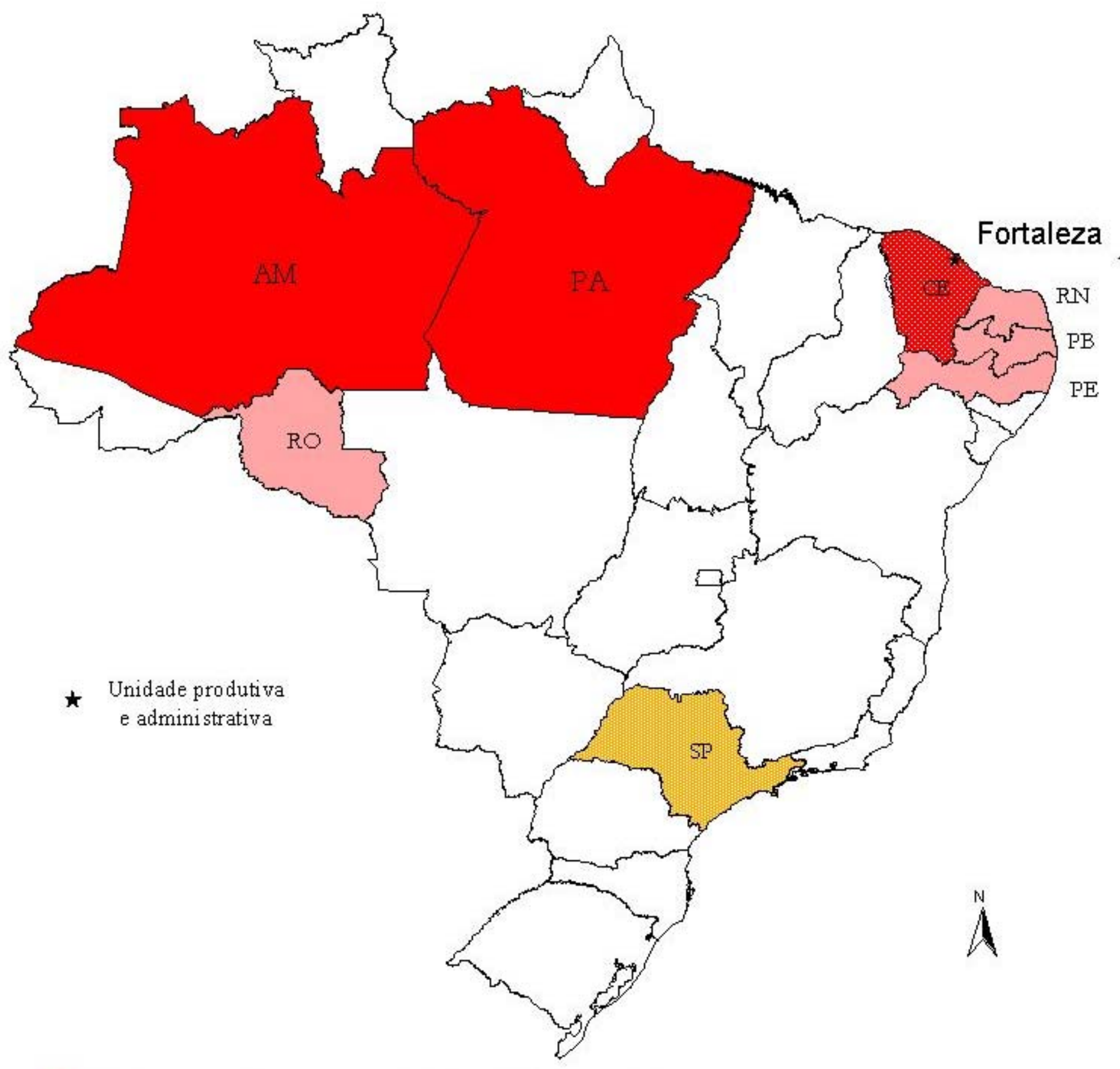

Estados com os fornecedores principais e distribuiçẫo principal

Estado abrigando os fornecedores secundários

Estados correspondendo à distribuiçẫo principal

Área de distribuiçẫo secundária

Estados em que o laboratório nẫo atua

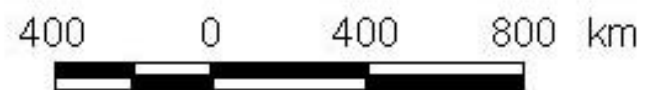




\section{mapa IX.4}

Circuito espacial de produção do laboratório Amazonas: 2003

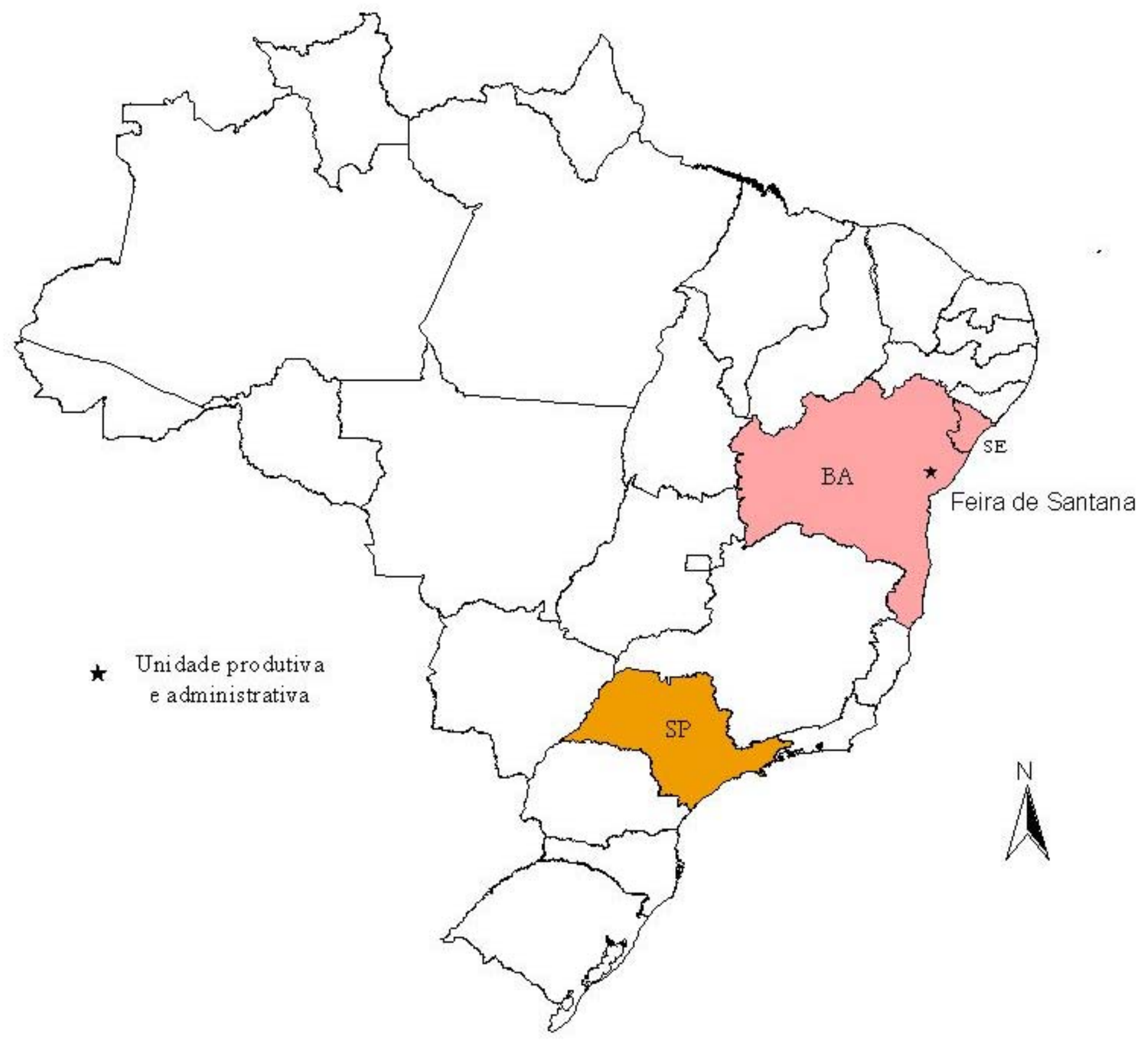




\section{mapa IX.5}

Circuito espacial de produção do laboratório Anchieta: 2005

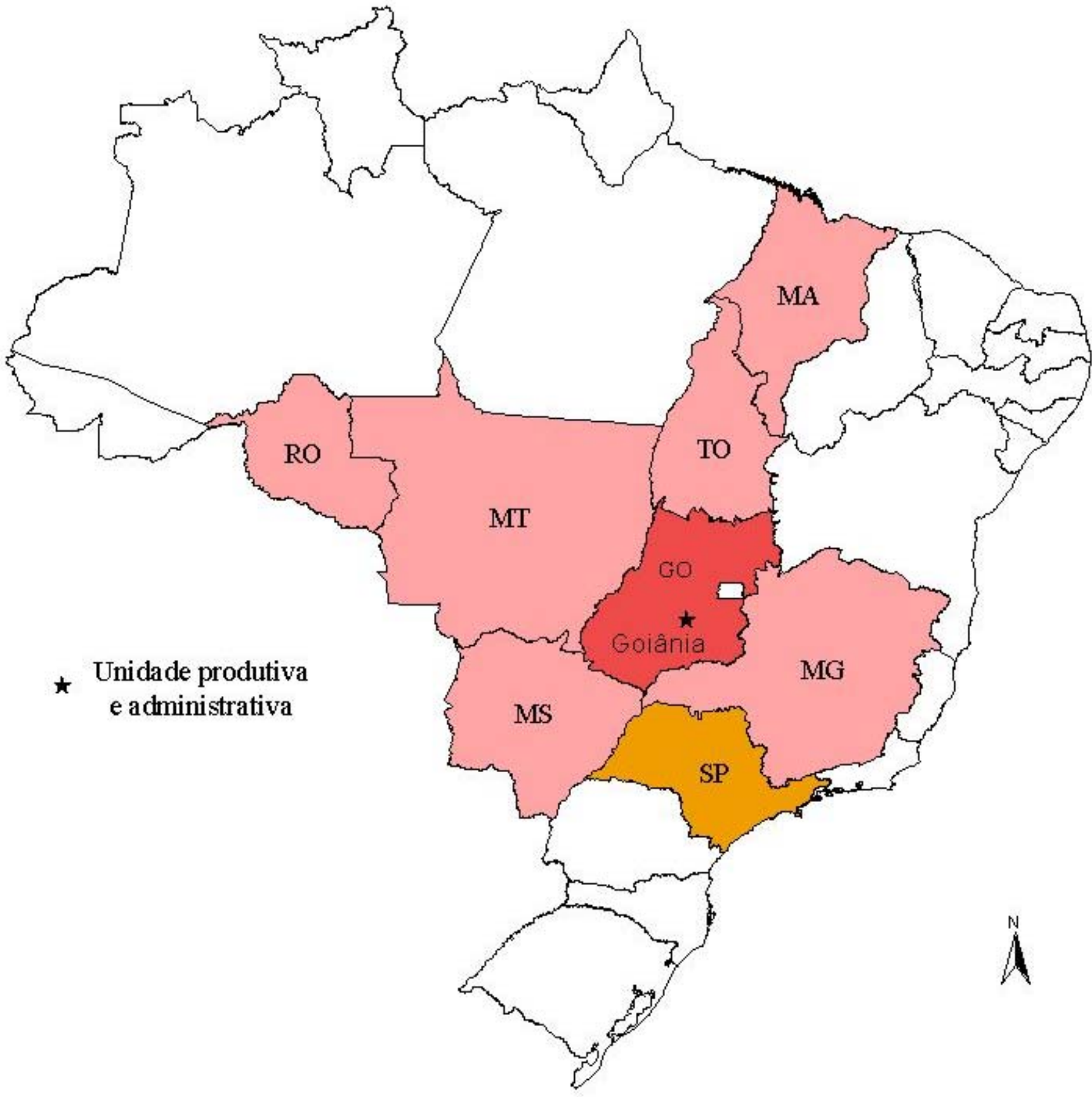




\section{mapa IX.6}

Período informacional: Unidades produtoras de medicamentos registradas pela Anvisa, de 1976 a 1996. Ano-base: 2003
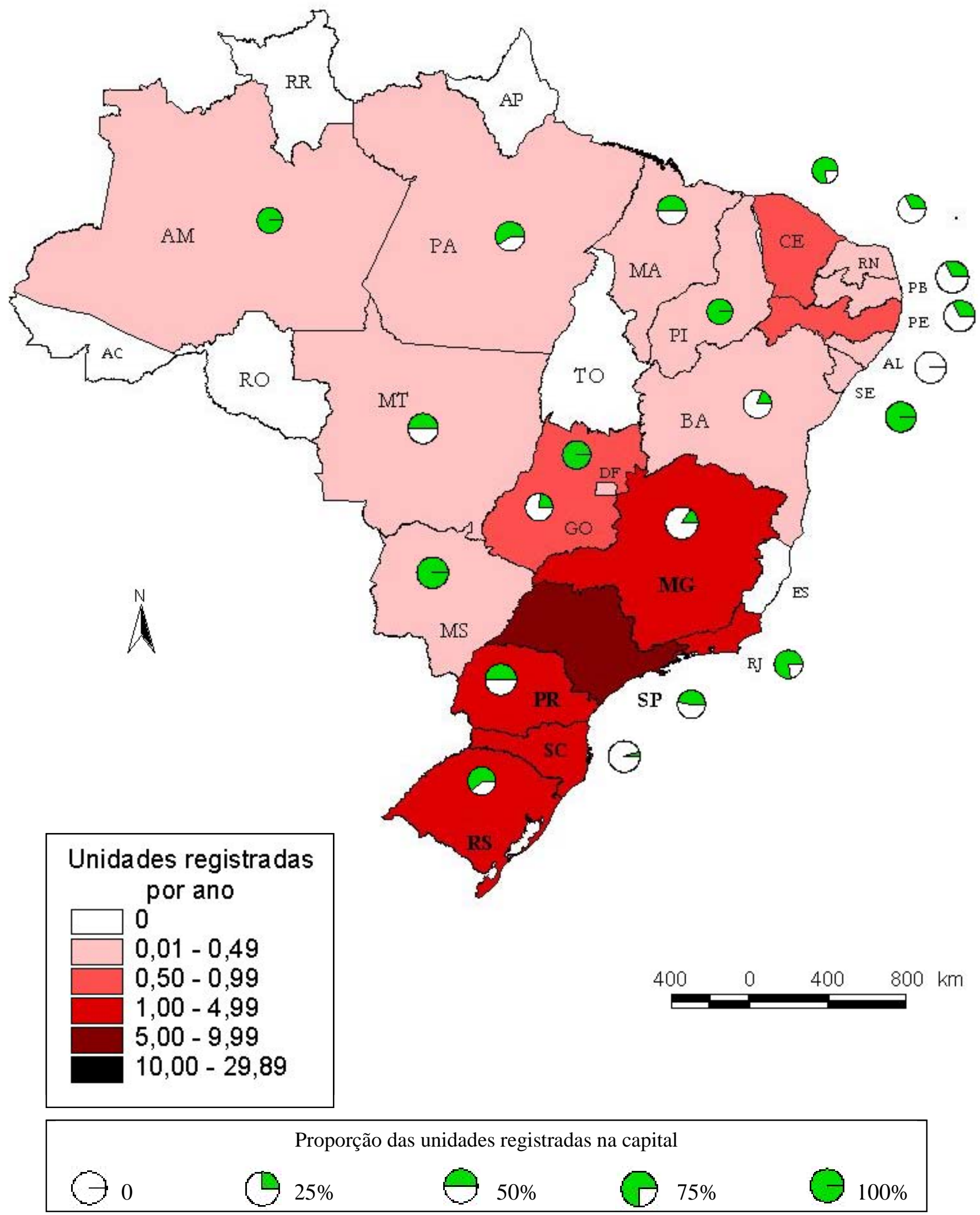

fonte: elaboração própria, com dados da Anvisa, Agência Nacional de Vigilância Sanitária, e do CNPJ, Cadastro Nacional da Pessoa Jurídica

coleta e preparação dos dados: Edilson e Edison Bicudo; cartografia: Edison Bicudo 
Período atual: Unidades produtoras de medicamentos registradas pela Anvisa, de 1997 a 2003. Ano-base: 2003
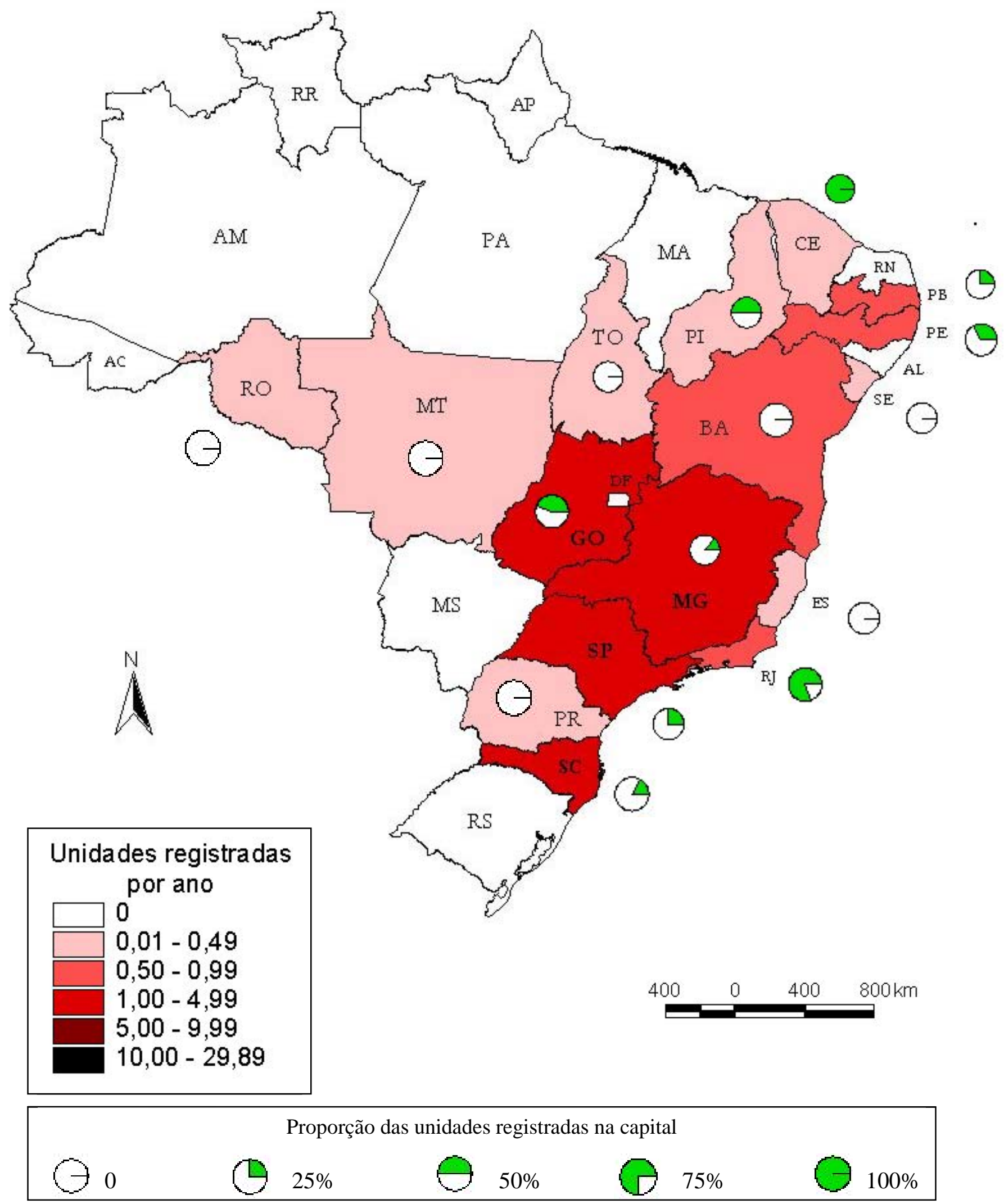

fonte: elaboração própria, com dados da Anvisa, Agência Nacional de Vigilância Sanitária, e do CNPJ, Cadastro Nacional da Pessoa Jurídica

coleta e preparação dos dados: Edilson e Edison Bicudo; cartografia: Edison Bicudo 